

\section{CIUDAD Y TERRITORIO ESTUDIOS TERRITORIALES

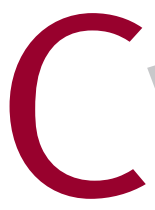

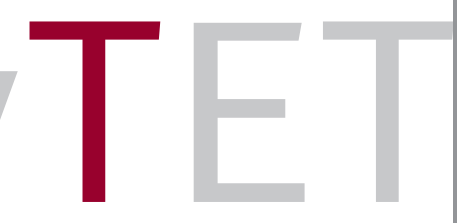

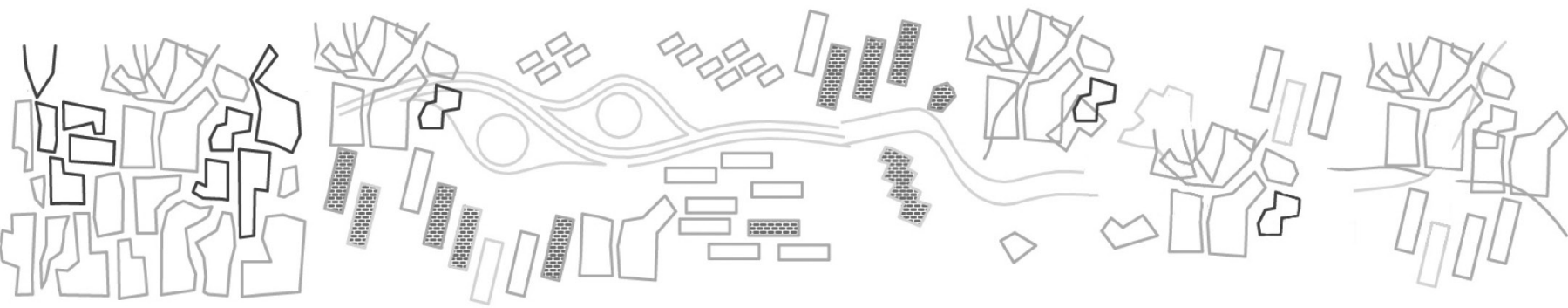

Vol. LIII. Cuarta época N. ${ }^{0} 207$ primavera 2021

Ley del Suelo de 2015: Urbanismo sostenible y vivienda Infraestructura verde y Ordenación del Territorio en España

Evaluación de la efectividad en la regeneración urbana de nuestras ciudades

Movilidad, migraciones y nomadismo en la ciudad del siglo XXI

¿Es recuperable la ciudad como espacio para la infancia?

Sprawl logístico en la mega-región urbana de Madrid

Estudio de las vías pecuarias desde el paisaje

Ciudad informal y territorialidades: Armenia, Colombia Russell Sage Foundation y Forest Hills Gardens: Nueva York

Orígenes del urbanismo en la competencia entre ciudades: Houston

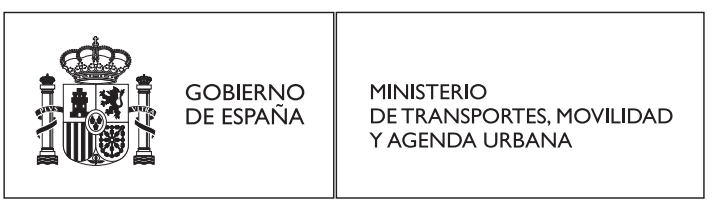




\section{Comité de Redacción/Editorial Board}

Rafael Mata OLMo - Universidad Autónoma de Madrid

Jorge OLCINA CANTOS - Universidad de Alicante

Omar BouAZZA ARIÑO - Universidad Complutense de Madrid

Graziella TROVATo - Universidad Politécnica de Madrid

Luis Ángel Collado Cueto - Universidad Autónoma de Madrid

Eduardo de SANTIAgo Rodríguez - Ministerio de Transportes, Movilidad y Agenda Urbana

\section{Consejo Asesor Internacional/International Scientific Advisory Board}

Antonio AcIerno. Universitá degli Studi di Napoli Federico II (Italia)

Arturo Almandoz MARTE. Universidad Simón Bolívar de Caracas (Venezuela) y Pontificia Universidad Católica (Chile) Rachelle ALterman. Technion Israel Institute of Technology (Israel)

Nacima Baron. Ecole Nationale des Ponts et Chaussées, París (France)

Paola BrIATA. Politecnico di Milano (Italia)

James BUCKLEY. University of Oregon (USA)

Joan BUSQUETS. Harvard University (USA)

Laurent Coudroy DE LILLE. Université de París-Est-Créteil (France)

Karen CHAPPLE. Berkeley University of California (USA)

Fernando de TERÁN TROYANo. Universidad Politécnica de Madrid (España)

José María DE UREÑA FRAncÉs. Universidad de Castilla-La Mancha (España)

Juan Carlos Del CAStillo DAZA. Universidad Nacional de Colombia, Sede Bogotá (Colombia)

Paulo V. DiAs CORREIA. Universidade de Lisboa (Portugal)

Elizabeth ESPINOSA DoRANTES. Universidad Autónoma Metropolitana. Unidad Azcapotzalco (México)

Ana María Fernández-MaldonAdo. TU Delft University of Technology (The Netherlands)

Fania FrIDMAN. Universidade Federal do Rio de Janeiro (Brasil)

Alvaro Antonio Gomes Domingues. Universidade do Porto (Portugal)

Josefina GómEz MENDozA. Universidad Autónoma de Madrid (España)

Laureano LÁZARo Araujo. Universidad Complutense de Madrid (España)

Jesús Leal Maldonado. Universidad Complutense de Madrid (España)

Francesco Lo PIccolo. Università degli Studi di Palermo (Italia)

Marta LORA TAMAYO. UNED Universidad Nacional de Educación a Distancia (España)
Ángel MENÉNDEZ REXARCH. Universidad Autónoma de Madrid (España)

Leandro MINUCHIN. Manchester University (United Kingdom)

Sergio Montero MuÑoz. Universidad de Los Andes,

Bogotá (Colombia)

Luis Moya GonzÁLez. Universidad Politécnica de Madrid

(España)

Demetrio MuÑoz GIELEN. Radboud University Nijmegen (The Netherlands)

Zaída Muxí MARTínez. UPC Universitat Politècnica de Catalunya, Barcelona (España)

Vincent NADIN. TU-Delft University of Technology (The Netherlands)

Michael NEUMAN. University of Westminster,

London (United Kingdom)

Luciano Parejo Alfonso. Universidad Carlos III de Madrid (España)

Fernando PARRA SUPERVÍA. Universidad Autónoma de Madrid (España)

Rubén Omar PESCI. FLACAM y Cátedra UNESCO

para el Desarrollo Sustentable (Argentina)

Héctor QUIROZ ROTHE. UNAM Universidad Nacional Autónoma de México (México)

Josep RoCA CLADERA. UPC Universitat Politècnica de Catalunya, Barcelona (España)

Nelson Saule. Pontifícia Universidade Católica de São Paulo (Brasil)

Guillermo TeLLA. Universidad Nacional de General Sarmiento, Buenos Aires (Argentina)

Catalina TURCU. UCL University College London

(United Kingdom)

Antonio VÁzqUEZ BARQUERo. Universidad Autónoma de Madrid (España)

Fernando VIVIESCAS MonSALVE. Universidad de Guadalajara (México) y Universidad Nacional de Colombia, Sede Bogotá (Colombia)

Alicia ZICCARDI. UNAM Universidad Nacional Autónoma de México (México)

Karl zIMMERER. Pennsylvania State University. (USA) 


\section{Índice/Contents}

\section{Estudios/Articles}

Ley del Suelo de 2015: Urbanismo sostenible y acceso a la vivienda Land Act 2015: Sustainable urbanism and housing accessibility Ildefonso ORTEGA-MORENO .

Infraestructura verde y Ordenación del Territorio en España Green Infrastructure and Spatial Planning in Spain.

Berezi ELORRIETA-SANZ \& Jorge OLCINA-CANTOS.

Evaluación de la efectividad en la regeneración urbana de nuestras ciudades. Lecciones aprendidas Evaluation of the effectiveness in the urban regeneration of our cities. Lessons learned

Eduardo RUBIO HUERTAS \& José Ma DE UREÑA-FRANCÉS.

Movilidad, migraciones y nomadismo. El urbanita y los espacios de ambivalencia y mediación en la ciudad del siglo XXI

Mobility, migrations and nomadism. The urbanite and the spaces of ambivalence and mediation in the city of the 21st century

Angelique TRACHANA \& Rubén Arturo CACSIRE-GRIMALDOS

¿Es recuperable la ciudad como espacio para la infancia? Aproximación teórica desde la perspectiva del urbanismo social, participativo y sostenible

Is the city recoverable as a space for children? Theoretical approach from the perspective of social, participatory and sustainable urban planning

Juan SeVILLA-ÁlvareZ \& Diego CoRRochano-FERnÁndeZ \& Alejandro GómEZ-GonÇALVES

\& Héctor RATO-MARTíN

Sprawl logístico en la mega-región urbana de Madrid: el espacio de la distribución entre la dispersión y la centralidad

Logistics sprawl in the urban mega-region of Madrid. The space of the supply chain between dispersion and centrality

Darío RIVERA-BLASCO \& Javier RUIZ-SÁNCHEZ

Propuesta metodológica para el estudio de las vías pecuarias desde el paisaje. Aplicación al Cordel de Gambogaz (Sevilla).

Methodological proposal for the study of livestock trails from the landscape. Application to the Cordel de Gambogaz (Seville)

Carmen VENEGAS-MORENO \& Irena GARCÍA-VÁZQUEZ \& Jesús RODRÍGUEZ-RODRÍGUEZ

\& Ana CoRonAdo-SÁnchez \& Juan José DomíngueZ-VELA \& Belén PEDREgAL-MATEOS

Ciudad informal, territorialidades de producción social del espacio urbano en asentamientos humanos (Armenia-Quindío (Colombia)

Informal city, territorialities of social production of urban space in human settlements Yonier CASTAÑEDA-PÉREZ \& Ana Catalina HERnÁNDEZ-RAmíREZ . 
Índice

La Russell Sage Foundation y Forest Hills Gardens: un laboratorio urbanístico en Nueva York entre el determinismo social y la estandarización de la vivienda

Russell Sage Foundation and Forest Hills Gardens: an urban laboratory in New York between social determinism and the standardization of housing

María Cristina GARCÍA-GONZÁLEZ \& Salvador GUERRERO-LÓPEZ

Los orígenes de la utilización del urbanismo en la competencia entre ciudades. El caso de Houston Origins of the use of urbanism in cities competition. Houston case

Carlos GARCÍA-VÁZQUEZ

\section{Experiencias/Urban Practices}

El corredor Biótico del Río. Medellín, Colombia.

Biotic River Corridor. Medellín. Colombia

LUCA BULLARO

\section{Estudios Comparados/Comparative Studies}

La protección, gestión y mejora del paisaje en España. Estudio comparado

Landscape protection, management and improvement in Spain. Comparative study

Rafael MATA-OLMO \& Daniel FERRER-JIMÉNEZ.

\section{Observatorio Inmobiliario/Spanish Real Estate Observatory}

2020: Un ejercicio difícil para el mercado de vivienda

A difficult exercise for the housing market

Julio RODRíGUEZ-LÓPEZ.

\section{Documentación/Documents}

Información sobre Tesis doctorales

Doctoral thesis information.

EI PGOU de Valladolid 2020, en el lado oscuro de la calle

Valladolid 2020 Urban Master Plan, on the sunny side of the Street

Manuel SARAVIA-MADRIGAL

\section{Libros y Revistas/Book Reviews}

Recensiones y reseñas de libros recibidos

\section{Listado de evaluadores 2020}


CIUDAD Y TERRITORIO

ESTUDIOS TERRITORIALES

ISSN(P): 1133-4762; ISSN(E): 2659-3254

Vol. LIII, № 207 , primavera 2021

Págs.5-22

https://doi.org/10.37230/CyTET.2021.207.01

CC BY-NC-ND

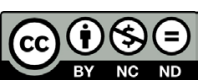

\title{
Ley de Suelo de 2015: Urbanismo sostenible y acceso a la vivienda
}

\author{
Ildefonso Ortega-Moreno
}

Abogado, Doctorando Urbanismo UMA (España).

RESUMEN: Desde una perspectiva jurídica, se analiza el paso de un urbanismo extensivo a uno sostenible, cambio de tendencia que, en lo referente a la Ley de suelo en España, se observa claramente tras la aprobación de la Ley de suelo de 2007. Se analiza el proceso de configuración normativa de la norma desde 2007 al 2015. Prestamos especial atención a las reservas de suelo y de vivienda de protección oficial, de manera que no podemos entender un urbanismo sostenible sin el acceso efectivo por parte de la ciudadanía a una vivienda digna, adecuada y accesible. Al final del análisis, planteamos algunas propuestas para que el acceso a la vivienda sea efectivo, incidiendo en la necesidad de mejorar el control sobre el desarrollo urbanístico, y la actuación de las administraciones para dicho fin.

PALABRAS CLAVE: Suelo; Urbanismo; Sostenible; Vivienda.

\section{Land Act 2015: Sustainable urbanism and housing accessibility}

ABSTRACT: From a legal point of view, the transition from an extensive urbanism to a sustainable one is analyzed, a change that, according to the Spanish Land Law, is easily seen after the approval of the 2007 Land Law. The configuration process of the regulations from 2007 to 2015 is analyzed. In this process, we pay special attention to the land reserves and housing with official protection, so we cannot contemplate a sustainable urbanism without easy access to decent, adequate and affordable housing for everyone. At the end of the analysis, we put forward some proposals so that access to housing is effective, emphasizing the need for better control of urban development, as well as improving the performance of administrations.

KEYWORDS: Land; Urbanism; Sustainable; Housing.

Recibido: 21.01.2020; Revisado: 22.09.2020

Correo electrónico:" abogadolawyer@legal-service.es. № ORCID: https://orcid.org/0000-0001-6097-5596

El autor agradece los comentarios y sugerencias realizados por los evaluadores anónimos, que han contribuido a mejorar y enriquecer el manuscrito original. 


\section{Introducción}

a vivienda es el elemento base, estructural, a partir del cual los ciudadanos co- mienzan a desarrollar sus proyectos de vida. Sin vivienda asegurada, sin acceso a una vivienda digna, adecuada a las circunstancias personales y accesible en atención a la situación económica de cada uno, resulta difícil que alguien pueda ocuparse debidamente de otras necesidades vitales al ser "esclavos de su miseria y deficiencias" (VAQUER, 2014). Necesidades tales como formar una familia, invertir en un negocio, investigar o realizar otro tipo de tareas que enriquezcan al individuo y que, por ende, produzcan un efecto positivo, un efecto de contagio en los congéneres con los que se interrelaciona, así como en la sociedad en la que se integra.

En España, es evidente la dificultad que supone el acceso a la vivienda tanto en propiedad como en alquiler, al suponer la renta o el préstamo hipotecario un elevado porcentaje de la nómina, que es el principal obstáculo. Y si es un problema para los jóvenes y trabajadores empobrecidos, aún lo es más para los colectivos más vulnerables de nuestra sociedad, como son: personas dependientes, mujeres maltratadas, unidades familiares en extrema pobreza, etc. De manera que ya no solo es un problema el acceso a la misma, sino que también lo es la expulsión o desahucio por impago de renta de alquiler o de préstamo hipotecario ${ }^{1}$.

Que la sociedad no sea capaz de atender a sus ciudadanos de una necesidad tan vital y básica como es el acceso a la vivienda, principio programático reconocido en el artículo 47 de nuestra Constitución española (CE), es un foco de continuos conflictos. Así, el art. 47 de la CE dispone:

"Todos los españoles tienen derecho a disfrutar de una vivienda digna y adecuada. Los poderes públicos promoverán las condiciones necesarias y establecerán las normas pertinentes para hacer efectivo este derecho, regulando la utilización del suelo de acuerdo con el interés general para impedir la especulación. La comunidad participará en las plusvalías que genere la acción urbanística de los entes públicos".

Pero a pesar de lo previsto en el art. 47 de la $\mathrm{CE}$, las actuaciones de los poderes públicos en el marco normativo, han mostrado ser poco eficaces en el cumplimiento de los fines que se persiguen. Razón por la cual, analizamos esta materia desde la perspectiva de la Ley de suelo en nuestro país y proponemos mejoras de fondo en la misma, sin concretar la redacción en cada caso, pero sí el espíritu de lo que entendemos necesario articular. Y en esa tarea, el desarrollo de un urbanismo sostenible y el acceso a una vivienda digna, asequible y adecuada, son objetivos a materializar entorno a los cuales han de girar todas las propuestas, máxime cuando la crisis sanitaria (la Covid-19) ha reforzado la idea de tener que reconfigurarse el concepto de vivienda digna y adecuada ${ }^{2}$. $Y$ todo ello, sin olvidar que las competencias para planificar urbanísticamente residen en los municipios $y$, sin embargo, los planes de vivienda son competencias autonómicas, a los que se suma el Estado central, que ejerce competencias transversales para adoptar propios planes y destinar recursos (VAQUER, 2017:70).

En cuanto a urbanismo sostenible se refiere, creemos oportuno traer las consideraciones que aparecen en el prólogo de la "Nueva Agenda Urbana" (NAU) ${ }^{3}$, por contener principios muy interesantes para el objeto de nuestro trabajo.

La finalidad de la NAU, en el contexto de la Agenda 2030 para el desarrollo sostenible y el Acuerdo de París entre otros, es reconsiderar la forma en la que las ciudades se organizan y desarrollan hacia un modelo más sostenible. Modelo que facilite a las personas el acceso a las oportunidades y beneficios que sobre los espacios urbanos se producen en condiciones de igualdad. Es decir, las ciudades, en 750 de las cuales se concentra más del $60 \%$ de la riqueza mundial (BRITTON, 2017:1), son centros generadores de riqueza y de atracción de población, por lo que deben ser la solución a los problemas y no su causa.

\footnotetext{
' Según el INE (primer trimestre de 2014 al cuarto trimestre del año 2018), a fecha de 28 de marzo de 2019 se contabilizan 402.987 inscripciones de certificaciones por ejecuciones hipotecarias iniciadas en los registros de la propiedad. De manera que para el año 2018 se contabilizan 53.856 desahucios hipotecarios.

${ }^{2}$ Con la crisis sanitaria del Covid-19, las medidas de confinamiento ponen de manifiesto la necesidad de que las viviendas cuenten con espacio suficiente, terrazas y ventanas
}

al exterior, como soluciones para disminuir el impacto psicológico, que en sus moradores se produce al no poder salir a la calle (depresión, peleas familiares, etc.).

${ }^{3}$ Aprobada en Quito el 20 de oct. de 2016, en la conferencia de la ONU sobre Vivienda y Desarrollo Urbano Sostenible (Hábitat III). Refrendada posteriormente por la Asamblea general de la ONU el 23 de diciembre de 2016. Versión en español:

http://habitat3.org/wp-content/uploads/NUA-Spanish.pdf. 
Por tanto, se trata de una ciencia de las ciudades que establece principios, normas y sistemas para planificar, desarrollar urbanísticamente, mejorar y rehabilitar las zonas urbanas en base a cinco frentes fundamentales: políticas urbanas nacionales, legislación y normativas urbanas, planificación y diseño urbano, economía local y finanzas municipales e implementación local. Modelo donde la nueva gobernanza es vital, lo que implica tener que integrar en el proceso de decisiones a todos los agentes públicos y privados intervinientes en el desarrollo urbano del área que se trate, para hacer las ciudades más habitables mejorando la calidad de vida de sus moradores y usuarios.

Visto lo anterior, no podemos olvidar que la inmensa mayoría de la población española vive en ciudades ${ }^{4}$, tendencia que irá a más. Pues es en las ciudades donde los individuos encuentran satisfacción a sus necesidades, incluso encuentran canales más accesibles para exigir soluciones allí donde la ciudad no ofrezca alternativas al respecto.

Por consiguiente, los ciudadanos superan la percepción limitada de derechos en las ciudades hacia uno más holístico, integral y sostenible, como si fuera un todo, que es el derecho a la ciudad en el sentido de Lefevre (LEFEVRE, 1969), y cuya visión actual está bien sintetizada en la cita siguiente (BANDRÉs, 2014:97-103):

\begin{abstract}
"El derecho a la ciudad se configura como un derecho humano emergente que, extendiendo y complementando el catálogo de derechos proclamados en la Declaración Universal de Derechos Humanos de 10 de diciembre de 1948, determina el reconocimiento de un revalorizado estatuto de ciudadanía, derivado de la consideración de la ciudad como espacio público colectivo que garantiza a todos sus habitantes el goce más amplio de los derechos políticos, económicos, sociales, culturales y medioambientales".
\end{abstract}

Es decir, la ciudad ha de ser el agente canalizador de todas las demandas, y el factor resolutivo de todos los problemas. Donde el suelo, los espacios creados a partir de él, su regulación, los derechos y obligaciones que emanan del mismo, han de tratarse de forma integrada (PONCE, 2019:115-151) y no de forma parcial o sectorial como venía pasando de forma tradicional.

\footnotetext{
${ }^{4}$ El $80 \%$ de la población española vive en un área urbana, ocupando el $20 \%$ del territorio nacional. Véase pág. 12 de la Agenda Urbana Española 2019, extraído el día 07 de mayo de 2020 del siguiente enlace web del Gobierno de España: https://apps.fomento.gob.es/CVP/handlers/pdfhandler. ashx?idpub=BAW061
}

Derechos que muchos de ellos están protegidos constitucionalmente y tienen un evidente interés general, como son el derecho a la propiedad privada, a la educación, a la seguridad pública, al disfrute de un medio ambiente saludable, al acceso a una vivienda digna y adecuada o a la igualdad que, según Zamora, ha de incluir la perspectiva de género, de modo que, su ausencia, ha declarado nulos muchos planeamientos urbanísticos (ZAMORA, 2019). Los poderes públicos deben evitar la segregación urbana y promover la cohesión social, territorial y económica de las ciudades a través de la planificación y el desarrollo urbanístico sostenible, inteligente e integrado ${ }^{5}$.

Y en ese contexto, la Ley de suelo (sus textos refundidos y reformas, así como las distintas leyes autonómicas en materia de ordenación del territorio, urbanismo y vivienda), debe ofrecer las herramientas legales adecuadas para informar a la ciudadanía, facilitar las actuaciones de los servidores públicos, garantizar el acceso a los derechos por parte de los ciudadanos y remover los obstáculos que se presenten para la efectiva consecución del derecho a disfrutar de un medio ambiente urbano adecuado, con la obligación aparejada de conservación y uso racional de los recursos (sometido a sanción penal o expediente disciplinario). Así como posibilitar de forma efectiva el derecho a acceder y disfrutar de una vivienda digna, adecuada y asequible, que reduzca la especulación en la medida de lo posible y haga partícipe a la comunidad de las plusvalías que se generen ${ }^{6}$.

En consecuencia, en el presente trabajo se analiza la Ley de Suelo de 2007 (LS), el texto refundido de la Ley de Suelo de 2008 (TRLS) y el Texto Refundido de la Ley del Suelo y Rehabilitación Urbana de 2015 (TRLSRU) desde la perspectiva del acceso efectivo a una vivienda digna, dentro del marco del desarrollo de un urbanismo sostenible. Para concluir, expondremos una serie de propuestas que reflejen los postulados defendidos.

\section{Conflictos competenciales}

Antes de entrar en el análisis de la norma propuesta, es preciso contemplar el reparto de competencias que hizo la Constitución española, a

\footnotetext{
${ }^{5} \mathrm{Al}$ respecto, es muy interesante la Sentencia del TS de 10 de diciembre de 2018, que reflexiona sobre el principio de igualdad entre hombres y mujeres que ha de inspirar la planificación y desarrollo de nuestro urbanismo.

${ }^{6}$ Artículos 33, 45, 46 y 47 de la CE de 1978.
} 
través de los artículos 148 (sobre las competencias que podrán asumir las Comunidades Autónomas -CCAA-) y 149 (sobre competencias que corresponden en exclusiva al Estado central) y su conflictividad, que ha motivado que el Tribunal Constitucional (TC) se tenga que pronunciar en numerosas ocasiones.

Conflictividad judicial que obedece principalmente al carácter transversal de muchas de las competencias del Estado, que influyen de manera directa tanto en materia de urbanismo como de vivienda ${ }^{7}$. Pero también obedece a la potestad del Estado expresamente prevista en el art. 150.3 de la CE, que le permite

"dictar leyes que establezcan los principios necesarios para armonizar las disposiciones normativas de las CCAA, aun en el caso de materias atribuidas a la competencia de éstas, cuando así lo exija el interés general".

Lo que ha generado confusiones y falta de concreción sobre donde están los límites en lo que puede o no ser regulado desde una perspectiva estatal o autonómica, en cuestiones cuya potestad regulatoria se otorga a las CCAA.

Al respecto, recuérdese que el artículo 148.1.3 establece la posibilidad de asumirse por parte de las CCAA las competencias en materia de ordenación del territorio, urbanismo y vivienda. Así mismo, el artículo 25 de la Ley 7/1985, de 02 de abril, reguladora de las bases del régimen local establece que la planificación, gestión, ejecución y disciplina urbanística, junto con la promoción y gestión de vivienda protegida y la conservación y rehabilitación de edificios, son competencias propias de los municipios, en los términos previstos en la legislación estatal y autonómica ${ }^{8}$.

Por tanto, la extensa y a veces confusa maraña normativa existente en estas materias, ha dado lugar a sentencias del TC tan notorias como son la 61/1997, de 20 de marzo, y la 164/2001, de 11 de julio, las cuales comentamos sucintamente a continuación.

\footnotetext{
${ }^{7}$ A modo de ejemplo véanse competencias en derecho civil (sobre la regulación del uso de las viviendas a través de normas como el propio código civil, o normas especiales como la Ley de arrendamientos urbanos o la Ley de propiedad horizontal) o en la planificación general de la actividad económica que son de competencia estatal, según viene previsto en el artículo 149.1 de la CE, apartados 8 y 13.

8 Para lo cual habrá que estar a lo previsto en el Estatuto autonómico de cada CCAA y en las leyes que lo desarrollen. A modo de ejemplo, en el caso de Andalucía, destacan la Ley 1/1994, de 11 de enero, de ordenación del territorio de la Comunidad Autónoma de Andalucía, la Ley 7/2002, de 17 de diciembre, de ordenación urbanística de Andalucía, la Ley 5/2010, de 11 de junio, de autonomía local de Andalucía
}

La sentencia del TC 61/1997 anuló las dos terceras partes del Real Decreto Legislativo 1/1992, de 26 de junio, por el que se aprueba el texto refundido de la Ley sobre régimen del suelo y ordenación urbana. Ello generó problemas en la aplicación del ordenamiento urbanístico vía atribución de competencias, creación de organismos gestores o en las relaciones entre las corporaciones locales y su territorio, al residir en los municipios la gestión directa. Dejó clara la competencia exclusiva en las CCAA en materia de ordenación del territorio y de urbanismo, tanto legislativa como reglamentaria. $Y$ concreta que estamos en un Estado social de derecho que respeta la propiedad privada, pero sin perder de vista su transcendencia social, para lo cual los poderes públicos deberán impedir su especulación (FERNÁNDEZ CARBALLAL, 1997: 577-588).

En cuanto a la sentencia del TC 61/1997 se refiere, se dictó en relación a la Ley 6/1998, de 13 de abril, sobre régimen del suelo y valoraciones, que tenía como misión fundamental aumentar el suelo urbanizable, superando la visión residual de los suelos no urbanizables (SNU). En este contexto, el TC denegó a la ley estatal la potestad de reglar los criterios para la clasificación del suelo como SNU, así como lo afectante a la generación de oferta de suelo transformable.

Otras sentencias relevantes en materia de urbanismo son la sentencia del TC 141/2014, de 11 septiembre 2014 (respecto de ciertos contenidos del TRLS), la 143/2017, de 14 de diciembre (que declara la inconstitucionalidad de un número considerable de epígrafes del TRLSRU) ${ }^{9}$ y la 75/2018, de 5 de julio ${ }^{10}$. Lo que pone de manifiesto que, a falta de una mayor concreción competencial, que a buen seguro requeriría de una reforma constitucional para definir competencias (y por qué no, reforzar la posición del Estado central en esta materia para dotar de una visión global, integral, sostenible e inteligente a la ordenación del territorio y al urbanismo en España), los conflictos competenciales se seguirán produciendo, ya sean en estas o en otras nuevas

o la Ley $1 / 2010$, de 08 de marzo, reguladora del derecho a la vivienda en Andalucía.

${ }^{9}$ Véase el inciso 4 del artículo cuatro sobre la potestad de las administraciones públicas para que se aseguren las obras de conservación, o los incisos 1, 3 y 4 del artículo nueve sobre participación pública y privada en las actuaciones de transformación urbanística y en las edificatorias.

${ }_{10}$ Que confirma la constitucionalidad del inciso "construcción e implantación de instalaciones", en los epígrafes 4.b y 4.c del artículo once, en la necesidad de considerarse como expresos la concesión administrativa (el silencio administrativo será negativo) ante actos que autoricen obras de edificación, construcción e implantación de instalaciones de nueva planta o la ubicación de casas prefabricadas e instalaciones similares, ya sean provisionales o permanentes. 
normas que se aprueben, ya sea en el ámbito estatal o en el autonómico.

Por otra parte, en lo que a la materia de vivienda se refiere, es relevante la sentencia del TC 93/ 2015, de 14 de mayo de $2015^{11}$, la cual

"sitúa las medidas estatales de política económica en una posición prioritaria y excluyente frente a las autonómicas. Las CCAA a través de las medidas previstas en sus normativas de vivienda no tratan de regular el sector bancario o el mercado inmobiliario, sino que su objetivo es hacer efectivo el derecho a disfrutar de una vivienda digna" (ARIAS, 2019: 111),

por lo que la protección del Estado del sector inmobiliario para garantizar la estabilidad financiera es contundente (TEJEDOR, 2018: 6).

Es decir, el TC limita bastante las competencias propias de las CCAA en materia de vivienda, al chocar con la planificación de la actividad económica que es propia del Estado central ${ }^{12}$, como es el caso de la expropiación de viviendas vacías pertenecientes a entidades financieras. Lo que supuso un duro golpe a la capacidad de legislar de las CCAA en materia de vivienda, por emplear un criterio muy restrictivo.

Posteriormente el TC, mediante sentencia 16/ 2018, de 22 de febrero ${ }^{13}$, reconsidera su postura por una más conciliadora en materia de vivienda. En esta sentencia, el TC vuelve a incidir en las cuestiones anteriores, dejando claro que el derecho civil, la planificación de la actividad económica y la regulación de las condiciones básicas que limiten o garanticen la igualdad de todos los españoles en su acceso a la propiedad privada es competencia estatal. Pero remarca la potestad de las CCAA para impulsar la efectividad de la función social de la vivienda y el cumplimiento del interés general a pesar de su utilidad individual ${ }^{14}$. Esto supone que las CCAA pueden condicionar el uso de la misma a través de medidas concretas, como la de limitar el tiempo por el que una vivienda pueda estar vacía, sancionar o incluso expropiar de forma excepcional, a los efectos de que la vivienda cumpla su fin habitacional (ARIAS, 2019:118).

\footnotetext{
${ }^{11}$ Que declara la inconstitucionalidad y nulidad del inciso primero del número 3 del artículo 1 , de los números 5 y 6 del artículo 25 y del artículo 53.1.a) de la Ley $1 / 2010$ de 8 marzo y disposición adicional primera de Ley 4/2013 de 1 octubre de Andalucía.

${ }^{12}$ Art. 149.1.13 de la CE.

${ }^{13}$ Respecto a los art. 52.2.a), 66.1 y 72.2 de la Ley Foral 10/ 2010, de 10 de mayo, del derecho a la vivienda en Navarra tras redacción dada por la Ley Foral 24/2013, de 2 de julio, en el supuesto de sancionar e incluso expropiar a titulares cuyas viviendas estuvieran vacías por un período determinado.

${ }^{14}$ Sentencia del TC 37/1987.
}

En consecuencia, con la sentencia del TC 16/ 2018, de 22 de febrero, se produce una interpretación más flexible que la que se produjo con la sentencia del TC 93/2015, de 14 de mayo de 2015. Es decir, está más claro el margen de actuación de las CCAA, al poder legislar condicionando el uso de la vivienda, siempre que permita el cumplimiento del fin social para el cual está previsto $^{15}$. No obstante, resulta necesario definir mejor el régimen jurídico de actuación en materia de vivienda con una regulación más clara y coordinada con el urbanismo, con redacción básica a nivel estatal que deje mayor capacidad de actuación a las CCAA (TEJEDOR, 2018:12). Pues se ha demostrado una mayor actividad y eficacia en la actuación de muchas CCAA desde un punto subjetivo, al oponerse con medidas legislativas concretas a los desalojos (si no están sobradamente justificados y está clara la alternativa habitacional) y al ofrecer una acción pública para el cumplimiento efectivo de la entrega de viviendas (QUINTIÁ, 2017: 264).

\section{La Ley de suelo, de 28 de mayo de 2007 (LS)}

\subsection{Antecedentes y fundamentos de la norma}

El derecho urbanístico en nuestro país encuentra sus orígenes en la segunda mitad del siglo XIX (ensanche y reforma interior). De forma que, el 12 de mayo de 1956, se aprueba la Ley sobre régimen del suelo y ordenación urbana, que tratará por primera vez el territorio de forma integral (DÁvILAS, 1991:101-114) ${ }^{16}$. En esta norma, la clasificación del suelo se establece como técnica que determina la ordenación y ejecución urbanísticas entorno al principal protagonista que es el suelo urbanizable, dentro de un sistema rígido de desagregación de planes y su ejecución a través de la urbanización sistemática como rasgos más significativos.

Tras la aprobación de la Constitución de 1978, se definieron el derecho a la vivienda y las obligaciones de protección ambiental, creando un

\footnotetext{
15 Fundamento jurídico séptimo de la sentencia del TC 16/ 2018, de 22 de febrero.

${ }^{16}$ Entendido como el resultado de la dialéctica entre el urbanismo municipalista, a partir del Estatuto municipal de 1924, y las actuaciones urbanísticas estatales y sectoriales, como son los derivados de los planes de vivienda. La falta de vivienda y la ausencia de planes urbanísticos de conjunto originó que, a través de esta Ley, se intentará aunar las políticas de vivienda con el urbanismo, a los efectos de prever reservas de suelos de propiedad municipal o urbanizar adecuadamente (con los servicios pertinentes), los proyectos de viviendas que se fuera proyectando y ejecutando.
} 
nuevo orden competencial. Se aprobó el texto refundido del suelo de 1992, y se entró en un periodo accidentado mediante seis reformas y dos operaciones de "legislación negativa" a través de las sentencias del TC 61/1997 y la 164/2001. De manera que "el Estado ha de regular las condiciones para asegurar el resultado, pero no regular el contenido del derecho" (BЕAто,1999:17-48), dejando a la legislación autonómica urbanística y sectorial la clasificación del suelo y la valoración que el planificador hiciera de dicha norma (AGUDO, 2010:123-175).

Y en ese contexto, la LS deroga la Ley 6/1998, de 13 de abril, de régimen del suelo y valoraciones, así como una serie de artículos del texto refundido de la Ley sobre régimen del suelo y ordenación urbana aprobado por Real Decreto Legislativo 1/1992, de 26 de junio. Lo que supuso un "cambio de paradigma" en la política y legislación de nuestro país, al pasar de un urbanismo expansivo a otro más sostenible y respetuoso con el medio ambiente (QUINTANA, 2018). Es decir, se toma mayor conciencia y se protege más el medio ambiente, a través de informes como el de evaluación de impacto ambiental, que va cobrando cada vez más importancia desde un punto de vista normativo (GARCía URETA, 2019).

Cambio de paradigma que se entiende al observar que el suelo es un recurso limitado y, aun así, el modelo de crecimiento de ciudad ha consistido en ocupar nuevos suelos de manera desordenada, lo que se antojaba como algo insostenible. Por ello, se otorga un mayor protagonismo al desarrollo sostenible y a la regeneración de las ciudades haciéndolas más compactas, lo que llevaría a mitigar los efectos perniciosos de una urbanización dispersa y desordenada (tales como la segregación social, la falta de vivienda accesible, adecuada y digna, y la ineficacia tanto energética como de los recursos invertidos).

Proceso en el que hay una clara influencia europea, gracias a las políticas de cohesión territorial que tienen una finalidad decidida de mejorar el medio ambiente urbano y la calidad de vida de sus ciudadanos. Algunos informes y documentos europeos que han contribuido a mejorar nuestra legislación y nuestras políticas en materia de urbanismo sostenible son "La carta europea de ordenación del territorio", "El libro verde sobre el medio ambiente urbano", "La carta de Leipzig sobre ciudades europeas sostenibles", "La perspectiva territorial europea" y "La agenda territorial europea", cuyos contenidos siguen de actualidad (Ortega, 2018a: 381-395).

Y para ello, la LS desarrolla unas bases comunes en el régimen del suelo sobre las que desarrollar la autonomía en materia urbanística. Así mismo, configura la clasificación y categorización del suelo como algo ajeno a la regularización de la legislación estatal, clasificación que, con sus expectativas de revalorización, ha sido uno de los principales responsables de la especulación urbanística contra la que se debe combatir por imperativo constitucional.

Igualmente incide en la necesidad de compaginar el mundo rural y el urbano, que se han de proteger y regenerar como valores ambientales y económicos, potenciar sus particularidades, permitir la iniciativa privada en la urbanización de los suelos y evitar la especulación de los mismos mediante un uso y explotación de forma ágil y efectiva. Por lo que, en palabras de Parejo:

\begin{abstract}
"Se trata, (...) no ya evitar, sino siquiera mitigar, las consecuencias de los excesos en la clasificación de suelo con destino teórico final urbano, la promoción inmobiliaria para las más diversas variantes de uso residencial (con destrucción de tejido industrial) y, en suma, la especulación urbanística e inmobiliaria. Su idea motriz es la sintonización de nuestra política territorial-urbanística en la frecuencia comunitario-europea, que venía trasmitiendo en la banda determinada por el principio del desarrollo sostenible (senda perdida entre nosotros por la liberalización del suelo asumida en 1997) y acotada, de un lado, por el desarrollo económico-social en el marco del mercado interior, $y$, de otro lado, el objetivo del fortalecimiento de la cohesión social y territorial y de la protección del medio ambiente" (PAREJO, 2017: 2).
\end{abstract}

De modo que, el hecho en sí de urbanizar por urbanizar, no será lo que articule el desarrollo urbanístico del suelo, sino que también se ha de "considerar que existe una contraparte (las áreas no urbanizadas) imprescindible para que el conjunto funcione armónicamente" (FARIÑA, 2007: 300).

En cuanto al objeto del trabajo, se dispone la obligación de dotarse de reservas de suelos suficientes, que permitan la edificación de viviendas de protección oficial. Finalidad que enlaza con el principio programático contemplado en el artículo 47 de la CE, sobre acceso a la vivienda de forma digna, que además lo ha de ser de forma adecuada y universal.

\subsection{Aspectos destacados de la LS}

La LS incide en la necesidad de sentar las bases para que las regiones y municipios, dentro del marco de sus competencias, planifiquen y 
desarrollen un urbanismo sostenible ${ }^{17}$. Un urbanismo respetuoso con el medio ambiente y que facilite el acceso a una vivienda digna por parte de sus ciudadanos (que además tendría que serlo adecuada, asequible e inteligente $)^{18}$. Lo que hace que la LS suponga un "reencuentro entre las políticas de suelo y las de vivienda, dando cumplimiento cabal —hasta donde alcanza la competencia legislativa del Estado- al mandato del artículo 47 de la Constitución" (VAQUER, 2007: 256).

De manera que, para poder ofrecer viviendas, los municipios han de procurar dotarse de las reservas de suelo necesaria ${ }^{19}$ y proveerse de patrimonio público suficiente ${ }^{20}$, pues sin suelo, sin patrimonio, difícilmente los municipios pueden tener margen de actuación para promover un parque de vivienda adecuada, con un porcentaje garantizado de vivienda protegida en régimen de alquiler o de propiedad. Motivo por el cual, la LS establece la prohibición de la especulación y la obligación de fijar reservas de suelo para vivienda de protección oficial, que permita establecer un precio máximo en venta y alquiler en el acceso a la vivienda, hasta el $30 \%$ de la edificabilidad residencial (que debe ser fijado por las CCAA) ${ }^{21}$.

Es decir, trata de intervenir en el mercado de la vivienda, de manera que con ello se pretende que la administración pública adquiera las reservas de suelo necesarias para edificar viviendas de especial protección, o para desarrollar proyectos urbanísticos sostenibles de interés para la ciudadanía (Aviñó, 2015:62-79), en cumplimiento de los objetivos previstos en los planes territoriales y urbanísticos. Tarea de planificación territorial y urbanística que es una de las materias donde las administraciones competentes tienen una mayor discrecionalidad ${ }^{22}$, definiendo modelo de ciudad, objetivos a cumplir y medios a emplear (MORENO, 2014: 123-170).

Hay que decir que, la adquisición de patrimonio municipal de suelos (PMS), tienen la consideración de "activos", formando parte de un "fondo común”, de manera que cada actuación sobre cada elemento conformante del todo debe de retroalimentar al todo, es decir, los ingresos que se obtengan han de destinarse a mantener, conservar o incrementar el PMS existente (GARcía DíAZ, 2008: 101-112), por lo que no puede destinarse

\footnotetext{
${ }_{17}^{17}$ Véase art. 2, párrafo segundo de la LS.

${ }^{18}$ Art. 4 de la LS.

${ }^{19}$ Art. 10 de la LS.

${ }^{20}$ Art. 33 y 34 de la LS.

${ }^{21}$ Art. 10 de la LS.

22 Sobre dicha discrecionalidad, véase la sentencia del TS
}

para otros fines distintos al de la propia conservación o incremento del mismo (CANDELA, 2013: 7-26 $)^{23}$. En consecuencia, es muy necesario establecer un control exhaustivo del patrimonio público del suelo existente y de la contabilidad resultante de su gestión, bajo el principio de unidad de caja, donde los ingresos y los gastos deben estar en una única instancia (DíAz, 2008: 236-243).

Por último, a los fines de garantizar el acceso a una vivienda, la LS establece la obligación de que el suelo público se deba destinar a la construcción de vivienda pública protegida o, en su caso, a otros destinos de interés social, ya sean urbanísticos, de protección o mejora de los espacios naturales y de los bienes conformantes del patrimonio cultural. Tan es así que, en caso de que la administración titular no concluya las actuaciones urbanísticas planeadas por causa imputable a la misma, la administración regional podrá tomar las medidas cautelares que se estimen oportunas ${ }^{24}$.

\section{Avances introducidos a través del Real Decreto Legislativo 2/2008, de 20 de junio, por el que se aprueba el texto refundido de la Ley de suelo (TRLS)}

EI TRLS consiste en la refundición de la LS con los preceptos aún vigentes del Real Decreto Legislativo 1/1992, de 26 de junio, que aprobó el texto refundido de la Ley sobre régimen del suelo y ordenación urbana, que se considera un texto muy intervencionista (FERNÁNDEZ DE GATTA, 2009: 132-178). Dicha compilación se produce para evitar la dispersión normativa de materias intrínsecamente relacionadas, regularizar y armonizar conceptos, así como estructurar y ordenar en un único texto normativo todos los contenidos sobre la materia, adaptados a las competencias urbanísticas un poco más definidas, tras los distintos pronunciamientos del $\mathrm{TC}^{25}$.

EI TRLS desarrolla la función pública en la tarea de ordenar el territorio y su desarrollo urbanístico de forma sostenible, donde prima el interés general. De manera que el artículo tres, párrafo primero, dispone: 
"La ordenación territorial y la urbanística son funciones públicas no susceptibles de transacción que organizan y definen el uso del territorio y del suelo de acuerdo con el interés general, determinando las facultades y deberes del derecho de propiedad del suelo conforme al destino de este".

Respecto a la LS, el TRLS incorpora la necesidad de que los poderes públicos promuevan la consecución de un medio ambiente urbano adecuado, con un uso eficiente del suelo que se ocupe, que permita una movilidad adecuada, la accesibilidad universal, un uso eficiente de los recursos y de la energía, así como promover actuaciones de prevención, para reducir los impactos negativos de los residuos urbanos y la contaminación acústica ${ }^{26}$.

Entre otras novedades, introduce el deber de la propiedad de acometer las obras necesarias a instancia de los poderes públicos, para la mejora de la calidad y la sostenibilidad del medio urbano ${ }^{27}$. Consistiendo el resto en un esfuerzo normativo por detallar las restantes obligaciones de conservación en los suelos en sus distintas situaciones.

En lo referente a los criterios básicos de utilización del suelo, si bien se mantiene el límite mínimo de un $30 \%$ de reserva de los suelos destinados a uso residencial u otros usos productivos, lo cierto es que introduce una nueva reserva del $10 \%$ para los supuestos de suelos urbanizados que vayan a ser sometidos a un proceso de renovación o reforma urbanísticas.

Pero más llamativo es que recoge, de forma expresa (novedad respecto a la redacción previa), la posibilidad de eximir las mencionadas reservas en supuestos excepcionales, siempre que se garanticen las reservas previstas en el ámbito territorial de referencia para dichas actuaciones urbanísticas y las pertinentes reservas establecidas.

Para concluir con este apartado, señalar que esta norma nos parece aún muy laxa e insuficiente, como garante normativo desde una perspectiva estatal, para que el acceso a una vivienda digna, accesible y adecuada sea factible y una realidad para todos los ciudadanos de este país.

\footnotetext{
${ }^{26}$ Art 2.3 de la TRLS.

${ }^{27}$ Se constata la influencia que juega la UE en materia de desarrollo sostenible en el medio ambiente urbano, al observar como, por ejemplo, el 02 de mayo de 2007 (justo dieciséis días antes de la publicación definitiva de la LS) se firmó la Carta de Leipzig (firmada por los ministros europeos con competencias en la materia) sobre "Ciudades Europeas Sostenibles", cuyo contenido tiene una decidida finalidad de influencia en el desarrollo del urbanismo de
}

\section{Real Decreto Legislativo 7/2015, de 30 de octubre, por el que se aprueba el texto refundido de la Ley de suelo y rehabilitación urbana (TRLSRU)}

EI TRLSRU recoge los contenidos del TRLS y los de la Ley $8 / 2013$, de 26 de junio, de rehabilitación, regeneración y renovación urbanas (LRRR). Deroga parte del contenido de la LRRR con el presente texto refundido 28 "en la medida en que se refieran a alguno de los preceptos que la presente disposición deroga"29.

Pensemos que la LRRR supuso un avance incuestionable hacia el desarrollo de un urbanismo sostenible (QUINTANA, 2016: 15-64), tanto desde la perspectiva de la mera recuperación de edificios ("rehabilitación edificatoria"), como desde las actuaciones más complejas que suponen recuperar, rehabilitar, transformar barrios enteros, lo que se conoce como "regeneración y renovación urbanas". Y es que, no podemos olvidar que en España existen un gran número de edificaciones y barrios degradados, donde se aconseja su rehabilitación o renovación y la necesidad de acudir a otras formas de financiación, máxime al observarse la existencia de un enorme stock de viviendas aún vacías que deben de ocuparse (DE LA CRUZ, 2014: 29-40). Actuaciones que han de suponer una mejora de la calidad de las infraestructuras urbanas (públicas y privadas), así como de reconfigurar el paisaje urbano hacia uno más bello y amable con perspectiva global, de conjunto, para disfrute de sus ciudadanos (MoYA, 2014: 75-79).

Por tanto, la finalidad del presente texto es facilitar la tarea de los operadores jurídicos, al concentrar y simplificar en una norma toda la regulación estatal que afecta a la ordenación del territorio y el urbanismo de las regiones españolas.

Recordemos que venimos de una tradición urbanística centrada en un urbanismo expansivo, sin prestar atención de forma sistemática al mantenimiento, rehabilitación y recuperación de las zonas urbanas ya existentes. Por lo que se constatan graves problemas estructurales en nuestro país. Pero dicha tradición se rompe, de manera

nuestras ciudades y, por ende, impregna la legislación sobre la materia.

${ }^{28}$ La LRRR sigue vigente. Sitúa al "Informe de Evaluación de los Edificios" y las actuaciones sobre el medio urbano como ejes centrales de su articulado.

29 Deroga los artículos uno al diecinueve, las disposiciones adicionales primera a la cuarta, las transitorias primera y segunda y las finales duodécima, decimoctava, decimonovena y vigésima de la LRRR. 
que, en un informe para la Comisión Europea, se ha valorado positivamente los esfuerzos de nuestro país (DEL CASTILLO, 2013:83):

\begin{abstract}
"se quiere destacar el esfuerzo por el desarrollo urbano sostenible que se ha puesto y se está poniendo por parte de entidades locales, regionales y nacionales españolas, especialmente mediante los proyectos URBAN y URBANA. Se estima que España ha sabido responder bien a la oportunidad que han brindado las iniciativas comunitarias URBAN y los fondos europeos de cohesión, especialmente el FEDER, en apoyo del desarrollo urbano sostenible, más aún si se tiene en cuenta que no existe tanta tradición por el desarrollo urbano integrado como en otros países".
\end{abstract}

No obstante, hay una falta de enfoque global, completo, integrado y sostenible de nuestro urbanismo, que está excesivamente "fragmentado" (Del CAstillo, 2013:84):

"Sin embargo, se ha visto que muchos municipios y sus políticos no aplican del todo los principios del desarrollo urbano integrado y sostenible. Esto se debe, en gran medida, al contexto del sistema español en cuanto al desarrollo urbano sostenible que afecta también al nivel local. Ahí se consideran factores importantes que influyen negativamente como son: la falta de tradición de enfoques integrados para el desarrollo urbano en las políticas nacionales y regionales, la falta de profesionales familiarizados y educados para el desarrollo urbano integrado, así como la complejidad de los retos que actualmente se presentan a las ciudades. Muchos de estos factores se deben a la falta de una visión completa de lo que se quiere lograr con el desarrollo urbano. La visión actual está considerablemente fragmentada y separada en políticas sectoriales de desarrollo urbanístico, desarrollo económico local, desarrollo local ambiental, etc."

Sea como fuere, la LRRR (junto con el Plan Estatal 2013-2016 de fomento de alquiler, la rehabilitación y los fondos FEDER), han reforzado los esfuerzos y el impacto positivo de las actuaciones urbanísticas para dicho fin, a pesar de la crisis económica, dotando de recursos suficientes para la tarea de rehabilitación, regeneración y renovación de las edificaciones y los barrios o zonas urbanas degradadas de nuestro país, sin perder de vista la mejora de la eficiencia energética (tanto en los procesos como en los materiales empleados y edificaciones resultantes).

Por consiguiente, si bien se observa que, tanto el desarrollo normativo como las herramientas financieras disponibles para su efectiva aplicación, han sido guiados en todo momento por los principios de un urbanismo sostenible y eficiente desde el punto de vista energético y de su impacto en el medio ambiente urbano, garantizando el derecho a la ciudad para sus usuarios e incluyendo procedimientos de mayor transparencia (TORRES, 2016: 6-13), aun así, resultan insuficientes.

Pues bien, pasando al análisis del texto que ahora nos ocupa, prestamos atención a las modificaciones y adiciones más relevantes respecto al TRLS y la LRRR, en los temas de nuestro interés.

El título preliminar acoge como principio fundamental el derecho de los ciudadanos a tener una vivienda digna y adecuada, así como a disfrutar de una calidad de vida mínima. De manera que el desarrollo urbano ha de ejecutarse de forma sostenible, competitivo y eficiente, impregnando todas las actuaciones que conlleven a una rehabilitación de las edificaciones o a una regeneración o renovación de las urbes existentes.

Se definen varios conceptos de interés en la norma, de los cuales destacamos el de "actuaciones sobre el medio urbano", conceptualizado como obras de rehabilitación, regeneración y renovación, incluyendo las de sustitución, y suponiendo actuaciones integradas con impacto social, económico y ambiental. Otro interesante es el de "infravivienda", referido a las viviendas donde no se cumplan requisitos de superficie, dotaciones básicas, seguridad, habitabilidad y accesibilidad mínimos conforme ley.

Se incide en conceptos como son los de acceso universal de los ciudadanos, que implica que cualquier individuo, con independencia de la edad o deficiencia física que tenga, pueda acceder a su vivienda sin obstáculos que se lo impidan, incluso facilitando su acceso. Siendo que, a modo de ejemplo, en caso de que cualquier propietario de una comunidad de vecinos lo solicite, la comunidad de propietarios viene obligada a remover cualquier obstáculo existente y a habilitar los servicios necesarios para que cualquier persona mayor o con problemas físicos pueda acceder a su vivienda (instalando ascensores o elevadores mecánicos, etc.).

Son también objetivos la movilidad en coste y tiempo razonable, la implementación de medidas para la protección de la atmósfera (reducir polución del aire en nuestras ciudades es una prioridad), preferencia por las energías renovables (buscando la eficiencia y ahorro energéticos), la "perspectiva turística" en todas las actuaciones con impacto sobre el territorio, el uso racional del agua o fijar un mayor protagonismo sobre el patrimonio histórico y/o cultural.

Sobre los deberes y cargas del derecho de propiedad del suelo, es importante destacar la consolidación de la potestad de la administración 
pública, en los casos de "inejecución injustificada de las obras ordenadas", para su realización de forma subsidiaria. Supuesto que, entre otras zonas, se necesita activar en la Costa del Sol occidental, con decenas de urbanizaciones y unidades de ejecución inacabadas, mal conservadas, paralizadas o degradadas, lo que genera multitud de problemas en las infraestructuras ya existentes y en los pequeños propietarios que, en dichas áreas, tienen su vivienda o que se ven impedidos para acceder a una.

Continuando con el Título II, destacamos el énfasis que se hace en la necesidad de evaluar y someter a un control la viabilidad técnica y financiera de los proyectos urbanísticos, así como su sostenibilidad desde el punto de vista del medio ambiente.

En cuanto a la evaluación y seguimiento de la sostenibilidad del desarrollo urbano, y garantía de la viabilidad técnica y económica de las actuaciones sobre el medio ambiente, se incluye un nuevo epígrafe, del cual posteriormente se declaran nulos por el TC algunas partes del mis$\mathrm{mo}^{30}$. Dicho epígrafe versa sobre la exigencia de una memoria sobre la viabilidad económica ${ }^{31}$, que pone en valor la inversión necesaria y la atención de la conservación debida, así como armoniza las cargas y los beneficios.

Tan es así, que incluso afecta al contenido de la Ley de contratos de $2017^{32}$. De manera que la administración pública pasa de ser un mero agente contratante a un agente ordenador, a través del propio proceso de contratación. Introduce en las mesas de contratación criterios ambientales con un alto valor, para que los candidatos, al licitar por cualquier servicio prestado a la administración pública, adapten sus propuestas para cumplir con los parámetros de sostenibilidad económica y ambiental establecidos. Y ello es aún mayor si nos encontramos con procesos de adjudicación para ejecutar obras con impacto en el medio ambiente, ya sea urbano, ya sea rural. Siendo la variable ambiental un coste económico a valorar (SANZ, 2018:49-80).

Por otra parte, se otorga a las autonomías la potestad de regular los supuestos que transcienda el interés local, y deba de ejercerse la potestad de

\footnotetext{
30 Sentencia del TC 143/2017, de 14 de diciembre. Se declaran nulos los incisos a), b), c), d) y e) del artículo 22.5 en el presente texto de TRLSRU.

${ }^{31}$ Véase artículo 11 de la LRRR, donde se recoge una descripción exhaustiva de lo que debe de contener una "memoria de viabilidad económica", en las actuaciones sobre el medio urbano.

${ }^{32}$ Ley $9 / 2017$, de 8 de noviembre, de contratos del sector público, por la que se transponen al ordenamiento jurídico
}

ordenación por el ámbito territorial superior. Así, el artículo veintidós, párrafo siete del TRLSRU, preceptúa:

\begin{abstract}
"La legislación sobre ordenación territorial y urbanística establecerá en qué casos el impacto de una actuación de urbanización obliga a ejercer de forma plena la potestad de ordenación del municipio o del ámbito territorial superior en que se integre, por trascender del concreto ámbito de la actuación los efectos significativos que genera la misma en el medio ambiente".
\end{abstract}

EI TRLSRU introduce así mismo reglas específicas de las actuaciones sobre el medio urbano ${ }^{33}$, con un especial protagonismo de las actuaciones que impliquen una mejora de la accesibilidad universal y de la eficiencia energética, pudiendo ocupar cualquier tipo de superficie, incluso de dominio público, si para ello no existe otra solución técnica y está debidamente justificada la actuación (para instalar ascensores u otros dispositivos que garanticen la accesibilidad universal). En cuanto a la eficiencia energética, promueve medidas concretas como las de reducir un $30 \%$ el consumo energético o de agua en los edificios, a través de los distintos sistemas existentes.

Otro aspecto destacado es la regulación del nuevo "Informe de Evaluación de los Edificios", siendo testimonial su contenido al constar de un solo artículo, con un solo epígrafe, al ser anulado el resto por la sentencia del TC 143/2017, de 14 de diciembre ${ }^{34}$. No obstante, la regulación detallada para la exigencia y trámites en la elaboración de los Informes de Evaluación de los Edificios, se encuentra en la $\operatorname{LRRR}^{35}$. De manera que la administración podrá requerir, a los propietarios, que confeccionen dichos informes en edificios con una antigüedad superior a 50 años (plazo en el que se presupone que la estructura del edificio puede presentar riesgos sobre las personas), siendo la validez de dichos informes por período máximo de 10 años, que podría ser menor según legislación regional. Dichos documentos elaborados por técnicos especialistas en la materia, han de informar acerca del estado de conservación de los edificios, la accesibilidad universal, la eficiencia energética y su adecuación a la normativa vigente, e inscribirse en un registro autonómico

español las Directivas del Parlamento Europeo y del Consejo 2014/23/UE y 2014/24/UE, de 26 de febrero de 2014.

${ }^{33}$ Art. 24 TRLSRU

${ }^{34}$ Anula apartados 2 al 6 del artículo 29, así como el artículo 30 , sobre capacitación para suscribir el Informe de Evaluación de los Edificios.

${ }^{35}$ Art. 4 al 6 de la Ley 8/2013, de 26 de junio, de rehabilitación, regeneración y renovación urbanas. 
creado al efecto ${ }^{36}$. Estas medidas, si su control fuera efectivo, incidirían en las tan necesarias obras de rehabilitación en los edificios, a los efectos de que las viviendas cumplan su objetivo de resultar dignas y adecuadas para sus moradores.

Pasando al análisis del Título IV, trata las relaciones inter e intra administrativas, sobre la base de la coordinación y la colaboración. Llama la atención inicialmente por no ser un tema tratado con anterioridad en el TRLS de forma tan concreta y extensa, de manera que dedica tres artículos para dichas cuestiones. No obstante, la LRRR ${ }^{37}$ le dedica cinco artículos con una descripción más exhaustiva que la que hace el TRLSRU, y por tanto con plena vigencia, salvo en la parte declarada nula por la sentencia del TC 143/2017, de 14 de diciembre y en lo no coincidente con lo dispuesto en el TRLSRU.

En este apartado, el TRLSRU resalta la posibilidad de participación de la Administración General del Estado, beneficiándose económicamente otras administraciones de la colaboración y cooperación con la misma. Esto será así siempre y cuando esté previsto en los planes estatales, sea destinado a actuaciones de rehabilitación de edificios, o regeneración/ renovación de zonas urbanas degradadas, o limiten el problema de la infravivienda.

Así mismo, establece la promoción conjunta de las administraciones para la cohesión económica, social y territorial, desde un punto de vista de sostenibilidad ambiental. Para lo cual, concreta la vía de la firma de "Convenios interadministrativos de asignación de fondos", que tienen naturaleza administrativa, sometidas a la jurisdicción de lo contencioso administrativo. En este punto, recordemos que las relaciones interadministrativas se pueden entender como las conexiones con efectos jurídicos establecidos entre distintas administraciones públicas, ya sea directa, o indirectamente a través de "sociedades instrumentales", a los efectos de conseguir fines debidamente justificados, desde un punto de vista competencial y en términos de eficiencia (GALLARDO, 2016).

Con respecto a las disposiciones, la adicional primera concreta la necesidad de confeccionar censos con las construcciones desocupadas y las

\footnotetext{
${ }^{36}$ Art. 4 de la LRRR.

${ }^{37}$ Art. 15 al 19 de la LRRR.

${ }^{38}$ Resulta interesante la sentencia del TC 109/2017, de 21 de septiembre, que recoge como la cooperación entre administraciones, en un país como España conformado por comunidades autonómicas, con competencias propias y coincidentes en el mismo espacio, es un principio implícito que ha de informar el buen funcionamiento, el buen gobierno de las administraciones,
}

que necesiten mejora o rehabilitación. Se han de elaborar mapas de las áreas urbanas degradadas con necesidad de promover actuaciones urbanísticas de rehabilitación, regeneración y mejora. Y se ha de crear un "sistema público general e integrado de información sobre suelo y urbanismo" que permita a los ciudadanos acceder a la información por medios telemáticos. Y todo ello, tratando que los sistemas de información de las distintas administraciones sean compatibles entre sí, la central con las competentes, y con el catastro. Por lo que entendemos que, en dicha tarea, la Administración General del Estado ha de actuar como agente coordinador e impulsor de dichas actuaciones con un papel activo y propositivo.

En definitiva, se observa claramente un avance en la normativa del TRLSRU, como una apuesta decidida por el desarrollo de un urbanismo sostenible, una mejora de las condiciones de las edificaciones existentes y la promoción del acceso a una vivienda digna, adecuada y accesible de forma universal. No obstante, entendemos que la norma necesitaría de una mayor concreción. Por lo que, a continuación, haremos algunas propuestas de mejora.

\section{Conclusiones}

Las conclusiones que a continuación se exponen tienen un alto componente social, orientadas a posibilitar la efectiva accesibilidad a una vivienda digna y adecuada, que ha de ser entendida como un servicio de interés general de obligado cumplimiento, más allá de su consideración como un mero principio programático de obligación de medios (PONCE, 2011). Igualmente, se incide en la necesidad de velar por un efectivo cumplimiento de las normas de nuestro ordenamiento urbanístico, así como mejorar la relación entre administraciones mediante figuras como la de los consorcios (Toscano, 2016) ${ }^{38}$, lo que reforzaría el efectivo desarrollo de un urbanismo sostenible. De manera que, las políticas y el desarrollo normativo en materia de vivienda, no se pueden entender ni ser efectivas sin una mayor coordinación e interrelación con las políticas y desarrollo normativo en materia de urbanismo, concretando las bases

de manera que "dependen en buena medida de la estricta sujeción de uno y otras a las fórmulas racionales de cooperación, consulta, participación, coordinación, concertación o acuerdo previstos en la Constitución, y en los Estatutos de Autonomía", y todo ello bajo el principio general de "lealtad institucional" (por ejemplo, sentencia del TC 215/2014), que se positiviza a través de la Ley 40/2015, de 01 de octubre, de régimen jurídico del sector público, en su artículo 3.1.e. 
estatales y aclarando el margen de maniobra de las CCAA.

Por todo ello, entendemos necesario reflexionar y ahondar sobre las siguientes consideraciones:

\subsection{Mejorar la cooperación y coordinación entre administraciones}

Recordemos lo que establece el TRLSRU, que invita a pensar e interpretar que, en espacios donde confluyen varios municipios con necesidades y problemas comunes (como por ejemplo conurbación de la Costa del Sol occidental de la provincia de Málaga), toda actuación urbanística debería de ser gestionada por un órgano supramunicipal (ya sea a través de la Mancomunidad de municipios de la Costa del Sol occidental, ya sea a través de diputación provincial de Málaga -en el ejemplo propuesto-). De manera que las actuaciones urbanísticas han de acometerse teniendo a cada municipio como parte de un todo mayor, para mejorar así mismo la eficiencia y la eficacia desde una perspectiva holística, integrada, inteligente y sostenible (piénsese en la zona conurbada de la Costa del Sol occidental $-100 \mathrm{~km}$ de urbanismo desarrollado sin claridad en los límites municipales-, donde la propia norma andaluza prevé expresamente la posibilidad de constituir un consorcio urbanístico ${ }^{39}$.

Sobre lo anterior, un estudio detecta en la Península Ibérica 273 áreas urbanas funcionales (en su mayoría situadas en España), como son los ejes Málaga-Marbella, Sevilla-Dos Hermanas, Ría de Bilbao, Asturias Central, Vigo-Pontevedra, Bahía de Cádiz-Jerez de la Frontera, Murcia, Alicante-Elche, etc. (Gómez \& al., 2020: 93-128). Son economías urbanas circulares, áreas con intereses económicos, ambientales, urbanísticos y sociales comunes que, sin embargo, se ven limitados por las divisiones administrativas, impidiendo su desarrollo pleno desde un punto de vista global, integrado, inteligente y sostenible, bajo los principios de eficiencia y eficacia. Por consiguiente,

\footnotetext{
${ }^{39}$ No olvidemos que la Costa del Sol occidental contaba con un Plan de Ordenación del Territorio específico para la Costa del Sol occidental aprobado por Decreto el 18 de julio de 2006, que fue declarado nulo por sentencia del TS el 06 de octubre de 2010. Por lo que es lógico que, si hay un plan común para los municipios de la Costa del Sol occidental debiera de existir más colaboración y coordinación en el urbanismo de dichos municipios, por ejemplo, a través de un consorcio urbanístico en la Costa del Sol occidental. Véase, para el caso de Andalucía, artículo 93 de la Ley 7/2002, de
}

"el sistema de planificación, gestión y gobernanza integral de las áreas urbanas, que funcionan como mercados inmobiliarios y laborales diferenciados e internamente coherentes, debe implementarse de manera más activa" (Gómez, 2020:118).

Para lo cual sería necesario promover, aumentar y mejorar la coordinación y cooperación entre administraciones creando consorcios urbanísticos e incluso, por qué no, impulsar reformas desde un plano territorial que recoja la nueva realidad de nuestras ciudades, que elimine las posibles trabas entre administraciones para que dicha unión o mejor relación entre ciudades y administraciones sea lo más eficaz posible.

Respecto al tema de los consorcios, no debemos olvidar el éxito que han supuesto los mismos en materias como la recogida y gestión de residuos urbanos, transporte, bomberos o abastecimiento y saneamiento de aguas, teniendo experiencias como la de los consorcios urbanísticos de la CCAA de Madrid. Por lo que establecer

"una red consorcial, debidamente coordinada, con participación de los usuarios, pueda ser una vía a explorar ante la ciudad como fenómeno metropolitano" (Tolivar, 2020).

Igualmente, mejorar la coordinación y cooperación entre administraciones, posibilita presentar proyectos más atractivos y solventes desde un punto de vista técnico y financiero, para ser perceptor de fondos europeos mediante el desarrollo de prácticas urbanas más sostenibles (ORTEGA, 2018b: 42-85) $)^{40}$, como son las "Estrategias de Desarrollo Urbano Sostenible e Integrado" (EDUSI), que podrían aprovechase así mismo para captar fondos destinados a proyectos de viviendas sostenibles, inteligentes y asequibles económicamente, para su acceso por jóvenes, desempleados, jubilados u otros colectivos vulnerables. Sin olvidar, no obstante, la necesidad de regular mejor el marco jurídico básico en materia de urbanismo y vivienda, que ha de relacionarse de forma coordinada, concretando mejor el margen de actuación de las CCAA en ambas materias intrínsecamente relacionadas.

17 de diciembre, de ordenación urbanística de Andalucía (LOUA), sobre consorcios urbanísticos.

${ }^{40}$ Es palpable el impacto positivo que los fondos EDUSI han supuesto en el urbanismo de ciudades malagueñas como Estepona, Marbella, Cártama o Málaga capital (por citar algunas), que han sido todas beneficiarias de inyecciones de capital entre 10 y 15 millones euros cada una, por proyectos urbanísticos sostenibles (mejorando la calidad de vida de sus ciudadanos y el atractivo turístico de dichas zonas urbanas), como el proyecto "EDUSI Estepona- El jardín de la Costa del Sol". 


\subsection{Aumentar el control administrativo y jurisdiccional del desarrollo urbanístico}

Es preciso aumentar y mejorar los controles sobre las autoridades locales. Que las mismas cumplan los fines, objetivos y obligaciones del TRLSRU, las leyes estatales sectoriales afectantes al urbanismo (sobre todo en materia de medio ambiente), las normas autonómicas y los instrumentos de planificación y desarrollo urbanísticos existentes.

Igualmente, se han de establecer mecanismos de intervención directa y rápida que eviten que la inactividad administrativa local genere perjuicios sobre el territorio y la ciudadanía, difícilmente recuperables por la lentitud de los procesos y la posible negligencia o mala fe de las autoridades locales de que se trate en cada momento. Perjuicios que, en algunos casos, obligan a las administraciones públicas a asimilar multitud de irregularidades urbanísticas (normalizando legislativamente lo que debiera de ser sancionable administrativamente y, en ocasiones, incluso penalmente).

Pensemos en la resolución del Parlamento Europeo sobre la base del Informe Auken de 2009, que pone de manifiesto el grave perjuicio causado sobre los derechos individuales de los ciudadanos y el medio ambiente en nuestro país, como consecuencia de las prácticas urbanísticas abusivas y contra norma (SÁNCHEZ, 2009b: 9-38). Prueba de lo anterior, es la corrupción urbanística de Marbella, tolerada durante años, que supuso incluso la intervención del gobierno local mediante una gestora (SÁNCHEZ, 2009a: 173-206) ${ }^{41}$.

Por consiguiente, sin un efectivo control sobre nuestro urbanismo, que garantice un número adecuado de viviendas de protección oficial, se nos antoja difícil pensar en un urbanismo sostenible que permita la consecución, entre otros objetivos, del derecho de acceso a una vivienda digna, adecuada, accesible e inteligente por parte de toda la ciudadanía. Por lo que deben de incrementar los recursos humanos y técnicos para este fin.

\footnotetext{
${ }^{41}$ Resulta de interés la aprobación en Andalucía del Decreto-ley $3 / 2019$, de 24 de septiembre, de medidas urgentes para la adecuación ambiental y territorial de las edificaciones irregulares en Andalucía, como reacción a la más que manifiesta ausencia de procesos efectivos garantistas de la legalidad, que ha ocasionado la presencia de alrededor de
}

\subsection{Blindar reserva de suelos para viviendas de protección oficial}

Consideramos necesario blindar el porcentaje mínimo de reserva de suelos para viviendas sociales sobre la edificación concedida al mínimo del $30 \%$, sin establecer coletilla alguna que permita a las autoridades locales reducir el porcentaje efectivo, que impida el cumplimiento real del artículo 47 de la CE.

La salvedad existente en la norma es muy arbitraria, por lo que no se debe seguir sosteniendo ${ }^{42}$. Es decir, la posibilidad de eximir la reserva en supuestos excepcionales es una puerta abierta para que, en términos generales, no se respete una reserva mínima de suelo para la construcción de viviendas de protección social. Problema que se une al breve periodo establecido para la descalificación de vivienda protegida (según comunidad), que da pie a su incorporación al mercado en determinados supuestos y a que se pueda especular con viviendas de protección oficial, cuestión que, a nivel andaluz, entendemos igualmente a revisar y blindar.

Como ejemplo de lo anterior, véase Decreto 149/2006, de 25 de julio, modificado por el Decreto $161 / 2018$, de 28 de agosto, por el que se aprueba el Reglamento de viviendas protegidas de la Comunidad Autónoma de Andalucía y se desarrollan determinadas disposiciones de la Ley $13 / 2005$, de 11 de noviembre, de medidas en materia de vivienda protegida y el suelo. La cual prevé la descalificación de viviendas protegidas que hubieran estado ocupadas de forma efectiva por sus propietarios durante 5 años, o hayan pasado 10 años desde la calificación definitiva y no concurra en supuestos sobre suelos donde no es posible la descalificación (no pudiendo perjudicar a terceros en ningún caso).

Por tanto, no se pueden permitir condiciones tan laxas que den lugar a la pérdida de vivienda protegida, su incorporación al mercado de la vivienda y estar sometida al juego de la especulación, rompiendo con su finalidad social originaria (estar en manos de propietarios con escasos recursos económicos). Pues ello dificulta el acceso efectivo a una vivienda digna y adecuada por parte de los ciudadanos con menos recursos.

500.000 edificaciones en suelo no urbanizable, siendo unas 300.000 de carácter irregular. La mera lectura de la exposición de motivos son un clamor al descontrol y a los abusos urbanísticos y contra el territorio que se han cometido ante la pasividad de las administraciones públicas.

${ }^{42}$ Art. 20.1.b) del TRLSRU. 


\subsection{Promover otros modelos o tipos intermedios de tenencias de viviendas}

Encontramos otros modelos o tipos intermedios de tenencia de vivienda como son la propiedad compartida, la temporal o la colaborativa, que han de ser impulsadas de forma más decidida por parte de los poderes públicos, tanto desde un plano normativo, como presupuestario.

Las viviendas colaborativas ("cohousing") ${ }^{43}$, son modelos de vivienda a través de cooperativas, muy extendidas en Estados Unidos o los países nórdicos, con implementación cada vez más fuerte en áreas de nuestro país como Barcelona, y que podría ser una solución bastante económica para las rentas más bajas (jóvenes, desempleados de larga duración, madres solteras, jubilados, etc.).

Por su parte, la propiedad compartida consistiría en el supuesto donde el propietario adquiere un porcentaje en concepto de dueño y por el resto paga una renta (pudiendo incluso adquirir progresivamente un mayor porcentaje del dominio). Mientras que la propiedad temporal consistiría en la adquisición de la vivienda durante un número determinado de años. De manera que se presentan como dos figuras que pueden sustituir a la del titular en pleno dominio (NASARRE, 2014). Máxime cuando se está comprobando que la adquisición del pleno dominio del $100 \%$ de las viviendas es algo que ya sólo está al alcance de la clase media alta y alta, viéndose impedidos cada vez una proporción más amplia del sector de la clase trabajadora. Pues tener trabajo, tener un sueldo, ya no garantiza el acceso a una vivienda digna y adecuada.

Pagar por adquirir el pleno dominio de una propiedad, por ejemplo, en un $30 \%$ de la vivienda, complementado con el abono de una renta mensual por el resto del porcentaje de la vivienda, podría ser una solución. Ello supondría que, si una vivienda costase en el mercado 150.000 $€$, el adquirente sólo necesitaría desembolsar $45.000,00 €$ (más impuestos) para ser titular, y luego pagar una renta baja al titular por el restante porcentaje de la vivienda, conservando derecho de uso y disfrute en exclusiva mientras cumpla con sus obligaciones de pago de renta a perpetuidad. Los derechos de propietario frente a terceros (como comunidad de propietarios, pago de impuestos como el IBI, etc.), serían responsabilidad del adquirente, y sería traspasables a terceros inter vivos y mortis causa. Derecho a cobrar renta que también heredarían los sucesores del vendedor, o los terceros adquirentes por venta de dicho derecho de cobro en calidad de propietario del porcentaje de la nuda propiedad.

Por otra parte, habría que revisar el sistema hipotecario, a los efectos de que se facilite un nuevo modelo de tenencia y que, así mismo, posibilite la puesta a disposición de terrenos ya clasificados, no edificados y trabados como garantías hipotecarias.

\section{Pero para ello,}

"resulta indispensable reconsiderar la distribución constitucional de competencias. La actual fragmentación competencial, carente de un sustrato básico común, que establezca de forma efectiva los elementos comunes del modelo urbanístico español, no parece en exceso deseable ni operativa" (TEJEDOR, 2017: 476-477).

\subsection{Asegurar la construcción de viviendas dignas, asequibles, adecuadas e inteligentes}

La crisis del Covid-19 ha demostrado que es inhumano que, por ejemplo, una familia de nueve miembros (abuelos, hijos y nietos) habite una vivienda hacinados, con superficie y número de habitaciones insuficientes, sin terraza y sin ventanas con salida al exterior. Impidiéndose que dicha familia pueda vivir en unas condiciones dignas, incluso en supuestos de confinamiento por urgencia sanitaria, creando problemas de diversa índole (formación psicosocial de los menores, ansiedad, conflictos familiares, etc.).

Una sociedad formada por individuos estresados, deprimidos por no tener un espacio vital privado suficiente para dar rienda suelta a sus necesidades más personales, es un foco generador de conflictos, tanto en sus entornos privados como en la relación con sus vecinos y con la sociedad donde interactúan (más violencia en las casas y en las calles, inseguridad, revueltas sociales, etc.).

Sobre la conflictividad y el papel del urbanismo para su reducción, a través de actuaciones como

\footnotetext{
${ }^{43}$ Véase a modo de ejemplo guía publicada por "Cohousing Barcelona" en el siguiente enlace:
} 
son las de rehabilitar viviendas, generar un número suficiente de viviendas sociales o habilitar suficientes zonas públicas para el goce de la ciudadanía, han reflexionado mucho los autores americanos, que tantos problemas han tenido y siguen teniendo en sus ciudades. En este sentido, Parker introduce su teoría de la "urban experience", de manera que la experiencia urbana de sus moradores configura su comportamiento, siendo el acceso a la vivienda (tamaño, estado de conservación, etc.), y donde se viva (el lugar de ubicación de la vivienda en la ciudad) lo que configura luego en gran medida el carácter más o menos cívico e integrado de dichos ciudadanos (PARKER, 2004).

Por otra parte, en un mundo tan hiperconectado tecnológicamente como en el que vivimos, las casas y nuestro uso de las mismas deben ser también inteligentes con la ayuda de la implementación de las Tecnologías de Información y Comunicación (TIC), convirtiéndolas en más eficientes desde el punto de vista energético (véase concepto de casas pasivas $)^{44} \mathrm{e}$ inteligentes desde el punto de vista tecnológico, lo que se conoce como smart living. Concepto que, junto con los de smart governance, smart economy, smart mobility, smart environment y smart people, conforman el concepto global de smart city, como ciudad hiperconectada dentro de sí, pero también con otras ciudades del mundo, para estar al día de las necesidades de los ciudadanos y de las tendencias para su mejor satisfacción de forma eficiente y eficaz, gracias a las TIC (VILLAREJO, 2015).

En consecuencia, las casas deben ser eficientes y eficaces, tanto en términos de consumo energético como de satisfacción de las necesidades de sus moradores,

"integrando la tecnología en su configuración a través de la domótica, con adecuada conexión a internet y construida con materiales y de forma que permitan una mayor eficiencia y ahorro energéticos" (ORTEGA, 2020: 495-509).

Por lo que, el concepto de "smart living", es un concepto sobre el que nuestro ordenamiento jurídico ha de articular y promover, para que los poderes públicos y la iniciativa privada sean más proclives a su desarrollo, con cabida expresa en los planeamientos urbanos. De esta mane$\mathrm{ra}$, el acceso a una vivienda digna, asequible,

\footnotetext{
${ }^{44}$ El concepto de "Passivhaus" o casas pasivas (que busca el consumo energético en su mínimo exponente) es un concepto alemán muy presente en centro Europa y el mundo
}

adecuada e inteligente, por parte de cualquier ciudadano, podría ser una realidad más cercana.

\subsection{Concretar el Derecho subjetivo de acceso a la vivienda}

La infrafinanciación en materia de políticas de viviendas en España es una realidad incuestionable, de manera que la inversión en España, en relación al Producto Interior Bruto (PIB) es mucho menor de la mitad de lo que invierten de media los países de la UE (VAQUER, 2017:8384). Ese déficit de recursos supone una falta de suelos y de músculo financiero que posibilite la construcción o adquisición efectiva de viviendas protegidas para su puesta a disposición de personas en situación de vulnerabilidad o dificultad de acceder a viviendas en el mercado. Por tanto, aumentar los recursos o las reservas de suelo destinadas para viviendas de protección oficial, que es una decisión política, ha de ser un objetivo de los poderes públicos, para lo cual tienen que mejorar de forma más clara y garantista el articulado en los textos e instrumentos legales en materia de suelo, urbanismo y vivienda.

Así mismo, ha de garantizarse y reforzarse el derecho a reclamar en los juzgados, para que los poderes públicos remuevan los obstáculos y generen las condiciones y recursos necesarios queposibilite el acceso a la vivienda por parte de los ciudadanos más vulnerables. De manera que, todos los españoles, con independencia de su condición social o económica, deben tener garantizados su acceso a una vivienda digna y adecuada a sus circunstancias particulares, entendiéndose como un derecho subjetivo y universal. $Y$ en tal sentido (LÓPEZ, 2014: 49-91):

"la atribución a los individuos de poderes para la
defensa de sus derechos, susceptibles de tutela
judicial, constituye un mecanismo de extraordinario
significado. En todos los ámbitos de la vida social,
económica, política y cultural, el reconocimiento de
derechos subjetivos ha sido una vía eficaz de po-
tenciación de las finalidades de interés general. Lo
mismo cabría esperar en relación con la vivienda,
máxime si el correspondiente derecho subjeti-
vo gozara de preeminencia formal al encontrarse
establecido como derecho exigible en la misma
Constitución." (LóPEz, 2014: 56).

anglosajón (en países como EEUU). Para más información, se puede acudir a la página web del instituto alemán de casas pasivas, fundado en 1996: https://passiv.de/. 
"los planteamientos del autor son seguidos literalmente por J. Burón (BURÓN, 2011: 269-270), coincidiendo también con ellos, en cierta medida, otros autores, como el ya citado G. Pisarello (Pisarello, 2009: 51-52), que identifica un derecho subjetivo «habida cuenta de los desarrollos normativos» del artículo 47 de la Constitución, o L. Parejo Alfonso (PAREJO, 2012: 23) al sostener que el derecho constitucional a la vivienda «no pretende tanto reconocer una situación jurídica individualizada y dotada de acción ejercitable, cuanto definir una situación objetiva en que todos estén en condiciones de satisfacer la necesidad básica de refugio y habitación», de manera que «el derecho, si lo hay, es un derecho ciudadano a la acción de los poderes públicos que debe tener tal resultado»". (LÓPEZ, 2014: 58).

En definitiva, se ha de regular el derecho efectivo de acceso a la vivienda, vinculado a la planificación y al desarrollo urbanístico de forma más clara y decidida, que lo sitúe como un derecho subjetivo reclamable en los juzgados. Y con el mismo fin, los poderes públicos han de procurar movilizar recursos, garantizar la existencia de suelos y vivienda social suficientes, y bloquear la afección de protección social de dichas viviendas sine die, para que el contenido del artículo 47 de la CE pase de ser una ficción a una realidad, posibilitando que todos los ciudadanos de nuestro país tengan acceso a una vivienda digna, adecuada y accesible (y a poder ser inteligente).

\section{Bibliografía}

Agudo González, J. (2010): La intercambiabilidad del suelo urbanizable y no urbanizable. Revista Aragonesa de Administración Pública, $\mathrm{n}^{\circ} 36$ : 123-175.

Arias Martínez, M. A. (2019): Las competencias autonómicas en materia de vivienda frente a las competencias estatales de carácter transversal en la reciente jurisprudencia constitucional. Revista de Estudios de la Administración Local y Autonómica (REALA), Nueva Época, n 11: 106-121.

Aviñó Belenguer, D. (2015): La gestión sostenible del patrimonio público de suelo a través de la constitución de un derecho de superficie, Práctica urbanística: Revista mensual de urbanismo, $\mathrm{n}^{\circ}$ 134: 62-79.

Bandrés Sánchez-Cruzat, J. M. (2014): El derecho a la ciudad. Cuadernos de Derecho Local, $n^{\circ} 35$ : 97-103.

Beato Espejo, M. (1999): La administración del urbanismo tras la sentencia del Tribunal Constitucional 61/1997, de 20 de marzo, Anuario de la Facultad de Derecho, n 17: 17-48.
BRITTON, M. (2017): Global cities: The changing urban hierarchy, OXFORD ECONOMICS, december.

Candela Talavero, J. E. (2013): El patrimonio público del suelo y los entes locales. Revista CEMCI, $\mathrm{n}^{\circ}$ 18: 7-26.

DÁvilas LinAREs, J. M. (1991): La ordenación urbanística durante la primera mitad del siglo $X X$. Premisas para un tratamiento integral de los espacios urbanos, Investigaciones Geográficas, no 9: 101-114.

de La Cruz Mera, A. (2014): La Ley 8/2013, de 26 de junio, de rehabilitación, regeneración y renovación urbanas, Ciudad y Territorio: Estudios Territoriales, $\mathrm{n}^{\circ}$ 179: 29-40.

del Castillo, J. \& HaARich, S. N. (2013): Informe Final. Estudio sobre el Desarrollo Urbano Sostenible cofinanciado por el FEDER en España 20142020: Directrices Estratégicas y Prioridades de Inversión, INFYDE ID, Procedimiento Negociado $n^{\circ}$ 2012, CE, 160.AT.012.

Diaz Arroyo, A. (2008): La enajenación de bienes del patrimonio municipal de suelo y el principio de unidad de caja, Consultor de los ayuntamientos y de los juzgados: Revista Técnica Especializada en Administración Local y Justicia Municipal, n. ${ }^{\circ}$ 2: $236-243$.

FARIÑA TOJO, J. (2007): Las nuevas bases ambientales de la sostenibilidad en la ordenación y utilización del suelo, Ciudad Y Territorio Estudios Territoriales (CyTET), n 152-153, 291-300.

Fernández Carballal, A. (1997): El régimen jurídico. urbanístico en España tras la sentencia del Tribunal Constitucional 61/97 de 20 de marzo, Anuario da Facultade de Dereito da Universidade da Coruña, $\mathrm{n}^{\circ}$ 1: 577-588.

Fernández de Gatta Sánchez, D. (2009): El Texto Refundido de la Ley del Suelo de 20 de junio de 2008. En Martín Rebollo, L. (Coord.) \& Bustillo Bolado, R.O. (Coord.) Fundamentos de Derecho Urbanístico (pp. 132-178), España, 2a Ed. Thomson Reuters-Aranzadi.

Gallardo Romera, E. (2016): La nueva administración institucional en la Ley 40/2015, de 1 de octubre, de régimen jurídico del sector público, Actualidad Administrativa, $\mathrm{n}^{\circ} 10$.

García DíAz, G. (2008): La contabilización del patrimonio público del suelo de los ayuntamientos, Auditoría Pública, $\mathrm{n}^{\circ}$ 46: 101-112.

García URETA, A. (2019): Un comentario sobre la ley 9/2018, de reforma de la ley $21 / 2013$, de evaluación ambiental, Revista de Actualidad Jurídica Ambiental, $\mathrm{n}^{\circ} 87$.

Gómez Giménez, J. M., Vieira de Sá Marques, T. \& Hernández Aja, A. (2020): Procesos urbanos funcionales en Iberia: una aproximación a la integración del territorio urbano más allá de la metropolización, Cuadernos Geográficos, $n^{\circ} 59$ : 93-128.

LefeBVRE, H. (1969): El derecho a la ciudad, Barcelona, España, Ediciones Península.

López RAmón, F. (2014): El derecho subjetivo a la vivienda, Revista Española de Derecho Constitucional, $\mathrm{n}^{\circ} 102$. 
MoyA GonZÁLEZ, L. (2014): Reflexiones sobre aspectos físicos de la Ley 8/2013 de rehabilitación, regeneración y renovación urbanas. Ciudad Y Territorio Estudios Territoriales (CyTET), $\mathrm{n}^{\circ}$ 179, 75-79.

Moreno Linde, M. (2014): Consideraciones sobre los principios del derecho administrativo y su vigencia y aplicación en el ámbito urbanístico, Revista Andaluza de Administración Pública, $\mathrm{n}^{\circ}$ 90: 123-170.

NASARRe AznAR, S. (2014): La vivienda en propiedad como causa y víctima de la crisis hipotecaria, Teoría y Derecho: revista de pensamiento jurídico, $\mathrm{n}^{\circ}$ 16: 10-37.

Ortega Moreno, I. (2018 a): Los fondos europeos: incidencia en el desarrollo sostenible y el medio ambiente urbano de la Costa del Sol occidental, Revista de Actualidad Jurídica Ambiental, $n^{\circ} 83$ : $42-85$.

- (2018 b): Hacia la cohesión territorial de Europa: Perspectiva de la ordenación del territorio y el urbanismo, Revista de Estudios Europeos, $n^{\circ} 71$ : 381-395.

- (2020): Smart city: la revolución digital y el papel de las ciudades como garante de los derechos de los ciudadanos. En Sánchez-Archidona Hidalgo, G. (Coord.), Pastor García, A.M. (Coord.), \& Valencia Sáiz, A. (Dir.): Desafíos actuales del derecho: aportaciones presentadas al II Congreso Nacional de jóvenes investigadores en Ciencias Jurídicas (pp. 495-509). Madrid, España, Grupo Eumed.

Parejo Alfonso, L. J. (2017): La ordenación territorial y urbanística en el período 2007-2017, Práctica urbanística: Revista mensual de urbanismo, $\mathrm{n}^{\circ}$ 146.

PARKER, S. (2004): Urban theory and the urban experience. Encountering the city, New York, United States of America, Routledge.

Ponce SolÉ, J. (2011): El servicio de interés general de la vivienda, Grupo de estudios Ekiten- Thinking, $1 / 2011$.

- (2019): "El derecho a la ciudad y la Nueva Agenda Urbana: una aproximación integrada y sistémica a los derechos en la ciudad con referencia al derecho a la vivienda". En PonCE SolÉ, J. (Coord.), Migliari, W. (Coord.) \& Capdeferro Villagrasa, O. (Coord.): El derecho, la ciudad y la vivienda en la nueva concepción del desarrollo urbano. Desafíos transnacionales y transdisciplinarios en la nueva agenda urbana (pp. 115-151), Barcelona, España, Atelier.

QuiNTANA LóPEZ, T. (2016): "Hacia un modelo de urbanismo sostenible". En Quintana López, T. (Dir.) \& Casares Marcos, A. B. (Coord.), Urbanismo sostenible. Rehabilitación, regeneración y renovación urbanas (15-64), Valencia, Tirant Lo Blanch.

- (2018): Cambio de Paradigma: del urbanismo expansivo a la sostenibilidad (Lección inaugural, curso académico 2018-2019), León, España, área de publicaciones de la Universidad de León.

QuintiÁ PAstranA, A. (2017): El derecho a la vivienda y la dialéctica entre descentralización y recentra- lización. Revista Vasca de Administración Pública. Henrri Arduralaritzako Euskal Aldizkaria, n 109, vol. 1: 225-267.

Sánchez Blanco, A. (2009a): Urbanismo, prácticas municipales y evaluación institucional del Estado Español: la Resolución del Parlamento Europeo sobre el impacto de la urbanización extensiva en España en los derechos individuales de los ciudadanos europeos, el medio ambiente y la aplicación del Derecho comunitario, Revista de Estudios de la Administración Local y Autonómica, $\mathrm{n}^{\circ}$ 310: 9-38.

- (2009b): El control jurisdiccional del urbanismo de Marbella, 1991-2006, Revista de Estudios de la Administración Local y Autonómica, $\mathrm{n}^{\circ}$ 309: 173-206.

Sanz Rubiales, I. (2018): La protección del ambiente en la nueva ley de contratos: del Estado meramente «comprador» al Estado «ordenador», Revista de Administración Pública, $n^{\circ} 205:$ 49-80.

TeJedor BielsA, J. (2017): El derecho urbanístico en la encrucijada, Revista de Derecho Urbanístico y Medio Ambiente, $n^{\circ} 311:$ 453-478.

- (2018). A vueltas con las competencias sobre vivienda y la estabilidad del sistema financiero. Práctica Urbanística, no 151: 1-13.

Tolivar Alas, L. (2020): Gobierno de y desde la ciudad, XV Congreso de la Asociación Española de Profesores de Derecho Administrativo (AEPDA), lbiza, días 06 al 08 de febrero.

TORRES MARTínez, J. (2016): El Real Decreto Legislativo $7 / 2015$, de 30 de octubre por el que se aprueba el Texto Refundido de la Ley del Suelo y Rehabilitación Urbana. Su especial incidencia en la regulación de la rehabilitación urbana, Práctica urbanística: Revista Mensual de Urbanismo, $\mathrm{n}^{\circ}$ 138: 6-13.

Toscano GIL, F. (2016): Otra vez los consorcios administrativos: novedades introducidas por la Ley 40/2015 de régimen jurídico del sector público, Revista Vasca de Administración Pública, $\mathrm{n}^{\circ} 105$.

Vaquer Caballería, M. (2007): Los principios y derechos constitucionales inspiradores de la Ley de Suelo, Ciudad Y Territorio Estudios Territoriales (CyTET), $\mathrm{n}^{\circ}$ 152-153, 241-257.

- (2014): Derecho a la vivienda y garantía de un mínimo vital, El cronista del Estado social y Democrático de Derecho, $n^{\circ} 48$.

- (2017): Planes urbanísticos y planes de vivienda: la extraña pareja, Revista de Estudios de la Administración Local y Autonómica, $\mathrm{n}^{\circ}$ 7: 68-85.

Villarejo Galende, H. (2015): Smart Cities: Una apuesta de la Unión Europea para mejorar los servicios públicos urbanos, Revista de estudios europeos, n. ${ }^{\circ} 66$.

Zamora Roselló, M. R. (2019): La nulidad de los planes territoriales y urbanísticos: Análisis de la perspectiva de género, I Encuentro Red Docente de Excelencia de Género e Igualdad de la UMA, Universidad de Málaga. 


\section{Listado de acrónimos/siglas}

CCAA Comunidad Autónoma.

CE Constitución Española.

EDUSI Estrategias de Desarrollo Urbano Sostenible e Integrado

FEDER Fondo Europeo de Desarrollo Regional.

LOUA Ley $7 / 2002$, de 17 de diciembre, de Ordenación Urbanística de Andalucía.

LRRR Ley 8/2013, de 26 de junio, de Rehabilitación, Regeneración y Renovación Urbanas.

LS
NAU Nueva Agenda Urbana.

PMS Patrimonio Municipal del Suelo.

SNU Suelos No Urbanizables.

TC Tribunal Constitucional.

TRLS Real Decreto Legislativo 2/2008, de 20 de junio, por el que se aprueba el Texto Refundido de la Ley de Suelo.

TRLSRU Real Decreto Legislativo 7/2015, de 30 de octubre, por el que se aprueba el Texto Refundido de la Ley de Suelo y Rehabilitación Urbana.

TS Tribunal Supremo.

UE Unión Europea. 
CIUDAD Y TERRITORIO

ESTUDIOS TERRITORIALES

ISSN(P): 1133-4762; ISSN(E): 2659-3254

Vol. LIII, № 207, primavera 2021

Págs. 23-46

https://doi.org/10.37230/CyTET.2021.207.02

\title{
Infraestructura verde y ordenación del territorio en España
}

\author{
Berezi EloRrieta-SAnZ ${ }^{(1)}$ \\ Jorge Olcina-Cantos ${ }^{(2)}$
}

(1) Universidad de Barcelona. (2) Universidad de Alicante.

RESUMEN: La ordenación del territorio cuenta desde hace unos años con una herramienta de planificación sostenible: la infraestructura verde, que se ha ido incorporando en normas y planes territoriales de varios países occidentales. Entre ellos se incluye España, donde recientemente se ha publicado un borrador de estrategia estatal de infraestructura verde. El presente trabajo analiza la incorporación de la infraestructura verde a las políticas territoriales de las comunidades autónomas españolas mediante dos vías: la aprobación de estrategias específicas y su integración en los planes de ordenación territorial. Así, se identifican y analizan en profundidad aquellas comunidades autónomas que pueden considerarse ejemplo de buenas prácticas: Comunidad Valenciana, País Vasco y Cantabria, cuyos planes territoriales confieren a la infraestructura verde un papel importante en la definición, delimitación y gestión de los usos del suelo.

PALABRAS CLAVE: Ordenación del territorio; Infraestructura verde; Comunidades autónomas; Planificación sostenible.

\section{Green Infrastructure and Spatial Planning in Spain.}

ABSTRACT: Spatial planning uses in last years a sustainable planning tool: green infrastructure, which has been incorporated into territorial regulations and plans in several western countries. These include Spain, where an official document for the development of a green infrastructure strategy has recently been published by the central government. This paper analyses the integration of green infrastructure into the territorial policies of the Spanish autonomous communities through two different procedures: the approval of specific strategies and its integration into the spatial planning plans. We analyse in depth those autonomous communities that can be considered examples of good practices: Valencian Community, Basque Country and Cantabria, whose territorial plans give green infrastructure an important role in the definition, delimitation and management of land uses.

KEYWORDS: Spatial Planning; Green infrastructure; Autonomous Communities; Sustainable territorial management.

Recibido: 31.01.2020; Revisado: 09.06.2020

Correo electrónico: berezielorrieta@gmail.com; No ORCID: https://orcid.org/0000-0002-7473-2314;

Correo electrónoco: jorge.olcina@ua.es; No ORCID: https://orcid.org/0000-0002-4846-8126

Los autores agradecen los comentarios y sugerencias realizados por los evaluadores anónimos, que han contribuido a mejorar y enriquecer el manuscrito original. 


\section{Introducción y objetivos}

a ordenación del territorio ha ido mejorando sus procedimientos y métodos de trabajo en las últimas décadas, en relación con la aparición de normas que han priorizado la consideración de los elementos naturales y culturales del medio como piezas importantes a considerar en la planificación de nuevos usos (Lo Piccolo \& Todaro, 2013). Se ha pasado, en muchos países del mundo occidental, de concepciones básicamente económicas de la planificación territorial, que consideran el suelo como un espacio de posibilidades, de asignación directa de nuevos usos, a posiciones que valoran los recursos naturales y el patrimonio histórico-artístico como elementos básicos de los territorios. Actualmente, la planificación de los usos del suelo es una de las principales herramientas para su protección y para la conservación de la biodiversidad, especialmente en países que se encuentran en un periodo de intensificación de dichos usos, como es el caso de España (Foley \& al. 2005), por lo que es necesario implementar nuevas formas de planeamiento que tengan como objetivo la sostenibilidad del territorio (FARIÑA \& NAREDO, 2010).

Podemos destacar dos nuevos elementos que se han incorporado a la planificación normativa de los países europeos en las últimas décadas. Por un lado, el paisaje, que se ha ido convirtiendo en un instrumento operativo a la hora de establecer nuevos usos en el territorio. Los principios contenidos en el Convenio Europeo del Paisaje de $\mathbf{2 0 0 0}$ han sido integrados progresivamente en las normativas urbanísticas y del territorio de los países y regiones de la Unión Europea (JONES \& STENSEKE, 2011). Las unidades paisajísticas han pasado a ser un objeto de trabajo principal en los estudios de sostenibilidad ambiental. Por otro lado, la infraestructura verde territorial, como herramienta de trabajo de todo proceso de planificación. Se trata de un concepto que surge en la arquitectura del paisaje norteamericana de principios del siglo XX (de la mano de Law Olmstead), que recogerá ideas ambientalistas de los siglos XVIII y XIX (MeLL, 2008), y que se ha ido incorporando en las últimas tres décadas a la planificación territorial de diversas escalas, principalmente regional y local (BREUSTE \& al, 2015). Como conexión conceptual y aplicada entre ambos elementos, (WEBER \& al., 2006) describen la infraestructura verde como la presencia y distribución de características naturales en el paisaje que, además de favorecer los procesos ecológicos, contribuye también a la salud y el bienestar humanos. Los conceptos "naturales" de ecosistema y paisaje se combinan así con aspectos básicos en el funcionamiento humano de las sociedades (LAFORTEZZA \& al., 2013).
En cualquier caso no existe una definición universalmente aceptada de la expresión "infraestructura verde", debido a la variedad de finalidades en que ha derivado su manejo en planificación territorial (Agencia Europea del Medio Ambiente, AEMA, 2011). FERIA \& SANTIAGo (2017: 121) incluso se han referido a ella como "concepto-paraguas", ya que abarca múltiples componentes a diferentes escalas, desde los anillos verdes en la escala urbana hasta las redes regionales, nacionales o supranacionales para la conservación de los hábitats naturales. BENEDICT \& McMAHON (2002) definen la infraestructura verde como una red interconectada de espacios verdes que conserva los valores naturales y las funciones del ecosistema y proporciona beneficios asociados a las poblaciones humanas.

En la misma línea, más recientemente, la Comisión Europea (CE, 2014: 7) la ha definido como

"una red estratégicamente planificada de zonas naturales y seminaturales de alta calidad con otros elementos medioambientales, diseñada y gestionada para proporcionar un amplio abanico de servicios ecosistémicos y proteger la biodiversidad tanto de los asentamientos rurales como urbanos".

Esta definición recoge los tres rasgos esenciales de la infraestructura verde que resultan comunes a la mayoría de las definiciones (AEMA, 2011): en primer lugar, la búsqueda de un alto nivel de conectividad entre los espacios que la componen; en segundo lugar, su vocación multifuncional (con funciones no sólo ambientales, sino también sociales y productivas); y por último, la adopción de un enfoque estratégico para su planificación y gestión.

Como se desprende de su definición, la infraestructura verde no es sólo una red de espacios protegidos o de corredores ecológicos, se trata de un concepto que abarca mucho más territorio desde un prisma multiescalar, multifuncional y multisectorial (CALZADA, 2019). Así, aunque su principal misión es la conservación de la biodiversidad (función ecológica), tiene también funciones productivas y culturales, relacionadas con el desarrollo y la calidad de vida, de tal modo que su gestión se concibe desde una perspectiva sistémica. De hecho, la inversión en infraestructura verde puede comportar incluso beneficios económicos, pues su contribución a la mitigación de los efectos del cambio climático resulta más rentable que la adopción de soluciones tecnológicas (VALLADARES \& al., 2017). Los elementos que componen la infraestructura verde son diversos, específicos de cada territorio y muy dependientes de la escala (Fernández de GatTA, 2018), de forma que puede incluir desde grandes espacios naturales protegidos hasta áreas verdes 
urbanas. Esta estructura multiescalar obliga a que los diferentes niveles competenciales se articulen correctamente para una regulación coherente y coordinada.

Así las cosas, la infraestructura verde parece destinada a integrar la planificación espacial, ecológica y socioeconómica en diferentes escalas, y debe contar en los procesos de planificación como herramienta cartográfica principal, a partir de la cual se determinan los suelos a conservar y se ordenan los nuevos crecimientos urbanísticos o de infraestructuras y equipamientos.

Para integrar la infraestructura verde en las políticas territoriales, desde un punto de vista instrumental, pueden contemplarse dos opciones: por un lado, pueden desarrollarse instrumentos específicos de ordenación para la infraestructura verde; por otro lado, puede incorporarse la infraestructura verde en los planes de ordenación territorial. En la presente investigación se pretende analizar ambas modalidades de ordenación de la infraestructura verde en una selección de casos de estudio. Así pues, el objetivo de esta investigación es analizar la ordenación de la infraestructura verde en las comunidades autónomas españolas, ya sea mediante la aprobación de estrategias específicas o mediante la integración de la infraestructura verde en los instrumentos de planificación territorial regionales.

\section{Método de análisis}

La metodología empleada es una combinación de diferentes técnicas cualitativas. El estudio parte de una revisión bibliográfica sobre el propio concepto de infraestructura verde, su implantación en las políticas públicas de diferentes contextos territoriales y su integración en la ordenación del territorio. Para ello, se han empleado tanto fuentes de tipo académico como fuentes institucionales o provenientes de organizaciones especializadas. Por un lado, para el estudio del contexto europeo, han sido fundamentales los trabajos publicados desde la Agencia Europea del Medio Ambiente (AEMA) así como desde la propia Comisión Europea (CE). En el contexto español, a su vez, destaca la propia Estrategia Estatal de Infraestructura Verde y de la Conectividad y la Restauración Ecológicas como documento institucional, así como otras fuentes académicas como el estudio de Feria \& Santiago (2017) sobre la integración de la infraestructura verde en la planificación de algunas áreas metropolitanas españolas.

En segundo lugar, se ha procedido al análisis de contenido de diversos documentos normativos y de planificación de las comunidades autónomas. Siguiendo la secuenciación de tareas mencionada por BARDIN (2002), se ha partido de un preanálisis en el que se han identificado y seleccionado la legislación territorial y de paisaje y los planes territoriales y de infraestructura verde de las comunidades autónomas. A continuación, se ha procedido a la propia explotación del material, analizando la presencia de la infraestructura verde en los documentos; y por último, se ha realizado el tratamiento de resultados, presentando la información en forma de tablas para facilitar su comparación y la obtención de una fotografía general de la incorporación de la infraestructura verde en el marco legal e instrumental. Por un lado, se ha elaborado una tabla (FIG. 4) con la legislación de ordenación territorial y de paisaje de las comunidades autónomas, donde se detalla si las leyes mencionan o no la infraestructura verde en su articulado. Por otro lado, se ha diseñado otra tabla (FIG. 5) donde se recoge, para cada comunidad autónoma, la existencia o no de una estrategia específica de infraestructura verde, el instrumento de planificación territorial regional, y la incorporación de la infraestructura verde en el mismo, clasificando dicha incorporación como directa (cuando el plan incluye explícitamente la infraestructura verde en sus determinaciones), indirecta (no se menciona la infraestructura verde explícitamente, pero sí gran parte de sus componentes) o nula (no se menciona la infraestructura verde ni la mayoría de sus componentes).

Con los resultados de este análisis general por comunidades, se ha realizado una selección de casos de estudio que se han considerado de interés por sus avances en la incorporación de la infraestructura verde a los procesos y políticas de planificación territorial. Concretamente, se han seleccionado las tres comunidades autónomas que, en sus planes territoriales, han integrado de forma directa o explícita la ordenación de la infraestructura verde: la Comunidad Valenciana, la Comunidad Autónoma del País Vasco y Cantabria. Para estos casos de estudio, una revisión bibliográfica más profunda ha permitido caracterizar el marco regulador, instrumental y de gobernanza relacionado con la ordenación del territorio y la infraestructura verde.

Más allá de esta caracterización general, interesa conocer la incorporación pormenorizada de la infraestructura verde en los planes de las comunidades autónomas seleccionadas, y realizar un análisis comparado que permita identificar las tendencias actuales en cuanto a la concepción de la infraestructura verde en dichos planes. Para ello, en primer lugar, se ha puesto la atención en la identificación de los componentes de la infraestructura verde de los tres planes (FIG. 7), así como 
en la coherencia que guardan con la Estrategia estatal de infraestructura verde, empleando una lista de control (check-list) con los componentes recogidos en dicha Estrategia que serían susceptibles de ser incorporados en la ordenación del territorio de escala regional (FIG. 8). Es decir, se han excluido del análisis los elementos que la Agencia Europea de Medio Ambiente en su propuesta metodológica asocia a la escala urbana (AEMA, 2011). La lista de control permite una lectura tanto en vertical (incorporación de los componentes en cada comunidad autónoma) como horizontal (identificación de los componentes más o menos presentes en los planes), lo que nutre la interpretación y conclusiones finales. En segundo lugar, se ha puesto la atención sobre la adopción de un enfoque multiescalar en los planes, estudiando las funciones atribuidas a la infraestructura verde en cada escala territorial (FIG. 9).

En suma, la información extraída de un análisis de contenido más detallado de los instrumentos de planificación regional se ha volcado progresivamente en las FIGS. 7, 8 y 9, permitiendo comprender mejor cómo se regula la infraestructura verde en cada plan y facilitando el análisis comparado entre los tres casos de estudio.

\section{Infraestructura verde, herramienta de planificación territorial sostenible}

La difusión del concepto de infraestructura verde ha sido considerablemente rápida en el contexto internacional y particularmente en el europeo, donde, además de una larga trayectoria de políticas ambientales, existe una preocupación importante por las transformaciones recientes de los usos del suelo y la fragmentación del paisaje.

Con el fin de mejorar el estado de la infraestructura verde en las ciudades y regiones europeas, la Estrategia de Biodiversidad hasta 2020 (CE, 2011) ya incluyó este elemento en su objetivo 2 , que se refiere al mantenimiento y mejora de los servicios ecosistémicos y la restauración de ecosistemas degradados mediante la incorporación de infraestructura verde a la ordenación territorial, lo que contribuiría a hacer sostenible el crecimiento de la UE. Además, este documento preveía la elaboración de una estrategia específica de infraestructura verde, que finalmente se publicaría en 2013 bajo el título "Mejora del capital natural de Europa" (CE, 2013), y que seguía la línea abierta por los anteriores programas y estrategias ambientales, climáticas o de biodiversidad.
La estrategia europea tiene como objetivo crear un marco robusto para fomentar y facilitar proyectos de infraestructura verde mediante los instrumentos financieros, políticos y jurídicos existentes. Como resultado de este marco, la infraestructura verde es identificada específicamente como una de las prioridades de inversión en diferentes políticas y programas, como la política agraria, ambiental o de cohesión, de donde ha venido principalmente el acceso a la financiación (del Fondo Europeo de Desarrollo Regional y del Fondo de Cohesión). Paralelamente a la integración en las políticas sectoriales, la Unión también promueve la incorporación de la infraestructura verde en las actuaciones de las escalas inferiores, para que se desarrollen y apliquen marcos nacionales y regionales que promuevan la restauración y la infraestructura verde (CE, 2015: 7).

Así pues, la UE entiende la infraestructura verde como una herramienta estratégica en el marco de las políticas de cohesión territorial, conservación de la naturaleza y fomento de la sostenibilidad urbana (FERIA \& SANTIAGO, 2017), buscado su integración de forma transversal y considerando sistémicamente la infraestructura verde en los procesos de planificación y toma de decisiones (GoBIERNO DE ESPAÑA, 2019). En definitiva, cumpliendo con lo previsto en la estrategia de infraestructura verde, la UE no sólo ha realizado una reflexión conceptual, un diagnóstico de su estado y una apuesta por la inclusión de la infraestructura verde en la planificación desde una visión estratégica, sino que también le ha asignado instrumentos de financiación y recomendaciones de inversión específicas para los proyectos.

Este impulso proveniente de la esfera europea también se ha traducido en una considerable integración de la infraestructura verde en la planificación territorial de los Estados miembros (AEMA, 2011). Según los resultados del proyecto GRETA - Green infrastructure: Enhancing biodiversity and ecosystem services for territorial development, del observatorio ESPON (Observatorio en Red de la Ordenación del Territorio Europeo), los 32 estados miembros de ESPON incluyen la infraestructura verde en sus políticas públicas, más allá de las políticas propias dirigidas a la conservación de la biodiversidad, aunque solo 11 de ellos tienen políticas específicas de infraestructura verde a nivel nacional (GARCíA-BLANCO \& al., 2019), entre los que podemos citar a Francia, Alemania, Holanda o Austria, entre otros. A estos países se sumará España cuando se apruebe definitivamente el borrador de su estrategia estatal de infraestructura verde.

Las escalas regional y local en Europa también ofrecen buenos ejemplos de la incorporación de la herramienta de la infraestructura verde en la 


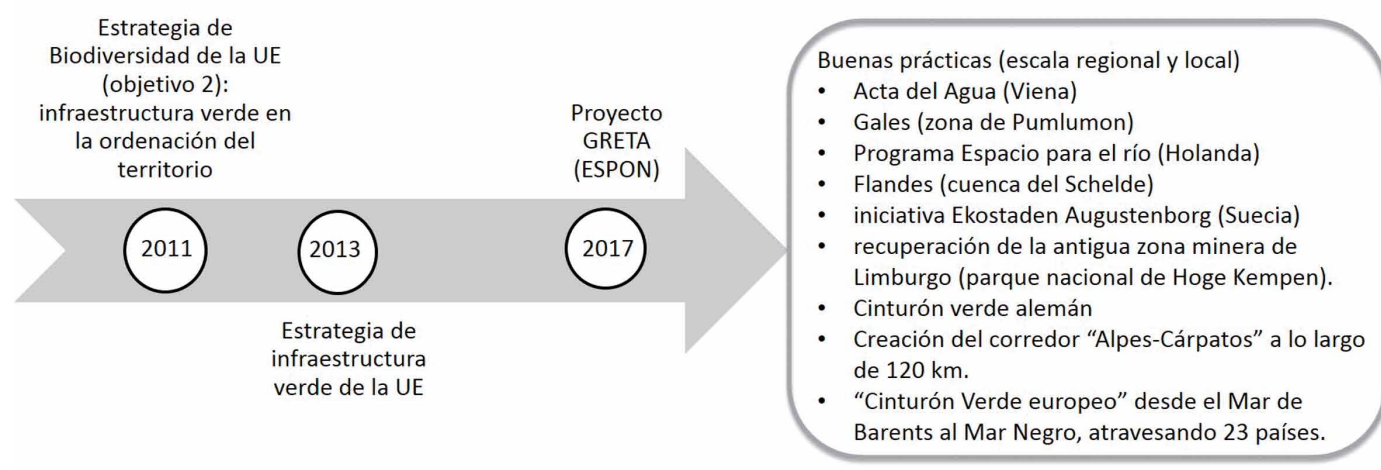

FIG. 1/ Principales hitos de la infraestructura verde en la Unión Europea.

Fuente: Elaboración propia.

planificación territorial (ver FIG. 1). Así, destacan las iniciativas desarrolladas en Gales (zona de Pumlumon), Flandes (cuenca del Schelde), la iniciativa Ekostaden Augustenborg (Suecia), o la recuperación de la antigua zona minera de Limburgo (parque nacional de Hoge Kempen), entre otras. Incluso se han llevado a cabo iniciativas supra-regionales y supra-estatales como la creación del corredor "Alpes-Cárpatos" a lo largo de 120 km., o del "Cinturón Verde europeo" desde el Mar de Barents al Mar Negro, atravesando 23 países.

En la escala local, hay dos aspectos concretos que recientemente han cobrado protagonismo como elementos de la infraestructura verde, en el marco del actual proceso de calentamiento climático: el desarrollo de sistemas de drenaje sostenible (verdeamiento de cursos fluviales urbanos; parques inundables; depósitos pluviales) y las acciones para la mejora del confort térmico que eviten los efectos del calor urbano, especialmente en verano (tejados verdes, fachadas verdes, manzanas verdes). De cara al futuro, los efectos del cambio climático se van a incorporar también como elementos de infraestructura verde tanto en la escala local como en la regional, a partir del empleo de modelos cada vez más ajustados (Vera-Rebollo \& al., 2019). Y en un doble sentido: por un lado, por el propio proceso de cambio climático y sus efectos en los elementos climáticos (cambios en las temperaturas y la precipitación); y por otro lado, por el incremento previsto de las manifestaciones atmosféricas extremas. De manera que se deberán incorporar a la infraestructura verde, de cara a la planificación territorial regional y local, efectos tales como las modificaciones en las áreas inundables o las sequías y su impacto en el abastecimiento urbano de agua, entre otros (ver FIG. 2).

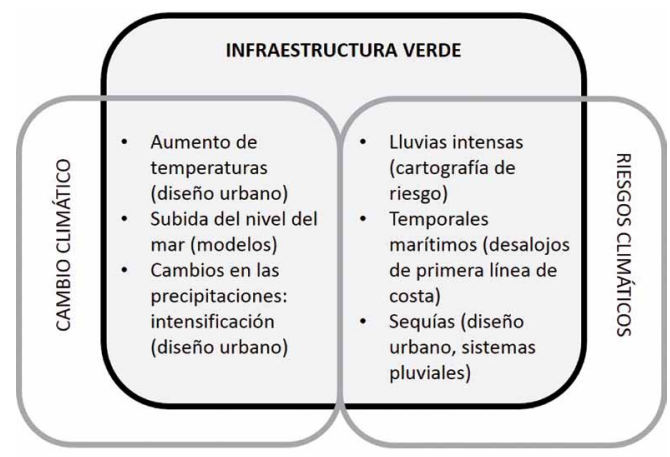

FIG. 2/ Aspectos del cambio climático y de los riesgos climáticos que pueden incorporarse a la infraestructura verde y la planificación territorial.

Fuente: Elaboración propia.

\section{La Estrategia Estatal de Infraestructura Verde y de la Conectividad y la Restauración Ecológicas}

El marco normativo referente a la protección de los sistemas naturales y los procesos ecológicos en España es amplio y complejo y las competencias se reparten entre las tres escalas principales: estatal, regional y local. En el campo de la infraestructura verde, los avances han sido significativos en los últimos años, aunque al ser un concepto relativamente reciente, la mayor parte de las normas básicas ambientales no la mencionan; sin embrago, sí citan otros conceptos que forman parte de la infraestructura verde (GoBIERNO DE EsPAÑA, 2019). 
El mayor referente normativo a nivel estatal para implementar estrategias de infraestructura verde viene dado por la ley española de Patrimonio Natural y Biodiversidad ${ }^{1}$, que pretende dar cumplimiento a las directrices provenientes de la UE e incorporar algunos de los objetivos de la estrategia europea sobre biodiversidad. Así, esta normativa fue la encargada de incorporar la infraestructura verde al ordenamiento jurídico español a partir de su reforma de 2015, y estableció la elaboración de una estrategia de infraestructura verde estatal para su diagnóstico y ordenación.

En mayo de 2019, el gobierno español publicó finalmente un borrador de Estrategia Estatal de Infraestructura Verde y de la Conectividad y la Restauración Ecológicas (ver FIG. 3), que derivó de las preliminares bases científico-técnicas, presentadas en 2017 y concebidas como el fundamento técnico y científico de la futura Estrategia estatal. El borrador de 2019 de la Estrategia fue asumido por un equipo amplio y multidisciplinar de expertos en diversas materias, aunque no estuvo exento de críticas por la escasa participación pública y transparencia en su elaboración. Aun así, la Estrategia deja de manifiesto la existencia de un interés político en impulsar la infraestructura verde desde el nivel estatal, dado que no existía hasta ese momento ningún instrumento de planificación en esta materia y escala.

El enfoque adoptado por esta Estrategia es el de la integración de los ecosistemas y sus servicios en la ordenación del territorio. No se presenta la infraestructura verde como una nueva figura de protección del patrimonio natural, sino como una herramienta integradora. A partir de la aprobación de la Estrategia, se supone que la normativa relacionada con las distintas intervenciones sobre el territorio debe integrar el concepto de infraestructura verde y las directrices emanadas de la Estrategia, lo que supone adoptar un nuevo modelo de planificación territorial.
La Estrategia estatal, como su propio nombre indica, adopta un enfoque estratégico cuya visión consiste en que, en 2050, existirá una red de infraestructura verde que permitirá asegurar el mantenimiento y mejora del capital natural garantizando soluciones naturales para los retos del bienestar humano, teniendo en cuenta el cambio climático. Para alcanzar las metas estratégicas, las diferentes administraciones son responsables de desplegar las actuaciones necesarias en cascada, desde las escalas superiores a las inferiores, con acciones adecuadas a cada nivel territorial, desde los corredores ecológicos regionales hasta los huertos urbanos.

La cuestión de la escala administrativa es un tema clave para implementar políticas de infraestructura verde, pues el propio concepto tiene un significado multiescalar. Por ello, el documento hace alusión explícita a la necesidad de un enfoque multiescalar así como de una buena coordinación interadministrativa, una cuestión clave si se tienen en cuenta los complejos problemas de gobernanza ambiental y territorial existentes (CE, 2019; FARINós \& ELORRIETA, 2017).

Una vez aprobada la Estrategia estatal, la ley de Patrimonio Natural y Biodiversidad establecía que las comunidades autónomas deberían desarrollar sus propias estrategias en un plazo máximo de tres años. La Estrategia estatal debe constituir una referencia para las estrategias regionales, siguiendo un proceso top-down en cascada, adaptando las orientaciones comunes a las realidades regionales. Sin embargo, como se observará en el siguiente apartado, ya hay algunas comunidades que se han avanzado a la publicación de la Estrategia estatal y han ido desarrollando sus propias iniciativas en los últimos años. Asimismo, existen ya algunos ejemplos en la escala local que han articulado instrumentos de planificación de la infraestructura verde, como Zaragoza, Vitoria-Gasteiz o Madrid.

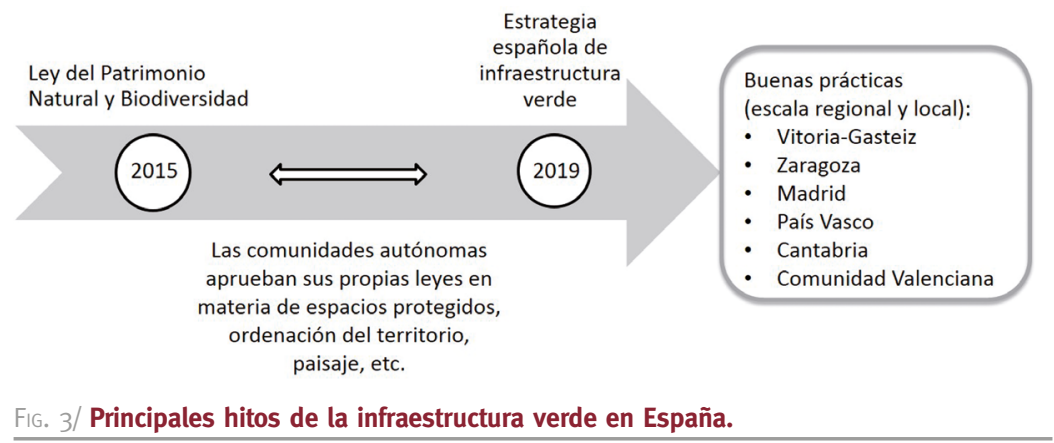

Fuente: Elaboración propia.

\footnotetext{
${ }^{1}$ Ley $33 / 2015$, de 21 de septiembre, por la que se modifica la Ley
}

42/2007, de 13 de diciembre, de Patrimonio Natural y Biodiversidad. 


\section{Incorporación de la infraestructura verde en los procesos de planificación territorial en España. Estudio regional}

Como se ha señalado, la infraestructura verde es un concepto que puede ser implementado a diferentes escalas y, de hecho, el enfoque adoptado en los instrumentos difiere en función de la escala territorial, dado que se le atribuyen finalidades distintas. Según la AEMA (2011), a escala regional o nacional las infraestructuras verdes aparecen vinculadas a los grandes sistemas interconectados de protección de la naturaleza, y su finalidad es la conservación de los ecosistemas naturales y los procesos ecológicos.

Para estudiar la escala regional, en primer lugar cabe hacer referencia a la distribución competencial: aunque el reparto de competencias en materia ambiental es complejo, las comunidades autónomas son las que ejercen la mayor parte de las competencias ambientales relacionadas con la infraestructura verde (como por ejemplo en conectividad ecológica). En efecto, entre otras cuestiones, las comunidades autónomas llevan trabajando desde los años noventa, junto con el gobierno central, en la declaración y gestión de los espacios que forman parte de la Red Natura 2000. En relación a las competencias en materia territorial, según la Constitución son exclusivas de las comunidades autónomas, y aunque la atribución de las competencias en paisaje es más ambigua, también las han asumido implícitamente y algunas comunidades han aprobado sus propios cuerpos normativos específicos (DE LA CRUZ \& MADURGA, 2019).
Como vemos, las comunidades autónomas son soberanas para implementar una amplia variedad de acciones relacionadas con la infraestructura verde, incluyendo su incorporación a la planificación territorial. El propio marco normativo de las políticas territoriales podría integrar de forma vinculante la conservación de la biodiversidad y la infraestructura verde en los instrumentos de planificación.

En efecto, si nos fijamos en la legislación de ordenación del territorio del conjunto de las comunidades autónomas, se aprecia que la cuestión ambiental ha adoptado progresivamente una mayor relevancia, con referencias expresas al concepto de desarrollo sostenible y, en menor grado, a la protección del paisaje (ELORRIETA \& al., 2016); de este modo, a menudo las leyes incorporan referencias a ciertos componentes de la infraestructura verde. En cambio, las referencias explícitas a la infraestructura verde desde un punto de vista integral son muy escasas. Solo dos leyes mencionan expresamente la infraestructura verde en su articulado y establecen las bases para su ordenación: la ley de Ordenación del Territorio, Urbanismo y Paisaje ${ }^{2}$ de la Comunidad Valenciana, y el anteproyecto de nueva Ley de Ordenación del Territorio de Galicia ${ }^{3}$. En cuanto a legislaciones específicas de paisaje, Cantabria ${ }^{4}$, Cataluña ${ }^{5}$, Galicia ${ }^{6}$ y el País Vasco ${ }^{7}$ disponen hoy en día de normas propias para ordenar y proteger el paisaje, pero dichas legislaciones no hacen mención alguna de la infraestructura verde específicamente, a diferencia de la mencionada ley valenciana, que regula conjuntamente la ordenación del territorio y el paisaje (FIG. 4).

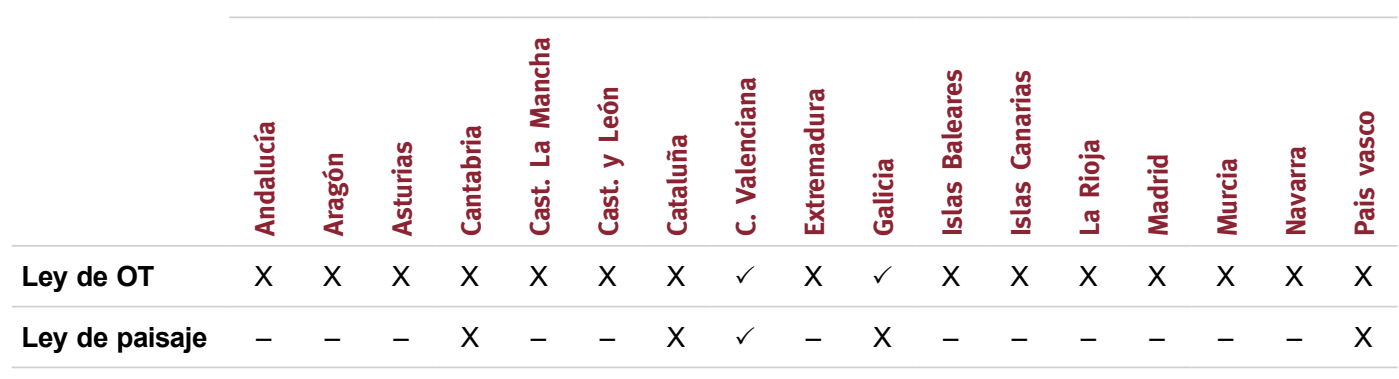

FIG. 4/ Menciones a la infraestructura verde en las leyes de ordenación del territorio y leyes de paisaje de las comunidades autónomas.

Fuente: Elaboración propia.

\footnotetext{
${ }^{2}$ Ley 5/2014 de Ordenación del Territorio, Urbanismo y Paisaje de la Comunidad Valenciana.

${ }^{3}$ Publicado en el DOG 192 del 8 de octubre de 2018.

${ }^{4}$ Ley 4/2014 del Paisaje de Cantabria.

${ }^{5}$ Ley 8/2005, de Protección, Gestión y Ordenación del Paisaje
}

de Cataluña

${ }^{6}$ Ley $7 / 2008$ de Protección del Paisaje de Galicia.

${ }^{7}$ Decreto 90/2014 sobre Protección, Gestión y Ordenación del Paisaje de la Comunidad Autónoma del País Vasco. 
A pesar de que todas las comunidades autónomas tienen su propia ley de ordenación del territorio, que en algunos casos ha sufrido sucesivas modificaciones, en general se han ido desarrollando sin incorporar regulaciones para la infraestructura verde, exceptuando los dos casos arriba mencionados. Llama especialmente la atención la ausencia de la infraestructura verde en las normas más recientes, como la ley de ordenación territorial de Extremadura ${ }^{8}$ de 2018, el anteproyecto de la nueva Ley de Territorio de Cataluña ${ }^{9} \mathrm{o}$ el anteproyecto de Ley de Ordenación del Territorio y Urbanismo de Cantabria ${ }^{10}$, ambos iniciados en 2017.

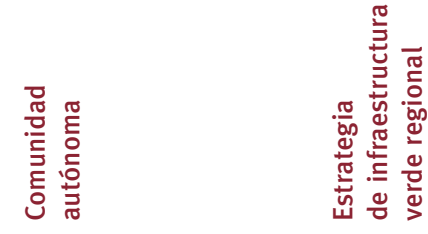

Plan Director para la Mejora de la Conectividad Ecológica. Una estrategia de infraestructura verde (2018)
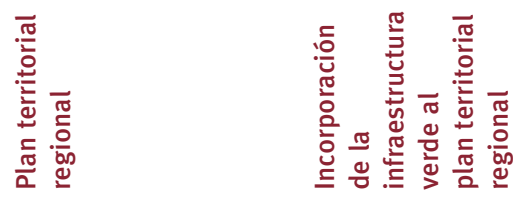

\begin{tabular}{llll}
\hline Andalucía & $\begin{array}{l}\text { Plan Director para la Mejora de la } \\
\text { Conectividad Ecológica. Una estrategia } \\
\text { de infraestructura verde (2018) }\end{array}$ & $\begin{array}{l}\text { Plan de Ordenación del Territorio } \\
\text { de Andalucía (2006) }\end{array}$ \\
\hline Aragón & & $\begin{array}{l}\text { Estrategia de Ordenación Territorial } \\
\text { de Aragón (2014) }\end{array}$ & Indirecta \\
\hline Asturias & & $\begin{array}{l}\text { Directrices Regionales de Ordenación } \\
\text { del Territorio (2016-avance-) }\end{array}$ & Indirecta
\end{tabular}

$\begin{array}{ll}\text { Cantabria } & \text { Plan Regional de Ordenación Territorial Directa } \\ & \text { (2018-aprobación inicial-) }\end{array}$

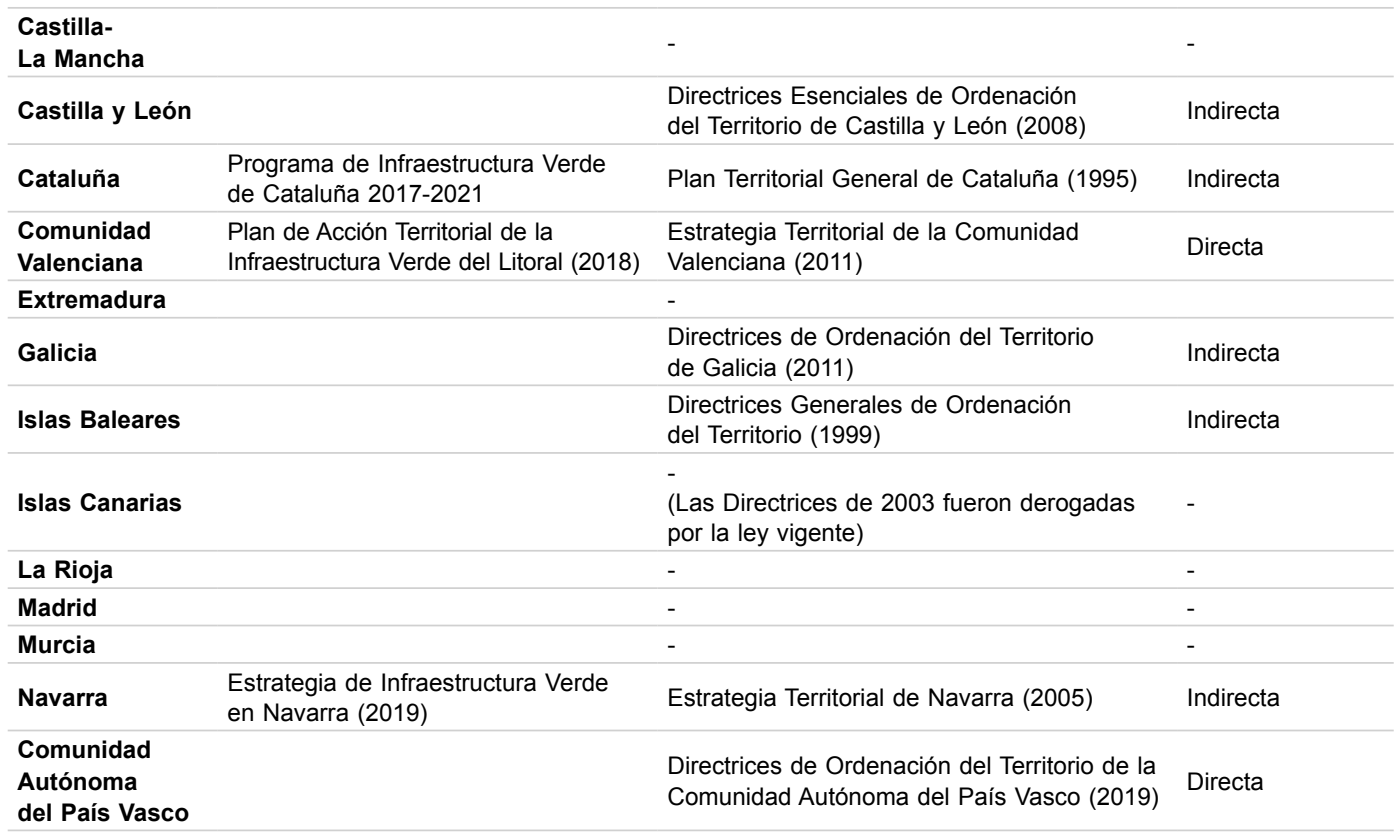

FIG. 5 / Instrumentos específicos de infraestructura verde e incorporación de la infraestructura verde a los instrumentos de planificación territorial en las comunidades autónomas españolas.

Fuente: Elaboración propia.

${ }^{8}$ Ley $11 / 2018$ de Ordenación Territorial y Urbanística Sostenible de Extremadura.

${ }_{9}^{9}$ Publicado en el DOGC 7377 del 25 de mayo de 2017

${ }^{10}$ Publicado en la web de la Dirección General de Urbanismo y Ordenación del Territorio. Disponible en: https://www.territoriodecantabria.es/-/anteproyecto-de-leyordenacion-territorio-y-urbanismo-de-cantabria-pendientede-aprobacion-consejo-gobierno-?inheritRedirect=true 
Más allá del marco legal, es conveniente poner el foco en el marco instrumental creado por las comunidades autónomas. Así, la integración de la infraestructura verde en las políticas territoriales puede realizarse bien a través de instrumentos específicos o bien incorporando la infraestructura verde en los planes de ordenación territorial, y aunque la Estrategia estatal apuesta por la segunda opción (GoBIERNO DE ESPAÑA, 2019), en las comunidades autónomas españolas se han dado ambas formas de integración (ver FIG. 5).

En cuanto a los instrumentos específicos dirigidos a regular la infraestructura verde, todavía son escasos, aunque ciertamente algunas comunidades autónomas han puesto en marcha sus propios planes o programas de forma muy reciente. Entre ellos, destaca el caso de la Comunidad Valenciana, que en 2018 aprobó un Plan de Acción Territorial de la Infraestructura Verde del Litoral, y cuyos avances se analizan en profundidad en un próximo apartado.

Andalucía ha aprobado recientemente un plan de infraestructura verde de carácter territorial, estratégico y transversal (JUNTA DE ANDALUcía, 2018). El plan identifica las áreas estratégicas a escala regional para la conectividad ecológica, y propone medidas que deben aplicarse a través de instrumentos sectoriales.

En el caso de Cataluña, la Generalitat ha impulsado un Programa de Infraestructura Verde a corto plazo como paso previo a la elaboración de su propia estrategia regional. El Programa propone actuaciones de mejora inmediatas y concretas más allá del nivel estratégico (GENERALITAT DE CATALUNYA, 2017). Hasta ahora ya se han dado algunos pasos importantes, como integrar la planificación de la infraestructura verde en la Estrategia del Patrimonio Natural y la Biodiversidad, en el Plan Director Urbanístico Metropolitano (que se encuentra en fase de avance) o cartografiar los servicios ecosistémicos de la provincia de Barcelona.

Finalmente, en la Comunidad Foral de Navarra se publicó en mayo de 2019 una Estrategia de Infraestructura Verde, que tiene su origen en la propia Estrategia Territorial Navarra (GoBIERNO DE NAVARRA, 2019). La Estrategia constituye básicamente una hoja de ruta, que se basa en la identificación y puesta en valor de las funciones de una serie de elementos de la infraestructura verde, y en su correspondiente zonificación.

Por lo que respecta a la integración de la infraestructura verde en los instrumentos de ordenación del territorio, aunque la salvaguarda de los espacios naturales suele ser un elemento importante de ellos, el contexto heterogéneo y fragmentado de las comunidades autónomas (FARINÓs \& ELORRIETA, 2017) hace que sólo algunos planes territoriales de aprobación más reciente hayan incorporado la infraestructura verde en sus regulaciones, y no siempre de forma explícita. Esta incorporación limitada puede estar relacionada con varios factores, como la elaboración tardía (2019) de la Estrategia Estatal, el retraso generalizado en la actualización de las normativas regionales de ordenación territorial, $y$, desde un punto de vista más técnico, la necesidad de disponer de cartografía temática digitalizada en las comunidades autónomas, que permitiría diseñar con mayor facilidad los criterios de utilización de las capas para la configuración de la infraestructura verde y emplearla en la gestión de los suelos de finalidad urbanística. Entre las comunidades que han incorporado la infraestructura verde de forma más directa, destaca de nuevo la Comunidad Valenciana, cuya Estrategia Territorial constituyó un instrumento que incluía elementos como la infraestructura verde y el paisaje. Desde entonces, como decíamos, sólo los planes más recientes han incorporado la infraestructura verde: el Plan Regional de Ordenación Territorial de Cantabria (pendiente de aprobación definitiva) y las nuevas Directrices de Ordenación del Territorio de la Comunidad Autónoma del País Vasco. Estas tres comunidades autónomas son, precisamente, las que se analizan en profundidad en próximos apartados.

En el resto de comunidades autónomas, cuyos planes territoriales ya tienen algunos años de vigencia, la incorporación de la infraestructura verde obligaría a una modificación de dichos documentos ya operativos, con lo que ello puede implicar de alteración de procesos aprobados o de pérdida de oportunidades de transformación del suelo por la falta de definición clara de criterios. Ahora bien, cabe subrayar que a pesar de que no incluyan explícitamente regulaciones para la infraestructura verde, sí ordenan gran parte de sus componentes como los espacios naturales protegidos, los corredores verdes o los espacios fluviales, entre otros (es por ello que la FIG. 5 alude a una incorporación indirecta). Asimismo, algunas comunidades autónomas han incluido también elementos de la infraestructura verde en sus planes de ordenación del litoral o planes territoriales de escala subregional, como los Planes de Ordenación Territorial de Navarra, los Planes Territoriales Parciales de Cataluña o los Planes de Ordenación del Territorio de Andalucía.

\subsection{La infraestructura verde en la Comunidad Valenciana: una apuesta de la administración regional con incipientes efectos prácticos}

La Comunidad Valenciana es un buen ejemplo de contradicción en el conjunto de regiones españolas en materia de ordenación territorial, que 
se manifiesta en las diferencias notables entre las formulaciones teóricas (estrategias y planes) y la realidad urbanística vivida durante las últimas décadas. A partir de la crisis desencadenada en 2008 la administración regional aprueba un nuevo marco de planificación territorial (BuRRIEL DE ORUETA, 2009) que cuestiona en buena medida los principios rectores del anterior modelo de crecimiento urbanístico expansivo y sin apenas límites en el territorio, manejado básicamente desde la escala local (CAPDEPÓN, 2016).

Su franja litoral es, sin duda, el "espacio de conflicto", de interés económico, en materia de planificación territorial y urbanística, al concentrar el porcentaje mayor de población y de actividades económicas, en particular el turismo de sol y playa, motor económico esencial de la economía valenciana (ARIÑO \& GARCÍA, 2018). No es de extrañar, de este modo, que la Comunidad Valenciana encabece la lista de regiones españolas de agresiones al espacio litoral, lo que manifiesta la necesidad de una protección efectiva de la franja litoral y de una gestión real del territorio.

Esta comunidad autónoma inició una nueva etapa en los procesos de ordenación territorial de escala regional y subregional en 2011, con la aprobación de la Estrategia Territorial de la Comunitat Valenciana $^{11}$ (ETCV). En este documento se manifestaba, de forma explícita, la apuesta por una planificación sostenible del espacio geográfico, siguiendo los principios establecidos por la Estrategia Territorial Europea (1999). A ello se sumó la apuesta decidida, en el ámbito europeo, por la gestión del paisaje como herramienta de ordenación del territorio. Así, junto a Cataluña, fue una de las regiones españolas que más temprano aprobó una normativa de planificación territorial que incorporaba la obligación de considerar el paisaje en los procesos de ordenación territorial ${ }^{12}$. Con este marco normativo (revisado y actualizado en $2014^{13}$ y en $2019^{14}$ ) se elaboró y aprobó la Estrategia Territorial de la Comunitat Valenciana que supuso una apuesta decidida por la sostenibilidad del territorio, empleando el paisaje como una herramienta de gestión fundamental.

Junto al paisaje, el otro gran componente de la ordenación del territorio establecido por la Ley de Ordenación territorial de la Comunidad Valenciana es la infraestructura verde. En efecto, la actual Ley de Ordenación del Territorio, Urbanismo y Paisaje incluye en su exposición de motivos, su apuesta decidida por este concepto:

\footnotetext{
11 Decreto $1 / 2011$, de 13 de enero, del Consell, por el que se aprueba la Estrategia Territorial de la Comunitat Valenciana

12 Ley 4/2004, de 30 de junio, de Ordenación del Territorio y Protección del Paisaje.
}

\begin{abstract}
"La definición de la Infraestructura Verde debe ser previa a la planificación de las nuevas demandas de suelo y debe abarcar todas las escalas del territorio..."
\end{abstract}

y dedica un título específico a la infraestructura verde, como método de trabajo en la planificación territorial, a diferente escala (regional, supramunicipal, municipal y urbana), de obligada observancia con carácter previo a la ordenación de usos y actividades en el territorio.

La Estrategia Territorial de la Comunidad Valenciana (Generalitat Valenciana, 2011) señala que uno de los objetivos principales de la política de paisaje es definir la infraestructura verde, a modo de una red interconectada conformada por los paisajes de mayor valor medioambiental, cultural y visual que se convertirá en la estructura básica ecológica. Define la infraestructura verde como una herramienta clave de planificación territorial que debe orientar los crecimientos urbanísticos del futuro preservando el territorio de mayor valor que debe quedar fuera de este proceso urbanizador. Además, la ETCV condiciona los futuros crecimientos de suelo con la capacidad de acogida del territorio, que debe ser definida por la infraestructura verde como fase previa a cualquier desarrollo urbanístico o territorial.

La ETCV ha dado un paso más en la caracterización de la infraestructura verde al incorporar componentes no exclusivamente naturales pero cuya integración cobra sentido al utilizar esta herramienta para la protección de espacios diversos tanto del litoral como de interior. Entiende la infraestructura verde como un sistema de gestión de espacios abiertos integral, que puede contener tanto elementos urbanos como elementos para conectar los espacios verdes de las ciudades con las de su entorno rural (CANTO, 2014), y que se define a partir de una serie de elementos del medio que se detallan más adelante en la Tabla 3 (FIG. 3). La infraestructura verde opera, además, en diferentes escalas de planificación (FIG. 5) al ser un método de trabajo capaz de adaptarse a las realidades territoriales, incluyendo el litoral como espacio de oportunidad y de conflicto.

El mismo año de aprobación de la Estrategia Territorial Valenciana, el gobierno valenciano elaboró un Plan de Acción Territorial (PAT) sobre Infraestructura Verde y Paisaje de la Comunitat Valenciana. Este PAT, que fue un documento muy

\footnotetext{
${ }^{13}$ Ley $5 / 2014$, de 25 de julio, de Ordenación del Territorio, Urbanismo y Paisaje.

${ }^{14}$ Ley $1 / 2019$, de 5 de febrero, de la Generalitat, de modificación de la Ley $5 / 2014$, de 25 de julio, de Ordenación Del Territorio, Urbanismo y Paisaje.
} 
ambicioso y con contenidos de enorme interés para la ordenación del territorio, nunca llegó a aprobarse como tal. Pero el trabajo cartográfico realizado ha pasado a formar parte de las capas existentes en el Sistema de Información Territorial de la Comunidad Valenciana, que incluye una capa específica sobre infraestructura verde de obligada observancia en los procesos de planificación territorial y urbanística ${ }^{15}$.

El último paso en la conexión entre paisaje e infraestructura verde ha sido la elaboración de un documento de Objetivos de Calidad e Instrucciones Técnicas para la ordenación y gestión de los Paisajes de Relevancia Regional de la Comunitat Valenciana (Generalitat Valenciana, 2019) ${ }^{16}$. La intención de este documento es facilitar los criterios que permitan la ordenación y gestión de los Paisajes de Relevancia Regional ${ }^{17}$ y su correcta articulación integrando en la infraestructura verde aquellos espacios capaces de conectar ecológica y funcionalmente los lugares más significativos. De manera que es evidente la intención de integración de estas dos herramientas de ordenación del territorio (unidades paisajísticas e infraestructura verde).

En general, la infraestructura verde es un elemento propio de los planes de acción territorial, que tienen, entre otras funciones, la definición de la infraestructura verde en su ámbito de actuación y han de establecer fórmulas participativas de gestión (CANTO, 2014). Pero la plasmación concreta del uso de la infraestructura verde como herramienta principal de la ordenación del territorio en la Comunidad Valenciana ha venido de la mano de la redacción y aprobación del PATIVEL, Plan de Acción Territorial de Infraestructura Verde del Litoral de la Comunidad Valenciana (Generalitat Valenciana, 2018). Ha sido una apuesta valiente del gobierno valenciano porque afecta al espacio geográfico de mayor deseo de transformación para uso urbano y con mayor valor económico.

Debe recordarse, como antecedente de este plan, que, en 2002, el gobierno autonómico presentó una Estrategia Valenciana para la Gestión Integrada de la Costa, que se apuntaba como la base de la política de la Generalitat Valenciana en este campo (Generalitat Valenciana, 2002). Sin embargo, no tuvo el desarrollo posterior esperado y, en conjunto, se puede afirmar que la región no ha contado con una política de gobierno especifica

\footnotetext{
15 Vid. esta capa de "infraestructura verde" en el visor carto-
gráfico de la Generalitat Valenciana. Disponible en: http://visor.gva.es/visor/. Consultado: agosto 2019.

${ }^{16}$ Este documento está en fase de exposición pública, desde el 6 de septiembre de 2019. La segunda fase, tras la aprobación del mismo, será la redacción de una instrucción
}

en materia de gestión integrada de áreas litorales, por lo menos de manera explícita.

No ha sido, por tanto, hasta la aprobación del PATIVEL cuando la Comunidad Valenciana ha aprobado un texto normativo que avala la gestión integrada del litoral, sumándose así a las iniciativas desarrolladas en otros territorios litorales de nuestro país. Incluso se ha ido más allá al apostar por la protección del paisaje y la definición precisa de la infraestructura verde para este espacio geográfico singular y complejo (VERARebollo \& al., 2019). El PATIVEL es un instrumento de ordenación del territorio de ámbito supramunicipal diseñado desde la urgencia y el pragmatismo para tratar de conseguir la rápida protección de determinados suelos de clara apetencia económica, mediante la aplicación de los principios y filosofía que propone la ordenación de la infraestructura verde.

Las áreas de protección seleccionadas pretenden evitar la consolidación de continuos edificados y de barreras urbanas; esto es, se intenta conservar las últimas ventanas de suelo potencialmente urbanizable que están sin urbanizar en la costa valenciana. Y ello bajo una doble finalidad: la protección y conservación de paisajes y entornos naturales, pero también la utilización de esta protección como oferta turística de calidad.

Acorde con los principios de ordenación integrada del espacio litoral y no solo de la estricta franja costera, este plan afecta a 3 ámbitos (ver FIG. 6) definidos a partir de su distancia, tierra adentro, de la línea de costa (GENERALITAT VALENCIANA, 2018):

a. Ámbito estricto, que comprende los suelos de los municipios litorales situados en la franja de 500 metros de amplitud medida en proyección horizontal tierra adentro desde el límite interior de la ribera del mar y coincidente con el área de influencia de la legislación de costas.

b. Ámbito ampliado, hasta los 1.000 metros de amplitud medida en proyección horizontal tierra adentro desde el límite interior de la ribera del mar, que dota de refuerzo y continuidad ecológica, funcional y visual a los suelos definidos en el apartado anterior y garantiza la amortiguación de los impactos sobre los mismos.

técnica de utilidad para las administraciones públicas

17 Se han identificado 40 Paisajes de Relevancia Regional (PRR) que se agrupan en 14 grandes conjuntos paisajísticos. Disponible en: http://politicaterritorial.gva.es/es/web/ planificacion-territorial-e-infraestructura-verde/paisatges-derellevancia-regional. Consultado: agosto 2019. 
c. Ámbito de conexión, hasta los 2.000 metros de amplitud medida en proyección horizontal tierra adentro desde el límite interior de la ribera del mar, donde se analizará, ordenará y garantizará la conectividad ecológica y funcional del espacio litoral con el resto del territorio.

En el PATIVEL se han aplicado los componentes de la infraestructura verde definidos inicialmente en la Estrategia Territorial de la Comunidad Valenciana, que se estructura en una serie de componentes principales que forman los pilares básicos (en esencia, los espacios naturales con protección), unos servicios ambientales (forestales y agrícolas), unos espacios de especial atención (contaminación, riesgos), unos conectores y una infraestructura verde de escala urbana (parque, paseos, plazas). No obstante, se han incorporado algunos nuevos, como criterio para la delimitación de los ámbitos de protección: los espacios de la zona marina, los espacios costeros de interés ambiental y cultural, y las áreas de influencia del cambio climático en la franja litoral (subida del nivel del mar, áreas de inundación por incremento de episodios de crecida fluvial). En este último aspecto, el PATIVEL resulta novedoso a escala estatal. Para ello ha tenido en cuenta, entre otros, el Informe de efectos del cambio climático en la costa española, avalado por el Ministerio de Transición Ecológica (LOSADA \& al., 2014), para estimar la evolución de la costa valenciana en un doble sentido: erosión por deriva litoral y efectos de temporales marítimos. Se ha preparado, además, una cartografía de detalle de los espacios costeros situados por debajo de $1 \mathrm{~m}$. sobre el nivel del mar, para determinar áreas conflictivas por subida del nivel del mar previsto en la costa valenciana en el señalado informe del Ministerio de Transición Ecológica.

Los suelos regulados con mayor detalle, en tanto son los específicos de este plan, son los que el PATIVEL define como suelos "no urbanizables de protección del litoral" y suelos "no urbanizables de refuerzo del litoral". Estos suelos podrán incorporarse a la red primaria de zonas verdes del municipio y ser adscritos a los procesos de gestión urbanística del planeamiento municipal. Por su parte, los suelos "no urbanizables de refuerzo del litoral", son los que refuerzan la protección de los suelos de la categoría precedente dotándoles de continuidad física y funcional.

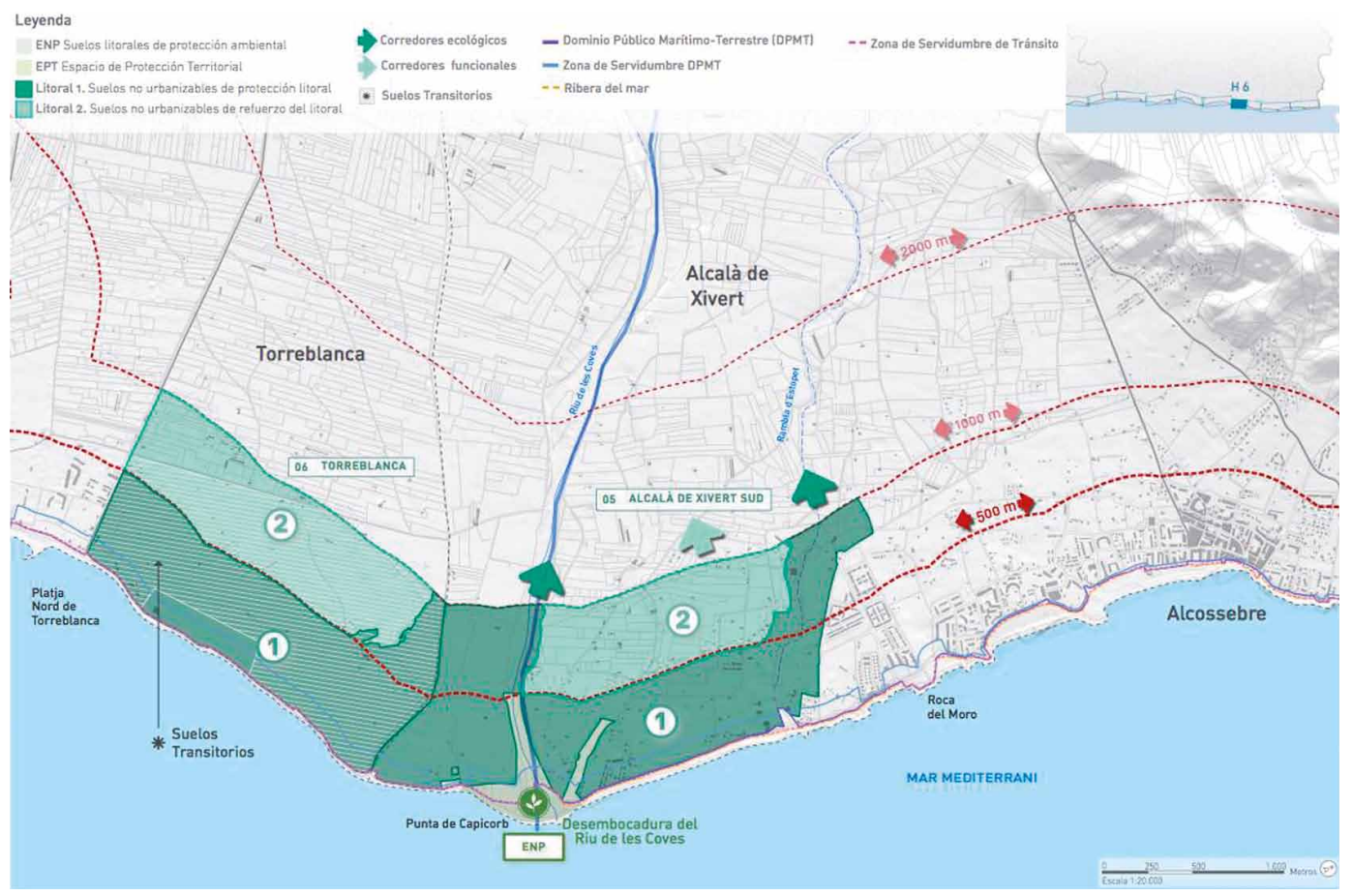

FIG. 6/ Plano de ordenación con tipología de suelos de protección. Sector de Cabanes-Torreblanca (Castellón). 
Como acción concreta, de importancia normativa, el PATIVEL ha delimitado 52 áreas que deben preservarse libres de edificación, como piezas clave de la infraestructura verde del litoral (Generalitat Valenciana, 2018) y que suponen, además de la protección de áreas que ya estaban declaradas como suelo no urbanizable, la desclasificación urbanística de 1.426 has de suelo en la franja litoral. Es decir, de suelos que podrían haberse urbanizado (VerA-Rebollo \& OLCINA, 2017). En su conjunto, el PATIVEL prevé la protección de un total de 7.500 ha del litoral de la región, cifra que integra el $12 \%$ de los suelos que aún no han sido urbanizados en la franja de $500 \mathrm{~m}$ desde el límite interior de la ribera del mar. Como novedad en la política de valorización del litoral, el PATIVEL incluye un catálogo de playas, basado en la diferenciación entre playas urbanas y naturales con su correspondiente normativa de usos y ocupaciones, e incorpora la delimitación y trazado de la Vía del Litoral de la Comunitat Valenciana, definida como un eje estructural que articule los núcleos costeros y que formará parte de la infraestructura verde del litoral.

\subsection{La infraestructura verde en la Comunidad Autónoma del País Vasco: un momento oportuno para su integración en la ordenación del territorio}

La Comunidad Autónoma del País Vasco (CAPV) es un territorio de orografía accidentada cuyo medio físico ha condicionado indudablemente el modelo de ocupación. Se trata de una comunidad autónoma de reducido tamaño y alta densidad de población, que ha evolucionado hacia una ciudad región en la que los límites de los centros y las funciones y actividades se difunden por territorios cada vez más amplios y diversos (Gobierno VAsco, 2019).

A pesar de la gran riqueza y diversidad de sus ecosistemas, en la actualidad es un territorio altamente fragmentado, debido principalmente al desarrollo de grandes infraestructuras lineales que han roto la continuidad ecológica entre espacios naturales. Asimismo, el crecimiento económico e inmobiliario entre los años 1995 y 2007 llevó a una expansión del suelo urbanizado con usos residenciales e industriales. En definitiva, las presiones sobre el medio físico en las últimas dos décadas han sido notables, hasta el punto de que se han intensificado algunos riesgos (como las inundaciones) para la población, que ocupa frecuentemente las áreas próximas a los cauces de los ríos y a sus desembocaduras.
En un territorio con estas particularidades, las políticas ambientales y de ordenación del territorio adquieren una especial relevancia. De hecho, paralelamente a las profundas transformaciones territoriales, las últimas décadas han dejado un importante despliegue de políticas públicas de protección ambiental, así como un amplio legado de instrumentos de planificación territorial. Además, actualmente se está tramitando el Anteproyecto de Ley de Cambio Climático del País Vasco, que prevé la incorporación de determinaciones relacionadas con el cambio climático en los instrumentos de ordenación territorial y urbanismo.

La CAPV ha sido una de las precursoras de la adopción de criterios de desarrollo sostenible en sus políticas territoriales y urbanísticas (ELORRIETA \& al., 2016), caracterizados inicialmente por un sesgo más bien ambientalista, con un enfoque de ordenación del medio físico y de los recursos naturales. El instrumento de planificación regional, que fue uno de los primeros planes territoriales regionales aprobados en el Estado español, ya dejó de manifiesto esta apuesta por la preservación del medio natural, incluso como elemento identitario ligado a la cultura vasca. Las denominadas Directrices de Ordenación Territorial (DOT) estaban reguladas por la Ley $4 / 1990$ de Ordenación del Territorio del País Vasco, y fueron aprobadas en 1997 como resultado de un largo proceso. El documento final se decantó por un carácter eminentemente estratégico y flexible, de ahí que la mayor parte de su contenido se caracterizara por una cierta indefinición bajo la forma de criterios, referencias y pautas de actuación generales (BENABENT, 2006). No obstante, como ya se ha señalado, las DOT como instrumento de ordenación del territorio mostraron una temprana preocupación por los aspectos ambientales, ya que incluyeron objetivos claros de integración de lo ambiental en la ordenación de usos del suelo (JAUREGUI \& ERQUICIA, 1992), siendo el primer instrumento regional español que estableció claramente como objetivo la planificación sostenible del suelo y de los paisajes (ELoRRIETA \& al., 2016). Asimismo, pese a ser anteriores a la publicación del Convenio Europeo del Paisaje y al Decreto 90/2014 sobre protección, gestión y ordenación del paisaje de la CAPV, ya reconocían el valor del paisaje y preveian que los planes subregionales identificaran la necesidad de tratamientos paisajísticos especiales y concretaran los estudios específicos para actuaciones que pudiera alterar el paisaje (URIARTE, 2014).

En el momento de su aprobación se preveía que se llevara a cabo una revisión de las Directrices al cabo de 8 años, cosa que en realidad no se produjo hasta 2019 , cuando las antiguas Directrices habían quedado manifiestamente obsoletas. 
Así, la aprobación definitiva ${ }^{18}$ llegaría después de nada menos que veintidós años de vigencia de las anteriores Directrices. Las nuevas DOT fueron publicadas bajo el ambicioso epígrafe "Lurraldea 2040" (Territorio 2040), como pretendiendo evocar un enfoque estratégico y un espíritu de innovación y anticipación a las futuras transformaciones del territorio.

A pesar de este retraso en la revisión de las DOT, lo cierto es que la ordenación del territorio de la CAPV ha sufrido un gran impulso en los últimos años, gracias a la aprobación de los planes de escala subregional; y también se han impulsado múltiples iniciativas en materia de paisaje, que ha experimentado un gran desarrollo normativo e instrumental. En cuanto a la planificación subregional, el mapa de los quince Planes Territoriales Parciales (PTP) está prácticamente completado, a falta de la aprobación definitiva del PTP de Tolosaldea. Los PTP son los encargados de concretar y ampliar las directrices regionales a la escala comarcal, así como establecer los criterios objetivos para el cumplimiento de las determinaciones de las DOT en la escala local; es por ello que, a la hora de territorializar las propuestas, han adquirido una mayor relevancia.

La nueva generación de planes territoriales es fiel al enfoque ambiental que instauraron las primeras DOT allá en los años noventa, profundizando en algunas materias y avanzando en nuevos conceptos. La mencionada revisión de las DOT, en efecto, presenta una clara vocación ambiental, aunque sigue distinguiendo entre simples recomendaciones y directrices vinculantes de ordenación y uso del espacio, y algunas cuestiones ambientales (como el paisaje o la adaptación al cambio climático) no adquieren el grado de obligatoriedad. También se han incorporado de forma decidida cuestiones relacionadas con la infraestructura verde y los servicios de los ecosistemas. De hecho, el tratamiento de la infraestructura verde como parte de la ordenación del medio físico, junto con la puesta en valor de los servicios de los ecosistemas, es el primero de los diez principios rectores de la revisión de las DOT. Así, las DOT siguen abiertamente la línea marcada por las instituciones europeas e internacionales en la identificación de los principales retos territoriales y ambientales.

En realidad el Gobierno Vasco ya había anticipado algunos trabajos para incorporar la infraestructura verde a los instrumentos de planificación territorial y urbanística. En 2016 se publicó la Metodología para identificación y representación cartográfica de la infraestructura verde, mientras que dos años más tarde, la Cátedra UNESCO de

\footnotetext{
18 Decreto 128/2019, de 30 de julio, por el que se aprueban definitivamente las Directrices de Ordenación Territorial de
}

Sostenibilidad, con financiación del Gobierno Vasco y de la Diputación Foral de Bizkaia, publicó la Guía metodológica para el cartografiado de los Servicios de los Ecosistemas de Euskadi. Estos trabajos serían fundamentales para integrar la infraestructura verde en la revisión de las DOT. Asimismo, se prevé que sean los Planes de acción del paisaje los que protagonicen la introducción de la infraestructura verde en el planeamiento territorial y urbanístico en la escala local (URIARTE, 2014), poniendo de relieve el vínculo entre políticas territoriales, paisaje e infraestructura verde.

La incorporación de la infraestructura verde en las Directrices regionales se da a lo largo de los diferentes apartados y documentos, desde las propias bases del modelo territorial, hasta las Normas de Aplicación. La Memoria dispone un apartado dedicado a la descripción y análisis del medio físico y la infraestructura verde de la CAPV, donde se manifiesta que la infraestructura verde forma parte del modelo territorial de las DOT y se remite a los anexos a la Memoria para conocer sus componentes, así como un enlace a la cartografía disponible en el geovisor del Gobierno Vasco. Concretamente, la infraestructura verde de la CAPV se compone de los elementos recogidos más adelante en la Tabla 3 (FIG. 3).

Las DOT se trazan como objetivos para la infraestructura verde y los servicios ecosistémicos los siguientes aspectos (GoBIERNO VASCO, 2019: 68): mantener y enriquecer el patrimonio natural y los servicios de la naturaleza; poner en valor los servicios de los ecosistemas como herramienta de gestión sostenible del territorio; integrar los elementos de la infraestructura verde en una red regional e integrar los espacios protegidos en una sola figura de protección; y cultivar los efectos positivos de la infraestructura verde (como la conectividad ecológica, la reducción de los riesgos ante catástrofes, la suficiencia y seguridad alimentaria, la preservación del paisaje, etc.).

Tal y como apunta el tercer objetivo, las DOT subrayan que en algunos espacios que forman parte de la infraestructura verde se solapan diversas figuras de protección, por lo que apuestan por integrarlos en una figura única en el futuro, más allá de mejorar la coordinación entre las figuras existentes. Además, reconocen la necesidad de una mayor interconexión entre los espacios protegidos, a través de la red de corredores ecológicos y de otros espacios de interés natural multifuncionales. Para los corredores ecológicos, identifican también los obstáculos críticos y zonas de conflicto que ponen en riesgo la funcionalidad de estos corredores, y proponen medidas de actuación para mitigarlos.

la Comunidad Autónoma del País Vasco. 
Por otro lado, las Normas de Aplicación dedican el Artículo 4 a las directrices en materia de infraestructura verde y servicios de los ecosistemas, también completadas por un anexo que recoge las categorías de ordenación del medio físico en función de su vocación, así como la regulación de usos de cada categoría. Las directrices en materia de infraestructura verde se caracterizan por un carácter inclusivo, flexible y estratégico, estableciendo ciertos criterios para aplicar las normas reguladoras de los espacios que la componen, realizar un seguimiento de su estado, e identificar y resolver posibles conflictos con la infraestructura gris o con otros usos del territorio.

Al igual que en el caso de la Comunidad Valenciana, las directrices sobre infraestructura verde son especificas para cada escala territorial (FIG. 5). En cuanto a los componentes de la infraestructura verde, las DOT establecen que los planeamientos territoriales y urbanísticos extenderán la red de infraestructura verde incorporando espacios relevantes en sus respectivas escalas, teniendo en cuenta otros espacios protegidos que no están en la infraestructura verde a nivel de la CAPV (como por ejemplo Lugares de Interés Geológico o el Registro de Zonas Protegidas de los Planes Hidrológicos, entre otros). Así, las DOT atribuyen ciertas funciones específicas no sólo al planeamiento urbanístico sino también al subregional, materializado en los Planes Territoriales Parciales.

El cambio climático es considerado en las DOT una cuestión transversal, por su influencia en las tres dimensiones de la sostenibilidad (la ambiental, la social y la económica). Entre las directrices relacionadas con el cambio climático se incluye también la de promover la infraestructura verde como medida de adaptación, así como restaurar los ecosistemas para mantener la resiliencia del territorio.

\subsection{La infraestructura verde en Cantabria: incorporación a una política territorial accidentada}

En Cantabria ha tenido lugar en las dos últimas décadas un importante proceso de urbanización y artificialización del suelo. La mayor parte del crecimiento urbanístico, además, se ha producido en modo de tejido urbano discontinuo y en la franja costera (DELGADO, 2010), con la consiguiente transformación de sus paisajes y ocupación de suelo. La principal causa de ello ha sido la expansión de las urbanizaciones y viviendas de segunda residencia asociadas al turismo y a la construcción de la autovía A-8. Así, la protección

\footnotetext{
${ }^{19}$ Ley de Cantabria 2/2004, de 27 de septiembre, del Plan
}

de los espacios naturales de la comunidad ha mostrado importantes carencias y deficiencias (Delgado, 2012), como la ausencia de instrumentos de ordenación de los recursos naturales o la modificación de los instrumentos de ordenación y protección ambiental existentes para sortear los problemas legales de ciertas urbanizaciones.

En efecto, a pesar de las problemáticas ambientales y paisajísticas existentes, durante más de quince años la normativa elaborada en relación con la ordenación territorial y urbanística tuvo un carácter meramente reactivo, ya que su objetivo fue, ante todo, la adaptación a la legislación estatal en esta materia y prácticamente no se articularon instrumentos propios. Así, durante varias décadas sólo existió en la Comunidad el planeamiento de escala municipal. En 2001 se aprobó la Ley 2/2001 de Ordenación Territorial y Régimen Urbanístico del Suelo de Cantabria, con un marcado carácter urbanístico, que sustituyó a la anterior legislación de 1990. Esta legislación territorial sufriría, en los años posteriores, varias modificaciones, generalmente más laxas y permisivas con las iniciativas urbanizadoras, que por lo tanto supusieron una reducción del nivel de protección de los espacios rurales y naturales. Actualmente se está tramitando un nuevo marco legal, que continúa apostando por legislar conjuntamente las competencias en ordenación del territorio y en urbanismo, y crea nuevos instrumentos de planificación, ya sea para los ámbitos subregionales como para determinadas materias sectoriales con incidencia territorial (RANDO, 2019).

El desarrollo tardío de las competencias en ordenación del territorio ha hecho que en Cantabria los instrumentos de planificación existentes sean considerablemente actuales, aunque también escasos e insuficientes (DELGADO, 2010). El primer instrumento de planificación la Ley 2/2001 llegaría en 2004 con el Plan de Ordenación del Litoral (POL) de Cantabria, que fue aprobado con rango de ley ${ }^{19}$. EI POL tuvo la virtud de formalizarse como primer instrumento de ordenación territorial de Cantabria en un momento en que prevalecía la cultura desarrollista, permitiendo paralizar determinados procesos urbanizadores que de otro modo habrían resultado irreversibles. A día de hoy este plan constituye, probablemente, el instrumento de ordenación territorial en vigor más importante con el que cuenta la comunidad autónoma, pues aún no ha sido aprobado el Plan Regional de Ordenación Territorial (PROT), y según la legislación, los fines y el contenido de ambos planes coinciden a rasgos generales.

Con la aprobación del POL y de las Normas Urbanísticas Regionales previamente al plan regional, 
se deduce que en Cantabria la aprobación de instrumentos de ordenación territorial ha seguido el sentido inverso a la cascada de planificación. El retraso en la aprobación del PROT ha representado, sin duda, un serio obstáculo para el desarrollo de una verdadera política de gestión y protección del territorio y del paisaje en la región. Actualmente, sin embargo, el PROT se encuentra en proceso de tramitación, y el paisaje posee una legislación específica ${ }^{20}$ desde 2014.

En abril de 2018 se produjo la aprobación inicial del PROT, que viene acompañado de un anteproyecto de ley del PROT que establece aspectos tales como su vigencia, contenido o desarrollo a escalas subregionales. Este plan será el encargado de establecer las pautas generales para alcanzar el modelo territorial deseado a escala regional, que parte de dos fundamentos generales: por un lado, el desarrollo de un sistema equilibrado y policéntrico de ciudades, y por otro, la protección del medio natural y la gestión del patrimonio. Así, se aprecia que el patrimonio natural y el paisaje tienen un papel relevante a lo largo del documento.

La infraestructura verde es tratada como parte del patrimonio natural en la memoria de ordenación del PROT. En el análisis y diagnóstico no adquiere demasiado protagonismo, de manera que no se realiza una evaluación específica de la infraestructura verde existente, sino que su futura consolidación se identifica como una oportunidad para la región. EI PROT reconoce, además, que la consolidación de la infraestructura verde apenas se ha empezado a trabajar en Cantabria (Gobierno de CANTABRIA, 2018: 35).

Ante estas carencias, las bases del modelo territorial contemplan la creación y desarrollo de una infraestructura verde regional como medida de valorización del patrimonio natural, regulando el uso eficiente del suelo desde su propia vocación y desterrando la visión residual del suelo rústico o espacio abierto (VEGA \& al., 2019). Las determinaciones más específicas para la infraestructura verde se recogen en el título sobre el patrimonio natural, si bien la clasificación de componentes y espacios resulta algo confusa pues existen diferentes divisiones en función de criterios como la escala, los componentes de la conectividad o el servicio ecosistémico que presta cada espacio.

En términos generales el PROT distingue dos tipos de espacios (FIG. 3): los núcleos, asociados a los biotopos bien conservados, y los conectores, que dan soporte a los ecosistemas integrados en los núcleos, conectándolos a escala regional y local. En realidad los componentes de la infraestructura verde no son definidos como espacios concretos en el PROT, a diferencia de lo que se definía en los otros planes territoriales estudiados, sino que se indica que formarán parte de ella todos aquellos espacios que prestan determinados servicios ecosistémicos. Así, la infraestructura verde se asocia a espacios terrestres o acuáticos que presten los siguientes servicios: conservación de la biodiversidad; conectividad ecológica; almacenamiento y captura de carbono; abastecimiento de alimentos; almacenamiento, suministro y regulación de los flujos de agua; y defensa del litoral. La cartografía donde se distingue la infraestructura verde también la clasifica según estas funciones, de manera que incluye espacios tales como corredores ecológicos, formaciones vegetales arboladas, terrenos de alta productividad agrícola, y masas de agua naturales o artificiales, entre otros.

EI PROT establece unos criterios generales para la regulación de usos en la infraestructura verde, pero también específicos para cada tipo de espacio, según el servicio ecosistémico que presten y según sean espacios núcleo o conectores. Las actuaciones a impulsar por las administraciones en los espacios núcleo van en la línea de la protección, conservación, uso sostenible de los recursos y potenciación de los servicios ecosistémicos, mientras que en los conectores se centran en mejorar los biotopos existentes, fomentar las repoblaciones forestales y, de nuevo, incentivar las actividades que aporten servicios ecosistémicos.

Aunque la infraestructura verde del PROT se entiende a nivel regional, también se indica que ésta debe ser completada y concretada a nivel local mediante los instrumentos propios de la planificación de mayor detalle o urbanística. De este modo, la infraestructura verde se conforma en una red continua y coherente que se desarrolla en tres escalas principales: regional, de cuenca y local. La escala regional o territorial tiene una implantación geográfica que rebasa el ámbito regional y transciende a un contexto supramunicipal; la escala de cuenca se desarrolla en el el ámbito de las cuencas hidrográficas y los elementos asociados a ellas; mientras que la escala local tendrá un desarrollo posterior a través del planeamiento urbanístico municipal.

Las determinaciones del PROT también incluyen la relación entre infraestructura verde y cambio climático, pues pretenden impulsar la infraestructura verde y las soluciones basadas en la naturaleza como medidas de adaptación al cambio

${ }^{20}$ Ley 4/2014, de 22 de diciembre, del Paisaje 
climático y a la sostenibilidad de los recursos naturales. En cambio, el apartado sobre la ordenación del paisaje, que tiene también un capítulo específico, no menciona explícitamente la relación con la infraestructura verde.

\subsection{Discusión y análisis comparado}

Las comunidades autónomas analizadas en los documentos de ordenación territorial aprobados manifiestan su apuesta defintiva en la incorporación de la infraestructura verde en sus procesos de planificación territorial integrada de escala regional. La Comunidad Valenciana, además, cuenta con un plan regional sectorial, el PATIVEL, que ha dado un paso más en la consideración de la infraestructura verde como herramienta efectiva de gestión territorial.
No obstante, hay que recordar que a pesar del enfoque innovador del PATIVEL para la protección de las zonas costeras, la mera declaración legal de protección de un área concreta por sí sola en un no garantiza su buena conservación, pues la viabilidad de una protección basada en la infraestructura verde pasa por la necesaria gestión efectiva y real de esa porción del espacio geográfico a diversas escalas de manera coherente e interrelacionada (PADILLA \& al., 2019), incorporando propuestas para la gestión de los suelos protegidos de manera conjunta entre las administraciones regional y local (VeRA-Rebollo \& al., 2019).

En cuanto a la incorporación de la infraestructura verde a los planes territoriales, ésta se ha dado con ciertas disparidades metodológicas, incluso a la hora de identificar los componentes de la infraestructura verde, como se aprecia en la FIG. 7.

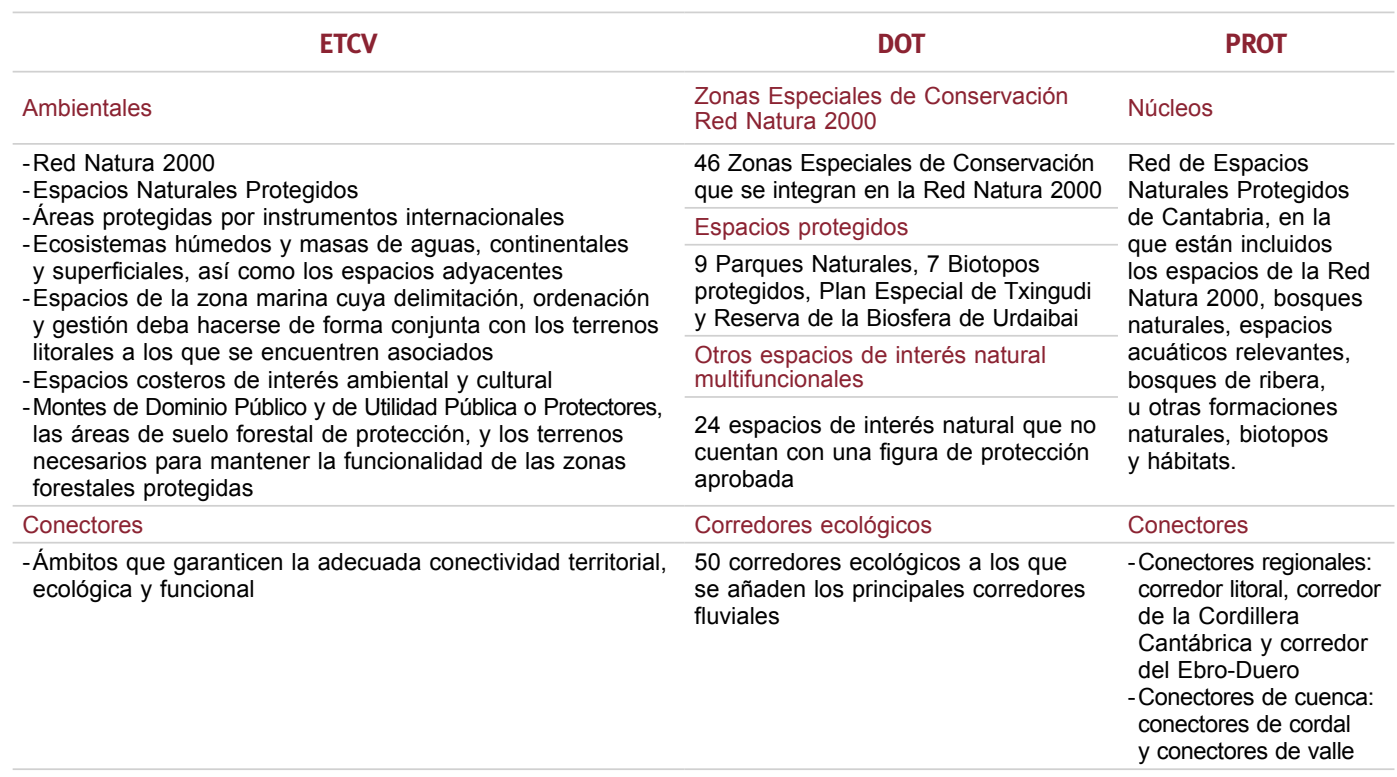

Culturales

-Espacios de elevado valor cultural

- Áreas agrícolas de elevada productividad y funcionalidad

Visuales/Sociales

Espacios de interés paisajístico

Áreas críticas

Zonas críticas respecto a probable incidencia de riesgos naturales

Otros

- Áreas que se definen en el planeamiento territorial, ambiental

y urbanístico por su interés para la conservación del paisaje,

la protección de espacios naturales y la biodiversidad

-Espacios públicos dentro del suelo urbanizado que

la planificación municipal considere relevantes para formar

parte de la infraestructura verde

-Espacios que tengan una cobertura legal ambiental, cultural

o sectorial específica

FIG. 7/ Análisis comparado de los componentes de la infraestructura verde en la ETCV, las DOT y el PROT.

Fuente: Elaboración propia a partir de Generalitat Valenciana (2011), Gobierno Vasco (2019) y Gobierno de Cantabria (2018). 
Esta diversidad de componentes integrantes parece justificada por la propia imprecisión en la definición de la infraestructura verde, como se ha señalado. La ETCV es la que tiene una idea más amplia en relación al tipo de elementos que pueden formar parte de ella, pues se tienen en cuenta componentes muy diversos, desde los ambientales hasta los de tipo cultural. Las DOT, por su parte, se ciñen a criterios básicamente ambientales a la hora de considerar los componentes, aunque la identificación de los espacios es muy rigurosa (con un listado donde son recogidos todos los espacios naturales y corredores que la componen), mientras que dicha identificación en el PROT es sólo indirecta (se cartografían los espacios que prestan determinados servicios ecosistémicos). En cualquier caso, queda en evidencia el potencial de la infraestructura verde para proteger elementos tradicionalmente desatendidos, ya sean elementos del medio natural (como los corredores ecológicos o los espacios sometidos a restauración ecológica), que elementos de carácter más antrópico (como los espacios agrarios o de interés paisajístico).

Por otro lado, en el presente análisis se ha creído interesante realizar una comparación de los elementos integrantes de la infraestructura verde analizados en los tres planes objeto de estudio con los componentes que se listan en la Estrategia española de infraestructura verde, para valorar el nivel de coherencia de los planes regionales con respecto a la Estrategia de nivel superior. Debe tenerse en cuenta en todo caso que los instrumentos analizados en este trabajo son de aprobación reciente, previa a la publicación del borrador de la Estrategia estatal.

La Estrategia española de infraestructura verde propone un total de 56 componentes que formarian parte de la infraestructura verde regional, donde se incluyen espacios naturales, agrarios, montes, $\mathrm{u}$ otro tipo de territorios. En este sentido, la FIG. 8 muestra la presencia o no de estos componentes en los tres planes territoriales regionales estudiados.

Componentes de IV / Comunidad autónoma - plan territorial

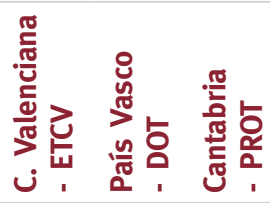

Zonas de Red Natura 2000

1. ZEPA

2. LIC/ZEC

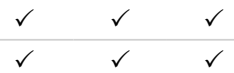

Espacios naturales protegidos

3. Parque nacional

4. Parque natural

5. Monumento Natural

6. Reserva natural

7. Área marina protegida

8. Paisaje Protegido

$\begin{array}{lll}\text { X } & \text { X } & \checkmark \\ \checkmark & \checkmark & \checkmark \\ \checkmark & \text { X } & \checkmark \\ \checkmark & \text { X } & \text { X } \\ \checkmark & \text { X } & \text { X } \\ \checkmark & \text { X } & \checkmark\end{array}$

Áreas protegidas por instrumentos internacionales

9. Humedales de Importancia Internacional, del Convenio relativo a los Humedales de Importancia Internacional especialmente como Hábitat de Aves Acuáticas (RAMSAR).

10. Sitios Naturales de la Lista del Patrimonio Mundial, de la Convención sobre la Protección del Patrimonio Mundial, Cultural y Natural.

11. Áreas protegidas OSPAR, del Convenio para la protección del medio ambiente marino del Atlántico del nordeste (OSPAR).

12. Zonas Especialmente Protegidas de Importancia para el Mediterráneo (ZEPIM), del Convenio para la protección del medio marino y de la región costera del Mediterráneo.

13. Geoparques declarados por la UNESCO.

14. Reserva Biosfera.

15. Reservas biogenéticas del Consejo de Europa.

Protección de Humedales

16. Zonas sensibles a la contaminación por nitratos.

17. Reservas naturales fluviales.

18. Zonas, cuencas o tramos de cuencas, acuíferos o masas de agua de protección especial.

$\begin{array}{lll}\checkmark & \checkmark & \checkmark \\ \checkmark & \checkmark & X \\ X & X & X \\ \checkmark & X & X \\ X & \checkmark & X \\ X & \checkmark & \checkmark \\ X & X & X\end{array}$

$\begin{array}{lll}\checkmark & \checkmark & X \\ X & \checkmark & X \\ X & \checkmark & \checkmark\end{array}$


Componentes de IV / Comunidad autónoma - plan territorial

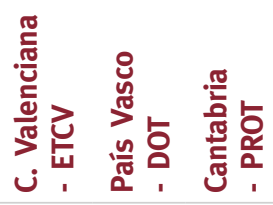

Montes

19. Zonas de Dominio Público forestal.

20. Montes de utilidad pública (MUP)

21. Montes protectores.

22. Montes privados y de socios sometidos a planes de gestión.

$\begin{array}{lll}\text { X } & \text { X } & \text { X } \\ \checkmark & \checkmark & \checkmark \\ \checkmark & \checkmark & \text { X } \\ \text { X } & \text { X } & \text { X } \\ \text { X } & \text { X } & \text { X } \\ \checkmark & \checkmark & \checkmark\end{array}$

23. Montes vecinales en mano común sometidos a planes de gestión.

24. Zonas de alto riesgo de incendio.

Zonas con gestión ambiental de dominio público

25. Zonas de Dominio Público hidráulico.

26. Zonas de Dominio público marítimo-terrestre.

27. Vías Pecuarias.

Espacios sujetos a actividades agrarias protectoras de la biodiversidad

28. Figuras de la PAC: condicionalidad, reverdecimiento, desarrollo rural.

$\begin{array}{lll}\checkmark & \checkmark & \checkmark \\ \checkmark & \checkmark & \checkmark \\ \checkmark & X & X\end{array}$

29. Áreas agrarias y forestales de alto valor natural (High Nature Value Farming-HNV)

30. Espacios sujetos a Contratos territoriales Agrarios

31. Áreas incluidas en Planes de razas autóctonas ganaderas.

32. Territorios con plantaciones para preservación de recursos genéticos.

33. Territorios con plantaciones sumideros de carbono.

34. Áreas con denominaciones de calidad (IGR)

$\begin{array}{lll}X & X & X \\ X & X & X \\ X & X & X \\ X & X & X \\ X & X & X \\ X & X & X \\ X & X & X\end{array}$

Territorios delimitados en figuras de conservación orientadas a especies

35. Especies Silvestres en Régimen de Protección Especial y Especies Amenazadas.

36. Colmenares.

$\begin{array}{lll}X & \checkmark & X \\ X & X & X\end{array}$

Lugares, espacios o enclaves definidos y con objetivos de conservación de biodiversidad

37. Áreas identificadas dentro del Catálogo Español de Hábitats en Peligro de Desaparición.

38. Espacios recogidos en Planes cinegéticos y cotos privados de caza.

\begin{tabular}{lll}
$\checkmark$ & X & X \\
X & X & X \\
X & X & X \\
X & X & X \\
X & X & X \\
X & X & X \\
$\checkmark$ & $\checkmark$ & X \\
$\checkmark$ & $\checkmark$ & $\checkmark$ \\
\hline$\checkmark$ & X & $\checkmark$ \\
\hline X & X & X \\
\hline X & X & X \\
\hline$\checkmark$ & $\checkmark$ & $\checkmark$ \\
\hline X & X & X \\
X & X & X
\end{tabular}

39. Espacios gestionados por Bancos de hábitat o de conservación de la naturaleza.

40. Áreas de conservación comunal.

41. Espacios incluidos en Acuerdos de Custodia del territorio.

42. Territorios en explotación en producción ecológica.

43. Zonas incluidas en el Inventario español de Lugares de Interés Geológico.

44. Cuevas y otras infraestructuras subterráneas.

45. Territorios históricos incluidos como Bienes de Interés Cultural.

46. Zonas donde se realicen acciones de lucha contra la desertificación del PAND.

47. Reservas privadas.

48. Corredores, áreas de montaña y otros elementos de conectividad.

49. Zonas de agricultura de montaña.

50. Reservas marinas de pesca.

Lugares delimitados y gestionados para la conservación de la biodiversidad en los siguientes planes e instrumentos de ordenación

51. Plan hidrológico y planes Hidrológicos de Demarcación.

52. Plan Estratégico del Patrimonio Natural y la Biodiversidad 2011-2017.

53. Plan de ordenación de los Recursos Naturales.

54. Planes de ordenación de los Recursos Forestales.

55. Plan de ordenación territorial y plan urbanístico.

56. Plan y estudio de paisaje (Convenio Europeo).

$\begin{array}{lll}\checkmark & \checkmark & \text { X } \\ \checkmark & \text { X } & \text { X } \\ \checkmark & \checkmark & \text { X } \\ \text { X } & \checkmark & \text { X } \\ \checkmark & \checkmark & \checkmark \\ \checkmark & \checkmark & \checkmark\end{array}$

FIG. 8/ Coherencia de los planes estudiados con los componentes contemplados por la Estrategia Estatal de infraestructura verde. 
Del análisis de la tabla se observa que los planes de la Comunidad Valenciana y la Comunidad Autónoma del País Vasco son los que presentan una mayor coincidencia con los componentes propuestos en la Estrategia estatal (mencionan aproximadamente la mitad de sus componentes). En el PROT de Cantabria, a su vez, se mencionan aproximadamente un tercio de los componentes de la lista de control, lo cual es consecuencia, en gran parte, de la indeterminada identificación de los componentes de su propia infraestructura verde. Además, hay que tener en cuenta que Cantabria tiene un desarrollo instrumental mucho menor en materia territorial y de medio ambiente, lo cual hace que el PROT no pueda fundamentarse en otros planes sectoriales de recursos naturales, forestal, de espacios fluviales, etc. para su propio contenido.

Los espacios naturales que cuentan con alguna figura de protección son, en general, los más claramente reconocibles en los tres planes analizados. Sin embargo, también hay que tomar en consideración que los planes no siempre mencionan exactamente los espacios o figuras de protección recogidos en la Estrategia estatal, simplemente porque, en ejercicio de sus competencias, la comunidad autónoma posee legislación propia y las figuras de protección o referentes derivados de ella son distintos a los estatales. En sentido contrario, los espacios agrarios son los grandes ausentes en los tres planes, aunque sí se suelen tener en cuenta indirectamente como proveedores de servicios ecosistémicos. También se aprecia una presencia desigual de otros enclaves que podrían ser potencialmente importantes para la conservación de la biodiversidad, pero que carecen de figuras de protección específicas o de una regulación pública (como las reservas privadas o las áreas de conservación comunal).

El dominio público (hidráulico, marítimo-terrestre) queda integrado, como elemento destacado, entre los componentes de la infraestructura verde. Por tanto la protección de los valores que integran estas estructuras territoriales al servicio de lo público queda totalmente garantizada en la infraestructura verde. E incluso se amplian sus áreas de influencia, restringuiendo los usos del suelo y amortiguando posibles impactos territoriales.

Por último, es interesante comprobar que los tres planes analizados subrayan el carácter multiescalar de la infraestructura verde, distinguen tres escalas de intervención (ver FIG. 9) y le otorgan funciones específicas a cada escala. En general, la escala local es la encargada de delimitar detalladamente los espacios que componen la infraestructura verde y corregir la posible fragmentación de los mismos, mientras que la regional articula los grandes espacios y corredores y la subregional cumple un papel de conexión entre ambas.

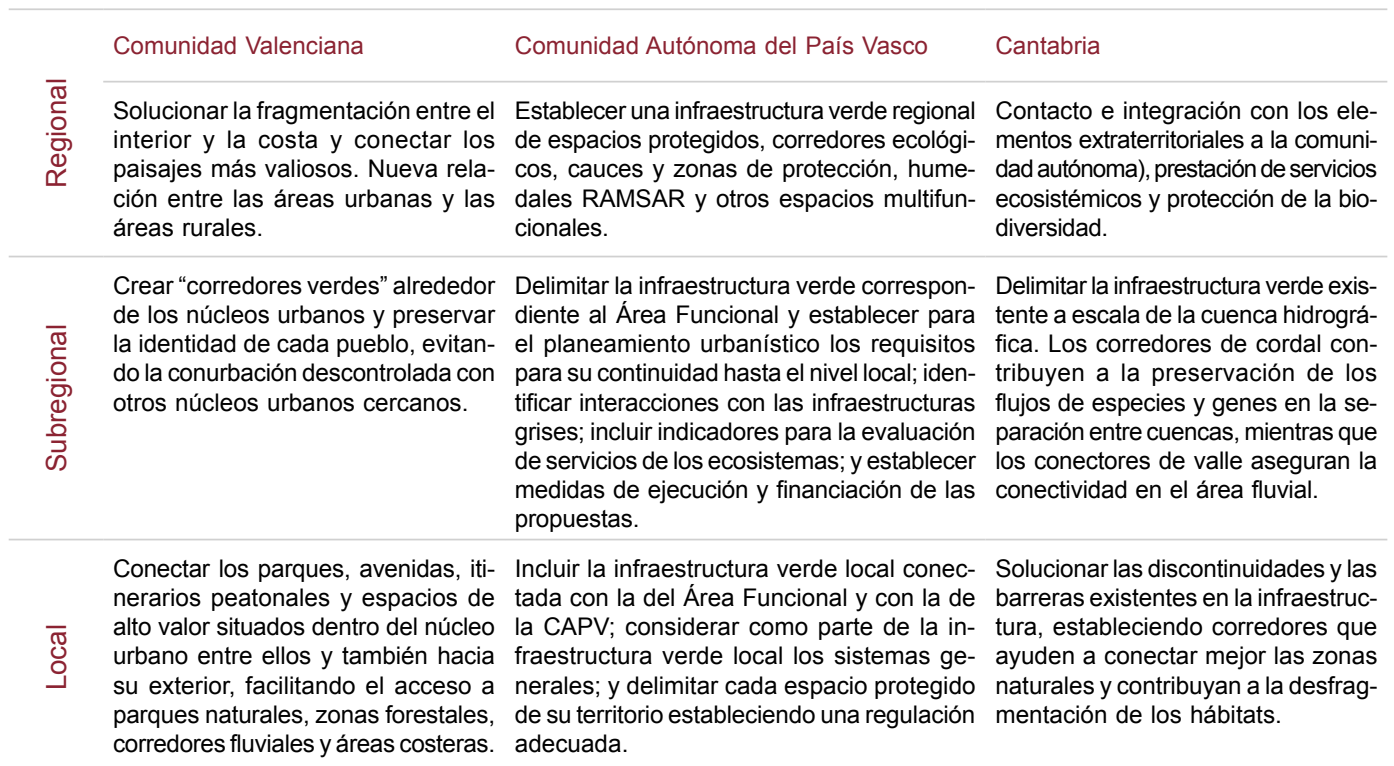

FIG. 9/ Funciones de la infraestructura verde en las diferentes escalas de planificación territorial en la Comunidad Valenciana, Comunidad Autónoma del País Vasco y Cantabria.

Fuente: Elaboración propia a partir de Generalitat Valenciana (2011), Gobierno Vasco (2019) y GobieRno de Cantabria (2018). 
La evaluación del efecto de estos planes es complicada, debido a su juventud. De los tres, tan sólo el PATIVEL está operativo; las DOT del País Vasco se aprobaron en julio de 2019 y las Directrices de Cantabria siguen el trámite de aprobación. En el proceso de tramitación del PATIVEL se presentaron 4.615 recursos por parte de propietarios afectados, ayuntamientos y colectivos profesionales ${ }^{21}$, especialmente en áreas que resultaban conflictivas por sus expectativas de transformación para uso residencial (Alcalá de Xivert, Oliva, Benissa y La Marina-Elx). Aunque ninguno de ellos ha prosperado, se ha conseguido, en un primer momento, detener procesos de urbanización en las áreas protegidas. A raíz de los efectos sufridos en la franja costera valenciana por la borrasca "Gloria" (enero 2020), han surgido algunas voces (colectivos de defensa ambiental, administración municipal) que han sugerido la necesidad de extender los criterios de protección establecidos en el PATIVEL a espacios con suelo urbanizable, y con programa aprobado, e incluso a áreas urbanas de primera línea de costa, cuestión que no entraba en la filosofía inicial del plan y que supone un conflicto de competencias. En 2020, dos años después de su aprobación, no se han desarrollado aún los planes de gestión previstos en la ley ni se ha realizado la propuesta de trazado definitivo de la vía verde litoral contemplada en el plan.

\section{Conclusiones}

El impulso a la infraestructura verde proveniente de la esfera europea ha hecho que su integración en el marco legal y en la planificación territorial de los estados miembros sea ya una realidad, de la cual también hallamos buenos ejemplos en el Estado español. Tras la nueva Ley de Patrimonio Natural y Biodiversidad de 2015 y la reciente publicación del borrador de la Estrategia Estatal de Infraestructura Verde y de la Conectividad y la Restauración Ecológicas, se prevé que las comunidades autónomas procedan a desarrollar sus propias estrategias de escala regional. De hecho, en ejercicio de sus competencias en ordenación del territorio, algunas comunidades han comenzado a integrar la infraestructura verde a sus políticas territoriales, aunque se trata de iniciativas concretas que, por el momento, cubren sólo una parte reducida del mapa estatal.

Esta integración de la infraestructura verde a las políticas territoriales regionales se ha producido por dos vías diferentes: en algunas comunidades

\footnotetext{
${ }^{21}$ Vid. documento elaborado al respecto por la Consellería de Habitatge, Obres Publiques i Vertebració del Territori de la Generalitat Valenciana. Disponible en:
}

se han aprobado estrategias o instrumentos específicos para la ordenación de la infraestructura verde, mientras que en otras, se ha optado por incorporar la infraestructura verde a los instrumentos de ordenación del territorio.

Por el momento las estrategias de infraestructura verde regionales son escasas, algo que resulta coherente si se tiene en cuenta que la Estrategia estatal ha sido presentada muy recientemente y que de ella deben emanar las regulaciones regionales. Aun así, algunas comunidades autónomas como Andalucía, Cataluña, la Comunidad Valenciana y Navarra han tomado la iniciativa poniendo en marcha sus propios planes o programas entre 2017 y 2019 , por lo que los primeros trabajos de infraestructura verde a nivel Estatal han provenido en realidad de las escalas inferiores. EI PATIVEL de la Comunidad Valenciana es un caso destacable, pues a pesar de centrarse en la franja litoral, constituye un documento integral de ordenación y gestión que regula usos del suelo futuros en la escala local. Es además un excelente ejemplo de la anticipación de los efectos del cambio climático en el territorio y el paisaje, puesto que ha incorporado esta variable como elemento integrante de la Infraestructura Verde regional.

En cuanto a los aspectos normativos de ordenación del territorio, la legislación territorial y de paisaje está aún lejos de acoger este nuevo elemento, pues únicamente las leyes de la Comunidad Valenciana (ordenación del territorio, urbanismo y paisaje) y Galicia (ordenación del territorio) aluden a la infraestructura verde. Varias leyes se han aprobado o revisado con posterioridad a la inclusión de la infraestructura verde en el ordenamiento legal estatal, por lo que omitir la infraestructura verde parece a todas luces una oportunidad perdida para la adaptación de la legislación regional a la nueva regulación española y europea.

A pesar de esta ausencia normativa ya existen varios ejemplos de integración de la infraestructura verde en instrumentos de ordenación del territorio de escala regional. En realidad, todos los planes territoriales regulan de una $u$ otra forma al menos una parte de los componentes de la infraestructura verde, aunque la integración explícita o directa es aún tímida en muchos de ellos.

El hecho de optar por la vía de la aprobación de un instrumento específico o la integración de la infraestructura verde en los planes territoriales no parece determinante para la efectividad de su regulación. Más bien resulta fundamental el

http://politicaterritorial.gva.es/documents/20551069/162407502/An álisis+de+las+alegaciones+e+informes+realizados+al+PATIVEL/ adf16e3f-11cf-405c-bfb9-4241413a7881. Consultado: mayo 2020. 
cumplimiento de la jerarquía jurídico-administrativa entre documentos normativos y administraciones competentes. Al igual que en cualquier proceso de planificación, para garantizar la coherencia de las intervenciones sobre el territorio lo más adecuado sería adoptar un proceso de planificación en cascada (PUJADAS \& FONT, 1998), incorporando la infraestructura verde como herramienta para la planificación en las estrategias o directrices territoriales de escala regional y posteriormente implementando su cumplimiento y mejorando sus contenidos (elementos integrantes) en las escalas inferiores (subregional, metropolitana y urbana). Para determinados elementos del medio que requieran un tratamiento específico se puede habilitar, como ha ocurrido en el caso de la Comunidad Valenciana, la redacción de un plan integral sectorial (litoral), teniendo siempre como referencia las determinaciones generales de la estrategia territorial regional. Lo importante es que se reconozca el valor de la infraestructura verde como herramienta para la gestión sostenible del territorio y ello supone una definición precisa de elementos integrantes y criterios de aplicación.

En cuanto a los planes territoriales de las comunidades autónomas que han incorporado la infraestructura verde, la ausencia de unas directrices comunes por parte de la escala europea o estatal en el momento de su elaboración ha contribuido a que presenten diferencias significativas en cuanto al significado y la metodología de planificación de la infraestructura verde en su articulado. Asimismo, los tres planes analizados no son completamente coherentes con las actuales directrices estatales, pues más allá de los espacios naturales protegidos y los corredores ecológicos, otros territorios reciben una atención limitada, como aquellos más antropizados pero con funciones ecosistémicas importantes (espacios agrarios) o los espacios naturales que carecen de figuras de protección específicas o de una regulación pública.

La consideración de la infraestructura verde como herramienta de planificación y gestión en los planes de ordenación territorial es un proceso reciente que tendrá un impulso importante en los próximos años gracias a la aprobación de la Estrategia Estatal de Infraestructura Verde y de la valoración de las bondades de este instrumento como plasmación efectiva de los criterios de sostenibilidad territorial en las escalas regional, subregional y local. Un aspecto fundamental para valorar la efectividad de la infraestructura verde como herramienta de planificación territorial en el futuro inmediato va a ser la conectividad real de espacios naturales o áreas de importancia patrimonial y cultural en el ámbito urbano (planes urbanísticos), que es, seguramente, el aspecto más complejo a desarrollar en la ordenación integral de los territorios. Pueden servir de ejemplo las experiencias desarrolladas en Berlín, con el desarrollo del Biotope Area Factor (BAF), así como, los casos del Space Green Factor en Malmo (Suecia), Seattle Green Factor (EE. UU.), Maryland Green Infraestructure (EE. UU.) o Greening Sydney Plan (Australia). Frente a una planificación física que se ha mostrado poco efectiva para garantizar el desarrollo sostenible especialmente en la escala urbana, la infraestructura verde se muestra ahora como un medio más eficaz para la planificación y gestión sostenible de los territorios.

\section{Bibliografía}

Agencia Europea del Medio Ambiente, Aema (2011): Green infrastructure and territorial cohesion. The concept of green infrastructure and its integration into policies using monitoring systems, Luxemburgo, Luxemburgo, Unión Europea.

ARIÑO, A. (dir.) \& GARCIA, P. (coord.) (2018): La sociedad valenciana en transformación (1975-2025), Valencia, España, Publicaciones de la Universitat de València.

Bardin, L. (2002): Análisis de contenido, Madrid, España, Akal.

Benabent, M. (2006): La Ordenación del Territorio en España, Sevilla, España, Universidad de Sevilla - Consejería de Obras Públicas y Transportes.

Benedict M.A. \& Mc Mahon E.T. (2002): Green infrastructure: smart conservation for the 21st century. Renewable Resources Journal, (20), 12-17.

BREUSTE, J.\& al. (2015): Introduction (special Issue on Green Infrastructure for Urban Sustainability). Journal of Urban Planning and Development, Vol. 141 (3).

Burriel de Orueta, E. L. (2009): La planificación territorial en la Comunidad Valenciana (1986-2009). [En línea]. Scripta Nova. Revista Electrónica de Geografía y Ciencias sociales, Vol. XIII (306). http://www.ub.edu/geocrit/sn/sn-306.htm

Calzada, P. (Dir.) (2019): Guía de infraestructura verde municipal. [En línea]. Red de Gobiernos Locales + Biodiversidad, Federación Española de Municipios y Provincias, Asociación de Empresas de Gestión de Infraestructura Verde, Asociación Española de Parques y Jardines Públicos. http://www.redbiodiversidad.es/sites/default/files/ GUIA Biodiversidad CAPITULOS1 5.pdf

CANTO, M. T. (2014): La planificación y gestión de la Infraestructura Verde en la Comunidad Valenciana. Revista Aragonesa de Administración Pública (43-44), 215-234.

CAPDEPón, M. (2016): Conflictos ambientales derivados de la urbanización turístico-residencial. Un caso aplicado al litoral alicantino. Boletín de la Asociación de Geógrafos Españoles (71), 31-57.

COMISIÓN EUROPEA (2011): Estrategia de la UE sobre la biodiversidad hasta 2020: nuestro seguro de vida y capital natural, Bruselas, Bélgica, Unión Europea.

- (2013): Infraestructura verde: mejora del capital natural de Europa, Bruselas, Bélgica, Unión Europea. 
- (2014): Construir una infraestructura verde para Europa, Bruselas, Bélgica, Unión Europea.

- (2015): Revisión intermedia de la Estrategia de la UE sobre la Biodiversidad hasta 2020, Bruselas, Bélgica, Unión Europea.

- (2019): Revisión de la aplicación de la política medioambiental. Informe de España, Bruselas, Bélgica, Unión Europea.

de LA Cruz, Á., \& Madurga, M. I. (2019): Los Instrumentos de Ordenación del Territorio en España. Estudio comparado de la legislación y los instrumentos vigentes. Ciudad Y Territorio Estudios Territoriales (CyTET), 51(199), 175-200.

https://recyt.fecyt.es/index.php/CyTET/article/ view/76722

Delgado, C. (2010): La ordenación territorial en Cantabria: normas, planes, proyectos y realidades. Cuadernos Geográficos, 47 (2010-2), 453-491.

- (2012): Protección y ordenación del medio natural en Cantabria. Normativa, instrumentos y conflictos territoriales. Boletín de la Asociación de Geógrafos Españoles (60), 115-140.

Elorrieta, B. \& Olcina, J. \& SÁnchez, D. (2016): La sostenibilidad en la planificación territorial de escala regional. Cuadernos Geográficos, 55 (1), 149-175.

FARINós, J. \& EloRRIETA, B. (2017): "La articulación territorial de España: cohesión a partir de una nueva gobernanza". En J. FARINós y J. OLCINA (coords), Geografía regional de España. Espacio y comunidades: bases para una regionalización renovada del territorio español (pp. 563-617), Valencia, España, Tirant lo Blanch.

FARIÑA, J. \& NAREDO, J. M. (Dir.) (2010): Libro blanco de la sostenibilidad en el planeamiento urbanístico español. Madrid, Centro de publicaciones del Ministerio de la Vivienda.

FERIA, J. M. \& SANTIAGO, J. (2017): Naturaleza y ciudad. Perspectivas para la ordenación de la infraestructura verde en los planes territoriales metropolitanos en España. Boletín de la Asociación de Geógrafos Españoles (74), 117-141.

FERnÁNDEZ de GatTA, D. (2018): La Estrategia estatal de infraestructura verde y de la conectividad y restauración ecológicas: un nuevo instrumento para proteger la biodiversidad. Actualidad Jurídica Ambiental (81), 57-120.

García-Blanco, G., Carrao, H. \& Fons, J. (2019): "La Infraestructura Verde en beneficio del desarrollo territorial estratégico: ESPON GRETA". En FUNDICOT, $9^{\circ}$ Congreso Internacional de Ordenación del Territorio: Planificación y gestión integrada como respuesta (pp. 514-531), Madrid, España, FUNDICOT.

Generalitat de Catalunya (2017): Programa d)Infraestructura verda de Catalunya 2017-2021. [En línea]. Generalitat de Catalunya. http://mediambient.gencat.cat/web/.content/home/ ambits dactuacio/avaluacio ambiental/infraestructura verda serveis ecosistemics/infraestructura verda/PIVC v10 144ppi.pdf

Generalitat Valenciana (2002): Estrategia Valenciana para la Gestión Integrada de la Costa, Valencia, España, D.G. de Puertos y Costas de la Consellería de Infraestructuras y Transporte de la Generalitat Valenciana.

- (2011): Estrategia Territorial de la Comunitat
Valenciana, Valencia, España, Consellería de Infraestructuras, Territorio y Medio Ambiente de la Generalitat Valenciana.

- (2018): Plan de Acción Territorial de la Infraestructura Verde del litoral, Valencia, España, Consellería de Vivienda, Obras Públicas y Vertebración del Territorio de la Generalitat Valenciana.

- (2019): Objetivos de Calidad e Instrucciones Técnicas para la ordenación y gestión de los Paisajes de Relevancia Regional de la Comunitat Valenciana, Valencia, España, Consellería de Política Territorial, Obras Públicas y Movilidad.

Gobierno de Cantabria (2018): Plan Regional de Ordenación del Territorio. [En línea]. Gobierno de Cantabria.

http://geoservicios.cantabria.es/Series/Descargas PROT/PROT AprobacionInicial Abril2018/C PLAN/Memoria/PROT 21 Analisis.pdf

Gobierno de España (2019): Estrategia Estatal de Infraestructura Verde y de la Conectividad y la Restauración Ecológicas. Borrador mayo 2019. [En línea]. Ministerio para la Transición Ecológica, Gobierno de España.

https://www.miteco.gob.es/images/es/borradoreeivcre infopublica tcm30-497133.PDF

Gobierno de NavarRa (2019): Estrategia de Infraestructura Verde en Navarra. [En línea]. Gobierno de Navarra.

http://internet.gccpublica.navarra.es/sot/ Documentos/INFRAESTRUCTURA\%20VERDE/ ESTRATEGIA\%20INF\%20VERDE.pdf

GoBIeRno VAsco (2019): Directrices de Ordenación del Territorio de la CAPV, Vitoria, España, Gobierno Vasco - Eusko Jaurlaritza.

Jauregui, P. \& ERquicia, J. M. (1992): Marco de Ordenación Territorial de la Comunidad Autónoma del País Vasco. Rev. Munibe, (44), 61-67.

Jones, M. \& STENSEKE, M. (eds.) (2011): The European Landscape Convention: Challenges of participation, Dordrecht, Holanda, Springer.

JUNTA DE ANDALUcía (2018): Plan director para la mejora de la conectividad ecológica en andalucía. Una estrategia de Infraestructura Verde. Informe de síntesis. [En línea]. Consejería de Medio Ambiente y Ordenación del Territorio, Junta de Andalucía. http://www.juntadeandalucia.es/medioambiente/ portal web/web/temas ambientales/biodiversidad $/ 6$ habitats y ecosistemas $/ 0$ plan conectividad/plan aprobado/PDMCEA sintesis 2018.pdf

LAFORTEZZA, R. \& al. (2013): Green Infrastructure as a tool to support spatial planning in European urban regions. iForest - Biogeosciences and Forestry, (6), 102-108.

Lo PICcolo, F., \& Todaro, V. (2013):La continuidad ecológicoambiental como estrategia de ordenación del territorio. Ciudad Y Territorio Estudios Territoriales (СуTET), 45(178), 789-797. https://recyt.fecyt. es/index.php/CyTET/article/view/76273

Losada, I.; Izaguirre, C. \& Diaz, P. (2014): Cambio climático en la costa española, Madrid, España, Oficina Española de Cambio Climático, Ministerio de Agricultura, Alimentación y Medio Ambiente.

MELL, I.C. (2008): Green Infrastructure: concepts and planning. FORUM Ejournal, Vol. 8 (June 2008), 69-80.

Padilla, A. \& al. (2019): El papel del inventario ambiental exhaustivo en el proceso de la configuración 
definitiva de la Infraestructura Verde del litoral sur de la Comunitat Valenciana. Boletín de la Asociación de Geógrafos Españoles, Vol. 82, 2805, 1-37.

PuJADAs, R. \& Font, J. (1998): Ordenación y planificación territorial, Madrid, Síntesis.

Rando, E. (2019): "Tres cuestiones jurídicas de actualidad en las políticas territoriales cántabras". En FUNDICOT, $9^{\circ}$ Congreso Internacional de Ordenación del Territorio: Planificación y gestión integrada como respuesta (pp. 81-97), Madrid, España, FUNDICOT.

URIARTE, M. (2014): Planificar la infraestructura verde urbana. Revista Vasca de Administración Pública. Herri-Arduralaritzako Euskal Aldizkaria (99-100), 2.873-2.895

Valladares, F., Gil, P. \& Forner, A. (coord.) (2017): Bases científicotécnicas para la Estrategia estatal de infraestructura verde $y$ de la conectividad $y$ restauración ecológicas, Madrid, España, Ministerio de Agricultura y Pesca, Alimentación y Medio Ambiente.

VeGA, J.J. \& al (2019): "Una propuesta para la integración de la infraestructura verde en el modelo territorial de Cantabria". En FUNDICOT, $9^{\circ}$ Congreso Internacional de Ordenación del Territorio: Planificación y gestión integrada como respuesta (p. 497), Madrid, España, FUNDICOT.

Vera-Rebollo, J.F. \& Olcina, J. (2017): Análisis de la coherencia metodológica y de los datos utilizados en la memoria justificativa del PATIVEL. [inédito] Conselleria de Vivienda, Obras Públicas y Vertebración del Territorio de la Generalitat Valenciana, Universidad de Alicante.

Vera-Rebollo, J.F.; Olcina, J. \& Sainz-Pardo, A. (2019): La incorporación de la infraestructura verde en la ordenación territorial. El plan de acción territorial de la infraestructura verde del litoral de la Comunidad Valenciana, PATIVEL. Ciudad y
Territorio. Estudios Territoriales, Vol. LI (200), 467-490.

Weber T.; Sloan, A. \& Wolf, J. (2006) Maryland's Green Infrastructure assessment: development of a comprehensive approach to land conservation". Landscape and Urban Planning, Vol. 77 (1-2), 94-110.

\section{Listado de acrónimos/siglas}

\section{AEMA Agencia Europea del Medio Ambiente \\ CAPV Comunidad Autónoma del País Vasco \\ CE Comisión Europea \\ DOT Directrices de Ordenación Territorial}

ESPON Observatorio en Red de la Ordenación del Territorio Europeo

ETCV Estrategia Territorial de la Comunitat Valenciana

GRETA Green infrastructure: Enhancing biodiversity and ecosystem services for territorial development

PAT Plan de Acción Territorial

PATIVEL Plan de Acción Territorial de Infraestructura Verde del Litoral

POL Plan de Ordenación del Litoral

PROT Plan Regional de Ordenación Territorial

PTP Planes Territoriales Parciales 
CIUDAD Y TERRITORIO

ESTUDIOS TERRITORIALES

ISSN(P): 1133-4762; ISSN(E): 2659-3254

Vol. LIII, № 207 , primavera 2021

Págs. 47-64

https://doi.org/10.37230/CyTET.2021.207.03

\title{
Evaluación de la efectividad en la regeneración urbana de nuestras ciudades. Lecciones aprendidas
}

\author{
Eduardo RUBIO-HUERTAS ${ }^{(1)}$ \\ José Må de Ureña-Francés ${ }^{(2)}$
}

(1)Ingeniero de Caminos, Canales y Puertos. Doctorando de la UCLM. (2) Profesor Emérito de Urbanismo y Ordenación del Territorio en la UCLM.

RESUMEN: Las experiencias de regeneración o rehabilitación urbana, ante la ausencia de evaluaciones concretas, han de ser programadas con previsiones de impactos medibles y cuantificables, garantizando el acierto de las decisiones. Se pretende establecer un marco actualizado de cómo se han evaluado las operaciones de regeneración urbana desde una perspectiva internacional, donde las secuelas de la crisis han hecho reflexionar sobre la necesidad de asegurar el cumplimiento de los objetivos. Se ha realizado una revisión bibliográfica de las experiencias en el mundo occidental, especialmente en España, identificando los factores determinantes, así como los casos de éxito.

PALABRAS CLAVE: Regeneración urbana; Rehabilitación urbana; Evaluación de la regeneración; Indicadores urbanos; Métodos de evaluación urbana.

\section{Evaluation of the effectiveness in the urban regeneration of our cities. Lessons learned}

\begin{abstract}
The urban regeneration actions must be programmed with predictions of measurable and quantifiable impacts, guaranteeing the correctness of decisions. It is intended to establish an updated framework of how urban regeneration operations have been evaluated from an international perspective, where the aftermath of the crisis has led to reflection on the need to ensure compliance with the objectives. A bibliographic review of the experiences in the western world, especially in Spain, has been carried out, identifying the determining factors, as well as the success cases.
\end{abstract}

KEYWORDS: Urban regeneration; Urban rehabilitation; Evaluation of regeneration; Urban indicators; Urban evaluation methods.

Recibido: 23.02.2020; Revisado: 08.10.20

Correo electrónico: erubioh@ciccp.es; № ORCID: https://orcid.org/0000-0002-5247-4326;

Correo electrónico: Josemaria.urena@uclm.es; № ORCID: https://orcid.org/0000-0002-0404-1454

Los autores agradecen los comentarios y sugerencias realizados por los evaluadores anónimos, que han contribuido a mejorar y enriquecer el manuscrito original. 


\section{Introducción}

E $\mathrm{n}$ las primeras dos décadas del siglo $\mathrm{XXI}$, se ha podido constatar una cierta tendencia hacia la globalidad como contrapunto a la amplia diversidad de metodologías, enfoques y criterios de análisis. Sería deseable que los sistemas de medida de sostenibilidad urbana, satisfacción con nuestros entornos, cumplimiento de expectativas y calidad de vida en general, pudiesen ser evaluables bajo patrones internacionales, estándares reconocidos y aceptados por todas las comunidades o países, que estuviesen basados en datos fáciles de obtener. Sin embargo, en la práctica de la regeneración urbana abundan la falta de uniformidad de criterios, el enfoque local, los intereses sectoriales y la secuencia temporal cortoplacista. Incluso desde el mundo académico y de la investigación, el análisis de la efectividad de las intervenciones de regeneración urbana puede llegar a ser tan dispar que se enfrentan teorías eminentemente sociológicas o humanísticas con visiones más aritméticas.

Ante este escenario, una postura pragmática puede ser la observación (crítica y analítica) de la experiencia, identificando no solo los casos de éxito, sino también los de menor impacto, con el fin de diseccionar los mecanismos de evaluación, tanto en la fase de concepción y diseño inicial de las iniciativas, como de la implementación de medidas, asociados a los programas y/o proyectos concretos de regeneración urbana. De este modo, se puede constatar qué planteamientos de partida son los más adecuados, cómo influye el marco teórico inicialmente propuesto, cómo se implementan los objetivos que se pretenden conseguir, qué instrumentos de gestión, control y seguimiento resultan más adecuados y qué agentes deben ser movilizados para la consecución de los objetivos deseados.

Pero este planteamiento no siempre resulta fácil de llevar a cabo, habida cuenta de numerosos factores que influyen en los procesos de regeneración urbana. Además, es una evidencia que existen tantas experiencias como modelos de gestión desarrollados (HERnÁndeZ-AJA \& MATESANZ, García \& Rodriguez, 2014) y, en consecuencia, cualquier pretensión de unificar criterios, indicadores numéricos $u$ otros elementos de ponderación para conseguir un automatismo para evaluar los resultados de los procesos de regeneración urbana, se torna una utopía.

Los aspectos determinantes sobre los que hoy en día se desarrollan las políticas de regeneración urbana son de carácter económico, social, físico y ambiental (PARKINSON, 2014), en una mezcla heterogénea con diferentes proporciones. El carácter de actuaciones integradas sugiere una evolución sobre enfoques tradicionales basados en políticas sectoriales que habitualmente se han venido desarrollando en las ciudades de forma independiente (p.e. rehabilitación de viviendas, mejora/reurbanización de espacios públicos, inclusión social, fomento de la actividad económica o mejora de la eficiencia energética de edificios e infraestructuras). La Regeneración Urbana Integrada (RUI) parte de la premisa de que la actuación de forma coordinada sobre áreas concretas produce sinergias positivas, por lo que se incluyen medidas que inciden sobre el espacio urbano, la calidad medioambiental, la promoción económica, la empleabilidad, la integración y bienestar social y la gobernanza comunitaria en la concepción y diseño de los programas y proyectos de regeneración urbana (NAVARRo \& RODRÍGUEZ, 2015a).

Por lo general, la mayor parte de las evaluaciones realizadas sobre las actuaciones de regeneración urbana son a posteriori y se centran en el grado de ejecución de las intervenciones, siendo mucho menor el número de evaluaciones de la efectividad de esas intervenciones en la calidad de vida de los habitantes y en la corrección de los aspectos que favorecieron la vulnerabilidad de esos barrios donde se ha actuado tras identificar la necesidad de su regeneración (HUUB \& BECKERSB, 2012).

El artículo presenta una síntesis de los factores que intervienen en la evaluación de los programas de regeneración urbana a partir de una revisión bibliográfica, especialmente en el ámbito anglosajón como referente en el inicio de los programas de regeneración integral y en el de España, como caso concreto.

\section{Evolución de la regeneración urbana desde mediados del siglo XX}

La magnitud del problema es bien distinta en algunas partes del mundo donde el reto en sí es, más que una "regeneración urbana", la propia "generación" estricta de asentamientos urbanos con unos mínimos de habitabilidad y dignidad. En Latinoamérica unos 90 millones son chabolistas (BANCo Mundial, 2019), más de 250 millones solo en Asia Oriental y Pacífico (BAKER \& GADIL, 2017) y en África casi 60 millones (SolEs I Coll, s.f.). Según datos de ONU Habitat, el porcentaje de población urbana que vivía en este tipo de asentamientos a nivel mundial en el año 2014 era del $29,8 \%$. 
Las realidades de países de la vieja Europa, como Francia con su problemática asociada a los "grandes ensambles" (GuerRand, 2004), Gran Bretaña y sus iniciativas como el New Deal for Communities Programme, pionero en el enfoque de intervenciones de regeneración basadas en áreas (LAWLESS, 2007), Italia o la apuesta por el reciclaje de su inmenso patrimonio arquitectónico (GASTALDI, 2017) o en los Países Bajos (Aalbers \& Van BeCKHoven, 2009), presentan diferencias en su evolución. Diferencias, tanto entre sí, como con los antiguos países socialistas donde el período de influencia soviética se caracterizó por el "urbanismo de bloques" (SAIZ, 2004), los escandinavos en su apuesta por la reinvención de los centros históricos (García-Hípola \& BeLtrán, 2011) o incluso los del Arco Mediterráneo, como es el caso de España y sus particularidades asociadas a cuatro décadas de dictadura.

Los procesos de regeneración urbana reglados, focalizados tanto en áreas concretas (barriadas), como en ciudades completas, han sido una constante desde mediados del siglo XX hasta la actualidad. Por lo general, en el denominado "mundo occidental"1, los enfoques han ido sufriendo transformaciones con el transcurso del tiempo en base a continuas adaptaciones, de acuerdo con los intereses de (algunos o diversos, pero no siempre todos) los agentes que intervienen en esos procesos complejos. Es habitual hablar de generaciones de políticas de regeneración, en referencia a períodos temporales con sus propias características económicas, sociales o políticas, con distintos protagonistas que implican políticas o maneras de afrontar los problemas identificados desde determinadas perspectivas (CARMON, 1999).

La denominada "era del bulldozer" fue una primera generación de políticas de intervención en las ciudades, puesta en marcha en la década de los 50, donde la recuperación del espacio físico degradado a través de intervenciones basadas en el saneamiento de los enclaves marginales de las ciudades mediante la sustitución de infraviviendas y el desplazamiento de sus habitantes, fueron la tónica habitual (SHORT, 1982), a través de actuaciones lideradas por las administraciones públicas (GiBSON \& LANGSTA, 1982). Es la etapa de la renovación (o reconstrucción).

Una segunda generación de regeneración urbana se manifestó en los años 70 y 80 , poniendo el énfasis en la etapa de la rehabilitación, tanto de viviendas como de los espacios públicos,

\footnotetext{
${ }^{1}$ A los efectos del presente artículo, se entiende como
} "mundo occidental" el formado por los países de tradición introduciendo el concepto de integralidad como elemento necesario para conseguir la mejora no solo del entorno físico, sino de sus habitantes, implementando acciones de carácter social e involucrando a la sociedad civil en los procesos a través de lo que se comenzó a llamar "participación ciudadana" (MOULAERT \& PARRA \& SWYNGEDOW, 2014). De esta época vienen fenómenos tan actuales como son los procesos de gentrificación (SMITH, 1979), por los que la población tradicional de los barrios es desplazada por nuevos residentes de mayor poder adquisitivo, generalmente tras un proceso de mejora y rehabilitación, tanto de las viviendas como del entorno físico (GRIFTH, 1996), aunque a veces también sucede por "contagio" de una zona adyacente a barrios de mayor poder adquisitivo.

La tercera generación de regeneración urbana comenzó a desarrollarse a principios de los años 80 , tras considerarse por parte de algunos gobiernos (fundamentalmente conservadores) en EEUU y en el Reino Unido el fracaso de los programas sociales de las décadas anteriores, desarrollándose una serie de alianzas entre los poderes públicos y privados, tanto a nivel individual, como con los agentes empresariales, inversores, comerciantes, etc. (Gibson \& Prathers, 1977).

Navarro (2015a) aporta la descripción de una nueva generación de tendencias en regeneración, con su origen a finales de los años 90 y principios del siglo XXI, la revitalización, donde el concepto de regeneración urbana integral se consolidó como marco de referencia para la programación de actuaciones, tanto a nivel de barrio como en ciudades completas. Las actuaciones van dirigidas a los espacios físicos y a las personas, potenciando las coaliciones o alianzas entre distintos agentes de los ámbitos privado y público, fomentando la participación inclusiva en órganos de gestión; es la época de las grandes intervenciones en el mundo occidental y sobre todo en Europa, asentada de forma global la importancia de las ciudades en el desarrollo socioeconómico de los estados. En esta generación, donde las ciudades, incluso los barrios, compiten entre sí para ser más atractivos de cara a los inversores y residentes potenciales, los proyectos culturales toman protagonismo como catalizadores de algunos procesos de revitalización de los barrios degradados, incorporándose al catálogo de medidas o herramientas habituales en los programas como impulso y valor añadido de los entornos (BIANCHINI \& PARKINSON, 1993; ApARICIO A., 2013).

anglosajona (y su traslación a los EEUU), así como los países europeos no procedentes del bloque soviético. 
La generación actual de políticas de regeneración urbana va más allá del concepto de integralidad y supera incluso los ámbitos de planificación tradicionales, es el tiempo de la reinvención. La cumbre de la Organización de las Naciones Unidas (ONU) celebrada en Nueva York el 25 de septiembre de 2015, marcó un punto de inflexión en la manera de entender diversos ámbitos de actuación a nivel de políticas de intervención, entre otros aspectos, sobre las ciudades. La aprobación de la Agenda denominada "Transformar nuestro mundo: la Agenda 2030 para el Desarrollo Sostenible" estableció los 17 Objetivos de Desarrollo Sostenible (ODS), entre los cuales cabe reseñar el Objetivo 11: Lograr que las ciudades y los asentamientos humanos sean inclusivos, seguros, resilientes y sostenibles, cuya primera meta, con un horizonte temporal establecido en 2030, consiste en:

"asegurar el acceso de todas las personas a viviendas y servicios básicos adecuados, seguros y asequibles y mejorar los barrios marginales" (ORganización de LAS NaCIONES UnidAs, 2015).

Con el vigente enfoque global de las actuaciones de regeneración, los ámbitos basados en áreas ceden paso a la creación de estrategias de ciudad, conectando incluso con cuestiones supramunicipales que abarcan más allá de las conurbaciones urbanas, compartiendo visiones con la Ordenación del Territorio como disciplina científica. En relación con el marco financiero de esta cuarta generación, PARKINSON (2014) afirma:

\footnotetext{
"Habrá que pasar de un modelo de desarrollo basado en las subvenciones públicas a otro en el que las asociaciones público-privadas, la innovadora ingeniería económica, una mayor cantidad de reciclaje de fondos mediante mecanismos destinados a tal fin con el sector público asuman mayores riesgos, pero también obtengan mayores recompensas". (p. 23).
}

En el caso concreto de España, y debido a las particularidades del conflicto civil y de la posterior implantación de un régimen totalitario centralista, la generaciones o políticas de recuperación de áreas urbanas han venido presentando ciertos desfases con el contexto europeo. Consecuentemente los procesos de renovación se generalizaron desde la década de los 60 hasta el final de la dictadura (en 1975), comenzando entonces la etapa de la rehabilitación hasta mediados de los 90, donde se inicia el predominio de la regeneración hasta el cambio de paradigma que supuso la crisis global inmobiliaria, para finalmente instaurarse la revitalización como práctica habitual en los programas e intervenciones (RUBIO \& UREÑA, 2020).

Tal como se representa en la FIG. 1, hay dos momentos/etapas adicionales relevantes: una etapa justo anterior a la desaparición del franquismo en la que las asociaciones de vecinos consiguieron bastante fuerza a la hora de plantear sus reivindicaciones y una etapa justo posterior a la dictadura, en la que se interviene solo en los elementos públicos de los barrios periféricos mediante reurbanización y re-equipamiento. Esta segunda etapa es muy evidente en cuanto hay ayuntamientos democráticos (muchos de ellos de ideología progresista) y ambas se producen ante todo en barrios periféricos (CERVERO-SÁNCHEZ, 2020). Son dos hechos relevantes porque el primero matiza la pura renovación (sustitución) y el segundo porque todavía no se interviene sobre los edificios lucrativos (vivienda y comercio en los barrios periféricos), si no solo sobre los espacios de acceso público (calles, parques, etc.), esto es sobre la urbanización y sobre los equipamientos.

Solo en la última década el impulso de la financiación europea ha favorecido la implementación del concepto de reinvención en forma de las Estrategias de Desarrollo Urbano Sostenible (EDUSIs), que abarcan conceptos más allá de la integrali-

\section{Contexto anglosajón y Europa Occidental}

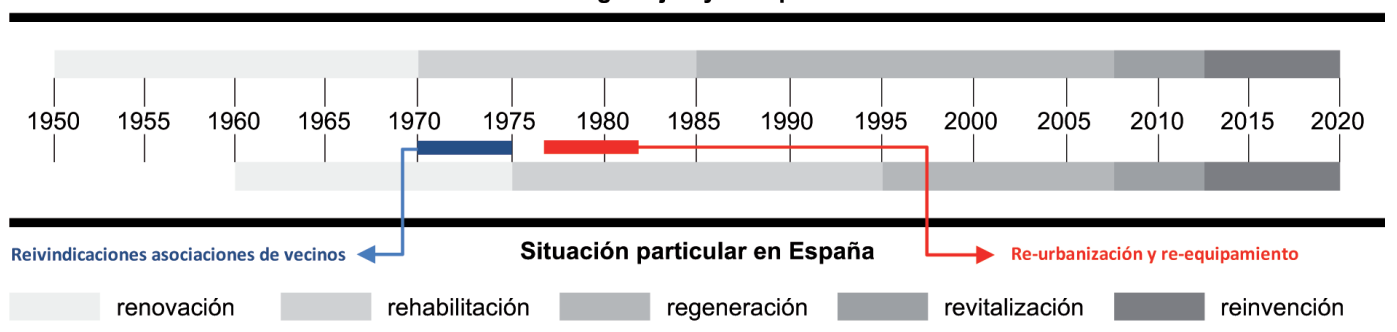

Evolución comparada de las políticas de mejora urbana.

Fuente: Elaboración propia basada en estudios previos de los autores. 


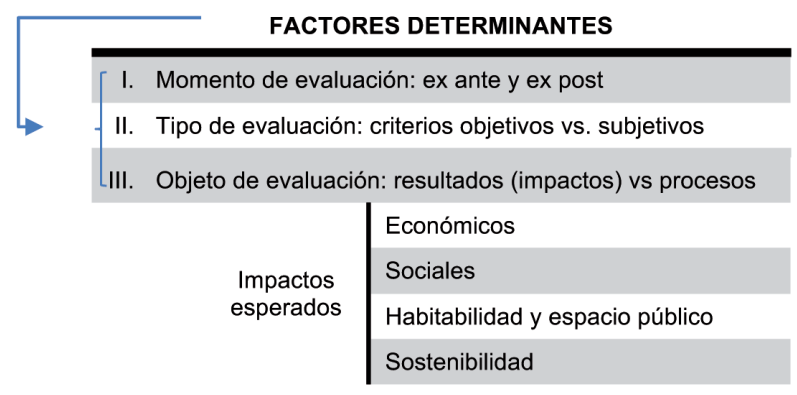

MÉTODOLOGÍAS DE EVALUACIÓN

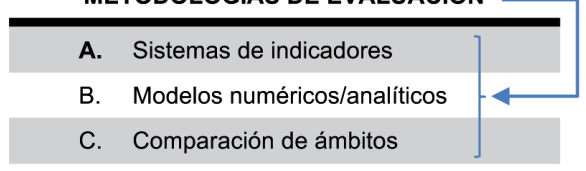

FIG. 2/ Resumen de factores y metodologías para la evaluación de programas de regeneración urbana.

Fuente: Elaboración propia basada en estudios previos de los autores.

dad, tal como se ha descrito anteriormente, incluyendo elementos como la sostenibilidad en toda su acepción.

\section{Aspectos clave para la evaluación de las consecuencias de las actuaciones de regeneración urbana}

A la hora de evaluar los impactos de las intervenciones o iniciativas de regeneración urbana basadas en áreas (Area-Based Interventions o ABls por sus siglas en inglés), la producción de definiciones, estudios, guías o tratados es tan amplia que costaría condensar solamente las tendencias, grupos de trabajo, evolución o líneas de investigación existentes al respecto, pues el tema se ha tratado desde innumerables puntos de vista, con enfoques que han variado a lo largo del tiempo en función de parámetros geoespaciales, socioeconómicos, e incluso bajo la continua influencia de los avances tecnológicos en lo relacionado con el tratamiento de la información, las posibilidades de la geolocalización o herramientas más avanzadas como la metodología BIM (Building Information Modeling), PSS (Planning Support Sytems), etc. Las secuelas de la última crisis han hecho reflexionar a las administraciones, como depositarios de la capacidad de decidir sobre el destino de las inversiones públicas, respecto de la necesidad de asegurar el cumplimiento de los objetivos marcados.

Se exponen a continuación (ver FIG. 2) una serie de factores que son determinantes en los procesos de regeneración urbana, y en base a los cuales suelen desarrollarse diversos métodos de evaluación de dichos procesos, pudiendo estar interrelacionados entre ellos, de acuerdo con los objetivos que predominan en el marco o políticas de referencia que rigen los distintos programas. Generalmente, en la práctica ni los factores, ni los métodos son excluyentes entre sí.

Las investigaciones sobre este tema concluyen que faltan herramientas prácticas y accesibles para comparar y seleccionar alternativas de intervención en la escala de barrio, incorporando criterios de sostenibilidad en el proceso de toma de decisiones (SIMÓN-RoJo \& HERNANDEZ-AJA, 2011), especialmente en lo que se refiere a aspectos sociales y económicos, de manera que se asegure la efectividad de las inversiones.

\subsection{Factores determinantes: momento de evaluación (ex ante y ex post)}

Si bien la metodología de evaluación ideal (utópica) es aquella que permite hacer previsiones fiables desde antes del inicio de los programas, incluyendo todo su ciclo de ejecución y sus consecuencias, como por ejemplo en los actuales programas de regeneración financiados por la Unión Europea, donde uno de los componentes en los documentos de diseño son los sistemas de indicadores y los valores esperados de mejora en un determinado período (es decir, una evaluación ex ante), la evidencia empírica es que frecuentemente se producen circunstancias imprevistas y/o sobrevenidas que alteran de forma más o menos significativa las condiciones de partida. Por ello, las evaluaciones a lo largo de los programas, incluso las que no están inicialmente previstas en su concepción, se hacen necesarias, siendo el de la comparación entre áreas una buena manera de llevarlas a cabo, con las limitaciones y reservas inherentes a dicha falta de planificación (MongIL, 2010). 
El ejemplo más significativo de evaluación ex post en España lo constituye el proyecto RUCOSA ${ }^{2}$ en el que se han analizado 81 programas de regeneración urbana (desarrollados en Andalucía entre los años 1990 a 2015) en base a tres elementos fundamentales: las condiciones de partida, el desarrollo del proyecto de intervención y sus impactos, de manera que se establecen una serie de escenarios evaluativos en función de la calidad sustantiva (diagnóstico, diseño, objetivos y medidas de los programas) y su lógica interna (coherencia entre las áreas de actuación y el diagnóstico, en los objetivos y en las actuaciones), generando diversos niveles de profundidad en el análisis y sus conclusiones (NAVARRO \& Rodríguez, 2015b).

\subsection{Factores determinantes: tipo de evaluación (criterios objetivos vs. subjetivos)}

No todo es "ciencia exacta" en relación con la evaluación de los programas de regeneración urbana, ni en su dimensión sustantiva (diagnóstico, objetivo y actuaciones), ni en su dimensión procedimental. Los análisis de satisfacción residencial evidencian la importancia de variables subjetivas interrelacionadas entre sí a la hora de valorar o considerar determinadas actuaciones que persiguen la complacencia de los residentes, pues se trata de identificar prioridades dentro de los programas para conseguir la mayor satisfacción (Von BREYMANN, 2014).

Desde el siglo pasado ya se ha venido manejando el concepto de indicadores de bienestar subjetivo (Subjective Well-Being o SWB por sus siglas en inglés) como alternativa a los clásicos indicadores sociales y económicos, ya que para entender el bienestar de una persona hay que medir las reacciones cognitivas y afectivas tanto respecto de su vida en general, como a diferentes aspectos de ella (DIENER \& SUCH, 1997). Resulta evidente pensar que una adecuada integración entre ambos enfoques puede aportar mejores resultados en los análisis tanto de diagnóstico, como de evaluación, pues no solo los SWB poseen una importante componente subjetiva, sino que el impacto de las medidas contenidas en los programas puede hacer cambiar la percepción en los residentes en función de si han sido directamente beneficiarios de alguna de ellas (NAVArRo, Rodríguez, Zapata \& MAteos, 2015a).

\footnotetext{
${ }^{2}$ Regeneración Urbana y Cohesión Social en Andalucía, financiado por el Fondo Europeo de Desarrollo Regional, en
}

\subsection{Factores determinantes: objetos de evaluación (resultado/impactos) vs. procesos}

A la hora de evaluar los programas, es importante considerar los objetivos previamente establecidos, enmarcados en el concepto de integrabilidad, porque dependiendo de ellos, las metodologías empleadas pueden variar sustancialmente.

\subsubsection{Impactos económicos}

Numerosos tipos de análisis inciden en los impactos económicos directamente asociados a las inversiones previstas (en fase de diagnóstico) o realizadas (en fase de ejecución). Estos análisis están muy presentes en los programas más actuales (Cervelló \& Segura, 2010; Morandi \& Pessina \& ScAvuzzo, 2010), habida cuenta de la participación del sector privado en los programas de regeneración que podrían denominarse de "cuarta generación", como se ha señalado anteriormente, y que por pura lógica han de poder estimarse con cierta precisión tanto las necesidades, como los resultados desde el punto de vista del rédito económico. Si bien tradicionalmente los resultados han primado sobre la propia gestión de los programas de regeneración urbana, en la actualidad la evaluación en términos de eficiencia de los recursos y los aspectos financieros están ganando protagonismo (JIMÉNEZ, MolinA \& NiCOLÁS, 2017).

\subsubsection{Impactos sociales}

La salud y el empleo se identifican como aspectos clave para una buena calidad de vida, factores ambos interrelacionados (en sus vertientes física y psíquica) e íntimamente relacionados con la vulnerabilidad y la desigualdad. La focalización de algunos programas de actuación en el empleo, en términos de acceso y de movilización social del individuo (NAVARRo, Rodríguez, ZAPATA \& MATEOS, 2015b), implica realizar evaluaciones específicas con metodologías analíticas y también empíricas.

En el caso de la salud, existen evidencias de su mejora para los residentes en áreas de regeneración urbana, debido a que la transversalidad de

el marco de la convocatoria de $1+D+i$ de la Consejería de Fomento de la Junta de Andalucía en 2013. 
las medidas implantadas repercute en los factores de riesgo que favorecen los niveles sanitarios en estas áreas (SERRANo \& al., 2014).

\subsubsection{Impactos en la habitabilidad y el espacio público}

La primera evidencia que se constata al evaluar de manera genérica los programas de actuación en áreas muy degradadas es que el factor catalizador de las mejoras en los barrios es la intervención sobre el espacio físico y su forma urbana. Esta hipótesis se sustenta en la génesis propia especialmente de los asentamientos "informales", donde la adaptación al medio es su fundamento y en donde las mínimas condiciones de acceso y conectividad constituyen la única forma de urbanidad en sus inicios, a partir de la cual su evolución y mejora va construyendo ciudad en la medida que los propios ocupantes del asentamiento disponen de más recursos.

Del mismo modo en las actuaciones sobre barrios planificados las medidas que antes son percibidas como positivas en términos cuantitativos e incluso cualitativos, son las que afectan al medio físico, tanto al espacio público (reurbanización, nuevas dotaciones) como a las ayudas directas para la rehabilitación o mejora de viviendas, (SÁNCHEZ DE MAdARIAGA, 2004).

\subsubsection{Impactos sobre la sostenibilidad}

En la actualidad, y al hilo de los 17 Objetivos de Desarrollo Sostenible, se han llevado a cabo metodologías para evaluar los procesos de regeneración urbana a partir de indicadores relacionados directamente con esos ODS (SÁNCHEZ DE MADARIAGA \& GARCIA \& SISTRO, 2018) de manera que faciliten la planificación coordinada con las agendas urbanas aplicables en razón de la ubicación del área (la FIG. 3 muestra un ejemplo).

\subsubsection{Medición de resultados vs. medición de procesos (gobernanza y participación ciudadana)}

Al margen de los impactos (o resultados), uno de los objetivos considerado clave como factor de éxito en los procesos de RUI, con especial incidencia en las actuaciones localizadas en barrios (las ya descritas ABIs), es la participación ciudadana, en cualquiera de las acepciones actuales: gobernanza, empoderamiento de la sociedad civil, etc. Los enfoques sectoriales tradicionales no tenían en cuenta a los residentes/usuarios ni se preveían órganos de control ni de gestión que incorporasen a representantes de los vecinos o sus asociaciones. En los años 80 fueron tomando fuerza los colectivos vecinales, impulsando e incluso liderando algunas actuaciones rehabilitadoras de relevancia (MANERo, 2010).

El impulso de la ciudadanía en la regeneración urbana en las iniciativas de los programas URBAN y similares de la Unión Europea (UE) ha evolucionado desde el nivel inicial de mera información/ constatación de las actuaciones, hasta la participación integral en todas las fases y órganos de decisión. Si bien las evaluaciones finales de los programas denotan que dichos procesos de participación ciudadana han quedado lejos de los objetivos perseguidos, lo cierto es que se ha

\begin{tabular}{lccc}
\hline Indicador & Unidades & Umbral verde & Umbral rojo \\
\hline Áreas verdes deportivas y de ocio & $\mathrm{m}^{2}$ per cápita & 27,55 & 6,67 \\
\hline Concentración de $\mathrm{NO}_{2}$ & $\mathrm{ug} / \mathrm{m}^{3}$ & 14,37 & 40 \\
\hline Concentración de $\mathrm{O}_{3}$ & días & 25 & 87,25 \\
\hline Concentración de partículas PM $_{10}$ & días & 3 & 35 \\
\hline Accesibilidad a la vivienda & $\%$ & 4,19 & 6,31 \\
\hline Resiliencia Urbana & índice & 50 & 10 \\
\hline Uso de transporte sostenible & $\%$ & 1 & 0,43 \\
\hline Vivienda protegida & \% sobre el total & 7,97 & 2,63 \\
\hline Vulnerabilidad urbana & \% sobre el total & 6,03 & 35,85 \\
\hline Accesibilidad a las áreas verdes urbanas & \% sobre el total & 23,88 & 4,99 \\
\hline Fig. 3/ Indicadores y umbrales estadísticos ODS 11 - Ciudades y comunidades sostenibles. & \\
\hline
\end{tabular}


instaurado una "manera de hacer" en la cual la gobernanza tiene un papel protagonista, estando presentes en la actualidad en cualquier proceso de RUI (DE Gregorio, 2013). Así, en la mayoría de los estados de la Europa Occidental se han implementado políticas en las ABls que implícitamente conducen a reconsiderar las formas de gobernanza local, aunque los mecanismos son diferentes en cada país, dependiendo de la tradición nacional respecto de los enfoques democráticos pluralistas (AtKInSON \& CARMICHAEL, 2011).

Muchas iniciativas de rehabilitación han sido conceptualmente bien diseñadas (diagnósticos acertados y medidas acordes al marco teórico) pero a la hora de su evaluación, tanto en la fase de implementación, como respecto de los resultados obtenidos, no se ha evaluado adecuadamente el papel de los habitantes y de los promotores (públicos y privados) en la dotación de viviendas de calidad, asequibles para los grupos de población con menos recursos (DWIJENDRA, 2013), evidenciando algunos fracasos motivados por la escasa participación de los actores o beneficiarios de dichos procesos. Esas situaciones se dieron fundamentalmente en las décadas finales del siglo pasado y ponen de manifiesto el problema existente cuando la práctica de la evaluación tiene lugar exclusivamente dentro de las estructuras de poder, por lo que la tendencia actual se basa en una evaluación participativa, con enfoques que abarcan desde los aspectos prácticos hasta los más intervencionistas que persiguen una auténtica transformación (TAYLOR \& BALLOCH, 2005). Políticas urbanas que fomentan la mezcla e integración de diferentes grupos sociales (las denominadas políticas de ingresos mixtos) mediante la producción de viviendas para los grupos sociales de ingresos más bajos (FRASER \& CHASKIN \& BAUZIN, 2013) también han puesto de manifiesto este fenómeno, pues el distanciamiento entre los planteamientos teóricos que rigen su diseño y los resultados que evidencian el paso del tiempo a medio y largo plazo (LUDWIG \& al., 2008) es notorio, al no contemplar aspectos como la toma en consideración de las distintas sensibilidades de los grupos sociales, tan dispares ente sí por su propia naturaleza.

En España los primeros procesos recientes de movilización y organización ciudadana por barrios se producen a finales de los años 1960's debido a la fuerte crisis urbana existente (carencia de servicios y equipamientos urbanos básicos, parque de viviendas inadecuado, etc.) y la falta de libertades políticas que permitiesen dialogar con los ayuntamientos, percibidos como ineficaces. La conquista más emblemática del derecho a la ciudad (LEFEBVRE, 1969) se produce en la vivienda y en la educación. Además, en el ámbito del urbanismo, pronto aparecen técnicos que de manera voluntaria o por afinidad ideológica, comienzan a apoyar con sus conocimientos la plasmación de las reivindicaciones vecinales, produciéndose los primeros contactos entre vecinos, técnicos y administraciones.

El final de los años 1970's y primera mitad de los 1980's fueron años de una profunda renovación de la cultura urbanística española. Las peculiaridades políticas de la transición determinaron que los nuevos planes hubieran de responder a los nuevos enfoques de calidad urbana y a las carencias infraestructurales elementales, que en otros países habían constituido la preocupación de generaciones de planes precedentes (EZquiaga, 2011).

En la primera etapa de ayuntamientos democráticos, la participación ciudadana se acrecentó,

\begin{abstract}
“...se hizo el mejor planeamiento (...) porque estuvieron representados en los municipios los movimientos... Veías en cada ayuntamiento a concejales que eran dirigentes vecinales, la época que vivieron como dirigentes vecinales les permitió transmitir las reivindicaciones que habían visto durante los últimos 15 o 20 años..." (Álvarez-MorA, 2020, págs. 164-165).
\end{abstract}

Pasados unos años, la participación se convirtió en un aspecto más bien formal. Solo más recientemente y vinculado a actuaciones urbanísticas de detalle, ha vuelto a aparecer como elemento clave para la asunción/empoderamiento de las actuaciones y para asegurar un buen apego para que las mejoras obtenidas sean cuidadas por los vecinos. Ejemplos como la gestión de la regeneración urbana del barrio de La Mina en San Adrián del Besós, en la que a pesar del intenso proceso de participación ciudadana (VELÁZQUEZ \& VeRdAGUeR, 2011), casi diez años después los vecinos seguían recelando de la intervención, indicando que no habían sido atendidas bastantes de sus demandas. En otros casos de reconfiguraciones de espacios púbicos problemáticos (calles, alamedas, plazas, etc.) también han destacado la relevancia de la participación ciudadana (RUIZ-APILÁNEZ \& UREÑA \& Solís, 2014).

\subsection{Metodologías: sistemas de indicadores}

Un indicador es:

"una variable o atributo relevante, determinado en función de su capacidad de medir los resultados de un objetivo a cumplir. Un dato estadístico, cuantificable o cualificable, de la realidad que puede verificarse a través del tiempo y proyectar su tendencia futura" (MARIANI, 2010, p.2) 
o también:

"una interpretación empírica de la realidad cuyas tres principales funciones son la simplificación, la cuantificación y la comunicación" (OCDE, 1997. p.1).

Los indicadores deben poseer la mayor precisión posible, pertinencia con el tema a analizar, sensibilidad a los cambios, fiabilidad y ser fácilmente obtenibles.

Analizando los estudios o metodologías referentes a la regeneración urbana (CusIDÓ, 2007; Agencia d'Ecología Urbana de Barcelona, 2011), se ha profundizado en los aspectos relacionados con la necesidad de medir, ponderar y prever las consecuencias de las actuaciones planteadas. El concepto de "sistemas de indicadores" está presente en la práctica totalidad de las referencias bibliográficas que describen herramientas, metodologías o simplemente parámetros medibles sobre la sostenibilidad urbana, la vida en las ciudades o la evaluación de los resultados obtenidos tras materializar programas de inversiones, de manera que pueden compararse distintos enfoques según las necesidades de información para las cuales se han diseñado, los ámbitos geo-políticos o espaciales para los cuales se han concebido, o incluso los parámetros de medición que pretenden determinar (RUEDA, 1999). Estos sistemas de indicadores son imprescindibles en la mayor parte de los procesos con concurrencia competitiva para acceder a la financiación de determinados programas de regeneración (p.e. el programa Europeo URBAN), constituyendo herramientas que permiten monitorear los objetivos perseguidos en los procesos de regeneración urbana (MARIANI, 2010), de manera que las conclusiones preliminares sirvan para un mejor enfoque de los problemas a afrontar, de las decisiones para programar inversiones y de la consecución de resultados.

Los sistemas de indicadores son frecuentes en los planes de recuperación del patrimonio urbano de los centros históricos, facilitando la participación ciudadana e interinstitucional en su gestión, simplificando la transparencia de la información en la identificación de las buenas prácticas, en la definición de los objetivos de planificación y en el seguimiento de los planes y proyectos (HugONY \& RocA, 2008). También son frecuentes en la evaluación de la Rehabilitación Urbana Integrada para ser analizados antes y después del plan o proyecto, para facilitar la comunicación entre los actores (vecinos, técnicos y administración), que al disponer de un modelo de análisis común puedan llegar a consensos sobre prioridades, para determinar causas y consecuencias de la elección de alguno de los elementos en detrimento de otros (HERNÁNDEZ \& al., 2015).
Las fuentes de los datos son diversas, pudiendo obtenerse información más genérica de bases de datos oficiales, con el nivel de desagregación del que se disponga -muchas veces no coincidente con la delimitación de las áreas intervenidas, con sus consiguientes inconvenientes- o bien mediante encuestas o entrevistas con los actores (Verdaguer, 2005).

La cantidad de información disponible es muy abundante, tanto como se quiera profundizar en los análisis concretos, por ello es determinante acotar los ámbitos temáticos, el tiempo y el marco espacial. En los estudios de diagnóstico de las ABIs, un primer grupo de indicadores clásicos se refieren al entorno (estado del espacio público, viviendas, servicios existentes), y por otro a las personas, en relación con su calidad de vida (demográficos, socioeconómicos, asociativos y de implicación en la vida pública) (Navarro \& ECHAVES \& MOYA, 2015a).

Los sistemas de indicadores relacionados con la sostenibilidad han sido habituales en las metodologías para la planificación, gestión y evaluación de la regeneración urbana desde principios del siglo XXI (VARGAS-YÁÑEZ, 2015). Los ciclos y procesos del metabolismo urbano en general y la rehabilitación edificatoria y del espacio público, han ido incorporando cada vez más peso ambiental. Bajo la denominación de "sustentabilidad" se han incorporado elementos integrados en los procesos que sean ambiental, social y económicamente adecuados para los habitantes actuales y venideros (BLANCO \& WAUtIEZ \& LLAVERO \& RIVEROS, 2001). Este enfoque de sostenibilidad adquiere especial relevancia en las grandes intervenciones, como por ejemplo, la estrategia de regeneración urbana denominada Urban Land Consolidation (ULC), empleada por el gobierno de Taiwan como herramienta para la renovación urbana con el objetivo de redensificar los espacios urbanos, donde la utilización de sistemas de indicadores como herramientas para la toma de decisiones de gran calado ambiental, social, político o económico se hace imprescindible (LIN, 2010).

A pesar de la incesante búsqueda de fórmulas repetitivas de aplicación directa, los indicadores denominados de $3^{a}$ generación tratan de poner la atención sobre el valor de lo local frente a la creciente globalización del enfoque de la sostenibilidad.

\footnotetext{
“...bajo ninguna argumentación científica o política puede ser homogeneizado el significado de la calidad de vida para todas y cada una de las ciudades del mundo. El derecho a la identidad, a la diferencia y a la diversidad no es negociable. Significa ello que la replicabilidad de las experiencias exitosas debe hacerse con responsabilidad" (LEón, 2013, p.179).
} 


\subsection{Metodologías: métodos numéricos/analíticos}

El análisis de la gran cantidad de información a procesar hace oportuno el empleo de modelos de evaluación de vulnerabilidad urbana (MEVU) basados en formulaciones matemáticas y estadísticas Salas \& Yepes, 2019a; (Bottero \& MondinI \& OpPIo, 2016). Los MEVU han de ser coherentes y compatibles con las herramientas empleadas para planificar estrategias de regeneración urbana, es decir, robustos frente a la incertidumbre, participativos como medio de incorporar las percepciones subjetivas de los interesados, consideradores de la naturaleza dinámica de vulnerabilidad urbana, abordadores de múltiples objetivos para mejorar la capacidad estratégica e implementadores de procesos cognitivos como forma de potenciar enfoques discursivos (SALAs \& YePES, 2019c). Se basan en complejos tratamientos estadísticos, métodos de análisis de decisión multicriterio cuando, además de varias alternativas, son distintos los factores de los que depende la decisión final, con una ponderación específica (FÉLIX \& RIONDET-COSTA \& PALMA-LimA, 2019).

Estas herramientas de planificación o decisión han sido desarrolladas en las últimas décadas y usadas en la implantación de infraestructuras o grandes dotaciones, donde los impactos económicos de la inversión y de los retornos esperados son fundamentales ${ }^{3}$.

En el caso de la RUI, las decisiones presupuestarias sobre planificación afectan a un espacio o área y la evolución de estas herramientas pasa ineludiblemente por la incardinación con sistemas de información geográfica (CERVERo \& AgustínHERnÁNDEZ, 2018), especialmente desde los años 90 (Lo \& Faber, 1997; Grande \& SECondinI \& VIRGILIO, 1999). Algunas herramientas complejas, basadas en estudios matemáticos/estadísticos, permiten evaluar de manera previa los escenarios de futuro que determinadas decisiones sobre infraestructuras vinculadas a los programas de regeneración urbana (SALAS \& YePES, 2019b).

\subsection{Metodologías: comparación de casos similares entre barrios intervenidos y no intervenidos}

Los programas y proyectos de regeneración urbana persiguen mejorar la calidad de vida en las áreas urbanas donde se desarrollan, por lo que la

\footnotetext{
${ }^{3}$ Un ejemplo de esta concomitancia son los modelos de priorización de áreas urbanas para proyectos integrados de revitalización y movilidad sostenible (Transit Oriented Development - TOD), como describen CAmpos-SÁnchez \& AbARCA-Álvarez
}

evaluación de su impacto tiene que comparar los cambios en la calidad de vida de los residentes respecto a su estado previo a la ejecución del proyecto, aunque esta comparación a veces no resulta fiable, puesto que la transformación puede que se deba a otras circunstancias distintas al proceso de regeneración urbana (RHODES \& TYLER \& BREnNAN, 2005). Un método de evaluación para asegurar que el cambio se origina en la intervención realizada es la comparación a lo largo del tiempo con lo que ocurre en otras áreas similares, donde no se han desarrollado intervenciones.

La metodología parte de la selección de ámbitos de comparación semejantes, esto es, con simimilares condiciones físicas y socioeconómicas. "Áreas experimentales", donde se han ejecutado programas de regeneración urbana integral y "áreas equivalentes", donde no ha habido intervenciones (al menos de carácter integral). Tanto las áreas experimentales, como las equivalentes, pueden haber sido beneficiarias de programas propios de las políticas sectoriales (vivienda, acción social, promoción económica, rehabilitación urbana, etc.). Es evidente que, a mayor número de casos de comparación, el análisis de las diferencias obtenidas mejora sustancialmente, aunque no menos importante es la metodología y condiciones empleadas en la elección y delimitación de esos pares semejantes y en su propia comparación. Básicamente, las áreas comparables han de presentar niveles similares de vulnerabilidad urbana en el momento previo a la puesta en marcha de las intervenciones de regeneración integrada en las áreas experimentales. Se han de definir una serie de criterios a la hora de establecer las áreas equivalentes respecto de una análoga experimental.

Al evaluar las diferencias obtenidas tras el análisis de los datos en relación con un período de tiempo determinado, conviene analizar en qué grado estas diferencias se deben a la aplicación de los programas de regeneración integral propiamente dichos o, por el contrario, obedecen a las diferencias en las condiciones de partida de las áreas comparables. Los indicadores o análisis que se realicen para comparar las áreas experimentales y semejantes pueden ser imprecisos o introducir posibles errores, debido a que los parámetros que se midan no tengan suficiente nivel de detalle o sean excesivamente genéricos desde los puntos de vista sectorial y espacial.

\& SeRRA-Coch \& ChAstel (2019), utilizados para facilitar la toma de decisiones a la hora de planificar inversiones asociadas a las infraestructuras del transporte, de gran calado económico. 


\section{Resultados de las evaluaciones: aciertos y fracasos}

Un recorrido por las actuaciones más relevantes de regeneración urbana y sus distintas evaluaciones, desde mediados hasta finales del pasado siglo, a través de los diferentes enfoques empleados para dar solución a los problemas planteados, muestra cómo se afrontan de distintas maneras en las ciudades problemas como la creación de guetos, la proliferación de la delincuencia o la deficiente movilidad. Se establece como prioridad la necesaria conveniencia de establecer unos objetivos en la fase de planificación que tengan en cuenta no solo factores propiamente asociados a la regeneración física de los espacios, sino también a sus consecuencias socioeconómicas (Segado-VÁzquez \& Espinosa-Muñoz, 2015).

Las experiencias con falta de evidencia de los resultados muestran que hay una serie de factores que las caracteriza. Se trata de una comprensión inadecuada de la teoría que subyace tras los problemas que provocan la situación de degradación de un barrio, el método seguido para su evaluación y una falta de información sobre el impacto de las intervenciones en los resultados clave que se han diseñado (RHOdEs, TYLER, \& BRENNAN, 2005; NAVARRO, 2015b).

Invertir en la rehabilitación del patrimonio arquitectónico, además de asegurar su protección en el tiempo, contribuye a la involución de ciertos procesos de degradación en centros históricos de las ciudades, poniendo en valor edificios como contenedores de actividades que pueden llegar a lideran los cambios de tendencias tanto desde el punto de vista físico o demográfico, como social y económico. Una adecuada planificación que vaya más allá de la dimensión local, con un enfoque territorial que tenga en cuenta la posición del área de intervención en la realidad geográfica de su entorno, puede favorecer la creación de centralidades que favorezcan la creación de oportunidades competitivas de los entornos intervenidos (Solis, UREÑA \& MoHÍNO, 2018). Para la evaluación de los resultados, conviene sin embargo no perder de vista los peligros de la excesiva especialización de estos centros históricos rehabilitados, y en concreto la prevalencia de los usos asociados al sector terciario, pues como ya puso de manifiesto TROITIÑO (1998):

\footnotetext{
"los responsables municipales y las administraciones turísticas deben ser conscientes de que convertir las ciudades históricas en «producto turístico», aun cuando esta función sea muy importante en la economía de su ciudad, implica asumir graves riesgos" (p. 213).
}

La diversidad de usos, así como el enfoque del espacio público como lugar de convivencia, sociabilización y motor de la vida en las ciudades, favorecen la conservación de los centros históricos frente a los procesos de abandono, degradación o incluso gentrificación. El concepto de sostenibilidad social (CALANTONIO \& DIXON, 2011), en un contexto de recesión económica ha evolucionado hacia el fomento de inversiones responsables y la responsabilidad social corporativa de inversores y promotores, donde las asociaciones público-privadas son frecuentes, incluso con la participación del denominado "cuarto sector" (organizaciones no gubernamentales), desarrollándose mecanismos adaptados a este nuevo escenario como convenios institucionales, herramientas de financiación o sistema de monitorización (estos últimos permiten la evaluación continua de los programas).

Algunas medidas para revitalizar los centros de las ciudades han sido favorecer la presencia de familias de clase media, sin hijos, o jóvenes profesionales, con viviendas en propiedad con el fin de paliar el contraste socioeconómico, pero la consecuencia inmediata ha sido el aumento de los precios, tanto de las viviendas, como de los alquileres y por tanto los procesos de gentrificación se han desencadenado de manera implacable (TELLOCAmpos \& Aguilar-Martínez, 2013), desplazando a los habitantes tradicionales. Iniciativas como la intervención pública favoreciendo la construcción o la rehabilitación de edificios para vivienda social dirigida a estos colectivos más vulnerables ayudan a equilibrar los efectos de las políticas de regeneración, aunque en estos casos los procedimientos de evaluación solo tienen sentido a posteriori y con intervalos temporales muy amplios.

Conviene no perder de vista los efectos colaterales asociados a determinadas intervenciones donde, después de procesos de regeneración urbana de barrios de vivienda social, se produce más gentrificación cuando la regeneración se ha hecho en barrios relativamente centrales y solo muy raramente se produce cuando se hace sobre barrios periféricos. La razón puede ser que en barrios centrales se facilita el contagio de barrios cercanos de clase alta y en la periferia es menos posible (Leal, 2004; Leal \& Sorando, 2013).

Otras experiencias basadas en el contacto íntimo y directo con los residentes y usuarios de los barrios afectados han reportado resultados positivos mediante la adopción de un enfoque antropológico, el denominado "urbanismo participativo" (CASTRILLO, 2014), constatando, al igual que sucede con las iniciativas URBAN, una mejora en la implantación 
de una cultura de la participación de la sociedad y de escucha por parte de las administraciones. En estos casos, la evidencia de los resultados se constata en el nivel de satisfacción de los propios residentes como partícipes de los procesos.

Experiencias innovadoras de autofinanciación de las actuaciones por parte de los residentes, más allá de la mera rehabilitación de viviendas, mediante procesos de economía local como han supuesto las cooperativas vecinales (RosA, MÁRQUEZ \& NAVAS, 2017), son fácilmente evaluables ya que la implicación de los vecinos posibilita el acceso a la información sobre los datos de resultados, tanto desde el punto de vista económico (inversión/capitalización), como de la satisfacción o en lo relativo a aspectos sociales (integración, empleabilidad, identidad barrial).

Un factor determinante para lograr el éxito de los programas de intervención es la implicación de los profesionales encargados de la gestión de los procesos en todas sus fases, la perspectiva bottom-up o "desde abajo" en castellano (Navarro, 2015c). Por su carácter de integrabilidad, los distintos ámbitos de gestión involucrados en los procesos de regeneración urbana precisan del personal especializado en materias como la planificación territorial, las infraestructuras, la promoción económica y cultural, la educación y los servicios sociales o incluso la seguridad. En consecuencia, cuanto más estrecho sea el grado de participación en los procesos de concepción y definición de actuaciones, mayor será la implicación de los responsables de su materialización y gestión en el día a día de su implantación, así como en los procesos de evaluación.

Un elemento central habitual en los esquemas que buscan la regeneración integral es la concentración en los primeros años de la iniciativa de actuaciones para mejorar el entorno físico de la zona en cuestión. Este aspecto se ha identificado como importante no solo como una forma de mejorar la apreciación de los residentes como de los posibles nuevos vecinos, sino también como un elemento clave de la estrategia diseñada para implantar nuevas actividades (RHODES \& TYLER \& BRENNAN, 2005). En definitiva, la mejora de los aspectos físicos (vivienda, urbanización, etc.) es mucho más rápida que la mejora de los aspectos sociales y económicos (empleo-paro, formación, integración social). Los primeros pueden hacerse en 5-10 años y los segundos requieren al menos 30 años (una generación). Por ello las actuaciones socioeconómicas deben mantenerse mucho más tiempo que las físicas. Este decalaje temporal en las actuaciones presenta dificultades a la hora de evaluar los procesos, poniendo de manifiesto la conveniencia de programar actividades que se mantengan en el tiempo.

En la gran mayoría de los procesos de regeneración urbana identificados como "casos de éxito" no cambian el modelo urbano o morfología del barrio (p.e. se mantiene el modelo de bloque abierto cuando esa era la situación previa) y solo en muy pocos casos se cambia dicho modelo, cuando se compagina rehabilitación de edificios y tejidos con derribo y reconstrucción de partes del barrio. Ejemplos de esta combinación son la Unidad Vecinal de Absorción "UVA" de Fuencarral en Madrid, el barrio de la Mina en Sant Adrià de Besòs y su enfoque integral innovador (JORNET \& LLOP \& PASTOR, 2008), el barrio de Bijlmermeer en Amsterdam o el barrio de Regent Park en Toronto.

La flexibilidad debe ser una condición determinante en las políticas de regeneración urbana, de manera que los diferentes actores intervengan en cada fase del proceso, desde la percepción de los problemas a solucionar, hasta la construcción de estrategias que relejen su percepción de esos problemas bajo un enfoque basado en evidencias y el conocimiento de lo que funciona, todo ello en un marco que permita adaptarse a las circunstancias en el tiempo. Esto último es importante en tanto en cuanto los aspectos sociales y laborales de los programas de regeneración urbana son los que arrojan menos resultados positivos y además requieren la continuidad de las actuaciones durante más años.

Algunos ejemplos en el contexto occidental de cómo enfocar la evaluación de los programas de regeneración urbana pueden ser los Empowerment Zones en EEUU utilizando mecanismos cruzados (internos y externos al programa) basados en indicadores que se repiten a lo largo del tiempo, los Hommes and Communities en Reino Unido centrados en análisis coste-beneficio o la Politique de Ville en Francia a través del Observatorio Nacional sobre las Zonas Urbanas Sensibles creado por Ley y que actúa mediante la evaluación sistemática de indicadores previamente establecidos (APARIcIO \& DI NANI, 2011).

\section{Discusión y conclusiones}

Tal como se constata en la bibliografía consultada, las evaluaciones de los programas de 
regeneración urbana han tendido hacia la eficacia frente a la efectividad, es decir, se han centrado sobre el cumplimiento de los aspectos instrumentales más que en asegurar que las actuaciones resuelven las causas que originan la vulnerabilidad. Los factores que intervienen en los procesos de regeneración integral de áreas urbanas son variados, complejos y diferentes entre sí, por lo que una correcta evaluación pasa por el análisis en fases previas, en las de implementación y en posteriores a la finalización de las actuaciones.

Han sido diversas las maneras de evaluar dichas intervenciones, desde metodologías basadas en criterios subjetivos, sistemas de indicadores más o menos complejos, procesos de gobernanza y participación ciudadana, hasta otras que miden los impactos económicos de las actuaciones en las zonas intervenidas o incluso las que estudian la comparación de casos similares intervenidos y no intervenidos.

Como se ha explicado anteriormente, los análisis de satisfacción se basan en componentes fuertemente subjetivas y por tanto su estandarización es compleja. Si bien la información necesaria para la evaluación ha de proceder de encuestas a residentes, distinguiendo entre aquellos que han sido directamente beneficiarios de medidas específicas de los programas de actuación y los que no lo han sido (NAVARRO \& RodríGUEZ, 2015b; NAvARro \& Rodríguez \& Zapata \& MAteos, 2015a), los resultados en dichas evaluaciones pueden no ser tan representativos de la realidad como pudiera esperarse. Los efectos de los procesos de mejora en la calidad de vida de los residentes, de acuerdo a determinadas estrategias de intervención, no pueden sino arrojar resultados a medio o incluso largo plazo, por lo que el análisis de informaciones obtenidas en base a experiencias puntuales y/o localizadas en el tiempo no parece el más adecuado. Del mismo modo, es evidente que la mera expectativa de que exista una continuidad en la intervención sobre los aspectos que confieren el carácter de vulnerabilidad a las áreas intervenidas (y su tutela por parte de los gestores de los programas) confiere por sí misma una cierta sensación positiva entre los residentes, frente a la sensación de desamparo que impregnan actuaciones en sentido contrario.

Los sistemas de indicadores como herramienta para la evaluación de planes o programas de rehabilitación han evolucionado en el último medio siglo acorde con los cambios en los enfoques del concepto de regeneración urbana propiamente dicho y con la incorporación de criterios de sostenibilidad, integrabilidad o gobernanza. Sin embargo, la evaluación de estos programas presenta dificultades por la precisión temática y espacial de la información disponible para referirse a los temas concretos que pretende la regeneración, pues es posible que no haya datos o indicadores estadísticos específicamente para dichos temas o zonas sobre los que se actúa; quizás haya datos o indicadores estadísticos desagregados, pero que no coincidan con la delimitación de los barrios intervenidos, por lo que los datos no son precisos espacialmente para medir lo que ha sucedido en esos barrios.

Tal como sugiere LEÓN (2013), la evaluación de los procesos de regeneración basada en indicadores ha de descender al nivel de lo local, pues cada modelo de sociedad tiene sus propios estándares de calidad de vida. Pero incluso en una misma ciudad, cada barrio, por lo general coincidente con una determinada área de intervención, presenta su propia idiosincrasia que debería ser tenida en cuenta a la hora de establecer los sistemas de indicadores a considerar para diagnosticar sus problemas, para establecer las medidas para paliarlos y para evaluar la efectividad de las actuaciones realizadas.

Enfoques sofisticados, con tratamientos estadísticos modelizados de la información obtenida procedente de la gran cantidad de datos (aunque a veces no lo suficientemente precisa), que facilitan las tecnologías digitales, si bien aporta un plus de mejora en cuanto a su fiabilidad, minimiza la aplicabilidad de las herramientas por entidades o administraciones no siempre dotadas de los medios necesarios para su procesamiento.

Evaluar la efectividad de la regeneración urbana en base al grado alcanzado de participación ciudadana y gobernanza, a pesar de que es una práctica que se ha venido generalizando en las dos últimas décadas, arroja resultados un tanto decepcionantes en lo que a implementación de la planificación colectiva se refiere, si bien muestran una cierta progresión en cuanto a lo que DE GREGorio (2013) denomina "manera de hacer las cosas".

Sin embargo, conviene no perder de vista los problemas que la participación pública mal entendida puede originar. Situaciones como la deriva asamblearia, donde la efectividad se pierde por la discusión de los aspectos más intrascendentes 
de las decisiones a tomar, o la intromisión de decisores ajenos a los verdaderamente implicados que se instauran casi de manera profesionalizada en los foros de discusión y participación, e incluso personas o colectivos interesados en cuestiones meramente particulares (o sectoriales) que pueden llegar a condicionar la gestión de los programas. Este enfoque crítico no es novedoso, pues la bibliografía ya lo evidencia, incluso en la sociedad británica, considerada pionera de los enfoques participativos en programas considerados de referencia como el City Challenge (DALGLEISH, 1996).

En cuanto a la evaluación de los resultados de la RUI a partir de factores económicos, el giro de las políticas de un marcado social durante las décadas de los 60 y 70 (LAWLESS \& BROWN, 1986) hacia posiciones más neoliberales, sobre todo impulsadas por los gobiernos conservadores de EEUU y Gran Bretaña, favoreció la presencia del capital privado como agente llamado a liderar los procesos de cambio y mejora de la ciudad degradada (NABARRO, 1980).

Es de esperar que, para esos agentes empresariales, la eficiencia de los procesos de regeneración sea evaluable en términos de impactos económicos. Pero este enfoque a veces dista de los planteamientos de mejora social, equidad y sostenibilidad que impregnan el carácter integral de los programas. Por este motivo las metodologías de evaluación basadas en factores económicos no pueden ser sino complementarias de otros procesos globales de análisis de resultados, constituyendo los aspectos relacionados con el incremento de las tasas de actividad, la revalorización de inmuebles (viviendas y locales) o el aumento del precio de los alquileres, factores a tener en cuenta como indicadores de buenos resultados, pero solo en el marco de unas previsiones donde otra serie de aspectos globales puedan tener como consecuencia los anteriores, y por supuesto siempre dentro de los límites previstos compatibles con la mejora de la calidad de vida de los residentes.

La comparación de barrios en los que se ha intervenido con otros similares no intervenidos como método de evaluación de la eficiencia de las medidas desarrolladas presenta no pocas dificultades en la práctica. Desde la propia delimitación y selección de las áreas comparables (NAVARRO, ECHAVES \& MOYA, 2015b) dadas las peculiaridades y singularidades de cada barriada y sus habitantes, las dificultades para conseguir "testigos" con similares parámetros de población, localización, condiciones físicas o situación socioeconómica, hasta la propia manera de discernir si las mejoras en las condiciones de vida de los residentes son consecuencia de los impactos que los programas de regeneración urbana han conseguido (NAvarRo \& Guerrero \& Moya, 2015) frente a otras consecuencia propias del contexto general de la ciudad o incluso de acciones inherentes a las tradicionales políticas sectoriales que actúan de forma continuada.

\section{Bibliografía y referencias}

Aalbers, M. \& Van Beckhoven, E. (2009): The integrated approach in neighbourhood renewal: more than just a philosophy?, Tijdschrift voor Economische. Sociale Geografie: Vol. 101, No. 4, 449-461.

Agencia d'Ecología Urbana de Barcelona (2011): Sistema de indicadores y condicionantes para ciudades grandes y medianas. Barcelona (España): Ministerio de Fomento.

Álvarez-Mora, A. (2020): MAET 1 Ciudad. Jornada de Debate sobre las Relaciones entre Proyecto Arquitectónico, Proyecto Urbano y Plan de Ordenación Urbana, (págs. 164-165).

Aparicio, A. (2013): Los centros históricos de Toledo y Cuenca. Nuevos equipamientos socioculturales para la recuperación funcional. Polígonos. Revista de Geografía, 25, 19-56.

- \& DI NANI, R. (2011): Modelos de gestión de la Regeneración Urbana. Madrid (España): SEPES Sociedad Estatal de Suelo.

AtKInson, R. \& CARMichael, L. (2011): Neighbourhood as a new focus for action in the urban policies of West European states. En I. SMITH \& E. LEPINE \& M. TAYLOR (Edits.), Disadvantaged by where you live? London, United Kingdom: Policy Press.

BAKER, J. \& GADIL, G. (2017): Obtenido de http://hdl.handle.net/10986/27614

Banco Mundial (2019): Informe anual 2019. Poner fin a la pobreza, invertir para generar oportunidades. Obtenido de https://www.bancomundial.org/es/ about/annual-report

BiANCHINI, F. \& PARKINSON, M. (1993): Cultural Policy and Urban Regeneration: The West European Experience. Manchester, United Kingdom: Manchester University Press.

Blanco, H. \& Wautiez, F. \& Llavero, A. \& Riveros, C. (2001): Indicadores regionales de desarrollo sustentable en Chile: ¿Hasta qué punto son útiles y necesarios? EURE, Volumen XXVII, $n^{\circ}$ 81, 85-95.

BotTero, M. \& MondinI, G. \& Oppio, A. (2016): Decision Support System for evaluating urban regeneration. Procedia-Social and Behavioral Sciences, 223, 923-928. 
Calantonio, A. \& Dixon, T. (2011): Urban Regeneration and Social Sustainability. London (United Kingdom): Wiley-Blackwell.

Campos-Sánchez, F. \& Abarca-Álvarez, F. \& Serra-Coch, G. \& ChAstel, C. (2019): Evaluación comparativa del nivel de Desarrollo Orientado al Transporte (DOT) en torno a nodos de transporte de grandes ciudades: métodos complementarios de ayuda a la decisión. EURE, Volumen 45, $n^{\circ} 134,5-29$.

CARMON, N. (1999): Three generations of urban renewal policies: analysis and policy implications. Geoforum, 30, 145-158.

CAStRILlo, M. (2014): ¿Urbanistas «en transición»? El enfoque antropológico del mejoramiento urbano y sus efectos sobre la concepción urbanística. Ciudad y Territorio. Estudios Territoriales, Volumen XLVI, $n^{\circ}$ 179, 81-97.

Cervelló, R. \& Segura, B. (2010): Un modelo para evaluar y optimizar el impacto espacial de las inversiones en regeneración urbana. Investigaciones Regionales, 17, 125-138.

Cervero, N. \& Agustin-Hernández, L. (2018): Evaluación gráfica de la rehabilitación urbana del poblado dirigido de Caño Roto. ACE - Arquitectura, Ciudad y Entorno, Año 13, núm. 37, 155-182.

Cervero-SÁnchez, N. (2020): La inciativa ciudadana, como origen del cambio urbano. La remodelación del Poblado Dirigido de Orcasitas en Madrid. Ciudad y Territorio Estudios Territoriales, $n^{\circ} 204$, 277-294.

Cusıdó, O. (2007): Herramientas para la evaluación continua: Observatorio e indicadores de seguimiento. En X. Casanovas, Método RehabiMed Arquitectura Tradicional Mediterránea I. Rehabilitación Ciudad y Territorio. Barcelona (España): Collegi d'Aparelladors i Arquitectes Tècnics de Barcelona para el consorcio RehabiMed. Obtenido de http://www.rehabimed.net/es/2015/11/metodo-rehabimed-arquitectura-tradicional-mediterranea-irehabilitacion-ciudad-y-territorio/

DaLgLeISH, K. (1996): An analysis of the City Challenge decision-making process: The Dearne Valley Partnership and Sheffield. Masters (United Kingdom): Sheffield Hallam University.

DE Gregorio, S. (2013): La Iniciativa Comunitaria URBAN como factor de transformación de la práctica de la regeneración urbana: aproximación al caso español. Ciudad y Territorio. Estudios Territoriales, Volumen XLVI, $n^{\circ} 180,253-275$.

de Manuel, E. \& López, J. (2017): Dinamizar la regeneración urbana desde la escala barrial: aprendizajes y transferencias del proyecto Barrios en Transición. Ciudades, 20, 21-44.

Diener, E. \& SuCH, E. (1997): Measuring quality of life: economic, social and subjetive indicators. Social Indicator Research, 40, 189-216.

DWIJENDRA, N. (2013): Quality of affordable housing projects by public and private developers in Indonesia: The case of Sarbagita Metropolitan Bali. Journal of Geography and Regional Planning, Vol. 6(3), 69-81.
EZquiAgA, J.M. (2011): Sueños de la razón: genealogía de los paradigmas para una teoria del planeamiento en el pensamiento de Fernando Terán. Ciudad y Territorio Estudios y Territoriales, n.160-170, 497-506.

Félix, R. \& Riondet-Costa, D. \& Palma-LimA, J. (2019): Modelo de avaliação de áreas urbanas para receber projetos integrados de revitalização e mobilidade sustentável. EURE, Volumen 45, $n^{\circ} 134,77-98$.

Fraser, J. \& Chaskin, R. \& Bauzin, J. (2013): Making Mixed-Income Neighborhoods Work for Low-Income Households. Cityscape, 15(2), 83-100.

Garcia-Hípola, M. \& Beltrán, M. (2011): Hibridacción y destrucción selectiva como estratagias propulsoras en centros históricos de Salamanca y Estocolmo. Ciudades, 14, 133-156.

GASTALDI, F. (2017): La regeneración urbana en Italia a partir de la reutilización del patrimonio público inmobiliario: un catálogo de herramientas y protocolos. Ciudades, 20, 155-178.

Gibson, F. \& Prathers, J. (1977): Does Anything Work? Evaluating Social Programs. Beverly Hills (EEUU): Sage Publications.

- \& Langsta, M. (1982): An Introduction to Urban Renewal. London (United Kindom): Hutchinson.

Grande, G. \& Secondini, P. \& Virgilio, G. (1999): Development of an explorative analysis for public choices with the aid of a GIS: the Rimini metropolitan area housing market case study. A demand side analysis. 2nd AGILE Conference on Geographic Information Science, (págs. 15-17). Roma (Italia).

GRIFTH, J. (1996): Gentrifcación: Perspective on the return to the central city. Journal of Planning Education and Research 11 (2), 241-255.

GuerRAND, R. (2004): Cinquante ans après l'appel de l'abbé pierre, une nouvelle crise du logement populaire en France. Ciudades, 8, 37-70.

Hernández, A., al. (2015): Recuperando la ciudad. Estrategia para el. Madrid (España): Instituto Juan de Herrera (IJH).

- al. (2014): Análisis de las políticas estatales y europeas de regeneración urbana y rehabilitación de barrios. Ciudad y Territorio. Estudios Territoriales, Volumen XLVI, $n^{\circ} 179,182-191$.

Hugony, C. \& RocA, J. (2008): Indicadores para la evaluación de las ciudades históricas. ACE - Arquitectura, Ciudad y Entorno, Año III, núm. 8, 219-238.

HuUb, P. \& BeCKers, P. (2012): Evaluating regeneration policies for rundown industrial sites in the Netherlands. European Real Estate Society (ERES): eres2012_269, 2151-2169. Obtenido de www.ideas. repec.org/p/arz/wpaper/eres2012_269.html

Jiménez, C. \& Molina, P. \& NicolÁs, O. (2017). Procedimientos innovadores de gestión y financiación en actuaciones de rehabilitación y regeneración urbana. Ciudades, 20, 89-110.

Jornet, S. \& Llop, C. \& PAstor, J. (2008). El Plan Especial de transformación urbana del barrio de La Mina, Barcelona. Premio Nacional de Urbanismo. Urban, $n^{\circ} 13,166-169$. 
LAWless, P. (2007). Continuing dilemmas for area based urban regeneration: evidence from the New Deal for Communities Programme in England. People, Place \& Policy Online: 1/1, 14-21.

Lawless, P., \& Brown, F. (1986). Urban Growth and Change in Britain. London (United Kingdom): Harper and Row.

LEAL, J. (2004). Segregation and social change in Madrid metropolitan region. The Greek Review of Social Research, 113, 81-104.

LeAL, J. \& SoRAndo, D. (2013). Rehabilitación urbana y cambio social en las grandes ciudades españolas. Monografías de la Revista Aragonesa de Administración Pública, XV, 205-236.

LefebVRe, H. (1969). El derecho a la ciudad. Barcelona (España): Península.

LEÓN, S. (2013). Indicadores de tercera generación para cuantificar la sustentabilidad urbana. ¿Avances o estancamiento? EURE, Volumen 39, $n^{\circ} 118,173-198$.

LIN, K.-L. (2010). Determining key ecological indicators for urban land consolidation. International Journal of Strategic Property Management, 14:2, 89-103.

Lo, C. \& FABER, B. (1997). Integration of Landsat Thematic Mapper and Census Data for Quality of Life Assessment. Remote Sens Environ, 62, 143-157.

Ludwig, J., Kling, J., Katz, L., Sanbonmatsu, L., Liebman, J., Duncan, G. \& Kessler, R. (2008). What Can We Learn about Neighbourhood Effects from the Moving to Opportunity Experiment? American Journal of Sociology, 114, 144-88.

MANERo, F. (2010): La participación ciudadana en la ordenación del territorio: posibilidades y limitaciones. Cuadernos geográficos, 47, 47-71.

MARIANI, G. (2010): Indicadores Urbanos y Ciudad. La Ciudad Viva. Obtenido de http://www.laciudadviva.org/blogs/?p=7336; http://www.laciudadviva.org/blogs/?p=8012 http://www.laciudadviva.org/blogs/?p=8393

MoNGIL, D. (2010). Intervención integral en barrios: conceptos, instrumentos y elementos de mejora. Ciudades, 13, 139-161.

Morandi, C. \& Pessina, G. \& Scavuzzo, L. (2010): Strumenti innovativi per la riqualificazione de quartieri residenziali in Italia: tre casi esemplari. Ciudades, 13, 103-122.

Moulaert, F. \& Parra, C. \& Swyngedow, E. (2014). Ciudades, barrios y gobernanza multiescalar en la Europa urbana. EURE, Volumen 40, n० 119, 5-24.

NABARRo, R. (1980): Inner City Partnerships An Assessment of the First Programmes. Town Planning Review, Vol. 51, No. 1, 25-38.

NAVARRO, C. (2015a): ¿Qué es la regeneración urbana? La idea y su práctica. En NAvARRo, C., Mejorar la ciudad transformando sus barrios. Regeneración Urbana en Andalucía (1990-2015) (págs. 15-22). Sevilla (España): Centro de Sociología y Políticas Locales - Universidad Pablo de Olavide.
- (2015b): La lógica de la regeneración urbana: gobernanza y redes de implementación. En NAVARRo, C., Mejorar la ciudad transformando sus barrios. Regeneración Urbana en Andalucía (1990-2015) (págs. 123-128). Sevilla (España): Publicado por el Centro de Sociología y Políticas Locales - Universidad Pablo de Olavide.

- (2015c): A modo de conclusiones: condiciones de partida, gobernanza y tipos de efectos. En NAVARRO C., Mejorar la ciudad transformando sus barrios. Regeneración Urbana en Andalucía (1990-2015) (págs. 123-128). Sevilla (España): Centro de Sociología y Políticas Locales - Universidad Pablo de Olavide.

— \& Rodríguez, M. (2015a): El diseño de los proyectos de regeneración urbana: la adaptación del "frame" y los "escenarios evaluativos". En Navarro, C., Mejorar la ciudad transformando sus barrios. Regeneración Urbana en Andalucía (1990-2015) (págs. 35-51). Sevilla (España): Centro de Sociología y Políticas Locales - Universidad Pablo de Olavide.

— \& Rodríguez, M. (2015b): Informe 4.2 Regeneración urbana y modelos de gobernanza: Estudio comparado de casos. Proyecto de I+D+i Regeneración Urbana y Cohesión Social en Andalucía (RUCOSA), Universidad Pablo de Olavide, Centro de Sociología y Políticas Locales, Sevilla (España).

- \& Echaves, A. \& MoyA, R. (2015a): Los proyectos de regeneración urbana y sus barrios: selección y caracterización de los casos. En NAVARRo, C., Mejorar la ciudad transformando sus barrios. Regeneración Urbana en Andalucía (1990-2015) (págs. 23-34). Sevilla (España): Centro de Sociología y Políticas Locales - Universidad Pablo de Olavide.

— \& Echaves, A. \& MoyA, R. (2015b): Informe 1.3 Los proyectos de regeneración urbana y sus barrios: selección y caracterización de los casos. Sevilla (España): Centro de Sociología y Políticas Locales - Universidad Pablo de Olavide.

- \& Echaves, A. \& Moya, R. \& Betanzos, J. (2015). Informe 2.1 ¿Ha cambiado el barrio? La delimitación de áreas experimentales y equivalentes. Proyecto de $\mathrm{I}+\mathrm{D}+\mathrm{i}$ Regeneración Urbana y Cohesión Social en Andalucía (RUCOSA), Universidad Pablo de Olavide, Centro de Sociología y Políticas Locales, Sevilla (España).

— \& Guerrero, G. \& Moya, R. (2015). Informe 2.2 Los impactos de la regeneración urbana: cambios temporales en áreas experimentales y equivalentes. Proyecto de I+D+i Regeneración Urbana y Cohesión Social en Andalucía (RUCOSA), Centro de Sociología y Políticas Locales-Universidad Pablo de Olavide, Sevilla (España).

— \& Rodriguez, M. \& Zapata, A. \& Mateos, C. (2015a): ¿Cómo han afectado los proyectos a los residentes? En Navarro, C., Mejorar la ciudad transformando sus barrios. Regeneración Urbana en Andalucía (1990-2015) (págs. 81-112). Sevilla (España): Centro de Sociología y Políticas Locales Universidad Pablo de Olavide. 
- (2015b): Informe 3 El impacto de los proyectos de regeneración urbana: el contexto a la exposición a las medidas de regeneración urbana. Proyecto de I+D+i Regeneración Urbana y Cohesión Social en Andalucía (RUCOSA), Centro de Sociología y Políticas Locales - Universidad Pablo de Olavide, Sevilla (España).

Organización de Cooperación y de Desarrollo Económico (OCDE) (1997): Un sistema de indicadores urbanos. Gabinete de Estudios y Estadísticas, Ayto. de Vitoria-Gasteiz (España).

OrganizACIÓN DE LAS NACIONES UNIDAS (ONU) (2015): Resolución 70/1 de la Asamblea General "Transformar nuestro mundo: la Agenda 2030 para el Desarrollo Sostenible" A/RES/70/1. Obtenido de https://www.un.org/ga/search/view doc. asp?symbol=A/70/L.1\&Lang=S

PARKINSON, M. (2014): Regeneración urbana integrada en 2014: nada nuevo bajo el sol y ¿Qué pasa con España? Ciudad y Territorio. Estudios Territoriales, Volumen XLVI, $n^{\circ} 179,11-27$.

Rhodes, J. \& Tyler, P. \& Brennan, A. (2005): Assessing the Effect of Area Based Initiatives on Local Area Outcomes: Some Thoughts Based on the National Evaluation of the Single Regeneration Budget in England. Urban Studies, 42 (11), 1919-1946.

Rosa, C. \& MÁrquez, M. \& NavAs, D. (2017). Hacia un nuevo modelo de gestión y autofinanciación de la regeneración de barriadas obsoletas. Ciudades, 20, 45-70.

Rubio, E. \& UREÑA, J.M. (2020): Metodología para evaluar la regeneración de barrios no planificados: el Barrio de San Antón en Cuenca. A: LLoP, C. \& Cenvera, M. \& Peremiquel, F. (eds.). "IV Congreso ISUF-H: Metrópolis en recomposición: prospectivas proyectuales en el Siglo XXI: Forma urbis y territorios metropolitanos, Barcelona, 28-30 Septiembre 2020". Barcelona: DUOT, UPC, 2020, p. 1-16.

RUEDA, S. (1999): Modelos e Indicadores para ciudades más sostenibles. Taller sobre indicadores de Huella y Calidad Ambiental Urbana. Fundación Fórum ambiental en colaboración con la Agencia Europea de Medio Ambiente.

Ruiz-Apilánez, B. \& Ureña, J. \& Solís, E. (2014): La revitalización de la calle: estrategias basadas en la remodelación. Ciudad y Territorio Estudios Territoriales, $n^{\circ} 181$, 393-412.

SAIZ, J. (2004): Los cambios en la vivienda de la exRepública Democrática Alemana a pafrtir de la reunificación. Ciudades, 8, 68-35.

Salas, J. \& Yepes, V. (2019a): A discursive, manyobjective approach for selecting more-evolved urban vulnerability assessment models. Journal of Cleaner Production (Capítulo 3). https://doi.org/10.1016/j.jclepro.2017.11.249

- (2019b): MS-ReRO and D-ROSE methods: assessing relational uncertainty and evaluating scenarios' risks and opportunities on multi-scale infrastructure systems. Journal of Cleaner Production. Vol. 216, 607-623. https://doi.org/10.1016/j.jclepro.2018.12.083
- (2019c): VisualUVAM: A Decision Support System Addressing the Curse of Dimensionality for the Multi-Scale Assessment of Urban Vulnerability in Spain. Sustainability 2019, 11, 2191. https://doi.org/10.3390/su11082191

SÁNCHEZ dE MAdARIAGA, I. (2004): Infraestructuras para la vida cotidiana y calidad de vida. Ciudades, 8 , 101-133.

Sánchez de Madariaga, I. \& García, J. \& Sistro, R. (2018): Mirando hacia el futuro: ciudades sostenibles. Los Objetivos de Desarrollo Sostenible en 100 ciudades españolas. Madrid (España): Red Española para el Desarrollo Sostenible (REDS).

Segado-VÁzquez, F. \& Espinosa-Muñoz, V. (2015): La ciudad herida. Siete ejemplos paradigmáticos de rehabilitación urbana en la segunda mitad del siglo xx. EURE, Volumen 41, $n^{\circ} 123,103-129$.

Serrano, E. \& al. (2014): Evaluación del impacto en salud de intervenciones de regeneración en la bahía de Pasaia: percepciones de la población afectada. Gaceta Sanitaria: 28(6), 442-449.

SHort, J. (1982): Housing in Britain: The Post-War Experience. London (United Kingdon): Methuen.

Simón-Rojo, M. \& Hernandez-Aja, A. (2011): Herramientas para evaluar la sostenibilidad de las intervenciones urbanas en barrios. Informes de la Construcción, Vol. 63, 41-49.

SMiтH, N. (1979): Toward a Theory of Gentrification A Back to the City Movement by Capital, not People, Journal of the American Planning Association, 45:4, 538-548.

Soles I Coll, G. (s.f.): El derecho a la ciudad en África Subsahariana. Obtenido de: https://www.africaye.org/derecho-ciudad-viviendaafrical

Solis, E., UReÑA, J. \& Mohíno, I. (2018): Centralidad territorial y especialización funcional como guía para la intervención en municipios con conjunto histórico. El caso de la región urbana madrileña. ACE: Architecture, City and Environment, 13 (37), 99-132.

TaYlor, D. \& Balloch, S. (2005): The politics of evaluation: an overview. En TAYLOR, D., \& BALLOCH, S. (Edits.), The politics of evaluation. Bristol, United Kingdom: The Polity Press.

Tello-Campos, C. \& Aguilar-Martinez, A. (2013): Regeneración y calidad de vida urbana en el centro antiguo de las ciudades de Montreal y México: una comparación. Economía, Sociedad y Territorio, vol. XIII, núm. 41, 121-149.

TroItIÑO, M. A. (1998): Turismo y desarrollo sostenible en ciudades históricas. Eria, 47, 211-227.

VARGAS-YÁÑEZ, A. (2015): Los indicadores de sostenibilidad de los municipios españoles: una propuesta metodológica a la vista de su evolución entre 2002-2015. Il International Congress on Sustainable Construction and Eco-Efficient Solutions. Sevilla (España).

Velázquez, I. \& Verdaguer, C. (2011): Regeneración urbana integral, tres experiencias europeas innovadoras: Île de Nantes, Coin Street y Barrio de la Mina. Madrid (España): SEPES Entidad Estatal de Suelo. 
Verdaguer, C. (2005): Evaluación del espacio público. Indicadores experimentales para la fase de proyecto. En Hernández, A., Proyecto en trabajo de investigación: Periferias, Sostenibilidad y Vitalidad Urbana. Madrid (España): Escuela Técnica Superior de Arquitectura de Madrid.
Von Breymann, H. (2014): La satisfacción residencial como herramienta de evaluación de proyectos de rehabilitación urbana. Ponencia presentada en el VI Seminario Internacional de Investigación en Urbanismo, Barcelona-Bogotá. Barcelona (España). 


\title{
CIUDAD Y TERRITORIO
}

ESTUDIOS TERRITORIALES

ISSN(P): 1133-4762; ISSN(E): 2659-3254

Vol. LIII, № 207, primavera 2021

Págs. $65-76$

https://doi.org/10.37230/CyTET.2021.207.04

CC BY-NC-ND

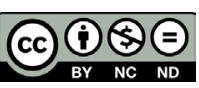

\section{Movilidad, migraciones y nomadismo. El urbanita y los espacios de ambivalencia y mediación en la ciudad del siglo XXI}

\author{
Angelique Trachana ${ }^{(1)}$ \\ Rubén Arturo CACSIRE-GrIMALDOS ${ }^{(2)}$
}

(a) Dra. Arquitecta, Profesora de la Universidad Politécnica de Madrid, Escuela Técnica Superior de Arquitectura de Madrid.

${ }^{(2)}$ Arquitecto, Doctorando en la Universidad Politécnica de Madrid, Escuela Técnica Superior de Arquitectura de Madrid.

RESUMEN: Desde un enfoque interdisciplinar, se trata de definir la condición del urbanita contemporáneo y su espacialidad. La conceptualización de lo nómada abre nuevos caminos para pensar las diferentes movilidades, la construcción de las identidades y las transformaciones espaciales de la gran ciudad en el mundo global e interconectado. El estudio se plantea sobre tres líneas directrices: una aproximación al reconocimiento del sujeto contemporáneo ‘urbanita’ y el cambio de sus referentes estables por referentes inestables, los efectos de la mediación tecnológica en la vida nómada y las transformaciones de su entorno, es decir, el sujeto, su entorno y la mediación. El urbanita contemporáneo en constante 'errancia' va erosionando continuamente las estructuras instauradas sedentarizantes, de vigilancia y control de la gran ciudad, instituyendo espacios de relaciones transitorias y de carácter ambivalente.

PALABRAS CLAVE: Nómada; Urbanita; Mediación; Instituyente; Ciudad fragmentada.

\section{Mobility, migrations and nomadism. The urbanite and the spaces of ambivalence and mediation in the city of the 21st century}

ABSTRACT: From an interdisciplinary approach, this paper is about defining the condition of the contemporary urbanite and its spatiality. The conceptualization of the nomad opens new paths to think about the different mobilities, the construction of identities and the spatial transformations of the big city in the

Recibido: 01.12..2019; Revisado: 02.06.20

Correo electrónico: anqelique.trachana@upm.es; № ORCID: https://orcid.org/0000-0002-4398-4543;

Correo electrónico: racacsire@unap.edu.pe; NºRCID: https://orcid.org/0000-0003-1063-3023

Los autores agradecen los comentarios y sugerencias realizados por los evaluadores anónimos, que han contribuido a mejorar y enriquecer el manuscrito original 
global and interconnected world. The study is based on three guidelines: an approach to the recognition of the contemporary urban subject and the change of its stable references by unstable references, the effects of technological mediation on nomadic life and the transformations of its environment, that is, the subject, its environment and mediation. The contemporary urbanite in constant 'wandering' is continually eroding the established sedentary, surveillance and control structures of the big city, instituting spaces of transitory and an ambivalent nature relations.

KEYWORDS: Nomad; Urbanite; Mediation; Instituting; Fragmented city.

\section{Una aproximación a la condición "nómada"}

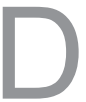
esde la perspectiva de la sociología y la filosofía, el análisis de las subjetividades en el mundo urbano contemporáneo parece orientarse hacia la condición nómada. El nomadismo y el movimiento se adoptan como categorías epistemológicas y metodológicas para estudiar los cambios estructurales en las urbes globales. Según el sociólogo francés, Michel MAfFesoli (1999: 138-140), uno de los fundadores de la sociología de la vida cotidiana, en sus análisis de la posmodernidad y de las "tribus urbanas", las identidades ahora se construyen imaginativamente sin ideologías afirmadas y empíricamente vividas. El individuo-urbanita busca resquicios de libertades entre la soledad y la pérdida de identidad en el mundo globalizado. Una aportación significativa a la definición del nuevo urbanita y su espacialidad, viene del pensamiento poshumanista de SLOTERDIJK (2012) y BRAIDOTTI (2009), para quienes es la adopción creativa de una vida móvil y su vitalismo frente al sedentarismo, la forma de vida que corresponde al urbanita-nómada en la era del capitalismo industrial.

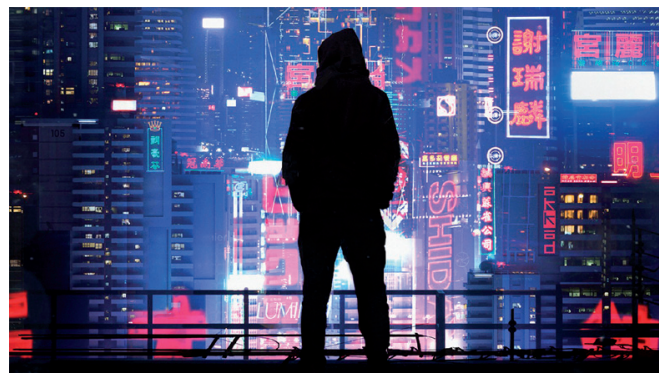

FIG. 1/ En la gran ciudad.

Fuente: https://wallhere.com/es/wallpaper/1677147

La vida del siglo XXI, orientada hacia un nuevo orden mundial, debido fundamentalmente al cambio estructural que están atravesando las grandes ciudades, en detrimento de las pequeñas, se basa en la creciente movilidad poblacional. La movilidad de escala mundial sin precedentes tiene como factores principales, en primer lugar, la creciente brecha entre países ricos e industrializados frente a países sumidos en pobreza, constituyéndose en una enorme atracción, en la esperanza de alcanzar mejores condiciones de vida para un grueso de población en pobreza y extrema pobreza. En segundo lugar, es innegable el hecho de que en países de Europa, Norteamérica, Canadá y Japón, principalmente, la población está envejeciendo y la decreciente tasa de natalidad sólo podrá ser compensada con la inmigración inducida. Así lo determina el nuevo pacto sobre migración de la Organización de Naciones Unidas, firmado en diciembre del 2018 que, por otro lado, reconoce la migración como un derecho humano, que así debe ser reconocido por todos los Estados. Factores que podrían desatar históricas avalanchas migratorias y reconformaciones demográficas de enorme impacto son los conflictos internos, autocracias, dictaduras, guerras civiles, terrorismo, extrema pobreza, desastres naturales y otros que generan desplazamientos internos, locales y nacionales enlazados a los movimientos poblacionales internacionales. Tras toda migración internacional subyace una serie de causas internas locales y nacionales.

Para estas poblaciones inmigrantes en la gran ciudad, las perspectivas son la precariedad y la temporalidad laboral, la inestabilidad relacional y los desplazamientos. En una vida cotidiana en cuya forma de habitar, la movilidad y la conectividad son las características principales, se suma todo un elenco de categorías urbanas de vida precaria que se desenvuelve en espacios "genéricos", medios de transporte, cibercafés, delivery y otros "no lugares" y, que supone una transformación radical de la vida cotidiana entendida desde el sedentarismo. El cambio y la innovación como valores de la sociedad de la información y el conocimiento, la necesidad de buscar las oportunidades allí donde se encuentren, diversos vagabundeos y múltiples anomías, la movilidad, en definitiva, que conlleva la vida contemporánea, perfila el 'nómada' como categoría emergente en las urbes globales del siglo XXI.

La elaboración filosófica del concepto de lo nómada relaciona la movilidad, el desplazamiento 
y el cambio como claves en el análisis de la identidad de las personas adoptadas transnacionalmente. Las diversas formas de alteridad en las sociedades sedentarias están contribuyendo, todas ellas, a desarrollar un sentimiento de cultura común y de una solidaridad (DELEUZE \& GUATTARI, 2010). La circulación de los individuos de comunidad en comunidad, establece entre éstas lazos no institucionales y favorece, en su sentido más fuerte, una cultura común en que los emigrantes, refugiados, artistas, intelectuales, científicos, comerciantes y otras especies migratorias contribuyen todos a desarrollar el sentimiento de una pertinencia común.

Como una categoría transversal y atemporal, examinada en otros tiempos con la misma intensidad, lo nómada, asociado con la inestabilidad y la transitoriedad, los modos de ser y de pensar que podían calificarse como confusos, flotantes, descompuestos o simplemente aventureros, son en nuestros días ampliamente vividos por toda una serie de marginalidades tendientes a convertirse en la centralidad de la sociedad que está en curso de elaboración. "Es, en este sentido, que la errancia, con relación a ciertos valores burgueses establecidos, puede ser una prueba de creatividad" en lo que concierne la vida contemporánea. Un ideal tipo, de una forma quizá algo exagerada, pero que

"resalta la dimensión vagabunda de la vida que es, a la vez, fecundante, potente, y bulliciosa, al tiempo que no se acomoda a las formas institucionales de dominación por ser demasiado racionales y singularmente abstractas" (MAFFESOLI, 1999: 137).

Karl Marx aludía a la bohemia como aquel lado de la sociedad combinada de

"lagartones arruinados de dudosos medios de existencia, de aventureros, de desechos corruptos de la burguesía, vagabundos (...), rateros, charlatanes (...), rufianes encargados de casas públicas, mozos de cuerda, escritorzuelos, organilleros, traperos, estañadores, mendigos, en resumen, toda esa masa confusa, descompuesta, flotante que los franceses llamaban la bohemia".

Según MAFFEsol (1999: 132),

"el nomadismo no está únicamente determinado por la necesidad económica o la simple funcionalidad. Su móvil es otro: el deseo de evasión. Es una especie de pulsión migratoria que incita a cambiar de lugar, de hábito, de compañeros, y ello para realizar la diversidad de facetas de la personalidad".

Así, frente a la uniformidad étnica, el vitalismo, la función dinámica de la exploración, la pulsión de migración, la integración y naturalización de marginalidades es la animación social o ampliación de las potencialidades sociales, en su más fuerte sentido, las que distinguen nuestra época y esta clase "urbanita nómada" siempre en evolución, transformación y subversión de lo establecido. Su impulso en todas las facetas de la sociedad -demográfica, económica, cultural y moral- puede ser observada como pulsión creativa. Dentro del pensamiento poshumanista de SLOTERDIJK (2012) y BRAIDOTTI (2000), el nomadismo representa una aguda consciencia de no fijación de límites, el intenso deseo de rupturas, de transgresiones, de subversión de lo establecido, un estar en una frontera. El nómade está en disposición para un cambio de posición, para sobrepasar el límite. Toda subversión no tiene por qué asumir únicamente una filosofía afirmativa en una lógica ciega y perversa que se alimenta a sí misma con la idea de 'progreso' ilimitado del capitalismo, heredada de la llustración y el Humanismo (MAUREIRA, 2016: 9). La subversión desde una perspectiva de la propia trayectoria, de lo que somos, de nuestro ser contemporáneo como individuos, se desgaja de la idea de subordinación del individuo a un orden social que ha fomentado el capitalismo.

Estar en la vanguardia, el que marcha en primera línea, como indica el término, por su propia situación ejerce violencia contra el orden establecido. No se trata de un análisis
"a partir de categorías psicológicas, de un indivi- duo agitado o desequilibrado, sino de la expresión de una constante antropológica: aquella de la pulsión del pionero que marcha siempre adelante en su búsqueda de El Dorado". Entendida esta búsqueda,
"tanto como el oro para los alquimistas medievales, no concierne sólo la posesión de un bien material o cambiable, sino que es el símbolo de una búsque- da sin fin, la búsqueda de sí en el marco de una comunidad humana donde los valores espirituales son las consecuencias de la aventura colectiva. Es por ello que la frontera debe forzarse siempre a fin de que la aventura en sus diversas modulaciones pueda continuarse" (MAFFESOLI, 1999: 128-129).

En el imaginario colectivo, el mito del caballero errante, cualesquiera sean las figuras contemporáneas que pueda tomar, se mantiene presente. En el marco de las sociedades industriales y posindustriales, la pulsión del viaje, la fuga, la errancia, el nomadismo como cambio de experiencias y aprendizaje, que tiene raíces arcaicas, están profundamente grabados en nuestra estructuración y es el recuerdo de una juventud arquetípica de las cosas y del mundo. Sirve de anamnesis a lo que fue el acto fundador de un amor, de un ideal, de un pueblo, de una cultura, revigorizando con ello la entidad en cuestión, redinamizándola, dándole una nueva vida. Sigue siendo una visión, un sueño atrayente que recuerda lo instituyente que relativiza la pesadez mortífera de lo instituido. 
Al destacar el aspecto extraño, extranjero, nómada del cual está modelada una cultura atropellando lo establecido de las cosas y de las personas, como dice MAFFESOLI, (1999: 128),

"el nomadismo es la expresión de un sueño inmemorial que siempre se ha encontrado entorpecido de diferentes maneras por lo instituido: el cinismo económico, la reificación social o el conformismo intelectual".

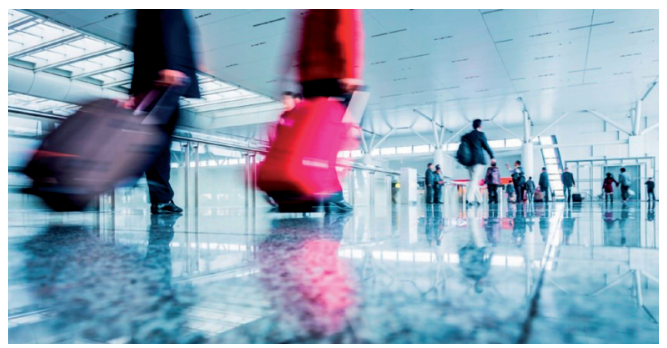

FIG. 2/ En el aeropuerto.

Fuente: https://www.skyscanner.es/noticias/

\section{El urbanita contemporáneo nómada}

\subsection{Lo instituyente frente a lo instituido}

Si el nomadismo constituye una condición humana, condición existencial o estado espiritual asociados al emprendimiento y la creatividad, si representa lo instituyente frente a lo instituido, la línea metodológica de este trabajo se dirige a demostrar el nomadismo como una manifestación de las ciudades globales de finales del siglo XX e inicios del siglo XXI, consecuencia de un conjunto de factores que están generando impactos, cambios y reconfiguraciones de orden social, económico, político-institucional y espacial de la gran ciudad experimentada en estas últimas décadas.

\section{Efectivamente,}

"la vida individual e institucional es cada vez más móvil e inter-localizada. Una cantidad de aspectos de la movilidad contemporánea transforma las subjetividades y las relaciones sociales. La educación intercultural contemporánea se centra en las influencias socioculturales, en las creencias y comportamientos de las personas. Para una porción creciente de la población, el trabajo y el ocio se unen y fusionan, y estos vínculos entre ellos se vuelven dominantes. Los viajeros traen su mundo -y a ellos mismos- a otros mundos: sus experiencias, identidades, imaginación, hábitos y habitus. Las tecnologías modernas hacen que el significado de 'viajar' se haya alterado. Las movilidades virtuales y corporales se superponen, con importantes implicaciones para la experiencia del tiempo y del espacio. El flujo simultáneo y ahistórico de imágenes y presentes fuerzan al ser humano hacia una experiencia deshumanizada, carente de límites temporales y espaciales; (...) pueden tener cierta transcendencia para los lugares donde se articulan estas movilidades, teniendo en cuenta la capacidad transformadora que se suele asociar a ellas" (GAGGIOTTI \& al, 2015: 6-7,9)

Los desequilibrios demográficos debidos a los crecientes movimientos poblacionales se reflejan en la configuración espacial de lugares de partida y principalmente ciudades de destino, que se verán cada vez más alteradas en su configuración espacial como consecuencia inevitable de la composición social móvil e inestable. Inexorablemente el ser de lo social hoy es fluidez, circulación, un perpetuo devenir. Para MAfFEsoli (1999: 139), "la sociabilidad va a reposar en un interaccionismo simbólico informal y a la vez muy sólido". La metrópolis global, como fenómeno de análisis e interpretación de las tendencias sociales urbanas, presenta además una serie de manifestaciones y comportamientos que conjuntamente, podemos aventurar, configuran el 'nuevo urbanita'.

El enfoque temporal de la vida nómada merece una atención especial. Esta concepción innovadora de lo nómada, se encuentra en el devenir y no en el pasado ni en el presente; organiza una narrativa que abandona el modo de organizar lo social, el mito del orden, de una determinada forma de reunir gente, definir experiencias, personalidades, identidades e historias. LAW (1994) considera esta forma de cómo se concibe lo colectivo-institucional abierta, imaginativa, ingeniosa y de una nueva dimensión estética, en términos de GUILLET DE MonTHOUx (1998). La emergente "clase creativa" de las grandes ciudades (FLORIDA, 2009), podría hacerse extensible en esta masa fluctuante en que la subjetividad nómada se acomoda a la indeterminación y la incertidumbre y, frecuentemente, al riesgo, la iniciativa, la inventiva y la creatividad que le es propia.

Al tiempo-espacio en que se viven relaciones diferentes que en la vida sedentraria, Deleuze \& GUATTARI (2010), asumiendo una crítica a la polarización social que la sectorialización espacial y la movilidad dominante del capital global produce, llaman espacio in-between, un espacio social como intersticio. Así mismo, frente al efecto de homogeneización bajo el paraguas de una supuesta hibridación cultural de la globalización, FELIU FABRA (2015) defiende un concepto de "traslación", en tanto que desplazamiento que permite al nuevo urbanita

\footnotetext{
"crear puentes, acercar y relacionar lenguajes, códigos, emociones y puntos de vista que en un principio podrían parecer contradictorios" (GAGGIOTTI \& al., 2015: 7).
} 


\subsection{Referentes inestables frente a referentes estables}

El nomadismo y el movimiento como epistemología para leer del mundo contemporáneo adopta el montaje, el pastiche, el bricolaje y el collage como metodología frente a la perspectiva de un mundo estructurado. El nomadismo metodológicamente permite una narración de historias en la "liminalidad" (TURNER, 2005 ) evitando y desafiando cualquier pretensión de leer estados unitarios y estables, en

"una desconexión activa de cualquier intento de fijación, definición, clasificación, codificación (GaggiottI \& al., 2015: 8).

Entre las capas de la propia subjetividad se lee esta "traslación" continuamente como la experiencia de la "deriva" pasando por los "no-lugares" de la "ciudad genérica" y la multi-culturalidad, más que inter-culturalidad en Europa. "Traslación" viene a significar relación que organiza un discurso no lineal y basado en una estructura definida por una sucesión causal. Los significados se conforman entre voces distintas como collage. La "traslación" se asume como estrategia de conocimiento y como estrategia política para poner en movimiento aquello inmovilizado y predefinido desde la modernidad: la identidad, la memoria, el territorio, la cultura. Así frente a ideologías del dominio de la gente y de las cosas, se presentan lógicas y sus narrativas que se gestan en un pensamiento del cambio, a saber, aquello que hace pensar el ser en perpetuo devenir. El pensamiento posthumanista, al contrario que el capitalismo que fomenta un sedentarismo (el consumo y acumulación de mercancías) opone una "liberación", la consciencia nómade, que supondría la adopción creativa de una vida móvil.

SLOTERDIJK (2012) critica fuertemente la pereza y el inmovilismo del ser humano que se aleja de la "ejercitación de la vida" dejándose llevar por la costumbre y el hábito sin atender a las tensiones verticales (ascéticas) de la vida que incitan al cambio. En su propuesta de "ética nómade", lo que define al nomadismo no es el viajar, sino la subversión de las convenciones establecidas; no es la carencia de hogar, sino el ser capaz de recrearlo en cualquier parte; no es el rechazo y aversión por crear bases estables, sino el hecho de aprender a vivir en transición sin adoptar ningún tipo de identidad como permanente. Es el vitalismo poshumanista,

"la apelación a la vida como potentia. La característica fundamental de lo vivo es detentar un tipo particular de organización, a saber, una organización "autopoiética” (MAUREIRA, 2016: 2-4).
Como diría SLOTERDIJK (2007: 1-3),

"el sujeto que se define por su referencia a una patria es como un animal que hubiera hecho suyo el privilegio de las plantas de echar raíces. Claro está que ese animal con raíces representa una imaginaria forma híbrida que, bajo condiciones históricas distintas, deberá pagar el precio de su imposibilidad biológica".

El inicio de ese cambio histórico decisivo lo marca la ciudadanización y la movilización de las formas de vida. "El fin de la civilización sedentaria inaugura una época de crisis permanente del concepto de patria" y esta transformación de la conciencia del ser humano actual respecto a sus condiciones de residencia, conforma el nuevo 'urbanita'. "La falsa conexión entre el territorio y su propietario es hasta hoy uno de los legados más efectivos y problemáticos de la era sedentaria", ya que en ella se afirma el reflejo básico de "todo uso aparentemente legítimo de la violencia, la así llamada 'defensa de la patria'. Esta falacia reposa sobre la obsesiva equiparación entre el espacio y la identidad, la falacia originaria de la razón territorializada". Ese error fatal se ha puesto, cada vez más, al descubierto desde que la gran onda de movilidad transnacional, sin precedente en la historia, ha relativizado la ligazón entre pueblos y territorios.

Así la tendencia hacia la identidad de un "sí mismo" "multilocal", es característica de la modernidad avanzada, del mismo modo que la tendencia hacia el espacio poliétnico o "desnacional". Cuando el discurso de la Modernidad habla de la patria se refiere a un punto de partida del movimiento hacia el espacio terráqueo abierto y no al claustro regional ineluctable de antes.

Zigmunt BAUMAN (2019: 21), sitúa el inicio de estos cambios en las "tres gloriosas décadas" que siguieron el final de la Segunda Guerra Mundial, tres décadas de crecimiento sin precedentes y de afianzamiento de la riqueza y de la seguridad económica del próspero occidente y que significó la consolidación de la gran ciudad moderna e industrial. El poder económico propio del capitalismo y de la industrialización se reconoce como periodo de la gran ciudad y del abandono del campo. Además, el vertiginoso avance de las tecnologías digitales y las comunicaciones, que terminan por explicar la plenitud de estos movimientos, llegaba en las décadas de los 80 y 90 y con ellas el nómade urbano del s. xxi y su desconexión del territorio. Estos grandes cambios suscitados en el último tercio del siglo $\mathrm{XX}$ tendrían consecuencias muy complejas, en este siglo XXI.

Es un hecho de que el mundo moderno ha crea-do una nueva política del espacio y una dinámica particular en cuanto a las formas de residencia. Residir significa formar parte de un sistema-espacial. 
En la cultura de los sentimientos, cualquier emigración, dejar su 'origen', por supuesto, es también un cambio vivido de manera traumática, que tiene que ver con el dolor y con el sufrimiento, pero la estructura de la "comunidad nomádica" tiende a naturalizarse como la de un "sí-mismo" sin espacio y la de un espacio sin "sí mismo". La convergencia entre espacio y el "sí-mismo" como identidad se ve afectado por la globalización con la consecuencia de que

"incontables habitantes de los Estados nacionales modernos no se sienten estar consigo mismos ni en su casa, y estando consigo mismos tampoco se sienten en su casa" (SLOTERDIJK, 2007: 2).

La 'errancia' del inmigrante o el 'vagabundeo' del viajero influyen decisivamente en la configuración del 'urbanita', persona que ha nacido o que vive en la gran ciudad y prefiere la vida en ella a la vida en el campo o una ciudad pequeña. El 'urbanita' será entonces la expresión máxima de la sociedad moderna, a la que BAUMAN (2019) caracteriza por estas condiciones como "líquida" y representada principalmente por una 'juventud' nacida en este medio siglo. MAFFESOLI (1999: 132) reconoce en este nomadismo un móvil como el deseo de evasión

“El sexo, la vivienda, la educación, el trabajo, no tienen la estabilidad o la delimitación precisa y funcional que era lo propio del mundo moderno, sino que se mantienen fundamentalmente ambiguos, polisémicos, en resumen, abiertos a la aventura con todo lo que ella tiene de indeciso, de azaroso, de no previsible".

El urbanita entonces, es quien plantea nuevas conductas y configuraciones nómades que tienden a cambiar los referentes estables por referentes inestables siempre dentro de la gran ciudad.

\section{Espacios de ambivalencia y mediación}

Del análisis de la espacialidad que corresponde a una vida nómade resulta La ciudad genérica

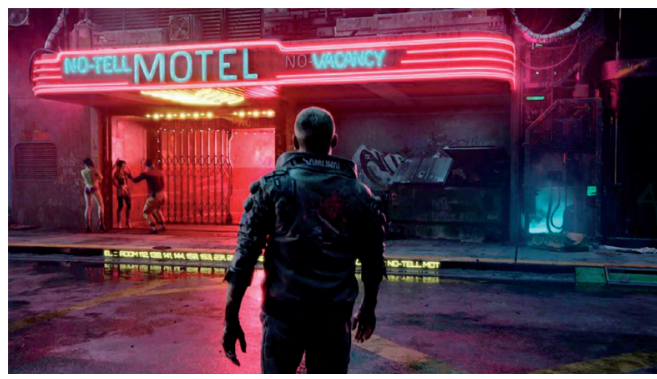

FIG. 3/ El hotel.

Fuente :De la película "No-tell Motel"
(KoOlHAAs, 2006), descrita como un espacio sin identidad. Los espacios que el urbanita nómada transita, se relaciona y establece transacciones en la urbe sin por ello establecer vínculos afectivos, son los espacios

"en que las personas se reúnen sin por ello querer (o poder) establecer un vínculo entre su identidad y la localidad. Eso puede aplicarse a todas las zonas de paso, en estricto y amplio sentido del término. Ya sean localidades destinadas al tránsito, como estaciones, puertos, aeropuertos, calles, plazas y centros comerciales, o se trate de instalaciones diseñadas para una estancia limitada como los centros vacacionales o las ciudades turísticas, plantas fabriles o asilos nocturnos. Tales espacios pueden poseer su propia atmósfera; sin embargo, su existencia no depende de una población regular o un colectivo en 'sí-mismo' que estuviera arraigado a ellos. Lo propio de ellos es no detener a sus visitantes, paseantes u operantes. Son tierra de nadie, a veces repleta, a veces vacía. Desiertos de paso que pululan en los centros sin núcleo y en las periferias híbridas de las urbes contemporáneas" (SLOTERDIJK, 2007).

Las periferias híbridas pueden aquí tener un sentido tanto metafórico como literal. Periférica se puede considerar una relación inocua e insubstancial, en el sentido más convencional. Espacios híbridos en la frontera entre lo físico y lo mental son también una fase intermedia del espacio y el tiempo, de una liminalidad ambigua cuando no se está en un sitio ni en otro sino en un umbral; un estado ambiguo que puede ser de apertura y cierre, de inclusión y exclusión, de una situación que se ha dejado atrás y otra que está por llegar y en todo caso nos aleja de referentes estables. Espacios ambivalentes, de límites indefinidos son aquellos donde la gente se reúne, pero las formalidades establecidas por los rituales sociales ya no se aplican. La idea del nomadismo está estrechamente vinculada a esta 'liminalidad' de un modo de ser -y organizar- donde no se aplican las restricciones habituales. Las normas culturales se relajan y se sustituyen por los vínculos entre individuos. El sentido de comunidad, como sugiere Victor TURNER (2005), es una fase, una etapa transitoria, un rito de paso, una pausa dentro de la empresa definitoria de una cultura aunque no sea necesario pasar de un rol estable a otro (GAGGIOTTI \& al., 2015: 5).

En estos espacios de ambivalencia en la sobremodernidad definida por Marc Augé (2000), la comunicación y el lenguaje son reducidos a una mínima expresión o son sustituidos por acciones mecánicas. Augé se refiere a los "no lugares", "como aquellos espacios que no se pueden definir como relacionales, históricos o preocupados por la 'identidad', a pesar de que puedan ser espacios de encuentro. A esta categoría 
pertenecen los aeropuertos o centros comerciales, omnipresentes en el mundo contemporáneo, pero carentes de un significado claro y estable por sí mismos. Son, en gran medida, dependientes de los significados definidos temporalmente por el paso entre lugares estables, como tradicionalmente lo fueron el hogar y el trabajo; lo público y lo privado (GAGGIOTTI \& al., 2015: 5). Aparentemente indeterminados y en su mayoría no reconocibles visual o morfológicamente actúan como recipientes vacíos y receptivos de significación; permiten una potente -aunque momentánea y transitoria- reconstrucción y recreación de los roles, que también puede ser subversiva de órdenes poco profundos y aparentemente fijos y, tal vez, momentos, incluso, poéticos y creativos, que desvían las trayectorias individuales y generan cambios vitales.

Son, en definitiva, estos espacios de una liminalidad ambigua o espacios indefinidos, abiertos a la significación, los que permiten múltiples interpretaciones. Pueden ser espacios abandonados por el centro, espacios sin gobernanza que pueden ser reclamados y apropiados por los de abajo y reconstruidos simbólicamente una y otra vez. El significado de estos lugares es, por esto, transitorio (KociatkieWicz \& Kostera, 2011: 7-8).

En este estado de movilidad sin precedente en la historia, en que las poblaciones aflojan sus vínculos con el espacio, el tiempo es el parámetro sustancial de la experiencia del entorno. Los medios de trasporte unen puntos del espacio y las telecomunicaciones conectan los individuos con otros individuos en diferentes puntos lejanos, lo que "aumenta dramáticamente el número de las zonas de paso" donde las personas que las frecuentan no establecen una relación física. Así las sociedades globalizadas y móviles se polarizan simultáneamente a un 'polo nómada' sin espacio o a un 'sí-mismo' sin espacio y al espacio sin 'sí-mismo' (SLOTERDIJK, 2007: 4). En este terreno, las culturas regionales, que habían florecido con devoción al espacio, se van replegando sobre sí mismas y menguando o contaminándose y mestizándose y, en última instancia, tendiendo a la desaparición.

Sucede pues, que la globalización y el relativismo, que se balancea entre el límite y lo ilimitado, lo objetivo y lo subjetivo, entre el vértigo de lo infinitamente grande y lo infinitamente pequeño, propicie la condición nómade. El nómada urbano de hoy conforma un mundo que partiendo de las pequeñas regiones que lo componían está creciendo, abriendo sus fronteras y dentro de esta amplitud uno se da cuenta de la inmensa pequeñez que se trae consigo (BENítez, 2010: 254). Su mundo se ha quedado pequeño porque puede atraparlo con una mirada, con una imagen, una noticia, estar simultáneamente aquí y allá. El espapacio se ha acelerado y se ha convertido en tiempo.

La tendencia actual hacia formas de vida de individuos centrados en sí mismos, como una nueva evidencia del vitalismo del 'urbanita nómade', da por sentado "que nadie hará por ellos lo que ellos no hagan por sí mismos". En las sociedades posthumanistas constituidas por individuos, la inestabilidad como función del tiempo se enfrenta a la estabilidad como función del espacio y se recomiendan nuevas técnicas inmunológicas como estrategias existenciales ante el debilitamiento de las relaciones entre sujetos, sujeto y objeto, sujeto y lugar; la licencia general para mantener relaciones de infidelidad o relaciones reversibles.

La sobremodernidad como productora de espacios que no son en sí lugares antropológicos como las vías aéreas y ferroviarias, las autopistas y los habitáculos móviles llamados 'medios de transporte' como aviones, trenes, automóviles o los aeropuertos y las estaciones ferroviarias, las estaciones aeroespaciales, las grandes cadenas hoteleras, los parques de recreo, los supermercados y finalmente la madeja compleja de las redes de cables o sin hilos que movilizan el ciberespacio a los fines de una comunicación tan extraña, a menudo no pone en contacto al individuo más que con otra imagen de sí mismo (Augé, 2000: 83-85). Más que de espacios, los marcos sociales de la "modernidad líquida" dependen de los tiempos. Es innegable la necesidad y dependencia de la 'sociedad líquida', a la que Bauman relaciona con la aventura y el viaje más que con el trabajo y con el automóvil tanto como el teléfono móvil, el vivir en el tiempo más que en el espacio.

El enfoque temporal es una concepción innovadora que permite la identificación de las características de la ciudad nomádica. Estas difieren también entre el día y la noche como se expone en el estudio sobre la ciudad y el nomadismo "Es viernes para siempre, Marilín" (RodRIGUEZ, 2011: 21-22), donde el desenfreno de la noche rompe el orden del día y configura la otra ciudad. La cultura del consumo y del ocio vinculada a los no-lugares y las redes es la otra característica sujeta a la temporalidad y los ritmos de la ciudad del s. XXI. Los signos de la libertad y la identidad del nómada urbano, inserto en la estructura de la sociedad de consumo, son según BAUMAN (2019: 90), el "compartir la dependencia del consumo -la dependencia universal de comprar- eso es la conditio sine qua non de toda libertad individual; sobre todo de la libertad de ser diferente" debido

\footnotetext{
"al carácter genuino de la libertad de elección del consumidor, especialmente su libertad de autoidentificarse por medio del uso de productos y espacios masivamente comercializados".
} 
Bauman equipara el "templo del consumo" con la estrategia antropofágica que, según Lévi Strauss, es la supresión de los elementos que caracterizan al otro como tal.

\section{La sociedad globalizada}

\begin{abstract}
"se articula en base a los parámetros del sistema capitalista centrado en el hiperconsumo, que juega un papel determinante en la comercialización de los gustos y estilos de vida (...) en una vorágine de aceleración que se hace difícil de asimilar" (MAUREIRA, 2016: 2).
\end{abstract}

En la nueva carrera del consumo donde se vislumbra la gran escala de la competencia de ofertas 'nuevas y mejores', no es de extrañar que

"cada ciudad trata de acaparar la mayor variedad de ofertas de negocio, comercio, ocio y así lograr una posición de supremacía sobre otras poblándose de íconos de la modernidad global" (Muxi, 2009: 29).

Los espacios del ocio como espacios de la mediación entre lo laboral (subyugante) y la residencia (controlada) son ficción de una vida paralela. Entre los espacios reales identificados como espacios de 'trabajo' y como 'residencia' y estos espacios "ficticios" de libertad y de evasión se establece un constante movimiento rotatorio. Entre el trabajo (institucionalmente) "vigilado" y la residencia permanentemente "controlada" (por los padres), existe, por decirlo así, un estado intermedio representado por el "escapismo" y la "huida"; una rebelión contra el poder del control y la vigilancia, un viaje de huida hacia el paraíso de la libertad, del descontrol y la seducción (MAFFESOLI, 1999; RODRIGUEZ, 2011). Es allí donde el nómada de la gran urbe intercambia cierto tipo de afectividad y busca placer, sexo, alcohol, estupefacientes, y "los otros". Es donde goza en el ritmo y la temporalidad de la fiesta "efímera", que es lo "alternativo" a la cotidianidad, una experiencia acontecida entre lo real y lo virtual.

En la sociedad 'líquida' las condiciones de actuación de sus miembros cambian antes de que las formas de actuar se consoliden en unos hábitos y en unas rutinas determinadas y la relación entre tiempo y espacio es la velocidad. La idea misma de velocidad cuando pasó a depender de la tecnología -de los medios de transporte y comunicacióny sus límites se han roto, lleva a situaciones de simultaneidad y emerge el sujeto inter-localizado que permite la tecnología. Efectivamente, las distancias desaparecen y los espacios también, siempre en referencia al movimiento, en la "ciudad precaria" (Iто, 2000) se

"revaloriza la noción de velocidad por encima de la de movimiento. Si el movimiento es lo extensivo, el nómada no se desplaza, no huye, ni migra, habita en la velocidad intensiva. Y este habitar es el que le permite al nómada reterritorializarse en su propia desterritorialización, es decir, hacer de la ciudad difusa su hogar como la vivienda de "la chica nómada de Tokio" de Toyo Ito (Díaz, 2014).

Esa joven, que se abre al mundo, es el prototipo que habita en el movimiento y la velocidad, que representa la ciudad nomádica, dispersa y fragmentada. En la "ciudad precaria" se reconoce un mosaico de valores, de modos de vida, de construcciones a más no poder diversas, las cuales se constituyen en un

"ritmo intenso donde la circulación desenfrenada
de todas las cosas (de bienes como de símbolos)
no deja de provocar una especie de ebriedad
tanto a los habitantes de la ciudad que buscan
un contrapunto para la monotonía de sus vidas,
como al extranjero de paso que, en cierto modo,
se siente en su casa dentro de ese flujo del juego
de las diferencias" (MAFFESOLI, 1999: 135).

Por tanto, los nuevos ritmos de vida cotidiana del inmigrante, el viajero, el turista y el nuevo urbanita nómada son prácticamente coincidentes: la relajación de las reglas, la flexibilidad de programas y horarios en el trabajo se superponen a las actividades sedentarizantes de la gran ciudad sujetas a horarios, añaden valor a sus competencias y terminan imponiéndose a estas. El teletrabajo, la disponibildad en cualquier tiempo y espacio, la capacidad de adaptación y cambio, el aprendizaje continuo, las herramientas más actualizadas y las nuevas técnicas de trabajo repliegan el ser humano en un segundo plano, vuelven la vida privada inconstante, la familia débil y desvinculan la vida laboral de la vida política y por las vías institucionales. Las subjetividades se han constreñido en una vida precaria y la flexibilización en todos sus aspectos vuelve etéreas las estructuras sólidas y su espacialidad precaria.

La desterritorialización y la virtualización, a través del teléfono móvil e internet, así como el automóvil que insta siempre a moverse, generan sobre la corporalidad del urbanita con respecto al suelo, una necesidad de despegarse en aras de deslizarse a lo largo de una espacialidad amorfa y fluida. Su vida es un modo de reterritorializarse, que consiste precisamente en habitar dicha dispersión de la 'ciudad precaria' (DíAz,2014). La desterritorialización y reterritorialización como procesos activos no son sólo físicos, sino también psicológicos, mentales y espirituales y, consecuentemente, a esta movilidad virtual le corresponde una espacialidad de límites indefinidos, un modo de ser -y organizar-donde no se aplican las restricciones habituales de la sociedad estable, territorializada, sino que la sociedad se sustituye por los vínculos entre individuos que forman comunidades de paso y virtuales. 
Esta aparente anomia social resulta compuesta por individuos que buscan establecer vínculos elegidos y temporales, individuos que se reconocen libres. La liquidez de los vínculos sociales en las redes de comunicación de manera instantánea y desde su zona de confort, al pulsar una tecla, basta para construir un puente o un muro de carácter afectivo y relacional por medio de juicios binarios de likes o dislikes. La sociabilidad se constituye así por enlaces temporales en cuya elasticidad, resistencia y multiplicidad reside su fuerza. Los vínculos débiles y los "espacios lisos", en términos de Deleuze \& GuatTari (2010), cuyos rasgos se borran y se desplazan con las trayectorias, son característicos frente a los espacios que están perfectamente referenciados con líneas que unen puntos y trayectos como en las ciudades occidentales que utilizan la cuadrícula como base de diseño. A estos últimos se refieren como "espacios estriados". Mientras que los primeros sin demasiados controles, no institucionalizados, son movimiento y representan la libertad y el nomadismo, estos son inactivos, ordenados y posibles de controlar. Los espacios lisos se entienden también como un estado de ánimo, una manera de moverse, una desconexión activa del territorio, de los intentos de fijación, definición y clasificación (GAGGIOTTI \& al., 2015: 5).

La navegación sin límites por las redes, los dispositivos móviles y el tecno-nomadismo son la forma de estar y de experimentar la vida productiva de un estilo basado en el movimiento y la fobia al compromiso. "Es la cultura de la privatización móvil y esta reconfiguración de la vida es parte de un proceso más amplio, en que la movilidad global se lleva a cabo a costa de los entornos naturales y las economías y culturas locales" (GAGGIOTTI \& al., 2015: 7). En consecuencia, las personas en vez de verse a sí mismas como parte de una comunidad humana, se consideran, cada vez más, como recursos, cooperando con otros recursos para lograr la máxima eficacia del sistema hipercapitalista.

El nomadismo inter-localizado puede mantener e incrementar la conciencia relacional antagónica a la ciudad (institucional y sedentaria), de naturaleza física y sólida y de no existir una tal 'mediación' tecnológica entre el ser corporal y la ciudad sólida, sus relaciones serían tensas, punzantes y con aristas. Sin embargo, su nexo virtual altamente informe, flexible, y "liquido" es capaz de amalgamar sutilmente estructuras rígidas y sólidas y no solamente transformar la percepción de los referentes espaciales sino de generar diversas transiciones en el pensar y sentir; y a pesar de la eficiencia del sistema disciplinario, reminiscencia de la modernidad que sigue gobernando gran parte de los aspectos de la vida actual, generar resquicios para una vida de espíritus libres, indisciplinados y anómicos del nomadismo contemporáneo.

Tal mediación resulta de dominio cognitivo al posibilitar las informaciones y las relaciones creando una sensación de simultaneidad e inmediatez, de un eterno presente de la sociedad neoliberal e informatizada contra toda jerarquía temporal e histórica intensificando el deseo de liberación de las coacciones del espacio-tiempo. No es de extrañar entonces, que el elemento más acorde a estas condiciones de la vida contemporánea fluida, veloz e individual sean los dispositivos electrónicos. Se incorporan de tal forma en nuestra vida cotidiana que se convierten en extensiones de nuestro cuerpo. Más que probablemente, otro instrumento de control, se constituyen en un elemento que posibilita la aventura con sus múltiples accesos. Nos permiten relacionarnos con los otros, con los extraños, con inmediatez. Se convierten en el gestor que moviliza incesantemente esta capa flexible y fluida del urbanita nómada.

En este contexto hipertecnológico y de la vida móvil "el hábitat pierde todo vínculo con su habitante y ya no es un lugar confortable y acogedor, sino un lugar frío, efímero y transitorio" (CARMONA, 2017: 156). De hecho una ingente cantidad de hogares, que se han convertido en alojamientos turísticos, comparten su vida íntima con los extraños. El cambio de los usos residenciales a otras formas de coliving, alquileres de usos compartidos para estudiantes y otros migrantes, espacios de mediación de la vida cotidiana no hogareña y tantas otras formas se están adaptando a la vida nómada. Es justamente, ese efecto de calor de hogar político y cultural, lo que se ve afectado por la globalización y, en consecuencia, los habitantes globales contemporáneos no sienten en sus casas intimidad que, por otro lado, pueden experimentar en cualquier parte y frente a su portátil.

Tоуо Iто (2000: 46) decía que para "nosotros, habitantes de la ciudad, como nómadas sólo podemos reconocer hoy la 'casa' uniendo varias de sus funciones que están esparcidas en medio de la ciudad como si fueran pedazos de un cristal roto". De allí vaticinaba en torno a "El Pao de las muchachas nómadas de Tokio" y el camino irrevocable al que se dirigiría la ciudad nomádica.

\footnotetext{
"Precisamente la muchacha que vive sola y que vaga por la inmensa llanura de los media, llamada Tokio, es la que más disfruta de la vida de esta ciudad, pero, ¿qué es una casa para ella? El concepto de casa para ella está desperdigado por toda la ciudad y su vida pasa mientras utiliza los fragmentos del espacio urbano en forma de collage. Disfruta de la comida y comenta cosas en los restaurantes o cafés bar, obtiene nuevas informaciones en los cines o en los teatros, examina bien la ropa en las boutiques y mueve su cuerpo en
} 
un club deportivo. Para ella, el salón es el café bar y el teatro, el comedor es el restaurante, el armario es la boutique, y el jardín es el club deportivo. La muchacha nómada deambula por estos espacios muy de moda y pasa la vida cotidiana como en un ensueño. Su vivienda es una tienda-cabaña, o sea el pao, que se puede trasladar de un punto a otro, y en cuyo centro está colocada la cama y otros tres muebles a su alrededor Iто (2000: 61-62)".

El cambio radical de la antaño indesligable relación entre la casa, la ciudad y el territorio sugiere ahora la representación de la ciudad como collage, la 'casa expandida' y el habitar vinculado con la tecnología y el suelo, a la vez. El espacio urbano está absorbiendo al de la vivienda urbana, de tal manera que no es posible imaginarse otra cosa.

\begin{abstract}
"Lo que crea a duras penas la imagen total de la casa uniendo los pedazos de la ciudad (los espacios ficticios de la ciudad), no son sólo las muchachas nómadas. A estas alturas, todos los habitantes de las grandes ciudades están obligados a disfrutar, ni más ni menos, la vida de tipo collage basada en tal experiencia simulada" (...). "Los fragmentos de la casa, esparcidos estratégicamente en los espacios comerciales, se reexportan de nuevo a la vivienda y empieza a formarse la casa como un collage de espacio simulado" (Iто, 2000: 63-64).
\end{abstract}

Tal como tiende a desintegrarse la casa en la ciudad, la sociedad individualista y la familia ausente están desintegrando inexorablemente la trama social. La trama social del individuo vivida como collage frente a la idea de estructura social arroja fuera los referentes estables como el hogar (la casa) y el lugar (la ciudad) que se van alejando a la presencia de todos aquellos referentes inestables y los espacios de ambivalencia y mediación. Finalmente, el nomadismo urbano en la figura del nuevo urbanita, de pertenencias múltiples, descentrado y fragmentario, potencia y deriva en continuo desarraigo y la virtualidad de los espacios simulados que habita definen el posthumanismo al que estamos inmersos.

\section{Conclusiones}

La reflexión sobre y desde lo nómada abre nuevos caminos para pensar las movilidades, las subjetividades y lo social; las organizaciones en un mundo que es global e interconectado, real y virtual al mismo tiempo. La 'ciudad', nos damos cuenta, es un término que corresponde a la ciudad histórica, es decir, la que cuenta con la mayoría de estructuras estables de clara concepción sedentaria, pero que la vida nómada, las migraciones, los viajes, el turismo, las movilidades de toda clase y las tecnologías de última generación van transformando continuamente convirtiendo el espacio en función del tiempo y donde la velocidad y la instantaneidad articulan lo individual con lo social.

La ciudad "precaria", o ex-ciudad sujeta a diferentes atenciones, análisis e interpretaciones precisa diferentes técnicas y estrategias urbanísticas también. Como reducto de la ciudad material que la ciudad virtual va devorando, sus estructuras sólidas, históricamente definidas como espacio socialpúblico y familiar-privado están fracasando. Todo parece indicar que los hogares y las ciudades experimentan cambios estructurales pues, la residencia no representa la comunidad tradicional de la familia y la ciudad está dando paso a la vorágine de lo público polarizado por lo mercantil. A la velocidad de las comunicaciones y la tecnología digital, las distancias -emocional, interpersonal, intergeneracional...-se hacen, cada vez, más pronunciadas y se hace difícil desarrollar y compartir afectos con los que están físicamente cerca y más fácil con los que están lejos.

La experiencia nómada se traduce en individualismo, una especie de claustrofobia intrapersonal, y sin embargo, se siente uno bien expuesto junto a extraños en los no-lugares 'globales'. Si bien las relaciones físicas se están convirtiendo en "líquidas", fluidas e inestables, el nomadismo no es simplemente una fluidez sin fronteras, sino una aguda consciencia de no fijación de límites, el intenso deseo de continuar irrumpiendo, transgrediendo, es lo que define a lo post-humano y, en definitiva, un movimiento de la consciencia a un plano que es post-conciencial y post-subjetivo.

Todas las formas de la errancia que podamos detectar están inscritas en la estructura misma de la naturaleza humana. Anamnesis del mito fundador, la figura del errante, estructuralmente ambivalente, fascina e inquieta a la vez. Representa el escapismo y la huida, la rebelión contra el poder, el control y la vigilancia. Esta perspectiva proporciona claves para repensar las estrategias y programas urbanos cuya implementación establece algún tipo control.

La condición nómada del urbanita contemporáneo expresa el vitalismo, motor del cambio que hunde sus raíces en el bios. En ella han de reconocerse inventiva, emprendimiento, innovación y creatividad para sobrevivir que muchas veces trasciende el ritmo individual, cotidiano, acelerado, inseguro, vitalista, emprendedor y arriesgado hacía emprendimientos colectivos y liderazgos dentro de 
su comunidad. Estas nuevas iniciativas, participación, comunicación, movimiento bottom up se podrían asumir en los haceres en la micro-escala de la ciudad, en lo local y particular sensible, con formas de actuar nuevas que jaquean los sistemas instituidos.

La narrativa nómada que abandona el mito del orden, que amalgama y reúne gente, experiencias, personalidades, identidades e historias, es abierta, imaginativa, ingeniosa y creativa, pues concibe nuevas formas de lo colectivo e institucional. El movimiento, la transición o el nomadismo también gestan sentido de comunidad y pueden de hecho servir para poblar el imaginario de una comunidad global, incrustada en lo post-colonial y corporativo transnacional. En la macro escala urbana, la incesante movilidad permite a los otros, los de fuera entrar en 'la ciudad' y que los de la ciudad se vayan, de modo que en el continuo cambio, radica la novedad, innovación, mezcla, pluralismo, descubrimiento, conocimiento y creatividad.

El nomadismo que puede inspirar historias infinitas, traducir conceptos, presentar y representar explicaciones alternativas del status quo, explicaciones de las transiciones y cambios, no recrea exactamente un antagonismo entre asentamiento y movimiento. Esta concepción innovadora de lo nómada representa lo instituyente frente a lo instituido, estrechamente vinculada a un estado de "liminalidad" indefinida, un modo de ser -y organizar- donde no se aplican las restricciones y las normas de la convivencia tradicional o preindustrial como anamnesis de las sociedades locales y rurales como un paraíso perdido. Estas normas se sustituyen por los vínculos entre individuos, que comparten la misma información en vez de ideales, y que se comunican a distancia.

La ciudad actual se presenta fragmentada localmente y conectada globalmente. La relación de la urbe y el urbanita se concibe con lazos frágiles. En otros términos, se presenta una separación entre lo construido y lo vivido por lo, que pensar la nueva ciudad y el habitar implica evaluar las consecuencias de la vida móvil, muy en particular, las olas migratorias y tratar la humanización de los espacios de transición de los movilizados por las condiciones de la vida contemporánea del hipercapitalismo y el poshumanismo.

La aportación de este análisis es centrar el urbanita frente al urbanismo. A partir del análisis de su figura constituyente y su potencial humano, toda estrategia de gestión de la gran ciudad adquiere sentido como gestión de recursos humanos antes que territoriales. Frente a esta inversión del habitual binomio ciudad-ciudadano, se abre una nueva perspectiva, un enfoque cualitativo con la adopción de nuevos instrumentos de análisis del tejido social, en que son las personas los sujetos de estudio.

\section{Bibliografía}

Augé, M. (2000): Los "no lugares", espacios del anonimato: una antropología de la sobremodernidad, Barcelona, Gedisa.

BAumAn, Z. (2019): Modernidad líquida, España, Fondo de Cultura Económica.

Benitez, E. (2010): Infinito, nihilismo y nomadismo: tres paradojas de la sociedad postmoderna. Ontology Studies: Cuadernos de ontología, (10): 245-255.

BRAIDOTTI, R. (2000): Sujetos nómades: corporación y diferencia sexual en la teoría feminista contemporánea, Buenos Aires, Paidós.

- (2009): Transposiciones: sobre la ética nómada, Barcelona, Gedisa.

CARMOnA, M. (2017): El Objeto en el marco de la vida: de la Un home a la muchacha nómada de Tokio. (Tesis Doctoral), Madrid, Universidad Politécnica de Madrid.

Deleuze, G. \& Guattari, F. (2010): "Tratado de nomadología: la máquina de guerra”. En Mil mesetas. Capitalismo y esquizofrenia (pp. 359-431), Valencia, PRE-TEXTOS.

DíAz, E. (2014). Nomadismo y generalidad: Toyo Ito y la ciudad precaria. ECOSDEASIA. <http://revistacultural.ecosdeasia.com/nomadismo-y-generalidadtoyo-ito-y-la-ciudad-precaria/>

Feliu FABRA, M. (2015): Identidad relacional y traslación. La subjetividad nómada desde el arte y el pensamiento contemporáneos. Scripta Nova, 19 (510-3): 1-42.

FLoRIDA, R. (2009): Las ciudades creativas: por qué donde vives puedes ser la decisión más importante de tu vida, Barcelona, Paidós.

GAGGIOTTI, H.\& al (2015): El nomadismo y el movimiento como epistemologías del mundo contemporáneo. Scripta Nova, 19 (510-1): 1-12.

Guillet DE Monthoux, P. (1998): Estetik som organisationsteori - om relationen mellan konst och företagande. In B. CZARNIAWSKA (Ed.), Organisationsteori pa svenska (pp. 172-193), Malmö, Liber.

Іто, T. (2000): Escritos, Murcia, España, Colegio Oficial de Aparejadores y Arquitectos Técnicos.

Kociatkiewicz, J., \& Kostera, M. (2011): Transitional Space. Tamara. Journal for Critical Organization Inquiry, 9 (3-4): 7-9.

KoolmaAs, R. (2006): La ciudad genérica, Barcelona, Gustavo Gili.

LAW, J. (1994): Organizing modernity, Oxford, UK, Cambridge, Mass., USA, Blackwell.

MAFFESOLI, M. (1999): Nomadismo fundador. Nómadas, 18 (10): 126-142.

Maureira, M. (2016): Posthumanismo: más allá de antropo-técnica y nomadismo. Cinta de moebio, (55): 1-15.doi:10.4067/s0717-554×2016000100001 
Muxí, Z. (2009): La Arquitectura de la ciudad global, Buenos Aires, Argentina, Nobuko.

Rodriguez, T. (2011): Estudio sobre la ciudad y el nomadismo en "Es viernes para siempre, Marilín". udenar.edu.com, 1-28.

http://ceilat.udenar.edu.co/wp-content/ uploads/2011/11/ESTUDIO-SOBRE-LA-CIUDAD TANNIA-RODRIGUEZ.pdf>
SLoterdiJk, P. (2007): Patria y globalización; notas sobre un recipiente hecho pedazos. Observaciones filosóficas, http://www.observacionesfilosoficas.net/ patriayglobal.html>

- (2012): Has de cambiar tu vida, Valencia, Pre-Textos.

TURner, V. W. (2005 ): La selva de los símbolos: aspectos del ritual ndembu, Madrid, siglo XXI. 
CIUDAD Y TERRITORIO

ESTUDIOS TERRITORIALES

ISSN(P): 1133-4762; ISSN(E): 2659-3254

Vol. LIII, № 207, primavera 2021

Págs. 77-94

https://doi.org/10.37230/CyTET.2021.207.05

CC BY-NC-ND

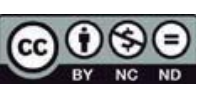

\title{
¿Es recuperable la ciudad como espacio para la infancia? Aproximación teórica desde la perspectiva del urbanismo social, participativo y sostenible
}

\author{
Juan SeVILLA ${ }^{(1)}$ \\ Diego CoRrochano ${ }^{(2)}$ \\ Alejandro GómEZ-GonçALVES ${ }^{(3)}$ \\ Héctor Rato(4)
}

\author{
(1)Departamento de Geografía. Universidad de Oviedo. \\ (2)Departamento de Didáctica de las Matemáticas y de las Ciencias Experimentales. \\ Universidad de Salamanca \\ (3)Departamento de Geografía. Universidad de Salamanca. \\ ${ }^{(4)}$ Colegio Internacional Meres
}

RESUMEN: La concepción que el ser humano tiene del espacio urbano es decisiva en la estructuración de su pensamiento. Este hecho tiene una gran importancia para la población infantil al condicionar el desarrollo de experiencias que asientan destrezas y capacidades, favoreciendo el aprendizaje significativo. Sin embargo, la progresiva deshumanización de las ciudades ha ido restringiendo el contacto directo de la población infantil con el medio urbano. En este trabajo se analizan algunas iniciativas de reencuentro de este sector de la población con la ciudad (La Ciudad de los Niños por Francesco Tonucci, Ciudades Amigas de la Infancia de UNICEF) y el papel que hoy en día está jugando el urbanismo social, participativo y sostenible como corriente convergente con dichas iniciativas. A través una revisión de documentación institucional, de proyectos y de fuentes bibliográficas se analizan los fundamentos de estas formas de entender la construcción de la ciudad. Y se estudian algunos ejemplos de nuestro país que evidencian cómo esta corriente urbanística puede servir como modelo de intervención en municipios comprometidos con los programas defensores de la infancia.

PALABRAS CLAVE: Ciudad; Urbanismo; Infancia; Tonucci; UNICEF.

Recibido: 08.03.2020; Revisado: 13.07.2020

Correo electrónico: sevillajuan@uniovi.es; № ORCID: https://orcid.org/0000-0001-6235-0020;

Correo: dcf@usal.es; No ORCID: https://orcid.org/0000-0002-6085-9744;

Correo: algomez@usal.es; NNoRCID: https://orcid.org/0000-0002-4988-4623;

Correo: hector.rato@gmail.com; No ORCID: https://orcid.org/0000-0002-4492-0736 "

Los autores agradecen los comentarios y sugerencias realizados por los evaluadores anónimos, que han contribuido a mejorar y enriquecer el manuscrito original [1] Los autores desean agradecer el interés y el permiso de reproducción de imágenes de Francesco Tonucci y de los equipos de Col.lectiu Punt 6, HUCAMP Arquitectos y Paisaje Transversal. Ha sido fundamental el asesoramiento prestado por İcaro Obeso durante el período de investigación. 


\title{
Is the city recoverable as a space for children? Theoretical approach from the perspective of social, participatory and sustainable urban planning
}

\begin{abstract}
The conception of urban space is decisive in the structuring of thought. It is important for children because it conditions the development of experiences that consolidate skills and abilities, favouring meaningful learning. However, the development of children has encountered obstacles in the contemporary period due to a progressive dehumanization of cities. In this study we have analyzed some initiatives that encourage children encounter with their cities (The City of Children by Francesco Tonucci; Child Friendly Cities by UNICEF), and also the role that social, participatory and sustainable urban planning is playing as converging current with these initiatives. The fundamental bases of these ways of understanding the city are analyzed through a review of institutional documents, projects and bibliographic sources. And some examples from Spain are studied in order to demonstrate how this urban trend can serve as a model of intervention in municipalities committed to child defence programs.
\end{abstract}

KEYWORDS: City; Urban planning; Childhood; Tonucci; UNICEF.

\section{Introducción: habitabilidad y potencial educativo de la ciudad}

\begin{abstract}
os factores y las experiencias espaciales son esenciales en la adquisición de autonomía y responsabilidad, así como en la estructuración del pensamiento, en la construcción de la identidad personal y en la formación de una conciencia cívica y cultural durante la infancia. Resultan decisivos en la adaptación social y en el desarrollo intelectual y condicionan, a la postre, el mantenimiento de una sociedad de progreso y civilizada (ARANDA, 2001 2010; HeRnández, 1986; MinIsterio de Educación, Cultura y Deporte, 2014; MinISTERIo de EducACIóN Y CIENCIA, 2006, 2007).
\end{abstract}

La concepción y el diseño del espacio urbano, en el que se concentra la mayor parte de la población de los países europeos (EUROSTAT, 2016), se convierte en un asunto esencial para los procesos de enseñanza-aprendizaje en el período contemporáneo. Por ello, han adquirido gran importancia desde la perspectiva educadora. Una mayor facilidad para desenvolverse de manera segura y autónoma en los primeros años de vida, desarrollando destrezas y capacidades individuales, multiplicando y diversificando las experiencias de exploración, observación y reflexión, favorece el aprendizaje significativo, a la vez que propicia una educación más sólida (RıssotTo \& TonUCCI, 2002).

La organización de la ciudad, según sea el diseño y los criterios con que se concibe, puede enriquecer o, por el contrario, dificultar la exploración directa del entorno. Puede condicionar las capacidades para identificar, interpretar, diferenciar, relacionar y clasificar las propiedades y los efectos de aquellos elementos y dimensiones que configuran los procesos naturales y humanos, las formas de vida, las manifestaciones culturales, etc. Estimula o limita, por tanto, la conceptualización del espacio y de la sociedad. El medio urbano constituye así, al tiempo, escenario y objeto de aprendizaje (ArAnda, 2010; Ministerio de EduCACIÓn, Cultura y DEPORTE, 2014; MinISTERIO de EdUCACIÓN Y CIENCIA, 2006, 2007).

El diseño de espacios para el desarrollo en sociedad constituye asimismo una responsabilidad pública en la medida en que su habitabilidad y las experiencias vitales derivadas, incluidas las relaciones interpersonales, pueden intervenir en la formación del pensamiento cívico. Su configuración puede alentar la transmisión de un sistema de valores reconocidos que convierten al individuo en ciudadano: le conciencian desde el punto de vista de la cohesión y la interdependencia positiva, de la mejora y la transformación social, y le animan a la participación en esferas como la solidaridad, la igualdad, la no discriminación y la resolución pacífica de conflictos, así como en el cuidado del legado cultural y en la relación de respeto del ser humano con el medio (ARANDA, 2001; Calle \& al., 2008; HeRnández, 1986; MinisteRIO de Educación, Cultura y Deporte, 2014; Ministerio de EduCACIÓN Y CIENCIA, 2006; 2007; SeVILLA, 2014; TEY \& CIFRE-MAS, 2011).

Aparte del aprendizaje informal que resulta de las vivencias cotidianas al margen de la escolarización, la morfología, la estructura y la función del 
espacio urbano pueden aprovecharse igualmente en la programación didáctica de la enseñanza reglada como recurso externo que fomenta la creatividad y la curiosidad, elevando la motivación, la atención y la participación activa. La ciudad se convierte en un entorno ideal para sustentar la enseñanza dirigida al conocimiento del medio social, pero también ofrece múltiples posibilidades para aprender sobre el medio natural (CAÑAL \& García-CARMONA \& CRUZ-GuZMÁn, 2016). Además, el entorno urbano es especialmente útil cuando se trabajan contenidos naturales, sociales y culturales de manera dinámica e interrelacionada (GómEZ-GonçALVES \& CoRRochANo, 2018). Su aprovechamiento es pertinente dadoque se adecúa a las características contextuales y cognitivas de los alumnos, respetando principios metodológicos fundamentales en las primeras etapas educativas: la globalidad, la significatividad, la interacción, la experimentación, el trabajo cooperativo y el carácter lúdico, entre otros. Asimismo, mantiene la premisa de la búsqueda del aprendizaje a través de la progresiva construcción de esquemas de conocimiento interconectados y asentados en la comprensión de las relaciones entre contenidos secuenciados. Por tanto, se puede identificar una clara vocación pedagógica de los espacios urbanos que cristaliza en el concepto de "ciudad educadora", compuesto por tres ámbitos o dimensiones en los que la ciudad contribuye a formar al individuo: a) la ciudad como contenedor de recursos didácticos; b) la ciudad como agente educativo del que aprender; c) la ciudad como contenido educativo (TRILLA, 2005).

La programación de actividades en un espacio de aprendizaje externo al aula aporta, en definitiva, un elevado valor añadido a la acción educativa con la aplicación de métodos consecuentes con los principios señalados, como el aprendizaje basado en la resolución de problemas o el método científico, entre otros (ARANDA, 2010; Cuenca, 2011; Ministerio de Educación, Cultura y Deporte, 2014; Ministerio de Educación y Ciencia, 2006, 2007).

En cualquier caso, el desarrollo de experiencias con cierto grado de autonomía en contacto directo con el entorno urbano (por ejemplo, la exploración y recogida de información, la orientación, la manipulación, la identificación e interpretación de atributos y cualidades de las realidades observadas, la formulación y verificación de hipótesis, etc.), encuentra obstáculos en el período contemporáneo debido a la progresiva deshumanización y merma ambiental de las ciudades, que han priorizado la función económica al bienestar ciudadano. Los espacios apropiados para interactuar, donde las situaciones y los fenómenos reales que suscitan curiosidad, interés, asombro o sorpresa se convierten en motivo de aprendizaje y enriquecimiento intelectual, pierden protagonismo en tiempo reciente o presentan características contrarias a las necesidades de los grupos con mayor dependencia, entre ellos la población infantil (CUENCA, 2011; Freeman \& Tranter, 2011; Lopes \& CoRdoviL \& Neto, 2014; TonucCl, 2009b).

El hecho de que actualmente los niños vivan en ambientes urbanos desnaturalizados y tecnológicos, pero sin disfrutar del aire libre y de espacios verdes, propicia que se pierdan experiencias vitales fundamentales para su aprendizaje. Actualmente los niños juegan mucho menos al aire libre de lo que lo hacian generaciones pasadas (CLEMENTS, 2004; Segovia, 2017). En las ciudades de hoy en día se han incrementado las zonas de ocio infantil asociadas al consumo localizadas en espacios cerrados (centros comerciales). La aparición de las nuevas tecnologías como forma de diversión, que incluso a veces llegan a intentar suplir mediante entornos virtuales la propia naturaleza, junto la urbanización deshumanizada, han contribuido a disminuir de manera considerable el tiempo que los niños pasan en espacios exteriores, ocasionando el incremento de la obesidad infantil y la falta de socialización (FREIRE, 2011; NAVARRo, 2013). En este sentido, son bien conocidos los beneficios físicos, mentales y sociales que proporciona el contacto con el entorno (ver revisiones en GILL, 2014; KENIGER \& al., 2013). En el caso de la infancia en concreto, este contacto con los elementos naturales del medio favorece el desarrollo intelectual, social y físico de los niños (KELLERT, 2002), aumentando su salud y bienestar (MALLER \& TOWNSEND, 2006), reduciendo sus niveles de ansiedad (WELLS \& Evans, 2003), favoreciendo la creatividad y la resolución de problemas (MALLER \& TOWNSEND, 2006) y ayudando a mejorar sus relaciones sociales (BURDETTE \& WhitAKER, 2005). Por lo tanto, parece necesario que las ciudades promocionen y proporcionen espacios verdes y con calidad ambiental para que el niño pueda experimentar por sí mismo y de forma autónoma, junto a sus iguales, los beneficios de interactuar con los elementos naturales del medio. Estos espacios verdes deben integrarse en múltiples escalas, desde el paisajismo alrededor de las viviendas y escuelas, hasta los sistemas conectados de corredores urbanos, vías verdes, parques y jardines (CHAWLA, 2015).

A mediados de la pasada centuria se conocen en Europa propuestas singulares que plantean la dotación de espacios específicos para actividades lúdicas en la ciudad: por ejemplo, la de la paisajista Lady Allen of Hurtwood en barrios londinenses, defendiendo la creación de áreas de juego como 
soporte para ejercitar la libertad individual; o la de la urbanista Jakoba Mulder en Amsterdam, encaminada al aprovechamiento de intersticios en la trama urbana para satisfacer las necesidades de la población infantil (GARCIA-GonZÁLEZ \& GUERRERO, 2019). Esta preocupación se mantiene en las décadas siguientes, en la medida en que las dinámicas de los espacios urbanos no resuelven suficientemente esta cuestión.

Desde el ámbito académico e institucional se ha tomado conciencia de estos hechos en las últimas tres décadas y se han concebido e impulsado iniciativas que persiguen la recuperación de la ciudad como espacio para el desarrollo intelectual y social de la infancia (BARTLETT \& al., 1999; BOYDEN \& Holden, 1991; Driskell, 2002; Simone \& EsteVes, 2017; SPENCER \& BLADES, 2005). Es particularmente destacable el célebre trabajo La Ciudad de los Niños de Francesco Tonucci, maestro, pedagogo e investigador del Instituto de Psicología del Consiglio Nazionale delle Ricerche (CNR) italiano, en la base del proyecto homónimo iniciado en Italia en 1991 y promovido desde 1997 a escala internacional (Asociación de VIANDANTES A PIE, 2002; MARTínez, 2004; Tonuccl, 1994, 2009a, 2009b). Es también muy conocida la iniciativa liderada por United Nations International Children's Emergency Fund (UNICEF) bajo la denominación Ciudades Amigas de la Infancia, que comparte principios con el proyecto de Tonucci y se gesta en la misma época a partir de dos hechos principales: la puesta en marcha del programa Alcaldes defensores de los niños en 1992 (en Dakar, Senegal), cuando el papel de los Gobiernos locales en el cumplimiento de los derechos de los niños se incorpora a la agenda internacional; y la declaración del bienestar de los niños como indicador de un entorno saludable, democrático y con buena gobernanza, tomada durante la conferencia de Naciones Unidas sobre asentamientos humanos Habitat II (Estambul), en 1996 (UNICEF Comité Español, https:// ciudadesamigas.org/municipio-amigo-infancia/).

Desde una perspectiva teórica en el campo de la planificación y la ordenación del espacio urbano, el presente trabajo tiene por objetivo subrayar la validez de nuevas formas de diseño de la ciudad que vienen a favorecer su rehumanización y su recuperación ambiental y tienden a invertir la tendencia denunciada en los proyectos en favor de la infancia. Más específicamente, se analiza el emergente urbanismo social, participativo y sostenible, preconizado por un número creciente de colectivos profesionales y ciudadanos, con un corpus teórico y metodológico progresivamente construido durante las últimas décadas, como herramienta válida para facilitar el reencuentro de la población infantil con la ciudad. Este objetivo se apoya en la constatación de que esta corriente urbanística ha registrado algunos resultados satisfactorios en la mejora de la habitabilidad y de la experiencia urbana en operaciones parciales recientes. De ahí la pertinencia de su valoración como modelo a extender en el mundo urbano contemporáneo (y particularmente en las redes de municipios certificados como afines a la infancia). En definitiva, el urbanismo social, participativo y sostenible se plantea aquí como corriente a tener en cuenta por las instancias responsables del planeamiento urbano para beneficio de todos los grupos de población, incluida la infantil, que es clave en el desarrollo futuro de la ciudad; aparte de servir como necesario modelo de intervención para los gobiernos locales comprometidos con los programas de Tonucci y UNICEF en el apartado de la planificación física.

\section{Procedimiento de trabajo}

Para responder a la pregunta de si es recuperable la ciudad como espacio para la infancia, desde la perspectiva planteada, se ha seguido un procedimiento de trabajo basado en una profunda revisión de documentación institucional, de proyectos y de fuentes bibliográficas desde dos puntos de vista pocas veces coincidentes: desde una vertiente pedagógico-educativa y desde otra vertiente urbanístico-geográfica. Para ello, se ha comenzado por consultar los documentos oficiales del Estado español que regulan y ordenan las enseñanzas en Educación Infantil y Primaria, particularmente en lo que se refiere a objetivos, contenidos y principios metodológicos, además de bibliografía especializada en el campo de la conceptualización del espacio y la sociedad, en la perspectiva de la didáctica de las ciencias sociales y experimentales, de la pedagogía y de la psicología ambiental.

Por otro lado, se ha realizado una aproximación sintética a la misma cuestión desde la óptica del urbanismo, prestando atención a la evolución de los espacios urbanos en la última centuria, en sus rasgos morfológicos, estructurales y funcionales, con el fin de observar en qué medida han mudado su concepción y su diseño. En este punto, han sido empleados estudios geográficos y arquitectónicos sobre el crecimiento espacial, la reforma y la rehabilitación de las ciudades contemporáneas, y también acerca de la función urbana desde una perspectiva sociológica y de ecología urbana, así como los propios estudios y los célebres dibujos en los que Francesco Tonucci presenta su teoría sobre La Ciudad de los Niños. El trabajo se completa, en esta fase, con imágenes aéreas del Vuelo Americano Serie B 1956-57 y del Plan Nacional 
de Ortofotografía Aérea (PNOA) que evidencian las características urbanas señaladas.

Una vez establecida la base teórica, la investigación se ha centrado en caracterizar los dos principales movimientos internacionales de recuperación del espacio urbano para la población infantil, el señalado de Tonucci y el impulsado por UNICEF para crear Ciudades Amigas de la Infancia, coetáneos y convergentes en sus postulados esenciales. Se han expuesto las claves que sus promotores y los académicos establecen para adecuar la ciudad a las necesidades de los niños, de acuerdo con sus publicaciones y documentos gráficos fundamentales; lo que ha conducido, en suma, junto a las consideraciones pedagógicas introductorias, a la identificación de una serie de rasgos, a modo de estándares de calidad, que permiten caracterizar la afinidad de una ciudad a las necesidades de la infancia.

A continuación, dado el objetivo de evidenciar el interés del urbanismo social, participativo y sostenible como herramienta en la recualificación de la ciudad como espacio para el desarrollo integral de la infancia (necesaria en el cometido de alcanzar las condiciones óptimas señaladas por Tonucci y UNICEF), se ha llevado a cabo una profundización de la revisión bibliográfica y de la consulta documental institucional. En concreto, se han seleccionado trabajos que exponen los fundamentos teóricos y metodológicos de esta corriente urbanística. Se trata de publicaciones y documentos técnicos de investigadores y colectivos profesionales responsables de su impulso.

Finalmente, para valorar si la corriente urbanística aludida lleva a la práctica los estándares de afinidad con la infancia previamente definidos, se ha revisado una muestra de proyectos representativos, tanto con enfoque transversal como sectoriales temáticos, realizados por equipos que, además, han contribuido al enriquecimiento teórico y metodológico de este movimiento en España. Se han analizado sus planteamientos y resultados, y se han reproducido algunos planos, infografías y fotografías que ilustran sus características principales. También se han elaborado algunas figuras a partir de los originales (confeccionados, en este caso, con Adobe Illustrator). Se opta por un contraste con ejemplos españoles por la exposiciónde nuestras ciudades a tendencias y ritmos económicos muy contrapuestos en las últimas décadas, por su contenido sociodemográfico cambiante en este inicio de siglo y por permanecer pendiente, más que en países de su entorno, el reencuentro entre naturaleza y ciudad. Motivos, todos ellos, querealzan el impacto que han podido tener las nuevas visiones de la ordenación de la ciudad.

\section{3. ¿Qué implica la adecuación del espacio urbano a las necesidades de la infancia?}

\author{
3.1. La Ciudad de los Niños \\ según Francesco Tonucci
}

Al avanzar la pasada centuria, la ciudad ha tendido a planificarse, regularse y reformarse atendiendo, sobre todo, a los requerimientos de sus funciones económicas principales y del flujo del tráfico motorizado generado por estas (FIG. 1). Se ha generalizado una pérdida de escala humana que coloca al peatón en segundo plano, incluso fuera del nivel de calle, en muchos casos (HERRMAnN, 2016; Tonucci, 2009a). Pese a que en nuestro país se ha impuesto la planificación a la hora de diseñar e incorporar las nuevas piezas urbanas, los espacios dotacionales para el encuentro, la relación y la construcción social han ido perdiendo protagonismo o se han constituido de acuerdo con los estándares que marca la legislación de manera inconexa y limitados por una red viaria pensada para la circulación rodada (FIGs. 2a y $2 b$ ), dentro de una trama urbana donde progresivamente se ha ido diluyendo la concepción del espacio vivido. Entre los ejemplos más evidentes y quizás más estudiados se encuentran los espacios verdes urbanos, cuya construcción en nuestras principales ciudades se ha realizado de manera estricta desde mediados de la década de los ochenta del siglo pasado, pero cuya integración en el tejido urbano consolidado y en la ciudad vivida por los ciudadanos sigue presentando grandes desafíos (DíAZ \& Rodríguez, 2003; Gómez, 2013; Gómez-GonçALVES \& SÁnchez \& Ceballos, 2018). Por tanto, progresivamente la ciudad se convierte en un lugar más fragmentado y jerarquizado socialmente que, además, por lo señalado, pierde identidad, solidaridad y seguridad. Asimismo, viene a caracterizarse por una creciente especialización (ToNuccl, 1994, 2009a, 2009b). En efecto, se produce una especialización funcional de los distritos urbanos que origina en el ciudadano, cada vez más, la pérdida de una experiencia urbana completa e integrada en un espacio fácilmente abarcable. Se detecta, en definitiva, una merma de la riqueza de experiencias al transitar y vivir la ciudad. De hecho, el ciudadano necesita emplear con frecuencia el transporte rodado para desplazarse con el fin de acceder a determinados servicios, equipamientos e infraestructuras dotados en escaso número o con una localización única (Fernández \& Fernández, 2019; SeVILLA, 2014)

Dado este devenir de la ciudad, las consecuencias son importantes para la infancia: puede alterarse 


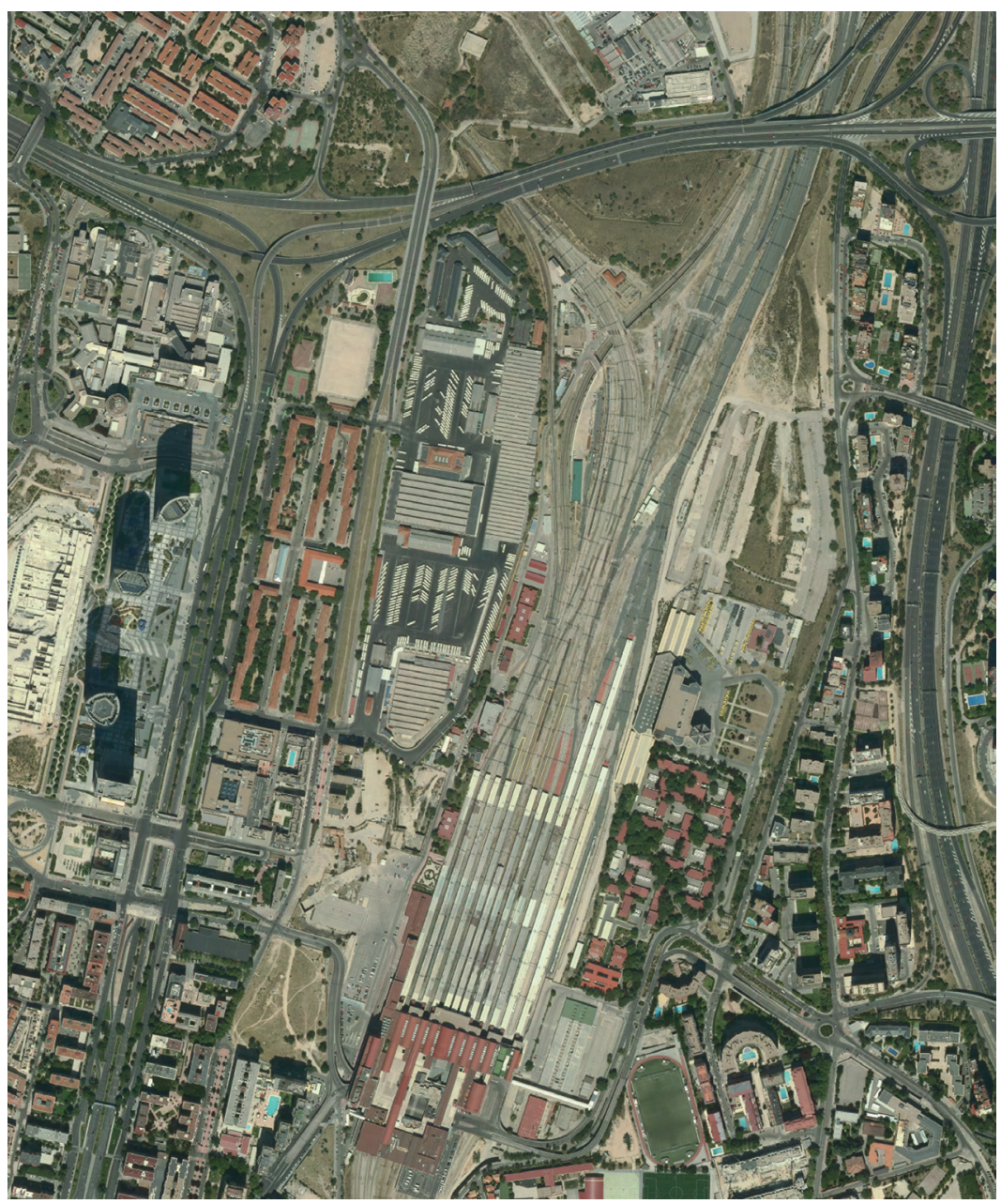

FIG. 1/ Preponderancia de la función económica y pérdida de la escala humana en la concepción de la ciudad. Entorno de la estación de Chamartín en el norte de Madrid: imagen aérea del distrito.

Fuente: Plan Nacional de Ortofotografía Aérea-PNOA, 2017.
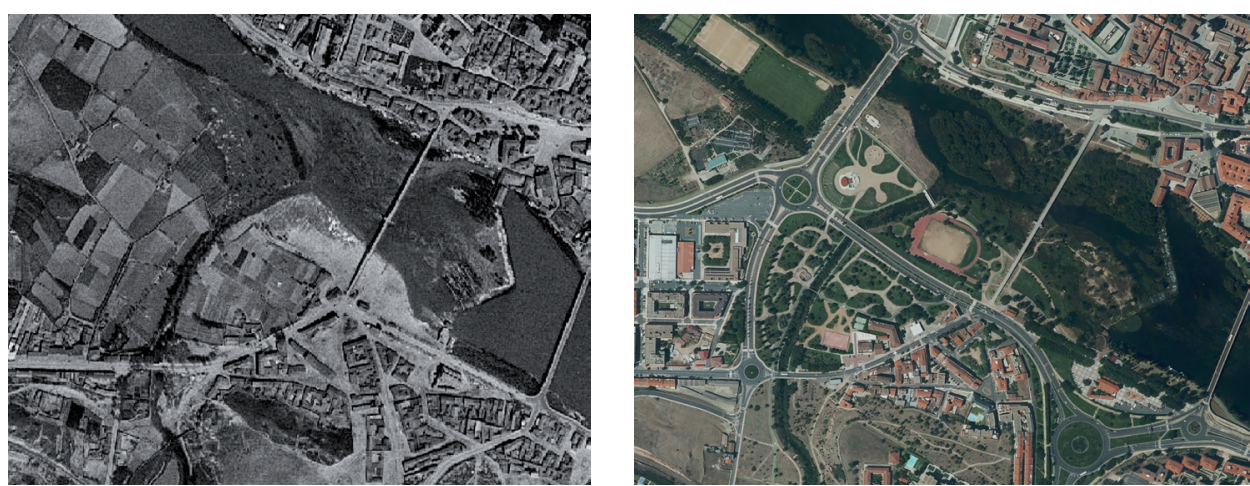

FIGS. 2 A Y 2 B/ Los espacios para el paseo, el ocio y la relación social se convierten en sectores inconexos, limitados por un complejo entramado de red viaria concebida para el transporte motorizado. Ribera meridional del río Tormes en Salamanca, a mediados de la década de 1950 (izquierda) y en 2017 (derecha).

Fuente: Vuelo Americano Serie B 1956-57 y PNOA 2017. 
el movimiento y el disfrute autónomo de experiencias fundamentales para el crecimiento y la puesta a prueba de capacidades fundamentales, como la socialización, el juego, la exploración, el descubrimiento, la superación de obstáculos, la detección del riesgo, la resolución de problemas, etc. (FIG. 3). Al perder capacidad de movimiento autónomo se genera entonces mayor dependencia de otros entornos, recursos y agentes más limitantes para el aprendizaje y el entretenimiento. Incluso, desde el punto de vista de los docentes, el uso de los espacios urbanos y de la enseñanza fuera del aula está disminuyendo debido a la gran cantidad de problemas que supone para los educadores abandonar la escuela y recorrer la ciudad con grupos de niños y niñas (DYMENT, 2005), aunque se hayan demostrado los efectos positivos que tiene el desarrollo de la enseñanza en espacios donde los alumnos entran en contacto con la naturaleza (Almers \& Askerlund \& KJellström, 2018; Malberg DYG \& WISTOFT, 2018).

En ese contexto, promovido por el CNR italiano a partir de 1991 y encabezado por Francesco Tonucci, el proyecto La Ciudad de los Niños alienta a las Administraciones locales a adoptar una nueva forma de gobierno municipal tomando como parámetro al niño y sus necesidades. Se articula sobre dos ejes: la recuperación de la autonomía de movimiento y la participación de los niños en el gobierno de la ciudad a través de consejos específicos (Alaparone \& Rissotto, 2001; TonucCI, 1994, 2009a, 2009b).

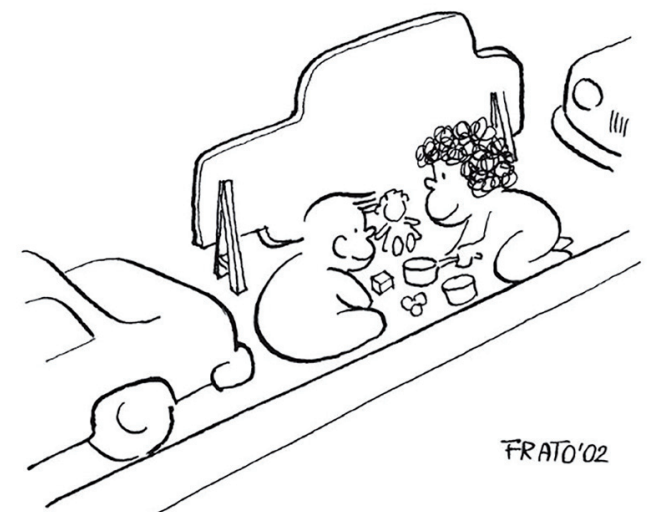

FIG. 3/ El proyecto de Francesco Tonucci ha trascendido asimismo en razón de su ingenio creativo, que reivindica un espacio adecuado para el desarrollo intelectual y social de la infancia. Reproducción de dibujo de 2002.

Fuente: Tonuccl, 2009b.

\footnotetext{
${ }^{2}$ El artículo recoge lo siguiente: “1. Los Estados Partes garantizarán al niño que esté en condiciones de formarse un juicio propio el derecho de expresar su opinión libremente en todos los asuntos que afectan al niño, teniéndose debidamente en cuenta las opiniones del niño, en función de la edad y madurez del niño. 2. Con tal fin, se dará en
}

Para recuperar autonomía de movimiento, el proyecto propone, entre otras medidas, que los niños y las niñas vayan a la escuela sin compañía de un adulto a partir de los 6 años. Es una propuesta de difícil aplicación pero posible si se trabaja y colabora de manera conjunta con las familias, las escuelas y las instituciones locales, estudiando los itinerarios, sus características y las potenciales intervenciones, incluida la colaboración gremial y ciudadana organizada para una vigilancia social de la infancia. Además de fomentar la autonomía, esta práctica inculca en la comunidad valores de solidaridad y educación vial (GILES-CORTI \& al., 2011; LIN \& al., 2017; TonUCCI, 2009a).

Por otro lado, el proyecto busca facilitar la experiencia infantil en la ciudad promoviendo la habilitación de lugares en los que los niños se desenvuelvan para desarrollar y explotar sus capacidades sin la compañía y el control constante del adulto: vías peatonales, aceras, redes de carriles para bici, plazas, parques y espacios públicos amplios con diseños ricos en mobiliario y juegos, variados y no estandarizados. Se trata de una visión del espacio que emana de la interpretación que la propia infancia hace de sus necesidades en los consejos y grupos de trabajo impulsados por Tonucci, en atención al artículo 12 de la Convención de la Organización de las Naciones Unidas (ONU) de los Derechos del Niño².

\subsection{La promoción de Ciudades Amigas de la Infancia por UNICEF}

El principal organismo internacional involucrado en la defensa de los derechos de la infancia converge con las ideas de Tonucci desde el momento en que identifica la garantía social y jurídica de protección y atención a la infancia con la promoción de su autonomía. Desde UNICEF se entiende que el desempeño autónomo y el ejercicio responsable de sus derechos facilita la construcción de una percepción positiva de control sobre su desarrollo físico, mental, espiritual, moral, psicológico y social (UNICEF COMITÉ ESPAÑOL, 2009, 2017).

En un contexto de acelerada urbanización de las sociedades globales, al tiempo que de crecientes competencias y responsabilidad de los municipios sobre la calidad de vida de sus ciudadanos en el

particular al niño oportunidad de ser escuchado, en todo procedimiento judicial o administrativo que afecte al niño, ya sea directamente o por medio de un representante o de un órgano apropiado, en consonancia con las normas de procedimiento de la ley nacional." (UNICEF COMITÉ ESPAÑOL, 2015). 
marco de la descentralización administrativa, se concibe la iniciativa Alcaldes defensores de los niños en 1991, a propuesta del Director Ejecutivo del UNICEF. Esta iniciativa impulsa el ámbito local como el espacio administrativo más idóneo para ejecutar políticas y planes integrales de promoción y defensa de los derechos de la infancia y la adolescencia, incluyendo su participación en los procesos de decisión. A lo largo de la década de los noventa surgieron redes de alcaldes implicados y a partir de 2000 se trasladó el compromiso al conjunto del municipio -ya no solo personalizado en la figura del alcalde-.

Se construirá en lo sucesivo el concepto de Ciudades Amigas de la Infancia, que será aplicable a cualquier sistema de gobierno local comprometido con la aplicación de la Convención sobre los Derechos del Niño, debiendo garantizar la capacidad de: a) participar activamente en la vida social e institucional, e influir en las decisiones a tomar respecto al modelo de localidad; b) disponer de servicios básicos sin riesgo de marginación, exclusión, violencia, explotación o abuso por motivo étnico, religioso, de género, socioeconómico y cultural; c) desplazarse y experimentar la localidad de manera autónoma para el juego y la relación con sus iguales; d) disfrutar de un entorno limpio y saludable, no contaminado, dotado de zonas ricas en vegetación y fauna para el disfrute y aprendizaje (UNICEF COMITÉ ESPAÑol, 2009).

La Ciudad Amiga de la Infancia coloca así a los niños en el centro de las políticas locales, constituyendo sus voces, necesidades, prioridades y derechos como un componente esencial de los proyectos y las decisiones.Además, impulsa alianzas entre los agentes responsables del cumplimiento de este compromiso (sociedad civil, asociaciones, escuela, empresas, organismos públicos, etc.), con apoyo en los Consejos de Infancia y Adolescencia.

Desde el punto de vista del modelo de la ciudad, el Sello de Reconocimiento Ciudad Amiga de la Infancia, con vigencia cuadrienal, exige el estudio de rasgos físicos, socio demográficos y funcionales de la localidad para su diagnóstico y la mejora de la planificación urbana. Se tienen en cuenta la evolución histórica del núcleo, las características de su población (composición, dinámica natural y migratoria, estructura socio-económica y laboral), las condiciones ambientales, la ordenación de los terrenos o la accesibilidad y la dotación de servicios (medios de transporte, cuerpos de seguridad, servicios sociales, culturales, educativos, sanitarios, etc.). Las dinámicas de trabajo y las propuestas derivadas se dirigen, en buena medida, a la adaptación de espacios y edificios públicos para personas con diversidad funcional, la regulación del tráfico, el control del impacto acústico y la contaminación ambiental, la mejora de la iluminación como elemento de seguridad, la dotación de transporte público debidamente adaptado a la demanda ciudadana en horarios e itinerarios, la proliferación de espacios y corredores con áreas verdes, o la programación de actividades, talleres y espectáculos en el espacio público, entre otros aspectos (PLATAFORMA de INFANCIA \& UNICEF COMITÉ Español, 2018; Programa Ciudades Amigas de la Infancia UNICEF ESPAÑA, 2013).

\subsection{Propuesta de estándares para un diseño urbano afín a la población infantil}

De acuerdo con los principios pedagógicos expresados y en atención a los planteamientos de los programas en favor de las necesidades de la infancia, se entiende que la concepción y el diseño de la ciudad deben incorporar rasgos capaces de promover una experiencia urbana asentada en la autonomía y la participación con el fin de favorecer el desarrollo completo de destrezas y capacidades. Han de ser ricos los escenarios propicios para la compresión y la conceptualización de procesos y fenómenos naturales, sociales y culturales. La ciudad ha de ser, en definitiva, un espacio inductor de intelecto, conciencia e identidad. De ahí la utilidad de identificar una serie de indicadores o estándares cualitativos que alimenten modelos urbanos deseables en aspectos funcionales, infraestructurales y ambientales. En este sentido, se recoge a continuación un listado de rasgos que han de caracterizar a las ciudades sensibilizadas con el aprendizaje y el desarrollo de niños y niñas, de acuerdo con los postulados de La Ciudad de los Niños y Ciudades Amigas de la Infancia:

- Distribución equilibrada de usos y funciones en el conjunto del tejido urbano.

- Dotación de servicios y equipamientos sociales, sanitarios, educativos, culturales y de seguridad conforme a las características demográficas.

- Proliferación de plazas y espacios no edificados de uso público con los tipos de instalaciones y actividades solicitados para la relación, el ocio y el esparcimiento.

- Dotación de infraestructura de alumbrado ajustada al uso del espacio.

- Existencia de una red conectada de parques, jardines y corredores verdes en el conjunto del área urbana y su franja periurbana. 
- Accesibilidad peatonal a través de una red de itinerarios ininterrumpidos conforme a la demanda y experiencia cotidiana.

- Atenuación de los flujos de tráfico generados por vehículos motorizados particulares.

- Disponibilidad de un sistema de transporte público combinado, flexible y sostenible.

\section{Identificando herramientas para una ciudad más propicia a la infancia: aproximación al urbanismo social, participativo y sostenible}

\subsection{Rasgos diferenciales de un nuevo enfoque para entretejer la ciudad}

Prestar atención al urbanismo social, participativo y sostenible como herramienta favorecedora del desarrollo de la infancia tiene sentido teniendo en cuenta algunos de sus fundamentos principales. Se plantea como alternativa a paradigmas urbanísticos que no han logrado revertir procesos de pérdidas económicas y otros aspectos, como la desigualdad, la vulnerabilidad, el desarraigo, la fractura social o la merma ambiental. Busca recuperar la ciudad como construcción colectiva y extender el campo de la participación ciudadana frente al declive provocado por decisiones a menudo ajenas a la experiencia y a la voluntad del grueso de la población (VERDAGUER \& VELÁZQUEZ, 2012). Defiende la relevancia de las actividades cotidianas (productivas, domésticas, de desarrollo personal y comunitarias, comprendidas las lúdicas) como factor que ha de orientar la configuración de la ciudad (VALDIVIA \& al., 2017), incluida la regeneración de espacios degradados o en desuso (TrachanA, 2012).

Se trata de un movimiento que crece en los inicios de este siglo, al tiempo que cristaliza la noción de desarrollo urbano sostenible en esferas institucionales globales y europeas. $Y$ recoge, en cierto modo, la herencia de algunas experiencias de vínculo entre urbanismo y participación ciudadana conocidas en el último tercio del siglo pasado, en muchos casos apoyadas en una movilización vecinal sostenida por urbanistas y profesionales involucrados en el diseño urbano (BLANCAFORT \& REUS, 2016). Ahora se actualiza esta visión con la incorporación de pautas de trabajo, técnicas y métodos de nuestro tiempo. Destaca la importancia del proceso y del trabajo horizontal, desprovisto del principio jerárquico que otorga primacía a los agentes de la administración, con el fin de conceder protagonismo al espacio a proyectar y a cada grupo de actores de acuerdo con nuevas formas de relación, comunicación y movilización de nuestro tiempo, hoy con flujos más constantes y diversos debido a los cambios sociales y tecnológicos. Persigue, en definitiva, aprovechar una suerte de inteligencia colectiva que conduzca a mejores soluciones para la ciudad (DOMBLÁs, 2015; GRUPO DE EstudIOS Y Alternativas 21 -GEA21-, http://www.gea21.com/ archivo/urbanismo/; PAISAJE Transversal, 2012a, 2012b).

Es relevante el hecho de que esta corriente urbanística se concibe como producto de un consenso de ámbitos científicos y profesionales (arquitectura, ingeniería, geografía, sociología, derecho, economía, ecología...) interesados en diseñar un espacio urbano equitativo, integrado, sostenible y garante de calidad de vida. Interesa por elaborar diagnósticos y proponer soluciones creativas e innovadoras, a la vez que económicamente realistas y flexibles, a las oportunidades y problemas de la ciudad con la participación conjunta de actores institucionales, profesionales, científicos, económicos y sociales, incluyendo entes privados y públicos (coordinando a sus distintos departamentos), colectivos asociativos y ciudadanos individuales, mediante el desarrollo conjunto de espacios y dinámicas para el diálogo, el debate y la negociación ${ }^{3}$.

La atención se centra en aspectos como el diseño del espacio público, la adecuación de los modelos constructivos, la dotación de equipamientos, la regeneración del tejido urbano, la eficiencia energética, la integración social, la reactivación económica, la rehabilitación del patrimonio, la atenuación de impactos ambientales, la accesibilidad, la eliminación de barreras y la movilidad, entre otros. Una de las críticas que han recibido el urbanismo y la planificación urbana contemporánea es que, en la inmensa mayoría de los casos, cumple con las exigencias legales y técnicas recogidas en las distintas legislaciones urbanísticas, pero en muy pocas ocasiones se tienen en cuenta a los usuarios de los espacios urbanos cuando se diseñan, algo que es muy evidente en el caso de los espacios verdes urbanos (GómEZ-GonçALVES \& SÁnCHEZ \& Ceballos, 2018; Puyuelo \& Gual \& Galbis., 2005). Por tanto, en este nuevo urbanismo las intervenciones se abordan desde una metodología

\footnotetext{
${ }^{3}$ Para optimizar este método y dotarle del necesario equilibrio
} y de equidad, en ocasiones se introduce la figura del mediador, 
participativa basada en el desarrollo de mesas de trabajo, foros, talleres y actividades para percibir puntos de vista, intereses y prioridades de las personas implicadas en el uso y disfrute del espacio, consiguiendo promover procesos de transformación más transparentes (FIGs. 4 y 5); a lo que contribuyen la difusión de información y la concienciación como factores conducentes a que el ciudadano conozca el proyecto de ciudad, se identifique, participe, se apropie del espacio y compruebe el cumplimiento de lo proyectado, más allá del tradicional trámite de información pública y respuesta a alegaciones que se ha revelado insuficiente para incorporar la participación ciudadana (BLANCAFORT \& ReUs, 2016; FRANK, 2006; GEA21, http://www.gea21.com/archivo/urbanismo/; Paisaje Transversal, 2012a, 2012b, 2019; https://paisajetransversal.com/).
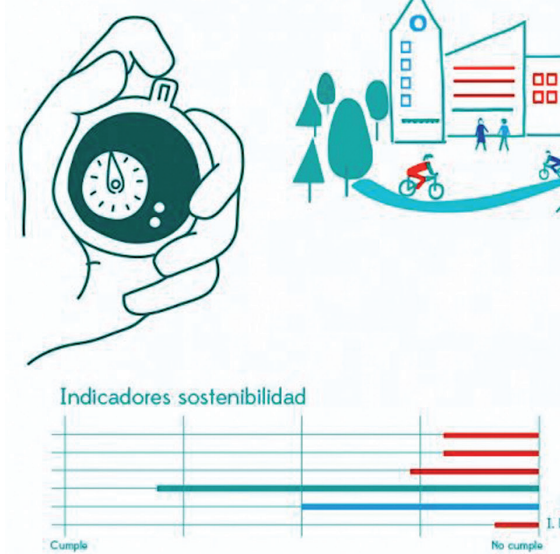

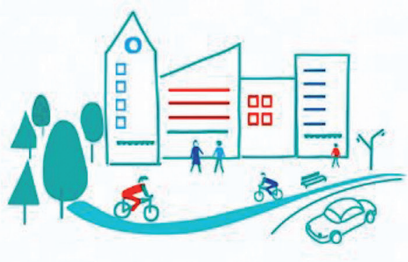

\section{INPAR}

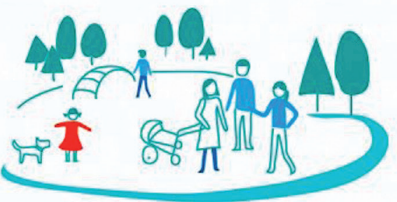

Espacio Público

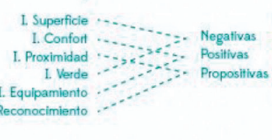

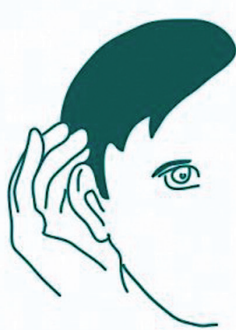

Opiniones ciudadanas

FIG. 4/ Esquema sintético de la herramienta Indicadores Participativos (INPAR) empleada por el equipo de Paisaje Transversal.

Fuente: Paisaje Transversal, https://paisajetransversal.com/.

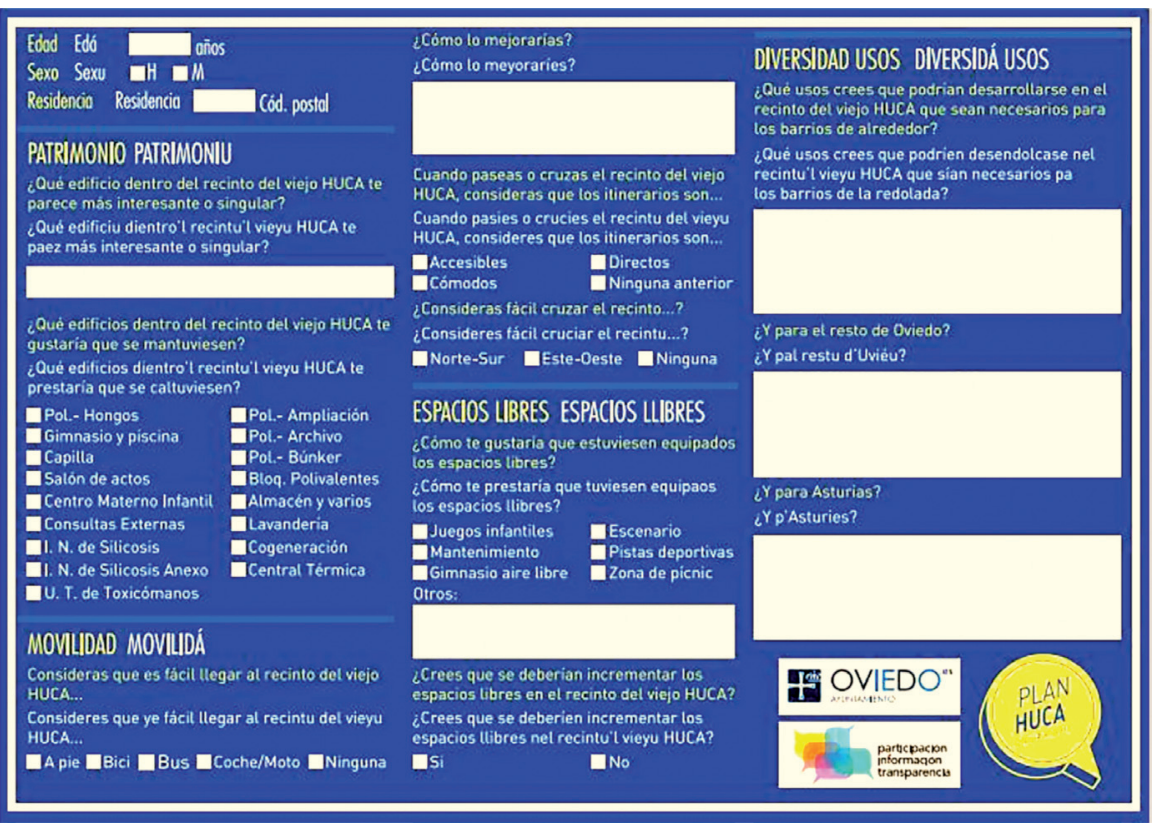

FIG. 5. Reproducción de los documentos elaborados para la campaña de información, consulta y participación ciudadana sobre la renovación del espacio de la antigua ciudad sanitaria de Oviedo.

Fuente: Paisaje Transversal, https://paisajetransversal.com/. 


\subsection{Proyectos creativos en la verificación de una corriente con valor ciudadano añadido}

La valoración positiva del urbanismo social, participativo y sostenible en la perspectiva de una recualificación de la ciudad conforme a las determinaciones de Tonucci y UNICEF implica asimismo la revisión de planteamientos y resultados de algunos proyectos clave con el fin de observar si se contemplan rasgos urbanos alineados con los indicadores señalados más arriba.

Partiendo de aspectos generales funcionales, el urbanismo social, participativo y sostenible encuentra beneficio en plantear una vocación diversa para cada tramo del tejido urbano, traducida en una distribución equilibrada de usos del suelo, acompañada de una dotación de servicios y equipamientos ajustados a la demanda de cada núcleo. Somete a crítica el carácter monofuncional limitante de las áreas residenciales no centrales y considera básica una línea estratégica de reactivación y diversificación económica para cualquier sector urbano (ensayada notablemente, por ejemplo, en la regeneración urbana participativa en el barrio Virgen de Begoña, Madrid -Fıg. 6-, por Paisaje Transversal, 2012a). La reactivación pasa por el refuerzo de la identidad gremial, la formación y el reciclaje profesional para la mejora de la competitividad, así como por la rehabilitación del tejido degradado para su repoblación a través de la ayuda a la creación de nuevos negocios, además de infraestructuras y equipamientos con servicios públicos (véase el ejemplo de Estrategia de Desarrollo Urbano Sostenible e Integrado-EDUSI- del Cabanyal-Canyamelar- Cap de França por Va Cabanyal!, de 2016, ejemplo icónico por la intervención ciudadana). Esta corriente cuestiona, por tanto, la jerarquización y la limitación de usos según áreas urbanas y se fija en la distancia de los lugares de residencia a los equipamientos básicos y a los espacios comunitarios ("entorno equipado" y "entorno comunitario", por Col.lectiu Punt 6, como sustento de su auditoría de seguridad urbana con perspectiva de género).

Las mismas nociones de "entorno equipado" y "entorno comunitario" conllevan la percepción del espacio público como entorno de convivencia, intercambio, debate y juego (FIG. 7). Defienden un entorno público abierto dotado de mobiliario, elementos vegetales y pavimentos pensados para un uso diverso cotidiano que fortalezca la pertenencia a la comunidad y la red social en contacto directo, frente a la emergencia de la esfera virtual; a lo que ha de contribuir una concepción estética que agrade, genere identificación y atraiga a la población (VALDIVIA \& al., 2017). También se conocen experiencias de urbanismo participativo para la mejora del aprovechamiento

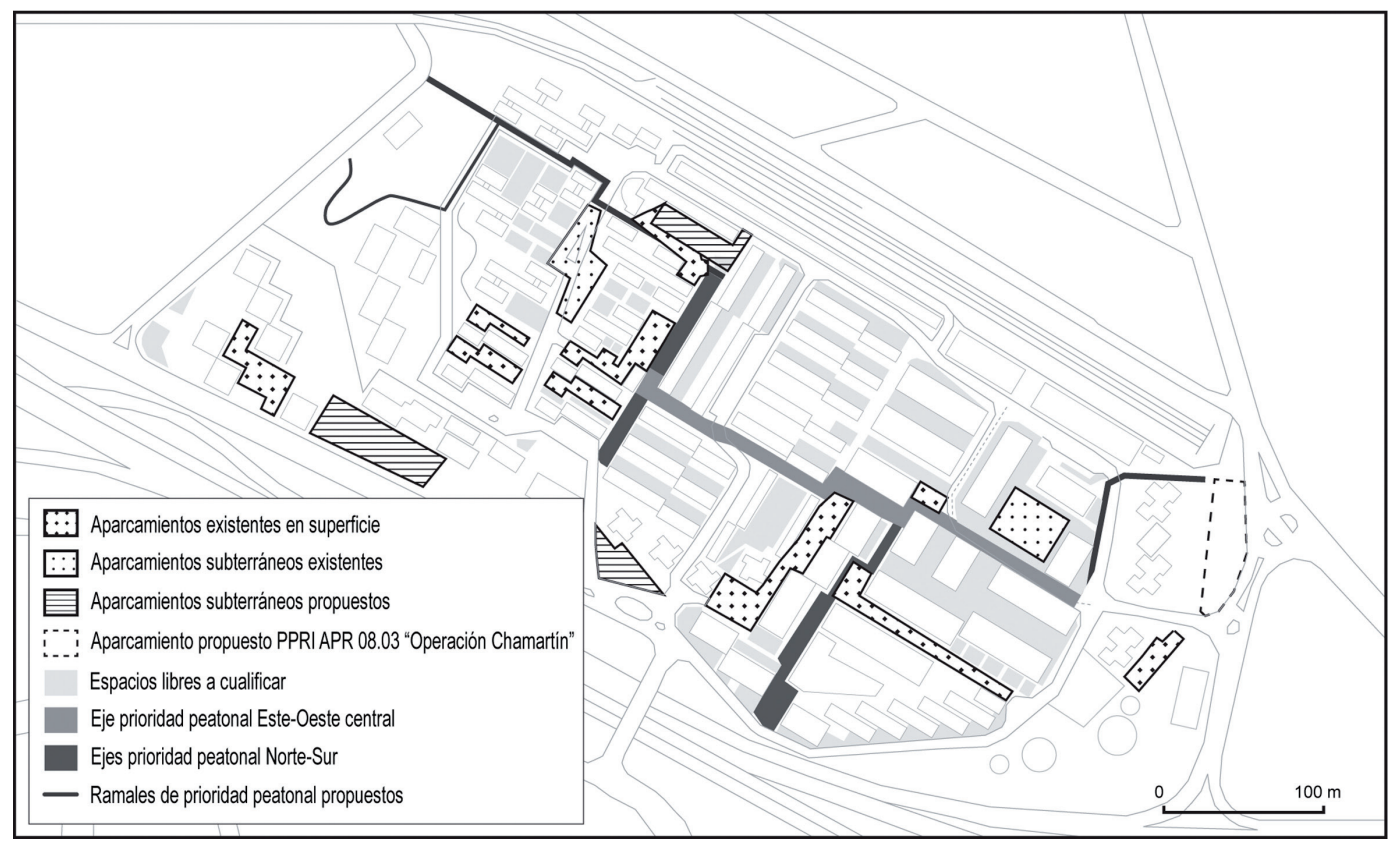

FIG. 6/ Recualificación del espacio en el proceso de regeneración urbana participativa del barrio Virgen de Begoña. Elaboración propia a partir del plano original. 

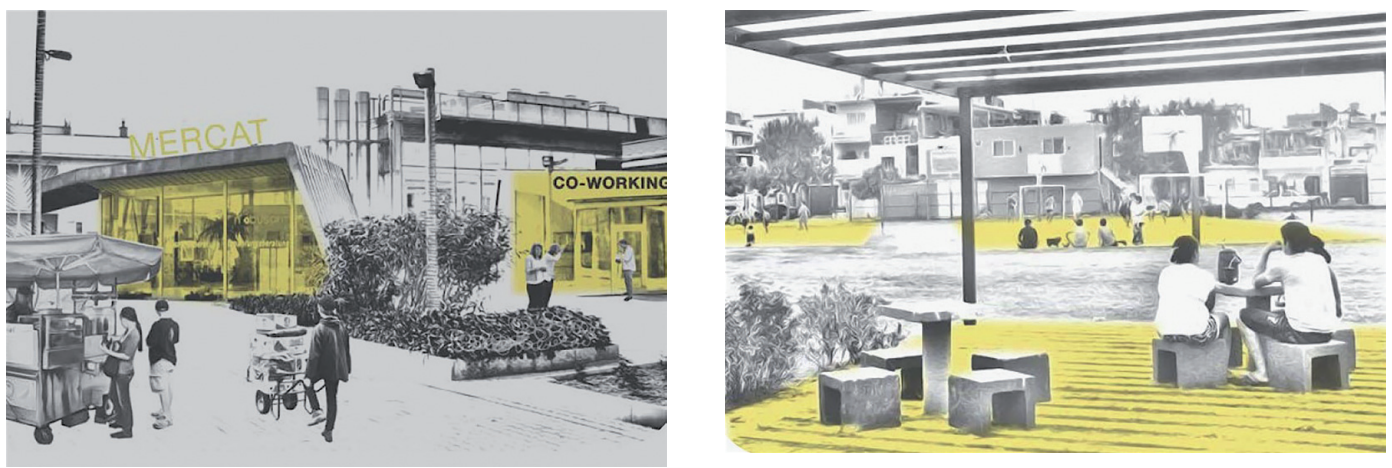

FIG. 7 a y 7 b/ Infografías expresivas de los conceptos "entorno equipado" y "entorno comunitario" que subrayan la dotación de mobiliario, elementos vegetales y equipamientos para un uso cotidiano y la construcción de una identidad comunitaria. Reproducción de los originales elaborados por A. Molina para Col.lectiu Punt 6.

Fuente: VALDIVIA \& al., 2017.

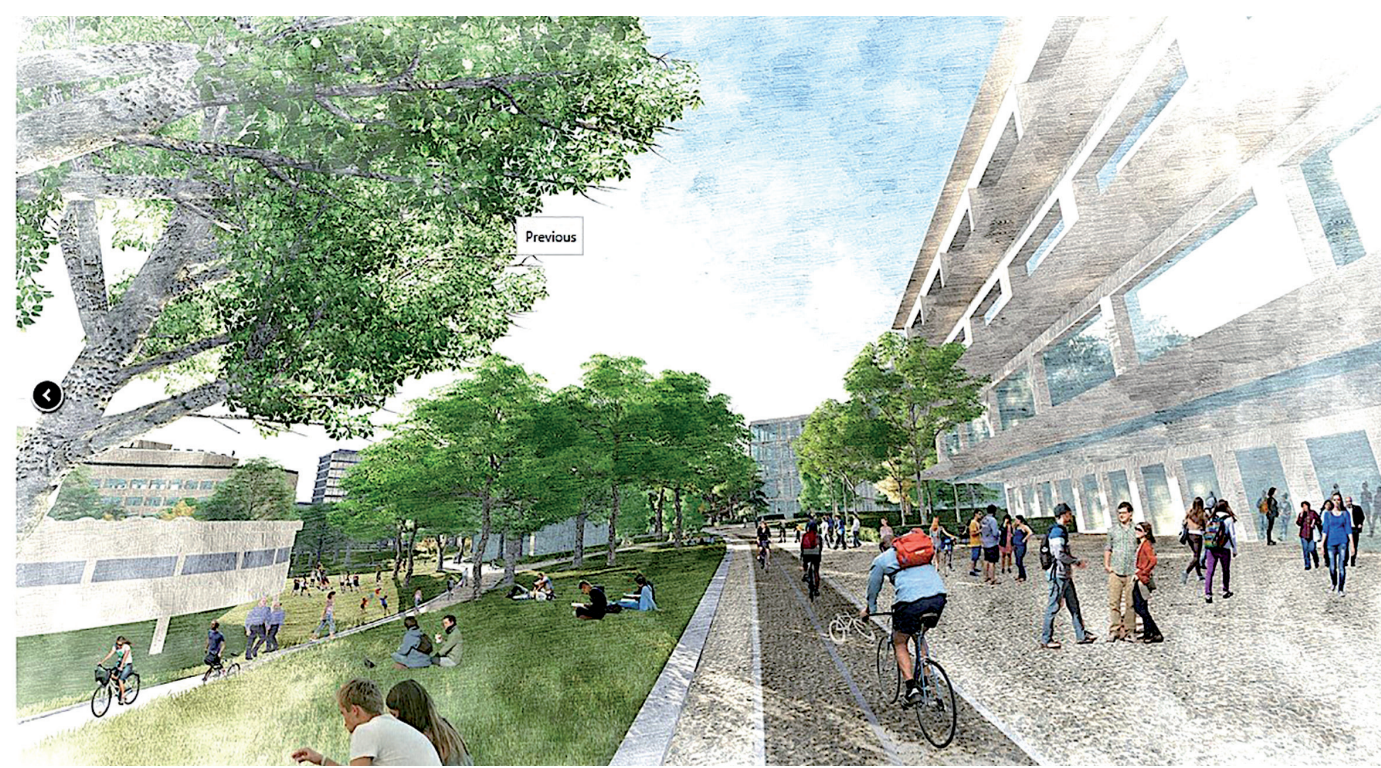

FIG. 8/ Interpretación del espacio en la ordenación del ámbito del antiguo Hospital Central de Asturias (HUCA) en El Cristo-Buenavista de Oviedo.

Fuente: reproducción del original elaborado por Juan Tur, Alexandra Delgado y Daniel Cortizo, HUCAMP Arquitectos, reproducido en http://www.arquitecturaviva.com/es/Info/News/Details/11414.

del espacio abierto protagonizadas por niños, en relación con el mobiliario óptimo y con los usos permitidos, como el proyecto Solar en el barrio de La Soledad de Palma de Mallorca (Arquitectives, https://www.arquitectives.com/solar).

En la dimensión estética participa la iluminación, que puede reforzar la consideración positiva del conjunto urbano, pero a la vez ha de asistir a la ciudadanía en el uso del espacio y, en nuestro tiempo, respetar el criterio de la eficiencia energética. Es significativa, en esta línea, la experiencia piloto del proyecto Córdoba LUZe en el barrio de
Axerquía Norte, acometido por impulso municipal en 2014 con la participación de las empresas Creara, Inersur, Aureolighting y del colectivo profesional Paisaje Transversal. Se ha basado en la incorporación de lámparas eficientes y en el estudio de ubicaciones óptimas para favorecer la visibilidad de señalizaciones y de recodos de la vía pública especialmente frecuentados o que requieren una mejora de la habitabilidad y de la seguridad. También se ha destinado a reducir el alumbrado donde no es tan necesario (PaISAJE Transversal, https://paisajetransversal.com/portfolio/ambienteurbano-nocturno-cordoba-luze/). 


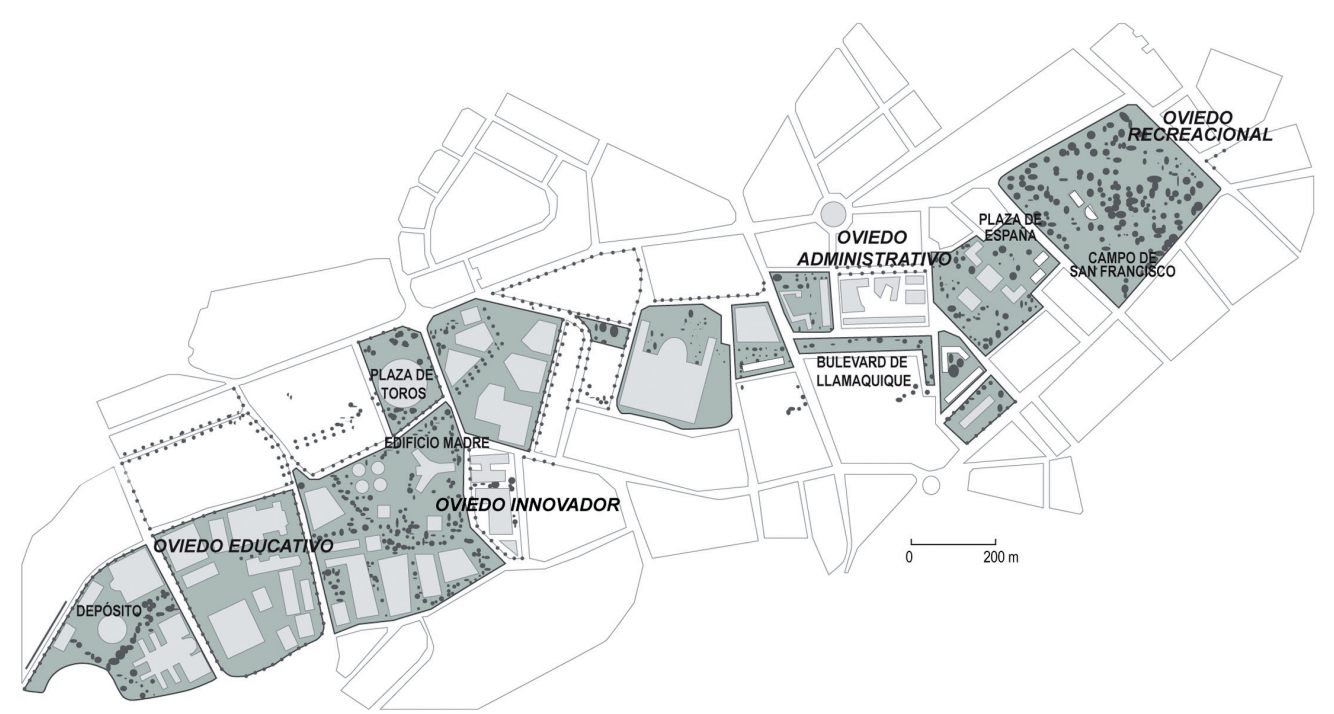

FIG. 9/ Plano del corredor verde propuesto por HUCAMP! para conectar la antigua ciudad sanitaria de Oviedo con el centro urbano.

Una habitabilidad renovada pasa, por otro lado, por un reencuentro de la dinámica urbana con elementos territoriales de dominante rural y natural; es decir, por la proliferación de parques, jardines y huertos e incluso por su interconexión a través de corredores tanto en la ciudad compacta como en la franja periurbana, dadas sus repercusiones positivas en esferas variadas como la gestión ambiental y la restauración ecológica, la educación, la promoción del ocio saludable, la integración socio-laboral, etc. Son aspectos analizados por el Centro de Estudios Ambientales de Vitoria-Gasteiz (El espacio agrícola entre la Ciudad y el Campo. Desarrollo de un Catálogo de Buenas Prácticas Urbanas con Criterios de Sostenibilidad) para consolidar el denominado Anillo Verde vitoriano, promovido por numerosas entidades y asociaciones (Gobierno Vasco, 2003; Verdaguer, 2013).

El espacio verde es clave no solo en operaciones periurbanas sino también de reforma interior como la promovida para la ordenación del ámbito del antiguo Hospital Central de Asturias (HUCA) en el distrito El Cristo-Buenavista de Oviedo. El proyecto HUCAMP!, seleccionado previa convocatoria de un concurso internacional en 2017, vincula el objetivo de regeneración a la habilitación de una gran campa como elemento central y organizador de usos en un distrito evocador del rico entorno rural asturiano, en el que el ciudadano puede satisfacer en plena ciudad el disfrute de valores paisajísticos y ambientales (TuR \& Delgado \& CoRTizo, 2019). Más allá, partiendo de la propia campa, se plantea un corredor con senda para la movilidad peatonal y ciclista que busca una nueva conectividad con el centro histórico y con distritos renovados del norte de Oviedo, encadenando zonas verdes y espacios abiertos que favorecen la continuidad en el tránsito (FIGS. 8 y 9).

En esta línea que concibe HUCAMP!, se conoce un completo proyecto de promoción de la movilidad peatonal impulsado por el Ayuntamiento de San Sebastián, denominado Donostia Camina, que diseña una red de itinerarios peatonales seguros y ambientalmente cuidados para la interconexión de las diferentes zonas (SANZ, s.f.). Se debe añadir que la facilidad para un desplazamiento peatonal seguro en itinerarios cotidianos es un asunto del que se conocen, además, acciones de colectivos urbanistas inspiradas directamente por Tonucci y otros investigadores dedicados a promover la movilidad infantil (ver FIG. 10). Sirvan de ejemplo las analizadas en la guía Camino Escolar. Pasos hacia la autonomía infantil por GEA21 (ROMÁn \& SALís, 2010), por ejemplo, en Barcelona, en Granollers, en San Sebastián, en Zarauz, en Madrid... O la que promueve el Servei Catalá de Trànsit con la asistencia técnica del propio gabinete de GEA21: Els camins escolars (SerVEI CATALÁ DE TRANSIT, 2016).

El control espacial de la contaminación ambiental, la aminoración del impacto acústico y la apuesta por la sostenibilidad llegan asimismo de la mano de los sistemas de transportes combinados, flexibles y no contaminantes. O de la atenuación de tráficos motorizados y el fomento de la movilidad "blanda", complementarios de las cuestiones anteriores, de 


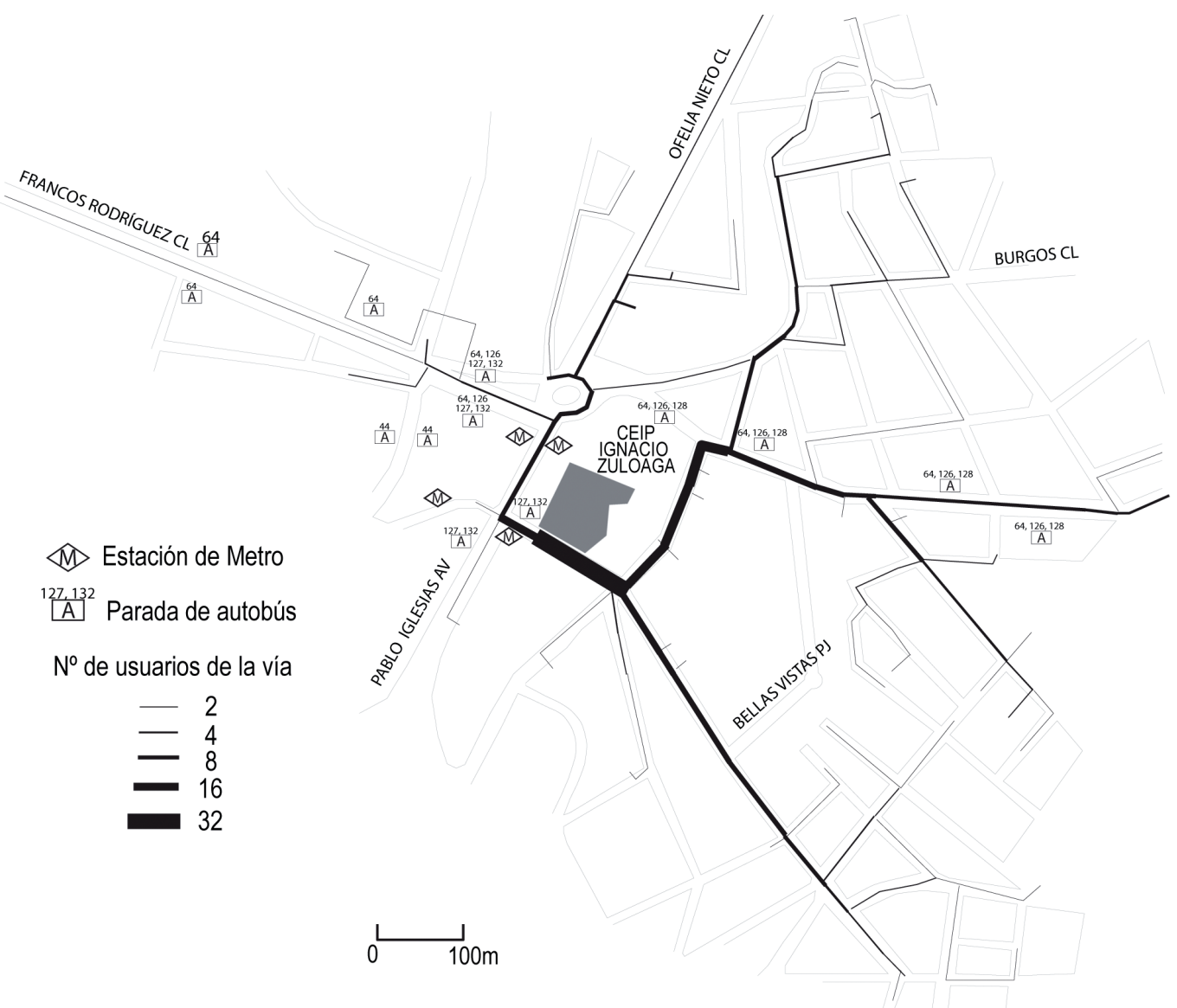

FIG. 10/ "Araña de movilidad" del Colegio Ignacio Zuloaga (proyecto Madrid a pie, Camino Seguro al Cole).

Sobre las rutas más utilizadas se prevé el calmado del tráfico (cambios de pavimentos, ensanche y continuidad de aceras sobre intersecciones). Elaborado a partir del original de la Dirección General de Movilidad de Madrid.

Fuente: Román \& SALIS, 2010..

las que el proyecto de ecobarrio de Trinitat Nova, en Barcelona, coordinado por GEA21 con las consultorías Aiguasol, Ecoinstitut e Idees, ofrece medidas representativas: accesibilidad intermodal, incorporación a red de itinerarios ciclistas preexistente, restricción de la velocidad para el tránsito motorizado, construcción de plataformas y pasos elevados para evitar barreras a la movilidad peatonal (GAFFRON \& HUISMANS \& SKALA, 2008). También merecen reseña los catálogos de buenas prácticas en la movilidad al trabajo vinculados a la experiencia de planes de movilidad sostenible en empresas: sistemas de información actualizada para la elección de alternativas óptimas, incentivos y ayudas al uso de transportes alternativos, servicio de vehículos compartidos y/o colectivos con rutas adaptadas, flexibilización de la jornada laboral son algunas de las medidas que favorecen una dinámica urbana más amable (VEGA, 2005, 2006).

\section{A modo de conclusión: una concepción urbana emergente en contextos de desafío comunitario y global}

El análisis realizado reafirma la consideración en favor del urbanismo social, participativo y sostenible como una alternativa válida para recuperar la ciudad como espacio para la infancia, dados la definición y el cumplimiento de objetivos convergentes con los estándares cualitativos elaborados a partir de los planteamientos de Tonucci y UNICEF. En efecto, las prioridades de los agentes impulsores del paradigma urbanístico aquí presentado vienen a encontrarse con las establecidas por los programas internacionales defensores de la infancia; una perspectiva que merece ser tenida en cuenta por las entidades locales 
para una recualificación de la ciudad en su dimensión física y de ordenación de usos y actividades, teniendo en cuenta, además, el reto de alcanzar las metas de la Agenda 2030 y los Objetivos del Desarrollo Sostenible aplicados al ámbito urbano. Obsérvese que estas metas y objetivos se alinean, en buena medida, con las razonables prioridades ya referidas (Gobierno de España, https://www. agenda2030.gob.es/objetivos; ONU,https://www. un.org/sustainabledevelopment/es/developmentagenda/). En cualquier caso, se revela adecuado el requerimiento firme a los municipios interesados en obtener certificaciones que avalen su sensibilidad hacia el desarrollo infantil, de optar por esta forma de intervención en la ciudad.

La elaboración del estudio con este planteamiento se ha orientado a realzar el emergente cambio de enfoque que se está produciendo en la manera de construir la ciudad, en el que es especialmente relevante el papel del planeamiento urbanístico como instrumento al servicio de los agentes territoriales. Ciertamente las ciudades de nuestro país y de los países de nuestro entorno se enfrentan a un contexto complejo: se solapan la concentración constante de población en áreas urbanas, la recuperación de una recesión económica grave y la necesidad de afrontar definitivamente un desafío ambiental que condicionará nuestro desarrollo futuro. En este sentido, presentar en el estudio experiencias emergentes españolas realizadas por equipos dotados de una conciencia ciudadana renovada como vía de contraste se ha revelado una decisión pertinente. Parece oportuno, además, que desde el ámbito académico y de la investigación se les preste atención como modo de contribuir a su visibilidad y como aval de cara a la sensibilización de los técnicos y gestores de la Administración.

Los retos de investigación futura han de encaminarse hacia el estudio de experiencias municipales particulares, en ciudades con características diferentes y que ocupan posiciones distintas dentro de la red urbana, con el fin de analizar la correlación entre tipos de intervención urbana y grado de cumplimiento de los objetivos en favor de la infancia. La perspectiva del presente trabajo merece, además, una profundización en aquella dimensión que se refiere a los modos de implementación de la participación infantil, respecto a la identificación y expresión de los problemas urbanos, al desarrollo de trabajo de campo y a la propuesta de cambios y formulación de soluciones creativas. Para ello, en un futuro se podrán tomar como referencia los estándares elaborados en este trabajo con el objetivo de tratar de evaluar las propuestas existentes dentro del movimiento urbanístico aquí analizado. Además, se podría profundizar más en cómo se han desarrollado las metodologías participativas en el diseño de los nuevos espacios urbanos y caracterizar con detalle el hilo común existente entre las experiencias con mejores resultados, de modo que pueda llegar a extrapolarse a otras ciudades.

Conviene mencionar asimismo que la forma de hacer ciudad que se ha analizado en este trabajo no es única ni incompatible con otros movimientos contemporáneos. Por ejemplo, a la base experiencial de los programas internacionales señalados, se puede sumar la de otros movimientos con impacto en tiempo reciente, como Nós Propomos! Cidadania e Inovação na Educação Geográfica, encabezado por un grupo de geógrafos portugueses y que se ha extendido por Portugal, Brasil, España, Colombia Perú y México, con aprovechamiento de sinergias entre universidades, ayuntamientos y escuelas (Rodríguez \& Claudino, 2018).

Asimismo, alineadas con la visión de ciudad afín a la infancia, las iniciativas ciudadanas guiadas por la superación de problemas comunitarios, de acuerdo con las necesidades y demandas de sus usuarios y apoyadas en las denominadas "prácticas económicas alternativas", como huertos urbanos, bancos de tiempo, centros sociales autogestionados, etc. (GómEZ-GonçALVES, 2019; SÁNCHEZ, 2019), constituyen otro objeto de estudio que puede presentar vínculos y rasgos compartidos con el tema aquí presentado. Con todo, reviste interés comparar su efecto con el de otras corrientes de intervención muy distintas, fundamentadas en la mercadotecnia territorial, que arrojan resultados llamativos en la mejora del disfrute urbano ante la búsqueda de una transformación de la ciudad como espacio experiencial atractivo.

\section{Bibliografía}

Alaparone, F.R. \& Rissotto, A. (2001): Children's Citizenship and Participation Models: Participation in Planning Urban Spaces and Children's Councils. Journal of Community and Applied Social Psychology, 11, 421-434.

Almers, E. \& Askerlund, P., \& KJellström, S. (2018): Why forest gardening for children? Swedish forest garden educators' ideas, purposes, and experiences. The Journal of Environmental Education, 49(3), 242-259. doi:

10.1080/00958964.2017.1373619

ARANDA, A. M. (2001): Identidad y educación ciudadana en contextos a escala Global. Aula: Revista De Pedagogía de la Universidad de Salamanca, 13, 37-50.

- (2010): Didáctica del conocimiento del medio social y cultural en Educación Infantil, Madrid, Síntesis Educación.

ARquITECTIVES: Solar. Recuperado de: https://www. arquitectives.com/solar [consultado 05/09/2019]. 
ARquitecturaViva.com: Tur, Delgado y Cortizo: reordenación urbana del HUCA. Recuperado de: http:// www.arquitecturaviva.com/es/Info/News/ Details/11414 [consultado 15/09/2019]

AsOCIACIÓN DE VIANDANTES A PIE (2002): Entrevista con Francesco Tonucci. Boletín CF+S, 19, edición digital. Recuperado de: http://habitat.aq.upm.es/ boletin/n19/afton.html [consultado 01/08/2019]

BARTLETT. S \& al. (1999): Cities for Children: Children's Rights, Poverty and Urban Management, Londres, Earthscan Publications for UNICEF. https://www.amazon.com/s? i=stripbooks\&rh=p 27 \%3ASheridan+Bartlett\%3BRoger+Hart\%3BDavid +Satterthwaite\%3BXimena+de+la+Barra\%3BAlfre do+Missair\&s=relevancerank\&language $=$ es\&text $=$ Sheridan+Bartlett\%3BRoger+Hart\%3BDavid+Satt erthwaite\%3BXimena+de+la+Barra\%3BAlfredo+M issair\&ref=dp byline $\mathrm{sr}$ book 1

BLANCAFORT, J. \& Reus, P. (2016): “Los orígenes de la participación ciudadana en el urbanismo contemporáneo". En J. Blancafort \& P. Reus (Coords.), La participación en la construcción de la ciudad (pp. 44-59), Cartagena, Universidad Politécnica de Cartagena.

Boyden, J. \& Holden, P. (1991): Children of the Cities, Londres, Zed Books.

Calle, M. \& al. (2008): "La formación en didáctica de las ciencias sociales del maestro de Educación Infantil. Una propuesta adaptada al espacio europeo de educación superior". En R.M. ÁvILA, M.A \& CRUz M.C \& Díez (Coords.), Didáctica de las ciencias sociales, currículo escolar y formación del profesorado [recurso electrónico]: La didáctica de las ciencias sociales en los nuevos planes de estudio (pp. 113-134), Jaén, Universidad de Jaén, Servicio de Publicaciones.

Cañal, P. \& García-Carmona, A. \& Cruz-Guzmán, M. (2016): Didáctica de las Ciencias Experimentales en Educación Primaria, Madrid, Paraninfo.

ChaWLA, L. (2015): Benefits of nature contact for children. Journal of Planning Literature, 30(4), 433-452.

Clements, R. (2004): An investigation of the status of outdoor play. Contemporary Issues in EarlyChildhood, 5(1), 68-80.

CuencA, J. M. (2011): "Concepciones del alumnado en educación infantil para la comprensión del medio sociocultural: Papel de las experiencias y el aprendizaje lúdico". En M.P. Rivero (Coord.), Didáctica de las ciencias sociales en educación infantil (pp. 111-129), Zaragoza, Mira Editores.

Díaz, E.M. \& Rodríguez, I. (2003): "Las secuelas de la ciudad negocio: los parques urbanos de Madrid". En L. López, C.E \& ReleA \& J. Somoza (Eds.), La ciudad: nuevos procesos, nuevas respuestas (pp. 193-204), León, Secretariado de Publicaciones y Medios Audiovisuales.

DomblÁs, U. (2015): Socialization, Learning And Perception Of Urban Landscape: The Case Of Estella-Lizarra. WIT Transactions on The Built Environment, 153, 841-851.

DRISKELL, D. (2002): Creating better cities with children and youth: a manual for participation, París, Londres, Earthscan, UNESCO.

DymeNT, J.E. (2005): Green School Grounds as Sites for Outdoor Learning: Barriers and Opportunities.
International Research in Geographical and Environmental Education, 14(1), 28-45.

Eurostat (2016): Urban Europe-statistics on cities, towns and suburbs-executive summary. Recuperado de: https://ec.europa.eu/eurostat/statistics-explained/index.php/Urban_Europe_-_statistics_on_ cities, towns and suburbs - executive summary [consultado el 1 de diciembre de 2019].

FERNÁNDEZ, G. \& FeRnÁNDEZ, V. (2019): “La construcción de la ciudad a lo largo de la historia (II): la ciudad industrial". En G. Fernández, Atlas de Geografía Humana de España (pp. 397-447), Madrid, Paraninfo.

FRANK, K.I. (2006): The potential of Youth Participation in Planning. Journal of Planning Literature, 20(4), 351-371.

Freeman, C. \& Tranter, P. (2011): Children and their urban environment: changing worlds, London y Washington D.C., Earthscan.

FREIRE, H. (2011): Educar en verde. Ideas para acercar a niños y niñas a la naturaleza, Barcelona, Graó.

Gaffron, P. \& Huismans, G. \& Skala, F. (Coords.) (2008): Proyecto Ecocity. Manual para el diseño de ecociudades en Europa, Libro I, Bilbao, Bakeaz, GEA21.

García-GonzÁlez, M. C., \& Guerrero, S. (2019): Sobre el espacio de juego infantil en la ciudad moderna: Lady Allen of Hurtwood versus Jakoba Mulder. Ciudad y Territorio Estudios Territoriales (CYTET), 51(200), 311-326.

GEA21: Quiénes somos. Recuperado de: http://www.gea21.com/quienes-somos/ [consultado 15/09/2019].

GEA21: Urbanismo. Recuperado de: http://www.gea21.com/archivo/urbanismo/ [consultado 15/09/2019].

Giles-Corti, B. \& al (2011): School site and the potential to walk to school: The impact of street connectivity and traffic exposure in school neighborhoods. Health \& Place, 17, 545-550.

GILL, T. (2014): The benefits of children's engagement with nature: A systematic literature review. Children Youth and Environments, 24(2), 10-34.

Gobierno de España. Agenda 2030: Objetivos de Desarrollo Sostenible. Recuperado de: https://www.agenda2030.gob.es/objetivos [consultado 20/09/2019]

Gobierno VAsco (2003): Criterios de sostenibilidad aplicables al planeamiento urbano, Serie Programa Marco Ambiental $n^{\circ} 23$, Bilbao, Departamento de Ordenación del Territorio y Medio Ambiente, Sociedad Pública de Gestión Ambiental.

Gómez, A. (2013): Localización y acceso al verde urbano de la ciudad de Salamanca. Boletín de la Asociación de Geógrafos Españoles, 63, 125-145.

GómEz-GonçALVES, A. (2019): "Huertos urbanos: laboratorios para la enseñanza y el aprendizaje práctico de la alternatividad”. En J.L. SÁnchez (Coord.), Espacios y prácticas económicas alternativas en las ciudades españolas (pp. 87-106), Cizur Menor (Navarra), Thomson Reuters Aranzadi.

— \& Corrochano Fernández, D. (2018): El uso de los espacios verdes urbanos como recurso didáctico en el aula de Educación Primaria. En A. García DE LA VEGA (Ed.), Contribución didáctica al aprendizaje de la geografía (pp. 641-649). Universidad 
Autónoma de Madrid y Asociación de Geógrafos Españoles.

- SÁnchez, J.L. \& Ceballos, A. (2018): El impacto de las políticas de austeridad en los espacios verdes urbanos según la percepción de los usuarios. Estudio de caso en tres ciudades españolas. Boletín de la Asociación de Geógrafos Españoles, $77,398-427$.

HernÁndez, C. (1986): Los valores sociales, un instrumento para el conocimiento social del niño: Su reflejo en la comunicación publicitaria. Infancia y Aprendizaje. Journal for the Study of Education and Development, 35, 109-122.

Herrmann, M. G. (2016): Instrumentos de planificación y diseño urbano para promover al peatón en las ciudades. Un estudio comparado entre Chile y Alemania. Revista Urbano, 34, 48-57.

Keniger, L. \& al (2013): What are the benefits of interacting with nature? International journal of environmental research and public health, 10(3), 913-935.

LIN, E-Y. \& al. (2017): Social and built-environment factors related to children's independent mobility: The importance of neighbourhood cohesion and connectedness. Health \& Place, 46, 107-113.

Lopes, F. \& Cordovil, R. \& Neto, C. (2014): Children's independent mobility in Portugal: effects of urbanization degree and motorized modes of travel. Journal of Transport Geography, 41, 210-219.

Malberg Dyg, P., \& Wistoft, K. (2018): Wellbeing in school gardens - the case of the Gardens for Bellies food and environmental education program. Environmental Education Research, 24(8), 1177-1191. doi: 10.1080/13504622.2018.1434869

Maller, C. \& Townsend, M. (2006): Children's mental health and wellbeing and hands-on contact with nature. International Journal of Learning, 12(4), 359-372.

Martinez, M. (2004): Entrevista a Francesco Tonucci. Autor de Cuando los niños dicen basta. Educación y biblioteca, 139, 29-34.

Ministerio de Educación Y Ciencia (2006): Real Decreto $1630 / 2006$, de 29 de diciembre, por el que se establecen las enseñanzas mínimas del segundo ciclo de Educación infantil. Boletín Oficial del Estado, 4, jueves 4 de enero de 2007, 474-482.

- (2007): Orden ECI/3960/2007, de 19 de diciembre, por la que se establece el currículo y se regula la ordenación de la Educación Infantil. Boletín Oficial del Estado, 5, jueves 5 de enero de 2008, 1.0161.036.

Ministerio de Educación, Cultura y Deporte (2014): Real Decreto 126/2014, de 28 de febrero, por el que se establece el currículo básico de Educación Primaria. Boletín Oficial del Estado, 52, sábado 1 de marzo de 2014, 19.349-19.420.

NavarRo, V. (2013): Playgrounds del siglo XXI: Una reflexión sobre los espacios de juego de la infancia. Arquitectonics: Mente, Territorio y Sociedad, 25, 189-202.

ONU: Objetivos de Desarrollo Sostenible. Recuperado de: https://www.un.org/sustainabledevelopment/es/ development-agenda/ [consultado 20/09/2019]

Paisaje Transversal: Córdoba Luze Ambiente Nocturno. Recuperado de: https://paisajetransversal.com/ portfolio/ambiente-urbano-nocturno-cordoba-luze/ [consultado 13/12/2020]
Paisaje Transversal: Eje de Accesibilidad VDB. Recuperado de: http://paisajetransversal.com/ portfolio/eje-de-accesibilidad-vdb/ [consultado 05/09/2019]

Paisaje Transversal: Hacemos. Recuperado de: http://paisajetransversal.com/concepto/ [consultado 01/09/2019]

Paisaje Transversal: Somos. Recuperado de: http://paisajetransversal.com/oficinal [consultado 01/09/2019]

Paisaje Transversal (2012a): A participar se aprende participando. VdB; Acción y reflexión críticas en el proyecto para la regeneración urbana participativa en el barrio Virgen de Begoña (Madrid). Hábitat y Sociedad, 4, 15-31.

Paisaje Transversal (2012b): Nuevos tiempos, nuevas estrategias: Hacia una metodología urbana en beta permanente. Revista La Ciudad Viva, 6, 1-4.

- (2019): Escuchar, co-crear y transformar la ciudad colectivamente". Ciudad sostenible, resiliente e innovadora, 36, 17-22.

Plataforma de InFANCIA \& UNICEF Comité Español (2018): Manifiesto de Oviedo, Madrid, UNICEF Comité Español.

Programa Ciudades Amigas de la Infancia UNICEF EsPaña (2013): La ciudad que queremos: una ciudad amiga de las personas, Madrid, UNICEF Comité Español.

Puyuelo, M., Gual, J. \& Galbis, M. (2005): Espacios abiertos urbanos y personas mayores: una experiencia llevada a cabo en distintos parques de la ciudad de Castellón sobre el diseño y su interacción con la población anciana, Castellón de la Plana, Universitat Jaume I.

Rissotro, A. \& Tonuccl, F. (2002): Freedom of movement and environmental knowledge in elementary school children. Journal of Environmental Psychology, 22, 65-77.

Rodríguez, M.A. \& Claudino, S. (2018): Nosotros proponemos. Ciudadanía, sostenibilidad e innovación geográfica ante los desafíos educativos de la sociedad, Barcelona, Editorial Graó.

Román, M. \& Salis, I. (2010): Camino escolar. Pasos hacia la autonomía infantil, Madrid, GEA21 Grupo de Estudios y Alternativas.

SÁNCHEZ, J.L. (Coord.) (2019): Espacios y prácticas económicas alternativas en las ciudades españolas, Cizur Menor (Navarra), Thomson Reuters Aranzadi.

Sanz, A. (s.f.): Donostia camina. Pasos de una estrategia. Proyectos y propuestas para el peatón en San Sebastián, San Sebastián, Gabinete de Prensa, Publicidad y Publicaciones, Ayuntamiento de San Sebastián.

SegoviA, C. (2017): La vida de la infancia en la ciudad y su conflicto con el mundo adulto. Kultur: revista interdisciplinària sobre la cultura de la ciutat, 4(8), 149-168.

Servei Catalá de Transit (2016): Els camins escolars, Dossier técnic de seguretat viària $n^{\circ} 27$, Barcelona, Generalitat de Catalunya, Departament d'Interior.

SeVILLA, J. (2014): "Una propuesta didáctica en el entorno urbano para la formación en valores en Educación Infantil”. En J. PAgès \& A. SAntisteban (Eds.), Una mirada al pasado y un proyecto de futuro. Investigación e innovación en didáctica de las ciencias sociales (pp. 107-118), Barcelona, Universidad Autónoma de Barcelona. 
Simone, M. \& Esteves, M. (2017): O espaço público e o lúdico como estratégias de planejamento urbano humano em: Copenhague, Barcelona, Medellín e Curitiba. Cadernos Metrópole, 19(39), 635-663.

SPEnCER, C. \& Blades, M. (2005): Children and Their Environments: Learning, Using and Designing Spaces, Cambridge, University Press.

TEY, A. \& CIFRE-MAS, J. (2011): El profesorado ante el reto del aprendizaje ético y el desarrollo de las competencias sociales y ciudadanas. El modelo adoptado en el programa Barcelona, Aula de Ciutadania. Revista De Educación, 1, 225-242.

Tonuccl, F. (1994): La ciudad de los niños. Cuadernos de Pedagogía, 229, 8-12.

- (2009): Ciudades a escala humana: La ciudad de los niños. Revista De Educación, 1, 147-168.

- (2009): ¿Se puede enseñar la participación? ¿Se puede enseñar la democracia? Investigación en la escuela, 68, 11-24.

TrachanA, A. (2012): Urbe ludens: espacios para el juego en la ciudad. Ciudad y Territorio Estudios Territoriales (CyTET), 44(173), 423-444.

TRILLA, J. (2005): La idea de ciudad educadora y escuela. Educación y ciudad, 7, 73-106.

Tur, J. \& Delgado, A. \& Cortizo, D. (2019): HUCAMP! La campa de todos. Una apuesta por la regeneración urbana estratégica en Oviedo. Ciudad sostenible, resiliente e innovadora, 36, 62-66.

UNICEF Comité Español (2009): Pongamos a la infancia en la agenda política local. Manual básico para responsables políticos municipales, Madrid, UNICEF Comité Español.

- (2015): Convención sobre los derechos del niño Madrid, UNICEF Comité Español.

- (2017): Participación infantil: marco clave del programa Ciudades Amigas de la Infancia, Madrid, UNICEF Comité Español.
VALdIVIA, B. \& al (2017): Entornos habitables. Auditoría de seguridad urbana con perspectiva de género en la vivienda y el entorno, Barcelona, Col.lectiu Punt 6.

VegA, P. (2005): El transporte al trabajo. Planes de movilidad sostenible en empresas, Madrid, Instituto Sindical del Trabajo, Ambiente y Salud.

- (2006): Catálogo de buenas prácticas en la movilidad al trabajo, Madrid, Instituto Sindical del Trabajo, Ambiente y Salud.

Verdaguer, C. (2013): El campo y la ciudad, áreas de reencuentro. Hacia una Nueva Cultura del Territorio. Hábitat y sociedad, 6, 11-40.

— \& VeLÁzQUeZ, I. (2012): La ciudad de abajo a arriba. Aportaciones para la práctica y la teoría del urbanismo participativo. Hábitat y sociedad, 4, 7-11.

UNICEF Comité Español: Ciudades Amigas de la Infancia. Recuperado de: https://ciudadesamigas. org [consultado 15/08/2019]

Wells, N. \& Evans, G. (2003): Nearby Nature: A Buffer of Life Stress Among Rural Children. Environment and Behavior, 35(3), 311-330.

\section{Abreviaturas}

CNR: $\quad$ Consiglio Nazionale delle Ricerche

EDUSI: Estrategia de Desarrollo Urbano Sostenible e Integrado

GEA21: Grupo de Estudios y Alternativas 21

HUCA: Hospital Universitario Central de Asturias

ONU: Organización de las Naciones Unidas

PNOA: Plan Nacional de Ortofotografía Aérea

UNICEF: United Nations Internacional Children's Emergency Fund 


\title{
CIUDAD Y TERRITORIO
}

ESTUDIOS TERRITORIALES

ISSN(P): 1133-4762; ISSN(E): 2659-3254

Vol. LIII, № 207, primavera 2021

Págs. 95-118

https://doi.org/10.37230/CyTET.2021.207.06

\section{Sprawl logístico en la mega-región urbana de Madrid. El espacio de la distribución entre la dispersión y la centralidad}

\author{
Darío RIVERA-BLASCO \\ Javier RuIz-SÁncheZ
}

Arquitectos. Universidad Politécnica de Madrid (UPM).

\begin{abstract}
RESUMEN: Los nuevos modos de distribución y consumo en las grandes ciudades están implicando transformaciones significativas en el modelo de implantación de las actividades logísticas en las regiones urbanas. El presente artículo analiza la evolución de dicho modelo y las tendencias en la nueva ciudad de la distribución (freight village) en la mega-región urbana de Madrid a través de un análisis secuencial 1998-2008-2018. El modelo resultante, que caracterizamos como "sprawl logístico", es resultado de una serie de tendencias que sintetizan un escenario complejo y en permanente transformación. Mientras algunas de ellas se consolidan (el arco logístico A2-A4) otras (centros de gravedad vs distancia, tamaños medios y tipos de implantación) responden a ajustes tanto de la coyuntura económica como de las nuevas formas de distribución y hábitos de consumo, lo que permite aportar datos para un ejercicio de prospectiva y eventual planificación y toma de decisiones, tanto sectoriales como comprehensivas.
\end{abstract}

PALABRAS CLAVE: Planeamiento Urbano; Logística; Madrid; Nuevas regiones metropolitanas; Sprawl.

Recibido: 03.03.2020; Revisado: 18.06.2020

Correo electrónico: dario.rivera@upm.es; No ORCID: https://orcid.org/0000-0003-2939-2119;

Correo electrónico: javier.ruiz@upm.es; NºRCID: https://orcid.org/0000-0001-7272-9114

Los autores agradecen los comentarios y sugerencias realizados por los evaluadores anónimos, que han contribuido a mejorar y enriquecer el manuscrito original. 


\title{
Logistics sprawl in the urban mega-region of Madrid. The space of the supply chain between dispersion and centrality
}

\begin{abstract}
New ways of distribution and retail in big cities produce significant changes in the implementation of a new logistics operative model in urban regions. This paper shows the evolution of that model and the tendencies of a so-called freight village in the Urban Megaregion of Madrid through the sequential analysis 1998-2008-2018. The resulting model, some kind of "logistics sprawl", emerges out of a number of tendencies from the basis of a complex and evolving scenario. Although some of these tendencies are consolidated (the logistics arch formed by roads A2-A4), others (gravity center analysis vs distance, medium size and warehousing establishments types) respond to adjustments from economic environment, the new distribution models and retail and shopping habits, permitting data collection for a prospective analysis and eventual planning and decision making.
\end{abstract}

KEYWORDS: Urban Planning; Logistics; Madrid; New Metropolitan Regions; Sprawl.

\section{Introducción. El marco logístico en el área metropolitana de Madrid}

as distancias a las centralidades metropolitanas de las implantaciones de almacenaje y distribución en las últimas décadas se han incrementado proporcionalmente al desarrollo urbano y económico de las ciudades. Aspectos relacionados con la cadena de suministro global, como es el caso del tiempo y la distancia, ahora analizadas, hacen que, a la hora de explicar el posicionamiento de actividades de distribución dentro de las mega-regiones urbanas, la escala regional dé el salto a escalas mayores, nacional e incluso internacional. Estructuras económicas globalizadas en constante cambio así lo propician, y hacen que la toma de decisión de localizaciones de distribución a todas las escalas tenga ahora más relevancia a la hora de modelar el paisaje suburbano.

En los últimos cinco años la renta de las personas en Madrid ha ido recuperando progresivamente el nivel anterior a la crisis de 2008, lo que significa más gasto en bienes de consumo, que sumado a la "multicanalidad" incorporada a nuestros hábitos de consumo, lo que ha significado para el ecommerce ritmos de crecimiento de doble dígito, muy superiores a los del medio habitual de compra en "tienda física". Este pujante "comercio electrónico" hace que los operadores online ligados a la nueva economía de plataformas (SRNICEK, 2017) necesiten estar cada vez más cerca del cliente finalista para poder ahorrar costes de envío y acortar al máximo los tiempos de entrega. El negocio del e-commerce movió en España en 2018 la cantidad de 21,8MM€ (datos de la Comisión Nacional de los Mercados y la Competencia -CNMC-) lo que significa un crecimiento acumulado en cinco años del $260 \%$ (interanual superior al $27 \%$ ). España es la que más crece de la UE, aunque partiendo, lógicamente, de una base más baja que la mayor parte del resto de países.

Por otro lado, las plataformas de transporte intermodal, puertos, aeropuertos, Ferrocarriles (FFCC), hubs en definitiva, originan nuevas dinámicas de relación con las infraestructuras de interconexión propiciando flujos de bienes de consumo cada vez más complejos y superpuestos, y que, aun siendo en parte promovidas por el modelo desarrollista basado en políticas fundamentadas en grandes inversiones públicas de las últimas dos décadas, ha permitido, entre otros factores, que la ciudad de Madrid, claro ejemplo de este modelo, pueda ascender al Top 20 (VV. AA., 2019) de ciudades con mayor actividad en distribución y servicios ( $\mathrm{y}$ volumen y capacidad de Infraestructuras) a nivel mundial. Se enclava en dicha clasificación dentro del grupo de Global Contenders y en progresivo ascenso hacia el grupo de las "Big Seven" (las siete regiones mejor posicionadas en la cadena de suministro global), un ascenso que, por otro lado, se produce en una dirección quizás poco aconsejable desde el punto de vista de la optimización de los recursos y de los impactos derivados.

El aeropuerto de Madrid-Barajas, con su terminal de mercancías, o los "puertos secos" de Abroñigal y Coslada en la región de Madrid, y Azuqueca de Henares en Guadalajara, dentro del área de influencia del Área Metropolitana de Madrid (AMM), son infraestructuras de FFCC conectadas directamente a los puertos más importantes del Mediterráneo, como son Barcelona o Valencia; $y$, ya en construcción, el puerto seco de Marchamalo-Guadalajara, que se conectará en el futuro con el pujante puerto de Tarragona. Estas infraestructuras de comunicaciones intermodales 
se suman a una logística basada en el FFCC más sostenible, aunque el principal medio de transporte de mercancías siga siendo el de vehículos por carretera. Este transporte por carretera de los vehículos pesados españoles arrojó por ejemplo en 2015 un volumen de 1.258 .749 millones de toneladas ${ }^{1}$, con subidas anuales en torno al 5-6\% desde el año 2014 y que continúan en similar tendencia hasta nuestros días. A esto habría que sumar el volumen de mercancías de los camiones extranjeros recibido en nuestro país, que en concreto para la región de Madrid fue en 2015 de 72.644 MT expedidas y 79.728 MT recibidas.

Con este panorama descrito se corre el serio riesgo de colapsar no solo la capital ${ }^{2}$ sino también las vías de comunicación rodada que la circunvalan y la penetran en todo su Área Metropolitana, por lo que parece apropiada una apuesta por la intermodalidad en el transporte de mercancías, la creación de más infraestructuras de intercambio FFCC-carretera y también con la introducción en el centro de las metrópolis de Plataformas de Distribución Urbana (PDU) -como el caso de la creada por Amazon en la antigua sede de la editorial Gustavo Gili en pleno Eixample de Barcelona-, puedan reducir un $25 \%$ el coste del reparto del denominado last mile (último metro de la distribución al destino final con volúmenes muy pequeños, con una problemática específica y complejidad en aumento derivada de los modelos de comercio electrónico) y reducir las distancias recorridas en un $45 \%{ }^{3}$.

Los factores de distancia y tiempo y las nuevas solicitaciones funcionales de las implantaciones logísticas se superponen a una estructura territorial de redes de transporte, modelo urbano y de planeamiento y disponibilidad y coste del espacio, dando lugar a una evolución del modelo espacial de la cadena de distribución.

En cuanto a las cifras globales de inversión y volumen de desarrollos inmobiliarios en general y logísticos en particular, nos encontramos en una situación de estabilización del número de proyectos en 2019 respecto de 2018 pero con un ligero crecimiento en la inversión, debido al repunte de los precios de la construcción en España en los últimos años. El volumen de inversión total previsto en 2019 en España en proyectos

\footnotetext{
${ }^{1}$ Fuente: Encuesta permanente de Transporte de Mercancías por Carretera (MINISTERIO DE FOMENTO).

2 Fuente: EL PAis 15/11/2019 publica el artículo "El efecto Amazon corre el riesgo de colapsar la capital" en el que se exponen datos como que 8.000 vehículos de reparto de mercancías a tiendas y viviendas entran al día en el área restringida al tráfico de Madrid 360 y que la patronal CEL propone crear PDU (puntos de distribución urbana) en los barrios de la ciudad para desatascar el problema, por ejemplo.
}

inmobiliarios se estima que ha superado los $12.000 \mathrm{M} €$, de los cuales los logísticos representan un $16 \%$ del total igualando ya al residencial. Mientras la inversión inmobiliaria total ha ido creciendo año a año desde 2014, la inversión logística en los últimos 5 años ha crecido más del doble, con una absorción de volumen ejecutado desde los $400.000 \mathrm{~m}^{2}$ en el año 2014 hasta los más de $900.000 \mathrm{~m}^{2}$ estimados para 2019 para el caso concreto de Madrid ${ }^{4}$. De las cifras globales para 2019, a Madrid le corresponderían más de 4.000 M€ (que supone más del 35\% del total de España), con una inversión en logística estimada en unos $800 \mathrm{M}^{5}$. Si atendemos a un crecimiento del PIB en España para 2019 del $2 \%{ }^{6}(3,4 / 3,3 / 3,1 / 2,6 \%$ respectivamente en $2015 / 16 / 17 / 18$ ) nos encontramos con que el sector inmobiliario -y en particular el logístico- han crecido muy por encima de estas cifras y a contracorriente de la tendencia a la baja del PIB, recuperando, en parte, lo perdido en los años anteriores a 2014 durante el periodo de crisis económica.

Respecto de las cifras sobre la actividad y el empleo en la región de Madrid, la logística crea 183.000 empleos desarrollados en unas 30.000 empresas, cuya actividad genera más de 9.500 millones de euros al año, el 5,7 \% del PIB regional, en los más de $38 \mathrm{Mm}^{2}$ dedicados a actividades logísticas en $2017^{7}$. En datos estadísticos recientes $^{8}$ el sector de la logística presenta incrementos de contratación laboral con retroceso del paro de $3,4 \%$, así como incremento en el número de empresas y cifras de negocio, si bien los precios de los servicios logísticos tienden a crecer, mientras que, por el contrario, los costes laborales retroceden. Este aspecto podría generar desajustes y conflictos en el futuro.

Se constata, por lo tanto, que la diversidad de factores que toman parte en el posicionamiento urbano del movimiento de mercancías y bienes de consumo en torno a las grandes ciudades es elevado, asumiendo que lo es también el número de externalidades indeseadas que éste genera, tales como la congestión, polución y ruido, o las consecuencias indirectas, como el impacto sobre la huella ecológica o el aumento de consumo de recursos en nuestras ciudades, proporcional al consumo de bienes en la sociedad urbana actual.

\footnotetext{
${ }^{3}$ Fuente: ZETES

${ }^{4}$ Fuente: Consultora Inmobiliaria Estrada\&Partners Asesoría Inmobiliaria. Madrid.

${ }^{5}$ Fuente: CBRE. Informe Mercado Inmobiliario 3T 2019. España.

${ }^{6}$ Fuente: Banco de España.

7 Fuente: Página web oficial de la ComUnidad DE MADRID. Noticias: $20 / 04 / 2018$.

${ }^{8}$ Fuente: Página web cadenadesuministro.es. Noticias: Resumen junio de 2019 .
} 
Por ello, este estudio se presenta como una contribución posible a la identificación de estrategias urbanas y políticas que puedan mitigar los efectos indeseados de la logística ineficiente tanto a la escala global como a la local, ayudándonos de nuevas herramientas a la hora de analizar, comparar y proponer medidas encaminadas a hacer más efectiva y sostenible la futura ciudad de la distribución, asumiendo lo imparable de la interconectividad global de las cadenas de suministros (KhanNa, 2016).

Los últimos años están apuntando claves y tendencias de cara a la mejora futura en la cadena de suministro "hiperglobalizada", con un modelo complejo de "plena movilidad intersectorial de factores implicados" (RODRIK, 2018). Estas tendencias van a estar fundamentadas en tres dilemas o pilares básicos a definir a futuro, pero que ya están siendo apuntadas: i, en primer lugar, la reducción del impacto ecológico sobre todo reduciendo las distancias entre productores y consumidores -no solo para disminuir la contaminación y el consumo energético, sino para poder reaccionar convenientemente ante posibles desabastecimientos causados por catástrofes o perturbaciones- renunciando a un mayor beneficio a corto plazo; ii, en segundo lugar, hacer más sostenibles a los operadores logísticos tomando como base un principio de equilibrio mucho menos desigual entre los costes y los beneficios, traducido por ejemplo en un mercado laboral más justo, evitando así posibles desajustes y carencias de mano de obra no cualificada mal remunerada, y desarrollando el principio de eficiencia de equipos cohesionados entre gestores y trabajadores (managers \& workers) (RODRIK, 2018), incluso mejorando la cualificación de éstos últimos y reduciendo brechas salariales, como apunta Rodrik (2011) explícitamente como consecuencia directa del reajuste de las cadenas globales de suministro en el caso de China y otros países de oriente asiático; y iii, en tercer lugar, la capacidad de readaptación (resiliencia) por parte de la sociedad y las instituciones que permita anticiparse ágilmente a los crecientes problemas de gobernanza y soberanía derivados de la economía excesivamente globalizada imperante en nuestros días, que choca en cierta manera con la toma de decisiones más locales, regionales o incluso nacionales de índole espacial, apuntando el difícil equilibrio entre globalización comercial efectiva y soberanía local en términos de decisión (RODRIK, 2011).
A tenor de lo expuesto anteriormente, y partiendo de la comprensión de la problemática planteada, podemos concluir que si se analiza convenientemente la relación entre la gestión de la gobernanza y la ocupación del territorio, que deben necesariamente tender a encontrarse en el punto de equilibrio deseado, ahondaremos en una programática correcta de ordenación del territorio y toma de decisiones que esté fundamentada a partir de los cambios en los hábitos de consumo demandados por la sociedad en nuestro tiempo y propiciados por las nuevas tecnologías. En la era tecnológica y global en la que vivimos, "el poder del lugar físico seguirá prevaleciendo" (MITCHELL, 1999), ya sea para las relaciones de consumo -almacenamiento y distribución de mercancías-, como para "las interacciones cara a cara que tanto nos importan" -y que son tan necesarias desde el punto de vista socio-psicológico, inseparable de los hábitos actuales de la población que, en último término, pueden llegar a moldear el territorio-. Sirva esta reflexión para justificar la oportunidad de este estudio.

\section{2. Ámbito espacial. Aproximación al área de estudio}

La "ciudad global" presenta una variedad de formas y niveles relacionales-comunicativos, de manera que la llamada "ciudad de la distribución" (freight village, en la literatura internacional) y las recientes preferencias de la actual "ciudad del consumo" se representan en complejas disposiciones espaciales por las innumerables reciprocidades existentes entre ellas. Este estudio aborda una comprensión de la casuística sectorial de la implantación de las cadenas de distribución en la región urbana de Madrid, basada en un análisis comparativo primero y una aproximación prospectiva después, con el objetivo de estimular el conocimiento y la ordenación del territorio de la logística en torno a la ciudad de Madrid.

La población global que vive en las grandes ciudades está creciendo imparablemente ${ }^{9}$, de tal manera que de facto podemos hablar de una urbanización global con un nivel de concentración de actividad en las ciudades y megaciudades y en el que buena parte de los desafíos urbanos de las propias megaciudades del futuro tienen que ver precisamente con la planificación en el territorio

\footnotetext{
9 Teniendo en cuenta los estudios que fijan el crecimiento de la población mundial, que en menos de 40 años -en el horizonte del año 2050- alcanzará los 9.600 M. hab. -actualmente somos 7.200 M.-, de los cuales el $67 \%$ vivirán en zonas urbanas -, si extrapolamos esa media mundial a los países de la
}

OCDE ésta se eleva al $87 \%$ según el WSB14 Global Vision Report (Cuchi \& al, 2014) en base a DESA (1999-2013). La consecuencia de estos datos será, sin duda, el protagonismo de las Mega-regiones y Megaciudades como fenómeno espacial a tener necesariamente como centro de la agenda urbana. 
desde el punto de vista de las implantaciones logísticas, infraestructuras conectivas al servicio de las cadenas de distribución a escala global. Aspectos socioeconómicos e infraestructurales, como la disponibilidad de suficiente mano de obra y unos suelos en condiciones óptimas de precio y conexión a las redes de infraestructuras de alta capacidad, no deben de ser desdeñados respecto de otros factores como la distancia y el tamaño o volumen adecuados o aconsejables desde el punto de vista tanto eficiente como ecológico, en sentido amplio.

En el caso que nos ocupa, el ámbito de estudio sobrepasa los límites administrativos de la provincia o Comunidad Autónoma de Madrid. La escala ya no es, por lo tanto, meramente regional, sino que se instala en un marco territorial suprarregional, inspirado en cierto modo en un ámbito similar al reflejado en la siguiente imagen, que puede corresponder para el caso con el "área caliente" (sombreada en rojo) de los espacios logísticos más "deseables" en Europa (FIG. 1), apoyados en el caso del Área Metropolitana de Madrid en una estructura radial de infraestructuras de comunicación desde el centro de la Península hacia los nodos exteriores.

Para establecer el ámbito de estudio de forma más exacta partimos de la siguiente premisa/hipótesis: los flujos de la distribución y los asentamientos logísticos definen los límites de las mega-regiones urbanas de la misma forma que los flujos del transporte de pasajeros definen el área metropolitana de una gran ciudad. En el caso de Madrid la red de transporte público de pasajeros coincide prácticamente con la región administrativa estricta, salvo la excepción de Guadalajara capital.

El término de Mega-región (RodRIGUE, 2004) viene utilizándose en diferentes estudios desde principios del siglo XXI y viene a sustituir a otros como Megalópolis (GoTTMANN, 1961) o Macroregión (BURNS, 2009), para ser utilizado en estudios geográficos y urbanísticos relacionados con el planeamiento territorial. Variables de estudio a escala regional empleadas en la planificación de población, empleo, vivienda, transporte, actividades y flujos de mercancías, son ahora enmarcadas en áreas denominadas Mega-regiones, como en el caso acuñado como "freight" (GIFFORD, 2010 y HARRISON \& al., 2012) que incluye la carga, el transporte o el flete de mercancías, en definitiva, la cadena de distribución.

Existen diversos métodos para la delimitación de aglomeraciones urbanas y metropolitanas, como por ejemplo el basado en cuatro aproximaciones principales (RocA, 2003, a partir de BuRNs, 2009): i. morfología del continuo urbanizado; ii. aglomeración urbana derivada de la aproximación demográfica; iii. delimitaciones económicas basadas en el porcentaje de profesiones consideradas como específicamente urbanas; y, finalmente, iv. métodos funcionales relacionados con la movilidad.

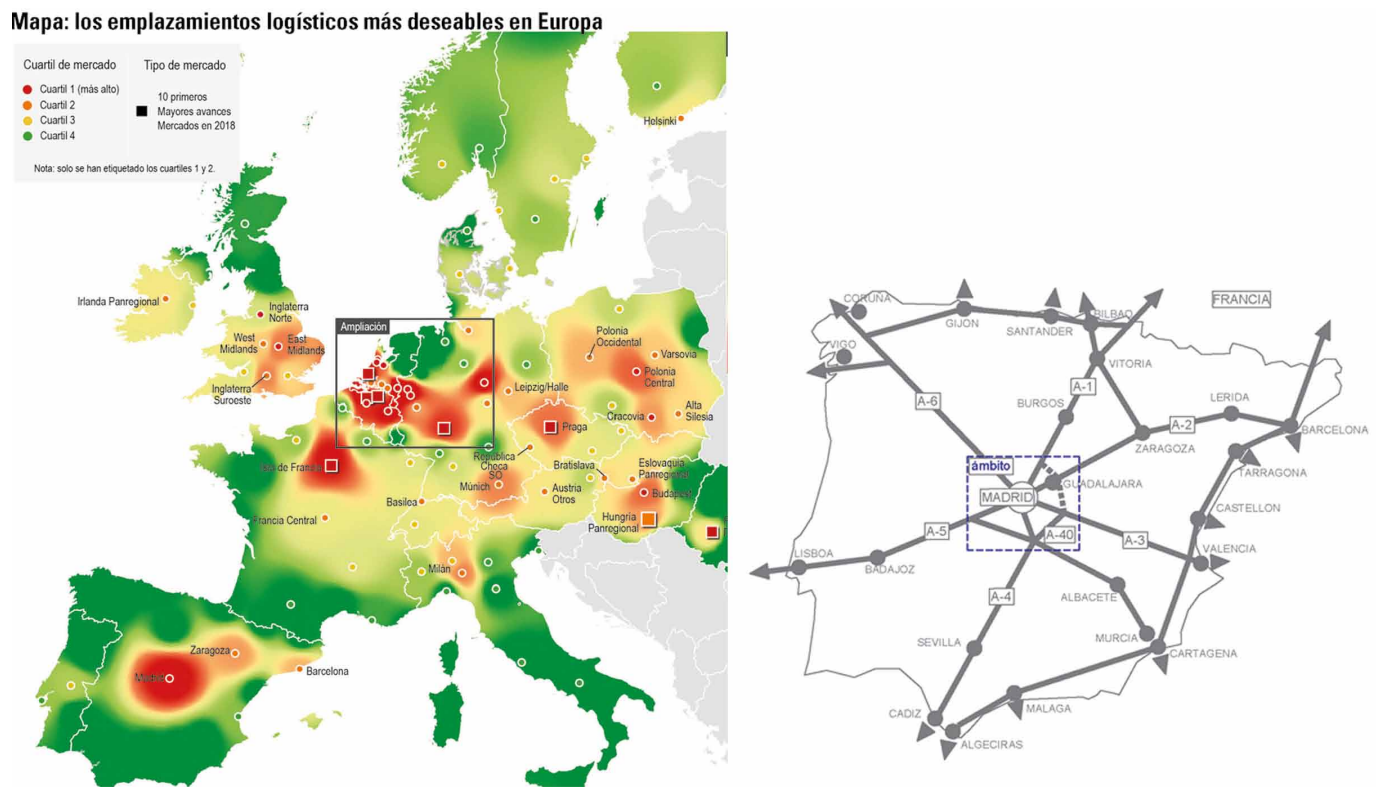

FIG. 1/ Emplazamientos Logísticos más deseables en Europa, entre los que se encuentra la Región Urbana de Madrid y su relación con la infraestructura de transporte básica de la península lbérica. 
Los métodos que se han demostrado más efectivos -v. gr. el método SMSA ${ }^{10}$, datos 1960"sancionaron el protagonismo de las relaciones funcionales" (BuRNs \& al., p. 73) frente a las otras tres variables, focalizándose, sobre todo, sobre los flujos. Mientras tanto, la delimitación metropolitana aplicada al territorio español por parte de la UPC parte de un criterio iterativo de agregación municipal ${ }^{11}$. Este último método, simplificado y al mismo tiempo enriquecido con los flujos efectivos, es aquí el más conveniente para delimitar el área de influencia interregional del continuo urbano desde una perspectiva de implantación logística.

Tanto basado en la afirmación de la premisa de partida, como por otra parte atendiendo al método de delimitación elegido (el considerado más adecuado al caso de estudio, dado el papel de las administraciones locales en la decisión de los modelos espaciales en España), se procede a establecer el área que se podría definir como Mega-región Urbana de Madrid. Para el caso logístico ello vendría sustentado por un criterio basado en dos aproximaciones principales: el de la agregación municipal (rosario de municipios a lo largo de las principales infraestructuras de movimiento de mercancías) a modo de continuidad urbana logística; y el de la actividad logística en términos de intensidad mínima identificada en cada municipio (al menos un emplazamiento logístico de superficie significativa -polígono o nave- ubicado en su Término Municipal (TM).

Una vez sintetizados y mapeados los resultados obtenidos del análisis a partir de este método (agregación de municipios con actividad logística contrastada) para los tres periodos 19982008-2018, correspondientes a las tres últimas décadas, se aproxima el perímetro de influencia suburbana/macrorregional, siempre desde la perspectiva del almacenaje y la distribución de bienes de consumo, que va más allá de su área metropolitana o región administrativa definidas en sus momentos respectivos (años sesenta a ochenta del pasado siglo) tal y como se ha adelantado. Así aparece y se hace visible una Megaregión Urbana definida por un área de 2.057,71 $\mathrm{Km}^{2}$, que es la superficie que suman los $34 \mathrm{mu}$ nicipios con presencia logística repartidos entre cuatro provincias: Madrid (M), Guadalajara (GU), Cuenca (CU) y Toledo (TO) y dos regiones administrativas/comunidades autónomas: Comunidad de Madrid (CM) y Castilla-La Mancha (C-LM). Estos son los límites administrativos incluidos

\footnotetext{
10 Standard Metropolitan Statistical Areas, Bureau of the Census (EE.UU.).

${ }^{11}$ Estudio Prospectivo del Sistema Urbano del Sudoeste Europeo (1998-2001), Universidad Politécnica de Cataluña con
}

dentro del área de influencia del territorio "sirviente" estimado en el presente estudio en torno a la gran ciudad de Madrid.

\section{La génesis de las implantaciones logísticas en la mega-región urbana de Madrid 1998-2008-2018: un periodo de expansión entre las dos crisis}

\section{1. Ámbito temporal. Periodos de estudio}

Con este marco de expansión y desarrollo inmobiliario global, y en particular logístico, de los últimos años en la Región Metropolitana de Madrid, el estudio divide estos años en tres periodos:

1. Periodo 1 de análisis: anterior a 1998; en que la mayor parte de las iniciativas tuvieron una marcada componente estratégica pública, incluso directamente orientada o promovida por la Comunidad de Madrid (se trata de un periodo de consolidación de infraestructuras de transporte de FFCC y de la red viaria arterial tras la ejecución efectiva de acciones ligadas al Plan para el Transporte en las Grandes Ciudades, la más significativa la orbital M-40, y actuaciones logísticas de iniciativa pública, como el Citi-PAC de Coslada o el Plan Parcial 1 del PAU del Arroyo Culebro (RUIz SÁNCHEZ, 2000);

2. Periodo 2: 1998-2008; que coincide con el boom económico previo a la crisis de 2008 , en que la iniciativa privada aprovecha el nuevo marco de accesibilidad regional para la consolidación del Arco Logístico del sureste metropolitano madrileño; y

3. Periodo 3: 2008-2018; que coincide con la crisis y los años de recuperación, y que supone un periodo de innovación en el sector, ligado a las nuevas tecnologías (internet, comercio electrónico), y progresivo aumento del peso específico del llamado B2C (business to consumer) frente al tradicional B2B (business to business), progresivo incremento de la distribución domiciliaria al comprador final frente

financiación FEDER a través del Programa INTERREG IIC y, Expansión Urbana de las metrópolis del Sudoeste Europeo (EURMET), FEDER- INTERREG IIB. 
al reparto tradicional a tiendas, y que está modificando las demandas de localización del sector.

Esta evolución en el tiempo, que abarca las tres últimas décadas, incluye una comparativa de las distancias entre las implantaciones logísticas a las centralidades urbanas y el crecimiento paulatino del volumen de almacenaje (a lo ancho y a lo alto ${ }^{12}$ ), que junto con los flujos direccionales que de ello se derivan, y que son aquí analizados, conforman el ya bautizado sistema del "Arco Logístico" de la Región Metropolitana de Madrid.

\subsection{Periodo 1. Hasta 1998}

Inicialmente se han identificado los polígonos industriales de los años '80 de los municipios de Coslada, San Fernando de Henares y el distrito madrileño de Villa de Vallecas, en el Este urbano metropolitano, en los que precisamente se instalaron inicialmente (hace unos 30 años) las primeras empresas de la distribución y el transporte de mercancías pioneras y antecedentes de concepto de la logística actual y su derivada espacial sobre el territorio para el Periodo 1 (hasta 1998).

De forma paralela a esta implantación en el Este metropolitano se inició también en los años '80 una incipiente centralidad logística del Sur, con el centro de transporte de la empresa El Corte Inglés en Valdemoro ( $2^{a}$ corona metropolitana), que junto con el gran centro público de distribución alimentaria Mercamadrid ('80-'90) destacaron, principalmente, por su tamaño, inusual para aquellos años debido a su carácter de Centros de Transporte integrado, integrando servicios complementarios al mero almacenamiento, fraccionamiento y distribución. Posteriormente (primeros años '90), y también en el sur, comenzaron a instalarse superficies logísticas de volumen medio (entre 12-20.000 $\mathrm{m}^{2}$ de techo), entre las que destacan el Centro Logístico de Abastecimiento en Arroyo Culebro (PP1 del PAU Arroyo Culebro, Getafe) en la $1^{\text {a }}$ corona metropolitana y el Polígono Industrial La Postura (Valdemoro) ya en la $2^{\mathrm{a}}$ corona, de iniciativa pública el primero, privada el segundo.

En el corredor Este destacan, en este periodo inicial y situados justo entre la $2^{\mathrm{a}}$ y $3^{\mathrm{a}}$ coronas, el Polígono Industrial La Barca-Los Picones (Alovera) y el ZAL de Miralcampo (Azuqueca de Henares), ambos en la provincia de Guadalajara y de tamaño

\footnotetext{
12 Paulatinamente en el tiempo se ha ido demandando más anchura y altura de nave de almacenaje en concordancia con las nuevas tecnologías de extinción de incendios y cambios
}

grande (mayores de 20 mil $\mathrm{m}^{2}$ ). En la provincia de Madrid, y en el corredor de la A-2, no se promueven polígonos logísticos de relevancia -salvo los indicados anteriormente para la zona cercana a la capital-, ausencia de producción de suelo que quizás explica la más rápida colonización durante estos años de la provincia limítrofe por el flanco oriental, ofreciendo Guadalajara más facilidades en la gestión del suelo y atractivos fiscales a las implantaciones empresariales.

Sin embargo es en recientes ampliaciones de estos polígonos industriales pioneros y cercanos a la ciudad de Madrid (Coslada, San Fernando de Henares, Vallecas Villa) - debido a su perfecta situación respecto de la gran ciudad y la Red Viaria Arterial-, y en la renovación puntual y modernización de algunas zonas interiores a ellos, donde se han situado las principales compañías de paquetería y reparto exprés de la logística del negocio B2C (business to consumer) o e-commerce en el siglo XXI: Vallecas (Seur, Correos Express); Coslada polígonos CITI y ZAL (MRW, El Corte Inglés, Azcar-Dascher, Logipoint, TDN, Correos Express, Seur, Rhenus, Nacex, Sending, Envialia, DHL, etc.); Segunda Fase de Mercamadrid (Tudespensa.com, etc.).

Estas ubicaciones, junto con el nuevo Parque Industrial Puerta de Madrid en San Fernando de Henares (Amazon, Tipsa, TNT), con un tipo de logística que requiere inmediatez en la entrega y, por lo tanto, necesitan de una ubicación cercana al consumidor final -proximidad al continuo urbano de la gran ciudad-, se engloban dentro de lo que podríamos denominar como el nuevo "Arco Logístico Last Mile" de Madrid: un área representada por dos polos Este y Sur, conectados de forma circular por las autovías $\mathrm{M}-40$ y $\mathrm{M}-45$ y a 15 minutos aproximadamente en sentido radial del centro de la ciudad. Este Arco se está especializando en plataformas de este tipo de canal de distribución y representan lo que parece ser la demanda futura en relación con la centralidad logística del comercio electrónico en el área más próxima a Madrid.

Esta nueva centralidad del Este se ve reforzada, además, por la Zona Aeroportuaria de Barajas, en la que también existe un parque logístico especializado en los envíos exprés internacionales (Fedex, UPS, etc.) como gran hub internacional que completa este espacio logístico que podemos caracterizar como prime (FIG. 2). 

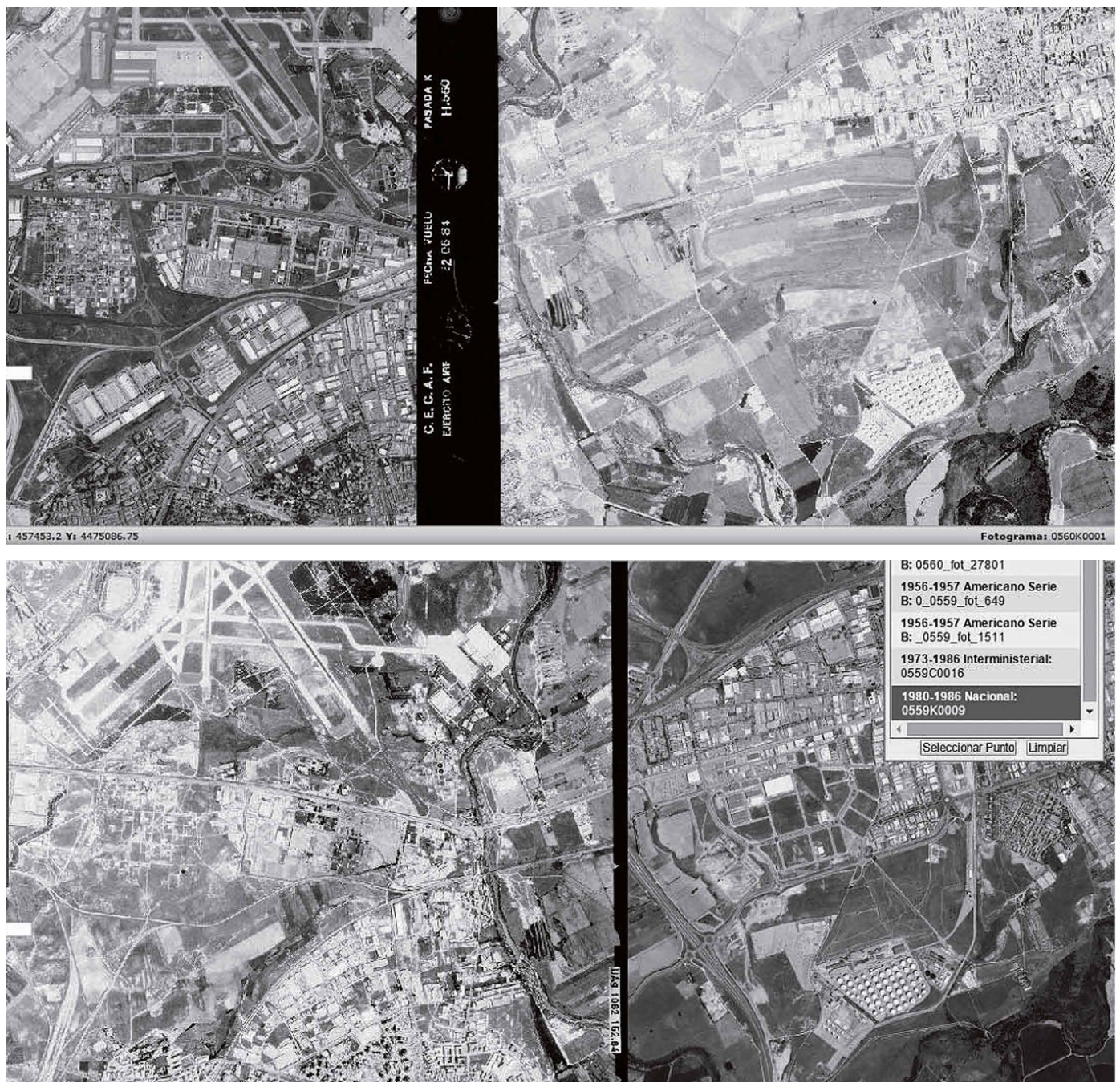

FIG. 2/ Fotomontaje: evolución (años 80`a la actualidad) de la centralidad logística del Este de Madrid, formada por el hub Aeropuerto Barajas y los municipios de Coslada y San Fernando, en el corredor A-2.

Fuente: Fototeca (IGN).

\subsection{Periodo 2. 1998-2008}

La génesis de desarrollos logísticos en el periodo intermedio, que va desde 1998 a 2008, sin duda la etapa más prolífica en cuanto a la expansión del sistema logístico madrileño, se traduce principalmente en la aparición de nuevas implantaciones en otros corredores viarios radiales, como el de la A-1 (Polígonos Norte y Sur del municipio madrileño de San Agustín de Guadalix), la A-3 (manzana logística de Rivas Futura, Polígono industrial de Mejorada del Campo y Polígono Miralrío en Velilla de San Antonio), y la A-5 (Plataformas de DIA en Arroyomolinos y Logista en Leganés), todos ellos en la provincia de Madrid y en la $2^{\mathrm{a}}$ corona metropolitana.
En el corredor de la A-2 surgen las siguientes nuevas implantaciones para este periodo intermedio: en la provincia de Madrid, destacar en Coslada la zona del CITI -Centro Internacional de Transporte Intermodal- y el PAL ( $2^{a}$ fase), en San Fernando de Henares el Polígono Puerta de Madrid ( $1^{a}$ fase), en Alcalá de Henares el Polígono La Garena $\left(2^{a}\right.$ fase), todos ellos en la $1^{\mathrm{a}}$ corona; en la $2^{\mathrm{a}}$ corona tenemos en Meco el Polígono I, de la empresa pública regional Arpegio (DASCHER, ZARA, etc.), en Azuqueca de Henares -ya en la provincia de Guadalajara- $2^{a}$ Fase de ZAL Miralcampo; y, ya en la $3^{\mathrm{a}}$ corona, en Alovera el Polígono I-3 e Industrial Ródano, en Cabanillas el Polígono R-2 y SI-21, en Torija, y a 70 km de Madrid, el Polígono I. S-5/6/8 (Leroy Merlin, Bridgestone y Primark), en Fontanar 
el Polígono industrial S-11 (C\&A) y en Yunquera de Henares el Polígono industrial Mohedano. Estos tres últimos municipios están en la cola del Corredor del Henares en su doble bifurcación viaria (A-2 y CM-101) y constituyen, de hecho, el límite efectivo del área de estudio por el este. Las grandes marcas internacionales se ubican aquí tanto por aspectos de oportunidad y eficiencia espacial como principalmente por una gran actividad promotora del grupo Gran Europa (GE), que ofrece soluciones de óptima ubicación en relación con los canales de distribución a escala nacional y oferta de un suelo competitivo en precio para el gran volumen que demandan.

En el otro gran eje logístico de Madrid, el corredor de la A-4 (Sur), se desarrollan en este periodo intermedio las segundas fases de Mercamadrid y Los Olivos, y el CLA-Área Empresarial Andalucía en el Arroyo Culebro, ambos en Getafe; en la $2^{\mathrm{a}}$ corona, en Pinto El Cascajal y La Atalaya, en Valdemoro la ampliación del CAD de El Corte Inglés, Polígono La Albresa, Polígono Las Canteras y Polígono El Quiñón (DHL); y, en la $3^{\mathrm{a}}$ corona, el Polígono La Carrasquilla en Ciempozuelos y en Aranjuez la plataforma de la empresa Cortefiel; ya en la provincia de Toledo, los Polígonos San Isidro, Ntra. Sra. del Rosario y Cuesta de la Reina en Seseña, y en Ontígola el Polígono Los Albardiales; en la zona de La Sagra, en Toledo, conectada con la A-4 aunque no directamente sobre la misma, destaca el Polígono industrial de Esquivias (operador logístico XPO). Se repite aquí la dinámica de implantación del corredor A-2 para la $3^{\mathrm{a}}$ corona, pero con un volumen significativamente inferior en la implantación de compañías internacionales respecto a aquel.

Como resumen de la dinámica de implantación para este periodo intermedio tenemos que los nuevos desarrollos e implantaciones se concentran en zonas progresivamente más alejadas de la capital con un tipo de promociones que desarrollan polígonos mucho más especializados en el gran tamaño de las parcelas -óptimas para la demanda logística nacional-y de dimensiones más acordes con la funcionalidad actual que demandan las plataformas en cuanto a la movilidad y operatividad.

\subsection{Periodo 3. 2008-2018}

En cuanto a las actuaciones que se han desarrollado más recientemente, y correspondientes ya a este tercer periodo, destacamos las siguientes en el corredor A-2: en la provincia de Madrid ( $1^{\text {a }}$ y $2^{a}$ coronas) en San Fernando de Henares el Polígono Puerta de Madrid ( $2^{\mathrm{a}}$ fase) -conocido por estar implantada la primera gran plataforma de Amazon en Madrid, Tipsa, ThyssenKrupp-, en
Torrejón de Ardoz el Polígono Casablanca I y II -plataformas de H\&M, Carrefour, SDF-, en Alcalá de Henares el Polígono Los Salobrales, M-100Aster y Polígono El Encín (aún en desarrollo de producción de suelo), y en Meco la ampliación de Inditex y el Polígono Mecosur -plataforma de Leroy Merlín e-commerce-; en la provincia de Guadalajara ( $3^{\mathrm{a}}$ corona), están en Cabanillas del Campo el SI-20 -segunda plataforma de Inditex después de la existente en Meco-y SI-21, y, por último, en Guadalajara capital , y conjuntamente con la contigua localidad de Marchamalo, La Ciudad del Transporte -con la tercera plataforma de Inditex-y, en Torija (S-3/7/9), polígonos actualmente con suelo urbanizado y con edificación en desarrollo.

En el corredor A-4 se han desarrollado: en la provincia de Madrid ( $1^{\mathrm{a}}$ y $2^{\mathrm{a}}$ coronas), en Getafe, Los Gavilanes M-50 -la segunda plataforma de Amazon, Coca-Cola, Decathlon-y en Pinto El Cascajal, sólo con algunas edificaciones; $y$, en la provincia de Toledo ( $3^{\mathrm{a}}$ corona), en Seseña el Polígono Pontón y en Illescas la plataforma Central Iberum (que, aunque vinculada a la infraestructura de la A-42, vía de menor incidencia logística, se considera dependiente del corredor A-4 a efectos funcionales) a tan sólo $32 \mathrm{Km}$ de Madrid ciudad -con la tercera plataforma de Amazon, Michelín, Toyota, Airbus-

En este periodo gana cierta presencia el corredor intermedio de la A-3 donde se ubican El Cañaveral en Madrid ( $1^{\text {a }}$ corona), en desarrollo de suelo en 2019, y en Tarancón (Cuenca) el Polígono industrial Senda de los Pastores (promovido por Prologis) más allá de la $3^{\mathrm{a}}$ corona (a $70 \mathrm{Km}$ de la capital) y con algunas edificaciones en uso en la actualidad, como por ejemplo la plataforma de Cortefiel, dada su competitividad en cuanto al precio de los alquileres por el menor precio del suelo y la mayor distancia a Madrid.

\subsection{Metodología}

La metodología se centra en definir tanto el área territorial de influencia de los asentamientos como las características de superficie, grado de ocupación y especialización de cada polígono de las implantaciones logísticas existentes en dicha área de cara a una comparativa interna. Estos datos obtenidos previamente en el rastreo son trasladados a unidades estimadas de capacidad de volumen de almacenamiento según se detalla a continuación y partiendo de los valores asignados en la FIG. 3. La metodología propuesta no desvirtúa por lo tanto la comparativa de casos desde el punto de vista global y pretende ser más fiel a la realidad en sus resultados. 


\begin{tabular}{|c|c|c|c|c|c|}
\hline VALORES & 1 & 2 & 3 & 4 & 5 \\
\hline PERIODO (tres décadas analizadas) & $<1998$ & $1998-2008$ & $2008-2018$ & & \\
\hline CARRETERA (corredor logístico) & $A-1$ & A-2 & A-3 & A-4 & $A-5$ \\
\hline CORONA (según distancia a centralidad) & $1^{\mathrm{a}}$ & $2^{\mathrm{a}}$ & $3^{a}$ & $>$ & \\
\hline SUPERFICIE ${ }^{13}$ (bruta del sector o polígono) & $<0,3 \mathrm{Mm}^{2}$ & $0,3-0,6 \mathrm{Mm}^{2}$ & $0,6-1 \mathrm{Mm}^{2}$ & $1-1,5 \mathrm{Mm}^{2}$ & $>1,5 \mathrm{Mm}^{2}$ \\
\hline COEFICIENTE (media especializ.-ocupac.) & $<20 \%$ & $20 \%-40 \%$ & $40 \%-60 \%$ & $60 \%-80 \%$ & $80 \%-100 \%$ \\
\hline
\end{tabular}

Valores de homogeneización para la obtención de indicadores.

Fuente: elaboración propia ${ }^{14}$, ver metodología.

En el trabajo de campo y en el análisis documental en el área de estudio no se han tenido en cuenta otras variables, tales como el empleo o la mano de obra disponible, políticas fiscales, etc., que no hayan sido las meramente físicas o espaciales.

Del factor de superficie de las implantaciones, que nos permite comparar el tamaño de cada polígono y el volumen de almacenaje existente, se obtiene el valor de la superficie homogeneizada para cada implantación, resultado de multiplicar el valor de la superficie bruta del sector por un coeficiente de homogeneización que, a su vez, se obtiene en base al grado de especialización logística del polígono y el nivel de ocupación del mismo según los valores de la Tabla 1 y atendiendo a la siguiente fórmula:

\section{Sup. Bruta (1 al 5) x Coef. Especialización/ Ocupación (1 al 5) = Indicador Sup. Homogeizada $\left(\mathrm{m}^{2}\right)$}

La operación que da lugar al volumen de almacenamiento unitario de cada implantación consiste en convertir la unidad de superficie homogeneizada de la fórmula anterior, obtenida en $\mathrm{m}^{2}$, en la de volumen de almacenaje, en $\mathrm{m}^{3}$, empleando, para ello, unos coeficientes de conversión en función de los aprovechamientos edificatorios medios $u$

\footnotetext{
${ }^{13}$ Los valores de superficie y coeficiente de homogeneización asignados a cada caso y multiplicados entre si dan lugar al valor o indicador perseguido y unidad del estudio a comparar en función de su superficie bruta homogeneizada y, por lo tanto, a los resultados de los indicadores globales y los parciales segmentados por categorías según periodos, municipios, radiales y coronas, ya sea en valores absolutos o porcentajes correlativos. 14 Todos los datos de tablas y figuras de elaboración propia, así como datos de localización en mapas, se basan, de acuerdo con la metodología, en la revisión de los planeamientos,
}

ocupación de las parcelas, así como la altura media de las edificaciones o naves logísticas, que han sido obtenidos en función de los polígonos analizados, en base a las consultas realizadas y a los proyectos ejecutados en los años de experiencia, y que se traduce según la siguiente fórmula:

Indicador sup. Homogeneizada x 0,615 x 10 m (altura edific.) $=$ Indicador Vol.

Almacenamiento $\left(\mathrm{m}^{3}\right)$

En cuanto a los resultados del indicador del volumen de almacenamiento, que es necesario para comparar con otros estudios coetáneos en el ámbito internacional, se tiende a un modelo óptimo de capacidad, por lo que el resultado total se entiende como un máximo de almacenamiento obtenido para los modelos estándares de implantaciones tipo existentes y sin estimación de ratio vacante que, por cierto, es muy bajo en el caso de Madrid según algunos estudios recientes sobre el sector.

\subsection{Implantaciones en el ámbito temporal: resultados generales}

De todo lo anterior podemos deducir que entre los orígenes del espacio logístico madrileño y la

\footnotetext{
los datos de las Comunidades Autónomas y la comprobación y medición, en su caso, por parte de los autores.

${ }^{15}$ La ocupación del polígono (superficie bruta) depende de la consolidación y la especialización del grado de actividades logísticas implantadas en él yendo del valor del 1 al 5 según \% estimado en el trabajo de campo. Por otra parte, el factor de aprovechamiento del suelo neto u ocupación de la parcela concreta donde se edifica la nave logística se establece en $0,6 \mathrm{~m}^{2} \mathrm{c} . / \mathrm{m}^{2} \mathrm{~s}$. que es el óptimo para esta tipología.
} 


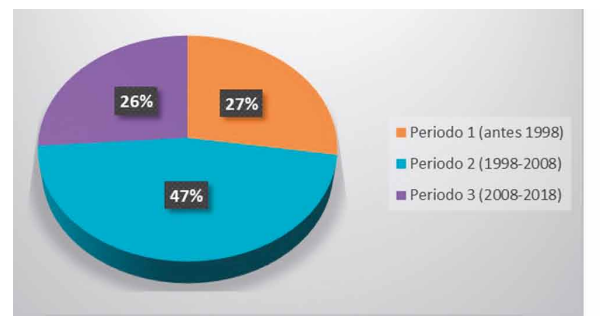

\begin{tabular}{|c|c|c|}
\hline Porcentaje (\%) & Superficie (Mm2s) & Volumen (Mm3) \\
\hline $27,40 \%$ Periodo 1 (antes 1998 ) & 17,719 & 50,636 \\
\hline 46,44\% Periodo 2 (1998-2008) & 19,156 & 85,818 \\
\hline $26,16 \%$ Periodo 3 (2008-2018) & 15,325 & 48,334 \\
\hline $100,00 \%$ TOTAL PERIODOS & 52,200 & 184,788 \\
\hline
\end{tabular}

FIG. 4/ Gráfico de distribución porcentual del volumen de almacenamiento logístico en la Mega-región de Madrid por periodos analizados.

Fuente: Elaboración propia, ver nota 14.

situación actual, que está claramente centralizada en torno al corredor A-2 y el hub aeroportuario, ha existido una tradicional y homogénea implantación logística principalmente ubicada en el entorno del espacio fronterizo existente entre las regiones de Madrid y Castilla-La Mancha (Provincias de Guadalajara y Toledo inicialmente) entre la $2^{a}$ y $3^{a}$ coronas y en las zonas de máxima accesibilidad de los corredores de la A-2 y A-4.

En solo una década, durante el Periodo 2 de análisis (1998-2008), se desarrolló casi tanta superficie logística como en el resto de los periodos 1 y 3 . Si nos fijamos en el gráfico de distribución porcentual del volumen de almacenamiento logístico en la Mega-región urbana de Madrid (ver FIG. 4), se observa que en la distribución de la implantación logística en los tres periodos establecidos en el estudio subyacen cuestiones relevantes tales como el grado de especialización (intensidad de actividades logísticas en un mismo polígono o sector) y el nivel de ocupación (derivado en parte por la "virulencia" inmobiliaria del periodo previo a la crisis económica de 2008), que van a servir de base para el análisis y tratamiento estratificado de los datos $^{16}$. Un ejemplo de ello es que la diferencia de superficie de suelo desarrollado entre los periodos analizados es sensiblemente menor a la diferencia que realmente existe en el volumen, que es la magnitud real de la capacidad de almacenaje existente.

Si trasladamos los resultados del estudio a la realidad espacial obtenemos una morfología urbana o conurbación de naturaleza direccional Este-Sur, con una implantación logística apoyada principalmente en los dos corredores infraestructurales A-2 y A-4 de la Red Arterial, que acaban conformando un Arco Logístico tan rotundo que adjetiva el espacio logístico madrileño (FIG. 5).

\footnotetext{
${ }^{16}$ En adelante, a no ser que se especifique lo contrario, la
} unidad representada en los gráficos es el $\mathrm{m}^{2}$ homogeneizado
La distribución porcentual de las implantaciones en cada uno de los corredores con, al menos, alguna presencia, arroja unos resultados muy expresivos de la rotundidad espacial del plano anterior, que prioriza el arco direccional A-2 y A-4 (FIG. 6).

En la bibliografía especializada se empieza a acuñar la expresión Arco Logístico A-2 / A-4 ( DE SANTIAGO, 2007), y en un estudio específico del profesor López de Lucio (2014), excesivamente sintético pero expresivo de la casuística, se observan claramente identificadas las centralidades anteriormente detalladas del Este y el Sur más contiguas a la ciudad de Madrid, que consolidan el epicentro del Arco que crece direccionado por el peso relativo de los corredores A-2 y A-4 hacia los asentamientos de la $2^{a}$ y $3^{a}$ coronas metropolitanas en sus extremos.

Esta realidad espacial viene potenciada en gran medida por el prolífico escenario global de desarrollismo económico ocurrido hace una década, enmarcado de forma particular en una regulación urbanística excesivamente local, por un lado, y que ha derivado en un problema de orden geopolítico y escala suprarregional por otro. Este modelo de gobernanza a diferentes escalas de poder entre las diferentes administraciones y sus relaciones intergubernamentales ha alimentado en gran medida ciertas "tensiones especulativas entre las actividades productivas y las residenciales o recreativas" (DAVEZIES, 2008) en el ámbito de las mega-regiones. Es por ello que el patrón espacial está íntimamente ligado al modelo de gobernanza y, más concretamente, a las políticas urbanísticas y territoriales, con una localización en ocasiones excesivamente ex-urbana de estas plataformas de distribución.

en base a superficie, ocupación e intensidad / especialización, y que representa la capacidad de almacenamiento. 


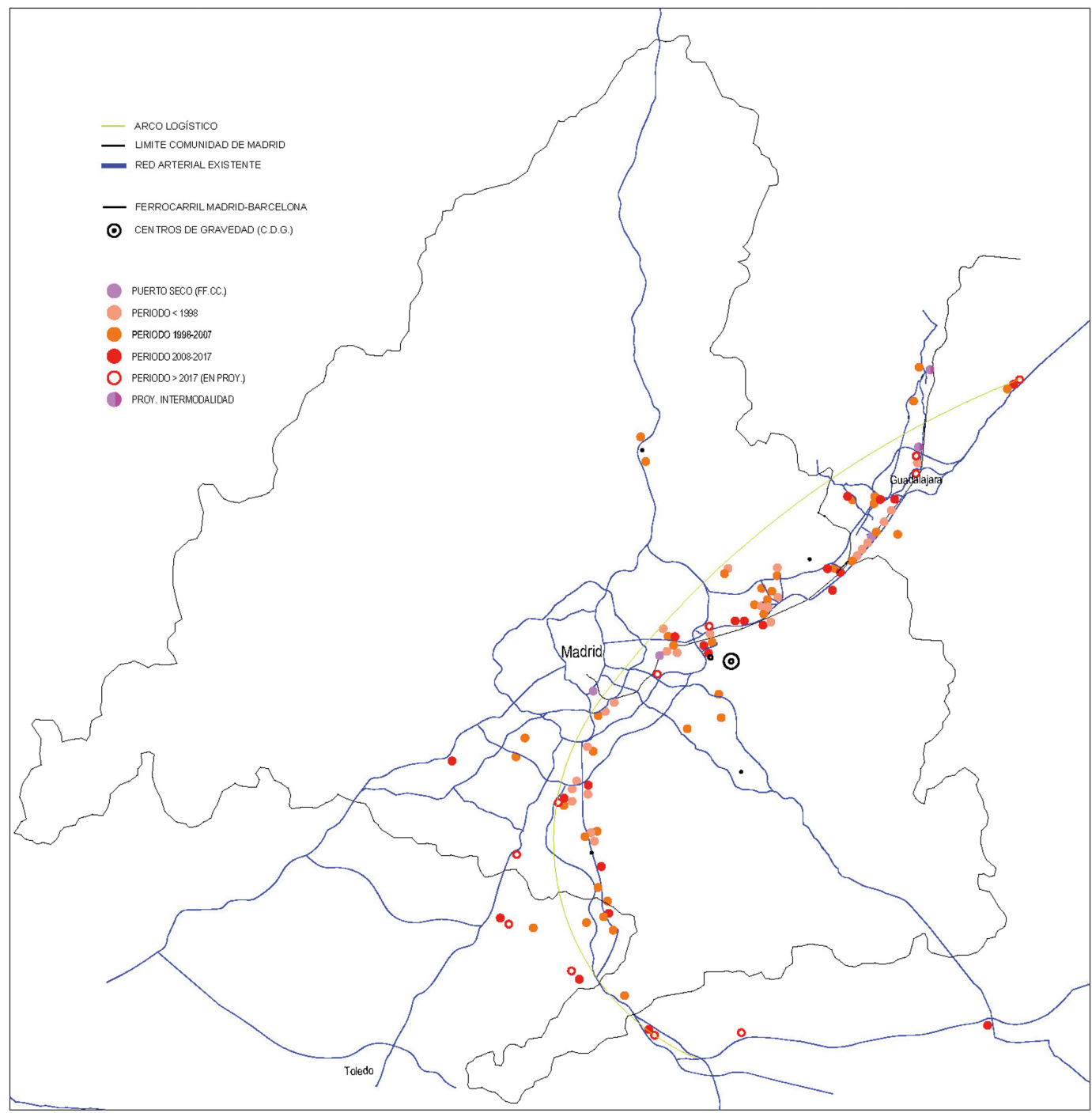

FiG. 5/ Total de implantaciones en el Arco Logístico de Madrid diferenciadas por periodos (puntos de colores marrón, naranja y rojo para hasta 1998, 1998-2008 y 2008-2018 respectivamente).

Fuente: elaboración propia, ver nota 14.

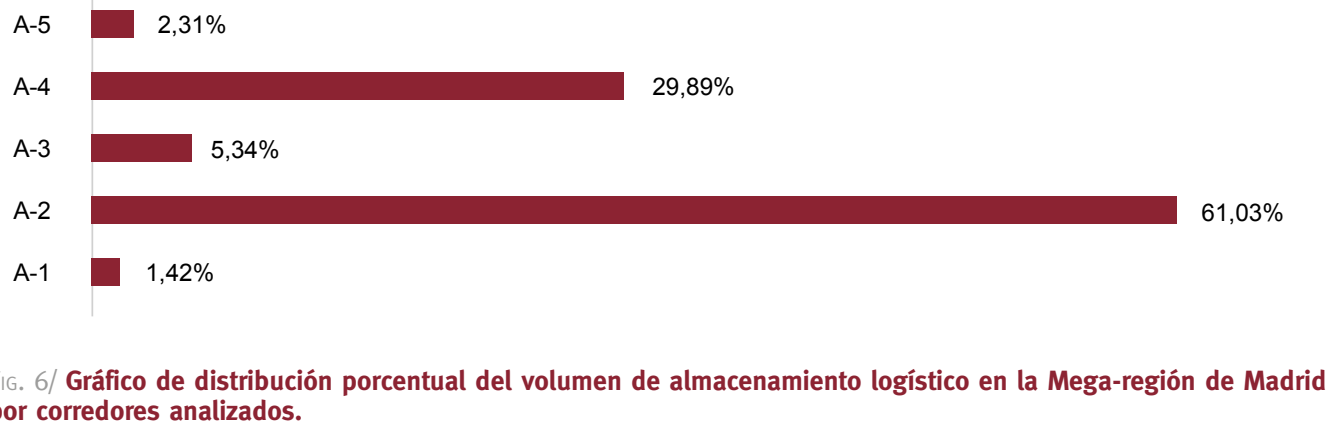
por corredores analizados.

Fuente: elaboración propia. 
Consecuencia de todo lo anterior, estamos en disposición de formular la hipótesis de que disponemos en la actualidad de un escenario espacial logístico en la Mega-región Urbana de Madrid -y en otras mega-regiones fuera de nuestras fronteras- altamente disperso o en sprawl logístico, dibujando asentamientos cada vez más alejados de los centros urbanos tradicionales.

Este modelo de ocupación del suelo (productivo) está altamente implantado tanto aquí como en otras áreas de todo el mundo, y ha evolucionado en las últimas décadas únicamente teniendo como referencia la escala global -sin tener necesariamente en cuenta la influencia que sobre lo global pudieran tener las connotaciones locales y regionales de su territorio-, y ha definido dinámicas de posicionamiento de dichas actividades logísticas sobre los "territorios servidos" (servant territories) (RAIMBAUlt, 2014), generando así unos espacios urbanos altamente fragmentados y jerarquizados en función de la presión del mercado inmobiliario, en lugar de establecerse en función del lógico ordenamiento urbano y de un equilibrado planeamiento territorial. Es ésta una cuestión de vital relevancia, a abordar en futuras investigaciones, sin entrar en aspectos como la diferenciación social por rentas municipales en relación con las ubicaciones elegidas por la logística.

\section{Evolución del sprawl logístico. Resultados de la escala regional: Baricentros (C.D.G.), volúmenes y distancias respecto de las implantaciones logísticas en el área de estudio}

Partimos en este punto analizando primero los datos de superficies y volúmenes de implantación en relación con el posicionamiento de las provincias y regiones-comunidades involucradas para ver qué grado de actividad logística alcanzan en función de los resultados, interpretados desde el punto de vista de la escala regional y realizando una lectura de ellos en clave de distancias e intensidades geográficas, y comparando en paralelo los datos obtenidos con los mostrados en otros estudios similares.

La logística, como hemos visto en el punto anterior, se configura más allá de la Región de Madrid traspasando sus límites administrativos con una clara tendencia a la expansión año tras año. En el área de $2.057,71 \mathrm{Km}^{2}$, que suman los $34 \mathrm{mu}$ nicipios analizados (por comparación, según el estudio de Gifford, 2011, para las Mega-regiones de Piedmont y Cascadia, el número de municipios implicados es de 78 y 14 , respectivamente, lo que podría plantear una hipótesis añadida sobre el papel del mapa administrativo, que aquí esbozamos para Madrid) repartidos en cuatro provincias (Madrid, Guadalajara y Toledo, por orden de incidencia, más Cuenca que cuenta con una única implantación en Tarancón sin apenas un peso significativo) y dos comunidades autónomas (Madrid y Castilla-La Mancha). El peso porcentual de la logística en cada una de las provincias, según periodos, se distribuye tal y como se representa en los gráficos (ver FIG. 7).

Atendiendo al gráfico anterior se demuestra, en base a los porcentajes totales a 2018 por provincias en él representados, que la logística desborda la propia Comunidad de Madrid. Aunque esta Comunidad uniprovincial mantenga el $62,10 \%$ del volumen, Castilla-La Mancha representa un total de $37,90 \%$, en la que el reparto entre sus tres provincias es de: Guadalajara el $27,60 \%$, Toledo un $9,25 \%$ y Cuenca tan solo un $1,05 \%$.

Si se atiende a los parciales por periodos resultan aún más expresivos de la evolución del sprawl: Madrid baja 9 puntos entre 1998 y 2018; Guadalajara es más regular con aproximadamente 29 y 28 puntos entre 1998 y 2018; y, Toledo, que no tenía peso específico en el Periodo 1 (hasta
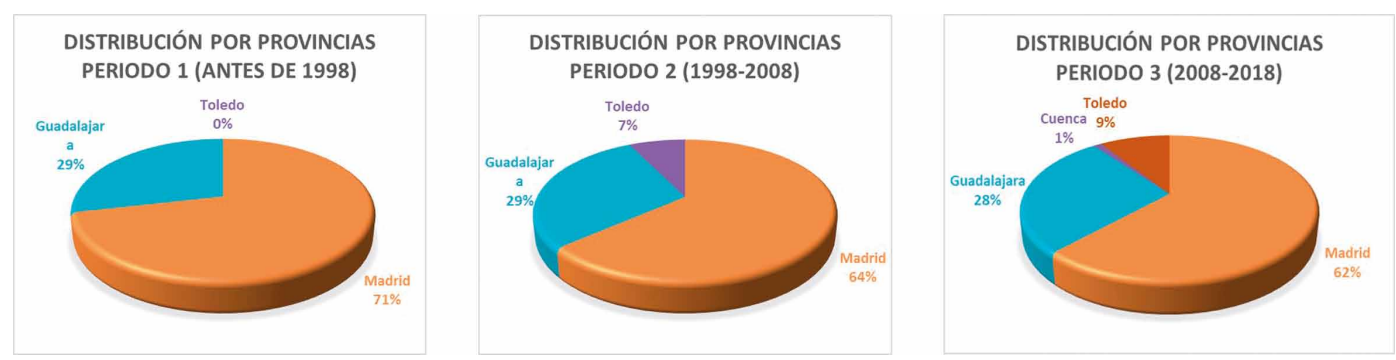

FIG. 7/ Gráficos de distribución porcentual del volumen de almacenamiento logístico en la Mega-región de Madrid por provincias y por los tres periodos analizados (los porcentajes se representan sin decimales). 
1998), como se observa en el gráfico, en cambio, es la única provincia que manifiesta una clara subida en el Periodo 2 (y ratificada en el Periodo 3) en detrimento de las provincias de Madrid y Guadalajara.

En relación con lo indicado anteriormente las conclusiones a estos datos son:

a. La provincia de Madrid baja en tanto por ciento de volumen de implantaciones logísticas año tras año;

b. Guadalajara se mantiene prácticamente igual, con una ligera bajada en el Periodo 3 en favor de la oportunidad desarrollada por Toledo; $y$,

c. Es Toledo, en particular, la única provincia que no deja de tener un crecimiento sostenido en los dos últimos periodos, en detrimento de Madrid como significativa expresión de un modelo de sprawl más gravitacional, el de los dos últimos periodos, que un modelo más homogéneo ocurrido en el Periodo 1.

Es por esto que para este estudio es clave el análisis baricéntrico de la evolución de las implantaciones por periodos como constatación del sprawl logístico y la colonización de nuevos territorios más allá de la escala regional de Madrid, que la convierten en una incipiente Mega-región urbana.

Hemos llevado a cabo una ligera comparación con otros casos de estudio equivalentes y significativos: citamos aquí el de Atlanta, en la mega-región del Piedmont Atlantic (PAM) de los EE.UU., que parece oportuno puesto que se asemeja en tamaño al caso de Madrid. En el estudio realizado en este y otros casos por L. Dablanc y otros autores (DABLANC \& al. 2012 y 2014) se analiza el mismo fenómeno en función del número de almacenes logísticos por municipio y la distancia media de estos al baricentro, un método dinámico- comparativo que nos permite extraer conclusiones muy interesantes para un mismo espacio temporal.

Con relación a este ejemplo (ver FIG. 8), cabe apuntar además que el sistema urbano de Atlanta tiene semejanzas morfológicas con el de Madrid, tal y como se puede observar en las imágenes, lo que permite establecer ciertos paralelismos a la hora de realizar un análisis comparativo respecto de ciertos datos obtenidos: dispersión creciente de los pesos geográficos y movimiento de sus centralidades o baricentros en el mismo periodo de tiempo.

El método seguido en el análisis de ambos casos de estudio (Madrid y Atlanta) es similar, exceptuando las diferencias de homogeneización utilizada en el caso de Madrid y que permite afinar ligeramente el análisis.

Dentro de las 90 implantaciones logísticas analizadas en el caso de Madrid, partimos de una superficie media de cada una de $0,6 \mathrm{Mm}^{2}$, en un total aproximado de $52 \mathrm{Mm}^{2}$ de suelo existente para este tipo de implantaciones en toda la megaregión Urbana de Madrid.

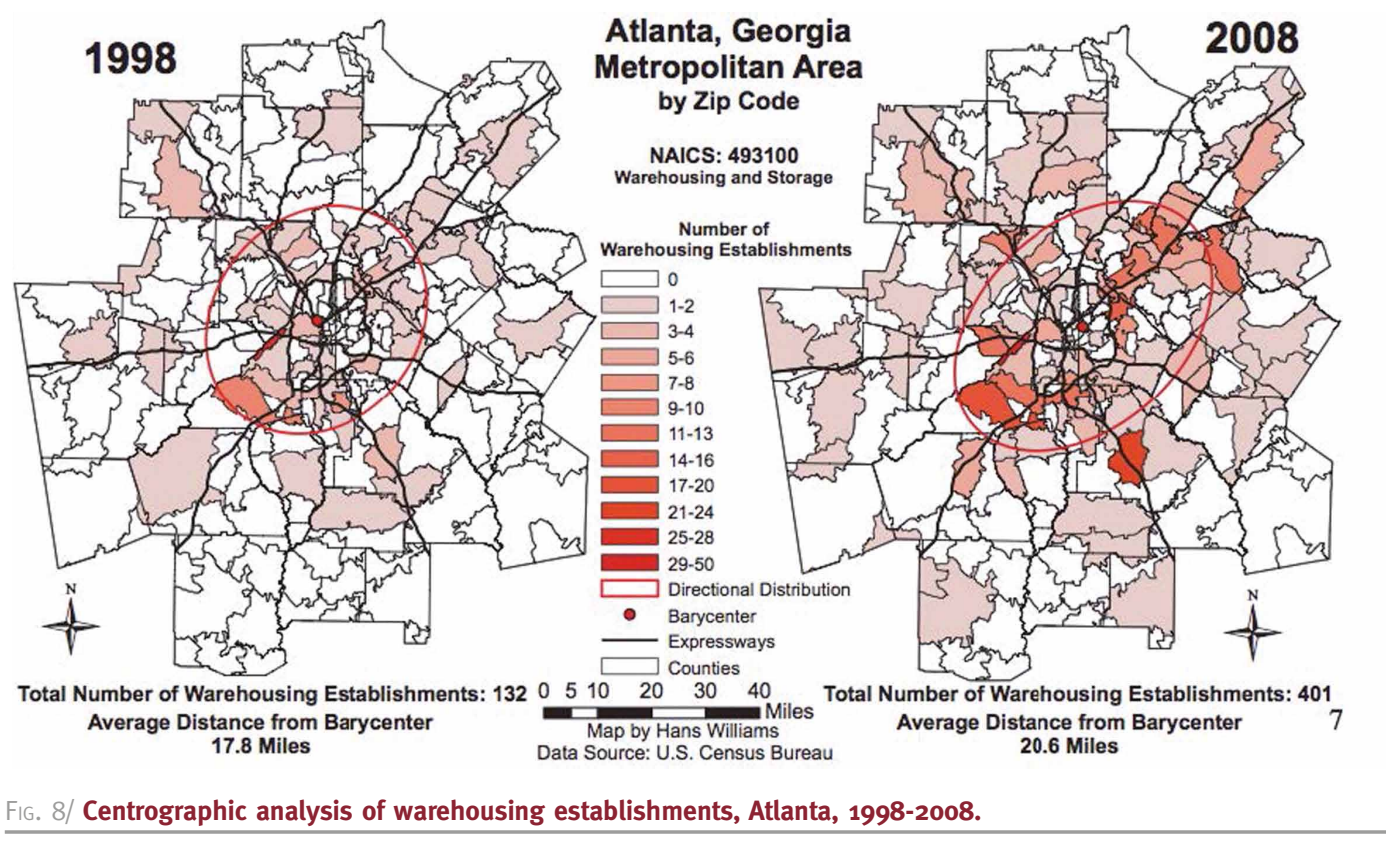

Fuente: DabLANC \& al (2012). 
En cuanto a los resultados parciales de las superficies medias estratificados por periodos, coronas y corredores son los que se comparan a continuación:

a. En cuanto a la superficie media de las aglomeraciones logísticas comparadas por periodo se obtiene que, para el Periodo 1 (hasta 1998), la superficie media es de 0,74 $\mathrm{Mm}^{2}$; para el Periodo 2 (1998-2008), de 0,45 $\mathrm{Mm}^{2}$; y, en el Periodo 3 (2008-2018), de $0,61 \mathrm{Mm}^{2}$.

a) Los datos de la superficie media comparadas por corona arrojan que en la $1^{a}$ corona existe una superficie media de $0,70 \mathrm{Mm}^{2}$; en la $2^{\mathrm{a}}$ corona de $0,52 \mathrm{Mm}^{2}$; $\mathrm{y}$, en la $3^{\mathrm{a}}$ corona de $0,58 \mathrm{Mm}^{2}$

b) $Y$ comparadas por corredor resultan respecto de los dos corredores principales, que en laA-2, la superficie media es de $0,59 \mathrm{Mm}^{2} ; \mathrm{y}$, en el de la A-4 de $0,57 \mathrm{Mm}^{2}$.

A destacar de estos resultados que tanto en el Periodo 2 como en la $2^{\mathrm{a}}$ corona existe un valor de superficie inferior a la media, derivada del ajuste de superficies en función de los precios más elevados.
Otro dato destacable de esta fase del estudio hace referente a la distancia que mide el sprawly que se representa por la variación del baricentro durante los periodos inicial y final de análisis, con una diferencia de 20 años entre ambos puntos si tomamos los años 1998 y 2018, y que resulta una distancia de desplazamiento de $2,9 \mathrm{Km}$ en la dirección Sureste. La FIG. 9 muestra el total de volumen de almacenamiento logístico por municipios en la Mega-región de Madrid en 1998 y 2018 respectivamente. La distancia media de las implantaciones al baricentro (C.D.G.) es de $19,1 \mathrm{Km}$ en el Periodo 1 (hasta 1998) y de 24,6 $\mathrm{Km}$ en el Periodo 3 (2008-2018) (representada esquemáticamente por una elipse en ambos casos), resultando una variación importante de dicha distancia con un fuerte crecimiento entre periodos. Este dato puede compararse con Seattle (Mega-región de Cascadia, EE.UU.), en base al estudio de Dablanc, arrojando resultados muy similares y homologables con los de la presente investigación. Si tenemos en cuenta que, en ambos estudios y para el Periodo 2 (19982008), la distancia de desplazamiento resulta de $4 \mathrm{Km}$ hacia el Noreste en el caso de Madrid y 3,4 $\mathrm{Km}$ hacia el Suroeste para Seattle (DABLANC \& al. 2014), esto demuestra que el sprawl logístico, medido en términos de desplazamiento de dicho baricentro, es una tendencia global, no exclusiva
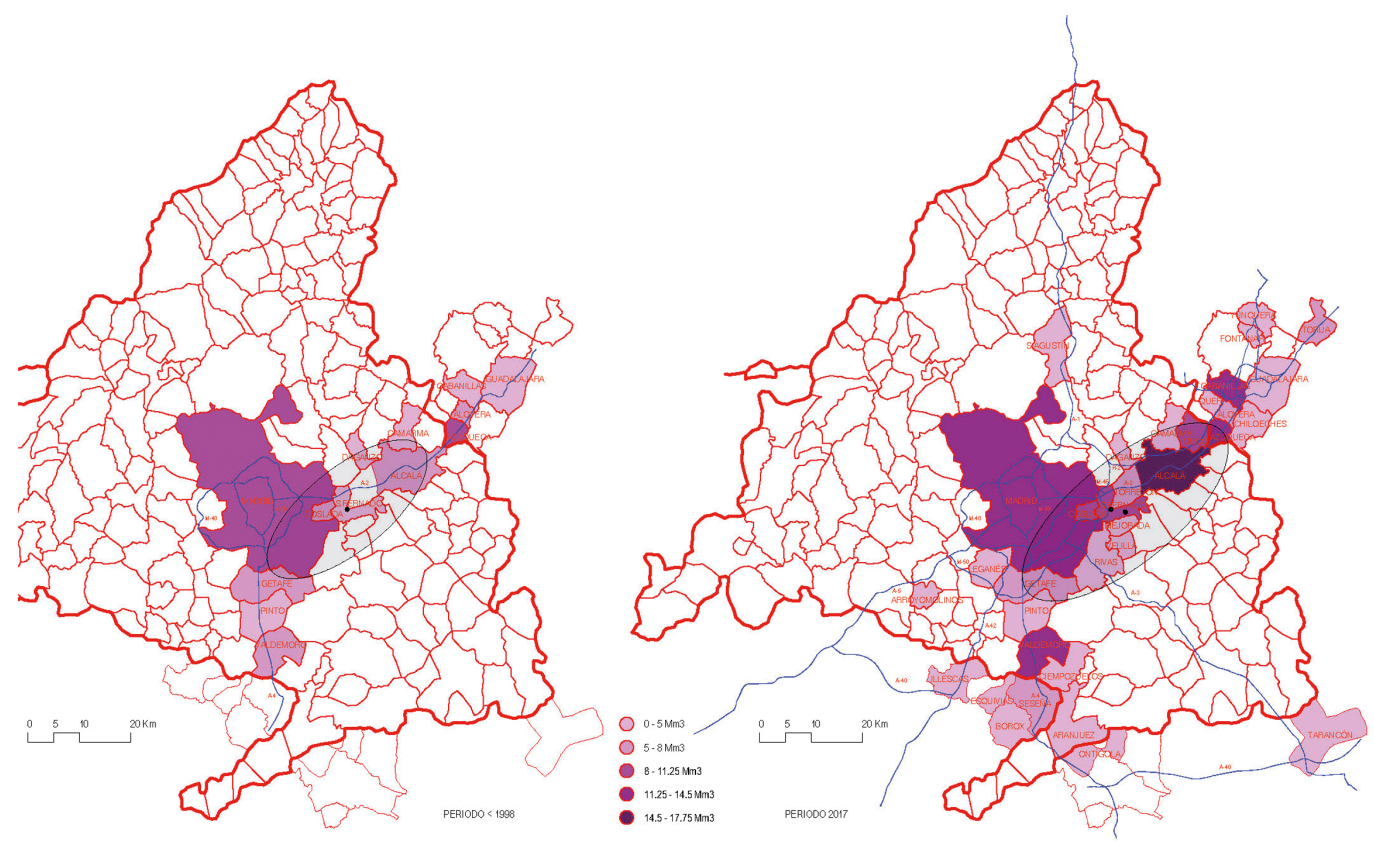

FIG. 9/ Total de volumen de almacenamiento logístico por municipios en la Mega-región de Madrid en 1998 y 2018 respectivamente. Fuente: Elaboración propia, medición de los autores.

Fuente: elaboración propia, medición de los autores. 
de la Mega-región madrileña. En el caso de Madrid ha existido un cambio de dirección en el periodo posterior de crisis económica, con un desplazamiento de este baricentro bastante notable $(7 \mathrm{Km})$ hacia el Sur en lugar del tendente a alejarse en la dirección Este siguiendo al corredor de la A-2.

En relación con el otro ejemplo, la comparativa con Atlanta, ciudad con una similitud formal a la disposición espacial de Madrid, los datos del estudio arrojan la cifra de $2 \mathrm{Km}$ (1,3 millas) hacia el Este (DABLANc \& al., 2012) en el Periodo 2 (19982008). Por lo tanto, estamos hablando de justo la mitad que Madrid en distancia del desplazamiento del baricentro en el mismo periodo, resultando de igual manera el doble de la distancia comparada con Paris $(2 \mathrm{Km})$ para dicho Periodo 2. Sirva como un ejemplo comparable, en este caso duplicando el resultado en relación con Madrid, el de la ciudad de Los Angeles (Mega-región de SouthCalifornia), que arroja una distancia de desplazamiento de baricentros de 9 Km (1998-2008), en este caso hacia el Norte. Todos estos datos han sido extraídos de estudios realizados por L. Dablanc junto a otros autores entre los años 2010-2014.

Quedan consolidadas, desde el punto de vista espacial, ciertas centralidades, como: i. la discontinua formada por Mercamadrid y el hub de la ciudad aeroportuaria, de proximidad a la ciudad de Madrid; ii. la centralidad continua, dentro de la $1^{\text {a }}$ corona, de Coslada-San Fernando-TorrejónAlcalá; y, por último, iii. compartiendo frontera Madrid-Guadalajara, ya en la $2^{\mathrm{a}}$ corona, la también continua de Alcalá-Meco-Azuqueca, estas dos últimas en el Este y formadas por la conurbación urbana conectada con el corredor de la A-2.

Por otro lado, colgada del corredor de la A-4 existe una centralidad aparentemente aislada en el sur con Valdemoro como epicentro, en la $2^{\mathrm{a}}$ corona, y; por último, más alejada que el resto, ya en la $3^{a}$ corona, tenemos el eje Cabanillas-Guadalajara, también en el corredor de la A-2 y dentro de la provincia limítrofe con Madrid a más de $50 \mathrm{Km}$ de distancia a la gran ciudad.

La evolución respecto de 1998 se puede comparar con el estudio también realizado para ese periodo (FIG. 9), tomando como base cartografía del modelo efectivo en 2018. En ella se representan todos los municipios que constituyen hoy el sistema de distribución, pero en este caso sin el relleno correspondiente a la ocupación logística ocurrida durante los 20 años posteriores. Además, se representa únicamente el baricentro de ese periodo inicial y se indica también la distancia media al mismo desde las implantaciones logísticas, que es sensiblemente inferior al del momento actual -existe una diferencia de 5,5 Km entre 1998 y 2018 en dicha distancia media-.

Entre los resultados de las distancias de desplazamiento entre baricentros por periodos ya se han indicado cuáles son los resultados globales, pero cabe destacar que en cuanto a los resultados parciales de los baricentros estratificados por periodos y corredores estos varían de forma mucho más notable que los referidos al global, mostrando la dicotomía existente en la dinámica entre los dos corredores principales en los periodos analizados.

Si tenemos en cuenta otras connotaciones, además de las espaciales, a la hora de relacionar este estudio con otros, como por ejemplo la relación con el incremento de la población por municipios para el mismo periodo (DE SANTIAGO, 2008), podemos encontrar ciertos paralelismos puntuales muy interesantes respecto del incremento de población y crecimiento del volumen logístico que resulta correlativo para algunos de los municipios analizados (Torija, Alovera y Meco, en el este, e Illescas, Seseña, Ontígola, Ciempozuelos y Valdemoro en el sur), que si bien en el estudio de población las dinámicas de crecimiento son expansivas y circulares en torno a la $2^{\mathrm{a}}$ y $3^{\mathrm{a}}$ coronas respecto de la $1^{\mathrm{a}}$, en claro estancamiento de población, en el estudio de la logística la extensión direccional se traduce en forma longitudinal apoyado en los corredores Este y Sur. Por el contrario, si atendemos a la dispersión tanto en el estudio de población como en el de la logística tenemos que esta se produce respecto de la $1^{\text {a }}$ corona hacia zonas más alejadas en ambos casos, obedeciendo por lo tanto a dinámicas similares, lo que se interpreta como un doble sprawl residencial y logístico existente en torno a la Mega-región urbana de Madrid para este periodo concreto de estudio (DE SANTIAGo, 2008).

\section{La escala local. Resultados: variaciones en el ranking logístico por municipios entre periodos}

Averiguar el grado de posicionamiento de las administraciones locales involucradas en el ámbito de estudio con el objetivo de interpretar capacidades y dinámicas municipales a la hora de acometer actuaciones de este tipo es el objetivo por el que principalmente se desarrolla este punto. La experiencia y cultura en la promoción de espacios logísticos y la realidad obtenida parece interesante abordarla desde el punto de vista de un posicionamiento local. 
Se trata de establecer, en un primer plano, un mecanismo que nos permita una lectura de los pesos porcentuales en el marco de la gobernanza y, sobre todo, de su influencia respecto de una escala local, para poder establecer ciertas directrices de actuación a futuro en relación con las potencialidades y las tendencias de cada municipio, así como del reequilibrio del conjunto del "territorio logístico" madrileño.

En un segundo plano está el análisis sobre la evolución de ese posicionamiento local, que obedece también, pero desde el punto de vista físico, a determinar pautas de los pesos logísticos municipales en relación con las centralidades geográficas de la logística en torno a Madrid apuntadas en los apartados anteriores, en relación con los estudios mencionados para otros países, y mucho más cercano a los métodos de análisis empleados para los desplazamientos geográficos que pautan dichas centralidades. Esto permitiría determinar a efectos de toma de decisión política qué tipo de actuaciones convendrían a futuro en relación con el planeamiento a escala territorial, aunque desde el punto de vista de la influencia local dentro del marco interadministrativo.

En un tercer estado se profundiza en las características del tipo medio de implantación para cada término municipal. Estos datos son relevantes tanto a la hora de predecir magnitudes como de comparativa entre municipios.

De los 13 municipios representados, pertenecientes a tres provincias (se indican las iniciales a la que pertenecen entre paréntesis) con incidencia en el peso logístico de la Mega-región urbana de Madrid, ocho pertenecen a Madrid, cuatro a Guadalajara y solamente uno a Toledo, siendo el porcentaje de cada uno de ellos en relación con el total y con su propia provincia el detallado en la Tabla 2 (ver FIG. 10). Estos 13 municipios acaparan prácticamente las tres cuartas partes del porcentaje global del total de los asentamientos logísticos existentes en la Mega-región urbana de Madrid, del total de 34 municipios analizados en todo el ámbito de estudio, por lo que el $27,40 \%$ restante se corresponde con los otros

\begin{tabular}{lcccc}
\hline Término municipal & puesto a $\mathbf{1 9 9 8}$ & puesto a $\mathbf{2 0 1 8}$ & $\begin{array}{c}\% \text { total } \\
\text { periodos }\end{array}$ & $\begin{array}{c}\% \text { total } \\
\text { provincia }\end{array}$ \\
\hline Alcalá de Henares (M) & $6^{\circ}$ & $1^{\circ}$ & $9,61 \%$ & $15,47 \%$ \\
\hline Madrid (M) & $1^{\circ}$ & $2^{\circ}$ & $8,01 \%$ & $12,89 \%$ \\
\hline Cabanillas del Campo (GU) & $10^{\circ}$ & $3^{\circ}$ & $7,65 \%$ & $27,74 \%$ \\
\hline Azuqueca de Henares (GU) & $2^{\circ}$ & $4^{\mathrm{a}}$ & $7,30 \%$ & $26,45 \%$ \\
\hline Valdemoro (M) & $3^{\circ}$ & $5^{\circ}$ & $6,94 \%$ & $11,17 \%$ \\
\hline Coslada (M) & $5^{\mathrm{a}}$ & $6^{\mathrm{a}}$ & $5,34 \%$ & $8,60 \%$ \\
\hline San Fernando de H. (M) & $8^{\circ}$ & $7^{\circ}$ & $5,16 \%$ & $8,31 \%$ \\
\hline Alcalá Meco (M) & - & $8^{\mathrm{a}}$ & $4,80 \%$ & $7,74 \%$ \\
\hline Getafe (M) & $4^{\circ}$ & $9^{\circ}$ & $4,27 \%$ & $6,88 \%$ \\
\hline Seseña (TO) & - & $10^{\circ}$ & $3,91 \%$ & $37,93 \%$ \\
\hline Alovera (GU) & $7^{\circ}$ & $11^{\circ}$ & $3,56 \%$ & $12,90 \%$ \\
\hline Torija (GU) & - & $12^{\circ}$ & $3,20 \%$ & $11,61 \%$ \\
\hline Torrejón de Ardoz (M) & - & $13^{\circ}$ & $2,85 \%$ & $4,58 \%$ \\
\hline TOTALES & & & $72,60 \%$ & \\
\hline
\end{tabular}

FIG. 10/ Tabla del ranking de municipios en distribución porcentual por volumen logístico, respecto del total y subtotal de cada provincia. Se omite el dato del estado intermedio, estando representada sólo situación inicial (1998) y resultante (2018). 
21 municipios no representados en ella por su baja incidencia respecto del conjunto.

En cuanto al porcentaje relativo de cada municipio en relación con cada una de las provincias a las que pertenece -interesante por similitud en cuanto a la legislación urbanística regional y las políticas de suelo locales y provinciales-, cabe destacar la suma de casi 30 puntos que alcanzan entre tan solo dos municipios (Alcalá y Madrid) dentro de esta comunidad autónoma uniprovincial, así como la asombrosa preponderancia del binomio Cabanillas - Azuqueca, en la provincia de Guadalajara, con más de la mitad de todo el peso relativo, ya en la Comunidad de Castilla-La Mancha.

Toledo, la otra provincia de esta Comunidad, con un peso considerablemente menor que Guadalajara, tiene en Seseña, con un 37\%, el ejemplo más destacado de un reparto más gravitacional ocurrido durante el periodo de desarrollismo del eje Sur. Toda la logística se ha concentrado recientemente en esta provincia en torno al corredor de la A-4 (solo existe un caso ubicado en la A-42 que está también conectado directamente con la A-4) y tan solo en unos pocos municipios que son limítrofes con la Comunidad de Madrid. La cercanía a los mercados laboral y de consumo de la gran ciudad tiene aquí su peso específico. Por el contrario, en el eje de la A-2 la consecuencia de localización responde más a criterios de posicionamiento estratégico respecto de la península y Europa.

De un análisis más en detalle, municipio a municipio, obtenemos un ranking en relación al resultado de superficie y especialización (volumen almacenable, en definitiva) en que en primer lugar $\left(1^{\circ}\right)$ está Alcalá de Henares $(\mathbf{M})$ en el corredor A-2, con casi $6 \mathrm{Mm}^{2}$ de superficie ordenada para la logística en 11 polígonos repartidos por su término municipal y un ratio de especialización/ ocupación cercano al $50 \%$, con una superficie media por polígono de $0,54 \mathrm{Mm}^{2}$. Se incluye en su término municipal el C.D.G. del Periodo 1 analizado para el estrato del corredor A-2. Su volumen logístico supone el $9,61 \%$ de total de la Mega-región urbana y el $15,47 \%$ del total de la provincia de Madrid. La variación que ha experimentado desde el Periodo 1 (hasta 1998) hasta la actualidad es de casi el $400 \%$-fuertes incrementos interanuales superiores al $20 \%-$, lo que demuestra tanto la vocación logística como la posición privilegiada respecto del corredor y la gran ciudad, subiendo del $6^{\circ}$ puesto al $1^{\circ}, y$ convirtiéndose en el principal polo de atracción de la logística a escala regional, crecimiento que se ha repartido uniformemente durante los tres periodos analizados.

En segundo lugar $\left(2^{\circ}\right)$ se encuentra Madrid capital (M) como centralidad principal y punto de convergencia de los dos corredores logísticos principales de la A-2 y A-4, con cerca de 4,5 $\mathrm{Mm}^{2}$ de superficie ordenada en 7 polígonos expresamente de uso logístico y repartidos por las inmediaciones de su área urbana central -ubicados principalmente en la periferia sur y sureste del término municipal-y un ratio de especialización/ ocupación de los mismos cercano al $60 \%$, con una superficie media por polígono de $0,63 \mathrm{Mm}^{2}$. Espacialmente incluye las áreas de atracción logística en torno a la ciudad aeroportuaria y a Mercamadrid -principal mercado mayorista de alimentación-, cuyo volumen y consolidación le hicieron ocupar el puesto $1^{\circ}$ durante el Periodo 1 , teniendo un volumen logístico que supone el $8 \%$ de total logístico de la Mega-región urbana y casi el $13 \%$ del total de la provincia de Madrid. La variación que ha experimentado desde el primer periodo (hasta 1998) hasta la actualidad está en torno al $150 \%$-con crecimientos interanuales moderados en los tres periodos en favor de la ocupación espacial de otros usos como los terciarios y residenciales mucho más rentables para la promoción inmobiliaria-. Ha bajado del $1^{\circ}$ al $2^{\circ}$ puesto en favor de Alcalá, convirtiéndose en el espacio más deseable del last mile de la distribución en la logística del ecommerce por la cercanía al consumidor final en un área de gran concentración de población.

Resulta significativo que una la localidad pequeña de extensión y población y alejada de Madrid como es Cabanillas del Campo (GU) ocupe el tercer puesto $\left(3^{\circ}\right)$ por encima de otra localidad más grande y tradicionalmente más potente desde la perspectiva logística como es Azuqueca de Henares (GU), que pasa del puesto segundo al cuarto al $\left(4^{\circ}\right)$. Cabanillas está situada en la $3^{a}$ corona y apenas aparecía como centro logístico en el Periodo 1 (puesto $10^{\circ}$ igualado con Guadalajara capital). Ha conseguido, por lo tanto, alcanzar el pódium en el ranking gracias a los fuertes crecimientos en los dos últimos periodos (Periodos 2 y 3, entre 1998-2008 y 2008-2018) en los que ha crecido hasta los $3,7 \mathrm{Mm}^{2}$ en los cuatro polígonos existentes y tiene una ratio de especialización/ocupación del $70 \%$. El ritmo de crecimiento ha sido del $400 \%$ (igual que Alcalá, pero con menos volumen total), materializado principalmente en el Periodo 3 con $1,5 \mathrm{Mm}^{2}$, un ratio del $80 \%$ de ocupación/especialización y más del $50 \%$ de toda la logística creada en este último periodo. 


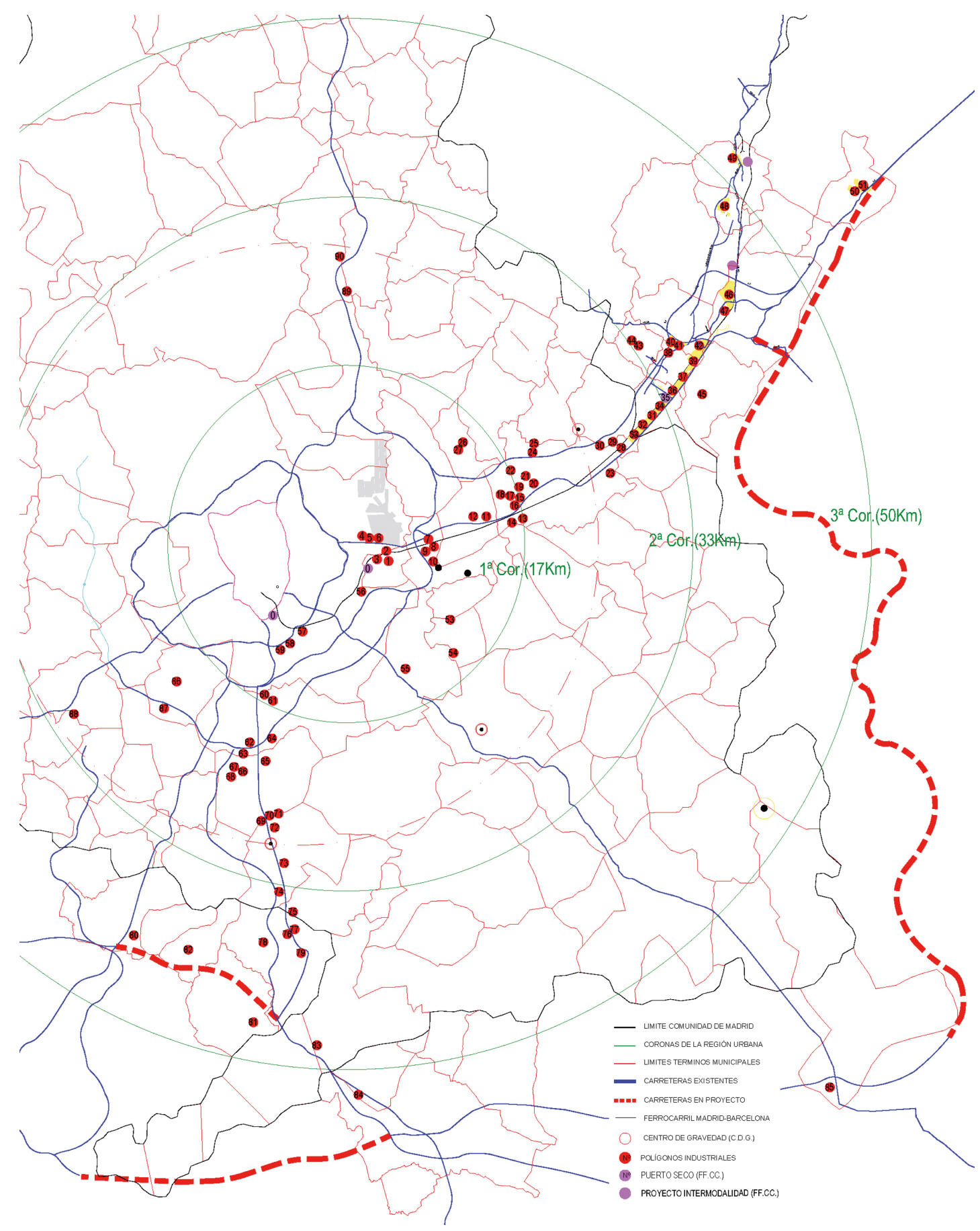

FIG. 11/ Total de las 90 implantaciones logísticas analizadas en la Mega-región urbana de Madrid posicionadas respecto de las coronas y los municipios a 2018.

Fuente: Elaboración Propia. 
En Azuqueca ha ocurrido un fenómeno algo diferente a Cabanillas. Con un volumen similar alcanzado en el Periodo 3, un total de los 2,4 $\mathrm{Mm}^{2}$ repartidos en los seis polígonos identificados en su término municipal -cuatro de ellos desarrollados durante el Periodo 1- apenas ha habido crecimiento durante el periodo 3. Esto es debido a la previa colmatación de todo su espacio potencial industrial y logístico, por lo que su incremento entre periodos baja hasta situarse cercano al $180 \%$. Son las dos caras del modelo de evolución (momentos de oportunidad, basados en ofertas de suelo y gestión) de dos localidades de la mis-ma provincia con la mayor influencia logística efectiva en los últimos 20 años en el corredor de la A-2 -se reparten entre ambas unos porcentajes en torno al $26-27 \%$ cada una dentro de la provincia lo que representa un total provincial del $55 \%$ y en torno al $7,5 \%$ cada una del total de la Mega-región urbana. Cada una de ellas se ha desarrollado en momentos distintos para alcanzar un peso específico equivalente.

En el puesto quinto $\left(5^{\circ}\right)$ está Valdemoro (M), siendo el primero que aparece en el corredor de la A-4. Ya desde los años 80'cuando El Corte Inglés decidió instalar allí su centro de trasportes principal para toda la península ha tenido un papel singular en la dinámica del tercio sur del Arco Logístico madrileño-de hecho como interés espacial apuntar que en su término municipal se incluye el C.D.G. del corredor A-4-, tanto por la ampliación del citado centro de transportes y la consolidación de los polígonos industriales más cercanos a la población como por la creación posterior de otros polígonos especializados y colgados de la A-4 repartidos por su amplio término municipal. En total tiene algo más de $3 \mathrm{Mm}^{2}$ de polígonos con incidencia logística, repartidos en 6 ubicaciones y una ratio de especialización/ ocupación cercana al $67 \%$, con una superficie media por polígono de $0,51 \mathrm{Mm}^{2}$. Su volumen logístico supone el $6,94 \%$ de total logístico de la Mega-región urbana y el $11,17 \%$ del total de la provincia de Madrid. La variación que ha experimentado desde el periodo 1 (puesto $3^{\circ}$ ) hasta la actualidad es ligeramente superior al $200 \%$-un crecimiento medio y constante alentado tanto por la excelente ubicación respecto de la gran ciudad como por su conexión directa a la A-4-, lo que ha conducido al $5^{\circ}$ puesto actual, que se debe entender como un éxito en una apuesta prolongada por el desarrollo de suelo logístico, y más teniendo en cuenta lo gravitacional del crecimiento en este corredor A-4 y con menos relevancia que el de la A-2. Se puede considerar como un claro ejemplo de crecimiento constante y homogéneo.
De Coslada (M) en el puesto sexto $\left(6^{\circ}\right)$ a Meco (M) en el puesto octavo $\left(\mathbf{8}^{\circ}\right)$-junto con San Fernando de Henares $(\mathrm{M})$ en el séptimo $\left(7^{\circ}\right)$ - todos se encuentran de nuevo en el corredor de la A-2 y en la provincia de Madrid. Entre estos tres destaca el carácter predominante de Coslada como centro neurálgico de la distribución de paquetería urgente y el de San Fernando, con el almacén central de Amazon para toda el área metropolitana de Madrid hasta 2018, con una clara vocación de zona de influencia y centralidad como "puerta de entrada a Madrid" desde el aeropuerto y desde Europa por carretera. El caso de Meco es bien distinto, puesto que limítrofe con Guadalajara, arranca sus desarrollos logísticos a raíz del polígono industrial que promueve la empresa pública del gobierno de la Comunidad de Madrid (ARPEGIO) durante el segundo periodo de análisis, proyecto que generó un efecto llamada que culminó con la construcción del almacén central de ZARA (empresa Inditex) en el centro peninsular y la posterior ampliación ya en el tercer periodo. Ubicados los tres polígonos existentes en el encuentro de las dos vías de comunicación principal (R-2 y A-2), espacialmente cuenta con el C.D.G. del corredor A-2 en su término municipal, lo que da una idea de lo idóneo de su distancia a Madrid $(40 \mathrm{Km})$ y sus excelentes comunicaciones, entre otras variables de peso.

Getafe (M) se sitúa en el puesto noveno $\left(9^{\circ}\right)$ como el segundo municipio en aparecer en el corredor de la A-4 tras Valdemoro $\left(5^{\circ}\right)$. Con el C.D.G. del primer periodo en el corredor A-4 en su término municipal y un crecimiento homogéneo y moderado en torno al $160 \%$, que le han hecho descender 5 puestos (desde el $4^{\circ}$ en el primer periodo) en el ranking. Tiene $3,25 \mathrm{Mm}^{2}$ de superficie industrial logística con un grado de especialización baja (en torno al $40 \%$ ), debido en parte a la presión de los precios y usos por ser contiguo a Madrid.

El ranking se finaliza con Seseña (TO) en el décimo puesto $\left(1^{\circ}\right)$, como tercer municipio en aparecer en el corredor A-4 dentro de los diez primeros puestos y el primero en Toledo (representa más de $1 / 3$ del total de la provincia), con la ratio de mayor especialización/ocupación (entre 80 y $90 \%$ ) junto con las localidades de Meco $\left(8^{\circ}\right)$ y Alovera (GU), en el puesto $11^{\circ}$. Los incrementos en estos últimos casos son exponenciales, con más del $2000 \%$ entre periodos.

No existe apenas peso específico de los otros corredores que no sean los de la A-2 o la A-4 en 
cuanto a influencia de la logística respecto del área global en torno a la Mega-región urbana de Madrid. Si quitamos el 5,34\% del corredor de la A-3, que incluye a las localidades madrileñas de Mejorada del Campo, Velilla de San Antonio, distrito Vallecas Villa -aun no estando a pie de corredor, pero sí en su área de influencia-, y Rivas Vaciamadrid, colgada directamente de la A-3 junto con Tarancón, ya en Cuenca, queda un $3,73 \%$ para el resto de corredores de la A-1 y A-5 (no existiendo ninguna implantación en el corredor A-6).

Como contraste, Guadalajara capital ostenta el menor incremento $(0 \%)$ entre periodos aun siendo precursora de la logística en el corredor con el polígono del Henares, lo que muestra una tendencia de esta ciudad al sector residencial y terciario, que ha posibilitado el elevado crecimiento logístico de otras localidades localizadas en el mismo área de influencia como el caso analizado en detalle de Cabanillas -por el tirón del grupo GE en el segundo periodo y de Inditex con los almacenes centrales para Madrid de Pull\&Bear y Zara Home en el tercer periodo- con precios mucho menores que los de la capital de la provincia y mucho más competitivos para la demanda de grandes volúmenes de almacenamiento.

Se deduce de este análisis espacial municipal la posibilidad de renovación de áreas industriales obsoletas de Pinto (M), que cuenta con $3,2 \mathrm{MMm}^{2}$ y solo un $20 \%$ de especialización logística -muy baja, por lo que cuenta con mucho recorrido de renovación urbana para la distribución-, gracias a su cercanía a Madrid y su buena posición respecto de la A-4.

Las posibilidades de colmatación de áreas ya desarrolladas en la época anterior a la crisis propicia, tanto en Torija (GU) como en San Fernando de Henares (M), expectativas de competitividad en cuanto a precio y disponibilidad de gran volumen, para plataformas que demanden lejanía o cercanía a la gran ciudad, respectivamente.

Es curioso y paradójico el binomio que resulta de los últimos puestos del ranking Torija (GU) en el puesto decimosegundo $\left(\mathbf{1 2}^{\circ}\right)$ y Torrejón

\footnotetext{
17 Según los estudios de la CE Urban Audit, de marzo 2016 y junio 2017 del INE (INE, 2016 y 2017), Torrejón de Ardoz es la $3^{\mathrm{a}}$ y $6^{\mathrm{a}}$ ciudad española con más empleo industrial de España en 2015 y 2016 respetivamente, y aun cuando la tendencia va en disminución sorprende el poco volumen logístico que atesora con unas circunstancias
}

de Ardoz (M) en el puesto decimotercero (13 $\left.{ }^{\circ}\right)$, como dos ejemplos de un mismo corredor y con situaciones opuestas por su localización (en 3-4 ${ }^{\mathrm{a}}$ corona y $1^{\text {a }}$ respectivamente), con un carácter eminentemente logístico del primero respecto del segundo mucho más industrial ${ }^{17}$. Si atendemos al tamaño de la población de ambos municipios (una diferencia del $1.000 \%$ ), sorprende que Torija le gana sensiblemente en volumen logístico a Torrejón de Ardoz, aun cuando éste tiene el factor cercanía a la gran ciudad a su favor. Son por tanto un claro ejemplo de apuestas por modelos de ciudad diametralmente enfrentadas, con unas políticas de desarrollo urbano que no consiguen equilibrar en la actualidad el binomio residencialindustrial, teniendo en cuenta las buenas aptitudes físicas y de excelente localización de ambos términos municipales. Conviene reflexionar, atendiendo a este ejemplo, sobre los "territorios sirvientes" y determinados tejidos industriales obsoletos a día de hoy.

El resto de los municipios apenas tiene peso específico, destacando entre todos ellos los casos de Camarma de Esteruelas (A-2 / R-2) y Ciempozuelos en Madrid, que junto con Ontígola en Toledo está situado en la A-4, que se completan con casos aislados, como le ocurre a lllescas en Toledo, que está situado en el corredor de la A-42.

Como resumen y en relación con las distancias a la ciudad principal (FIG. 11), cabe indicar que, de los 13 primeros municipios del ranking, 6 municipios se encuentran en la $1^{\text {a }}$ corona, 3 en la $2^{\mathrm{a}}$ y 4 en la $3^{\mathrm{a}}$, lo que es clarificador del reparto espacial, al que también influye el dato resumen del reparto por corredores: 3 están en la A-4 y los 9 restantes en la A-2 (sin incluir Madrid capital en ninguno de ellos). La tendencia es hacia el alejamiento de las implantaciones logísticas respecto de la ciudad de Madrid como demuestra el dato de que el $56 \%$ de las nuevas operaciones absorbidas por el mercado durante el año 2018 fue en la denominada $3^{a}$ corona, y en cuanto a preferencias de eje destaca la A-2 con un volumen de superficie contratada en ese mismo año de $459 \mathrm{M} \mathrm{m}^{2}$ respecto de los $900 \mathrm{M}$ $\mathrm{m}^{2}$ totales para Madrid ${ }^{18}$.

muy propicias: una ubicación privilegiada en el corredor A-2 y una cultura de asentamientos industriales histórica constatada, además, en los datos que revelan ambos estudios.

${ }^{18}$ Según datos de la consultora Aguirre Newman publicados en EL Pais el 29/04/19. 


\section{Conclusiones}

Como principales conclusiones es posible apuntar que:

1. La tendencia en la evolución de la distancia de traslación del baricentro entre periodos, en relación con el estudio sobre volumen logístico en los municipios, mide y determina con exactitud un sprawl logístico, que se puede considerar importante respecto de otras áreas de estudio y que representa una descentralización desde la ciudad central hacia los municipios frontera con la Comunidad de Madrid, arrojando unas cifras todavía más expresivas si lo referimos a los resultados estratificados por corredor. En cuanto a la comparativa con otras ciudades estadounidenses con estudios similares, cabe apuntar que Madrid se encuentra ligeramente por encima de Seattle y dobla en sprawl a Atlanta, lo que es significativo por cuanto se trata de núcleos asociados a un modelo de dispersión urbana típico de los EE.UU.

2. En cierta manera, la A-4 y la provincia de Toledo se presentan como una alternativa a futuro y más, si cabe, en tiempos de contención económica, por precio, de cercanía a Madrid -principal mercado finalista- y por la falta de oferta de suelo disponible en las otras localizaciones más consolidadas (Corredor del Henares A-2), aunque no sea la ubicación óptima y/o tradicionalmente "deseable".

3. Atendiendo al dato de la mayor concentración logística por municipio y, además, cercana a la capital -a caballo entre la $1^{\mathrm{a}}$ y $2^{a}$ coronas-, tenemos a Alcalá de Henares en primer lugar del ranking por municipios y por volumen, que es también la que presenta curiosamente unos de los precios más elevados de renta ${ }^{19}$ del espacio para el almacenaje en la región, debido a la falta de oferta y la casi total saturación de los espacios potencialmente aptos para tal uso en el municipio.

4. En cuanto a los resultados parciales por municipios, apuntar que algunos han llegado a su tope de admisión con una proporción muy alta de suelo industrial-logístico (Alcalá de Henares o Cabanillas del Campo) en relación al equilibrio en la variedad de usos recomendable, teniendo muy difícil el crecer más en este sentido, salvo en el caso de operaciones puntuales de renovación y/o desocupación; otros, presentan, al menos, la posibilidad de un nuevo polígono en desarrollo pero con poca relevancia en relación al volumen total municipal (caso de Madrid o Azuqueca de Henares); y, unos pocos (San Fernando de Henares, Torija, Marchamalo o Illescas) son los potencialmente mejor colocados en la actualidad para crecer a un corto plazo con garantías de suelo disponible en gran volumen y condiciones óptimas requeridas para este tipo de implantaciones.

5. Si relacionamos la superficie media de las implantaciones con los periodos y las distancias a la ciudad principal (coronas) destacamos que, en periodos de desarrollismo, y en la distancia media ( $2^{a}$ corona), los precios elevados y la falta de oferta en relación a la demanda hacen que las implantaciones a desarrollar se multipliquen en número en detrimento del tamaño de sus superficies, tiendan a alejarse de la ciudad principal y se eleve el porcentaje de especialización y ocupación.

6. Tenemos que, en solo una década, durante el Periodo 2 analizado (1998-2008), previo a la crisis económica, se desarrolló casi tanta superficie logística como en el resto de los periodos 1 y 3 (hasta 1998 y 2008-2018), sin una colmatación de la ocupación real posterior, aspecto que ayudó a la contracción de los precios durante el periodo de crisis económica, con la consiguiente ocupación y edificación de los espacios mejor localizados debido a la oportunidad y la oferta, aun cuando la coyuntura económica era claramente desfavorable.

7. Casi como síntesis, la Mega-región de Madrid ha alcanzado una madurez desde el punto de vista de la actividad logística al nivel de otras mega-regiones globales, que está permitiendo una progresiva adaptación tanto a los ciclos económicos como a las nuevas demandas técnicas y operativas del sector. No obstante, se constata que dicha madurez se está alcanzando con una ausencia de planificación regional centralizada, 
atendiendo a coyunturas espaciales y oportunidades, entre las que no son de poca importancia las derivadas de la dispersión competencial administrativa (comunidades autónomas y ayuntamientos) y los pesos específicos de las acciones públicas (en el caso de la Comunidad de Madrid, muy importante en el Periodo 1 (hasta 1998) y privadas. En cualquier caso, constatamos que en los últimos treinta años la región se ha transformado de manera considerable y previsiblemente va a seguir haciéndolo en un futuro inmediato. Este estudio pretende ser, en parte, una aportación a las consecuencias de una cierta desatención por parte de la planificación comprensiva, consecuencias que pueden ir de lo ambiental a un desproporcionado consumo de infraestructuras y tiempo de desplazamiento, lo que da lugar a continuos ajustes estructurales, y puede ser interpretado como una advertencia a tener en cuenta con respecto a los emergentes modos de distribución.

\section{Bibliografía}

BuRns, M.C. \& al. (2009): "El sistema metropolitano de la macroregión de Madrid”, en: Urban, número: 14, 72-79, Universidad Politécnica de Madrid, Departamento de Urbanismo y Ordenación del Territorio, Madrid

Cuchi, A. \& al. (2014): "Global Vision Report", en: World Sustainable Building Barcelona Conference 2014 (WSB14), 6-7, Green Building Council Europe (GBCe), Barcelona.

DABLANC, L. \& Ross, C. (2012): "Atlanta: A mega logistics center in the piedmont Atlantic megaregion (PAM)", en: Journal of Transport Geography, número: 24, 432-442, Elsevier, Amsterdam.

Dablanc, L. \& Ogilvie, S., \& Goodchild, A. (2014): "Logistics Sprawl: Differential Ware-housing Development Patterns in Los Angeles, California, and Seattle, Washington", en: HAL archives-ouvertes.fr Id: hal-01067793, Septiembre 2014, Centre pour la Communication Scientifique Directe, Francia.

Davezies, L. (2008): "La Republique et ses territoires, la circulationinvisible des richesses", en: La République des Idées, número: 112, Seuil, París.

DE SANTIAGO, E. (2007): "El sector logístico y la gestión de los flujos globales en la Región Metropolitana de Madrid", en: Scripta Nova (revista Electrónica de Geografía y Ciencias sociales), vol. XII, número: 259, Universidad de Barcelona, 15 de febrero de 2008.
- (2008): "Madrid 'ciudad única' (II). La explosión urbana en la región madrileña y sus efectos colaterales", en: Urban, número: 13, 138-164, Universidad Politécnica de Madrid, Departamento de Urbanismo y Ordenación del Territorio, Madrid.

GIFFORD, J. \& al. (2010): "Mega-regions and freight: Evidence from commodity flow survey and freight analysis framework", en: Transportation Research Board Annual Meeting 2011, George Mason University Transportation and Economic Development Center, Virginia.

Gottmann, J. (1961): Megalopolis. MIT Press, Cambridge, Mass.

Harrison, R., Johnson, D., \& Loftus-Otway, L. (2012): "Megaregion freight planning: A sinopsis", en: Report, \# FHWA/TX-11/0-6627-1, Center for Transportation Research, The University of Texas, Austin.

INE (2016): Urban Audit, Indicadores Urbanos, 6/20, Notas de Prensa del Instituto Nacional de Estadística, 1 de marzo de 2016, España.

- (2017): Urban Audit, Indicadores Urbanos, 7/21, Notas de Prensa del Instituto Nacional de Estadística, 20 de junio de 2017, España.

Khanna, P. (2016): Connectography: Mapping the Future of Global Civilization, Penguin Random House LLC, Londres (2017, traducción castellana de Pablo Hermida Lazcano, Conectografía. Mapear el futuro de la civilización mundial, Paidós, Barcelona).

LÓPEZ DE LuCIO, R. (2014): "Crónica y reflexiones en torno a un viaje al Arco Logístico de Madrid" en: Paisaje Transversal, 29 de abril de 2014. http://www. paisajetransversal.org/2014/05/DebatesUrbanosTour-periferia-logistica-Madrid.html

MitcheLl, W. J. (1999): E-topia. Massachusetts Institute of Technology, Cambridge, Massachusetts (2001, primera edición castellana, traductor: Fernando Valderrama, E-topía, Gustavo Gili, Barcelona).

Raimbault, N. \& Bahoken, F. (2014): "Quelles places pour les activités logistiques dans la métropole parisienne?", en: Territoire en Mouvement, número: 23-24, en: HAL archives-ouvertes.fr Id: halshs00945777, febrero 2014, Centre pour la Communication Scientifique Directe, Francia.

RodRIGUE, J. (2004): "Freight, gateways and mega-urban regions: The logistical integration of the Bostwash corridor", en: Tijdschrift Voor Economische En Sociale Geografie, número: 95(2), 147-161, WileyBlackwell, Hoboken, New Jersey.

RoDRIK, D. (2011): "La paradoja de la globalización", Antoni Bosch Editor, Barcelona.

- (2018): Populism and the economics of globalization. Journal of International Business Policy (2018). https://link.springer.com/article/10.1057\%2 Fs42214-018-0001-4

RUIZ SÁNCHEZ, J. (2000): "Planeamiento urbano territorial en Madrid. La experiencia reciente", en Urban, 5. Planeamiento urbano territorial en el siglo XXI. Otoño-invierno 2000-20001. pp. 122-142. ETSAM-UPM.

SRnicek, N. (2017): Platform Capitalism, Polity Press, Londres. 
VV.AA. Prologis (2014): Los emplazamientos logísticos más deseables en Europa, Prologis Research. https://www.prologis.com/logistics-industry-research
VV.AA. (2019): The Order of Established World Cities: Top 20. Demand and Disruption in Global Cities, JLL and The Business of Cities, 2019, JLL Jones Lang Lasalle IP, Inc. 
CIUDAD Y TERRITORIO

ESTUDIOS TERRITORIALES

ISSN(P): 1133-4762; ISSN(E): 2659-3254

Vol. LIII, № 207, primavera 2021

Págs. 119-140

https://doi.org/10.37230/CyTET.2021.207.07

CC BY-NC-ND

\title{
Propuesta metodológica para el estudio de las vías pecuarias desde el paisaje. Aplicación al Cordel de Gambogaz (Sevilla)
}

\author{
Carmen Venegas-MorenO ${ }^{(1)}$ \\ Irena GARCíA-VÁZQUEZ ${ }^{(2)}$ \\ Jesús RodríGUEZ-RodRíGUEZ ${ }^{(3)}$ \\ Ana Coronado-SÁnCHEZ ${ }^{(4)}$ \\ Juan José Domínguez-VeLA ${ }^{(5)}$ \\ Belén Pedregal-Mateos ${ }^{(6)}$
}

${ }^{(1)(2)(3)(4)(5) I n v e s t i g a d o r e s ~ d e l ~ C e n t r o ~ d e ~ E s t u d i o s ~ P a i s a j e ~ y ~ T e r r i t o r i o-U n i v e r s i d a d ~ d e ~ S e v i l l a . ~}$

(6) Profesora Departamento de Geografía Humana de la Universidad de Sevilla.

Directora del Centro de Estudios Paisaje y Territorio

RESUMEN: La relación entre el andar, la contemplación del paisaje y la red de caminos y vías pecuarias se argumenta recurriendo al origen de dichas vías, es decir, caminos trazados para facilitar el traslado de animales al ritmo lento de rebaños y pastores. Aunque en la actualidad la función trashumante es residual, las vías pecuarias están siendo recuperadas y utilizadas por las administraciones competentes con el objetivo de mejorar la articulación del territorio por el que transcurren, favorecer la biodiversidad y la diversificación paisajística en entornos urbanos y, en gran medida, para dar respuesta a las nuevas demandas ciudadanas relacionadas con el esparcimiento y las actividades deportivas y lúdicas propias de la sociedad actual. Este trabajo realiza una propuesta metodológica para estos itinerarios públicos desde la intervención en el paisaje, tomando como caso de estudio una vía pecuaria del Corredor Verde Metropolitano de Sevilla, el Cordel de Gambogaz, que discurre entre la capital hispalense y la localidad de Santiponce.

PALABRAS CLAVE: Paisaje en movimiento; Vías pecuarias; Caracterización paisajística; Propuesta metodológica. 


\title{
Methodological proposal for the study of livestock trails from the landscape. Application to the Cordel de Gambogaz (Seville)
}

\begin{abstract}
The relationship between walking, the contemplation of the landscape and the network of roads and livestock trails is argued by resorting to the origin of these roads, that is, trails designed to facilitate the movement of animals at the slow pace of herds and shepherds. Although the function of transhumance is currently residual, the livestock trails are being recovered and used by the competent administrations, with the aim of improving the articulation of the territory through which they pass, favoring biodiversity and landscape diversification in urban environments and, to a large extent, responding to the new citizen demands related to leisure, sports and recreational activities typical of today's society. This work makes a methodological proposal for these public itineraries from the intervention in the landscape, taking as a case study a livestock trail of the Metropolitan Green Corridor of Seville, the Cordel de Gambogaz, which runs between the capital of Seville and the town of Santiponce.
\end{abstract}

KEYWORDS: Moving landscape; Livestock trails; Landscape characterization; Methodological proposal.

\section{La percepción del paisaje ${ }^{1}$}

a Geografía de la percepción es una línea de investigación útil para el estudio del paisaje, ya que la observación del espacio que se habita explica en cierta medida el comportamiento geográfico y su relación con el paisaje (CAPEL, 1973; BERTRAND, 1978). Desde este enfoque, la fuente más común para el conocimiento subjetivo del paisaje es la construcción mental, a modo de croquis, que elabora un individuo respecto a la forma del territorio.

En relación con la elaboración individual de un mapa o croquis mental de un paisaje que se recorre, se toma como punto de partida la capacidad innata que el ser humano posee para interpretar el espacio (impresión consciente de la realidad física del entorno), entendiendo este espacio como un lugar de experiencia, de existencia o espacio vital. Igualmente lleva a cabo una simplificación de los estímulos que percibe, sustituyéndolos por conceptos para su mejor entendimiento (TUAN, 2007). Es decir, que los sentidos modifican los datos objetivos del mundo exterior, proporcionándoles cualidades que son puramente subjetivas (CAPEL, 1973), manifestándose dicha actividad mediante la curiosidad o la atención. Así la atención supone una actividad de la conciencia, en la medida en que una vez percibido, construye un objeto nuevo que antes aparecía indeterminado, por lo que la percepción conlleva la aprehensión y captación del objeto de manera unificada y cualificada (MERLEAUPONTY, 1975).

\footnotetext{
${ }^{1}$ Este artículo surge a partir de un trabajo técnico denominado Estudio para la determinación de criterios paisajísticos en la red de vías pecuarias de Andalucía, realizado en el Centro de Estudios Paisaje y Territorio-Universidad de Sevilla
}

Se considera pues que la atención es la responsable de mantener el control de la mirada y del conocimiento y, en el caso de que la experiencia decepcione o se frustre, se busca otra novedad o estímulo más satisfactorio. En este sentido, la curiosidad es una actividad proactiva que permite tomar decisiones en relación con el entorno o medio vivido, siendo un comportamiento que puede llevar a que se actúe o modifique el medio real o territorio atribuido (CAPEL, 1973; BESSE, 2010). Además, la forma en que se percibe este espacio vivido viene determinada por el modo en que las personas establecen vínculos funcionales o afectivos con dicho espacio, existiendo generalmente coincidencias entre los miembros de un mismo grupo cultural.

En suma, la percepción del paisaje viene conformada por representaciones vinculadas al entorno cultural del observador, por experiencias, recuerdos e intenciones individuales, así como por las formas físicas y espacios materiales que se expanden ante sus ojos. En este sentido, se entiende que una parte de la percepción tiene un marcado componente subjetivo y propio y que otra parte presenta un destacado trasfondo sociocultural que viene, en gran medida, conformado por convenciones sociales acerca de cómo valorar e interpretar lo que se percibe (Cosgrove, 2002). En esta misma línea, Nogué señala que el paisaje real está teñido de arquetipos que son transmitidos de generación en generación y que cada época, cada cultura, se identifica particularmente con determinadas formas del paisaje (NoguÉ, 2007). Por tanto,

a petición de la Secretaría General de Ordenación del Territorio y Sostenibilidad Urbana (SGOTSU) de la Consejería de Medio Ambiente y Ordenación del Territorio, Junta de Andalucía en 2018. 
se podría afirmar que la percepción del paisaje constituye una proyección de la propia identidad personal y social (GovindA, 2014).

Siguiendo esta línea de reflexión, en general, se considera que para percibir e interpretar el paisaje, además de una capacidad innata, se requiere un cierto diálogo entre sensibilidad y cultura para que la experiencia de percibir se torne consciente y se traduzca en una actividad o compromiso con el espacio vivido. En este proceso dialéctico entre sujeto y espacio vivido interviene la conciencia y su complejo funcionamiento, favoreciendo el reconocimiento de los lugares, su rememoración, y su integración mediante un sistema de signos y señales con origen en la propia cultura del sujeto.

En este sentido, según Luginbühl, se pueden distinguir tres niveles en cuanto a las relaciones que se establecen con el paisaje: una escala global fundamentada en la cultura; una escala local que deriva de las relaciones que vinculan al hombre con el medio y una escala individual según la cual, cada persona experimenta el paisaje de forma subjetiva (LUGINBÜHL, 2007; ORTEGA, 2010).

De esta forma, la sensibilidad necesaria para percibir el paisaje se entiende como manifestación natural de la inteligencia, de la forma de ver y de disfrutar del mundo. Asimismo, se ha dicho que en el caso de la cultura occidental contemporánea su visión del paisaje es muy intelectualizada y se percibe más a partir de ideales, aspiraciones y expectativas que de la observación diaria del entorno cotidiano (EsPAÑOL, 2007).

\section{El paisaje en movimiento}

A este proceso de percepción del paisaje se le puede sumar una circunstancia más, y es la relativa al movimiento. Esta apreciación dinámica convierte el itinerario en un hilo conductor de una sucesión de paisajes. La lectura y consideración del paisaje desde el movimiento como recuerdo personal no es nueva, ya a principios del siglo XVIII surgen los primeros intentos de establecer una relación teórica y práctica entre el caminar, el territorio y sus paisajes. Se llega a señalar que el espacio vivido es experimentado en gran medida en movimiento por un sujeto que lo codifica y dota de significado, siendo a su vez este sujeto, transformado por dicha experiencia sensorial. En este sentido, la forma contemporánea más auténtica de conocer el paisaje es recorrerlo a pie (KESSLER, 2000). Así, la información relativa al paisaje recorrido llega al sujeto a través de su sistema de receptores que, a su vez, es filtrada por el conjunto de valores individuales y colectivos. A partir de ello se elabora una imagen mental que tiene como referencia aquellos objetos que despiertan o fundamentan la atención. En esta operación perceptiva, ciertas imágenes estimulan el interés del espectador y se descartan otras, bien sea por similitudes o por diferencias y así se llega a organizar el espacio atravesado o recorrido.

En la selección de las imágenes mentales de los paisajes recorridos, aunque la vista predomina, la base de la relación observador-entorno se encuentra en el conjunto de los sentidos (la vista, el oído, el olfato, el gusto, el tacto) y en la memoria social (historia, origen, mitos...); y en general viene mediatizada por la experiencia personal. De modo que la vista, selecciona, ordena, categoriza objetos y dota de significado lo que se ve, siguiendo modelos aprendidos o pautas culturales. Se trata de un proceso continuo y dinámico entre sujeto (individuo) y objeto en movimiento (paisaje) fruto de la observación y el reconocimiento o identificación; lo que Roger denomina una artealización o interpretación de la realidad (Roger, 2007).

Esta interpretación tiene una estructura o delimitación espacio/temporal y posee un gran valor descriptivo mediante asociación y disgregación de ideas enlazadas unas con otras de manera espontánea, personal y subjetiva, y a una escala de proximidad o inmediatez. Así pues, en la percepción del recorrido se opera selectivamente, es decir, se eligen solo algunos elementos o aspectos significativos del paisaje; entre otros, ciertas referencias o puntos singulares del entorno que resultan llamativos para la atención y que suelen disponer de una carga de significado más o menos importante.

Además, el desplazamiento tiene el poder de crear formas y de comprender los elementos del paisaje en todo su significado y perspectivas: vista lateral, frontal, rodear, estar dentro, o situarse fuera, bajar o subir y, finalmente, la cuarta dimensión, que se entiende como el tiempo que transcurre mientras se desarrolla la secuencia visual. Así, el itinerario paisajístico se desarrolla a modo de una construcción mental, sólo perceptible mediante secuencias temporales encadenadas.

En general el grado de legibilidad del paisaje recorrido depende en cierta manera de la facilidad en que se identifiquen sus secuencias temporales y se integren en sus tramos, sus hitos, sus bordes o límites, dentro de un esquema global que a su vez se apoya en las experiencias sensoriales del sujeto, que conectan directamente con los recuerdos presentes y pasados para finalmente extraer de todo ello un sistema de orientación a modo de croquis. De modo que en un itinerario se encuentra un inicio, un final, tramos, límites, umbrales, hitos y elementos (APPLEYARD \& LYNCH \& MYER, 1971). 
Como se viene señalando, andar es la primera experiencia de vida que implica tomar conciencia del espacio próximo o afectivo, de habitarlo, de atravesarlo y, a la vez, supone el modo más natural de retener y memorizar el espacio recorrido, estando en general al alcance de cualquier persona. Igualmente, permite desarrollar todas las capacidades de percepción del paisaje -desde la configuración de un esquema mental hasta su compresión global-, siendo una forma y método perceptivo de conocimiento del entorno basado principalmente en las asociaciones de ideas generadas por las propias condiciones de la marcha, convirtiendo el propio cuerpo en un sistema de medición de las coordenadas antropológicas fundamentales (espacio/tiempo) que permiten descubrir la verdadera dimensión espacial de las distancias.

En este sentido, en los últimos años, profesionales de la arquitectura del paisaje ${ }^{2}$ con precedentes en corrientes culturales y artísticas occidentales que se desarrollaron en la segunda mitad del siglo XX -como el Situacionismo y el Land Art-, explican que el acto de andar en grupo proporciona nuevas claves que permiten profundizar en su interpretación; una experiencia que facilita el desarrollo de nuevas formas de comprender los lugares de una manera sensible e imaginativa y en la cual el camino es utilizado como hilo conductor. En esta experiencia sucede que la atención no es siempre uniforme. De modo que las escenas recorridas, aunque sean de manera casual o espontánea, despiertan una curiosidad desigual, quedando en la memoria una impresión compuesta de detalles concretos y de una idea general más o menos abstracta que se puede recordar, describir, interpretar o verificar y se configura bajo la forma de un relato (CABALLERO \& Domínguez \& ZOIDO, 2016).

\section{La percepción del paisaje en movimiento a través de las vías pecuarias}

La relación entre el andar, la red de caminos y vías pecuarias existentes y la contemplación del paisaje se argumenta de manera muy sencilla recurriendo al origen de dichas vías, es decir, caminos trazados para el movimiento del ganado, formulados para facilitar el traslado de animales al ritmo lento de rebaños y pastores. Se entiende que estos caminos

\footnotetext{
${ }^{2}$ Un ejemplo de interés es la experiencia "Stalker/ Osservatorio Nomade" formada por un colectivo de arquitectos e investigadores vinculados a la Universidad de Roma Tre que creó a mediados de los noventa una red de investigación para trabajar de manera experimental en las ciudades, mediante herramientas participativas. Para ello realizan paseos
}

eran, en otro tiempo, lugares simbólicos -símbolos públicos y áreas de cuidado, según Yi-Fu Tuan (TUAN, 2018)-, donde se desarrollaba la vida de ciertas comunidades nómadas. Y en este caminar trashumante se progresa al ritmo propuesto por los lugares; unas veces con paso más rápido, otras con paso lento y siempre de acuerdo o en sintonía con la diversidad del territorio que se atraviesa, permitiendo la contemplación e interpretación del paisaje que los rodea.

Si bien esa función trashumante ha pasado a ser residual en muchos casos, los caminos y vías pecuarias están siendo recuperados por las administraciones competentes en la actualidad para aprovechar esta gran red territorial con el objetivo de mejorar la articulación del territorio, favorecer la biodiversidad y la diversificación paisajística en entornos urbanos y, en gran medida, para dar respuesta a las nuevas demandas ciudadanas relacionadas con el esparcimiento y las actividades deportivas y lúdicas propias de la sociedad actual.

El progresivo reconocimiento de las vías pecuarias se culmina en España con la Ley 3/1995 de 23 de marzo (BOE 71/1995) en la que quedan plasmados, por primera vez en un documento de esta naturaleza, los usos y funciones que esta amplia red de caminos cumple en la actualidad. Así, tal y como señala Manteca Valdelande, las vías pecuarias, antes de la entrada en vigor de la ley, prestaban fundamentalmente dos servicios: comunicar áreas de pastoreo estacional y alimentar el ganado en ese tránsito. Con la nueva normativa, las vías pecuarias pasan a asumir otras funciones adicionales como servir de corredores ecológicos o como instrumento que contribuye a favorecer el contacto entre el hombre y el medio. Esta ley añade por tanto al uso tradicional otros usos compatibles y complementarios, como la práctica del senderismo, la cabalgada y otras formas de desplazamiento deportivo sobre vehículos no motorizados (MANTECA, 1995:153-154).

La citada Ley tiene su desarrollo en Andalucía mediante el Decreto 155/1998 de 21 de julio, por el que se aprueba el Reglamento de Vías Pecuarias de la Comunidad Autónoma de Andalucía (BosA 87/1998) en el que además de disponer los instrumentos necesarios para la protección de este patrimonio, se destaca su interés dada su enorme continuidad en el territorio andaluz, sus funciones ambientales y su carácter de dominio público.

por los espacios "indeterminados" o vacíos de la ciudad, que son ignorados o considerados un problema en la práctica urbana tradicional. Esta idea de caminar es utilizada como herramienta para reconocer la ciudad y sus transformaciones, evocar recuerdos y experiencias, y usar este conocimiento para abordar cuestiones de planificación urbana y territorial. 
Andalucía cuenta con una extensa red de vías pecuarias con una extensión de 34.082 kilómetros de longitud (IMA, 2018), siendo la Comunidad Autónoma que presenta la red más amplia dentro del territorio nacional.

Atendiendo a sus dimensiones, y siguiendo la clasificación básica de la red de vías pecuarias en cañadas (75 $\mathrm{m}$ de anchura), cordeles $(37,5 \mathrm{~m})$ y veredas $(20 \mathrm{~m})$, en Andalucía existen en torno a 8 mil kilómetros de las primeras, 7 mil de las segundas y 13 mil de las terceras. Pero, además, estas vías principales articulan el espacio y se conectan entre sí a través de otros ramales y coladas, en torno a 5 mil kilómetros, y se complementan con todo un conjunto de elementos de interés etnográfico como los abrevaderos, descansaderos, majadas, etc., asociados al tránsito ganadero (FIG.1).

Siguiendo los preceptos del reglamento de vías pecuarias de la región, se ha desarrollado el Plan para la Recuperación y Ordenación de la Red de Vías Pecuarias de la Comunidad Autónoma de Andalucía (BojA 74/2001), con la finalidad de dotar a esta extensa red de una dimensión de utilidad pública más allá del uso tradicional ganadero, destacando sus funciones medioambientales, paisajísticas, de desarrollo rural y de esparcimiento ciudadano.

En este sentido, el plan considera las vías pecuarias desde una triple perspectiva: (1) como elemento vertebrador del territorio y, concretamente, posibilitando la conexión del sistema urbano con los recursos naturales del entorno, propiciando la diversificación del paisaje o incidiendo en la planificación de las ciudades; (2) como elemento fundamental en la planificación ambiental, concretándose este papel en el establecimiento de corredores ecológicos y (3) como elementos que favorecen la fijación de la población en zonas rurales degradadas, por su alto potencial para el desarrollo de actividades socioeconómicas.

Así, en función de los usos previstos para cada ruta, ya sean rutas ganaderas, rutas turísticorecreativas o rutas ecológicas, se recogen las actuaciones específicas que se precisan para su recuperación y ordenación. En el caso específico de las rutas turístico-recreativas se destaca la necesidad de adecuación del firme para facilitar actividades de ocio, tales como el senderismo a pie, en bicicleta o a caballo; la instalación de

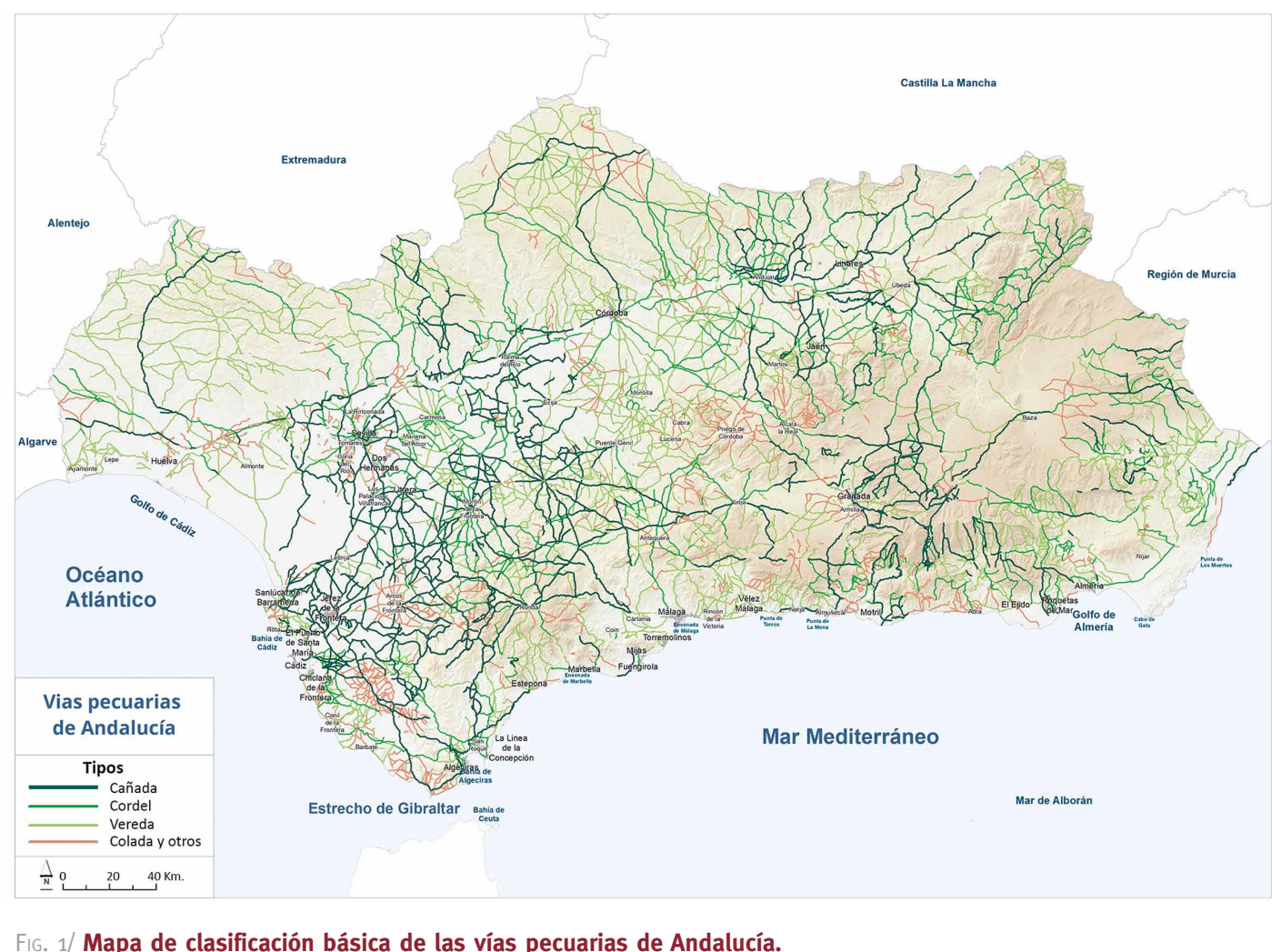

Fuente: Elaboración propia. 
equipamientos de uso público ligeros y las plantaciones a fin de conseguir una mejora paisajística, haciendo más atractivo el uso de las vías pecuarias como itinerarios de paseo, sobre todo en los entornos urbanos.

Por todo ello, resulta evidente que se trata de un importante patrimonio que tiene un profundo sentido histórico y, aunque las funciones seculares que dieron origen a estas vías se han ido perdiendo con el paso del tiempo, hoy sigue configurando un amplio soporte que adquiere nuevos usos al permitir a la ciudadanía salir fuera de los entornos urbanos, recorrer sus territorios y acceder a los paisajes, mediante formas de movilidad lentas, que permiten un acercamiento más directo y pausado. En esta idea también inciden distintas organizaciones ecologistas y sociales, desde las que se plantea la necesidad de favorecer la función social de estas vías, entendiendo que se hace necesario dotarlas de nuevas funcionalidades que impidan su abandono o usurpación, impulsando proyectos para su recuperación ecológica y paisajística y potenciando su uso recreativo, turístico y medioambiental, compatibilizándolo con su ancestral uso pecuario (CLAVERo, 2001).

Las vías pecuarias, por tanto, responden de manera idónea a las actuales tendencias de ocio relacionadas con la práctica deportiva y de esparcimiento, que se muestran atraídas por lugares considerados de interés ambiental, paisajístico, cultural o histórico, y asumen que pasear y andar pausadamente es una manera de conocerlos, además de una experiencia física y mental saludable.

Como señala Calvo Salazar la "red de vías pecuarias ha sido creada con criterios muy diferentes a cualquier otra red de comunicaciones actual". Estos caminos respetan el relieve en su trazado, conectan el sistema de asentamientos y ofrecen la posibilidad de recorrer el territorio de forma diferente, adaptándose a la escala humana. Así, la red de vías pecuarias facilita una aproximación distinta del ciudadano con el medio rural, más cercana a la percepción, donde cobran importancia otros sentidos como el oído, el olfato o el tacto en la contemplación de los paisajes (CALVo, 2001: 129).

Así pues, y siguiendo esta lógica, se está redescubriendo el caminar como una fuente de estímulos y el pasear como una elección vital o filosofía que permite percibir la belleza del camino en sí (CABAllero \& Domínguez \& Zoido, 2016). Esto es, la extensión del paisaje en sus márgenes y la consideración de sus pequeños detalles. Se trata de una visión estética o contemplativa de la naturaleza asociada a una emoción vivencial enriquecedora y agradable que aporta calidad de vida, en línea con los planteamientos que recoge el Convenio Europeo del Paisaje (CONSEJO dE EUROPA, 2000).

\section{Propuesta metodológica para el estudio y puesta en valor de una vía pecuaria desde un enfoque paisajístico}

Tomando como marco conceptual y normativo de referencia el Convenio Europeo del Paisaje, documento en vigor en España desde 2008, se han realizado numerosos trabajos que han intentado avanzar en el conocimiento, la conservación y gestión de los paisajes a través del desarrollo de procesos metodológicos, políticas e intervenciones de muy distinta naturaleza. En esta misma línea se inserta el presente trabajo, centrado en profundizar y poner en valor las estrechas relaciones que se establecen entre paisaje, movimiento y vías pecuarias a partir del desarrollo de una propuesta metodológica que favorezca la puesta en valor y cualificación de estas vías históricas para su uso y disfrute público.

En el desarrollo de esta propuesta metodológica se han tomado como referentes principales los estudios realizados en el Centro de Estudios Paisaje y Territorio de Andalucía, donde, a partir de la adaptación de la metodología británica del Landscape Character Assessment, se han desarrollado diferentes trabajos de caracterización de los paisajes de Andalucía, como la elaboración del Inventario de Recursos y el Sistema Compartido de Información sobre el Paisaje de Andalucía (ZoIDo, 2014) o el desarrollo de la metodología de los Catálogos de Paisaje de Andalucía y su aplicación a las provincias de Sevilla (ZoIDo \& Rodríguez, 2015), Granada y Málaga.

Asimismo, el citado Centro de Estudios ha desarrollado una línea específica de trabajo sobre las relaciones existentes entre paisaje e infraestructuras, con trabajos novedosos de gran utilidad que pueden ser considerados antecedentes de gran interés en la consideración del paisaje desde una perspectiva lineal (FERnÁndez \& Silva, 2015; ZoIDO, 2009; Las carreteras paisajísticas de Andalucía. Recurso para el disfrute y aprecio social del paisaje, 2017). De esta forma, este trabajo continúa esta línea de investigación teniendo en cuenta las particularidades de las vías pecuarias: itinerarios que se recorren lentamente, a pie o en bici, cuyo trazado está preestablecido y al que hay que dotar de una lectura paisajística.

Partiendo de estos conceptos e ideas y tomando como referentes metodológicos y conceptuales los trabajos anteriormente señalados, a continuación se detalla el proceso metodológico propuesto para la consideración de las vías pecuarias desde el paisaje como base para el desarrollo de futuras actuaciones encaminadas a la puesta en valor y uso social de estos itinerarios públicos. 
Esta propuesta metodológica se plantea con una estructura y contenidos mínimos que puedan ser comunes al conjunto de vías pecuarias con el objeto de favorecer el disfrute y aprecio social de los recursos paisajísticos asociados a dichas vías. En este sentido, se proponen cuatro fases de trabajo esenciales (FIG. 2): (1) planteamiento inicial y contextualización territorial de la vía pecuaria considerada; (2) análisis y caracterización paisajística; (3) diagnóstico paisajístico y (4) criterios y propuesta para la cualificación paisajística de la vía pecuaria. A continuación se explicitan cada una de ellas.

\subsection{Planteamiento inicial y contextualización territorial}

En primer lugar, imprescindible en cualquier trabajo con una dimensión espacial, se ha de realizar una contextualización territorial del ámbito por el que discurre la vía pecuaria considerada. El alcance de dicha contextualización se puede concretar dependiendo de las características formales de la vía y en función de diversas circunstancias como:

- la continuidad paisajística o escénica del ámbito en el que se inserta la vía;

- los rasgos, estructuras o componentes, tanto naturales como antrópicos, que definen el carácter del paisaje recorrido;

- la presencia de hechos territoriales de gran entidad que incidan de manera significativa en el propio recorrido pecuario;

- la existencia de una red de vías pecuarias o de otros itinerarios de uso público que permitan realizar un tratamiento conjunto de la misma para el disfrute y uso social;

- las determinaciones que la planificación física o sectorial recomienden respecto al tratamiento de un ámbito administrativamente delimitado.

Una vez establecido el alcance del contexto territorial de la vía, se ha de proceder a la descripción general del ámbito que recorre el itinerario identificado.

\subsection{Análisis y caracterización paisajística}

En relación con el análisis y la caracterización del recorrido han de abordarse los diversos aspectos que conforman la imagen paisajística del territorio, incluyendo los fundamentos naturales del paisaje, los procesos históricos que lo han ido configurando, así como las condiciones escénicas, los valores y significados que articulan su apreciación e interpretación. De manera sistemática, el reconocimiento del paisaje en el que se inserta el recorrido o camino a considerar debe comprender, al menos, los siguientes aspectos:

- Fundamentos naturales del paisaje, que incluyen no sólo los procesos de formación del relieve, sino también la evolución, diversificación o adaptación agroforestal de las formaciones vegetales naturales; las dinámicas y formas específicas que la climatología y la hidrología presentan en el contexto territorial de referencia; las limitaciones o potencialidades que la edafología o el relieve plantean a los sistemas de ocupación y aprovechamiento del territorio; etc.

- Procesos históricos que abarcan desde el desarrollo del hábitat humano y sus sistemas (asentamientos, ciudades, etc.) hasta los aprovechamientos del medio y cómo han evolucionado, destacando, para ello, las principales evidencias que muestren estos procesos culturales al observador.

- Percepciones y representaciones, que comprenden los significados adscritos al paisaje por las distintas culturas que se han aproximado a él, así como la interpretación de estos significados por la sociedad.

La idea esencial de este proceso de partida es plantear un análisis diacrónico de cómo todas estas dinámicas (naturaleza, cultura, interpretación simbólica) se han superpuesto y han interactuado a lo largo del tiempo y, sobre todo, cómo se muestran en el paisaje actual.

Una vez caracterizado el itinerario en su contexto paisajístico, el análisis se centra en el propio itinerario, destacando las condiciones de su recorrido, su conectividad con otros viarios, las condiciones escénicas que presenta, los recursos patrimoniales existentes y las incidencias que las políticas territoriales y urbanísticas tienen en el mismo.

Por lo que respecta al reconocimiento de las condiciones materiales y funcionales del itinerario resulta imprescindible realizar el trabajo de campo asociado que permita identificar cuestiones de interés como el estado del firme, la vegetación existente y las zonas de sombra, el uso que se hace del itinerario, etc. En definitiva, se trata de conocer las condiciones de partida del recorrido en el que se va a intervenir.

Igualmente, resulta necesario conocer la articulación y conectividad de la vía, tanto con la red de carreteras existente como con otros itinerarios de uso público que fomenten el establecimiento de una red en la que pudiera insertarse dicha vía. Asimismo, la conexión con espacios libres próximos al itinerario permite desarrollar una estrategia de disfrute completa y diversificada. 
En esta fase de análisis también es imprescindible abordar el estudio de las condiciones escénicas y de visibilidad que presenta el itinerario, con el objeto de conocer aquellos espacios del entorno de la vía que presentan una mayor o menor exposición visual, así como los puntos desde los que se obtienen las vistas más significativas desde el recorrido. En esta misma línea, se hace necesario la identificación de los recursos patrimoniales, tanto naturales como culturales, existentes que en muchos casos se convierten en los hitos paisajísticos del itinerario.

Finalmente, en esta fase analítica se hace necesario tomar en consideración las determinaciones de los distintos documentos de planificación física que afectan a la vía y su entorno, ya que las actuaciones previstas en los planes territoriales y urbanísticos de los espacios próximos al recorrido tienen una gran incidencia en las condiciones y usos del mismo.

\subsection{Diagnostico paisajístico}

A partir del análisis realizado, la siguiente fase metodológica supone la elaboración de un diagnóstico de los procesos del paisaje, de sus dinámicas, así como de los rasgos fundamentales que muestran. Este diagnóstico, que ha de ser sintético, debe identificar los principales valores y conflictos que se observan en el itinerario de la vía pecuaria y su entorno próximo.

En relación con los valores, se deben tomar en consideración los recursos y potencialidades del itinerario analizado. Para ello, se han de identificar aquellas circunstancias y elementos que contribuyen de manera significativa a la calidad paisajística del territorio por el que transcurre la vía pecuaria.

Por otro lado, deben identificarse también aquellas circunstancias que suponen un conflicto o amenaza para la calidad paisajística de la vía considerada o de su entorno inmediato.

\subsection{Criterios y propuesta para la cualificación paisajística de la vía pecuaria}

Finalmente, la caracterización y análisis previo permiten establecer el marco de intervención de la propuesta. Para el desarrollo de ésta, y como paso previo al propio proyecto de intervención, se han de establecer los criterios para la cualificación paisajística de la vía pecuaria considerada. Estos criterios han de ir encaminados no sólo a la adecuación de la vía pecuaria, sino también al fomento de los paisajes por los que transcurre.

Las propuestas planteadas para la vía pecuaria pueden ser muy diversas y dependerán de las características y circunstancias de la misma y de su entorno territorial, si bien se deberían establecer al menos criterios específicos en relación con: el tratamiento de las condiciones de la propia vía; la identificación y señalización del itinerario; la cualificación ambiental del recorrido; la puesta en valor de los elementos sobresalientes próximos; la integración paisajística de elementos discordantes y la divulgación y fomento del uso social y disfrute del itinerario.

Síntesis del proceso metodológico

PLANTEAMIENTO INICIAL Y CONTEXTUALIZACIÓN TERRITORIAL DE LA VÍA PECUARIA

$1 \quad$ Contextualización territorial

Descripción general del ámbito

ANÁLISIS Y CARACTERIZACIÓN PAISAJÍSTICA

Caracterización de los procesos y componentes del paisaje

Fundamentos naturales

Procesos históricos

Percepciones y representaciones

$2 \quad$ Análisis de las condiciones del itinerario

Condiciones de la vía

Conectividad y articulación

Condiciones escénicas y visibilidad

Identificación de recursos patrimoniales

Incidencias territoriales y urbanísticas

DIAGNÓSTICO PAISAJÍSTICO

$3 \quad$ Identificación de valores, recursos y potencialidades

Identificación de conflictos y/o amenazas para la cualificación de la vía

CRITERIOS Y PROPUESTA PARA LA CUALIFICACIÓN PAISAJISTICA DE LA VÍA PECUARIA

$4 \quad$ Tratamiento de la vía y señalización

Cualificación ambiental del recorrido

Divulgación e integración paisajística

Síntesis del proceso metodológico para la consideración de las vías pecuarias desde el paisaje.

Fuente: Elaboración propia 


\section{Análisis de caso: Consideración paisajistica del cordel de Gambogaz de Sevilla a Santiponce}

La validación empírica del método propuesto se ha llevado a cabo en una vía pecuaria situada en el entorno de la ciudad de Sevilla, concretamente el denominado cordel de Gambogaz, que forma parte de la fase II del Corredor Verde Metropolitano de Sevilla (Coria del Río-Santiponce) y se extiende por la vega del Guadalquivir entre los municipios de Sevilla, Camas y Santiponce (Corredor Verde del Área Metropolitana de Sevilla, 2003). Este cordel se corresponde con un itinerario que tiene origen en las proximidades de Sevilla capital y continúa hasta la localidad de Santiponce con una longitud aproximada de $7,8 \mathrm{~km}$. presentando un trazado llano, de gran rectitud y orientación dominante de sentido noroeste.

\subsection{Planteamiento inicial \\ y contextualización territorial del cordel de Gambogaz}

La fase II del Corredor Verde Metropolitano, del cual forma parte la vía pecuaria del cordel de Gambogaz, en concreto en su tramo 4, se sitúa al oeste de la aglomeración urbana de Sevilla, discurriendo en un eje de norte a sur que recorre en gran parte las tierras aluviales del Guadalquivir (FIG.3).

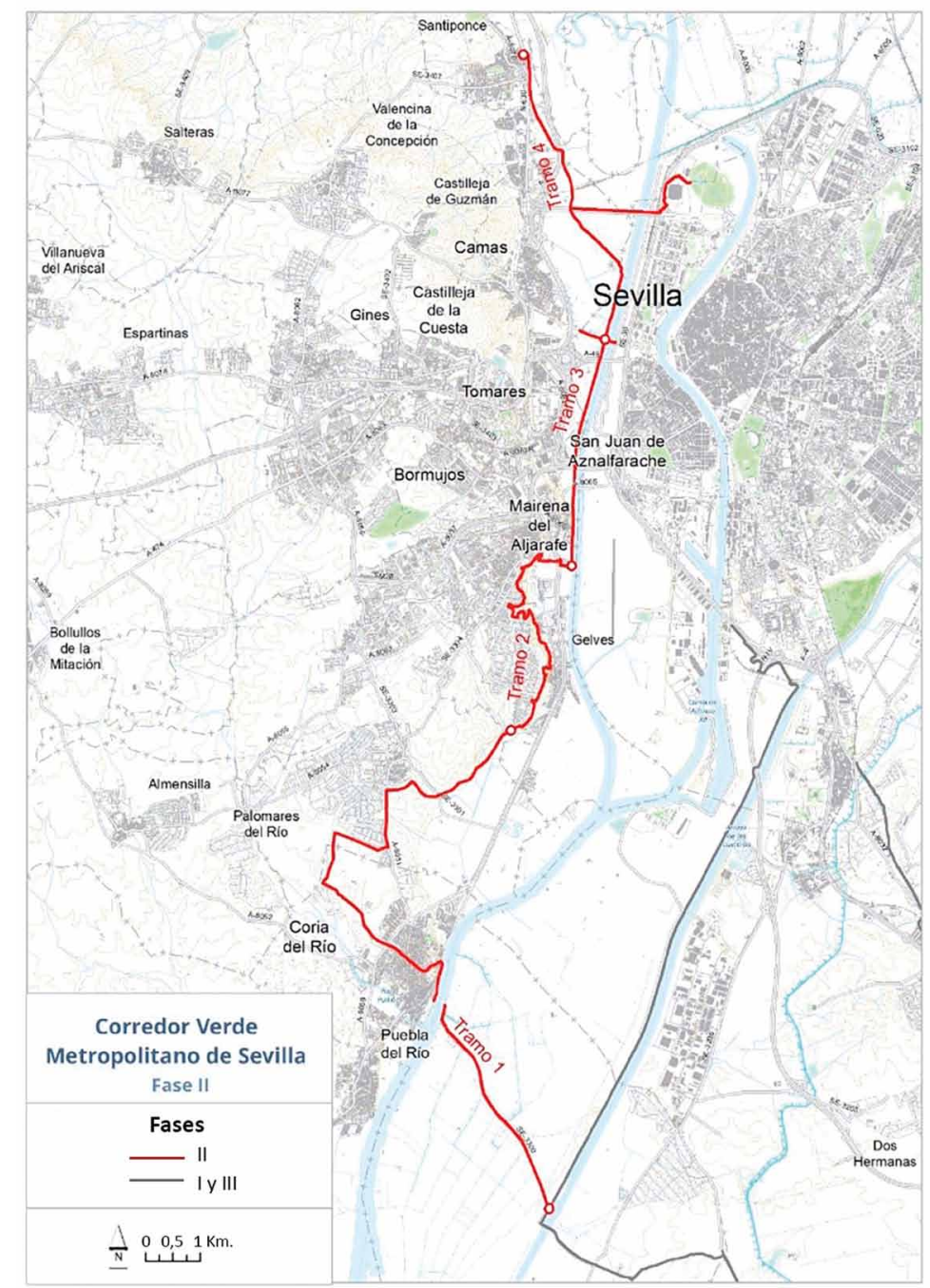

FIG. 3/ Mapa del Corredor Verde Metropolitano de Sevilla, fase II. El cordel de Gambogaz forma parte del tramo 4. 
Este espacio se puede considerar la transición entre el medio y el bajo Guadalquivir, limitando este último con la zona de marismas, aguas abajo de Coria del Río, siendo el valle del río y parte de su estuario en sentido amplio el marco geográfico de referencia. El Guadalquivir condiciona la orografía de este espacio desarrollando un relieve predominantemente llano, si bien las coberturas detríticas y depósitos de piedemonte que se desarrollan al oeste del sector de vegas y terrazas y que se muestran topográficamente elevadas respecto al mismo, presentan una importancia trascendental desde el punto de vista geohistórico para la configuración del paisaje de este territorio.

Este territorio ha sufrido una intensa ocupación a lo largo de la historia, dando lugar a un área densamente poblada cuya centralidad recae en la ciudad de Sevilla, y una red de asentamientos urbanos en su entorno metropolitano que, en el sector oeste, adquiere una gran densidad y elevada atomización de núcleos. Éstos ocupan un relieve situado a mayor altitud respecto a las vegas y terrazas (caso de los núcleos de Castilleja de la Cuesta, Tomares, Mairena del Aljarafe), existiendo otros que se sitúan, al menos parcialmente, en el escarpe de elevada inclinación de transición al valle (núcleos urbanos de Santiponce, Camas, San Juan de Aznalfarache, Gelves, Palomares del Río y Coria del Río).

Se trata de un ámbito de gran dinamismo y tensiones territoriales, propias de un espacio de vocación metropolitana, donde las funciones urbanas, comerciales e industriales y los patrones de consumo y movilidad contemporáneos asociados son los predominantes (ZOIDO \& RODRÍGUEZ, 2015).

\subsection{Análisis y caracterización paisajística}

\subsubsection{Caracterización de los procesos y componentes del paisaje}

Tal y como se recoge en el apartado 4, para abordar el análisis y la caracterización paisajística de la vía pecuaria resulta imprescindible conocer los procesos y estudiar los componentes relacionados con el paisaje por el que transcurre dicha vía. De manera sintética, a continuación se recogen los aspectos más destacados para el cordel de Gambogaz:

\section{a. Fundamentos naturales}

El marco geográfico de referencia de este corredor pecuario es el espacio de transición que se conforma entre el curso medio y bajo del río Guadalquivir, donde el elemento articulador y referente territorial de primerorden es el propio río.
El Guadalquivir y sus afluentes condicionan la topografía del valle, determinando un relieve predominantemente llano, donde el cauce, la vega y las terrazas aluviales representan el eje central del territorio. Se trata de espacios llanos, de origen aluvial donde los aportes sedimentarios han desarrollado roquedos detríticos, principalmente arenas y gravas, y donde las altitudes no superan los 10-20 metros.

Al oeste de las vegas y terrazas, en la margen derecha de río, las coberturas detríticas y los depósitos de piedemonte, formados por margosas principalmente, han supuesto la formación de un escarpe, sobreelevado respecto a éstas, que, en algunos sectores de la transición al valle -como por ejemplo entre Castilleja de Guzmán y Camas-, crea marcadas pendientes que pueden alcanzar los 100 metros.

Por el noroeste se encuentra el Campo de Tejada, unidad morfológica que conecta visualmente con las estribaciones de Sierra Morena, y que ocupa una plataforma de marcado perfil alomado, fruto de la erosión de una activa red hidrográfica sobre los materiales deleznables que la conforman.

Con carácter general, y apoyado en un benigno clima mediterráneo, este territorio posee unas condiciones edáficas favorecedoras, que ayudan a explicar la pronta ocupación humana y el establecimiento de asentamientos permanentes desde el II milenio a. C. En general los suelos del ámbito poseen una elevada fertilidad y una alta capacidad agronómica, y han sido el soporte productivo en el que se han desarrollado los usos intensivos de regadío, principalmente en las áreas de vegas, y de olivar y vides en las plataformas del Aljarafe. Estos espacios productivos se han ido reduciendo de manera significativa a medida que los desarrollos urbanos han ido extendiéndose por el ámbito, fundamentalmente en las últimas décadas del siglo XX (FIG. 4).

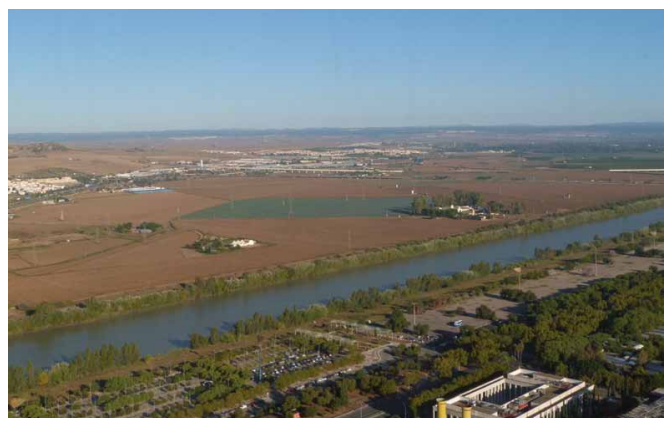

Vista del sector noroeste de la aglomeración urbana de Sevilla por el que transcurre el cordel de Gambogaz. 


\section{b. Procesos históricos}

Los condicionantes del medio físico determinaron el carácter estratégico y singular de este territorio -en la encrucijada entre la cornisa del Aljarafe y la vega del Guadalquivir y con este río como eje vertebrador-, cuyo proceso de ocupación inicial estuvo marcado por la evolución del tramo final del cauce del Guadalquivir y su desembocadura. En este sentido, el poblamiento del ámbito se inicia cuando los bordes bajos del Aljarafe y el valle aluvial del Guadalquivir se hacen habitables a finales del II mil. a. C., registrándose la presencia de los primeros poblados tartésicos en los puntos elevados.

A partir de este momento se suceden importantes transformaciones en estas fértiles tierras, como la introducción de nuevos cultivos con la llegada de los fenicios -entre los que destacan la vid y el olivo-, o la reestructuración agropecuaria que trae aparejada la entrada en la órbita romana a partir de la fundación de la colonia de Itálica en el 206 a. C. y que se irá intensificando durante los siglos de auge del Imperio.

Durante el período que transcurre desde la decadencia de la Itálica romana hasta que se hace efectivo el dominio visigodo (siglos IV al $\mathrm{VI}$ ), se va modificando el modelo de territorio y la concepción del espacio anterior, reduciéndose la población de los núcleos urbanos en favor de un hábitat rural cada vez más disperso, al tiempo que se abandonan las grandes villas en el campo. El sistema de alquerías implantado por los musulmanes recupera en parte el de las villas romanas, aunque con algunos reajustes, como la expansión del olivar o la proliferación de las huertas. Asimismo, las crónicas árabes documentan el abandono de la ciudad de Itálica y la conformación de un nuevo núcleo a orillas del río que daría lugar a la primitiva villa de Santiponce.

Tras la conquista castellana de la ciudad de Sevilla y su entorno, las tierras de Santiponce se convierten en un señorío eclesiástico y pasan a pertenecer al monasterio de San Isidoro, al igual que el cortijo de Gambogaz y sus tierras, entregados primero al Cabildo de la Catedral de Sevilla y, posteriormente, al monasterio de Santa María de las Cuevas. En esta etapa bajomedieval, la Vía de la Plata se consolida como camino y como una de las cañadas principales de la Mesta.

Las inundaciones que se suceden en 1595 y 1603 por las crecidas del Guadalquivir, suponen la destrucción del núcleo original de Santiponce y su traslado al cerro de San Antonio, más alto y protegido del alcance de las riadas, sobre las ruinas de Itálica.
Durante la primera mitad del siglo XIX, los procesos desamortizadores permitieron la adquisición de tierras por parte de la burguesía. En el caso de Santiponce, tras la desamortización del monasterio de San Isidoro en 1835, las tierras de su propiedad pasaron a manos privadas, aunque no se produjeron grandes cambios en los cultivos. En lo que respecta al cortijo de Gambogaz, que estaba en posesión de los cartujos del monasterio de Santa María de las Cuevas, fue comprado en 1851 por Ignacio Vázquez Gutiérrez, figura clave en la modernización del campo andaluz y pionero de la mecanización de las labores agrícolas y de la aplicación de técnicas agrícolas innovadoras. Tras la guerra civil española, el cortijo de Gambogaz pasó a ser propiedad del general Queipo de Llano.

En relación con las infraestructuras del ámbito, en 1903 se construye el ferrocarril de Cala a San Juan de Aznalfarache, paralelo a la carretera de Extremadura (N-630). Estuvo en uso hasta 1958 y tras su desmonte sirvió de base para la construcción en 1975 de la "autovía de Camas" en la parte final de la N-630.

Asimismo, las condiciones de navegación del cauce bajo del Guadalquivir se habían ido degradando como consecuencia de la dinámica natural del río y de la necesidad de un mayor calado. Por este motivo, los proyectos de cortas de meandros se inician a mediados del s. XVIII y continuaran a lo largo de los siglos XIX y XX, desde la corta de Merlina en 1784 hasta la de la Cartuja en 1975 Los objetivos principales eran proteger la ciudad de Sevilla de las inundaciones y facilitar la navegación hasta el mar y supusieron una importante transformación en los terrenos cercanos al río (ZoIDO, 2013).

\section{c. Percepciones}

En relación con el estudio de las percepciones, destacan las representaciones iconográficas históricas sobre el espacio que recorre el cordel de Gambogaz, vinculadas por una parte con las vistas de conjunto de la capital sevillana desde la cornisa oriental del Aljarafe y, por otra, con la presencia dominante de la ciudad romana de Itálica y del monasterio de San Isidoro del Campo, con la población de Santiponce como telón de fondo. Asimismo, el río Guadalquivir constituye un referente de primer orden, común a estas temáticas, y presente en la mayor parte de las representaciones del ámbito.

En lo que respecta a la imagen externa o de conjunto de la ciudad de Sevilla, desde el siglo XVI se desarrolla un amplio repertorio de imágenes topográficas de la ciudad como consecuencia de la importancia que adquirió Sevilla como metrópoli de las Indias, siendo 


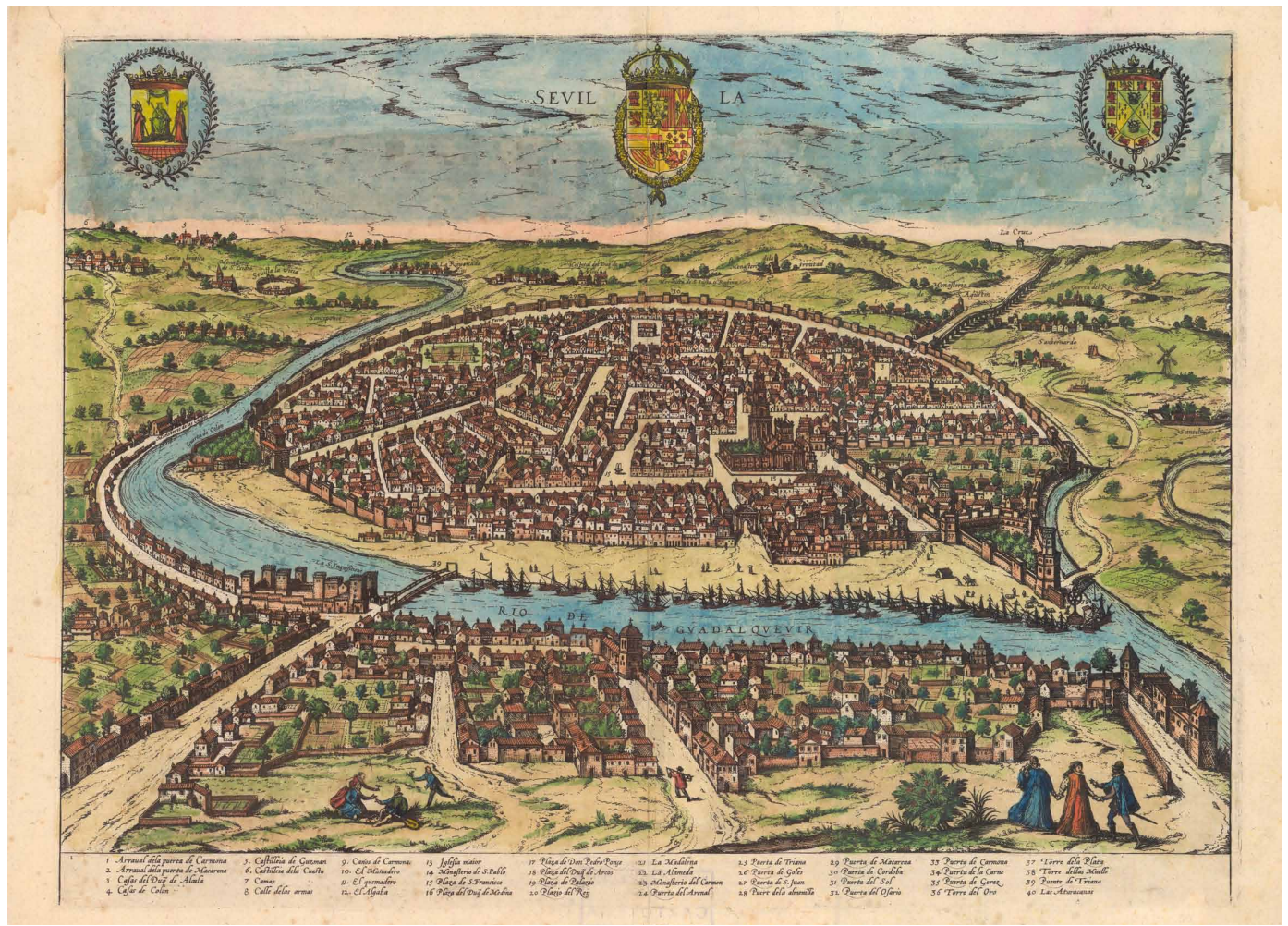

FIG. 5/ Vista general de Sevilla, copia del dibujo de A. Brambilla de $\mathbf{1 5 8 5}$ en el Civitates Orbis Terrarum, F. Hogenberg y G. Braun; Colonia, 1588.

Fuente: Instituto Geográfico Nacional, Ministerio de Fomento, 31-C-16, CC-BY 4.0. ign.es.

sus rasgos más identitarios su carácter monumental, la preeminencia de la Giralda en su perfil aéreo y la presencia del río Guadalquivir. Desde finales del siglo XVIII y durante todo el siglo XIX, las representaciones culturales de la ciudad se multiplican y este prestigio adquirido por la capital favorecerá la frecuentación por parte de los viajeros que la visitaban de otros lugares del entorno de Sevilla. En el caso del Aljarafe, las percepciones se centraron en las localidades de San Juan de Aznalfarache y de Santiponce, donde se ubicaba el monasterio de San Isidoro del Campo y las ruinas de "Sevilla la Vieja” (Itálica), destacándose en ambos casos sus valores históricos y patrimoniales (ZOIDO \& RODRÍGUEZ, 2015).

Ambas piezas comienzan a tomar protagonismo como hitos importantes del territorio. Así, las vistas generales de Sevilla y sus alrededores que se realizan a partir de la segunda mitad del s. $\mathrm{XVI}$ incorporan ya las referencias de San Isidoro del Campo y de Sevilla la Vieja, representada por su elemento más destacado, el anfiteatro.

Un ejemplo de ello es la Vista general de Sevilla, grabado de Ambrosius Brambilla realizado en 1585, en la que aparecen Itálica, el monasterio y el pueblo de Santiponce detalladamente situados al noroeste de Sevilla (FIG. 5). Esta vista de Sevilla fue muy conocida tras ser incluida en el tomo IV del Civitates Orbis Terrarum, una obra de gran difusión por toda Europa.

En los siglos XVII y XVIII, se realizan distintas obras iconográficas y cartográficas que aportan una visión detallada de cómo se encontraba el pueblo de Santiponce, Itálica, el monasterio de San Isidoro y el territorio circundante. Algunas de estas obras se centran en escenas de la vida de San Isidoro, otras en las posesiones del monasterio e incluso hay documentos de tipo administrativo, pero su interés para este trabajo reside en la representación de hitos y elementos territoriales tales como el cauce de la Madre Vieja, el curso del Guadalquivir, el trazado urbano del nuevo núcleo de Santiponce, los cortijos, el trazado de los caminos, así como en el conocimiento que ofrecen de los cultivos: huertas y alamedas, prados, olivares, viñedos y tierras de labor.

En el siglo XIX se produce un nuevo resurgir de Itálica, que coincide con la recuperación de su nombre clásico y con las vistas de Andalucía realizadas, sobre todo, por los pintores románticos británicos. El avance de las excavaciones en el 
s. XX, y en especial la recuperación de algunas calles de la ciudad y el descubrimiento de parte del graderío del teatro, suponen el nacimiento de una nueva visión sobre Itálica. Aunque el anfiteatro conserve su protagonismo, las imágenes de la primera mitad del s. XX comienzan a abrir la mirada hacia una Itálica más amplia y compleja, pero sobre todo desde la propia Itálica. Las vistas se dirigen hacia la cornisa del Aljarafe, la vega y el Guadalquivir. También son de gran interés las vistas sobre el pueblo de Santiponce y hacia Sevilla (ZOIDO, 2013).

\subsubsection{Análisis de las condiciones del itinerario}

El análisis de las condiciones de la vía se ha realizado a partir del trabajo de campo y del estudio de la documentación histórica y cartográfica, que permite constatar las distintas situaciones en las que se encuentra el itinerario por lo que respecta a sus características formales y perceptivas.

\section{a. Condiciones de la vía}

La primera aproximación al análisis requiere realizar un recorrido por la vía pecuaria objeto de estudio que permita reconocer por donde discurre el itinerario y sus condiciones generales más básicas, como el estado del firme y la vegetación existente.

El comienzo del itinerario, abordándolo desde la ciudad de Sevilla, se inicia en las inmediaciones de Torre Triana y continúa con un sentido este-oeste recorriendo parte del viario urbano hasta el paso subterráneo que salva la carretera de Cádiz-Huelva. Tras este paso continúa en dirección oeste hacia Camas a través del puente de la Señorita y enlaza con el recorrido del Corredor Verde que transcurre paralelo al río Guadalquivir por un camino compactado con albero, en dirección norte.

Esta primera parte del recorrido se encuentra en su mayor parte bajo un efecto de atrincheramiento propiciado por la vegetación ribereña y por el talud correspondiente a las obras de defensa hidrológica, circunstancia que condiciona notablemente las vistas laterales.

Continuando el recorrido se accede al trazado original del cordel de Gambogaz a partir de la desviación hacia el cortijo del mismo nombre (ver FIG.6), y sigue en dirección noroeste hasta el punto de confluencia con el viaducto de Itálica (SE-30).

Esta sección del recorrido se desarrolla por un terreno llano, con un trazado recto que permite una gran amplitud de vistas por la propia horizontalidad que presenta la vega

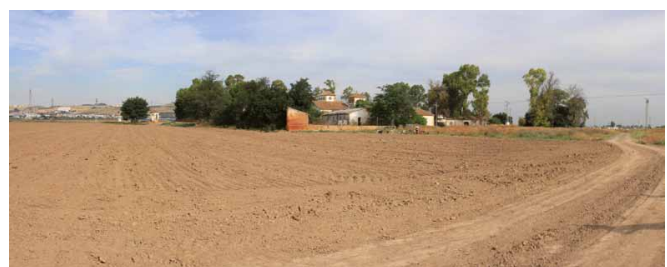

FIG. 6/ Paso del cordel de Gambogaz junto al cortijo que le da nombre.

Fuente: CEPT.

de Sevilla y por la ausencia de vegetación arbórea a excepción de la existente en las inmediaciones del cortijo de Gambogaz, donde destaca la presencia de una arboleda de cierto interés.

A partir de aquí toman protagonismo dentro de la vía pecuaria las grandes infraestructuras existentes en el territorio que atraviesan esta parte de la vega en condiciones sobreelevadas para evitar posibles inundaciones debido a los recurrentes desbordamientos de las aguas del río Guadalquivir: el viaducto de Itálica, la carretera E-803 (Autovía Ruta de la Plata) que se desarrolla en talud y el viaducto del ferrocarril de Sevilla a Huelva.

Se trata de una carretera asfaltada, con ausencia de bermas laterales y que se encuentra algo encajada, debido fundamentalmente a las citadas infraestructuras. La vegetación está asociada principalmente a las lindes de parcelas donde se desarrollan los usos deportivos e industriales existentes, a las pantallas vegetales propias de las vías existentes y a la vegetación riparia asociada al cauce semipermanente que se desarrolla bajo la Autovía Ruta de la Plata.

La parte final del recorrido presenta abundante vegetación arbórea formada por paraísos, ailantus, adelfas y otras especies de carácter ornamental (palmeras, cipreses) debido a la existencia de dos construcciones destinadas principalmente a usos hosteleros y de restauración.

A poco más de $0,5 \mathrm{~km}$. existe una rotonda de circulación de salida y entrada de la SE-30 que conecta con la carretera nacional $\mathrm{N}-630$ (antigua Vía de la Plata). A partir de este punto, el Corredor Verde discurre en paralelo a la carretera N-630, y presenta un trazado asfaltado, sin arcén o berma lateral hasta que cruza un pequeño túnel que salva dicha carretera de conexión con el norte peninsular y vía de peregrinación al formar parte del itinerario de la Vía de la Plata del Camino de Santiago. De este modo se finaliza el recorrido en el 
núcleo urbano de Santiponce, a la altura del teatro romano de Itálica que forma parte del Conjunto Monumental Ruinas de Itálica.

\section{b. Conectividad y articulación}

La puesta en valor de itinerarios y vías que conecten ámbitos urbanos densamente poblados con su entorno natural próximo, tal y como plantean las nuevas estrategias de recuperación de vías pecuarias, suponen que dichos itinerarios discurran por un territorio con una densa red de infraestructuras que lo atraviesan y articulan.

El caso del Corredor Verde Metropolitano de Sevilla se ajusta a esta realidad, en especial la fase Il que transcurre por un pasillo natural de comunicaciones norte-sur que ha sido utilizado como tal desde los primeros momentos de ocupación histórica del territorio. Asimismo, la necesidad de salvar el elemento natural de mayor entidad en el conjunto de la vega, el curso del río Guadalquivir, ha dado lugar al desarrollo de infraestructuras que permitieran las conexiones este-oeste. A ello hay que añadirle el hecho de ser un espacio estratégico en las inmediaciones de la ciudad de Sevilla, cuya centralidad en la aglomeración urbana es indiscutible.

En este pasillo natural se han sucedido de manera casi paralela las tres grandes infraestructuras de la histórica Vía de la Plata que han conectado la ciudad de Sevilla con el norte peninsular: la A-8078, la N-630 y A-66. En la actualidad, las dos últimas están directamente relacionadas con el cordel de Gambogaz: la carretera nacional N-630, visible desde el cordel y con la que se encuentra al final del recorrido del mismo en la entrada a la localidad de Santiponce; y la A-66, Autovía Ruta de la Plata, que también se hace presente durante gran parte del recorrido, debiendo salvarse por un viaducto a la altura del polígono industrial Los Girasoles (Camas).

En lo que respecta a las infraestructuras que discurren en dirección este-oeste salvando el río Guadalquivir y que se cruzan en el recorrido del cordel de Gambogaz, hay que señalar la SE-30, que se salva por el viaducto de Itálica una vez pasado el puente del Alamillo y el viaducto del ferrocarril Sevilla-Huelva. Por otra parte, hay que destacar como otro paso este-oeste para salvar el río la importancia del puente de la Señorita, que permite el tránsito peatonal y de bicicletas y es la vía de acceso al cordel de Gambogaz desde la ciudad de Sevilla.
Desde el punto de vista de la conectividad del cordel de Gambogaz con otros itinerarios públicos y recreativos hay que señalar la existencia de diversas infraestructuras pertenecientes a distintas administraciones públicas, como otros tramos del Corredor Verde, el trazado de la vía de peregrinación de la Vía de la Plata del Camino de Santiago, itinerarios ciclistas del Plan Andaluz de la Bicicleta, así como la Vía Verde de Ruinas de Itálica a Cala.

Esta conectividad del cordel de Gambogaz no se limita sólo a otros caminos e itinerarios, sino que posibilita el acceso y conexión con algunos espacios libres de interés de la aglomeración urbana de Sevilla, conformando una parte de la red de espacios libres metropolitanos e interconectados tal y como se determina en los documentos de planificación física del ámbito. Dentro de estos espacios públicos destacan especialmente las riberas del Guadalquivir, el Parque Metropolitano de Sevilla y el Parque Agrario de Camas.

\section{c. Condiciones escénicas y visibilidad}

Como ya se ha señalado, el territorio por el que transcurre el cordel de Gambogaz tiene unas condiciones topográficas determinantes en relación con la visibilidad del itinerario, existiendo una gran intervisibilidad entre la Ilanura aluvial del Guadalquivir en el fondo de valle y los espacios elevados próximos, como el escarpe del Aljarafe en la margen derecha del río.

Para abordar el tratamiento de las condiciones escénicas y de visibilidad de la vía pecuaria considerada se ha analizado el grado de exposición visual del entorno, así como las características específicas del propio recorrido desde el que se obtienen vistas de elementos o referentes visuales destacados.

En relación con la exposición visual, concepto que específicamente hace referencia al número de veces que un determinado espacio resulta visible desde un conjunto de puntos de observación, se han establecido tres categorías: muy alta, alta y moderada exposición visual.

- Muy alta exposición visual: el hecho geográfico fundamental en relación con esta categoría es el escarpe del Aljarafe en la margen derecha del río. La amplitud del valle y la elevación de esta cornisa permiten obtener vistas de estas elevaciones desde gran parte del recorrido del cordel. Por lo que respecta a la margen izquierda, los elementos arbóreos 


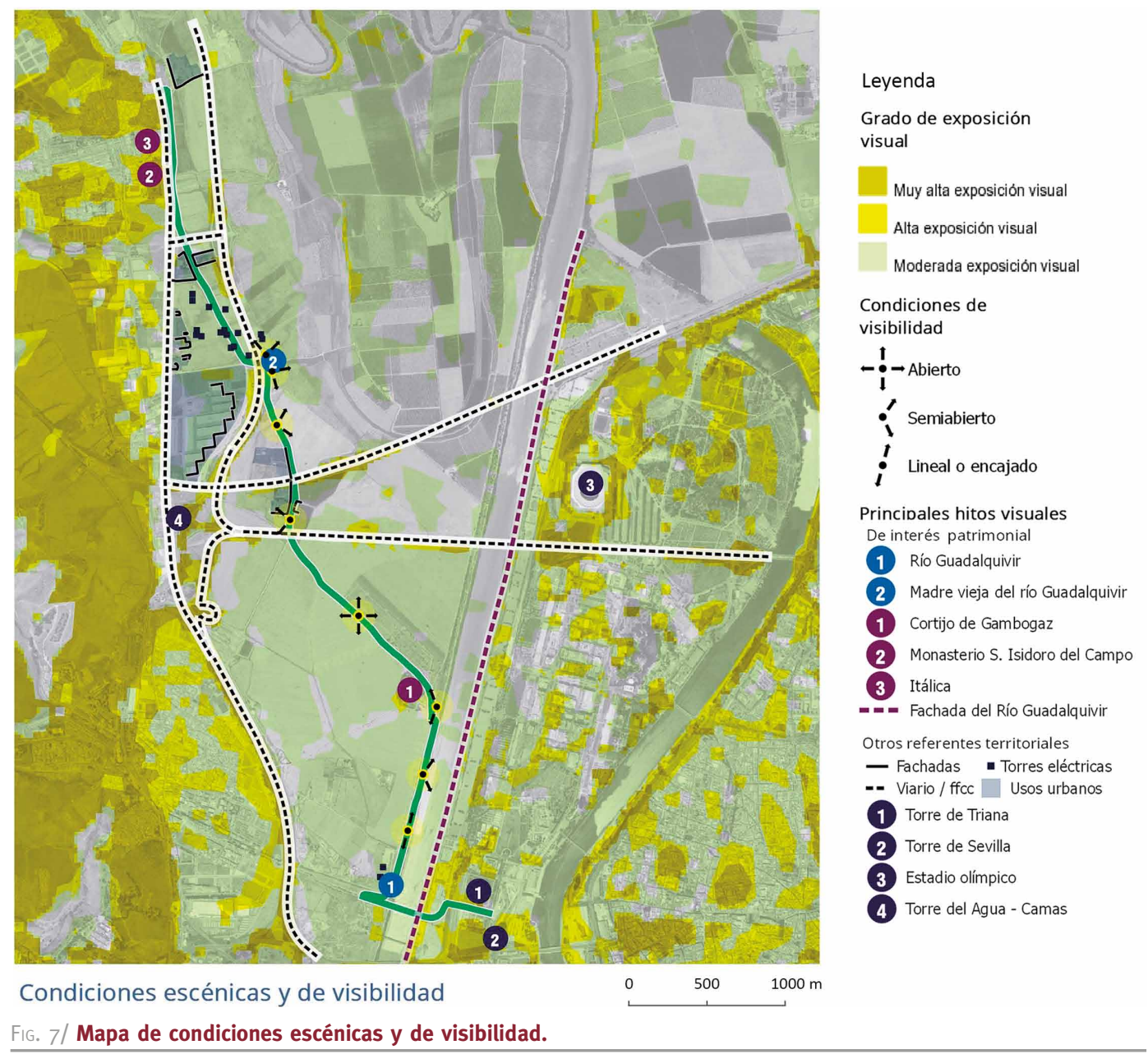

Fuente: Elaboración propia.

de la ribera del río se convierten en los más visibles desde el recorrido, así como las edificaciones más elevadas del sector norte de la Cartuja y, en un tercer plano, la fachada urbana interior de la dársena del Guadalquivir.

- Alta exposición visual: dentro de esta categoría se incluyen aquellas edificaciones de las localidades de Camas y Santiponce más próximas a las infraestructuras viarias, así como otras edificaciones destacadas de la ciudad de Sevilla.

- Moderada exposición visual: gran parte del valle del Guadalquivir por cuyas proximidades transcurre el cordel de Gambogaz se encuentra en esta categoría, ya que si bien son espacios muy llanos la amplitud que poseen permiten estar moderadamente expuestos a la visión desde el itinerario.

Por lo que respecta a visibilidad específica del cordel de Gambogaz (FIG. 7), hay que señalar que, al tratarse de un trazado lineal, son las condiciones de la topografía y de la vegetación del ámbito por el que discurre la vía las que tienen una mayor incidencia en la profundidad de las vistas frontales y laterales que se pueden obtener desde la misma.

Estas condiciones de visibilidad se determinan en función de la longitud y amplitud que alcanza la vista al recorrer el itinerario, pudiéndose distinguir desde vistas abiertas o semiabiertas a vistas completamente encajadas o cerradas.

Las vistas abiertas, que se caracterizan por tener una amplitud alta o panorámica y una profundidad también elevada, se concentran en el cordel de Gambogaz en el tramo que discurre entre el cortijo del mismo nombre y el viaducto de Itálica, al atravesar por tierras de labor con una cierta extensión, así como en el puente de la Señorita desde donde se obtienen amplias vistas del río Guadalquivir. 
Por otra parte, las vistas semiabiertas son las más comunes en el conjunto del recorrido, pudiendo alcanzar una longitud de visión de hasta $1,5 \mathrm{~km}$. pero con una amplitud media o parcial del campo visual. Ejemplos de estas vistas se localizan en las proximidades del cortijo de Gambogaz y en las proximidades de la fachada este del polígono industrial Los Girasoles, que ofrecen vistas hacia la vega del Guadalquivir y la cornisa del Aljarafe.

Finalmente, algunos de los tramos del recorrido presentan un campo visual lineal o cerrado donde la vista se encaja con una escasa amplitud lateral y con una profundidad media que no alcanza a la visión de un tercer plano. El tramo más representativo en este sentido se corresponde con la primera parte del recorrido cuando discurre por la margen derecha del Guadalquivir en dirección al cortijo de Gambogaz, si bien existen algunas ventanas propiciadas por la existencia de elementos arbóreos de escaso porte o por la ausencia de vegetación, que muestran vistas del curso de agua y de la otra margen del río.

En lo que respecta a los principales hitos hay que señalar que se consideran así los puntos o elementos de atracción visual que focalizan las vistas del territorio en el que se localizan y sirven como puntos de orientación o de referencia dentro del campo visual en el que se sitúan.

Cumpliendo estas funciones, es posible identificar elementos visualmente destacados y con interés patrimonial, como es el caso en el cordel de Gambogaz del río Guadalquivir y la Madre Vieja, del cortijo de Gambogaz, del monasterio de San Isidoro del Campo o del teatro romano de Itálica.

Asimismo, existen otros elementos destacados por ser referentes visuales de gran entidad en el ámbito que, al igual que en el caso anterior, son muy visibles desde distintos puntos del recorrido y se convierten en elementos de referencia y orientación cuando se recorre el cordel. Es el caso de la Torre Sevilla, la Torre Triana o el estadio olímpico de Sevilla en la margen izquierda del río o de la torre de EMASESA de Camas en la margen derecha.

\section{d. Identificación de recursos patrimoniales}

En el entorno del itinerario del cordel de Gambogaz existen referentes patrimoniales de gran entidad, tanto de carácter natural como cultural, que suponen un aliciente para el recorrido recreativo y didáctico por el mismo.

En lo que respecta a los referentes naturales destaca especialmente el río Guadalquivir, un elemento estructural de primer orden en la conformación de la ciudad de Sevilla y su entorno, que condicionó el origen de la ciudad y su evolución histórica. En la búsqueda de una solución por controlar las inundaciones recurrentes se realizaron en el curso bajo del Guadalquivir desde finales del siglo XVIII sucesivas cortas para modificar el trazado del río a su paso por la ciudad. La última de estas grandes intervenciones fue la corta de la Cartuja (1982), determinante en la reorganización del espacio que recorre el cordel de Gambogaz. Por una parte, supuso una ruptura del trazado histórico de esta vía pecuaria, al quedar cortado el tramo que unía el monasterio de la Cartuja con el cortijo de Gambogaz por el paso del nuevo cauce artificial del río; pero, por otra parte, la presencia de este brazo y de su vegetación de ribera asociada se constituye en un recurso natural de gran relevancia para el Corredor Verde Metropolitano de Sevilla.

Otro referente, aunque más difícil de identificar visualmente, es la Madre Vieja del Guadalquivir, un brazo secundario de este río que transcurría paralelo al mismo entre Santiponce y San Juan de Aznalfarache y que conectaba con el cauce principal a través de uno de los tramos del Rivera de Huelva. El cauce de la Madre Vieja fue sufriendo diversas modificaciones hasta su desaparición, pero algunos pequeños cursos semipermanentes de agua han ocupado algunos tramos, permitiendo la vegetación de ribera asociada a los mismos observar por donde podía transcurrir.

Finalmente, otro elemento natural a destacar es la cornisa norte del Aljarafe, cuya relevancia territorial en el conjunto del ámbito la convierte en un referente ambiental y paisajístico de primer orden.

En relación con el patrimonio cultural presente a lo largo del recorrido se cuenta con elementos muy destacados y diversos en cuanto a entidad, tipología y época histórica, hecho que supone una oportunidad de conocer los procesos históricos más relevantes en la conformación de este espacio. En este sentido y de manera sintética se identifican: el teatro romano de la ciudad de Itálica, construido entre los siglos I a. C. y I d. C., el enclave monumental de San Isidoro del Campo, monasterio medieval actualmente perteneciente a la Red de Espacios Culturales de Andalucía y el cortijo de Gambogaz, una de las mejor documentadas y más paradigmáticas explotaciones agrícolas de toda Andalucía con origen en una alquería medieval.

\section{e. Incidencias territoriales y urbanísticas}

El cordel de Gambogaz discurre por la Aglomeración Urbana de Sevilla que ocupa una superficie de $4.900 \mathrm{Km}^{2}$, compuesta por $46 \mathrm{mu}$ nicipios y con una población total de 1.535.379 habitantes (INE, 2016). 
En este contexto territorial, donde las dinámicas y los flujos que se suceden tienen una clara vocación metropolitana, resulta de interés revisar las consideraciones que los documentos de planificación física, territoriales y urbanísticos, establecen para el cordel de Gambogaz y su entorno más próximo.

Desde una escala regional y subregional los documentos de planificación física que tienen incidencia en el cordel de Gambogaz y su entorno próximo son el Plan de Ordenación del Territorio de Andalucía (POTA, 2006) y el Plan de Ordenación del Territorio de la Aglomeración Urbana de Sevilla (POTAUS, 2009). Estos documentos tienen en común, en relación con el cordel de Gambogaz, una directriz general de protección ambiental y patrimonial de los espacios sobresalientes -en los que se incluyen la red de vías pecuarias y las márgenes fluviales-, que potencie su recuperación y su inclusión en las redes de espacios libres y fomento del uso público.

En esta misma línea se manifiestan los documentos de planificación municipal, que en el caso del cordel afecta a los municipios de Sevilla (PGOU de Sevilla, 2006), Camas (PGOU de Camas, 2000) y Santiponce (NNSS de Santiponce, 1993). En todos ellos se contemplan las afecciones derivadas de las leyes sectoriales y establecen su condición de suelo no urbanizable, si bien son conscientes de que esta circunstancia no siempre ha sido respetada, abogando todos por la necesidad del deslinde y amojonamiento de la vía pecuaria y su incorporación en el sistema de espacios libres metropolitano.

\subsection{Diagnóstico paisajístico del itinerario}

El diagnóstico en relación con los recursos paisajísticos del cordel de Gambogaz se centra en la identificación de manera sintética de los principales valores y conflictos que se observan en el ámbito de estudio, especialmente aquellos relacionados con el itinerario de la vía pecuaria (FIG. 8).

\subsubsection{Potencialidades y recursos}

En relación con los recursos y potencialidades y de manera muy sintética, se recogen tanto los principales valores paisajísticos del propio ámbito como aquellas circunstancias y elementos que

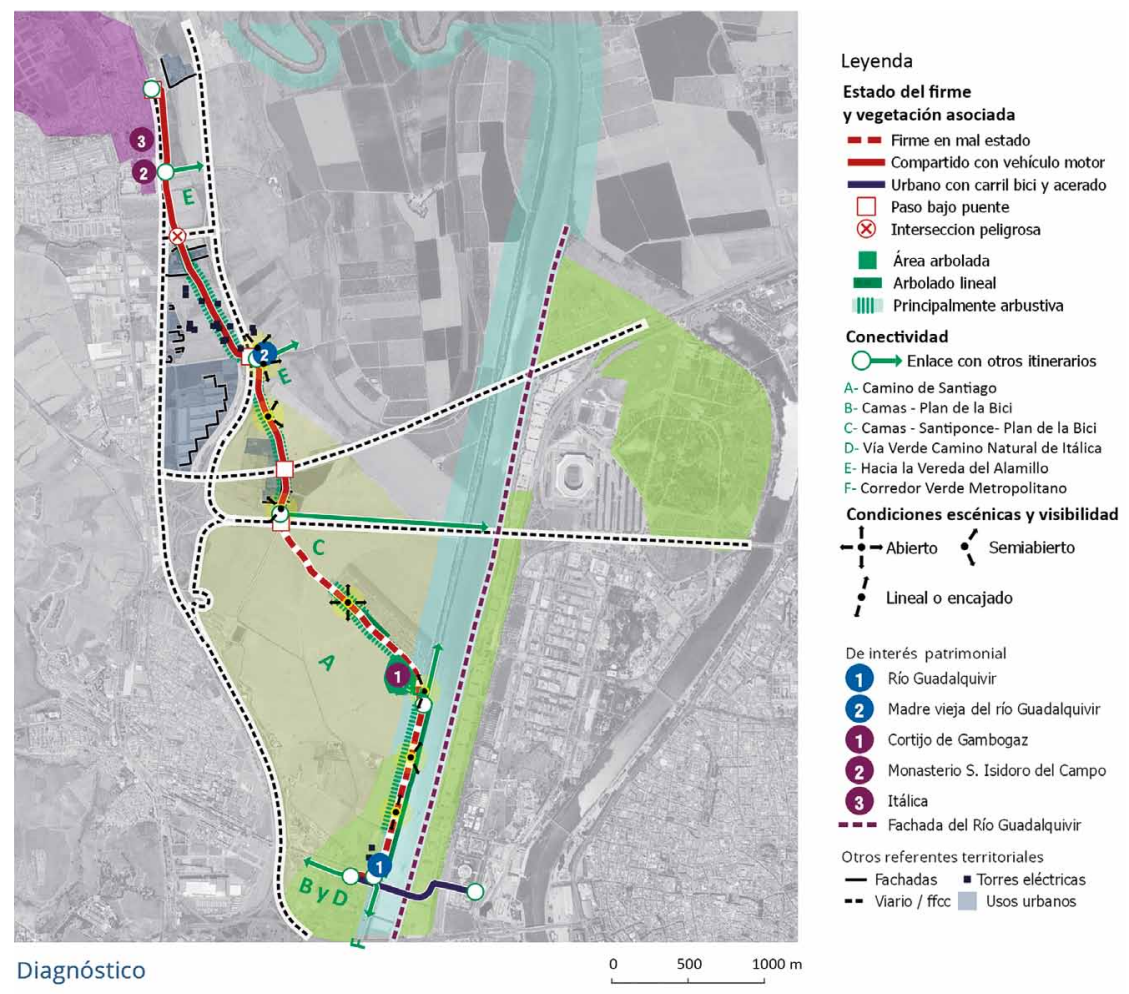

FIG. 8/ Mapa de diagnóstico. 
contribuyen de manera significativa a una mejor calidad paisajística del territorio por el que transcurre el cordel de Gambogaz. A continuación, se relacionan las principales potencialidades identificadas:

- El itinerario permite el acceso a un ámbito estratégico en el contexto de la aglomeración metropolitana de la ciudad de Sevilla, donde además se localizan espacios que cuentan con valores ambientales y paisajísticos como el río Guadalquivir y su vega y la cornisa del Aljarafe.

- Las condiciones escénicas del itinerario favorecen el establecimiento de vistas de conjunto sobre el sector noroccidental de la aglomeración urbana de Sevilla, así como una gran variedad de situaciones a medida que se recorre el camino: campos visuales abiertos o semiabiertos, ventanas hacia espacios sobresalientes, vistas de gran amplitud.

- El cordel de Gambogaz forma parte de la red de vías pecuarias existentes en la provincia, muchas de ellas recuperadas para el uso público, por lo que se articula una red de itinerarios relacionados con el uso recreativo y el disfrute social. Esta red está conectada con otros itinerarios verdes que permiten el recorrido, tanto peatonal como ciclista, de manera continua por el ámbito.

- Existen relevantes manifestaciones patrimoniales asociadas al itinerario que, debido a su emplazamiento y entidad, se convierten en importantes hitos paisajísticos del recorrido: cortijo de Gambogaz, monasterio de San Isidoro del Campo, Itálica (FIG. 9).

- La conectividad del cordel no sólo se establece con otros itinerarios de interés, sino que además conecta con espacios libres del ámbito metropolitano, contribuyendo a la consolidación de la red de espacios libres, metropolitanos y municipales, recogidos en la planificación física del territorio.

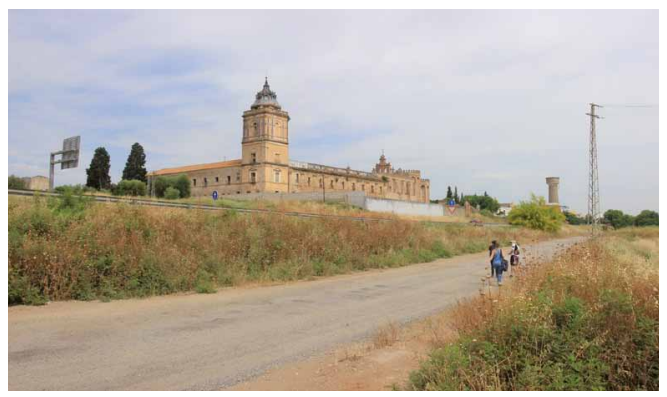

FIG. 9/ Cordel de Gambogaz a su paso por el monasterio de San Isidoro del Campo.
- La importancia del emplazamiento junto al eje vertebrador de la aglomeración urbana de Sevilla, como es el río Guadalquivir, así como la compleja herencia histórica de este territorio (Ruta de la Plata, trashumancia, restos arqueológicos) confieren a este espacio y al itinerario del cordel de Gambogaz una gran potencialidad para poner en valor esta riqueza territorial y paisajística existente.

\subsubsection{Conflictos y amenazas}

Por lo que respecta a las circunstancias que se pueden identificar como conflictivas o degradantes para la calidad paisajística del cordel analizado, se pueden señalar las siguientes:

- El uso recreativo y peatonal para el que se conciben las vías pecuarias en la actualidad no siempre se puede desarrollar dadas las condiciones en las que se encuentran algunos tramos del viario, con un firme inadecuado para el tránsito en bicicleta o de manera peatonal.

- La ausencia de vegetación de porte arbóreo en la mayor parte de los tramos del recorrido, así como las escasas zonas de sombra que permitan la estancia y el descanso.

- La compatibilidad de usos, tanto de carácter recreativo como de itinerario de acceso a instalaciones próximas, resulta difícil cuando estas últimas se realizan con vehículos motorizados de gran envergadura, existiendo tramos y puntos de cierta peligrosidad por la confluencia de tramos peatonales y rodados.

- Estos usos identificados requieren la existencia de una señalización clara en los accesos y cruces con otras vías que extreme las condiciones de seguridad en el tránsito y evite puntos de peligro. Aeste déficit de señalética reglada para el tráfico rodado se suma la escasez de elementos de identificación que orienten al usuario respecto al itinerario a seguir, así como otros de carácter divulgativo que aporten una información de interés sobre los elementos territoriales próximos.

- La alta incidencia visual de numerosas infraestructuras, tanto viarias y ferroviarias como relacionadas con la red eléctrica, que tienen una gran presencia a lo largo del recorrido. Igualmente, existen diversas traseras de polígonos industriales cercanos, así como edificaciones y construcciones de actividades terciarias con escasa integración paisajística. Asimismo, es posible encontrar en las proximidades del cordel algunas edificaciones que se encuentran en estado ruinoso y muy degradadas, circunstancia que no contribuye a la calidad de la experiencia paisajística a lo largo del recorrido. 


\subsection{Criterios para la cualificación paisajística del itinerario}

Como criterios para la cualificación paisajística del itinerario se contemplan un conjunto de ideas que pueden ser consideradas para la articulación de actuaciones concretas, vinculadas, tanto a la mejora de las condiciones de estancia de la propia vía pecuaria, como al fomento del acceso y la comprensión de los paisajes que esta recorre. En cualquier caso, estas ideas se plantean en un nivel propositivo intermedio, no sustituyendo en ninguna circunstancia al necesario proyecto específico de formalización y cualificación.

Estas ideas se agrupan en tres grandes categorías y a su vez se subdividen en objetivos dentro de cada una de ellas ${ }^{3}$ :

\subsubsection{Tratamiento de la vía y su señalización}

El buen estado de la vía y una adecuada señalización suponen elementos básicos para garantizar la realización del recorrido en unas condiciones apropiadas de comodidad y seguridad, permitiendo que el viandante o ciclista pueda disfrutar de la experiencia sensorial de forma plena. Dos aspectos son esenciales a tener en cuenta: por una parte, que el firme sea estable y libre de obstáculos, garantizando una efectiva separación con flujos de vehículos motorizados que comparten parte de los tramos. Por otra, que la señalización sea clara y sirva de orientación en todo el itinerario, indicando los accesos a la vía, enlaces con otros recorridos, puntos críticos con respecto a la seguridad (cruces, puentes, etc.) así como elementos de interés cultural o ambiental. Por tanto, los objetivos en la actuación deberían ser:

- Mejorar las condiciones de la vía: firme, puntos críticos y tramos compartidos con vehículos de motor.

- Estrategia de señalética. Accesos, tramos, enlace con otras vías, espacios de interés y puntos peligrosos.

\subsubsection{Cualificación ambiental del recorrido}

La vegetación presente en la vía y la existencia de un pequeño equipamiento que la acompañe, son dos de los elementos que más contribuyen

\footnotetext{
${ }^{3}$ En el trabajo que ha dado lugar a este artículo se incluyen una serie de fichas con los posibles lugares de actuación, los criterios específicos y un conjunto de proyectos de
}

a generar unas condiciones de confort en el itinerario y a que se desarrollen diferentes actividades complementarias asociadas al propio recorrido. La cualificación de los márgenes con especies autóctonas que han ido desapareciendo, principalmente por la acción antrópica, puede contribuir a la integración ambiental de la vía pecuaria con una mejor adaptación climática y con poco mantenimiento (FIG.10). Estos criterios se articulan a partir de los siguientes objetivos:

- Generar áreas de sombra a lo largo del recorrido y de minimización de ciertos frentes tensionados por las urbanizaciones.

- Proveer zonas de estancia y de pequeño equipamiento asociado (bancos, fuentes, papeleras) en lugares estratégicos.

\subsubsection{Sensibilización, uso y disfrute paisajístico}

La vía pecuaria puede ser un excelente elemento que contribuya a la identificación de la ciudadanía con sus paisajes. Por una parte, es necesaria la adecuación con miradores de aquellos espacios con singulares condiciones de visibilidad, incorporando además información que permita mejorar la lectura territorial y el conocimiento y comprensión de los elementos relevantes existentes. Por otra parte, se debe favorecer la mejora de las cualidades escénicas de determinados espacios en los que las infraestructuras y los usos periurbanos dominan la escena, fomentando la realización de acciones creativas y singulares que puede conducir a su mayor integración o a crear nuevos paisajes, y enriquecer la relación que el usuario tiene con ellos. En este sentido, los objetivos prioritarios serían:

- Adecuar puntos con especiales cualidades visuales e integrar dispositivos de divulgación de los recursos patrimoniales y de los paisajes asociados.

- Integrar infraestructuras y otros impactos negativos: acciones artísticas y de tratamiento vegetal.

\section{Conclusiones}

Las vías pecuarias son un elemento territorial, ambiental, patrimonial y cultural de primer orden en el conjunto de España, cuyo origen se encuentra en la importancia de la actividad ganadera

referencia que pretenden ejemplificar diferentes intervenciones en contextos similares. 


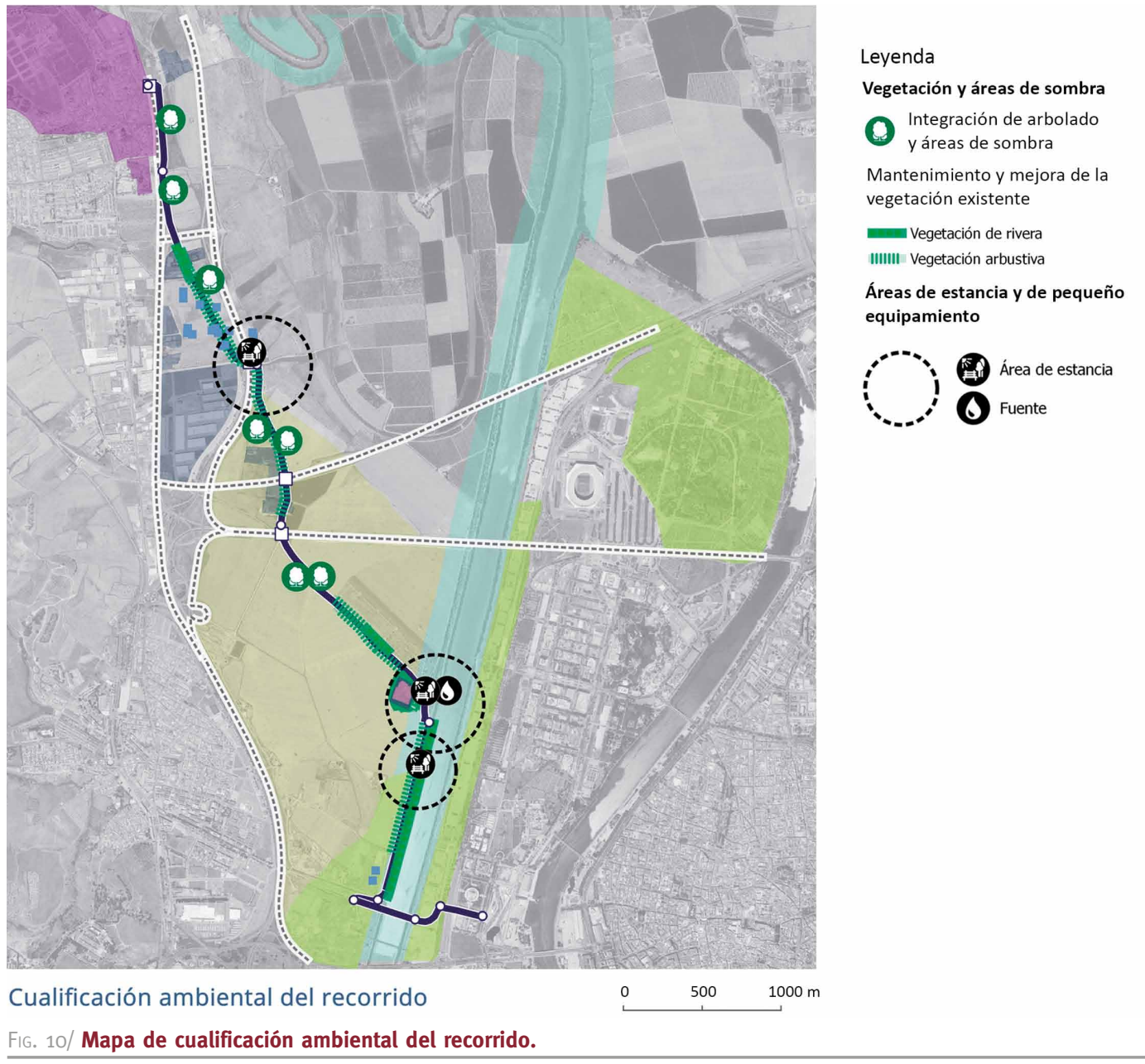

Fuente: Elaboración propia

y de la trashumancia a lo largo de la historia, siendo dichas vías consideradas como bienes de dominio público y formando parte, por lo tanto, del patrimonio de la sociedad.

Si bien hoy día el tránsito pecuario es la actividad tradicional y prioritaria de las vías pecuarias, la disminución de la trashumancia en la vida contemporánea ha abierto la posibilidad al desarrollo de otras actividades, complementarias y compatibles, en las mismas, tal y como recogen distintas regulaciones normativas vigentes: usos ecológicos y usos turístico-recreativos.

En el caso de Andalucía, existe una importante red de vías pecuarias deslindadas y en uso público que constituyen un patrimonio territorial y cultural de gran relevancia para la región, al tiempo que se configura como un valioso equipamiento para el acceso y disfrute de la naturaleza y del medio rural. Esta perspectiva de uso público acentúa su potencial como elemento para el acceso, conocimiento y disfrute del paisaje, en la medida en que su recorrido ofrece numerosas posibilidades y recursos: vistas del territorio circundante; claves explicativas de los usos y funciones -pasadas y presentes-, del itinerario; referencias de la construcción histórica del territorio por el que discurre, entre otros.

En este sentido, recorrer las vías pecuarias constituye un instrumento fundamental para descubrir el paisaje, asignándole valores y significados, y su recorrido no motorizado proporciona una forma de aproximación al territorio y a la naturaleza integradora y holística; aproximación en la que se conjugan los aspectos objetivos y subjetivos, materiales e inmateriales, visibles y no visibles, presentes y ausentes que se relacionan en torno a la noción de paisaje. 
Resulta imprescindible por tanto profundizar en el estudio de la vinculación existente entre paisaje y vías pecuarias, que aún no ha sido suficientemente desarrollada y que podría sustentarse en la relación fundamental que existe entre paisaje y movimiento, donde la apreciación dinámica del territorio convierte un itinerario en un hilo conductor de una sucesión de paisajes.

Esta vinculación entre paisaje y vías pecuarias favorece el potencial de las mismas como dotaciones para la sensibilización y el disfrute paisajístico de la población, y contribuye a incrementar el aprecio social por los valores ambientales, culturales y escénicos de los distintos ámbitos geográficos por los que discurren dichas vías.

Además, resulta necesario el desarrollo de procesos metodológicos de análisis y reconocimiento de los valores paisajísticos asociados a las vías pecuarias, que permitan sistematizar su consideración y los posibles criterios de intervención. En este sentido es imprescindible abordar el tratamiento paisajístico de las vías pecuarias a distintas escalas, teniendo en cuenta tanto el paisaje interior de la vía como el contexto paisajístico de la misma.

Igualmente, desde el punto de vista metodológico es aconsejable desarrollar la noción de diversificación paisajística en relación con las vías pecuarias siguiendo distintos enfoques (diversificación ambiental, escénica, funcional, de significados) tomando en consideración los nuevos usos que tanto desde la administración como desde la ciudadanía se han ido incorporando.

Finalmente, la puesta en valor de las vías pecuarias y su paisaje, en tanto que recursos endógenos con los que cuentan los diversos territorios, puede contribuir a implementar modelos de desarrollo socioeconómicos sostenibles; así mismo, en la medida que favorecen el contacto con la naturaleza y el desarrollo de actividades saludables, las vías pecuarias contribuyen a la mejora de la calidad de vida de la población.

\section{Bibliografía}

Agencia de Obra Pública de la Junta de Andalucia (AOPJA) (2017): Las carreteras paisajísticas de Andalucía. Recurso para el disfrute y aprecio social del paisaje, Consejería de Fomento y Vivienda, Junta de Andalucía. Centro de Estudios Paisaje y Territorio (CEPT), Universidad de Sevilla.

ApPleYARD, D. \& LYNCH, L. \& MyeR, J.R. (1971): The view from the Road. Cambridge, The Massachusetts Institute of Technology, $58 \mathrm{pp}$.

Bertrand, M. J. (1978): Pratique de la ville. Paris, Masson, $210 \mathrm{pp}$.
Besse, J.M. (2010): El espacio del paisaje. En III Jornadas del Doctorado en Geografía. Desafíos Teóricos y Compromiso Social en la Argentina de Hoy. La Plata: Universidad Nacional de La Plata, <jornadasdocgeo.fahce.unlp.edu.ar/programa-2010> (14 febrero 2013).

CAPEL, H. (1973): Percepción del medio y comportamiento geográfico. Revista de Geografía, $\mathrm{n}^{\circ} 7$, pp. 58-150.

Caballero Sánchez, V. \& Domínguez Vela, J.J. \& Zoido NARANJo, F. (2016): Experiencia del paisaje, movilidad y red viaria. Sevilla, Consejería de Fomento y Vivienda, Agencia de Obra Pública de la Junta de Andalucía, Universidad de Sevilla, Centro de Estudios Paisaje y Territorio.

Calvo Salazar, M. (2001): Mesa debate Las Vías pecuarias y los Corredores Verdes en la Ordenación del Territorio. En Conferencia Internacional de Vías Pecuarias y Corredores Verdes. Chiclana de la Frontera 21-24 noviembre 2001. Junta de Andalucía.

Clavero Salvador, J. (2001): Función social de las Vías Pecuarias. En Conferencia Internacional de Vías Pecuarias y Corredores Verdes. Chiclana de la Frontera 21-24 noviembre 2001. Junta de Andalucía.

Consejo de Europa (2000): Convenio Europeo del Paisaje. Florencia. Editado en español en Convenio Europeo del Paisaje. Textos y comentarios. Madrid, Ministerio de Medio Ambiente.

Consejo de Gobierno de la Junta de Andalucía (2001): Plan para la Recuperación y Ordenación de la Red de Vías Pecuarias de la Comunidad Autónoma de Andalucía, aprobado mediante Acuerdo del Consejo de Gobierno de fecha 27 de marzo de 2000. BOJA 74/2001, de 30 de junio.

Corredor Verde del Área Metropolitana de SeVilla (2003): Sevilla, Dirección General de Educación Ambiental, Consejería de Medio Ambiente, Junta de Andalucía.

Cosgrove, D. (2002): Observando la naturaleza: el paisaje y el sentido europeo de la vista. Boletín de la Asociación de Geógrafos Españoles, n³4, pp. 63-89.

Decreto 155/1998, de 21 de julio, por el que se aprueba el Reglamento de Vías Pecuarias de la Comunidad Autónoma de Andalucía. Boletín Oficial de la Junta de Andalucía, no 87 de 4/8/1998.

ESPAÑOL ECHÁNIZ, I. (2007): Carretera, movilidad y percepción. Criterios para la gestión de la función paisajística de las carreteras. En: 1er Congreso Paisaje e Infraestructuras. Libro de Actas (pp. 455-473), Sevilla: Consejería de Obras Públicas y ViviendaCentro de Estudios Paisaje y Territorio.

Fernández Salinas, V. \& Silva Pérez, R. (2015): Los paisajes en movimiento. El conocimiento paisajístico de Andalucía a través de la carretera. En DE La Riva, J., IBARRA, P., Montorio \& R., Rodrigues, M. (Eds.) Análisis espacial y representación geográfica: innovación y aplicación (pp. 953-960), Zaragoza, Universidad de Zaragoza-AGE.

GovindA, A. (2014): La senda de las nubes blancas. Gerona, Atalanta, 393 pp.

IMA Informe de Medio Ambiente en Andalucía. Informe 2018(2018). REDIAM, Consejería de Medio Ambiente, Junta de Andalucía.

KeSsLeR, M. (2000): El paisaje y su sombra. Barcelona, Idea Books, 86 pp. 
Ley $3 / 1995$, de 23 de marzo, de vías pecuarias. $B O E$ $\mathrm{n}^{\circ} 71$ de 24 de Marzo de 1995.

LuginBüHL, Y. (2007): Paisaje y calidad de vida. En 1er Congreso Paisaje e Infraestructuras. Libro de Actas (pp. 53-65), Sevilla, Consejería de Obras Públicas y Vivienda-Centro de Estudios Paisaje y Territorio.

Manteca Valdelande, V. (1995): Las vías pecuarias: evolución y normativa actual. Agricultura y Sociedad, $\mathrm{n}^{\circ} 76$ (julio-septiembre), pp. 153-186.

Merleau-Ponty, M. (1975): Fenomenología de la percepción. Barcelona, Península, 469 pp.

NoguÉ I Font, J. (2007): El paisaje como constructo social. En J. Nogué (Ed.) La construcción social del paisaje (pp. 11-24), Madrid, Biblioteca Nueva.

NNSS: Normas Subsidiarias Municipales de Santiponce (1993): Ayuntamiento de Santiponce. Junta de Andalucía.

Ortega Chinchilla, M.J. (2010): Percepción y representación. El territorio andaluz en la cartografía manuscrita del siglo XVIII. Granada, Universidad de Granada, 346 pp.

POTA: Plan de Ordenación del Territorio de Andalucía (2006): Junta de Andalucía.

POTAUS: Plan de Ordenación del Territorio de la Aglomeración Urbana de Sevilla (2009): Junta de Andalucía.

PGOU: Plan General de Ordenación Urbana de Camas (2000): Ayuntamiento de Camas. Junta de Andalucía.

PGOU: Plan General de Ordenación Urbana de Sevilla (2006): Ayuntamiento de Sevilla. Junta de Andalucía.
Prada Llorente, E.I. (2005): Paisaje agrario: antropología de un territorio. Ciudad Y Territorio Estudios Territoriales (CyTET), 37(144), 343-372.

Roger, A. (2007): Breve tratado del paisaje. Madrid, Biblioteca Nueva, $211 \mathrm{pp}$.

TuAn, Y.F. (2007): Topofilia: un estudio de las percepciones, actitudes y valores sobre el entorno. Barcelona, Melusina, $351 \mathrm{pp}$.

- (2018): Espacio y lugar. Una perspectiva humanística. En J. NoguÉ (Ed.) Yi-Fu Tuan. El arte de la geografía (pp. 53-110), Barcelona, Icaria.

Zoido Naranjo, F. (Dir.) (2009): Carreteras Paisajísticas. Estudio para su Catalogación en Andalucía. Sevilla, Consejería de Obras Públicas y Transportes, Junta de Andalucía y Centro de Estudios Paisaje y Territorio.

- \& al. (2013): El paisaje en el Conjunto Arqueológico de Itálica. Sevilla, Consejería de Educación, Cultura y Deporte, Junta de Andalucía.

- (2014): Bases para la realización del Sistema Compartido de Información sobre el Paisaje de Andalucía (SCIPA). Aplicación a Sierra Morena. Sevilla, Consejería de Medio Ambiente y Ordenación del Territorio, Centro de Estudios Paisaje y Territorio.

— \& Rodríguez, J. (Dir.) (2015): Catálogo de Paisajes de la provincia de Sevilla. Sevilla, Centro de Estudios Paisaje y Territorio, Consejería de Medio Ambiente y Ordenación del Territorio.

Recibido: 18.12..2019; Revisado: 09.07.2020

Correo electrónico: c.venegas@paisajeyterritorio.es; Nº ORCID: https://orcid.org/0000-0001-8682-1130;

Correo: irena.garcia@paisajeyterritorio.es; No ORCID: : https://orcid.org/0000-0003-2018-1884;

Correo: j.rodriguez@paisajeyterritorio.es; NoORCID: https://orcid.org/0000-0002-5202-6160;

Correo: acoronado@us.es; No ORCID: https://orcid.org/0000-0001-5702-9750;

Correo: velaboll@gmail.com; No ORCID: https://orcid.org/0000-0001-8366-4440;

Correo: bpedregal@us.es; NºRCID: https://orcid.org/0000-0003-1473-8463

Los autores agradecen los comentarios y sugerencias realizados por los evaluadores anónimos, que han contribuido a mejorar y enriquecer el manuscrito original. 
CIUDAD Y TERRITORIO

ESTUDIOS TERRITORIALES

ISSN(P): 1133-4762; ISSN(E): 2659-3254

Vol. LIII, № 207 , primavera 2021

Págs. 141-152

https://doi.org/10.37230/CyTET.2021.207.08

\title{
Ciudad informal, territorialidades de producción social del espacio urbano en asentamientos humanos
}

\author{
Yonier CASTAÑEDA-PÉREZ ${ }^{2}$ \\ Ana Catalina Hernández-Ramírez ${ }^{3}$
}

Docentes investigadores. Universidad La Gran Colombia (Armenia-Colombia).

RESUMEN: ${ }^{1}$ Se desarrolla la categoría de ciudad informal como acción de territorialización que se materializa por medio de producción social del espacio, en tanto proceso y producto de la segregación socioespacial urbana en la búsqueda del derecho al territorio. A su vez, se evidencia, a partir del caso de la ciudad de Armenia - Quindío (Colombia), cómo la configuración territorial de esta se debe, en gran medida, a la producción de ciudad informal, situación que debe ser tenida en cuenta por las diferentes políticas de ordenamiento territorial. Finalmente, se indaga en cómo las condiciones de un fragmento de ciudad informal en Armenia no solo han sido una respuesta de adecuación y superación de condiciones a las que han sido relegados sus pobladores, de igual forma, se revela que tal situación forma un escenario de su realidad que configura luchas por la territorialización de sus derechos.

PALABRAS CLAVE: Ciudad informal; Producción social del espacio; Segregación socio-espacial urbana; Derecho al territorio.

Recibido: 09.03.2020; Revisado: 18.06.2020;

Correo electrónico: castanedapyonier@miugca.edu.co; № ORCID: https://orcid.org/0000-0003-0484-0253.

Correo electrónico. hernandezramana@miugca.edu.co; No ORCID: https://orcid.org/0000-0003-0221-7636.

Los autores agradecen los comentarios y sugerencias realizados por los evaluadores anónimos, que han contribuido a mejorar y enriquecer el manuscrito original.

${ }^{1}$ Este artículo hace parte de los resultados que se arrojan en uno de los sectores de estudio del proyecto de investigación doctoral "Interpretaciones desde los intersticios. Una lectura de la producción social del espacio urbano informal en Armenia entre los años 1999-2019", que el autor CASTAÑEDAPÉrEz adelanta en el Doctorado en Estudios Territoriales de la Universidad de Caldas - Colombia.

${ }^{2}$ Arquitecto Universidad Nacional de Colombia, Magíster en Medio Ambiente y Desarrollo Sostenible Universidad de Manizales, Doctorando en Estudios Territoriales de la Universidad de Caldas, Docente-investigador Facultad de Arquitectura Universidad La Gran Colombia - Armenia (Armenia - Colombia). Líder del grupo de investigación en Territorio y Arquitectura Sustentable.

${ }^{3}$ Arquitecta Universidad La Gran Colombia - Armenia, Quindío. Magister en Hábitat Universidad Nacional de Colombia - sede Bogotá. Docente-investigadora Facultad de Arquitectura Universidad La Gran Colombia (Armenia - Colombia). 


\title{
Informal city, territorialities of social production of urban space in human settlements
}

\begin{abstract}
The category of informal city is developed as an action of territorialization that materializes the notion of the social production of space, as a process and product of urban socio-spatial segregation in the search for the right to territory. Subsequently, it is evidenced from the case of the city of Armenia (Colombia), how the territorial configuration of this and other cities is due, to a great extent, to the production of informal city, a situation that must be taken into account by the different policies of territorial ordering. Finally, it is investigated how the conditions of an informal city fragment in Armenia not only have been a response of adaptation and overcoming conditions to which their inhabitants have been relegated, in turn, it is evident that such situation forms a scenario of their reality that configures struggles for territorialization of their rights.
\end{abstract}

KEYWORDS: Informal city; Social production of space; Urban socio-spatial segregation; Right to territory.

\section{Introducción}

"La espacialidad humana en todas sus formas y expresiones se produce socialmente. Creamos nuestras geografías, para lo bueno y para lo malo, de forma justa e injusta. Por tanto, se puede decir de forma similar que creamos nuestras historias, bajo condiciones que no son de nuestra propia elección, sino en contextos del mundo real que ya han sido formados en el pasado por procesos socioespaciales (...)" (SoJA, 2014:149)

Los espacios urbanos informales, aceleradamente extendidos y presentes en gran parte de las ciudades del "sur global", son comúnmente vistos como una fuente de inestabilidad política y social, como la manifestación espacial de la exclusión social urbana, o como la producción de espacios al margen o en contraposición del orden formal (WACQUANT, 2007; TARDIN, 2006; DUHAU, 2003; ABRAMO, 2012a). Sin embargo, estos territorios empiezan a constituirse como una estrategia recurrente de acceso al espacio urbano, y su proliferación es evidencia de que no se trata de una maniobra excepcional de acción colectiva y resistencia (HARVEY, 2012); por el contrario, sus habitantes han demostrado que, en su formación social, estas territorialidades contienen diversas y creativas estrategias de producción de su propio hábitat (AUBÁN BORRELL, 2017) y, por tanto, son un producto espacial resultante de una necesidad social.

\section{Al respecto Fernández Wagner señala:}

"El acelerado crecimiento de las ciudades latinoamericanas que tendría lugar a partir de los años '50 provocado por importantes desplazamientos poblacionales, que superaban el crecimiento vegetativo de estas ciudades, encontrarán un parque habitacional que no podía albergar más población. Esto, asociado a la débil o inexistente planificación y/o un Estado con pocas posibilidades de construir viviendas nuevas provoca un proceso de asentamiento en tierras vacantes (en forma regular o irregular) en intersticios urbanos (en la mayoría de los casos en áreas no aptas para la urbanización) o la extensión de las periferias, así como el desarrollo de un proceso de construcción de viviendas por parte de los propios pobladores y la posterior lucha por la urbanización y regularización de los barrios. (FERNÁNDEZ WAGNER, 2008: 18)"

Esto significó que millones de nuevos habitantes urbanos pobres auto-produjeran su vivienda, los servicios, el equipamiento comunitario, su hábitat y su espacio; es decir, "construyeran" ciudad.

De ahí, la necesidad del estudio de estos hechos territoriales sin desconocer la vida social que allí ocurre, lo que requiere de un equilibrio analítico de lo que acontece entre su espacio y la sociedad, dado que, todo lo que es social coincide connaturalmente con lo espacial (APRILE-GNISET, 1992). Este enfoque evitaría, por un lado, que estos espacios sean vistos únicamente como un simple escenario $y$, por otro, que la conciencia espacial en la que estamos insertos intensifique múltiples formas de discriminación y multiplique las desigualdades urbanas existentes.

Se parte de la premisa de que la ciudad informal, en tanto hecho territorial y categoría de análisis, es producto de las dinámicas propias de una producción irregular del espacio urbano por parte de grupos humanos marginados o segregados; lo que es, a su vez, una acción colectiva sobre el suelo urbano motivada por la lógica de la necesidad (ABRAMo, 2003; ABRAMo, 2010; ABRAMo, 2012b; CraVINo, 2006) que impulsa a ejercer el derecho al territorio (NATES-Cruz, 2018), a la ciudad (LefEBVRE, 1968; HARVEY, 2012) y a la justicia espacial (SOJA, 2014).

En tal sentido, y con el fin de darle un anclaje espacial al análisis de estos conceptos, se reconocen 
dichas características de la ciudad informal al abordar una ruta representativa en Armenia-Quindío (Colombia); ciudad que, por su condición de capital en un departamento localizado en el centro el país, se ha consolidado en respuesta a procesos migratorios tanto internos como externos al recibir población, particularmente, durante el éxodo rural desarrollado a partir de la segunda mitad del siglo XX en Colombia. Estos eventuales traslados de población en busca de trabajo y oportunidades configuraron en la ciudad un proceso de segregación territorial que se refleja en desigualdades de acceso al suelo urbano.

Resulta pertinente ahora, acotar dos hechos que marcaron un antes y un después en las dinámicas geosociohistóricas de dicha ciudad, ambos ocurridos en el año 1999. Uno de ellos lo constituyó la adopción del primer Plan de Ordenamiento Territorial (POT) para el municipio de Armenia (CONCEJO Municipal de ARMENIA, 1999), a su vez, el primero aprobado en el país producto de la Ley 388 (CoNgReso De La República De Colombia, 1997). El segundo, el fuerte sismo que sacudió la región del eje cafetero colombiano el 25 de enero de aquel año, justo un día después del primer hecho mencionado. Estos sucesos (que desencadenaron nuevas migraciones) a su vez modificaron, en buena medida, el patrón de ocupación del espacio urbano y dieron lugar a una nueva ciudad que subvirtió a la anterior al cambiar los usos del suelo y aumentar aceleradamente el consumo, la ocupación y la apropiación de espacios urbanos. Ambos acontecimientos marcaron un período importante en la reconfiguración del territorio y pusieron de manifiesto diferentes miradas y apuestas institucionales sobre las dinámicas socioespaciales de la ciudad en ese momento histórico.

Con todo y lo anterior, con el fin de constatar que ninguna sociedad, por elemental que sea, escapa a la necesidad de organizar el campo operatorio de su acción (RAFFESTIN, 2011: 106), el presente artículo indaga en cómo las condiciones de un fragmento de ciudad informal en Armenia ha sido una respuesta ingeniosa y muy eficiente de adecuación y superación de condiciones desfavorables a las que fueron relegados algunos grupos poblacionales (Puente Burgos, 2003: 11). Asimismo, se evidencia que tal situación no es independiente del funcionamiento de la sociedad ni del resto de la ciudad, sino que, por el contrario, se forma un escenario de la realidad de manera dialéctica entre el habitante - espacio, quien termina por buscar autonomía, expresar horizontes y sentidos, y que, finalmente, sitúa luchas específicas en la permanente territorialización de sus derechos.

No se trata, por tanto, de una nueva conceptualización de los términos marginal, irregular o informal y segregación, sino de la ejemplificación de estos en un escenario de ciudad informal en perspectiva de ejercicios de territorialización; en una vía de pensamiento que reconoce la necesidad de avanzar en un conocimiento que piense a las ciudades con sus sujetos para hacerlas más democráticas y más justas (Fraser, 2008; Cravino, 2006) al considerar al menos tres elementos: reconocimiento, redistribución y participación.

De modo que, se presenta un ejercicio que involucra complejidades territoriales, algo que demanda la identificación de sujetos y/o actores, y sus intereses (en ocasiones semejantes o disímiles), así como de los entramados institucionales y las relaciones de poder existentes y convergentes en la ciudad informal - en tanto hecho territorial y categoría de estudio- en un contexto cercano. Todo ello con el fin de prever si desde esta otra ciudad es posible crear ordenamientos espacio-temporales alternativos en los que los grupos humanos y los individuos puedan satisfacer sus necesidades y deseos; es decir, diferentes respuestas a quienes viven las implicancias de un modelo que mira de costado a miles de habitantes - especialmente a los grupos desposeídos en el acceso a un hábitat digno-y que les otorgue la oportunidad de ejercer su derecho al territorio.

\section{La ciudad informal: producto y proceso de segregación socioespacial urbana}

"Mientras crece sobre un suelo que es propiedad de pocos, la ciudad no puede ser patrimonio de todos" (Aprile-GnISET, 1992: 796).

En las ciudades, el hábitat informal implica dos formas de transgresión -no necesariamente excluyentes- con relación al proceso de urbanización. La primera se asienta en la falta de títulos de propiedad, es decir, respecto a los aspectos de dominio; la segunda, en el incumplimiento de las normas de urbanización y construcción de ciudad. Cada una de ellas se materializa en diferentes tipos de informalidad en los cuales intervienen múltiples actores que definen distintas formas de segregación urbana.

Por su parte, al hablar de segregación socioespacial urbana, esta implica un distanciamiento y separación localizada de grupos de población en sectores específicos de ciudad, con ello, se conforman áreas socialmente homogéneas. De acuerdo con Clichevsky, este tipo de segregación se presenta en el momento en que los espacios destinados para diversos grupos humanos no son utilizados o configurados de una manera integradora (2000). Lo que, en muchas ocasiones, se traduce en guetos urbanos. 
También es posible entender la existencia de segregación socioespacial cuando esta se produce a partir de dinámicas de (des)(re)territorialización que lleva a grupos humanos, bien sea, a auto producir su hábitat por fuera de los estándares urbanísticos y normativos formales (CASTAÑEDA-PÉREZ 2019), o bien, a establecer áreas socioeconómicas y culturalmente homogéneas al intentar acceder a un efectivo goce y disfrute de la ciudad. Este tipo de situaciones, que ocurren tanto en escenarios de informalidad urbana, como en sectores formales de ciudad, se configuran, según Abramo (2012b), en

\begin{abstract}
"convenciones urbanas [que] son jerarquizadas y sirven de mecanismo cognitivo, un mecanismo que garantiza la estructura segmentada y jerarquizada de las externalidades de vecindad y, por lo tanto, de la estructura socioespacial urbana segmentada (segregada) y desigual. (Pág. 59)"
\end{abstract}

De igual manera, la intervención pública influye en la división del suelo a través de la imposición de normas urbanísticas-, sin embargo, son las relaciones sociales las que finalmente orientan la organización (y ocupación) del espacio urbano (RoNCAYOLO, 1990); aunque estas no precisamente se oponen a los intereses privados ni corrigen las disposiciones asociadas con la segregación.

\subsection{Acerca de la ciudad informal}

Ahora bien, la ciudad informal tiene como particularidad, por un lado, ser producto de la ocupación individual o colectiva de suelos públicos o privados que, en muchos de los casos, no cuentan con las características necesarias para ser urbanizados; $y$, por otro lado, el conformar barrios carentes de servicios básicos por autoconstrucción de viviendas precarias al margen de las normas urbanísticas. Según PINO VÁsqUEZ y OJedA LedESMA (2013) la ciudad informal está conformada por todas aquellas prácticas urbanísticas instauradas, desarrolladas y consolidadas por fuera de la legislación, las normas y las dinámicas de mercado que permiten un acceso formal al suelo urbano y a la vivienda; e involucran, por tanto, la adquisición de terrenos y la autoconstrucción de las viviendas.

Se trata entonces, de una realidad territorial conformada por sujetos individuales o colectivos y actores sociales públicos o privados que configuran las condiciones urbanas para la formación y establecimiento de dichas territorialidades, constitutivas de los espacios urbanos informales. A su vez, se han convertido en reflejo de la segregación socioespacial en las ciudades latinoamericanas en donde, según el programa de las Naciones Unidas para los asentamientos humanos (ONU-HÁBITAT) "una de cada cuatro personas que habitan en áreas urbanas están ubicadas es este tipo de lugares"
(2012: 64) como resultado de los movimientos migratorios campo-ciudad y a la movilidad interurbana que recientemente se concentra en las ciudades intermedias y pequeñas (JANOSCHKA, 2005). Lo que ha producido una narrativa discontinua del territorio que se manifiesta en las grandes e injustas desigualdades urbanas (SABATINI, 2006; VARGAS-DÍAZ \& al., 2010) ante la principal alternativa que han tenido muchos hogares para resolver, aunque de forma inadecuada, sus necesidades habitacionales.

Esta forma de producción (social) del espacio no obedece únicamente al carácter jurídico de la propiedad, la cual convencionalmente estipula que para tener derecho y disponer sobre de ella se debe gozar de un poder legal. Al contrario, esta configuración de nuevos territorios se sustenta en las bases del deber ser del derecho, que parte del supuesto de que todos somos libres e iguales ante la ley pero que, finalmente, termina sin incorporar efectivamente la vida urbana en el derecho. Tampoco obedece al ejercicio formal del mercado de suelo urbano y de las edificaciones que, se supone, es la lógica para el funcionamiento y la reproducción del capital que producen las ciudades modernas al operar dos lógicas principales: la del mercado y la del Estado. Según ABramo (2012b), existe una tercera lógica en este entramado de "ocupación popular del suelo urbano como forma dominante de acceso a la vivienda por parte de los pobres" (Pág. 38), entendida como la lógica de la necesidad.

De manera que, las distintas representaciones de informalidad, asociadas a la producción del espacio urbano, significan, en sí mismas, diferentes tipos de segregación al localizarse en determinados espacios urbanos apartados del contacto con otras clases socioeconómicas urbanas (VARGASDíAz \& al., 2010), lo que configura una compleja trama de factores en la aparición, permanencia e importancia de la construcción de la ciudad informal (FIG. 1).

\subsection{Algunas lógicas de la segregación socioespacial inmersas en la ciudad informal}

Llegados a este punto, vale la pena acotar una serie de lógicas señaladas por WACQUANT (2007) que, según sus palabras, alimentan la nueva marginalidad, reconfiguran los atributos de la pobreza urbana y, en conjunto, (re)establecen los rasgos de la segregación socioespacial en nuestras ciudades - a partir de procesos de territorialización-. Lo anterior, con el fin de considerarlas como potenciales advertencias epistemológicas aplicables a la ciudad informal y evidenciar su composición en tanto formas de segregación. 


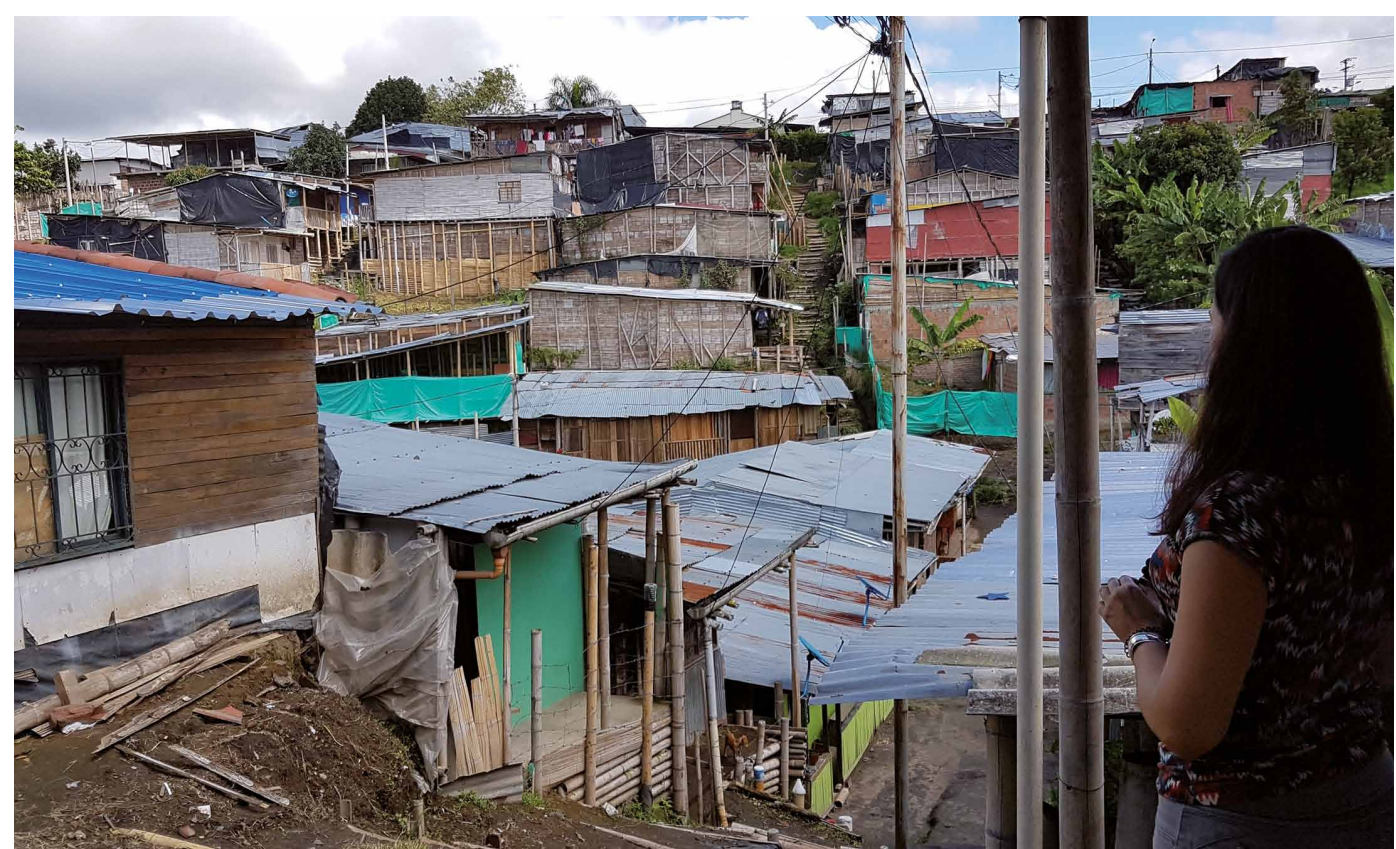

FIG. 1/ Panorámica del asentamiento humano Nuevo Armenia.

Fuente: Elaboración propia.

En primer lugar, Wacquant señala que la nueva marginalidad urbana no es producto de un posible atraso económico sino de la "desigualdad creciente en el contexto de un avance y una prosperidad económica global"; esta condición se evidencia en la ciudad de Armenia (contexto de estudio) en la diacronía de sus etapas de crecimiento ligadas a las primeras fases de (precaria) industrialización y a las continuas olas migratorias del campo a la ciudad. Situación que no ha sido marcada propiamente por sus avances dentro de la economía capitalista, sino por sus efectos negativos dado que allí se ha ampliado y profundizado el alcance de la marginalidad en una ciudad que, hace tres décadas, contaba con buenos índices sociales y económicos -dentro de los estándares nacionales-gracias a la pujante industria caficultora. Este modelo aureolar de la ciudad revela, a su vez, la sincronía de los fenómenos de diferenciación socioeconómica y espacial que provienen de la presión de las viejas tradiciones segregativas de la sociedad privilegiada local, conjugada con los especulativos mecanismos de la promoción inmobiliaria cuyas operaciones tienden a la creación o la mantención de la estructura espacial reservada a las élites.

En segundo lugar, el autor alude a la denominada "transformación de la esfera del trabajo" que se evidencia, para el caso de estudio, en la eliminación del empleo asalariado del sector rural de la región -y del país-, bien sea por los efectos de la economía cafetera o por las políticas relacionadas con lo rural que no hacen atractivo el trabajo en el sector agrícola. Lo anterior ha provocado que "una fracción significativa de la clase obrera se ha[ya] convertido en superflua" y generado una población trabajadora excedente para la economía local de Armenia, una ciudad continuamente "invadida por los éxodos de una larga guerra agraria" (APRILEGNISET, 1992: 167). Esta situación, presente en la capital del departamento del Quindío desde mediados el siglo XX, ha convertido a la ciudad en un escenario de confrontación social y de lucha de clases sobre el espacio urbano.

Al seguir la ruta planteada por Wacquant, en tercer lugar, se hace alusión a la "reconstrucción de los Estados de Bienestar" como grandes productores de desigualdad y marginalidad urbana al configurar en nuestras ciudades programas o políticas que, aunque destinados a amortiguar las consecuencias de la pobreza y sus impactos sociales y espaciales, también contribuyen a determinar las condiciones de aquellos que quedan relegados. En nuestro caso, este es el resultado, por un lado, de la inexistencia (o poca claridad) de políticas sobre el acceso al suelo urbano como consecuencia del 'achicamiento' de las estrategias que materialicen la función social de la propiedad privada y, por otro lado, la 'desarticulación' de las políticas nacionales en la aplicación de los subsidios 
para el acceso a la vivienda. Esto repercute en espacialidades que desconocen las realidades socioculturales de aquellos a quienes las referidas políticas pretenden cobijar; lo que en últimas se convierte en la privatización de políticas sociales. Situación que ha impedido que los habitantes de los espacios urbanos informales se constituyan en ciudadanos sujetos de derechos, relegándolos a la espera de alternativas de solución provenientes de agentes externos (CASTAÑeda-PÉReZ \& MeJía LoTERO, 2017; CASTAÑEDA-PÉREZ, 2018); un escenario propicio para la permanencia de los sistemas políticos tradicionales que ignoran las potencialidades y recursos de los grupos humanos.

Por último, el mencionado autor hace alusión a la concentración y estigmatización de las dinámicas espaciales en donde la nueva marginalidad urbana evidencia una tendencia a conglomerarse y acumularse en áreas específicas, claramente identificadas por las personas ajenas a ellas. Lo anterior, derivado del efecto del flujo direccional que marca la tendencia histórica de los espacios destinados a la clase dominante, lo que devela dinámicas segregativas residenciales y funcionales que, a su vez, obedecen a condiciones comparativas de localización y entorno. Esto, tradicionalmente en Armenia, corresponde con la ocupación irregular del suelo en laderas contiguas a quebradas cercanas, a su vez, al centro consolidado de la ciudad y, más recientemente, a sectores urbanos periféricos.

De ahí que la ciudad informal, generada tanto por procesos de desterritorialización —resultado ineludible de conflictos propiciados por la expansión de políticas que reducen la presencia del Estado en los diferentes campos económicos-, como por procesos de reterritorialización debido a múltiples factores como la pobreza y la falta de oportunidades; se convierta en territorios intersticiales ${ }^{4}$ producto de las políticas estatales en materia de vivienda, urbanismo y ordenamiento territorial. Es por esto que su surgimiento, consolidación y permanencia son, en esencia, una cuestión política que conlleva, inevitablemente, un trasfondo social. En palabras de TORRES (2009):

\begin{abstract}
"El hábitat autoproducido que alimenta la ciudad informal se ha convertido en una alternativa a la falta de repuestas de los gobiernos nacionales y locales frente a los déficits urbanos en materia de hábitat y vivienda (...) un estructurador de los territorios urbanos de la ciudad formal, mediante procesos de planeación no regulada pero que son admitidos. (Pág. 21)"
\end{abstract}

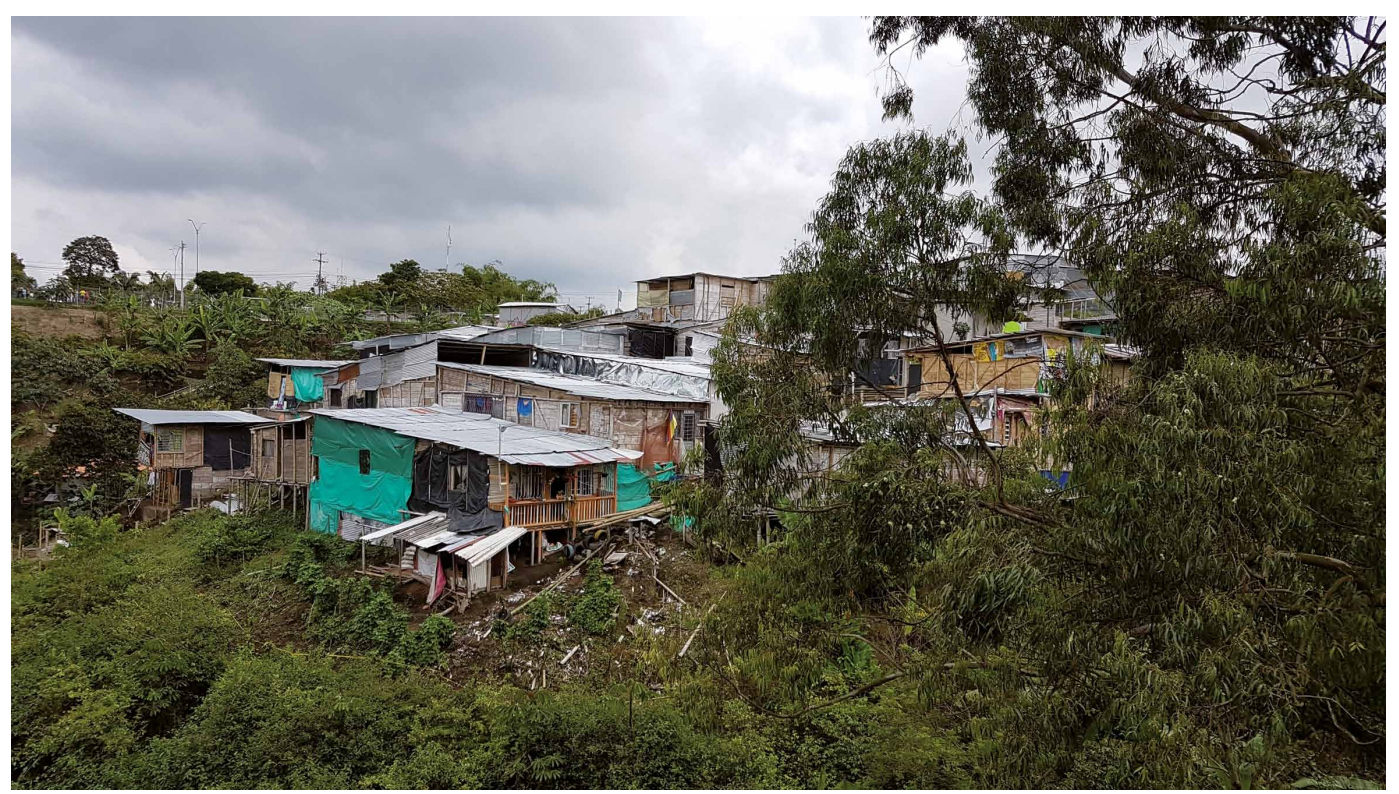

FIG. 2/ Vista del asentamiento El Tesoro desde el Asentamiento Nuevo Armenia.

Fuente: Elaboración propia.

${ }^{4}$ Considerados estos no solo como simples espacios físicos
remanentes de los diversos y discontinuos procesos planea-
ción centralizados, también como resultado de la amalgama de interacciones e irrupciones entre múltiples actores que coexisten en una situación o contexto espacial (intersticial) definido. 
En síntesis, este tipo de ciudad, al tratarse de una realidad socioespacial urbana, surge de la configuración de nuevos territorios que omiten los formalismos de la noción de propiedad al hacer uso de tierras incultas o baldías que, con el fin de subsanar una necesidad habitacional, crean redes de relaciones a partir de nuevas configuraciones espaciales enmarcadas en disputas por el territorio. Como resultado, son los habitantes quienes a partir de su posición de grupo o clase y su localización en la ciudad, se apropian del espacio urbano y lo significan (LICONA 2007) y, en consecuencia, construyen sobre este sentidos y modos de habitar.

De manera que, se puede entender la ciudad informal como un ejercicio de producción social del hábitat por parte de sujetos, actores y en ocasiones agentes (CAPEL SÁEZ, 2013) impulsados por necesidades que motivan acciones (emplazamiento, ocupación, implantación, habitación, dominio o apropiación) sobre el espacio en el acceso a bienes y servicios urbanos. A su vez, es posible encontrar, en dichas acciones, una

"conexión de eslabones semióticos, organizaciones de poder, circunstancias relacionadas con las luchas sociales" (Deleuze \& Guattari, 2004: 13),

las cuales necesariamente producen cambios en la espacialidad urbana y evidencian aquella esencia de la ciudad en tanto proceso, horizonte y práctica (FIG. 3).

\section{Desde una la realidad in situ}

Como ya se ha mencionado, los procesos de construcción de los espacios urbanos informales se presentan, generalmente, en zonas segregadas social y espacialmente, que son, a la larga, las que determinan las condiciones de vida de sus habitantes quienes, con frecuencia, son catalogados como invasores (CRAVINO \& VARELA, 2008). Ahora bien, conviene subrayar que dicho espacio de vida no solo se limita a la ubicación material donde se localizan los medios necesarios para el ejercicio del habitar y donde se desarrollan las relaciones sociales, sino que este

"se constituye en un sujeto mismo de producción. Así, el espacio adquiere una materialidad y una subjetividad propia que lo hacen histórico y dinámico" (JIMÉNEZ \& NovOA, 2014: 8),

lo que permite abordarlo como hecho territorial, como proceso y como producto a través de sus características propias.

A fin de comprender este fenómeno es necesario enfocarlo en marcos de desigualdad y exclusión, en los cuales, cada actor, ya sea público o privado, interviene en función de determinados intereses políticos, económicos y sociales, que favorecen u obstaculizan el proceso de formación y configuración territorial de nuestras ciudades. En esta ecuación, en la que por un lado encontramos sujetos vulnerables, errantes y sin tierra, y por otro lado nos topamos un espacio intersticial que puede encontrarse dentro de los límites territoriales o

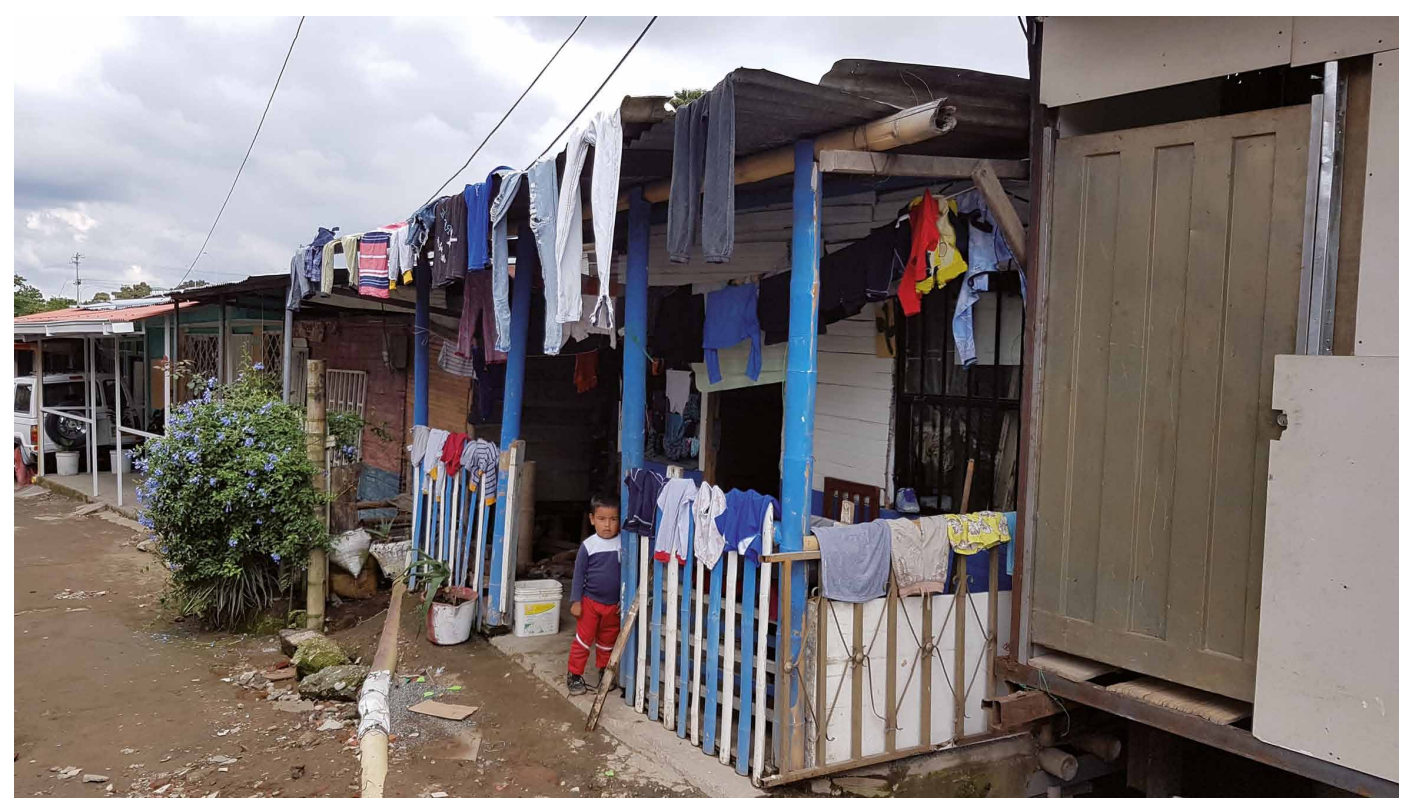

FIG. 3/ Vivienda del asentamiento Nuevo Armenia. 
puede pertenecer al poder jurídico y absoluto de un agente (bajo la idea de propiedad privada), se termina por definir el hecho territorial de la ciudad informal y todas las aristas que se derivan de él. En el caso de la ciudad de Armenia, a lo anterior se suman las necesidades habitacionales de la creciente y predominante población urbana, las actuales dificultades de empleo y los altos costos del suelo urbano disponible y de la vivienda comercialmente ofertada, constituyéndose en los principales factores del crecimiento informal de la ciudad. Una forma extendida de ocupación del territorio que reproduce la segregación socioespacial urbana.

Con el propósito de discutir acerca de un caso en concreto, en este punto, se hace referencia a un asentamiento humano informal de la ciudad donde se percibe la noción de territorialidad y de manejo territorial; es decir, donde existe afecto por el lugar y donde se han comenzado a establecer principios de organización entre los individuos que lo conforman. Es el resultado de un proceso de producción social del espacio que incorpora

"actos sociales, acciones de sujetos tanto colectivos como individuales que se despliegan sobre él, se expresan y encuentran en él prohibiciones" (LeFeBVRE, 2013);

es decir, múltiples entrecruzamientos en lugares determinados que reflejan, en buena proporción, la manera como históricamente nuestras ciudades se han configurado espacialmente.

Se trata del asentamiento informal de la ladera de la ciudadela Nuevo Armenia (etapas I y II) localizado en un terreno propiedad de la municipalidad de Armenia con destinación a uso público y que, en principio, hacía parte de las áreas de cesión obligatoria gratuita para el municipio ${ }^{5}$. Por esta razón, los procesos de ocupación y apropiación (promovidos inicialmente por los propios habitantes de la urbanización formal) han desencadenado en diversos conflictos, tanto frente al titular del predio, como con los vecinos del sector. Dichos procesos se originaron aproximadamente en el año 2002 sobre un terreno remanente del proyecto urbanístico Ciudadela Nuevo Armenia ${ }^{6}$.

Este asentamiento se caracteriza por tener largas y angostas calles, construidas entre el barro, las

\footnotetext{
${ }^{5}$ Artículo 20 POT 1999-2006 (Concejo Municipal de Armenia 1999) y Artículo 244 POT 2009-2023 (Concejo Municipal de Armenia 2009).

${ }^{6}$ Urbanización promovida durante el transcurso de la reconstrucción del eje cafetero post-terremoto de 1999, una alternativa de reubicación de familias en el marco de la conocida "vitrina inmobiliaria" del Fondo para la Reconstrucción y Desarrollo Social del Eje Cafetero (FOREC), un proceso catalogado como "novedoso" para la adjudicación de planes de vivienda en Armenia que consistió en una bolsa de oferta de
}

piedras, las llantas recicladas y la basura acumulada. Son calles que implican descensos y ascensos, con casas a sus costados, unas al lado de otras, construidas con madera, ladrillo, bahareque y lonas, entre otros materiales rudimentarios (FIG. 4). También es posible entrever allí, problemáticas en torno a la seguridad y el consumo de sustancias psicoactivas en las esquinas de las calles del barrio contiguo. Una de sus lideresas, al describir las condiciones bajo las cuales se formó el asentamiento, menciona que:

"este ha sido el resultado de olas migratorias de distintas zonas del país, e incluso de zonas internas del departamento, a razón del conflicto armado, del desempleo, de la pauperización de las zonas rurales y/o la falta de oportunidades, entre otras razones" (M. ZABALA, comunicación personal, 30 de abril de 2018).

Allí es posible visibilizar cultivos pequeños en la parte posterior de las viviendas que colindan con el arroyo La Cristalina y jardines con coloridas flores a lo largo de su callejón principal.

En el asentamiento, las dinámicas de producción, ocupación y apropiación del espacio son el resultado de un ejercicio de mercantilización irregular del suelo sobre el que se localiza el asentamiento. Se trata dela forma predominante de acceso a la tierra urbana (ABRAMO, 2012a) y una de las características de la formación socioespacial de las ciudades de la región como mecanismo de provisión de suelo y vivienda para sectores populares. Actualmente, las cerca de 45 familias que habitan este lugar se encuentran en proceso de creación de la figura de gestión comunitaria conocida como Junta de Acción Comunal (JAC) ${ }^{7}$, es decir, crear su propia organización social y adoptar un sistema de reglas de conducta y normas de convivencia con el fin de planificar y reglamentar el uso adecuado de su espacio vital.

Sin embargo, las condiciones de tenencia del suelo han generado múltiples inconvenientes para sus familias y líderes quienes han afrontado diversas acciones de desalojo por parte de autoridades civiles y policiales. Frente a ello, se han visto obligados a librar una disputa por la defensa de sus nuevas raíces, una lucha desigual por su condición de vulnerabilidad, ya sea por proyectos donde los damnificados seleccionaron su vivienda de una amplia gama de proyectos.

${ }^{7}$ La junta de acción comunal es una organización cívica, social y comunitaria de gestión social, sin ánimo de lucro, de naturaleza solidaria, con personería jurídica y patrimonio propio, integrada voluntariamente por los residentes de un lugar que aúnan esfuerzos y recursos para procurar un desarrollo integral, sostenible y sustentable con fundamento en el ejercicio de la democracia participativa (CONGRESO DE LA República de Colombia 2002). 


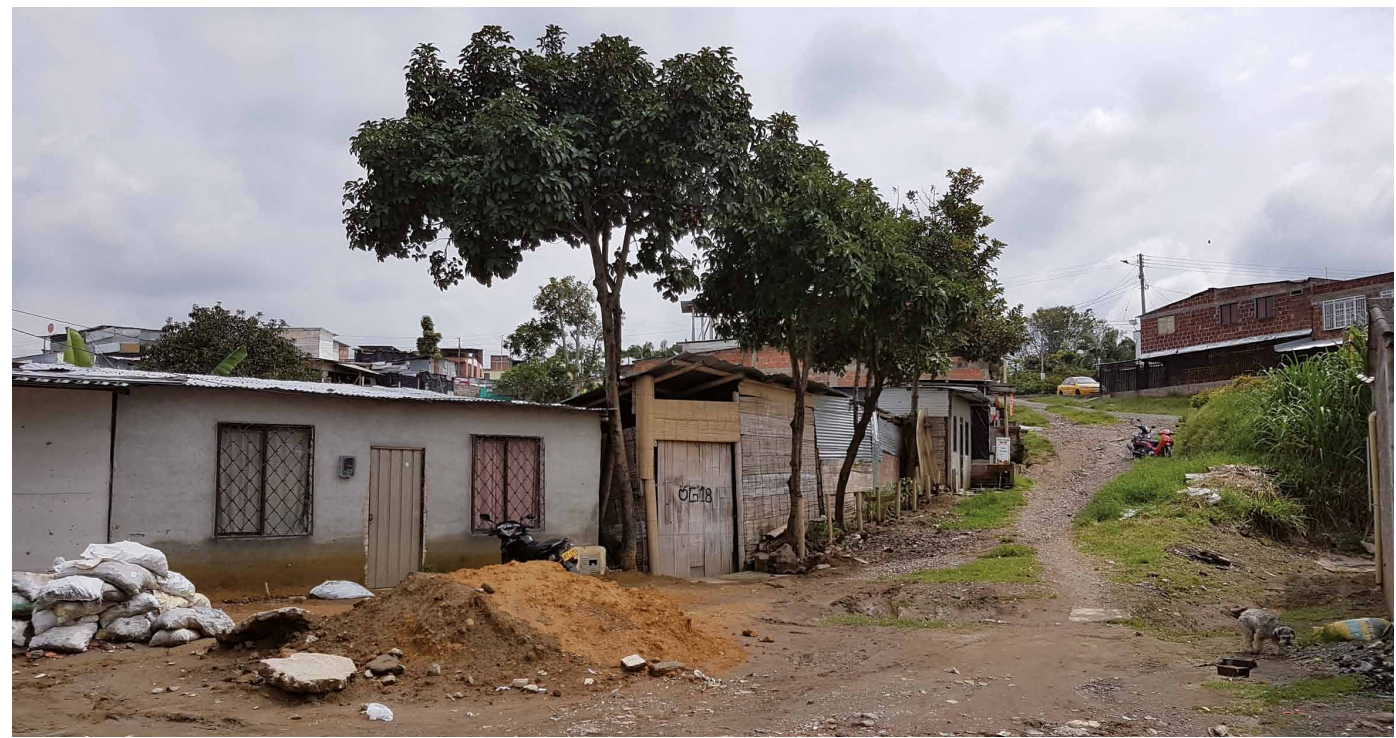

FIG. 4/ Calle del asentamiento Nuevo Armenia.

Fuente: Elaboración propia.

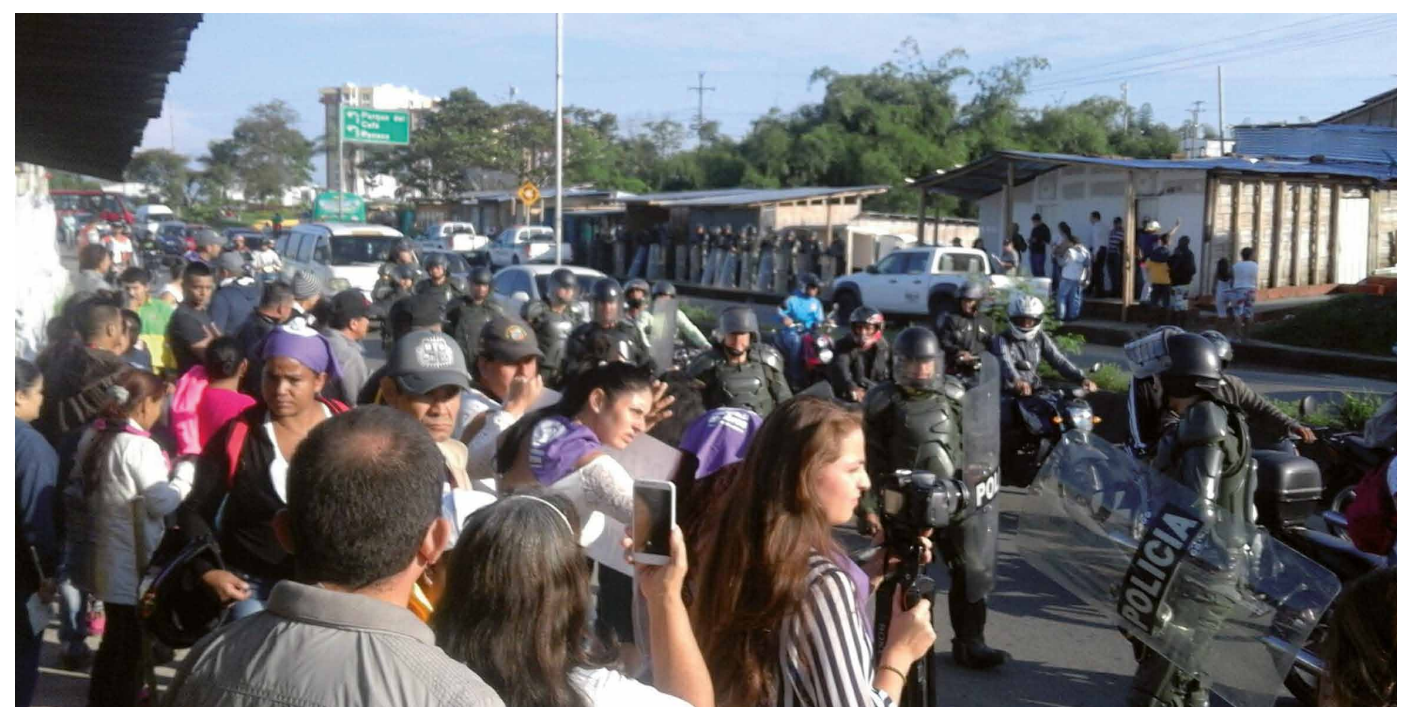

FIG. 5/ Intento de desalojo de habitantes del asentamiento.

la inseguridad infraestructural de sus viviendas, o por la incertidumbre de tenencia del suelo sobre el cual se localizan (FIG. 5). Son luchas que se han llevado a instancias legales, para lo cual han realizado distintos procesos organizativos y de pronunciamiento público que conllevan a la exigencia de derechos y de la intervención estatal para la mejora de las condiciones de vida de las familias que allí habitan. Este 'hacer frente' los ha marcado, porque han sufrido el temor de ser desalojados y de ser, nuevamente, desterritorializados.
Justo aquí se puede advertir una relación entre estos procesos de urbanización y pobreza, donde muchos de los pobladores que migran a las urbes terminan en peores niveles de vida ya que no pueden acceder a las ventajas que, suponen, les brindaría la ciudad (LeFEBVRE, 1968). Todo ello, en gran parte, porque la presencia del Estado es deficiente y el proceso de reconocimiento legal de estos territorios implica que allí se deben ofrecer todos los beneficios de una ciudad formal. En resumen, este tipo de territorializaciones son, para 
sus habitantes, formas de materializar el derecho al territorio, la vida y la ciudad.

Por otro lado, la disputa por la vivienda (que es entre otras por el territorio y el habitar) también les ha generado conflictos con la municipalidad frente a la naturaleza de la propiedad. Estas disputas oscilan entre la condición de la ilegalidad (como lo comprende el discurso institucional) y la apropiación del territorio. Más aún, cuando entre sus pobladores no ha sido fácil la configuración de una forma asociativa que permita la gestión acertada de sus procesos de territorialización, en tanto manifestación del 'estamos aquí' y 'tenemos derecho habitar'.

En definitiva, el espacio urbano informal presentado denota una serie de gestas que lo configuran como producto, como medio de acción -y de apropiación/dominio- desde lo social (individual o colectivo) sobre lo físico. Actos que otorgan derecho y valor de uso a espacios por medio de acciones de emplazamiento (dinámicas y procesos), de ordenación del suelo (poner en lugar, hacer un lugar) y de habitación; todo ello en busca de la preservación y ampliación del espacio vital con el fin de satisfacer la necesidad de habitar, permanecer y residir. Algo que, como se ha expuesto, no está exento de conflictos.

Estos son los ciudadanos que, al construir y defender su espacio de residencia, no sólo edifican una vasta ciudad nueva, sino que también, sobre esa misma base, proponen un orden de ciudadanía diferente y reflejan en su hábitat los códigos de la sociedad en la cual se inscriben como individuos. Por ello, han actuado con una lógica propia y fuerte: la de la ciudad informal; una lógica territorial que debe ser comprendida si se pretende proponer alternativas efectivas.

\section{Conclusiones}

El proceso de crecimiento urbano, conocido con el término de "urbanización", no solo se vincula en nuestros países al curso de producción de ciudad realizado dentro de las normas legales y urbanas vigentes; este puede también ser utilizado para referirnos a la acción de los propios habitantes de la denominada ciudad informal ya que en ella también se realiza un ejercicio de consolidación y/o expansión de suelo urbano (CRAVINO, 2006). Proceso que, a su vez, dinamiza un conjunto de acciones individuales y colectivas que promueven

\footnotetext{
${ }^{8}$ Conformado por la unión de la palabra y el contenido de urbano y rural para procurar comprender y explicar, en este
}

la producción de ciudad y la consolidación de asentamientos informales. Por tanto, una de las características físico espaciales predominante de las ciudades latinoamericanas se constituye a partir de la superposición de dos formas de producción del espacio urbano: la formal y la informal.

Por su parte, en las ciudades colombianas, en general, se ha dado una ocupación del suelo (urbano y rural) sin planificación en el mediano y largo plazo, se ha privilegiado la actuación individual y la localización de actividades comerciales, de servicios e industria por encima de la actividad residencial. Dichas acciones presionan el crecimiento de nuestras ciudades por medio del desplazamiento de población hacia zonas inadecuadas o de vocación agrícola donde se hacen necesarias altas inversiones en infraestructura urbana y equipamientos. Esta dinámica urbana ha sido costosa desde el punto de vista financiero, social, ambiental y urbano, y también en lo productivo (desde lo rural) al romper el "acontecer complementario" (SANTOS, 2005) de las relaciones de producción e intercambio entre ciudad y campo.

Dicho brevemente, la ciudad informal es una configuración socioespacial producto de la interacción entre fuerzas macroestructurales, políticas estatales y el esfuerzo de algunos grupos humanos por auto satisfacer la necesidad básica de habitar (FIG. 6). Esta se deriva de los actuales problemas para el acceso a la vivienda y al suelo urbano, en tanto proceso alternativo a los impuestos por el modelo de desarrollo dominante. Es, al mismo tiempo, resultado de la dependencia al modelo capitalista y de múltiples maneras de exclusión y marginación de poblaciones a ejercer su derecho al territorio.

El resultado: "islas de precariedad" (JANOSCHKA, 2006:89) presentes en la ciudad de Armenia, donde se percibe, por un lado, una histórica ocupación informal de suelo no apto al interior de la ciudad en áreas definidas por el POT como zonas de riesgo o de protección ambiental; $y$, por otro lado, una reciente ocupación discontinua del suelo rururbano ${ }^{8}$ que conlleva la extensión de las dinámicas económicas, productivas y culturales del centro de la ciudad. Estos procesos de consolidación y extensión modifican el territorio en cuanto su comprensión y organización al producir una estructura "Com-fusa" (AвRAmo, 2012b) de territorialidad. Es por esto que, en su problematización y manejo es necesario hacer confluir una perspectiva relacional a la forma como se concibe la segregación socioespacial urbana, de manera que se pueda construir una nueva mirada sobre la desigualdad

caso, la constitución y los procesos ocurridos en las áreas de expansión de las ciudades (CARDOSO AND FRITSCHY, 2012) 


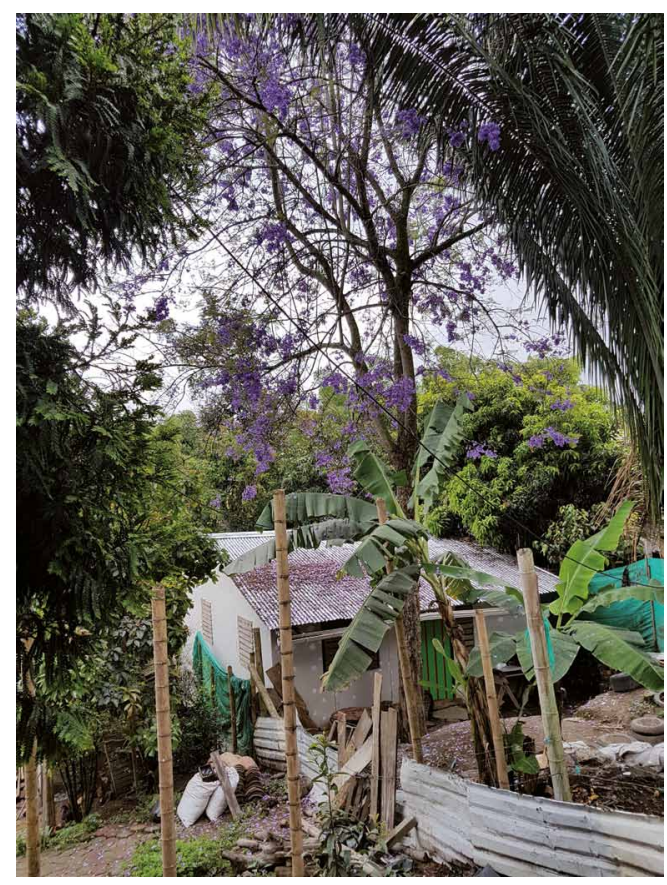

G. 6/ Vivienda del asentamiento Nuevo Armenia.

Fuente: Elaboración propia.

y la relegación, que supere, a su vez, el individualismo metodológico alentado por el positivismo y se convierta en el objetivo empírico principal de nuestras políticas públicas y los discursos oficiales sobre la materia.

En consecuencia, el estudio de las transformaciones espaciales no solo advierte una relectura del hacer ciudad, también requiere tener en el horizonte de análisis los conflictos y las dinámicas de conflictividad que definen este producto social en su conjunto. En tal sentido, se invita a (re)leer la ciudad informal

\begin{abstract}
"como obra, como valor de uso, como goce, como disfrute, como belleza y como creación colectiva de sus ciudadanos, sobre la que ellos deciden y en la que ellos intervienen" (LefEBVRE, 2013: 23).
\end{abstract}

A partir de allí, se les otorga a estas territorialidades un carácter de actividad creativa libre, una expresión de la potencialidad humana de apropiarse del espacio y convertirlo en lugar, adaptarlo, usarlo, transformarlo y verter sobre este la afectividad del usuario.

Se convierte en una invitación a debatir teóricamente dichas acciones y a reconocer que estos territorios constituyen y encarnan una territorialidad alternativa al modelo de desarrollo hegemónico, desde donde suelen diseñarse y ejecutarse las estrategias y políticas que han demostrado su desacierto en el abordaje de este hecho territorial. En consecuencia, se trata de pensar en la acción de ocupar desde la perspectiva del habitar, lo que significa concebir la apropiación de estos territorios a partir de su vivencia, de su adaptación, uso, transformación y carga de sensibilidad e imaginación por parte de quienes lo habitan y convierten en lugares.

\section{Bibliografía}

Abramo, P. (2003): “La Teoría Económica de La Favela: Cuatro Notas Sobre La Localización Residencial de Los Pobres y El Mercado." Ciudad y Territorio: Estudios Territoriales XXXV (136- 137): 1- 24.

- (2010): "Mercado Informal de Alquiler: Nueva Puerta de Acceso a Los Asentamientos Populares." En Arrendamiento y Vivienda Popular en Colombia Como Alternativa Habitacional, editado por Clemencia Escallón Gartner, 53- 78. Bogotá D.C.: Universidad de Los Andes.

- (2012a): "Ciudad informal Com-Fusa: El Mercado y La Producción de La Territorialidad Urbana Popular." En Irregular. Suelo y Mercado En América Latina, editado por Clara Eugenia Salazar, 85. México D.F.: El Colegio de México.

- (2012b): "La Ciudad Com-Fusa: Mercado y Producción de La Estructura Urbana En Las Grandes Metrópolis Latinoamericanas." EURE 38 (114): 35-69. https://doi.org/10.4067/S0250$\underline{71612012000200002}$

ApRILe-Gniset, J. (1992): La Ciudad Colombiana. Siglo XIX y Siglo XX. Bogotá D.C.: Banco Popular, Fondo de Promoción de la Cultura.

Aubán Borrell, M. (2017): "La Dignidad de Los Márgenes. Aproximaciones Afectivas a La Ciudad Informal." INVI 32 (91): 67-89.

Capel SÁez, H. (2013): "Actores, Agentes y Reglas de Juego." En La Morfología de Las Ciudades. III. Agentes Urbanos y Mercado Inmobiliario, 18-51. Barcelona: Del Serbal.

Cardoso, M. M., \& Fritschy B. A. (2012): "Revisión de La Definición Del Espacio Rururbano y Sus Criterios de Delimitación." Contribuciones Científicas GAEA, no. 24: 27-39

Castañeda-Pérez, Y. (2018): "Ciudades de Barro: Asentamiento Informal Fundadores Bajo de Armenia, Colombia." AUS, no. 23: 49-55. https://doi.org/10.4206/aus.2018.n23-08

- (2019): "Ciudades de Barro: Acacias Bajo, Un Asentamiento Informal en Armenia, Colombia." Ciudad y Territorio: Estudios Territoriales LI (201): 189-96.

- \& Mejia Lotero F. M. (2017): Construir Para Transformar. Alternativas Para El Desarrollo Autogestionado y Sustentable En El Asentamiento Informal El Milagro de Dios Del Municipio de Armenia. Armenia, Colombia: Universidad La Gran Colombia seccional Armenia.

ClicheVsKY, N. (2000): "Informalidad y Segregación Urbana En América Latina. Una Aproximación.” Medio Ambiente y Desarrollo. Vol. 28. Santiago de Chile. 
Concejo Municipal de Armenia (1999): "Acuerdo Municipal Nº01 de 1999 Por Medio Del Cual Se Aprueba El Plan de Ordenamiento Territorial Del Municipio de Armenia, Para El Periodo 1999-2006." Gaceta Municipal de Armenia, no. s.n.

- (2009): "Acuerdo Municipal N 019 de 2009 Por Medio Del Cual Se Aprueba El Plan de Ordenamiento Territorial Del Municipio de Armenia, Para El Periodo 2009-2023." Gaceta Municipal de Armenia, $\mathrm{n}^{\circ} .1185$

Congreso de la República de Colombia. (1997): "Ley 388." Diario Oficial, no. 43127.

- (2002): "Ley 743 Por La Cual Se Desarrolla El Artículo 38 Constitución Política de Colombia En Lo Referente a Los Organismos de Acción Comunal." Diario Oficial, no. 44826. https://www.funcionpublica.gov.co/eva/gestornormativo/norma.php?i=5301.

Cravino, M. C. (2006): Las Villas de La Ciudad: Mercado e Informalidad Urbana. Buenos Aires: Universidad Nacional de General Sarmiento.

Cravino, M. C., \& Varela, O. D. (2008): "Mil Nombres Para Mil Barrios. Los Asentamientos y Villas Como Categorías de Análisis y de Intervención." En Los Mil Barrios (in)Formales. Aportes Para La Construcción de Un Observatorio Del Hábitat Popular Del Área Metropolitana de Buenos Aires, Editado por María Cristina Cravino, 45-64. Buenos Aires: Universidad Nacional de General Sarmiento.

Dumau, E. (2003): "La Ciudad Informal. El Orden Urbano y El Derecho a La Ciudad", editado por X Encontro Nacional da Associação Nacional de Pós-Graduação e Pesquisa em Planejamento Urbano e Regional, 11. Belo Horizonte: ANPUR.

Deleuze, G., \& Guattari, F. (2004): Mil Mesetas. Capitalismo y Esquizofrenia. 6a. Valencia, España: Pre-textos.

FernÁndez Wagner, R. (2008): “Los Asentamientos Informales Como Cuestión. Revisión de Algunos Debates." En Los Mil Barrios (in)Formales. Aportes Para La Construcción de Un Observatorio Del Hábitat Popular Del Área Metropolitana de Buenos Aires, editado por María Cristina Cravino, 15:1344. Buenos Aires: Universidad Nacional de General Sarmiento. https://doi.org/10.24220/2318-0919v15n3a4207

FrASER, N. (2008): Escalas de La Justicia. Traducido por Antoni Martínez Riu. Barcelona: Herder Editorial.

Harvey, D. (2012): Ciudades Rebeldes: Del Derecho de La Ciudad a La Revolución Urbana. Madrid: Akal.

JanosCHKA, M. (2005): "De Ciudades Dispersas a Ciudades Perforadas. Una Nueva Fase de Transición Demográfica." En Gobernanza, Competitividad y Redes: La Gestión En Las Ciudades Del Siglo XXI, editado por Carlos De Mattos, 151-72. Santiago de Chile: Instituto de Estudios Urbanos y Territoriales, Pontificia Universidad
Católica de Chile.

- (2006): "El Modelo de Ciudad Latinoamericana Privatización y Fragmentación Del Espacio Urbano de Buenos Aires: El Caso Nordelta." In Buenos Aires a La Deriva. Transformaciones Urbanas Recientes, edited by Max Weich Guerra, 80- 117. Buenos Aires: Editorial Biblos.

Jiménez, C. \& NovoA, E. (2014): Producción Social Del Espacio. El Capital y Las Luchas Sociales En La Disputa Territorial. Bogotá D.C.: Ediciones desde abajo.

Lefebvre, H. (1968): El Derecho a La Ciudad. Paris: Ediciones Anthropos.

- (2013): La Producción Del Espacio. Editado por Juan Marqués. Madrid: Capitán Swing.

LiconA, E. (2007): Habitar y Significar La Ciudad. Mexico D.F.: Universidad Autónoma Metropolitana.

Nates-Cruz, B. (2018): "El Derecho Al Territorio Como Base de La Justicia Cognitiva." Disparidades. Revista de Antropología, no. En prensa.

Pino Vásquez, A., \& OJeda Ledesma, L. (2013): "Ciudad y Hábitat Informal: Las Tomas de Terreno y La Autoconstrucción En Las Quebradas de Valparaíso." INVI 28 (78): 109-40. https://doi.org/10.4067/S0718-83582013000200004

Onu-Hábitat (2012): Estado de Las Ciudades de América Latina y El Caribe. Rumbo a Una Nueva Transición Urbana. Nairobi: Programa de las Naciones Unidas para los Asentamientos Humanos.

Puente Burgos, C. A. (2003): "Urbanización Clandestina: La Discusión Teórica." Bogotá D.C. http://www.javeriana.edu.co/cendex/pdf/DT 005-03.pdf

Raffestin, C. (2011): Por Una Geografía Del Poder. Traducido por Yanga Villagómez Velázquez. Michoacan: El Colegio de Michoacan.

Roncayolo, M. (1990): La Ville et Ses Territoires. Paris: Gallimard.

SABATINI, F. (2006): La Segregación Social Del Espacio En Las Ciudades de América Latina. Washington DC: Banco Interamericano de Desarrollo.

SANTOS, M. (2005): "El Retorno Del Territorio." OSAL: Observatorio Social de América Latina 6 (16): 251-61.

SoJA, E. W. (2014): En Busca de La Justicia Espacial. Traducido por Carmen Azcárraga. Valencia, España: Tirant humanidades.

TARDIN, R. (2006): "La Ciudad Informal." En Las Otras Geografías, editado por Joan Nogué i Font y Joan Romero, 389-404. Valencia: Tirant Lo Blanch.

Torres Tovar, C. A. (2009): Ciudad informal Colombiana: Barrios Construidos Por La Gente. Bogotá D.C.: Universidad Nacional de Colombia, Sede Bogotá, Facultad de Artes.

VARgas-Diaz, I. C. \& al. (2010): "Propuestas de Procesos de Mejoramiento Barrial Participativo En Asentamientos Informales." INVI 25 (69): 59-96.

WacQuAnt, L. (2007): Parias Urbanos. Marginalidad En La Ciudad a Comienzos Del Milenio. Traducido por Horacio Pons. Buenos Aires: Manantial. 


\title{
CIUDAD Y TERRITORIO
}

ESTUDIOS TERRITORIALES

ISSN(P): 1133-4762; ISSN(E): 2659-3254

Vol. LIII, № 207, primavera 2021

Págs. $153-168$

https://doi.org/10.37230/CyTET.2021.207.09

CC BY-NC-ND

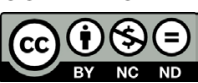

\section{La Russell Sage Foundation y Forest Hills Gardens: un laboratorio urbanístico en Nueva York entre el determinismo social y la estandarización de la vivienda}

\author{
María Cristina García-GonzÁlez \\ Salvador GUERRERO
}

Universidad Politécnica de Madrid

RESUMEN: En 1909, la Russell Sage Foundation promovió un experimento económico y social consistente en la implantación de una ciudad suburbio modelo en el barrio de Queens (Nueva York): Forest Hills Gardens. La que fuera primera ciudad-jardín americana sintetiza un ejercicio de equilibrio entre la filantropía y la especulación, entre la naturaleza y la ciudad, entre la comunidad y la privacidad, entre la segregación y la inclusión, entre el diseño urbano y el determinismo social, entre la industrialización y el arte, entre la tradición y la modernidad o entre la estandarización y la identidad. En Forest Hills Gardens se evidencian las contradicciones que surgen a menudo entre los resultados de lo que se hace y lo que se quiere hacer, en un momento de enorme trascendencia ante el cambio en la forma de hacer ciudad, alentado por los avances tecnológicos, en Estados Unidos.

PALABRAS CLAVE: Rusell Sage Foundation; Forest Hills Gardens; Nueva York; Unidad vecinal; Determinismo social; Vivienda.

The Russell Sage Foundation and Forest Hills Gardens: an urban laboratory in New York between social determinism and the standardization of housing

ABSTRACT: In 1909 the Russell Sage Foundation, an entity created by Olivia Rusell Sage, promoted an economic and social experiment consisting of the implantation of a model suburb town in the neighborhood

Recibido: 19.02.2020; Revisado: 14.05.2020

Correo electrónico: mariacristina.garcia@upm.es; № ORCID: https://orcid.org/0000-0001-5381-7055;

Correo electrónico: salvador.guerrero@upm.es; NºRCID: https://orcid.org/0000-0001-6766-8695

Los autores agradecen los comentarios y sugerencias realizados por los evaluadores anónimos, que han contribuido a mejorar y enriquecer el manuscrito original. 
of Queens (New York): Forest Hills Gardens. This was the first American garden-city and synthesizes an exercise of balance: between philanthropy and speculation, between nature and city, community and privacy, segregation and inclusion, urban design and social determinism, industrialization and art, and standardization and identity. In Forest Hills Gardens, the contradictions that often arise between what one does and what one wants to do are evident, in a moment of transcendental change in the way of city making in the United States encouraged by technological advances.

KEYWORDS: Rusell Sage Foundation; Forest Hills Gardens; New York; Neighborhood unit; Social determinism; Housing.

\section{Introducción}

E I modelo de la ciudad-jardín de Ebenezer Howard es quizás una de las apuestas urbanísticas que más interés e influencia ha suscitado en sus más de cien años de existencia. Estudios como los del urbanista francés Andrés Duany (DuAny, 2000), en el contexto del New Urbanism, apuestan por su persistencia como referente para la planificación urbana en el contexto de la crisis de confianza en la profesión del planificador. La interpretación de los conocidos esquemas de Howard - los tres imanes, el diagrama de la ciudad-jardín, el diagrama regional y el esquema de un sector- no sólo refleja un modelo de territorio y ciudad, sino también un modelo social, donde el hombre político es el protagonista.

En sus primeros años de existencia, la clave del éxito de la ciudad-jardín puede entenderse desde distintos puntos de vista. Además de la aproximación del propio Howard, destacó el crucial papel desempeñado por el arquitecto Raymond Unwin con la transformación de un concepto teórico quasi utópico en una propuesta urbanística viable, basada en aprovechar las oportunidades que ofrecían los adelantos de la técnica, en especial el ferrocarril poblador, que diría Arturo Soria y Mata, autor de la Ciudad Lineal de Madrid. El éxito de la primera ciudad-jardín inglesa, Letchwoth (1903), promovida por la First Garden City Ltd., demostró por primera vez que el proletariado, y más concretamente la aristocracia del proletariado, podía acceso a la propiedad de la vivienda. La experiencia fue difundida a través de publicaciones, congresos y exposiciones organizados por las numerosas asociaciones de ciudades-jardín que años más tarde se agruparon formando una federación, lo que dio lugar a la International Federation for Housing and Town Planning, convertida en una de las primeras redes de conocimiento del urbanismo en el periodo de entreguerras.

Esas redes que, evidentemente, se extendieron pronto al continente americano, y a Estados Unidos en particular, a través de la Russell Sage Foundation, entidad privada sin ánimo de lucro promovida por Olivia Russell Sage, que abanderó la puesta en marcha de Forest Hills Gardens en Nueva York, la primera iniciativa de ciudad-jardín en Estados Unidos. En este mismo contexto no puede obviarse que Ebenezer Howard había vivido en Estados Unidos, en Chicago más concretamente, de 1872 a 1875, y que la comunidad de Riverside -localizada a catorce kilómetros de Chicago había sido construida entre 1868 y 1870 con diseño de Frederik Law Olmsted Sr. y Calver Vaux-, puede considerarse en cierto modo un antecedente de Forest Hills Gardens.

Este artículo pretende mostrar el modo en que los valores culturales que dieron origen a la ciudad-jardín en Inglaterra, fueron asumidos y se transformaron en la cultura urbanística norteamericana. Para ello, se estudia un primer ejemplo de transferencia del modelo inglés de la ciudadjardín en Estados Unidos en base tanto a sus fuentes bibliográficas como al discurso historiográfico generado. Forest Hills Gardens, en el Nueva York de comienzos de siglo XX, fue un laboratorio urbanístico que fue abordado como un ejercicio de equilibrio entre la filantropía y la especulación, entre la naturaleza y la ciudad, entre la comunidad y la privacidad, entre la segregación y la inclusión, entre el diseño urbano y el determinismo social, entre la industrialización y el arte, y entre la estandarización y la identidad. En ella confluyeron los mayores expertos en los distintos campos profesionales involucrados en el desarrollo urbanístico de la ciudad neoyorkina: el abogado Robert de Forest, filántropo y experto en el problema de la vivienda, la Meyer Corporation, empresa inmobiliaria, William E. Harmon, propietario de la compañía Wood, Harmon \& Co., el paisajista Frederik Olmsted Jr., hijo del consagrado paisajista del mismo nombre que en 1900 había fundado la Landscape Architecture School en la en la "Harvard University", el arquitecto Grosvenor Atterbury, especialista en la construcción de vivienda social, y Clarence Perry, creador de la unidad vecinal en el seno de sus trabajos para la Russell Sage Foundation. 


\section{La Russell Sage Foundation: Olivia Russell Sage y el urbanismo de salón}

A finales del siglo XIX, el progreso del desarrollo industrial en los países más avanzados propició, a la par que se acentuaban las dramáticas y las miserables condiciones de vida del proletariado urbano, la creación de grandes fortunas personales. En Estados Unidos, a los capitales productivos como los de Andrew Carnegie, todopoderoso rey del acero, se sumaban los capitales extractivos, entre los que destacó el del cuestionado magnate Russell Sage. Éste legó toda la fortuna a su viuda, Olivia Russell Sage (1828-1918), a su muerte en 1906 , no habiendo establecido ningún tipo de disposición que limitase su uso.

Margaret Olivia Slocum Sage nació en 1828 en Siracusa, Nueva York, en el seno de una acomodada familia venida a menos cuyas raíces parece ser se remontaban a los peregrinos de Plymouth Colony y del Mayflower. La educación elitista para Olivia Sage fue posible por la acogida que le dispersaron algunos familiares cercanos que se encontraban en buena situación económica. Fue educada en la estricta fe presbiteriana y muy joven mostró inquietudes religiosas que le llevaron a implicarse en acciones de voluntariado. Durante casi veinte años Olivia Sage se vio obligada a trabajar como profesora en distintos colegios de Siracusa y Filadelfia para poder mantenerse. Ese periplo se complementó con su trabajo como institutriz en casas de familias relevantes del entorno neoyorkino, condición que supo aprovechar para mantener relaciones con una clase alta que estaba muy por encima de sus posibilidades económicas y sociales. El trabajo le facilitó la independencia económica. Persona intelectual, culta y agradable, y de gustos caros, pero no ostentosos, era consciente de que por medio de un matrimonio su situación no le permitiría ascender en el escalafón social, por lo que disfrutaba de sus altas relaciones sociales libre de compromiso alguno. También encontró en el movimiento sufragista un cauce para la reivindicación de los derechos de la mujer.

Su vida cambió cuando en 1869 se casó, a los 41 años, con el magnate afincado en Nueva York Russell Sage (1816-1906), conocido de su padre. Era también el dueño de una de las mayores fortunas norteamericanas con origen en los ferrocarriles y despegue en operaciones financieras en Wall Street de más que dudosa naturaleza, que incluía una denuncia y condena a cárcel por usura eludida con dinero el mismo año de su boda. Cuestionado profesional y personalmente, parece que el matrimonio con Margaret Olivia Slocum pudo tener más que ver con un lavado de imagen que con una cuestión de sentimiento sincero, pero ella se mantuvo siempre fiel a su memoria. Olivia Sage dedicaba sus esfuerzos a las actividades caritativas, con especial sensibilidad hacia la mujer, que tenían que ver más con una dedicación personal que económica, como de hecho venía haciendo desde sus tiempos de juventud, dado el carácter tacaño de su marido. $Y$ es que a los residentes de la Quinta Avenida se les reclamaba desde distintos foros una implicación más activa en la mejora de las duras condiciones de vida de los más desfavorecidos. Las caricaturas de la popular revista satírica Puck se sucedían en cada número entre las críticas a las grandes fortunas soportadas en el sufrimiento y la explotación de la población más desfavorecida y su petición de auxilio a Jane Stanford, Ellen Golud, amiga de Olivia Sage, John D. Rockefeller, J. Pierpont Morgan, Cornelius Vanderbilt, y al nada generoso Russell Sage, para eliminar los slums neoyorkinos (FIG. 1).
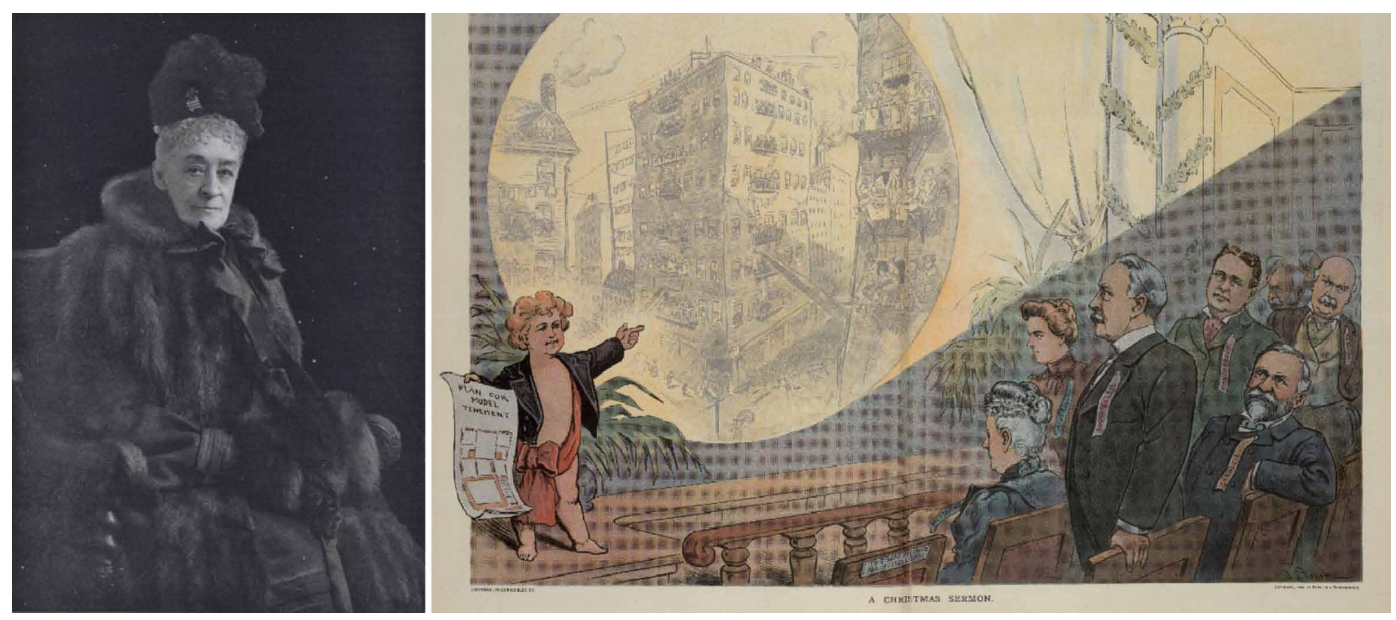

FIG. 1/ "Mrs. Russell Sage, una de las mujeres más ricas del mundo, que desembolsará la gran fortuna del difunto Russell Sage con fines caritativos y para el avance de la mujer" y "Un sermón de Navidad. Plan para modelo de viviendas".

Fuente: The New York Public Library Digital Collection; y J.S. Pughe (1900): Puck, Volumen 48, no 1.242. 
La herencia de su marido le permitió disponer libremente de unos 70 millones de dólares de entonces. El gran dispendio del que Olivia Russell Sage hacía gala en sus generosos pero impulsivos donativos (LA CORRESPONDENCIA DE ESPAÑA, 1913), preocupó a Robert Weeks de Forest, abogado y confidente de la familia Sage, y uno de los más activos filántropos y reformadores sociales de Nueva York. De Forest la animó a crear una fundación que ordenase esa dispersión económica en sus donaciones y se encargó de sentar sus bases. Frente a la ayuda y la asistencia directas, a las que tendían las obras filantrópicas de finales del siglo XIX, se propuso entonces una nueva forma de filantropía orientada a apoyar, con el fin de luchar contra la pobreza desde sus propias causas, el pensamiento científico, siempre con fines educativos y pedagógicos.

"Tengo casi 80 años y siento como si ahora estuviera empezando a vivir", dijo Olivia Sage al dirigirse al comité de la Russell Sage Foundation en su primer acto en abril de 1906 (GLENN, BRANDT \& ANDREWs, 1947). La fundación se inscribió en la ciudad de Nueva York en 1907 con una dotación económica de 10 millones de dólares, la mayor cantidad dedicada a este fin por una persona. La fundación se organizó en una serie de departamentos autónomos: Charity Organization, Child Helping, Industrial Studies, Remedial Loans, Social Work Interpretation, Studies in the Professions y el departamento de Survey and Exhibits. Este último sería de crucial importancia en el desarrollo de la urbanística norteamericana. Entre 1912 y 1927 estuvo bajo la dirección de Shelby Millard Harrison, el cual consolidó la sistematización del survey como análisis científico y estadístico desde la primera experiencia que fue la publicación del Pittsburgh Survey (1912), que se convirtió en el referente para los sucesivos surveys en los que colaboraría la fundación. Su división Recreation estuvo bajo la responsabilidad de Clarence Arthur Perry hasta su cierre en 1937 . Perry había sido contratado por la Russell Sage Foundation en 1909 con la finalidad de estudiar las posibilidades de optimizar los edificios escolares y los campos de juegos infantiles de modo que se permitiera su uso para otras actividades beneficiosas para la comunidad (PERRY, 1939).

La Russell Sage Foundation se sumaba así a las siete fundaciones personales que existían en 1906 en Estado Unidos desde el Peabody Fund (1867), y de entre las que destacaban la Rockefeller Foundation y las fundaciones de Andrew Carnegie. Frente a las ayudas y asistencias directas, a las que tendieron las obras filantrópicas de finales del siglo XIX, surgió una nueva forma de filantropía orientada a apoyar el pensamiento científico luchando contra la pobreza desde sus causas. Esta actitud educativa y pedagógica se hizo patente, en el caso de la Russell Sage Foundation, con su activo servicio de publicaciones sobre las investigaciones que la fundación o alguna de las instituciones bajo su patrocinio, como la Playgrounds Association of America, estuvieran llevando a cabo.

\section{The Sage Foundation Homes Company y la filantropía especulativa}

La vivienda era uno de los grandes problemas de Nueva York. La realidad social que testimoniaron los conmovedores reportajes del fotoperiodista Jacobo Riis en How the other half lived (RIIs, 1890), testigo que recogió Lewis W. Hine, el fotógrafo del Pittsburg Survey, eran el reflejo de la ciudad misma. La solución con la que expertos neoyorkinos abordaron la problemática de la vivienda para la masa obrera no se limitó a una política restrictiva basada en aprovisionar receptáculos habitacionales con estándares mínimos definidos en superficies y condiciones de salubridad, sino que apostaron por soluciones más innovadoras que fomentasen la vida familiar.

El avance de los medios de comunicación en las últimas décadas del siglo XIX generó las áreas suburbanas, que trajeron consigo la eclosión de promociones inmobiliarias individuales, de corporaciones y de asociaciones, con unas líneas de trabajo más o menos científicas. En base a estas experiencias, los trámites de la promoción inmobiliaria se simplificaron y reglaron de manera que se permitió el acceso a nuevos estratos sociales. A la larga esto dio lugar a la cuarta migración, que diría Lewis Mumford, consistente en el desplazamiento de la población de los centros urbanos a las periferias (MUMFORD, 1925). El proceso de suburbanización americana se había puesto en marcha.

Los nuevos barrios del extrarradio no estuvieron exentos de crítica. Por una parte, el activo comisionado Lawrence Vellier, cuyo libro Housing Reform. A hand-book for practical use in American Cities (VeIller, 1910) fue publicado por la Russell Sage Foundation, que fue el líder, junto con Robert de Forest, de la New York Tenement House Law (1901), y más tarde Edith Elmer Wood, que abordó el problema de la vivienda como un objetivo económico demandante de la acción estatal, eran partidarios de priorizar la limpieza de las slums y de eliminar las más de 350,000 dark rooms existentes en 1900 en la ciudad de Nueva York (BIRCH, 1978). En este contexto, en 1908, Robert de Forest, admirador de la filosofía inglesa de la ciudad-jardín, vio la oportunidad de llevar a cabo un experimento 
socioeconómico consistente en tutelar la implantación de una promoción suburbana de viviendas para clases trabajadoras. Respondía al lema de la fundación For the Improvement of Social and Living Conditions. Su referente era la exitosa ciudadjardín inglesa de Letchworth (1903), promovida por la First Garden City Ltd.

Robert de Forest pretendía demostrar cómo la práctica planificada de una implantación residencial podía generar una rentabilidad económica y servir de modelo a la producción masiva de viviendas asequibles para clases modestas. Proponía formular estándares que pudieran ser asumidos por otros operadores interesados en desarrollos de similares características. Es decir, establecer una sistemática de intervención reproducible (THE Sage Foundation Homes Company, 1912).

Al ser la promoción una inversión empresarial debía generar beneficios, por lo que se llevaría a cabo sobre principios estrictamente comerciales. Se quería evitar la especulación, por lo que no se contempló la adquisición de vivienda solo como inversión. El comprador debía ser futuro residente y debía retornar la inversión realizada. Figuras como Jacobo Riis y Edwin Seligman, prestigioso profesor de economía de la Columbia University, vieron la propuesta como una oportunidad de crear un laboratorio social y económico (STERN, Gilmartin \& Massengale, 1984). Para Robert de Forest, la propuesta era un experimento social de educación, de ahí su denominación de ciudad modelo.

Además de la gestión económica, los puntos clave que dotaron de singularidad a esta propuesta fueron cinco. En primer lugar, el papel del ferrocarril convertido en el más potente agente urbanizador, el "ferrocarril poblador" que diría Arturo Soria y Mata refiriéndose a los ferrocarriles americanos de la segunda mitad del siglo XIX. A la propuesta de superación de la dialéctica entre ciudad y naturaleza, se sumaron la superación de la dialéctica entre el medio físico y el medio social, y la búsqueda del equilibrio entre el individuo y la comunidad, que a la larga dio lugar al comunnity planning. La eficiencia en el diseño urbano y la estandarización e industrialización de los procesos de la producción de vivienda, que se aplicaron desde una aproximación fordista, se equilibraba con la estética de la naturaleza y la individualidad del arte.

Todo ello en el momento en el que la institucionalización del urbanismo empezó a tomar forma en el sentido otorgado por Millerson (MILLERSON, 1964). Se definieron sus competencias, su organización, su soporte teórico, los espacios de formación, los códigos de conducta y la crítica. Los arquitectos, arquitectos paisajistas y urbanistas empezaron a organizarse en asociaciones profesionales con el fin de intercambiar experiencias e imponer sus estatutos. Las publicaciones, libros, manuales y revistas se multiplicaron y se ocuparon de aspectos tanto conceptuales como de avances técnicos y legislativos. En 1909 se dictó el primer curso de urbanismo en Estados Unidos, en la Landscape Architecture School de Harvard University (GARcíAGONZÁlez \& GUERRERO, 2017), tuvo lugar la primera National Conference on City Planning en Washington, donde John Nolen presentó su ponencia “¿Qué necesita el city planning americano?” y propuso democratizar el espacio de ocio, ahondar en la identidad de la ciudad y parar de malgastar. El poderoso Commercial Club of Chicago financió y publicó el Plan of Chicago, de Burnham y Bennet, y Charles Mulford Robinson, publicó Modern Civic Art, Or the City Made Beautiful. En este contexto surgió la ideología americana de la gestión empresarial de la ciudad bajo la doctrina del liberalismo progresista y la exigencia de confiar en técnicos la tarea de dirigir las administraciones cívicas (ScotT, 1969).

Ese mismo año, la Russell Sage Foundation formó el Russell Sage Realty Development Committee, con una aportación de 1,5 millones de dólares con la finalidad de dar cuerpo a la idea de Robert de Forest. El tiempo y el coste eran los dos factores fundamentales en una primera aproximación a este tipo de promociones residenciales, y un modo evidente de la reducción de ambos era la racionalización del proceso productivo de cada una de las fases de la puesta en marcha del vecindario planeado.

Para sacar adelante el proyecto, de Forest seleccionó un equipo de trabajo formado por el arquitecto paisajista Frederick Law OImsted Jr. (18701957), de Olmsted Brothers, y el arquitecto, activista social y reformador de la vivienda, y experto en estandarización Grosvenor Atterbury (1869-1956) (Pennover \& Walker, 2017), que sería autor del edificio de la sede de la Russell Sage Foundation en Nueva York. Para la gestión económica contó con el conocido experto en gestión inmobiliaria William E. Harmon (1862-1928), de Wood, Harmon \& Co., y encargó el aspecto administrativo a Edward $\mathrm{H}$. Bouton, presidente de la Roland Park Company de Baltimore, y pionero del suburbio Roland Park (1890), en el que participó Frederick Law Olmsted Jr.; Bouton renunció en 1911 y fue sustituido por John M. Demarest, en calidad de vicepresidente y director general de la Sage Foundation Homes Company. En abril de 1909 los profesionales seleccionados se reunieron con Robert de Forest para marcar las bases del proyecto (KLAUS, 2002). 

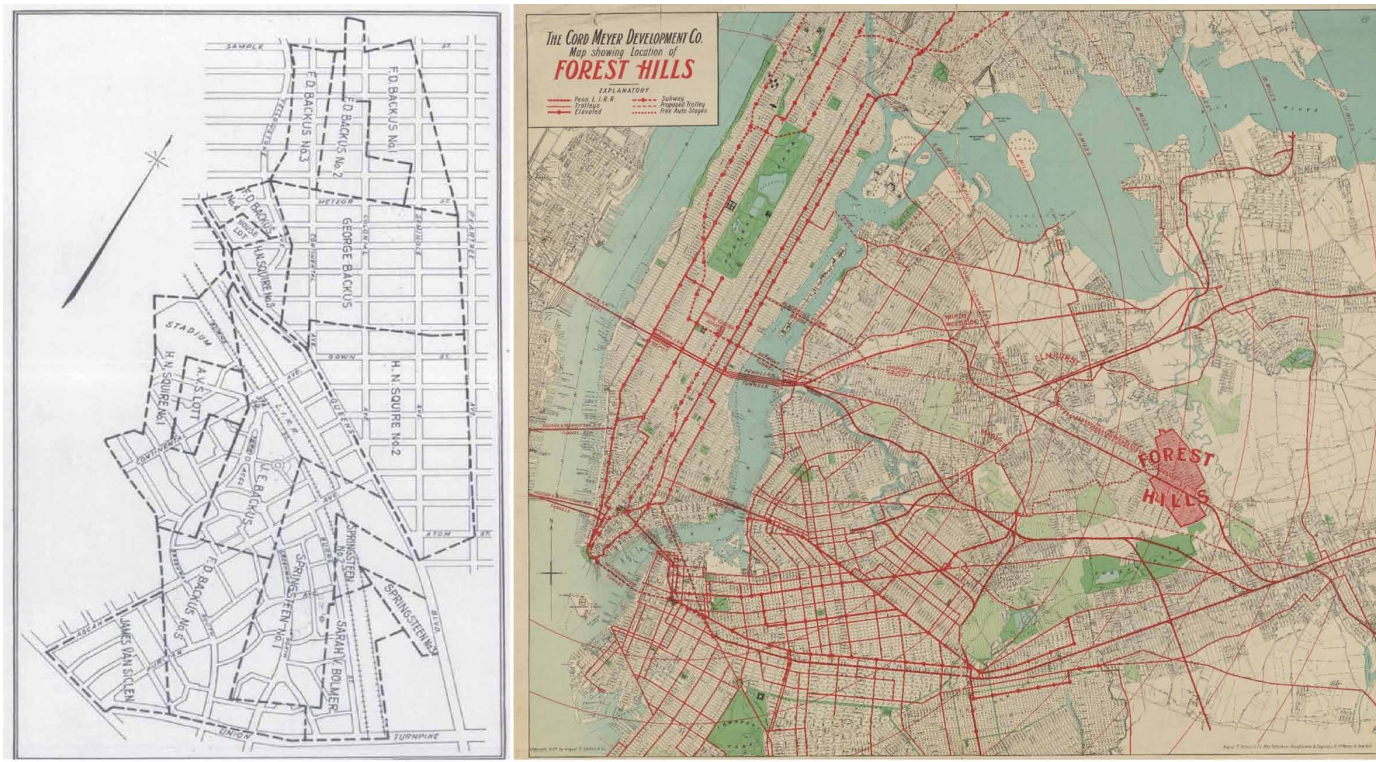

FIG. 2/ Delimitación de propiedades agrarias correspondientes a los terrenos de Forest Hills Gardens y plano de la Cord Meyer Development Co. (1902).

Fuente: Forest Hills Gardens Bulletin, (1924), Volumen 10, nº 6; y The New York Public Library Digital Collection.

\section{El ferrocarril como agente urbanizador}

De Forest centró su interés en el emplazamiento de la nueva ciudad modelo en el barrio de Queens. Con el desarrollo de las infraestructuras de comunicación, Manhattan había ido perdiendo su función residencial a favor de la franja suburbana. Hay que tener en cuenta que hasta 1870 el medio de transporte más utilizado era el de las compañías de ómnibus a caballo, pero la construcción de ferrocarriles elevados con tracción por cable o vapor, el puente colgante de Brooklyn y la apertura del metro electrificado a partir de 1904, permitió la invasión de Brooklyn y parte del Bronx. En 1898 Queens se incorporó al Gran Nueva York y el ferrocarril Long Island Rail Road lo conectó con Manhattan; el túnel de Steinway, abierto en 1907 , aunque sin uso en esos momentos por problemas de concesiones municipales del servicio de metro, el puente de Queensboro, abierto en 1909, y los túneles del ferrocarril de Long Island en 1910, llamaron la atención de los promotores que pasaron de Brooklyn a Queens. Queens se libraba del aislamiento que le había permitido conservar relativamente intacta su riqueza natural. (FIG. 3).

En 1906, según Wood, Harmon \& Co., los precios por parcela del Gran Nueva York oscilaban entre los 190 y 290 dólares en Staten Island, teniendo en cuenta que sólo había en esos momentos una conexión con ferry; en el vacío de Queens, entre 500 y 1.500 dólares, y en Jamaica, entre 500 y
2.000 dólares. En el Bronx, los precios se disparaban de 2.000 a 10.000 dólares hacia la orilla del río Hudson. Esos valores suponían que la clase económica que podía acceder al barrio de Queens y ser beneficiaria de este laboratorio social de la fundación no serían los trabajadores denominados por su característico vestuario de cuello-azul, sino las clases medias. Con los adecuados mecanismos de financiación, los precios atraerían no sólo a gente con capacidad de pago inmediato, sino a aquellos que tuvieran capacidad de ahorro, que tendrían una oportunidad de comprar una casa bajo términos de razonable seguridad financiera. Como la fundación esperaba obtener beneficios razonables, la mayor parte del remanente recaería en el comprador. Los rígidos métodos de distribución económica asegurarían al menos un valor equivalente a las propiedades similares, el acceso al ferrocarril era una garantía de revalorización de la inversión y los seguros protegerían al comprador de los infortunios.

La Russell Sage Foundation compró 19 hectáreas en Jamaica con la intención de ampliar luego la promoción, pero la noticia de su patrocinio se extendió y provocó un alza del valor del suelo en el entorno (WALLACE, 2018). Así pues, la fundación se decidió a negociar con la Cord Meyer Development Company. Esta firma familiar de bienes raíces, con un origen de la fortuna en los fertilizantes, se había percatado a principios de la década 

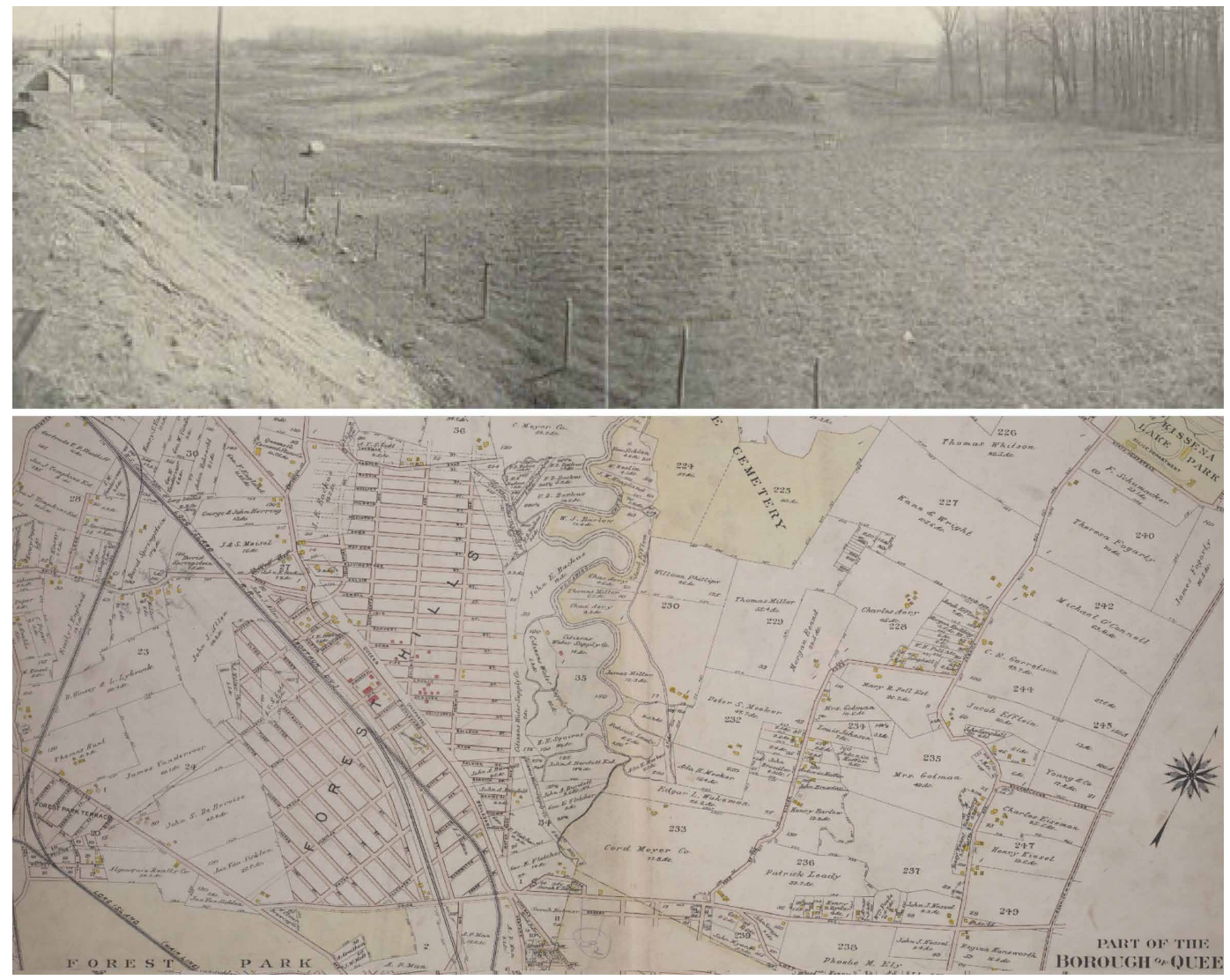

FIG. 3/ Los terrenos del emplazamiento de Forest Hills Gardens y la propuesta de parcelación de Forest Hills elaborada por la Cord Meyer Development Co. (1902).

Fuente: Forest Hills Gardens Foundation; y The New York Public Library Digital Collection.

de 1890 de que Queens no iba a ser capaz de conservar su ambiente rural y su estructura de propiedad de grandes terratenientes. Como resultado, compró una extensa granja y propuso un vecindario, Elmhurst, con viviendas, escuelas, tiendas y servicios, que prosperó e inspiró un crecimiento similar en las áreas contiguas. En 1906, la compañía adquirió 98 hectáreas a seis granjeros locales en la sección Hopedale de Whitepot, en Queens, donde se proponía una gran urbanización que denominó Forest Hills. La propiedad consistía en una amplia parcela de tierra ondulada, parcialmente arbolada, bien drenada, con descenso hacia el noroeste y de espaldas a Long Island, con suelo seco y marga arenosa libre de estratos rocosos. El nombre de Forest Hills aludía a la altura del terreno, en forma de colina, y a Forest Park, 217 hectáreas colindantes de parque urbano completado en 1898, en el contexto de la creación del Gran Nueva York.

La Russell Sage Foundation compró la superficie de Forest Hills, 57 hectáreas situadas a la derecha de las vías de ferrocarril, a la Cord Meyer
Development Company, por 15.000 dólares la hectárea. A la que se sumaron dos compras posteriores de un total de 25 hectáreas, 10 de las cuales serían destinadas a un club de tenis. La promoción se denominó Forest Hills Gardens.

Inicialmente, las vías del Long Island Railroad pasaban en Forest Hills a nivel del suelo, hasta que en 1912, en coincidencia con su electrificación, se elevaron para poder servir a ambos lados de las vías, y se construyó una estación, que fue sufragada por la compañía ferroviaria, por la Sage Foundation Home Company y la Cord Meyer Development Company, propietarios de las dos promociones colindantes, que abonaron los 40.000 dólares restantes. El proyecto del puente, realizado por Atterbury, utilizó estructura metálica recubierta de hormigón acabada en estuco Wolf, 1915).

En la promoción de Forest Hills Gardens, la fundación previó inicialmente la construcción de unas 800 viviendas. Siguió el modelo de ciudad suburbana londinense de Hampstead Garden Suburb 
de la Garden Suburb Development Company Ltd. de Hampstead (1905), de los arquitectos Raymond Unwin y Barry Parker, liderada por la singular Henrietta Barnett, creadora, junto a su marido, del Toynbee Hall. Ambas iniciativas carecían de tejido industrial productivo, frente a la ciudad-jardín de Letchworth, que contaba con una reserva de suelo industrial cerca de la estación de tren. El argumento esgrimido por la fundación fue que los avances tecnológicos de los medios de transporte permitían el acceso a lugares de trabajo distantes con costes asequibles para las masas trabajadoras. Se apostó así por el modelo de los commuters. Forest Hills Gardens tendría un carácter residencial, con acceso a las necesarias dotaciones sociales y deportivas asociadas, y actividades del sector terciario, como comercio y una zona de oficinas, vinculadas a la estación (The SAge Foundations Homes COMPANY, 1912).

\section{La naturaleza y la técnica}

Olmsted Jr. fue el responsable de la planificación del sitio. La fundación buscaba la calidad del diseño y dirigió su estudio al problema de mejorar el uso del suelo que ofrecía la subdivisión rectangular de la malla neoyorkina, tanto desde el punto de vista económico como desde el punto de vista estético. El trazado curvo del viario, que recuerda la ciudad de Riverside (Chicago), proyectada por Frederick Law Olmsted Sr. y Vaux en 1869 y antecedente en cierto modo de la ciudad-jardín inglesa, contrastaba con la trama neoyorkina de la propuesta inicial de la Cord Meyer Development Company para Forest Hills. Se rompían las interminables perspectivas y la homogeneidad espacial a favor de la individualidad, y se evidenciaba la escala más doméstica que se pretendía para el proyecto. A nivel práctico, se evitaba también el tráfico rápido.

Uno de los aspectos más valorados del proyecto fue el protagonismo de la naturaleza, no sólo por la proximidad de Forest Park, sino en el desarrollo de la urbanización. La naturaleza, con su sola presencia, aportaba beneficios de carácter higiénico y estético para el cuerpo y el alma. El derecho de todos a poder disfrutar de un pequeño jardín propio era concebido como el derecho a un trozo de paraíso en la tierra, que sería más necesario cuanto más desfavorables fueran las condiciones de la familia. Parecía producirse una apuesta decidida por un tipo edificatorio: la vivienda unifamiliar. Al mismo tiempo, se pretendía una idealizada forma de vida en el campo, en pleno contacto con la naturaleza, con un marcado carácter anti-urbano (MANN, 1958). Mostraba la capacidad del diseño urbano para influir en el comportamiento del grupo social de acuerdo a la satisfacción de sus demandas residenciales.
Olmsted aplicó tres principios en su diseño: una estructura viaria jerarquizada basada en un trazado de las vías estructurantes de trazado directo y simple, un bulevar de $38 \mathrm{~m}$. de ancho limítrofe con Forest Park, dos avenidas rectas pasantes de $24 \mathrm{~m}$. que enlazaban con el trazado urbano circundante, dos avenidas curvas de $21 \mathrm{~m}$. de ancho, Greenway North y South, radiantes desde la estación, que atravesaban el complejo hasta Forest Park, y vías secundarias de $18 \mathrm{~m}$. de ancho. El segundo principio hacía referencia a las calles locales, que habían de ser tranquilas y atractivas y dotadas de un carácter doméstico. (FIG. 4)

El tercer principio era la deliberada colocación de áreas de uso común para los residentes. El sistema de calles se entrelazaba con los espacios verdes que conectaban con los parques y el arbolado urbano, y se completaba con Forest Park. The Green, rodeado de vías de tráfico, era el parque de recreo direccional en la bifurcación de la Greenway, y a su lado se reservó el lugar para la escuela. Destacaban dos parques menores, un parque cercano a Forest Park que ocupaba parte de una manzana, denominado Olivia Park, y una manzana completa cerca de la vía de ferrocarril, Hawthorne Park.

La mayor novedad fue la figura del denominado setting appart. Estos eran espacios que ocupaban el interior de algunas manzanas y se reservaban para el uso exclusivo de los residentes; eran jardines comunales privados con acceso controlado. Este espacio podía, en un futuro, dedicarse a otros usos vinculados al comercio u otras actividades económicas. Para evitar los usos indeseados, se estableció la cláusula de molestia, donde se especificaba todo un listado de las actividades prohibidas por las molestias que pudieran ocasionar a los vecinos. A la larga, esta propuesta generaría tensiones entre lo público en el espacio colectivo y la privacidad en la vivienda. No se debe olvidar que la vida se preveía en comunidad y en los estatutos se presuponía un comportamiento entre los vecinos acorde con la moral y las buenas costumbres.

En el proyecto se definió hasta el último detalle de la urbanización, incluidas las aceras, tanto a nivel de pavimentos, de macadam bituminoso, como de bordillos; el alcantarillado; las redes de telefonía, de suministro de agua, electricidad, gas e iluminación; y las plantaciones de arbolado urbano y de parques. Se diseñaron con un criterio unitario las farolas y la señalización de calles y se añadieron elementos ornamentales como fuentes y estanques. El coste de la urbanización del viario y los jardines, que ocupaban un $32 \%$ y un $4 \%$ de la superficie total respectivamente, ascendió a cerca de un millón de dólares. 


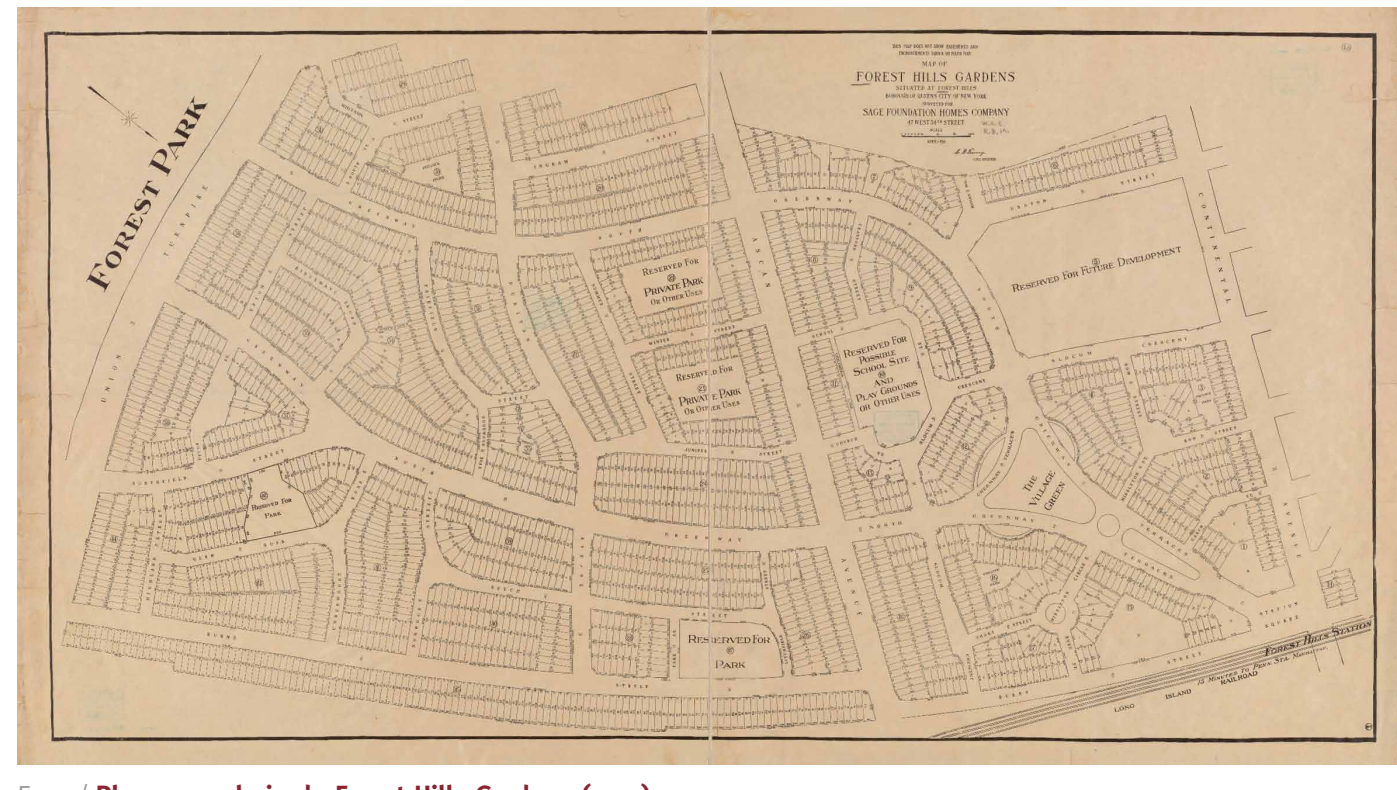

FIG. 4/ Plano parcelario de Forest Hills Gardens (1911).

Fuente: The New York Public Library Digital Collection.

La estación de ferrocarril, finalizada en 1913, era el punto de conectividad con la metrópolis y la puerta de acceso a la urbanización. La estación fue concebida como un conjunto unitario a modo de corazón de la comunidad. Olmsted Jr. diseñó la plaza, que conformaba un gran espacio público donde no faltaba el detalle ornamental de la fuente, y Atterbury fue el encargado de diseñar los edificios circundantes como entidades formalmente dependientes. La icónica torre de Forest Hills Inn, un hotel con 150 habitaciones, de estructura metálica y forjados de hormigón, enfatizaba la base casi feudal de la propuesta. La casa de apartamentos para residentes, oficinas a modo de distrito de negocios, restaurantes y tiendas eran los usos complementarios del conjunto. Desde este centro irradiaban las principales vías que atravesaban la comunidad hasta Forest Park. (FIG. 5)

Las 57 hectáreas iniciales se dividieron en 2.000 parcelas residenciales, cuya ocupación máxima era del 25 al $50 \%$, condicionado al ancho de fachada del edificio, por lo que el espacio construido máximo de Forest Hills Gardens era 32\% de la superficie total (FIG. 6). El vecindario se organizó en conjuntos multifamiliares de viviendas en rígida composición axial alrededor de las tranquilas vías. La implantación se organizó de forma progresiva; la primera fase fueron diez conjuntos multifamiliares de viviendas de distintas dimensiones. Cada grupo combinaba viviendas adosadas y aisladas con un máximo de 10
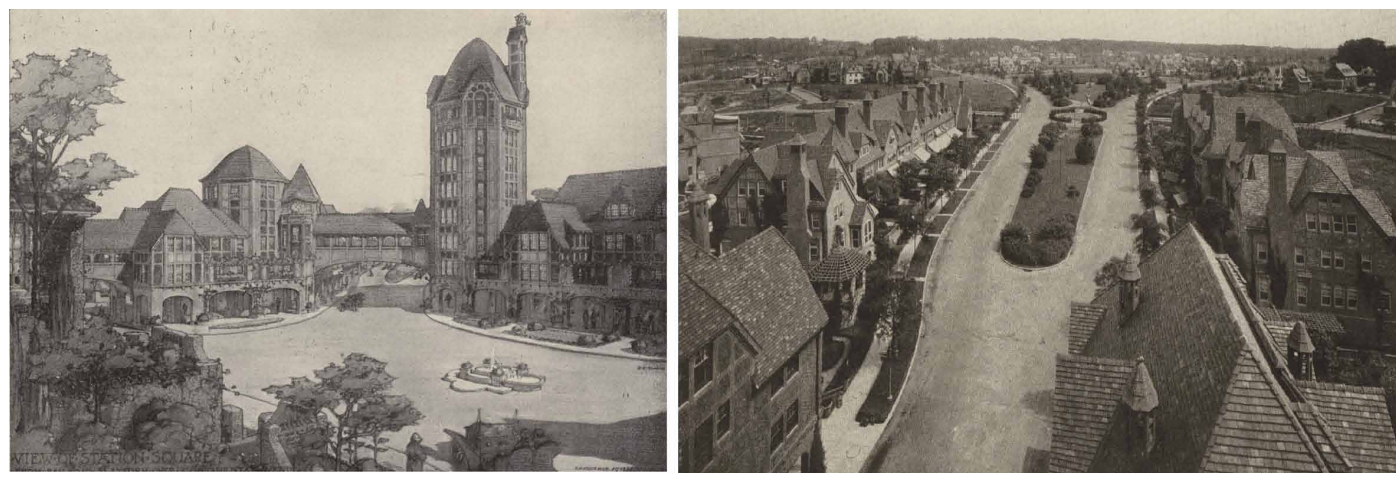

FIG. 5/ "Station Square mostrando el hotel y los housekeeping apartments y "El green village desde la torre del hotel".

Fuente: J. A. WALTERS (1911): A model Town in America, Arts and decoration, Volumen 3, nº 1; y C. C. May (1916): Forest Hills Gardens from the Town Planning Viewpoint, Architecture, Volumen $34, n^{\circ} 2$ 

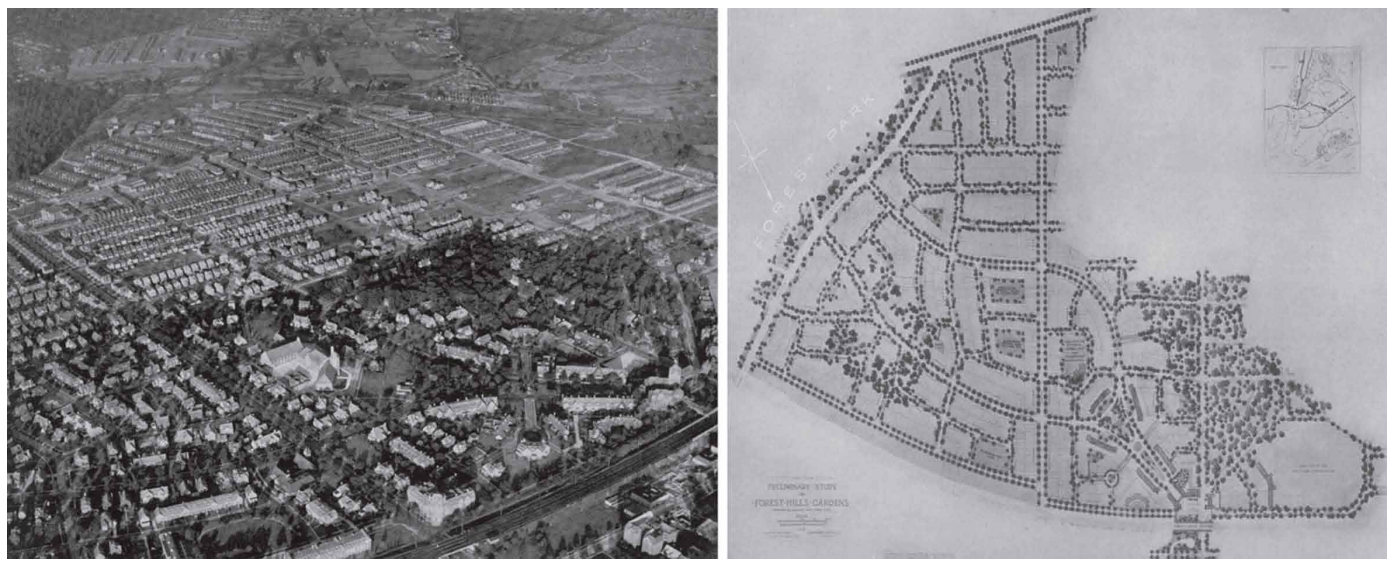

FIG. 6/ "El intento del arquitecto de individualizar un pueblo estandarizado: Forest Hills Gardens." y "Estudio preliminar de Forest Hills Gardens."

Fuente: L. MumFORD (1930): Mass-production and the modern house, The Architectural Record, Volumen LXVII, enero; y The Sage Foundation Homes Company (1913): Forest Hills Gardens.

unidades. Los lotes se repartirían entre distintos arquitectos, además de Atterbury, que debían presentar el proyecto a la compañía para ser aprobado previamente. Los conjuntos, de estilo inglés Tudor o georgiano se dotaron de un aire eminentemente pintoresco, a modo de casas de campo inglesas. Este imaginario, común en la mayoría de las ciudades-jardín, tenía su referente estético en la Arts and Crafts Exhibition Society, fundada en Londres en 1887 por William Morris.

\section{6. ¿Ordnung o democracia? Acerca del diseño urbano y el determinismo social}

El progresivo sobrecoste de las parcelas, el tráfico privado generado, que no estaba previsto, y la excesiva homogenización de la población, clase media blanca y protestante, pronto sembraron dudas sobre el experimento urbanístico. Los residentes de Forest Hills Gardens constituyeron un grupo social de carácter muy homogéneo, formado por comerciantes, oficinistas, arquitectos, artistas, ingenieros y pequeños empresarios. Para Atterbury, éste era parte del ensayo, abordado de un modo científico, ya que era imposible una ciudad modelo sin ciudadanos modelo.

En esta singular experiencia, el urbanismo, que fue visto como una vía de socialización de la arquitectura, se materializaba a través de una fórmula referida directamente al equilibrio entre comunidad y privacidad (Cıuccl, 1977). La planificación de la ciudad, de la vivienda y de la investigación social había encontrado en el vecindario la unidad elemental de todo asentamiento urbano. Este concepto se introdujo en España a partir de los años veinte de la mano del catedrático de urbanismo César Cort, con su actividad docente en la Escuela Superior de Arquitectura, en el concepto de la nucleología (GARcíA-GonZÁLEZ, 2018) (FIG. 7). Para John Nolen, fue la gestión privada de los espacios públicos lo que había permitido que las ciudadesjardín de Forest Hills Gardens y Hampstead fueran consideradas "más admirables que las ciudades de las cuales eran suburbios" (Nolen, 1916).

Para Lewis Mumford, la idea del community planning, con la creación de un centro o corazón del vecindario, partía de la experiencia de los university settlemens, como el Toynbee Hall de Londres, o la Hull-House de Jane Addams de Chicago. Cierto que la gran diferencia es que estos university settlemens o setttlement houses se localizaban en los barrios más depauperados de la ciudad, por lo que estaban más vinculados al concepto urbanístico de regeneración de barrios.

Años más tarde, Clarence Perry argumentó cómo las unidades vecinales, y Forest Hills Gardens fue su precedente, respondían a la tendencia natural al agrupamiento de individuos de similares características sociales o raciales (PERRY, 1929). Este hecho constatado no era de por sí criticable, pero sí estaba claro que podían derivarse consecuencias negativas a largo o medio plazo, como el fantasma de la segregación y el aislacionismo doméstico (BAUER, 1945).

El marketing y la difusión fueron muy activos por parte de la promoción. En sus panfletos, Forest Hills Gardens fue definida como un desarrollo suburbano, cerca de un parque de gran belleza natural, con escuelas, iglesias, instalaciones deportivas, especialmente las dedicadas al tenis, y con conexión directa con la estación de Pensilvania 

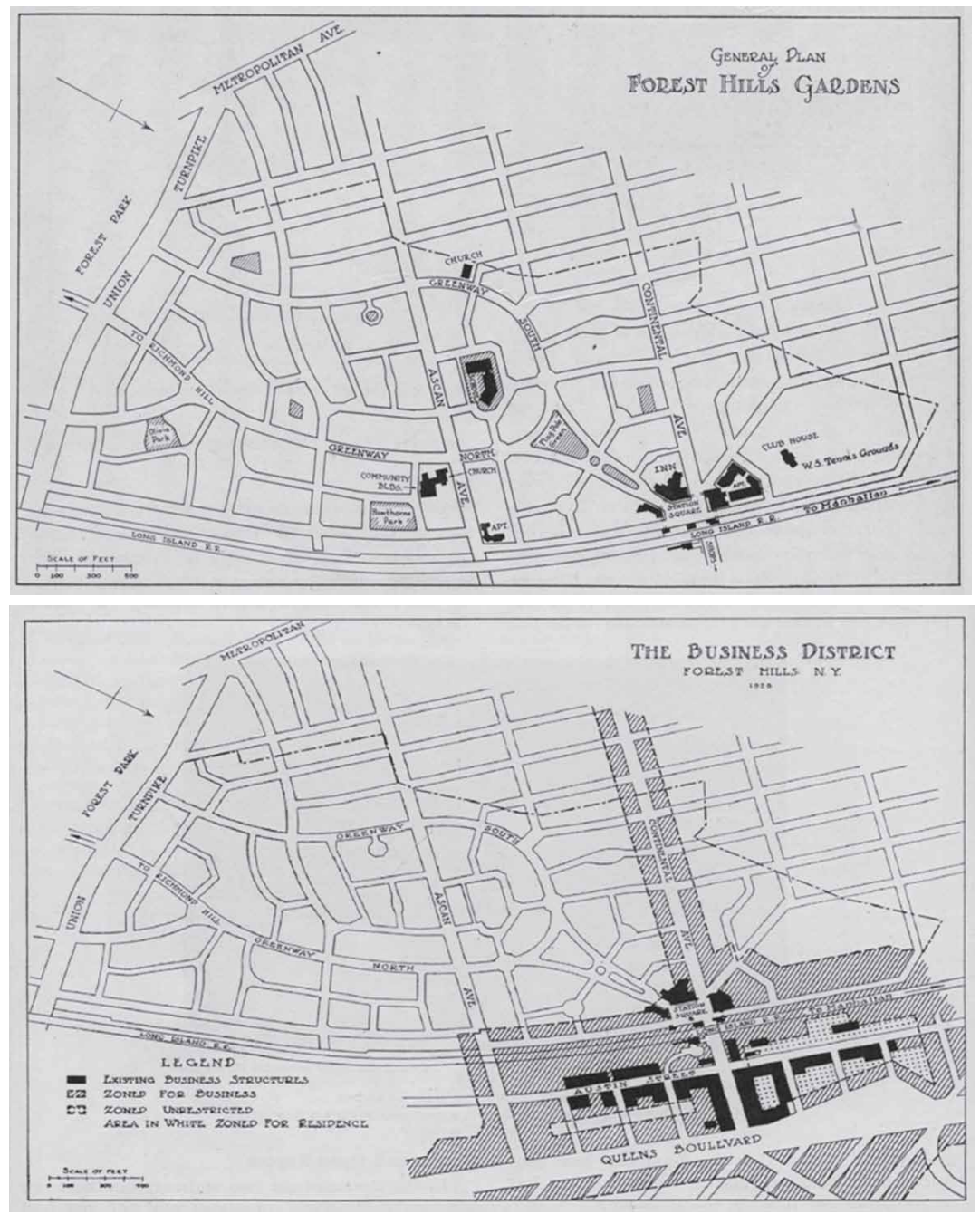

FIG. 7 / "Un desarrollo residencial que fue motivado con un propósito social y comercial." y "Para una comunidad commuter, el distrito de negocios local está bien localizado en el punto mejor conectado."

Fuente: C. A. PERRY (1929): Forest Hills Gardens as a neighborhood community. The Neighborhood Unit, a Scheme of Arrangement for the Family-Life Community, Regional Plan of New York and Its Environs, Volumen 7, Nueva York, USA Regional Plan of New York and Its Environs.

cada 15 minutos. El Forest Hills Gardens Bulletin era utilizado como un modo de comunicación entre los vecinos desde su número inicial de 1915.

“¿Por qué hemos elegido Forest Hills Gardens? Me gusta el lugar, me gusta mi casa y me gusta su gente". En estas frases, que pertenecen a una encuesta realizada en 1915 entre los residentes (Forest HILls Gardens, 1915), se sintetizan sus tres aspectos clave: el emplazamiento, la arquitectura y la población. Las motivaciones incidían en ese ideario social: los beneficios de la naturaleza (29\%), el ferrocarril, accesible en tiempo y dinero $(25 \%)$, la calidad de la urbanización y de la arquitectura $(21 \%)$ y la adecuada gestión económica con el respaldo de la fundación (15\%) y la sintonía con los vecinos, definidos como inteligentes y amigables, basada en la similitud de intereses e inquietudes (10\%).

Clarence Perry, residente desde 1912, también participó en la encuesta: "Quería un hogar cerca de la tierra verde entre vecinos accesibles y niños agradables. Quería tranquilidad, una casa modesta, pero de buen gusto, libre del conserje, y del metro y los elevadores. Quería estas cosas cerca de Broadway, y las encontré aquí". Y fue a partir de esta experiencia vital propia donde Perry conformó su teoría de la unidad vecinal (PERRY, 1926). 
Las revistas del reformismo social, las culturales, las de decoración, las de arquitectura y las técnicas, como Charities and the Commons, The Survey, The Scriber, Art and Progress, Beautiful House, The Craftman, Architecture, The Architectural Record, The Architectural Forum, Architecture and Building, Concre-Cement Age, The brick Builder y Brick Progress, entre otras, recogieron de forma entusiasta los avances.

\section{La estandarización y la prefabricación en la construcción de la vivienda}

El arquitecto Grosvenor Atterbury explicaba el posible éxito económico del experimento empresarial de Forest Hills Gardens como una ecuación basada en la relación entre la dimensión y la calidad de las viviendas y el valor del suelo. Atterbury tradujo este axioma a la racionalización del diseño, con las variables de la superficie de suelo por vivienda, y la construcción. Se trataba de imitar lo que Henry Ford había hecho para la industria del automóvil en la estandarización del proceso de construcción de la vivienda, pero añadiendo los conceptos de propuesta educativa, higiénica y estética.

La idea de racionalización de la producción de la vivienda social no era nueva para Atterbury. Había construido el primer edificio de viviendas sociales de Nueva York, Phipps Houses (1905), con la donación de Henry Phipps, socio de Carnegie, de un millón de dólares. Pero sobre todo, había trabajado a partir de 1905 en un prototipo experimental de vivienda unifamiliar aislada patrocinado por la Russell Sage Foundation. En esa experiencia, la estandarización se refería no sólo a los elementos constructivos, sino también a la organización científica del trabajo. Partía de la concepción de una vivienda como un proceso definido y cerrado, como la producción del automóvil. En el proceso identificó varias fases, entre ellas, la excavación de los sótanos, la disposición de la cimentación y de los muros y el levantamiento de la primera planta, la colocación de las escaleras, el levantamiento de la segunda planta, el cierre de la primera planta, el levantamiento y el cierre de la segunda planta, el levantamiento de los aguilones del tejado y el cierre del tejado.

Atterbury también definió los criterios generales de acuerdo a los cuales se debía proceder en los trabajos: máxima posibilidad de adaptación del diseño y de los materiales respecto a los métodos más económicos de construcción de edificios, y a los últimos y más eficientes equipamientos mecánicos, lo que suponía minimizar la necesidad de mano de obra y, por tanto, la repercusión de su coste; y el reajuste de la unidad edificatoria con el objeto de reducir su número al mínimo e incrementar su dimensión al máximo compatible con la seriación y la manipulación.
Para Atterbury, la originalidad en la arquitectura surgía de las condiciones de los materiales y, entre ellos, su interés se centró en el hormigón, para el que experimentó con sus posibilidades en la prefabricación. El uso del cemento parecía ofrecer los más prometedores campos para un radical ahorro del coste. De las tres posibilidades iniciales, la opción de estructura prefabricada por la introducción de hormigones en moldes in situ, y el uso de esqueletos o moldes permanentes, que se manufacturaban cerca del lugar y se rellenaban de hormigón in situ, eligió la estructura construida en fábricas localizadas en las inmediaciones de la obra con maquinaria específica de grandes unidades estandarizadas (CEMENT Age, 1910).

Estos estudios los aplicó comercialmente en Forest Hills Gardens. Su sistema consistió en modelar grandes paneles aligerados de hormigón en fábrica, en forma de grandes losas estándares, adecuadamente diseñadas, reforzadas y acabadas con maquinaria perfeccionada. Tanto el uso del panel hueco de hormigón como las tres secuencias de los procesos en la construcción de la manufactura, el transporte y el levantamiento fueron novedosos. Los paneles se manipulaban tres veces. Después de ser moldeados en fábrica, eran transportados en camiones hasta el lugar de construcción y se depositaban en espacios libres de la obra. Dado el considerable tamaño de los bloques, se requerían potentes grúas para erigirlas in situ. Para Atterbury, todo el proceso era simple, rápido y requería de sólo una pequeña cantidad de trabajo especializado (FIG. 8).

En el caso de Forest Hills Gardens, las paredes, los techos y los diferentes pisos, así como algunas piezas características tales como los porches, las chimeneas, las buhardillas y las escaleras, eran de hormigón prefabricado, en su mayoría con paneles de corazón hueco. El molde proporcionaba acabados de la superficie de la pared interior y exterior. Un panel tipo era de 2,40 m. de alto, y 22 $\mathrm{cm}$. de ancho, que corresponden a 9 pulgadas, con dos hojas de pulgada y media y 6 pulgadas de hueco, y con un peso 1,5 toneladas. Los paneles huecos aligerados de hormigón permitían el paso del cableado de electricidad y las instalaciones de fontanería. En este punto, en la eficiente vivienda se incorporaban las instalaciones necesarias para la puesta en servicio de modernos aparatos eléctricos que iban desde lavadoras a sofisticados sistemas de calefacción.

Atterbury tenía problemas de incompatibilidad de materiales con el hormigón, así que, dentro de los trabajos patrocinados por la Russell Sage Foundation, inventó el nailcrete, que empezó a comercializar en 1910. Era un hormigón mixto con una gran inocuidad al pino blanco y otros materiales que permitía acometer la madera fácilmente a las superficies de hormigón (CRAWFORD, 1995). El 

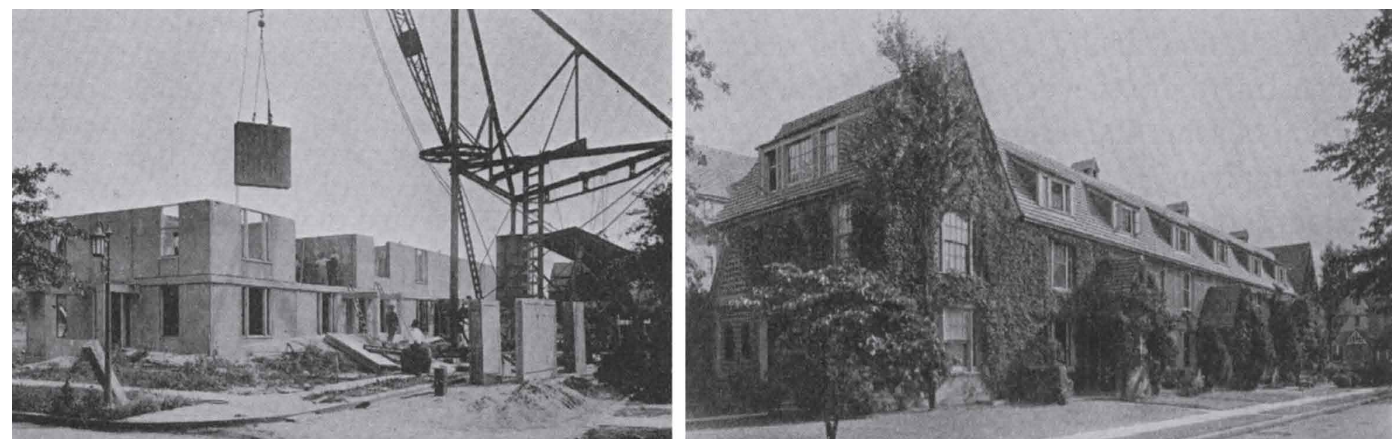

FIG. 8/ "Demostración en Forest Hils Gardens. Un bloque ensamblado por un finger gigante." y "El mismo grupo completo. Cada casa se compone de menos de cien unidades de obra industrializadas, en lugar de las cientos de miles de unidades de obra manuales de la construcción ordinaria."

Fuente: T. Adams (1931), Buildings: their uses and the spaces about them, Regional Plan of New York and Its Environs, Volumen 6, Nueva York, USA, Regional Plan of New York and Its Environs.
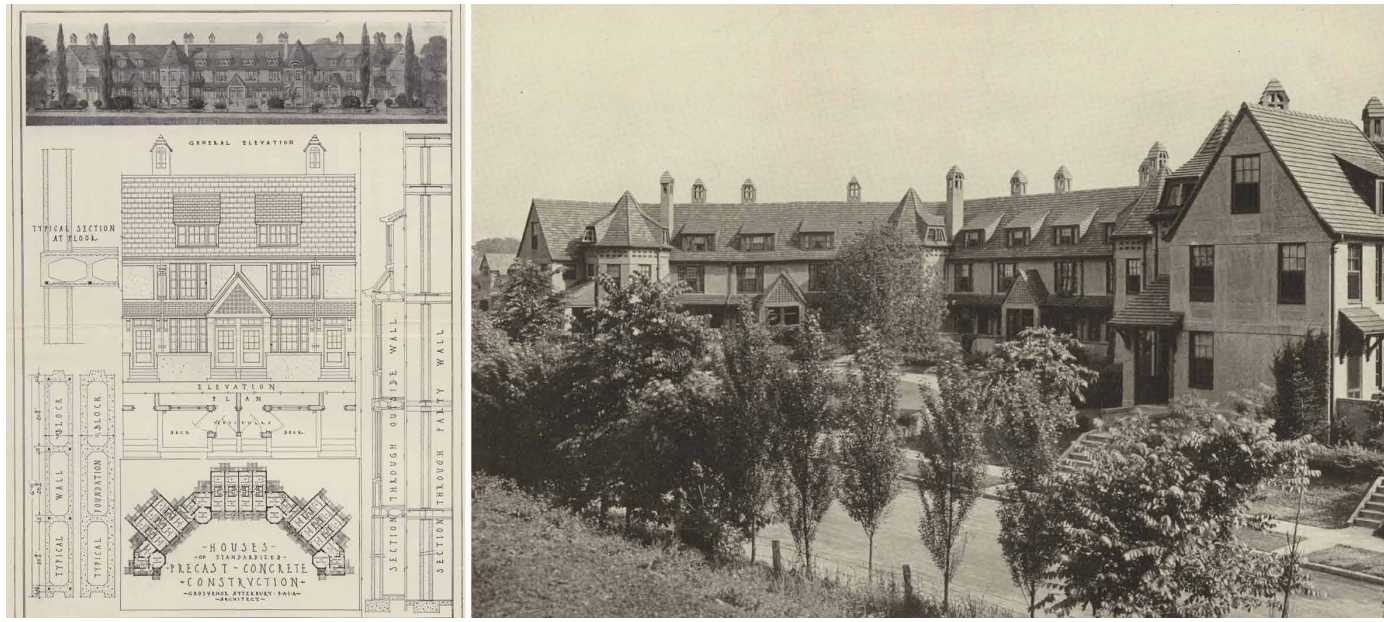

G. 9/ Viviendas (Grupo II) de Forest Hills Gardens.

Fuente: F. SQUIRES (1916): Progressive Architectural Construction. Architecture and Building, febrero; y C. C. May (1916): Forest Hills Gardens from the Town Planning Viewpoint. Architecture, Volumen $34, n^{\circ} 2$.

nailcrete era lo suficientemente blando para aceptar directamente los elementos de anclaje y sujeción de los paneles de acabado, normalmente de madera. Además, admitía remates y acabados de enfoscados, tanto en el exterior como en el interior.

Una vez que se añadían a la vivienda las puertas y las ventanas de madera, los porches, las buhardillas y la jardinería, no quedaba resto alguno de la fría presencia del hormigón. Se producía así un ejercicio de equilibrio entre la monotonía de la seriación y la estética de la individualidad. $Y$ se superaba también el contraste entre los avanzados modos industriales de construcción y de urbanización, y el imaginario pintoresquista de la arquitectura doméstica, donde la eficiencia también estaba presente, como en las clásicas cubiertas a dos aguas que cumplían su función como aislamiento térmico, y conalero que protegía de la lluvia.
Forest Hills Gardens fue un éxito respecto a la atractiva, robusta, exenta de mantenimientos y excepcional durabilidad de la construcción. Sin embargo, el excesivo coste de la planta de producción y la complejidad de los equipos necesarios para producir relativamente pocos paneles (menos de cien paneles por vivienda en suelo y techo), además de las grúas y maquinaria especializada necesarias para manipular los elementos prefabricados, no logró convertir este sistema en una industria rentable (FIG. 9).

En abril de 1922, John M. Demarest, director general de la Sage Foundation Homes Company, gestionó la cesión del control de las acciones a un sindicato mayoritariamente compuesto de propietarios, al considerar que la fundación había cumplido su cometido de dotar de un modelo de vivienda de calidad. La Russell Sage Foundation 

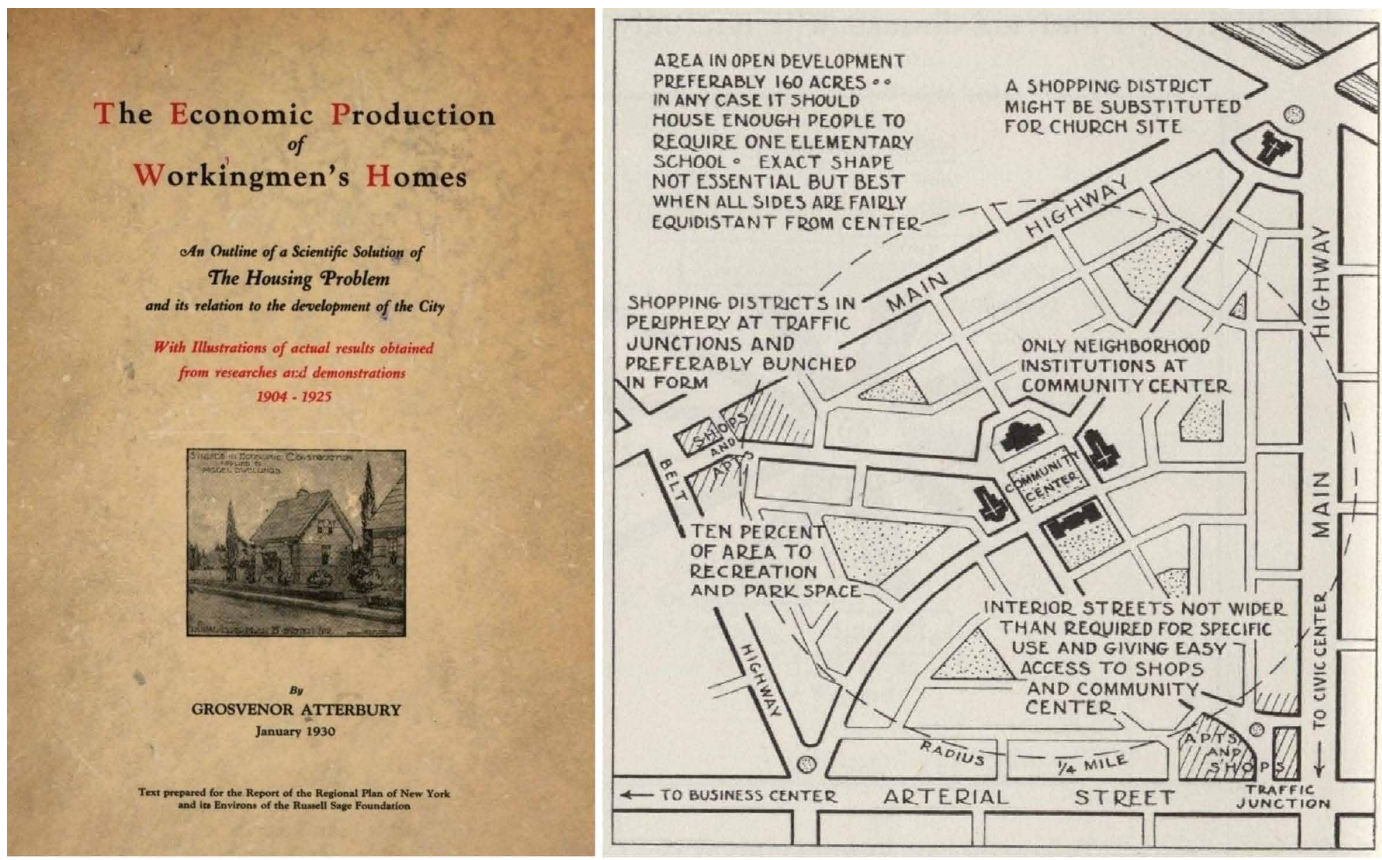

FIG. 10/ Portada de una publicación de Grosvenor Atterbury; y esquema de los principios de la unidad vecinal de Clarence A. Perry.

Fuente: G. ATTERBURY (1930): Housing conditions of economic production of workingmen's homes, Nueva York, USA, Russell Sage Foundation; y C. A. Perry (1929): The Neighborhood Unit, a Scheme of Arrangement for the Family-Life Community, Regional Plan of New York and Its Environs, Volumen 7, Nueva York, USA, Regional Plan of New York and Its Environs.

había invertido entre 1909 y 1922 más de una sexta parte de su capital en Forest Hills Gardens, 3 millones de dólares, y aunque triunfó en la calidad del espacio producido, falló en su supuesto inicial de generar beneficios económicos, ya que la fundación perdió alrededor de 300.000 dólares, y con el objetivo de generar viviendas de bajo coste (HАMMACK, 1988).

La fundación no promovió ningún otro desarrollo urbanístico, aunque sí invirtió en acciones en la City Housing Corporation para el proyecto de Sunnyside Gardens (1924), en Long Island. Esta empresa, fundada por el promotor Alexander Bing contó con los arquitectos Clarence Stein y Henry C. Wright, colaboradores ocasionales de la fundación, que materializaron la idea de la unidad vecinal de Perry en Radburn, Nueva Jersey (1928). Todos ellos, bajo el liderazgo intelectual de Lewis Mumford, eran miembros o simpatizantes de la American Regional Planning Association (1923), en el entorno de la ciudad-jardín. Sin embargo, la crisis de 1929 acabó con la compañía.

\section{The Regional Plan of New York and its Environments (1929)}

En 1918, Olivia Sage legó en su testamento una suma adicional de cinco millones de dólares a la fundación, con un deseo expreso de que una parte de los beneficios generados recayesen en la ciudad de Nueva York. De la mano de Charles Dyer Norton, promotor del plan de Chicago y amigo de Robert de Forest, la fundación desarrolló un ambicioso plan para Nueva York. En 1922 puso en marcha la Regional Plan Association, con Charles G. Meyer, de la Cord Meyer Development Company, y Alfred T. White, uno de los grandes propietarios y promotores de Brooklyn, y socio, entre otros, de la Russell Sage Foundation.

La fundación dedicó más de un millón de dólares al Regional Plan of New York and its Environments bajo la coordinación de Thomas Addams, eminente figura vinculada a la ciudad-jardín. La superficie que se vio afectada por el plan era de más de $12.950 \mathrm{~km}^{2}$ con cerca de 9 millones de habitantes, la mayor jamás considerada en un plan urbanístico hasta ese momento.

Adams dividió el territorio en seis sectores, adjudicados a Frederick Law Olmsted Jr., Thomas Adams, John Nolen, Harlam Bartolomew, George B. Ford y Edward H. Bennet. Les propuso trabajar con cuatro objetivos: el uso del suelo, la subdivisión y desarrollo del suelo, la circulación y los espacios abiertos y recreativos. Con las diferentes propuestas y los surveys previos de los aspectos 
económicos, legales y sociales, Adams generó el plano de síntesis. En el aspecto propositivo, sobre el área metropolitana se introdujeron nuevas infraestructuras como autopistas, rutas radiales, circunvalaciones, by-pass metropolitanos, nuevos ferrocarriles y suburbanos, vías de agua, y aeropuertos. Adams propuso descongestionar los densos espacios con la descentralización del tejido industrial y los negocios. Sin embargo, la propuesta se basaba en la creencia de que la región era fija, y que sólo en el crecimiento se encontraba el margen del cambio. La poca consideración de los efectos del automóvil y, sobre todo, la ausencia total de propuestas para resolver la problemática de la vivienda, fueron objeto de críticas demoledoras (JOHNSON, 1996).

De los doce volúmenes publicados del proyecto, un incontestable clásico en la literatura del urbanismo norteameriano, ocho de ellos, bajo la dirección de Shelby Millard Harrison, se dedicaron al Regional survey. El volumen VI, titulado Buildings: their uses and the spaces about them, contó con la colaboración de Atterbury e incluyó parte de su panfleto The economic production of workingmen's homes (ATTERBURY, 1930), donde expuso su experiencia en la estandarización y la prefabricación del hormigón en Forest Hills Gardens. El volumen VII, titulado Neighborhood and Community Planning y publicado también como obra independiente (PERRY, 1929), mostró cómo el automóvil estaba potenciando la creación de una ciudad de carácter celular. Su autor, Clarence Perry, tituló uno de sus capítulos como "Forest Hills Gardens as a neighborhood Community". (FIG. 10)

\section{Conclusión: sobre el equilibrio como hacedor de ciudades (o el fracaso de un triunfo)}

La ciudad-jardín fue un éxito en algunos de sus aspectos en Estados Unidos. Por una parte, y congruente con las teorías descentralizadoras defendidas por un amplio sector del progresismo norteamericano como reacción contra la ausencia de una política real, fue capaz de resolver los problemas de la congestión urbana. En segundo lugar, fue considerada como un instrumento válido para atraer el interés financiero de los empresarios por la estabilidad de las rentas que garantizaba como instrumento de ampliación del mercado del suelo y, por último, fue el modelo para substraer la fuerza de trabajo de la inestabilidad urbana (AV. VV., 1975).

Más de cien años después de su implantación, Forest Hills Gardens es uno de los suburbios más agradables y placenteros de la amalgama urbana que conforma el populoso barrio de Queens en la ciudad de Nueva York, hoy sometido a un proceso de gentrificación. Como materialización de una idea urbanística la iniciativa quedó restringida solamente a un suburbio de clase media-alta de hogares unifamiliares ordenados.

Sin embargo, más allá de su estado actual, en su historia convergen brillantes aspectos que permiten considerarla como una propuesta modelo, en la cual el urbanismo fue entendido al unísono desde un punto de vista social, económico, técnico y artístico y en cierto modo, también ecológico, con la puesta en valor de la naturaleza concebida como una green matrix, que diría Lewis Mumford. El proyecto fue abordado como una investigación científica en la cual fueron inherentes la apuesta por la innovación, que no se restringe sólo al aspecto técnico-constructivo, y su difusión. Se desarrolló como un experimento integral que abarcaba desde la escala arquitectónica a la escala urbana y territorial, pero también desde la escala individual a la escala social. Se puso en valor la especialización de los profesionales involucrados en el proceso y, si bien es cierto que esos profesionales fueron todos varones, no se puede olvidar que fue una mujer y filántropa, Olivia Russell Sage, a quien se debe este singular proyecto, en tanto que supo delegar en profesionales competentes que suplieran sus carencias. Unos aspectos, todos ellos inherentes a este modelo, que pueden ser reinterpretados desde la perspectiva de hoy.

\section{Bibliografía}

AA.VV. (1975): La ciudad americana, Barcelona, España, Gustavo Gili.

Atterbury, G. (1930): The economic production of workingmen's homes. An outline of a Scientific Solution of the Housing Problem and its relation to the development of the City with Illustrations of actual results obtained from researches and demonstrations 1904-1925, Nueva York, USA, Russell Sage Foundation.

BAuer, C. (1945): Good Neighborhoods. The Annals of the American Academy of Political and Social Science, $\mathrm{n}^{\circ} 242,104-115$.

BIRCH, E. L. (1978): Woman-Made America. The Case of EarlyPublic Housing Policy, Journal of the American Institute of Planners, Volumen $44, \mathrm{n}^{\circ} 2$, 130-144.

https://doi.org/10.1080/01944367808976886

Cement Age (1910): Studies in Economic Costruction, Cement Age, diciembre, 314-325.

Cluccl, G. (1977): Qualitá contro disgregazione urbana Forest Hills Gardens. Casabella, ${ }^{\circ} 41$, junio: 57-61.

CRAWFORD, M. (1995): Building the Workingman's Paradise: The Design of American Company Towns, Nueva York, USA, Verso. 
Duany, A; \& Plater-Zyberk, E. \& Speck, J. (2000): Suburban Nation, Nueva York, USA, North Point Press.

Forest Hills GARDENS (1915): Why we have chosen Forest Hills Gardens for our home, Nueva York, USA, Forest Hills Gardens.

Garcia-GonzÁlez, M. C. (2018). César Cort (1893-1978) y la cultura urbanística de su tiempo. Madrid, España, Abada Editores.

García-González, M. C. \& Guerrero, S. (2017): El urbanismo como acto de comunicación: Theodora Kimball Hubbard y la biblioteca de la Harvard Landscape Architecture School. Scripta Nova: revista electrónica de geografía y ciencias sociales, $n^{\circ} 21,553-559$.

Garden City Platted by Russell Sage Foundation (1910): The Survey, Volumen 25, $\mathrm{n}^{\circ}$ 9, 309-310.

Glenn, J. M. \& Brandt, L. \& AndRews, F. E. (1947): Russell Sage Foundation, 1907-1946. Nueva York, USA: Russell Sage Foundation.

Hammack, D. C. (1988): The Russell Sage Foundation. Social Research and Social Action in America, 1907-1947, Mariland, USA, UPA Editions.

Johnson, D. A. (1996): Planning the great metropolis: the 1929 regional plan of New York and its environments, Londres, Gran Bretaña, E \& F Spon.

KLaus, S. L. (2002): A modern Arcadia, Frederick Law Olmsted jr. and the plan for Forest Hills. Amherst y Boston, USA, University of Massachussetts Press.

LA CoRRESPONDENCIA DE EsPAÑA (1913): Lo que él ahorró él lo regala, 15 de septiembre de 1913.

Mann, P. H. (1958): The socially balanced neighborhood unit. The town planning review, Volumen $29, \mathrm{n}^{\circ} 2$, 91-98.

Mlllerson, G. (1964): The Qualifying Association. A Study in Professionalization. Londres, Gran Bretaña, Routledge \& Kegan Paul.

MumFord, L. (1925): The Fourth Migration, The Survey, Volumen $54, n^{\circ} 2,130-133$.
Nolen, J. (1916): City Planning, Nueva York, USA, D. Appleton and Company.

Perry, C. A. (1926): The rehabilitation of the local Community, Social Forces, Volumen $4, \mathrm{n}^{\circ} 3$, 558-562.

- (1929): The Neighbourhood Unit, a Scheme of Arrangement for the Family Life Community, Nueva York, USA, Russell Sage Foundation.

- (1929): City Planning for Neighborhood Life. Social Forces, Volumen 8, $\mathrm{n}^{\circ} 1,98-100$. doi: $10.2307 / 2570059$

- (1939): Housing for the machine age. Nueva York, USA: Russell Sage Foundation.

Pennover, P. M. \& Walker, A. (2017): The Architecture of Grosvenor Atterbury, Nueva York, USA, The Monacelli Press.

RIIS, J. A. (1890): How the other half lives: Studies among the tenements of New York, Nueva York, USA, C. Scribner's sons.

Scott, M. (1969): American City Planning since 1890, Berkeley, USA, University of California Press.

Stern, R. A. M, Gilmartin, G. \& Massengale, J. M. (1983): New York 1900: Metropolitan Architecture and Urbanism, 1890-1915, Nueva York, USA, Columbia University.

The Sage Foundation Homes Company (1912): Forest Hills Gardens. The suburban land development of The Russell Sage Foundation, Nueva York, USA, The Sage Foundations Homes Company, panfleto 1

VeILleR, L. (1910): A Model Tenement House Law, Nueva York, USA, Russell Sage Foundation.

WALLACE, M. (2018): Greater Gotham: A History of New York City from 1898 to 1919, Nueva York, USA, Oxford University Press.

Wolf, M. A. (1915): Surface treatment of concrete bridges for railway and Highway Traffic. ConcreteCement Age, Volumen 6, $\mathrm{n}^{\circ}$ 4, 169-175. 
CIUDAD Y TERRITORIO

ESTUDIOS TERRITORIALES

ISSN(P): 1133-4762; ISSN(E): 2659-3254

Vol. LIII, № 207 , primavera 2021

Págs. $169-180$

https://doi.org/10.37230/CyTET.2021.207.10

\section{Los orígenes de la utilización del urbanismo en la competencia entre ciudades. El caso de Houston}

Carlos García-VÁzQueZ

Catedrático de Composición Arquitectónica (Universidad de Sevilla)

RESUMEN: Este artículo analiza los orígenes de la utilización del urbanismo en la competencia entre ciudades por atraer actividades económicas. Temporalmente, pone el foco en la década de 1980, cuando, coincidiendo con un proceso similar en la economía, dicha práctica empezó a expandirse globalmente. Geográficamente, utiliza el Sunbelt estadounidense como caso de estudio. Comienza analizando la figura del "ayuntamiento-promotor" y abordando las raíces históricas del “urbanismo débil". En una segunda parte, se centra en el caso de Houston, una ciudad que no cuenta con plan urbanístico. El texto analiza las escasas herramientas que tiene el sector público para intervenir en ella, así como las que utilizan los promotores para eludir los riesgos que conlleva la ausencia de planificación. Finalmente, concluye con consideraciones sobre las ventajas y desventajas que esta ausencia comportó para Houston en el periodo analizado, así como sobre las razones que explican el apoyo ciudadano.

PALABRAS CLAVE: Competencia entre ciudades; Houston; Sunbelt; Zonificación urbanística.

\section{Origins of the use of urbanism in cities competition. Houston case}

ABSTRACT: This article analyzes the origins of the use of urbanism in the competition between cities in order to attract economic activities. Regarding the time period, it focuses in the 1980 , when this practice started to expand globally, in coincidence with a similar process in the economy. As for the geography, it uses the American Sunbelt as case study. It starts analyzing the figure of the 'developer-municipalities', and the historic roots of the 'weak urbanism' in the United States. In a second part, it focuses on the case of Houston, a city with no urban plan. It analyzes the few tools that the public administration has to operate in the city, as well as the tools used by developers in order to avoid the risks derived of the absence of planning. Finally, the article concludes with several considerations on the advantages and inconveniences of the no-plan policy for Houston in the analyzed period, as well as on the reasons that explain the support of the local community.

KEYWORDS: Cities competition; Houston; Sunbelt; Zoning; Land Use. 


\section{Introducción}

E n el ámbito económico, las ciudades contemporáneas se desenvuelven en un entorno global que Manuel Castells denominó "espacio de los flujos" (CAstells, 1995: 190 y ss.). Gracias a las tecnologías de la información, que ofrecieron a las empresas multinacionales un alto grado de libertad para elegir la ubicación de sus sedes, ese entorno es relativamente indiferente a las connotaciones propias de una localización geográfica concreta. No es ya crucial, como ocurría durante el siglo XIX y gran parte del XX, estar cerca de las fuentes de recursos naturales, contar con accesos a las redes fluviales interiores, o con infraestructuras nodales tipo puertos, enlaces ferroviarios o carreteras. El hecho de que las diferencias geográficas que históricamente discriminaban a los distintos lugares tengan cada vez menos trascendencia ha propagado por el planeta expectativas económicas en ciudades sin tradición en los circuitos económicos internacionales, a las que el espacio de los flujos está permitiendo competir por atraer empresas e industrias multinacionales. Ello explica la importancia que el tema de la competencia entre ciudades ha adquirido en la actualidad ${ }^{1}$. Este artículo indaga en sus orígenes históricos.

En efecto, la competencia entre ciudades no nació con la globalización. En algunos entornos, donde el ultraliberalismo económico tiene una larga tradición, este fenómeno cuenta con casi dos siglos de existencia. Es el caso del Sunbelt o "Cinturón del Sol", término con el que se designa a la franja de Estados Unidos comprendida entre el paralelo 37 y la frontera con México ${ }^{2}$. En ella se ubican 14 estados: la mitad sur de California, Arizona, Nuevo México, Texas, Oklahoma, Arkansas, Luisiana, Tennessee, Mississippi, Alabama, Georgia, Carolina del Norte, Carolina del Sur y Florida. También decenas de ciudades que se

\footnotetext{
1 John Friedmann fue pionero cuando, allá por los años 1980 , comenzó a publicar gráficos y listas que plasmaban jerarquías de ciudades en el espacio económico global, una práctica que se generalizaría entre geógrafos, economistas, historiadores y urbanistas en las décadas siguientes. En el presente, los rankings de ciudades son publicados periódicamente por organismos internacionales como la ONU, revistas económicas como Fortune, consultoras multinacionales como Mercer o institutos de estudios económicos. Estos rankings posicionan las ciudades según todo tipo de cuestiones: económicas (concentración de poder, oportunidades para la inversión, actividad constructora, infraestructuras de telecomunicaciones, etc.); sociales (coste de vida, criminalidad, seguridad, salud, cultura, educación, medio ambiente, etc.); y otras de lo más variopintas (como ser "amiga de los niños") Estas listas son reclamadas por las empresas multinacionales para decidir sobre la ubicación de sus sedes.
}

encuentran entre las más competitivas del sistema global de flujos: Los Ángeles, Dallas, Atlanta, Miami o Houston, protagonista de este artículo.

Los objetivos del mismo son:

- El estudio del origen de la competencia entre ciudades en el Sunbelt estadounidense, un fenómeno que se expandiría durante la globalización pero que nació mucho antes en esta región del planeta.

- El análisis del uso del urbanismo en la competencia entre ciudades en la década de 1980, periodo que podemos considerar como los albores de la globalización. Para este fin se usará como caso de estudio la ciudad de Houston.

\section{Antecedentes de la investigación:}

Por lo que respecta al primer objetivo, la tradición de la competencia entre ciudades en el Sunbelt en las décadas que van de 1930 a 1990 ha sido estudiada por Carl Abbott en sus libros The New Urban America. Growth and Politics in Sunbelt Cities (Аввотт, 1981) у The Metropolitan Frontier. Cities in the Modern American West (Аввотт, 1993). Más que en el urbanismo como disciplina, los libros de Abbott identifican en las políticas de crecimiento, y su apuesta por modelo suburbanopolicéntrico, el motor de dicha competencia. Una aproximación similar es la de Richard M. Bernard y Bradley R. en Sunbelt Cities. Politics and Growth Since World War II, Rice (Bernard \& Rice, 1983); así como de David C. Perry y A. J. Watkins en The Rise of the Sunbelt Cities, (PERRY \& WATKINS, 1977).

En cuanto al uso del urbanismo en la competencia entre ciudades, el periodo histórico aquí abordado no ha sido objeto de especial atención entre historiadores y urbanistas, que han centrado sus investigaciones en las últimas dos décadas. En

\footnotetext{
2 Tras la Segunda Guerra Mundial, en esta zona se produjo una auténtica revolución económica y territorial cuya evidencia más palpable fue el masivo traspaso de poder político y económico desde las ciudades del noreste de Estados Unidos, centros tradicionales de dicho poder. Entre 1970 y 1975, más de la mitad del incremento de la población del país se produjo en el Sunbelt. Este boom se concentró en las áreas urbanas. Si en 1940 tan sólo el $37 \%$ de sus habitantes vivía en ciudades, en 1970 lo hacian el $65 \%$. Este enorme crecimiento de las metrópolis del sur coincidía con un no menos radical descenso de la población de las ciudades del noreste, asfixiadas por las sucesivas crisis de sus sectores industriales tradicionales. En el Sunbelt, en cambio, se había implantado la industria del futuro, firmas electrónicas que desarrollaban su actividad en factorías limpias, donde trabajaba una mano de obra altamente cualificada.
} 
la recopilación de ensayos Essays on Sunbelt Cities and Recent Urban America, de Robert B. Fairbanks y Katheleen Underwoods (FAIRBANKs \& UNDERWOOD, 1990), destaca el de Robert Fisher, "The Urban Sunbelt in Comparative Perspective: Houston in Context", que localiza en las leyes territoriales de los siglos XVII, XVIII y XIX el origen del laissez faire urbanístico de Estados Unidos y, más concretamente, de las estrategias de planeamiento de Houston en la postguerra. En Antípolis. El desvanecimiento de lo urbano en el Cinturón del Sol (García VÁzQuez, 2011), Carlos García Vázquez indaga en las consecuencias morfológicas que dichas políticas comportaron para las ciudades del Sunbelt, un tema que dos libros muy difundidos han desarrollado para el caso de Houston: After the City, de Lars Larup (LARUP, 2000) y Ladders, de Albert Pope (PoPE, 1996).

Los temas de la zonificación y el planeamiento (o la ausencia del mismo) en Houston han sido fundamentalmente documentados por la revista Cite: The Architecture and Design Review of Houston, que comenzó a editarse en 1982, a comienzos de la década que este artículo aborda. Varios artículos son claves para entender este periodo: el de William Anderson y William O. Neuhaus, "Trading Toilets" (Cite 1, 1982); el de Joel Warren Barna, "The Development Ordinance and Its Discontents" (Cite 5, 1984); el de John Mixon, "Honor Thy Neighbor: A Zoning Starter Kit for Houston" (Cite 24, 1990); el de William F. Stern, "The Quilted City: Planning for Houston" (Cite 24, 1990). El rechazo de los electores a la propuesta de zoning que se sometió a referéndum en 1993, un hito importante en esta historia, es analizado en los artículos de Tom Curtis, "5,000 Voters Can't Be Wrong: How Zoning Came to Houston" (Cite 27, 1991); y de Donna H. Kristaponis, "Zonning Houston-Not" (Cite 31, 1994). Una recopilación de algunos de estos textos se encuentra en el libro "Ephemeral City. Cite Looks at Houston", de Barrie Scardino, William F. Stern y Bruce C. Webb (Scardino, Stern \& WebB, 2003).

\section{Metodología}

Metodológicamente, el artículo comenzará analizando el papel que, históricamente, los ayuntamientos del Sunbelt han venido desarrollando en la promoción y venta de sus ciudades, así como la labor que el urbanismo ha desempeñado en esta tarea. Tras apuntar algunas claves de la historia de esta disciplina en Estados Unidos, se verá cómo los ayuntamientos-promotor del Sunbelt optaron por asumir lo que hemos denominado un "urbanismo débil", escasamente prescriptivo y siempre atento a las cambiantes disposiciones de los promotores. Algunas de ellas llegaron a renunciar al urbanismo por considerarlo como una rémora para su crecimiento económico. Así ocurrió en Houston, la mayor ciudad de Estados Unidos sin plan urbanístico en el periodo analizado.

El trabajo se fundamenta sobre una búsqueda bibliográfica llevada a cabo durante una estancia de investigación en el College of Architecture de la Texas Tech University de Lubbock. La orientación de la búsqueda fue principalmente historiográfica, centrándose en libros y artículos de investigación sobre historia urbana e historia del urbanismo que han abordado la evolución de las ciudades del Sunbelt, y especialmente de Houston, tras la Segunda Guerra Mundial. El material así recogido se contrastó con visitas a más de una docena de ciudades del Sunbelt (Los Ángeles, San Diego, Las Vegas, Phoenix, Tucson, Albuquerque, Santa Fe, Lubbock, El Paso, Dallas, Austin, San Antonio, Nueva Orleans, Atlanta y Miami), así como a lugares específicos de Houston. Finalmente, todo ello se complementó con una serie de entrevistas con académicos de la Rice University de Houston y de la Texas Tech University de Lubbock.

\section{Las raíces históricas de la competencia entre ciudades y la utilización del urbanismo: los ayuntamientos-promotor en el Sunbelt}

En el Sunbelt la competencia entre ciudades no es un fenómeno asociable a la globalización. Desde su fundación en el siglo XIX, y cuando no eran más que pequeñas comunidades habitadas por colonos agrícolas, se vieron obligadas a rivalizar entre sí por acaparar recursos y mercados. Sólo las que lograban destacar como centros económicos de una determinada región tenían garantizada la supervivencia. Las demás estaban condenadas a desaparecer.

El liderazgo de esta naciente concurrencia entre ciudades fue asumido por los promotores privados. Ellos las dotaron de las infraestructuras necesarias para acceder a los recursos naturales y a los mercados de consumidores. Tal como defiende William D. Angel, y tal como ocurre hoy en día, las características locales de cada asentamiento eran poco relevantes, ya que cuando era necesario los flujos naturales eran violentados y modificados: si los ríos eran poco profundos, los promotores se encargaban de dragarlos; si la red fluvial discurría en sentido norte-sur, los promotores se ocupaban de construir vías de ferrocarril o canales de navegación en sentido sur-norte. Fueron ellos, y no los 
poderes públicos, los que doblegaron las barreras naturales para favorecer a sus respectivas ciudades (PerRy \& WatkIns, 1977: 109-128).

Para Carlos García Vázquez, Houston es un buen ejemplo de ello:

"En sus inicios, esta ciudad, que distaba unos 80 kilómetros del Golfo de México, vivía a la sombra de su vecina Galveston que, por su situación en la costa y su puerto natural, se perfilaba como futuro centro regional. Sin embargo, los promotores de Houston no se resignaron ante las barreras que la naturaleza oponía a sus expectativas económicas. En 1909 pusieron en marcha una iniciativa para construir un puerto interior en el poco profundo pantano de Buffalo, que conectaba la ciudad con la costa. Para transformarlo en un canal de aguas profundas era necesario acometer una costosísima obra de ingeniería. Los empresarios locales convencieron a los ciudadanos de la necesidad de afrontar el proyecto, emitieron bonos para financiarlo y constituyeron lobbies de presión en Washington para conseguir fondos adicionales del gobierno federal. En 1914 se inauguraba el Houston Ship Channel, al que se trasladaron las compañías petroleras de Texas, cuyas refinerías estaban situadas en otras localidades" (GARcía VÁZquEZ, 2019: 237).

El prometedor futuro de Galveston quedó así truncado.

Experiencias como esta explican que, en el Sunbelt, la figura del promotor haya sido glorificada. No es casual que Dallas, Dinastía, Falcon Crest y tantas otras series televisivas que han recreado los valores del gran empresario, hayan situado sus escenarios al sur del paralelo 37 . Sus protagonistas resumen la imagen mítica que el norteamericano medio tiene de sí mismo, marcada por el enaltecimiento del individualismo en un entorno geográfico que promete un mar de oportunidades. Las ciudades del Sunbelt siempre se han enorgullecido de ello. Dallas (a la que la revista Fortune definió en 1989 como "el lugar soñado para localizar un negocio") se ha promocionado a sí misma como un enclave "dinámico, optimista y orientado hacia la acción”. Phoenix, por su parte, ha llegado a alardear de la debilidad de sus instituciones públicas y de la energía del individualismo local. En la década de 1950, esta glorificación del promotor facilitó el consenso social en torno a una idea: poner los ayuntamientos en manos de los hombres de negocio y las élites profesionales locales. De esta manera, el desarrollo urbano de Dallas pasó a ser controlado por la Citizen's CharterAssociation, un grupo de empresarios; algo similar ocurrió en Phoenix con otro colectivo de promotores, el Phoenix 40; y en San Antonio, donde el $94 \%$ de los concejales elegidos desde

\footnotetext{
${ }^{3}$ En 1970, el gasto social medio por habitante en las ciudades del norte del país con más de 500.000 habitantes era
}

1955 pertenecen a la asociación empresarial Good Government League (GARCíA VÁZQUEZ, 2019: 237). Habían nacido los "ayuntamientos-promotor".

Lo primero que hicieron fue desdibujar las fronteras que separaban lo público de lo privado, trasladando al ámbito municipal los más agresivos manuales del mundo empresarial. No entendían que su principal cometido como administración pública fuera la distribución de los recursos. En realidad, para los muy conservadores habitantes del Sunbelt lo social no era prioritario. Exigían calidad en servicios básicos como carreteras, policías y bomberos, pero rechazaban pagar impuestos para financiar sistemas educativos, sanitarios o de transporte, que preferían contratar en el sector privado. Ello explica que, en los años 1970, los gastos sociales de las ciudades del Sunbelt no rebasaran el $50 \%$ de la media nacional ${ }^{3}$. De hecho, los ayuntamientos-promotor eran escuálidos en comparación con los del norte: mientras que Newark, en Nueva Jersey, contaba con 37,2 funcionarios municipales por cada 1.000 habitantes, Phoenix tenía 9,1 y Houston 8,0 (PERRY \& WATKINS, 1977: p. 173).

Llama la atención que esta indiferencia hacia las cuestiones sociales se produjera en un momento, los años 1950 y 1960, en el que Europa daba forma a su Estado del Bienestar. Pero la historia del Sunbelt era diferente. Robert Fischer explica su apego por el laissez faire a partir de una serie de anomalías históricas que evitaron que esta zona padeciera los traumas que convencieron al Viejo Continente de la necesidad de humanizar el capitalismo. Durante la Gran Depresión, los estados sureños todavía eran ajenos a la economía internacional, por lo que la sufrieron relativamente; la Segunda Guerra Mundial no les reportó destrucción, sino inversiones millonarias provenientes del Departamento de Defensa de Estados Unidos; $y$, cuando sus ciudades comenzaron a hacerse mayores de edad, ya en la década de 1950, estaban insertas en la atmósfera ideológicamente ultraconservadora de la Guerra Fría (FAIRBANKS \& UNDERWOOD, 1990: 33-58).

Al igual que la competencia entre ciudades, también la debilidad de la disciplina urbanística tiene larga tradición histórica en el Sunbelt. Los primeros inmigrantes que llegaron a Estados Unidos huían de una Europa lastrada por su pasado feudal, de una sociedad piramidal donde las élites sociales seguían gozando de privilegios insalvables. Como reacción a ello, los colonizadores británicos implementaron las leyes territoriales más liberales del planeta. Tras la independencia, este espíritu fue recogido por la constitución, que definió la tierra

de 21,58 dólares, mientras que en las del Sunbelt era de 8,87 (PERRY \& WatKInS, 1977: 174). 
como un derecho civil, y no como un bien público. Se reconocía así la potestad de urbanizar el suelo. El estado tan sólo podía regular cómo hacerlo, nunca dónde. En un país con un gran flujo de inmigrantes y cuyo territorio era virgen y gigantesco, ello equivalía a reconocer la facultad de negociar con una fuente inagotable de recursos. Especulación y libertad individual quedaron así asociados en el imaginario colectivo norteamericano.

Sobre esta base se materializó la denominada "conquista de la frontera", la colonización de las grandes llanuras del interior, un proceso que fue desplazando el límite occidental de Estados Unidos hacia el oeste, y que se prolongó hasta finales del siglo XIX. Tras la toma de un territorio, los promotores compraban al estado grandes superficies para parcelarlas y venderlas a particulares. Miles de asentamientos urbanos nacieron de esta manera. Entre ellos estaban las actuales ciudades del Sunbelt. Sus "padres fundadores" fueron especuladores, a menudo carentes de escrúpulos: Ios de Phoenix (ver FIG. 1), negociantes que construyeron los canales de irrigación del valle del Río Salt; y los de Houston, los hermanos Allen, dos promotores neoyorquinos.

Hasta la segunda mitad del siglo XIX no se cuestionó esta forma de proceder. Pero la industrialización, que atrajo a miles de personas hacia las ciudades, hizo que tan radical laissez faire urbanístico derivara en caos. El desorden físico, la suciedad, el abandono y los consecuentes problemas de salubridad, convencieron a la opinión pública de la necesidad de implementar algún tipo de regulación. La lucha en pro del reconocimiento del derecho de las administraciones a controlar la ciudad fue abanderada por el Park Movement, que consiguió que urbes como Chicago o Nueva York establecieran normas de alineación y edificación, así como estándares infraestructurales. En 1916, Nueva York aprobó el primer "zoning" de Estados Unidos, término utilizado para definir la ordenación del uso del suelo. El éxito de esta iniciativa animó al Departamento de Comercio a publicar un modelo de zoning e invitar a los estados a asumirlo. Tan sólo dos, Nueva Jersey y Massachusetts, lo declararon obligatorio. En el resto, cada ciudad conservó la potestad de decidir qué figuras urbanísticas eran de aplicación en su territorio, y el $85 \%$ optó por el zoning.

Pero los defensores de la regulación urbanística se toparon con la Quinta Enmienda de la Constitución, que establecía que "ninguna persona será privada de la vida, la libertad o sus propiedades sin un proceso legal; tampoco la propiedad privada será transformada en uso público sin una justa compensación". Ello significaba que, si un suelo era expropiado debía ser pagado a precio

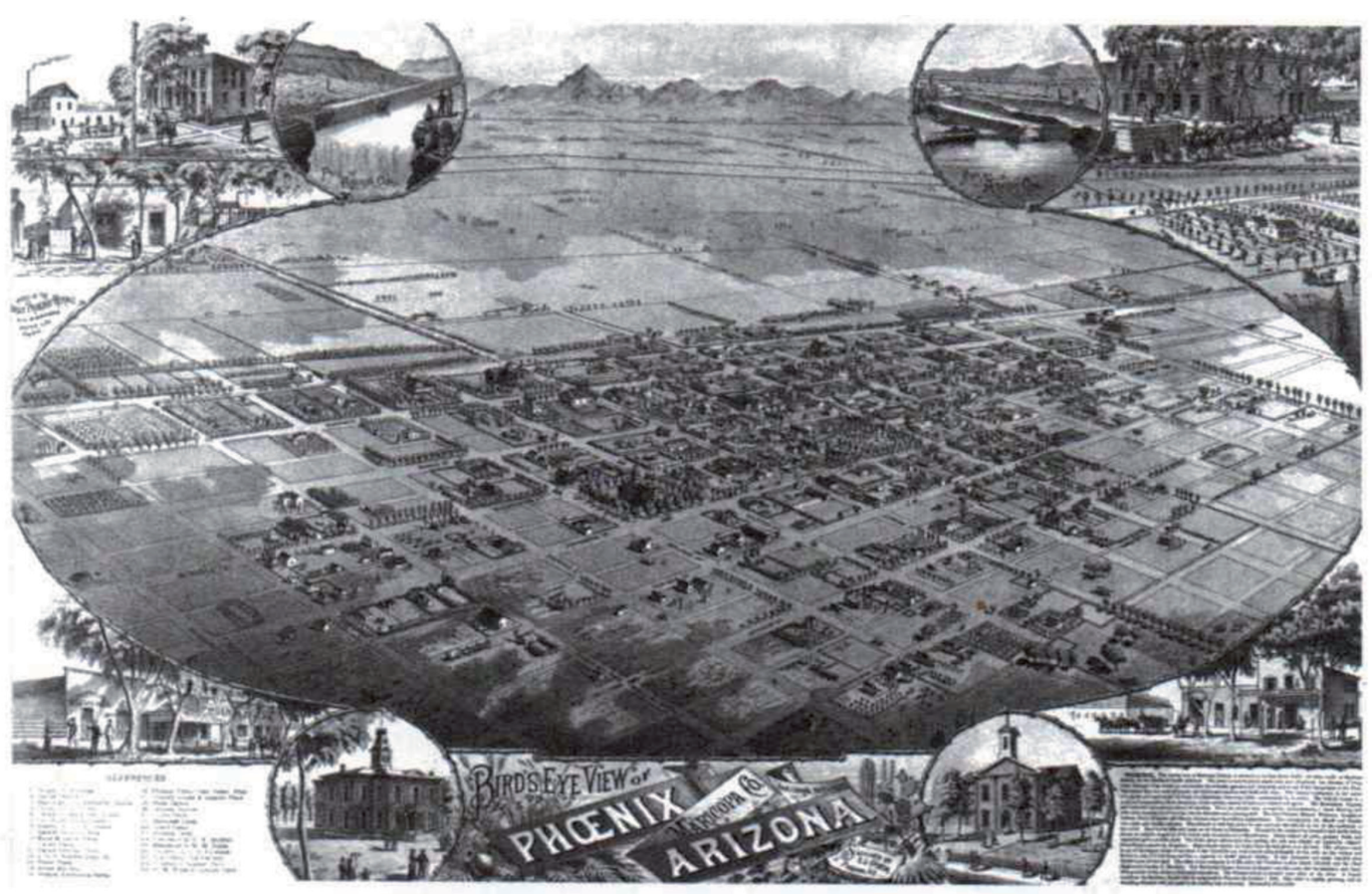

FIG. 1/ Vista aérea de Phoenix en el siglo XIX. 
de mercado, lo que prácticamente anulaba dicha posibilidad. La apelación a esta enmienda permitió que, a pesar de la casi generalización del zoning, la definición física de las ciudades siguiera en manos de los promotores. Tal como describe Sam Bass Warner:

"En la tradición americana el principal propósito del ciudadano es la búsqueda personal del beneficio; el objetivo de una ciudad es convertirse en una comunidad de 'money-makers'. (...) desde mediados del siglo XIX los éxitos y fracasos de las ciudades americanas han dependido de consecuencias no planificadas de las demandas del mercado (...) Lo que el mercado no podía hacer bien, las ciudades americanas no hicieron bien; lo que el mercado hizo mal o abandonó, es algo que nuestras ciudades fueron incapaces de superar" (PeRRY \& WatKINS, 1977: 281, traducción y adaptación del autor).

\begin{tabular}{lcc}
\hline & $\begin{array}{c}\text { Ordenanzas } \\
\text { de zoning }\end{array}$ & $\begin{array}{c}\text { Plan } \\
\text { General }\end{array}$ \\
\hline Albuquerque & 1953 & 1975 \\
\hline Atlanta & 1928 & 1948 \\
\hline Dallas & 1929 & 2006 \\
\hline Houston & - & 2015 \\
\hline Los Ángeles & 1920 & 1996 \\
\hline Miami & 1934 & 1989 \\
\hline Phoenix & 1930 & 1985 \\
\hline
\end{tabular}

FIG. 2/ Tabla comparativa de los años de implementación de dos figuras de planeamiento urbanístico (ordenanzas de zoning y plan general) en siete ciudades del Sunbelt.

Fuente: elaboración propia.

Así ocurrió en el Sunbelt. La tabla FıG. 2 muestra cómo a mediados de los años 1930 la mayoría de sus grandes urbes había adoptado e implantado el zoning, con la excepción de Houston (de la que trataremos en el siguiente apartado). Medio siglo después, en las décadas que nos ocupan (1980 y 1990), muchas de ellas habían dado el salto hacia alguna figura de planeamiento más general. Sin embargo, se trataba de una especie de "planeamiento a la carta", es decir, susceptible de ser modificado para ajustarse a los dictados de los promotores. Es lo que denominaremos "urbanismo débil", un sistema de planificación escueto, flexible y ambiguo ${ }^{4}$. Los ayuntamientos-promotor del Sunbelt encontraron en él un eficaz instrumento para lidiar en la competencia entre ciudades. Ello era especialmente evidente en las áreas metropolitanas, donde aquélla alcanzaba cotas de máxima tensión. Esto es así porque en Estados Unidos la

\footnotetext{
${ }^{4}$ Rem Koolhaas comentaba: "El zoning de Atlanta es muy interesante: su primer párrafo informa sobre lo que hay que hacer para proponer una alteración. Los reglamentos son tan débiles que la excepción es la norma. (...) Atlanta tiene una
}

administración pública está muy fragmentada en gobiernos municipales cuyos ingresos dependen de los impuestos locales, lo que explica que las ciudades de una misma área metropolitana luchen entre sí por atraer empresas, residentes, centros comerciales, etc. Sus ayuntamientos les ofrecen terrenos, exenciones de tasas, becas de formación, préstamos con intereses por debajo del mercado, etc. Mientras que unas ciudades ganan, otras pierden. Entre estas últimas suele encontrarse la ciudad madre, que no puede permitirse bajar los impuestos debido a los enormes costos sociales e infraestructurales que soporta.

En estos balcanizados entornos, un control demasiado estricto puede provocar que empresas y constructores deriven sus inversiones hacia las localidades vecinas. Sin embargo, un uso inteligente transforma al urbanismo débil en un activo. En los albores de la globalización, la región de Los Ángeles dio un buen ejemplo de ello, fenómeno estudiado por Dana Cuff (Cuff, 2000) y Roger Keil (KEIL, 1998). En la década de 1980, la mayor ciudad del Sunbelt sufrió un durísimo proceso de ajuste económico. Su inmensa área metropolitana no contaba con ningún plan de ámbito regional, aunque sí con infinidad de planes parciales y normativas locales que se convirtieron en un importante factor de competencia entre sus 163 ciudades. Manejándolas a su antojo, los ayuntamientos-promotor de la región urbana de Los Ángeles iniciaron una feroz competencia por atraer empresas globales que garantizaran a sus localidades determinados status de empleo y funcionalidad económica. Las ganadoras fueron las que lograron seducir a corporaciones de los sectores financiero (Bunker Hill), del espectáculo (Century City), multimedia (Culver City), de servicios al productor (Santa Mónica) o tecnológico (el condado de Orange). El resto tuvo que resignarse a acoger las actividades económicas que las demás rechazaban. Entre estas perdedoras se encontraban las "hub cities" de la autopista de Santa Ana, por las que tan sólo se interesaron los casinos y los clubes de alterne.

En ese periodo, también el entorno metropolitano de Phoenix supo hacer un uso inteligente del urbanismo débil (FIG. 3). La ciudad de Tempe apostó por él para atraer a la industria creativa. Como sede de la Arizona State University, principal generadora de empleo, sabía que estaba en disposición de seducir a los jóvenes profesionales de la entonces incipiente "clase creativa", cuya forma de vida sintonizaba con la de estudiantes y profesores. Su predilección por los ambientes urbanos

especie de zoning inverso, un zoning como instrumento de indeterminación, que hace que cualquier cosa sea posible en cualquier sitio". (KoOlHAAS \& MAU, 1995: 836, traducción y adaptación del autor). 
"a la europea", es decir, densos, animados y peatonales, convenció al ayuntamiento de la oportunidad de implementar códigos urbanísticos que incidieranen la concentración del desarrollo urbano en las áreas centrales, limitando la suburbanización de la periferia. También aprobó unas ordenanzas que protegían su pequeño pero pintoresco casco histórico. Esta estrategia estimuló una animada vida urbana, algo prácticamente inexistente en las ciudades vecinas. Eso sí, tuvo que pagar un precio por ello. Sus exigentes estándares urbanísticos ahuyentaron proyectos comerciales tan importantes como el gigantesco Fiesta Mall, que descartó la opción de Tempe en favor de Mesa, una vecina mucho más desregulada.

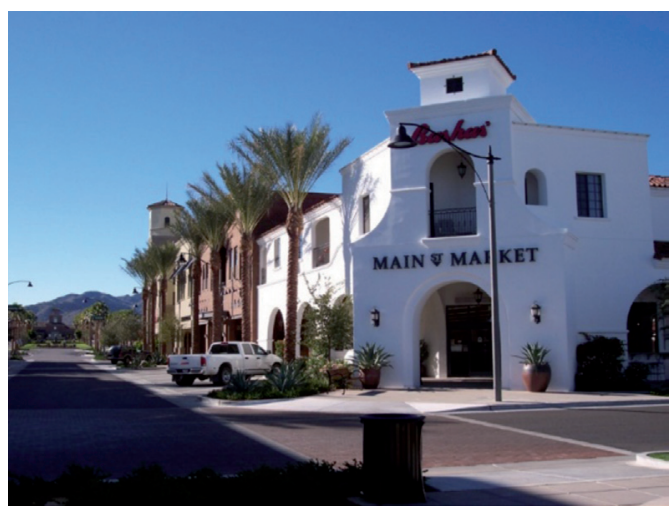

FIG. 3/Verrado, una ciudad del entorno de Phoenix que explota la marca "Far West".

Fuente: elaboración propia.

\section{Houston, la ciudad sin plan}

En 1969, Reyner Banham, Paul Barker, Peter Hall y Cedric Price publicaron un provocativo artículo donde hacían un llamamiento en pro de lo que ellos denominaban el "no plan" (BANHAM \& al., 1969: 435-443). Con el argumento de que "las ciudades más rigurosamente planificadas, como el París de Haussmann y Napoleón III, han sido casi siempre las menos democráticas", denunciaban la planificación urbanística y reclamaban el derecho de los ciudadanos a decidir libremente qué hacer con sus propiedades. El "no plan" era un apelo a ir más allá del urbanismo débil, a aventurarse en la desregularización total.

Este discurso formaba parte del utopismo propio de la década de 1960, pero era muy real en una de las capitales del Sunbelt, Houston, la ciudadicono de la derecha norteamericana:

\footnotetext{
${ }^{5}$ La referencia intelectual de los detractores del zoning es el libro Land Use Without Zoning, escrito en 1972 por Bernard
}

\begin{abstract}
"El mundo converge en Houston... Hora a hora las autopistas se atiborran, los rascacielos del downtown se elevan, los residentes de River Oaks se enriquecen, los suburbios van royendo su camino campo a través y lo que hace un par de décadas sólo era una mota en el mapa se convierte en algo más que una ciudad, en una idea, una visión, jel futuro aquí y ahora!" (Аввотт, 1993: 181, traducción y adaptación del autor).
\end{abstract}

Efectivamente, Houston es próspera, ultraliberal y ultraconservadora, y lo es desde que, en 1836, los hermanos Allen compraran las tierras pantanosas sobre las que se asienta con el único fin de especular con ellas. La defensa a ultranza de los derechos de los propietarios convirtió a esta ciudad en una gigantesca inmobiliaria. Tras visitarla en los años 1970, Reyner Banham la definió como una versión en la vida real del juego del Monopoly (citado por Bruce C. Webb en ScARDINO, STERN \& WeBB, 2003: 4), una ciudad ante la cual el Los Ángeles de la época de Chinatown parecía un estado socialista... Décadas más tarde, Sanford Kwinter y Daniela Fabricius enunciarían juicios similares:

\begin{abstract}
"no es una ciudad real, sino más bien una libre confederación de empresas e industrias que conforma una red etérea de infraestructuras compartidas y alianzas económicas" (KoolHAAs \& al., 2000: 547).
\end{abstract}

Con esta base ideológica, no es de extrañar que, en los años 1980, en los preludios de la globalización, Houston fuera la única gran metrópolis de Estados Unidos que no contaba con zoning. Promotores y ciudadanos estaban convencidos de la capacidad del mercado para regular la ciudad "de manera natural", por lo que en dos ocasiones (1948 y 1962) habían rechazado en referéndum la posibilidad de implementarlo ${ }^{5}$. Esta realidad convenció al ayuntamiento de que ni debía ni podía entrometerse en la lógica del mercado inmobiliario, lo que se tradujo en una reducción al mínimo de los controles urbanísticos. En Houston no existía ningún organismo público que regulase el desarrollo urbano, tan sólo departamentos y comisiones municipales que implementaban ordenanzas sectoriales que, de alguna manera, afectaban a la arquitectura y la forma urbana. Esta legislación se iba aprobando a medida que surgía la necesidad, normalmente por la irrupción de algún conflicto. En el año 2000 Houston contaba con 17 ordenanzas de uso de suelo que afectaban a cuestiones tan variopintas como la seguridad, el reciclaje o la cartelería comercial. A ellas había que sumar normativas de salud pública que prohibían determinadas instalaciones industriales e imponían accesos de emergencia, medidas antiincendios, patrones de ventilación, etc.

H. Siegan (SiEgAN, 1972), cuya máxima era: "la más efectiva de las ordenanzas es la competencia". 
En 1985, se publicaron las Development Ordinances que, por primera vez, establecían estándares preceptivos en solares y viario urbano, lo que permitía ejercer un mínimo control sobre cuestiones tan importantes como la densidad residencial. La intención, sin embargo, no era definir la ciudad, sino evitar que la ausencia de normas acabara comprometiendo su futuro crecimiento físico y económico. Por ejemplo, la obligación de retranquear los edificios una distancia que oscilaba entre los 3 y los 7,6 metros, dependiendo del ancho de calle, pretendía reservar suelo para futuras ampliaciones del viario. Aunque de manera indirecta, también la construcción de infraestructuras posibilitaba a las administraciones públicas establecer algún tipo de control sobre el desarrollo de Houston. En una ciudad absolutamente dependiente del automóvil, el diseño de la red de autopistas era un poderoso instrumento de regulación urbana. Lo mismo ocurría con las redes de abastecimiento de agua y saneamiento, sin las que no era posible colonizar nuevos territorios.

Ordenanzas sectoriales e infraestructuras, hasta ahí podía llegar la administración. El resto quedaba en manos de los promotores. Curiosamente, esta lógica acabó pasando factura a los más poderosos. En Estados Unidos, el zoning no sólo fija los usos de suelo, también los tamaños mínimos de parcela, los retranqueos, las alturas, etc. Una vez aprobado, es muy difícil modificarlo (muchos estados exigen, incluso, un referéndum), lo que lo convierte en una garantía de futuro: residentes y compradores saben que los usos, alturas y densidades de su barrio serán estables en el tiempo. En Houston, en cambio, la ausencia de zoning generó una incertidumbre que preocupaba a los que tenían propiedades en las zonas residenciales, comerciales y terciarias más exclusivas, propiedades cuyo valor estaba amenazado por el descontrol estético, la implantación de usos no deseados, la llegada de residentes no "adecuados" o, simplemente, la degradación ambiental derivada de la retirada de los poderes públicos. En estas áreas, la apertura de un casino o la construcción de un bloque de viviendas sociales podían significar el comienzo del declive, y era la inexistencia de zoning lo que lo hacía posible.

Los movimientos "no plan" relativizaban estas amenazas, argumentando que el desarrollo urbano de Houston seguía pautas muy similares al de ciudades que sí contaban con zoning. Hay que reconocer que, a pesar de que su definición física había quedado en manos de los promotores, no había clubes de alterne en los distritos financieros, ni casinos junto a las mansiones neovictorianas. Y es que Houston había conseguido conciliar los dictados del liberalismo con los beneficios que reportaba la planificación urbanística utilizando convenios privados o Covenants Conditions and Restrictions (CC\&R), regulaciones que los promotores introducían en las escrituras de compra-venta de los solares de sus emprendimientos más lujosos, y que el comprador se comprometía a cumplir cuando los firmaba. Un Common Interest Development (CID), entidad legal establecida por el promotor, se encargaría de que aquéllos se cumpliesen por un periodo de tiempo que oscilaba entre los 25 y 30 años $^{6}$. De esta manera, los promotores ofrecían a los propietarios seguridad sobre el futuro de los terrenos adyacentes al suyo. Desaparecía así la amenaza de las fluctuaciones de precios, tan cierta en las desreguladas ciudades del Sunbelt que muchos bancos se negaban a conceder hipotecas para la compra de viviendas situadas en zonas no protegidas por CC\&R. Ello explica que los 10.000 CIDs existentes en Estados Unidos en 1970, se convirtieran en 225.000 en el año 2000.

El número y tipo de restricciones que establecían los CC\&R variaba, pero solía cumplirse una máxima: eran más numerosas y estrictas cuanto más cara era la promoción. Las había de carácter urbanístico (que determinaban usos, densidades, alturas, distancias a linderos, etc.) y arquitectónico (que fijaban materiales, colores, tipos de verjas, etc.). Algunas incluso parecían prescribir un determinado estilo de vida, como ocurría en las urbanizaciones construidas por la empresa Leisure World, donde no podían residir personas menores de 45 años (FIG. 4).

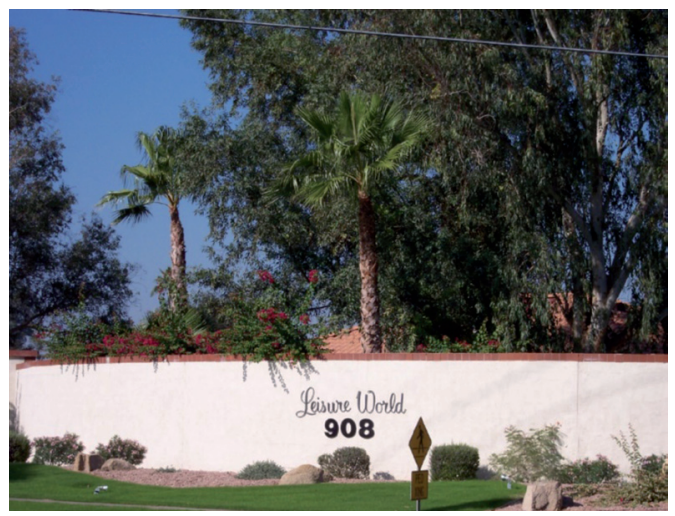

FIG. 4/ Leisure World, una comunidad cerrada de Mesa (área metropolitana de Phoenix) regulada por un CC\&R.

Fuente: elaboración propia. ${ }^{6}$ Si durante ese periodo no se había respetado, el CC\&R
podía ser decretado "fuera de uso" y perder su condición legal. 
Al haber sido establecidas por los promotores, los jueces solían considerar a las CIDs como entidades comerciales y no como lo que realmente eran,ayuntamientos informales que gobernaban a cientos de miles de personas ${ }^{7}$. Georges Greanias, quien fue candidato a la alcaldía de Houston por el Partido Demócrata, calificó los convenios privados como "planeamiento en la sombra", la fórmula que las ciudades del Sunbelt habían inventado para conciliar regulación y "no plan". Suponía que los instrumentos urbanísticos tradicionales (derecho de expropiación, zonificación funcional, establecimiento de ordenanzas, es decir, todo lo que a la administración pública le está vedado determinar) pasaban a manos de los promotores (GREANIAS, 1998: 28).

En Houston llegaron a haber más de 10.000 convenios privados, sobre los que tenían potestad 630 CIDs. El distrito financiero de Post Oak (el octavo de Estados Unidos), el Texas Medical Center (que contaba con un gobierno propio encargado de regular el tráfico, la señalización, los aparcamientos, la edificación, etc.) y el complejo espacial de la NASA (que tenía su propia organización urbanística e infraestructural) fueron frutos del planeamiento en la sombra. También las más exclusivas urbanizaciones residenciales (los suburbios de Bellair y West University, los antiguos pueblos del Memorial Drive, o edge cities como The Woodlands) contaban con ordenanzas y zonings propios establecidos por convenios privados. Gracias a ellos, en todos estos enclaves se respirabala rancia ostentación que caracteriza a la alta burguesía tejana. También gracias a ellos, en Houston imperaba un orden relativo: las industrias se concentraban a lo largo de las vías del ferrocarril o las autopistas, los bloques de apartamentos en las avenidas, los comercios en las arterias de tráfico y las gasolineras en las intersecciones viarias.

Como decíamos, la suplantación del urbanismo por el "planeamiento en la sombra" contaba con un consenso bastante transversal entre los ciudadanos de Houston. Sin embargo, la vulnerabilidad de esta estrategia se hizo repentinamente evidente en 1982, debido a la crisis económica desatada por la caída de los precios del petróleo. El impacto del denominado "Oil Crash" dejó sin empleo,

\footnotetext{
${ }^{7}$ De hecho, las únicas regulaciones rechazadas por los tribunales fueron las que atentaban contra la Constitución, normalmente por segregación racial o por orientación sexual.En e elegante distrito de River Oaks, la River Oaks Corporation impuso unas ordenanzas que establecían que sus residencias unifamiliares eran sólo para blancos. Estuvieron en vigor desde 1926 hasta 1955, cuando fueron declaradas ilegales.

8 Tan sólo la clase media apoyó la propuesta ( $63 \%$ a favor), temerosa de los riesgos que la desregulación comportaba para sus enclaves residenciales.

${ }^{9}$ La Baptist Ministers'Association, un grupo de líderes religiosos
}

en un periodo de 15 meses, a 160.000 houstonianos. Ello sirvió como caja de resonancia a las demandas de los colectivos pro-zoning, que aprovecharon la coyuntura para promover un nuevo referéndum. Todo apuntaba a que esta vez se había impuesto el acuerdo a favor de la implantación de un zoning. Según las encuestas, además del alcalde, el ayuntamiento y 160 organizaciones de propietarios, lo apoyaba el $67 \%$ de los ciudadanos. En 20 de noviembre de 1993 se sometió a consulta popular un borrador de zoning. El resultado fue del $51,9 \%$ en contra y el $48,1 \%$ a favor. Paradójicamente, entre los que votaron negativamente se encontraban los segmentos sociales más desfavorecidos de la ciudad: el $72 \%$ de la población afroamericana, el $68 \%$ de la clase mediabaja y el $58 \%$ de los hispanos ${ }^{8}$.

Probablemente los pobres de Houston tenían motivos para temer al zoning. Muchos de ellos habían emplazado actividades comerciales, empresariales e incluso industriales en sus viviendas, algo que ninguna regulación urbanística consentiría ${ }^{9}$. Sin embargo, los datos mencionados ponían en evidencia otra cuestión: la segregación racial que impuso la práctica del denominado "redlining". Esta fue implantada por la Home Owners' Loan Corporation (HOLC), una agencia gubernamental fundada en 1933, en plena Gran Depresión, para ayudar financieramente a las personas con problemas para pagar sus hipotecas. La política del redlining consistía en desaconsejar a los bancos la concesión de préstamos para adquirir propiedades en determinados barrios de las ciudades, considerados poco rentables por criterios de localización, valor y antigüedad de las viviendas, presencia de usos incompatibles con los residenciales o... por raza. De esta manera, los "Mapas de Seguridad Residencial" (Residential Security Maps ${ }^{10}$ ) de la HOLC hundieron los precios de solares y apartamentos situados en distritos predominantemente afroamericanos, a los que condenaron a un declive del que jamás lograrían recuperarse.

Los Mapas de Seguridad Residencial de Houston son muy elocuentes en una lectura sociológica del resultado del referéndum de 1993. Como estipulaba la HOLC, aquéllos calificaron sus áreas residenciales en cuatro categorías: "la mejor"

de raza negra, lo había advertido en una carta publicada antes del referéndum: "El zoning restringirá las iglesias y acabará con los trabajos de la comunidad negra; el zoning segregará a las minorías; el zoning subirá los alquileres y los impuestos; el zoning alimentará el chabolismo. No queremos que Houston se convierta en otra Dallas, Detroit, Washington, Chicago o St. Louis. Todas ellas son ciudades zonificadas. Todas ellas tienen áreas de pobreza y chabolismo mucho peores que las de Houston".

${ }^{10}$ Se redactaron Mapas de Seguridad Residencial para 239 ciudades de Estados Unidos. 
("best"), "aún deseable" ("still desirable"), "definitivamente en declive" ("definitely declining") y "peligrosa" ("hazardous") 11. La inmensa mayoría de estas últimas eran zonas cercanas al centro de la ciudad (las clases media y alta blancas ya habían iniciado su éxodo hacia suburbia), y estaban habitadas por población de color. Así ocurría en los denominados First Ward, Third Ward, Fourth Ward, Fifth Ward y Six Ward. En el este de la ciudad fueron señalados como barrios "peligrosos" Clinton Park y Brunsville (actualmente prácticamente demolido), y dispersos por el resto del municipio fragmentos de Near Northside, Cottage Grove y el West End. Como es de imaginar, ninguno de estos barrios, condenados por la HOLC al ostracismo, estaba protegido por CC\&Rs. Seis décadas después de la publicación del Mapa de Seguridad Residencial de Houston, la mayoría de los vecinos de estas áreas votó en contra del zoning en el referéndum de 1993. Las secuelas del redlining seguían alimentando una profunda desconfianza hacia la administración pública por parte de los sectores más desfavorecidos de la sociedad.

\section{Conclusiones}

La desregulación urbanística ha sido frecuentemente defendida como una de las claves del éxito de Houston en su competencia con otras ciudades estadounidenses. Es difícil negar que hay algo de cierto en este argumento. La ausencia de burocracia y la inmediatez con la que un proyecto puede materializarse han atraído a numerosos empresarios, que buscan evitar los trámites burocráticos que se ven obligados a implementar en ciudades con legislaciones urbanísticas más estrictas. El clima de laissez faire que se respira en Houston y la casi total exención de impuestos locales y estatales, cuadran un escenario perfecto para la inversión privada, lo que se ha traducido en crecimiento urbano y crecimiento económico.

A ello hay que sumar un fenómeno que suaviza los efectos negativos que pudieran derivarse de la ausencia de planificación. Sea por entender que es su contrapartida al consenso social existente en torno al "no plan", sea por el convencimiento de que, ante un problema, si no lo resuelven los ciudadanos con poder no lo va a resolver nadie, lo cierto es que los grandes magnates tejanos han desarrollado una envidiable conciencia cívica. Expresión de su filantropismo son los grandes

\footnotetext{
${ }^{11}$ Estos últimos barrios eran sombreados en rojo, de ahí el término "redlining".

12 Diseñado por Philip Johnson es, probablemente, el único
}

equipamientos culturales de Houston, como la Fundación Menil y su famosa Capilla Rothko, y sus principales espacios públicos, como Hermann Park, el corredor verde del pantano Buffalo o la plaza de la Transco Tower ${ }^{12}$. Todos ellos han sido promovidos, proyectados y financiados con capital privado.

Pero es innegable que Houston también ha pagado un alto precio por su empeño en la desregulación. Según una encuesta realizada por el Chicago Tribune en los días previos al referéndum de 1993, de entre las mayores ciudades norteamericanas era la que contaba con los peores transportes públicos, las peores dotaciones de parques, las peores redes de agua y alcantarillado, el peor sistema de mantenimiento de calles, etc. También era donde menos viviendas sociales se construían (18 veces menos que la media nacional) y donde peor se trataba a los peatones. Además, la desregulación urbanística impedía que se beneficiase de los fondos federales para rehabilitación urbana, y hacía que su crecimiento fuese prácticamente imprevisible, que la estructura funcional fuera complejísima, que el entorno natural estuviera siendo dilapidado y que la escasez de espacios públicos se hubiera convertido en crónica.

En definitiva, la ideología del "no plan" hacía mucho daño a Houston. Damnificadas eran las infraestructuras. El mantenimiento, sustitución y desarrollo de las redes públicas dejaba mucho que desear. De hecho, su deterioro obligó a imponer restricciones urbanísticas en determinadas zonas. Es el caso de la "moratoria de conexión a la red de saneamiento" que, en 1974 y debido a la imposibilidad de evacuar más aguas residuales, prohibió construir nuevos edificios en el Midtown. En un artículo titulado "Trading Toilets: the Subterranean Zoning of Houston", William $\mathrm{H}$. Anderson y and William $\mathrm{O}$. Neuhaus la calificaron como "perverso zoning subterráneo", ya que acabó canalizando el crecimiento de la ciudad hacia la periferia (ANDERSON \& Neuhaus, 1982: 12-14).

Damnificados eran los servicios públicos. La reducida presión impositiva de Houston ${ }^{13}$ generaba importantes déficits equipacionales. Ejemplo de ello era el cuerpo de policía, que en 1981 contaba con la mitad de efectivos que ciudades de tamaño similar, a pesar de tener, por aquel entonces, uno de los índices de criminalidad más altos del país. Si buscaban calidad, los ciudadanos de Houston habían de costear los servicios que recibían. El lema era: "Tienes lo que pagas". En las urbanizaciones del extrarradio, los propietarios abonaban

lugar que los houstonianos perciben como una verdadera plaza pública.

${ }^{13}$ Una cuarta parte de la de Boston y una quinta de la de Nueva York. 
una tasa anual a los promotores para que les proveyesen de colegios, instalaciones deportivas y sistemas de seguridad con estándares muy superiores a los del resto de la ciudad.

Damnificado era el patrimonio arquitectónico. El sacrosanto derecho a la propiedad hacía que el destino de edificios con valor histórico-artístico dependiera de la voluntad de sus dueños. Ello tuvo consecuencias devastadoras. Durante el boom inmobiliario de la década de 1990, cientos de inmuebles de comienzos del siglo XX fueron demolidos. Damnificado era el transporte público. Las autoridades de Houston solían argumentar que la baja densidad lo hacía inviable por ruinoso. Ello explicaba que la red de autobuses fuera minúscula y que los cuatro millones de houstonianos no contaran con metro ${ }^{14}$. Y damnificados eran los barrios pobres. En una ciudad así, el cuidado del espacio público recaía sobre los vecinos, que habían de ocuparse de la pavimentación, el mobiliario urbano, el arbolado, etc. Los más humildes no podían afrontar estos gastos. Su única esperanza eran los fondos federales, que solían llegar con décadas de retraso.

El fallido referéndum de 1993 privó a Houston de las herramientas que hubiera necesitado para hacer frente a todos estos problemas en las décadas posteriores, cuando no hicieron más que agravarse. Ello explica que veinte años después, en 2013, el alcalde de la ciudad encargara al Departamento de Planificación y Desarrollo que pusiera en marcha el proceso que desembocaría en el "Plan Houston". En realidad, más que un auténtico plan general de ordenación urbana, se trataba de una especie de plan estratégico que establecía un marco referencial para la toma de decisiones por parte de las administraciones públicas. Su informe final, "Plan Houston. Opportunity. Diversity. Community. Home", publicado el 30 de septiembre de 2015, definía una visión de ciudad y unos objetivos, y prescribía 12 estrategias para alcanzarlos.

Varias de ellas apuntaban a la necesidad de cambiar de rumbo:

La 3, "apoyar infraestructuras de calidad", señalaba la necesidad de renovar, entre otras, las precarias redes de abastecimiento y saneamiento. La 4, "nutrir barrios seguros y saludables", reconocía la importancia de los servicios sociales, especialmente los de salud, para abordar el problema de la pobreza. La 5, "conectar personas y lugares", se abría a la posibilidad de implementar sistemas de transporte alternativos al automóvil, aunque incidiendo más en la bicicleta que en una sólida red de transporte público. La 9, "proteger y conservar nuestros recursos", evidenciaba la insostenibilidad de la relación que Houston mantenía con su medioambiente, especialmente en lo referente al tema del agua. La 12, "celebrar lo que es único en Houston", destacaba el valor de los edificios distintivos y las zonas históricas de la ciudad, que llevaban décadas siendo dilapidados. Sin embargo, otras estrategias del Plan Houston confirmaban las prioridades tradicionales de la capital tejana. La 6, "apoyar nuestra economía global", reafirmaba la máxima de la competitividad para atraer inversiones y puestos de trabajo calificados como "deseables". La 2, "crecer responsablemente", seguía apostando por el crecimiento urbano (básicamente suburbano) como uno de los motores de la economía local. Y la 1 "gastar el dinero sabiamente", velaba por la salvaguardada de la política de bajos impuestos.

En definitiva, el Plan Houston, no era ningún punto y aparte en el idilio de la ciudad con el "no plan", sino más bien un pequeño paso atrás, una apuesta por el urbanismo débil que subsanara cuestiones tales como las deficiencias en infraestructuras públicas, la falta de servicios sociales, la desatención del patrimonio urbano y arquitectónico o la ausencia de alternativas al automóvil; todo ello sin poner en tela de juicio los objetivos y fundamentos de las políticas urbanas neoliberales. Como ocurrió con las Development Ordinances de 1985, la intención del Plan Houston parecía ser evitar que la ausencia de normas acabara comprometiendo el axioma de la competitividad, un axioma profundamente enraizado en las ciudades del Sunbelt, ciudades que, desde que se fundaron, se vieron obligadas a competir entre ellas, que nunca conocieron un urbanismo verdaderamente institucionalizado y a las que, paradójicamente, el desarrollo de la globalización ha convertido en modelos a seguir en amplias zonas geográficas del planeta.

\section{Bibliografia}

Аввотт, C. (1981): The New Urban America. Growth and Politics in Sunbelt Cities, Chapel Hill, Estados Unidos, The University of North Carolina Press.

- (1993): The Metropolitan Frontier. Cities in the Modern American West, Tucson, Estados Unidos, The University of Arizona Press.

Anderson, W. H. \& Neuhaus W. O. (1982): Trading toilets: the subterranean zoning of Houston. Cite. The Architecture and Design Review of Houston, $\mathrm{n}^{\circ}$ Agosto: $12-14$.

\footnotetext{
${ }^{14}$ En 2004, y tras 20 años de controversias, fue inaugurado el METRORail, un ferrocarril ligero.
} 
Banham, R. \& al. (1969): Non-plan: an experiment in freedom. New Society 13, $\mathrm{n}^{\circ} 338$.

Bernard, R. M. \& Rice, B. R. (1983): Sunbelt Cities. Politics and Growth Since World War II, Austin, Estados Unidos, University of Texas Press.

Castells, M. (1995 [1989]): La ciudad informacional. Tecnologías de la información, reestructuración económica y el proceso urbano-regional, Madrid, España, Alianza Editorial.

Cuff, D. (2000): The Provisional City. Los Angeles Stories of Architecture and Urbanism, Cambridge, Estados Unidos, The MIT Press.

FaIRBANKS, R. B. \& UndeRWOOd, K. (editores) (1990): Essays on Sunbelt Cities and Recent Urban America, Arlington, Estados Unidos, Texas A\&M University Press.

Gammage, G. (JR.) (1999): Phoenix In Perspective. Reflections On Developing The Desert, Tempe, Estados Unidos, Arizona State University.

Garcia VÁzquez, C. (2011): Antípolis. El desvanecimiento de lo urbano en el Cinturón del Sol, Barcelona, España, Gustavo Gili.

- (2019): La suburbanización del Sunbelt estadounidense tras la Crisis del Petróleo. El crecimiento como ideología y el debate medioambiental. EURE, Volumen 45, no 136: 233-254.

GreANIAS, G. (1998): Shadow planning. It's the way Houston works, for good-and for bad. Cite. The
Architecture and Design Review of Houston, $\mathrm{n}^{\circ} 42$ : 28-29.

KEIL, R. (1998): Los Angeles. Globalization, Urbanization and Social Struggles, Chichester, Estados Unidos, John Wiley \& Sons.

KoolmaAs, R. \& MAU, B. (1995): S, M, L, XL, Rotterdam, Holanda, 010 Publishers.

— \& al. (2000): Mutaciones, Barcelona, España, ACTAR.

LARUP, L. (2000): After the City, Cambridge, Estados Unidos, The MIT Press.

Perry, D. C. \& Watkins, A. J. (editores) (1977): The Rise of the Sunbelt Cities, Beverly Hills, Estados Unidos, Sage Publications.

Pope, A. (1996): Ladders, Houston y Nueva York, Estados Unidos, Architecture at Rice y Princeton Architectural Press.

ScArdino, B., Stern, W. F. \& WebB, B. C. (2003): Ephemeral City. Cite Looks at Houston, Austin, Estados Unidos, University of Texas Press.

SiegAn, B. H. (1972): Land Use Without Zoning, Lanham, Estados Unidos, Lexington Books.

\section{Listado de acrónimos/siglas}

CC\&R Covenants Conditions and Restrictions.

CID Common Interest Development.

HOLC Home Owners' Loan Corporation. 


\section{CIUDAD Y TERRITORIO}

ESTUDIOS TERRITORIALES

ISSN(P): 1133-4762; ISSN(E): 2659-3254

Vol. LIII, № 207, primavera 2021

Págs. 181-188

https://doi.org/10.37230/CyTET.2021.207.11

CC BY-NC-ND

(c) (i) $($ )

\section{El Corredor biótico del Rio. Medellín, Colombia}

LUCa BuLLARO

Arquitecto Ph.D. Profesor Asociado Facultad de Arquitectura Universidad Nacional de Colombia

\section{CRÉDITOS DEL PROYECTO}

NOMBRE: El Corredor biótico del Rio. Medellín, Colombia

LOCALIZACIÓN: Medellín, Colombia

FUNCIÓN: Corredor biótico

INVESTIGACIÓN: “Arquitectura y ciudad: análisis, proyectos, transformaciones” desarrollada en la Facultad de Arquitectura de la Universidad de Colombia, Medellín

AUTOR/ AUTORES: Luca Bullaro

EQUIPO DE INVESTIGACIÓN: Grupo de Investigación Transepto

FECHA DE DESARROLLO DEL PROYECTO: 2013 Primera Fase 2019-20 Segunda Fase

FECHA DE CONSTRUCCIÓN: 2019-20

SUPERFICIE DE LAACTUACIÓN: $90.000 \mathrm{~m}^{2}$

COSTE/PRESUPUESTO: 700.000 millones de pesos colombianos

CRÉDITOS DE LAS IMÁGENES: El autor

Este artículo es resultado de la investigación "Arquitectura y ciudad: análisis, proyectos, transformaciones" desarrollada por Luca Bullaro en la Facultad de Arquitectura de la Universidad de Colombia, Medellín (Grupo de Investigación: Transepto). Correo electrónico: lucabullaro@hotmail.com; No ORCID: https://orcid.org/0000-0003-1584-7063 


\section{Introducción}

Al principio del 2020 se inauguró la segunda fase Parque del río de Medellín, -uno de los proyectos públicos de transformación urbana más importantes de América latina- que tiene por objetivo integrar la ciudad con el río, generar un eje ambiental de conectividad para la ciudad, y un sistema de generosos espacios públicos.

La colocación de las vías de circulación, y del flujo de transporte mecánico, por debajo de la cota cero, permitió crear un sistema de espacios públicos y democráticos que llegan finalmente a proporcionar un fuerte diálogo con los elementos naturales presentes y una rápida conexión entre las dos franjas del rio gracias a la introducción de nuevos puentes peatonales.

Esta primera fase del proyecto logró transformar una zona contaminada y ruidosa en un pulmón verde de atracción social y comunitaria, con un sistema de actividades lúdicas, recreativas y comerciales, y una amplia área de juegos para los más pequeños.

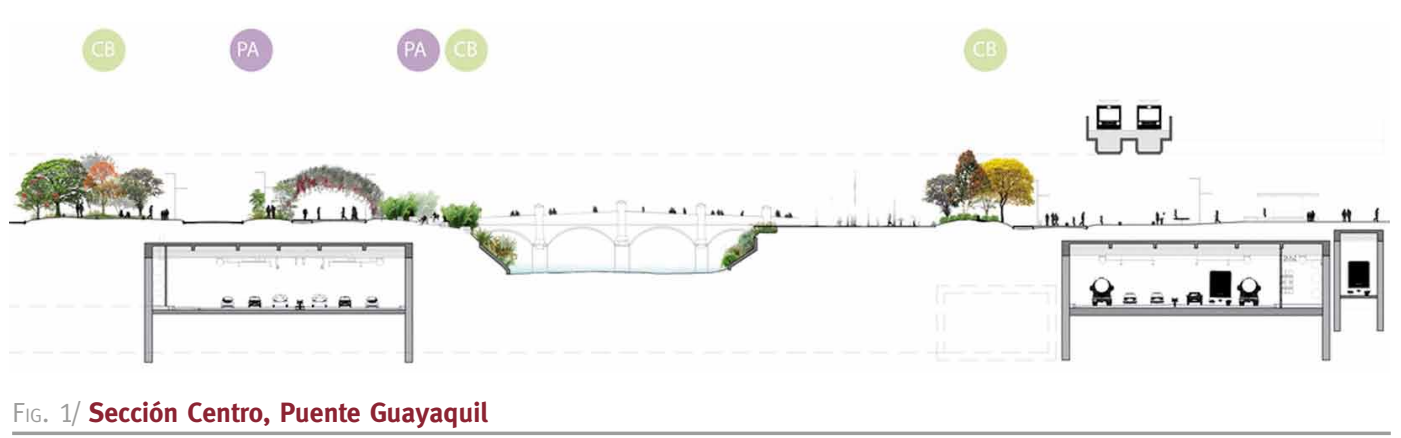

Fuente: Latitud arquitectos.

\section{Objetivos básicos del proyecto urbano}

El Concurso público internacional de anteproyecto de Parques del río, de 2013, tenía como objetivo la integración de los espacios urbanos entre sí y con el eje longitudinal del rio. El proyecto ganador, de la local oficina "Latitud", que surge en continuidad con el plan urbanístico "Medellín 20-30" y con el nuevo POT -plan de ordenamiento territorial- es una respuesta integradora de la red biótica de la ciudad, y "elemento estructurante -como escribe el urbanista Jorge Pérez Jaramillo-de los Macroproyectos urbanos de renovación urbana de la ciudad: la alternativa para generar un valle de Aburrá más integrado y articulado".

El corredor verde metropolitano pretende permeabilizar las actuales zonas de vegetación existente en la ciudad integrándolas a un sistema general para conferir protagonismo al eje del rio, el "estructurante natural de mayor impacto metropolitano".

"Es un proyecto fundamental para Medellín -escribe el urbanista Daniel Carvalho- una obra acorde con el plan estratégico de transformación urbana", que sigue las pautas fundamentales del crecimiento y de la transformación urbana en el próximo futuro.

La pujanza social de este parque lineal longitudinal reside también en su fuerte carácter transversal: fortalece las conexiones y fomenta la conexión peatonal y a través de ciclovías entre el centro administrativo, el centro antiguo y los barrios residenciales de Conquistadores, San Joaquín y Laureles.

El parque cuenta con más de setenta mil metros cuadrados de espacios públicos y proporciona a la ciudad unos nuevos lugares democráticos que conectan de forma contundente la parte oriental de Medellín con la occidental. El diseño general prevé la implantación de 2.600 nuevos árboles, la realización de tres kilómetros y medio de ciclorrutas y senderos peatonales, zonas de estancia y áreas picnic. 


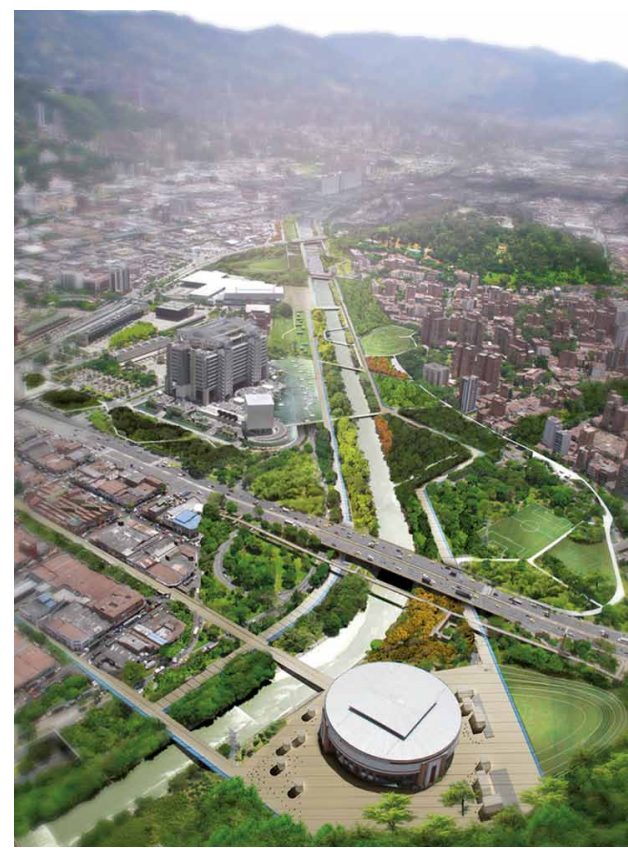

FIG. 2/ Vista aérea de la propuesta de proyecto.

Fuente: Latitud arquitectos

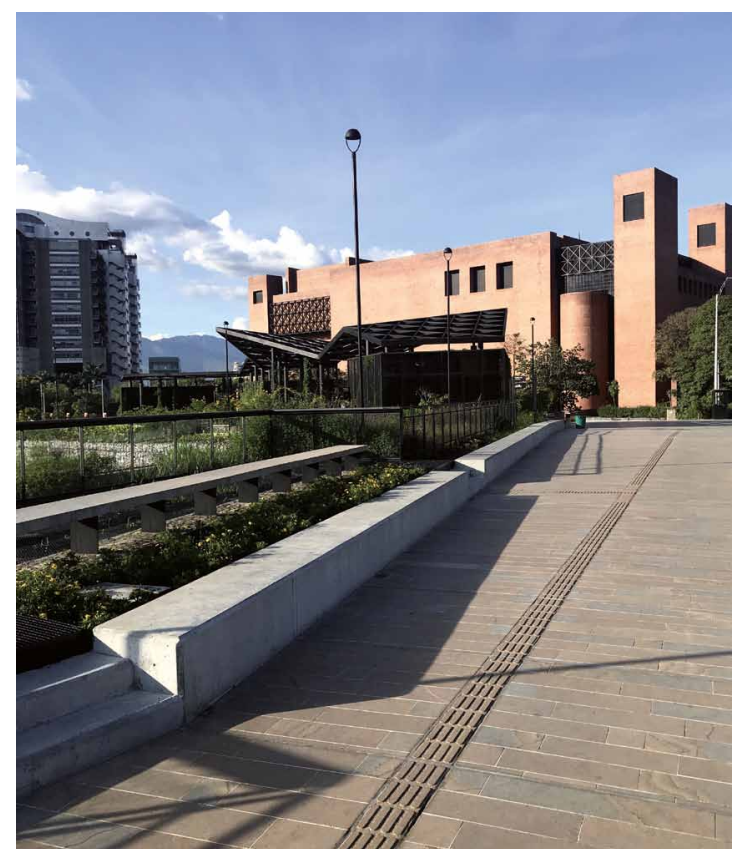

FIG. 3/ Uno de los nuevos puentes peatonales.

Fuente: Foto de Luca Bullaro.

\section{Contexto físico}

La ciudad de Medellín, a partir de los primeros años cincuenta, con la presentación del Plan Piloto de Paul Lester Wiener y Josep Lluis Sert, empieza a modificar de forma considerable la relación con su rio, columna vertebral del Valle de Aburrá.

Entre las dos laderas del valle, la ciudad se desarrolló en los últimos setenta años de forma mucho más rápida y caótica de aquella prevista por Sert, maestro arquitecto y urbanista español. Hoy en día es por extensión y número de habitantes la segunda ciudad de Colombia, una megalópolis caótica y contaminada, a pesar de las notables mejoras urbanas de los últimos años.

El Plan Piloto de los años cincuenta preveía la rectificación del rio, y la realización de una vía rápida para el transporte mecanizado paralela al curso de agua en lado occidental, y un parque lineal en la parte oriental, en relación directa con el centro antiguo y con los futuros centros económicos y administrativos que se ejecutaron en el transcurso de los años, respetando las indicaciones básicas del proyecto urbano general.

Lastimosamente, en lugar del extenso parque linear previsto por Sert, se realizó otra vía rápida que consolidó esta franja central como una barrera pensada únicamente para el transporte mecanizado rápido. Este doble sistema longitudinal es la actual columna vertebral de Medellín: un eje antiurbano, y antihumano: las dos carreteras asfixian el rio y generan una herida que corta la ciudad en dos grandes áreas. Cruzar este sistema transversalmente genera serias dificultades para los peatones y para las bicicletas.

En 2013 el concurso internacional de transformación del eje del rio representó la ocasión estratégica para ampliar el debate cultural, social y económico, sobre la relación de la ciudad con su rio. Ganó el primer premio el proyecto realizado por los jóvenes arquitectos locales del estudio "Latitud", que imaginaba el futuro de la franja del rio como un extenso jardín botánico, interconectados a los barrios adyacentes. El concurso proponía la separación entre el tráfico mecánico y aquello peatonal, localizando, en varios tramos, la circulación mecánica en vías deprimidas, para fomentar los flujos transversales directos, y vincular las áreas urbanas de los dos lados del rio. 
De este macro proyecto se emprendió, después de varios meses, la construcción de la primera etapa. Al principio de 2020 se inauguró también la segunda fase del proyecto: se colocó el sistema de vías rápidas bajo tierra y se abrieron dos puentes peatonales que permiten una cómoda y rápida conexión entre las partes orientales y occidentales de la ciudad, en correspondencia del centro antiguo y administrativo y de los extensos barrios residenciales de Conquistadores y de Laureles: esta operación consiente la integración entre la ciudad burguesa, la parte más popular del área comercial central y tradicional, y el área administrativa, que por varios decenios se mantuvo aislada del resto de la ciudad, y de la ciudadanía.

El nuevo Parque del río representa hoy en día otro paso en el camino hacia la renovación urbana y social que se emprendió desde hace algunos años: una importante operación de transformación urbana que apunta a convertir Medellín en una ciudad más ecológica e interconectada, más inclusiva e incluyente.
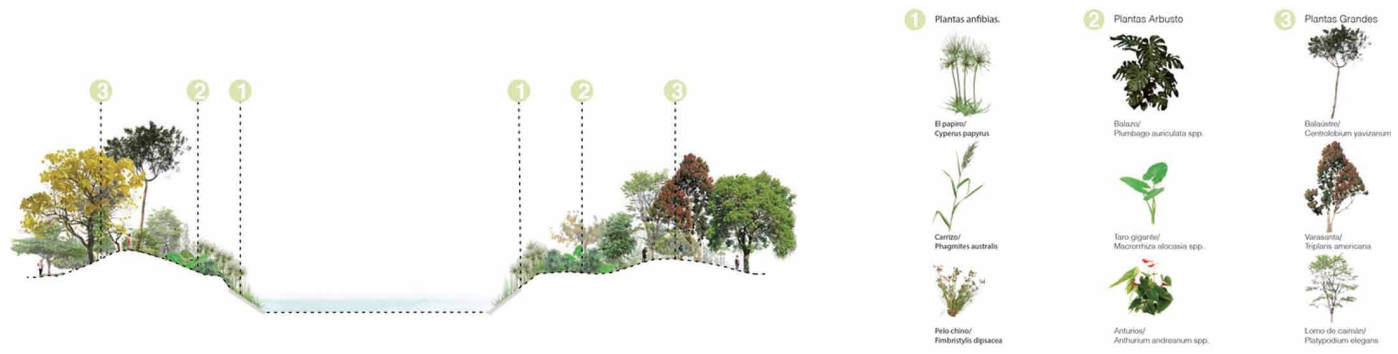

FIG. 4/ Corredor Biótico.

Fuente: Latitud arquitectos.

\section{Estrategias proyectuales generales}

El río como eje estructurante: se busca desarrollar un parque botánico de forma linear que articule los sistemas naturales de la ciudad en un circuito ambiental del Valle de Aburrá. El nuevo corredor biótico metropolitano se convertirá en un parque ambiental, cultural y deportivo.
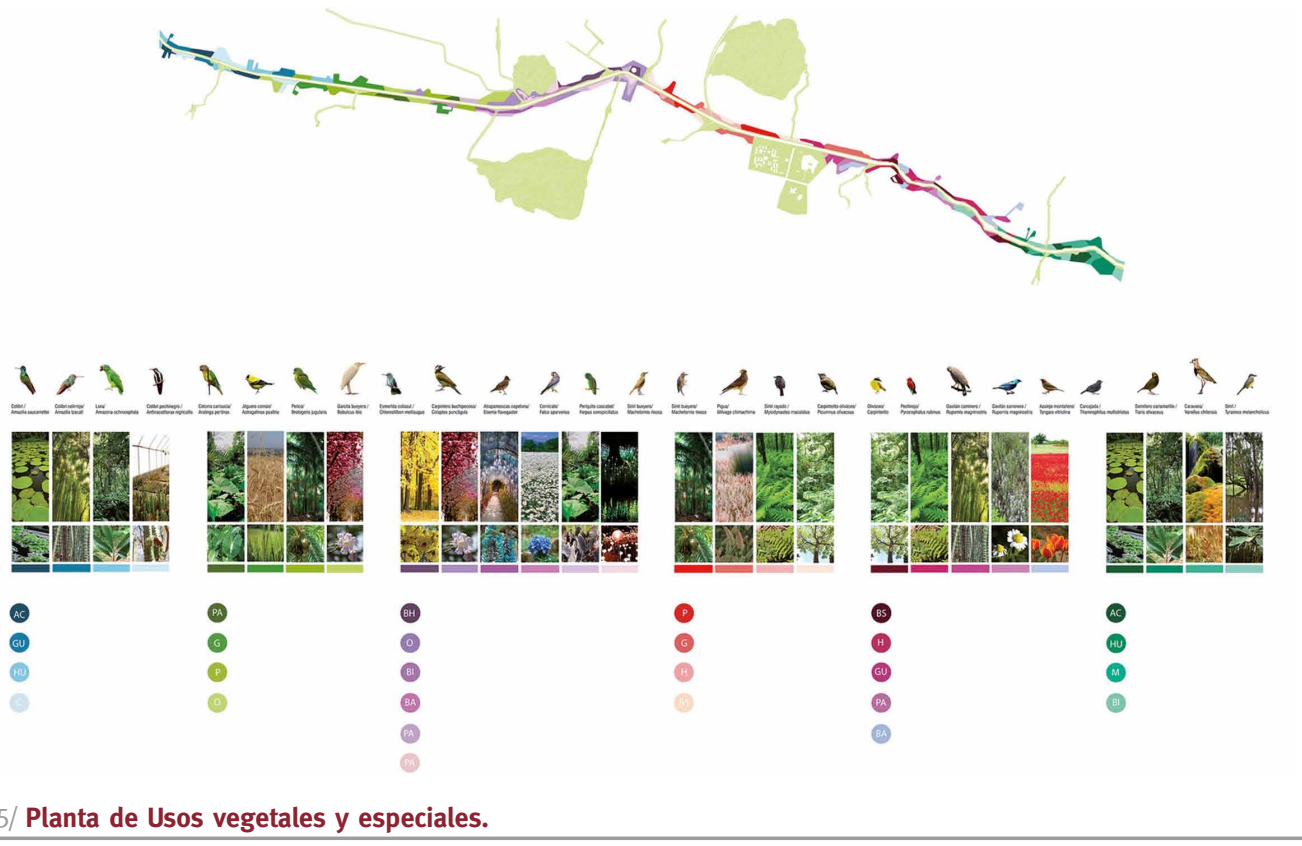

Fuente: Latitud arquitectos. 
Potenciación de los vacíos verdes urbanos y su vinculación al sistema ambiental: se categoriza, reutiliza y reconecta al corredor biótico los vacíos urbanos presentes en el área de influencia directa del río Medellín y sus afluentes.

Recuperación e integración de las quebradas: el proyecto, recuperando una de las ideas fuertes del Plan Piloto de los años cincuenta, pretende promover la protección de las quebradas transversales al rio a través de su integración en el corredor biótico metropolitano. Reconocer estos estructurantes naturales como fundamentales para el bienestar general del río y del valle de Aburrá. La incorporación a la red de espacio público y ambiental propuesta asegura el equilibrio y la recuperación del sistema biótico de la ciudad.

Reciclaje de estructuras subutilizadas en el área de influencia del corredor biótico: se prevén usos que complementen la vocación del Parque botánico.

\section{Las arquitecturas tropicales del parque}

Un sistema de arquitecturas permeables, en relación directa con los elementos naturales protagoniza algunas áreas estratégicas del parque.

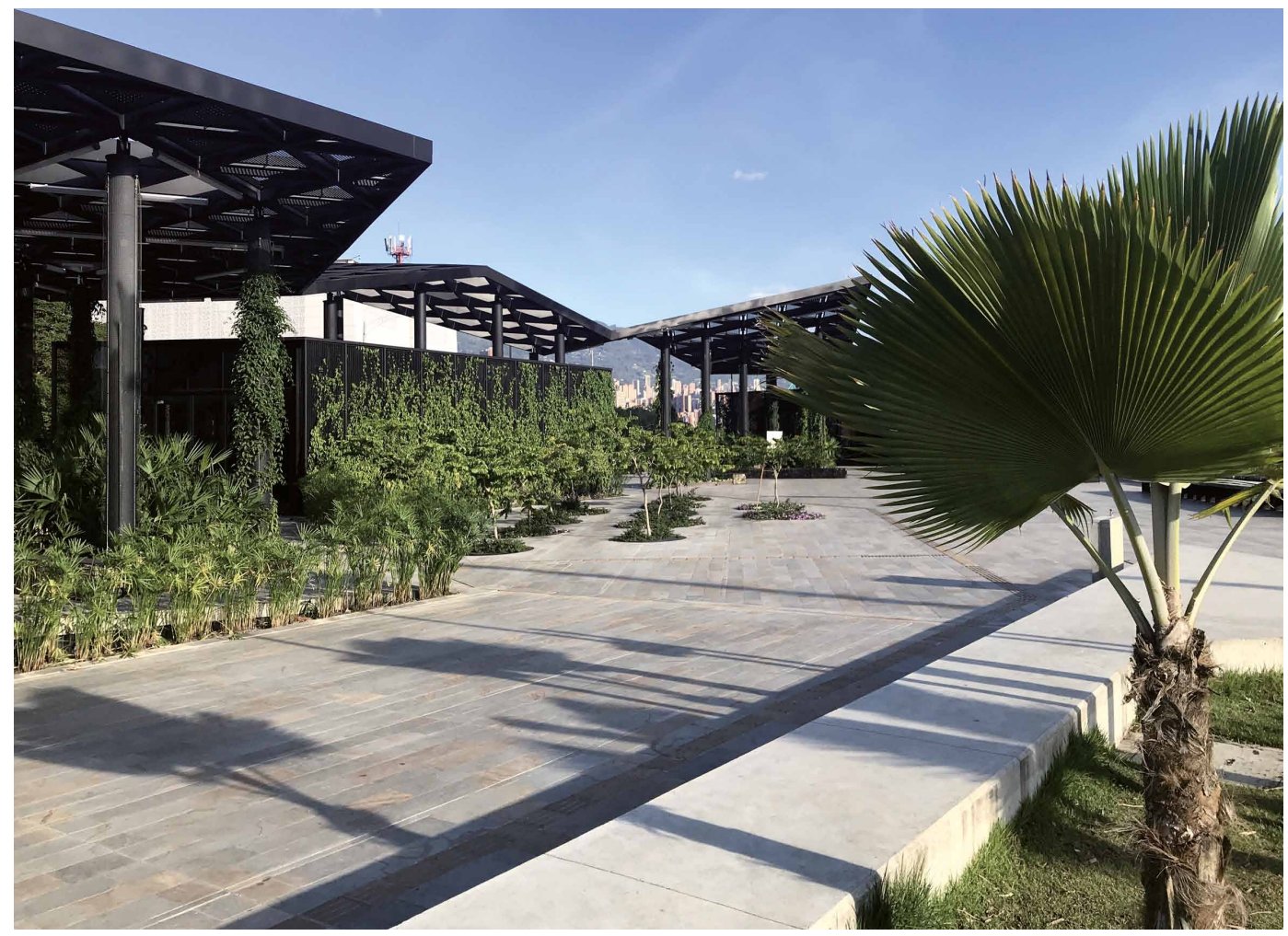

FIG. 6/ El sistema integrado de pérgolas urbanas, caminos y espacios de estancia.

Fuente: Foto Luca BulLARo.

El sistema de las marquesinas realizado en el costado oriental es fundamental para la producción de sombras y para generar espacios de estancias protegidos y frescos. La geometría, en planta, de los locales comerciales con sus respectivas pérgolas metálicas obedece a un sistema geométrico de tipo modular y prefabricado, cuyo patrón base es el triángulo. El uso de esta geometría en armónica y orgánica concatenación recuerda algunos proyectos modulares basados en la repetición de patrones 


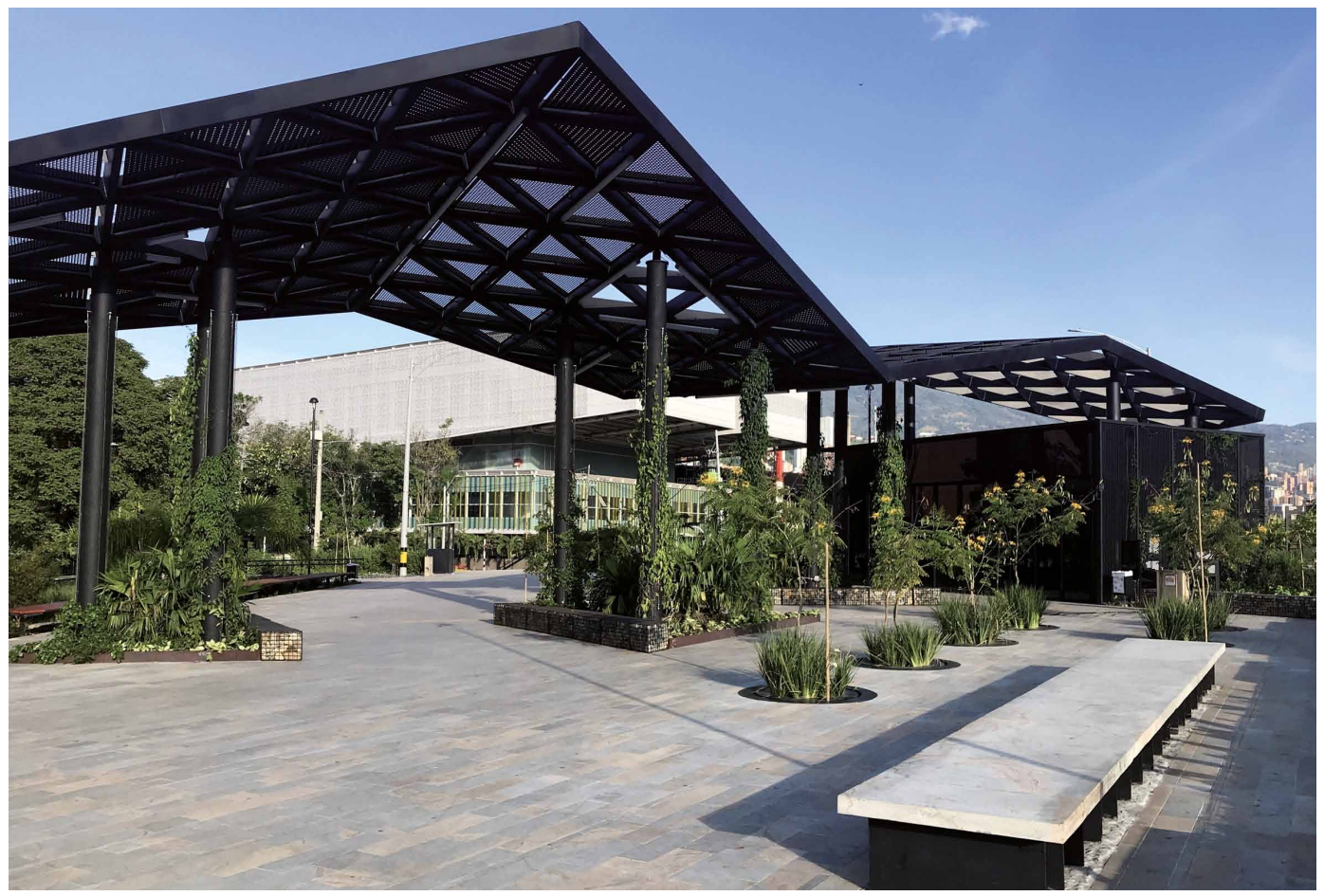

FIG. 7/ La concatenación entre sistemas naturales y artificiales en las pérgolas y en el espacio publico.

Fuente: Foto Luca Bullaro.

hexagonales desarrollados por Frank Lloyd Wright. La metodología de proyecto se puede asociar también a aquella utilizada en unos de los símbolos arquitectónicos de la renacimiento urbano y cultural de Medellín de los últimos años: el Orquídeorama, realizado en el área central del jardín botánico de la ciudad, a partir de un sistema de módulos espaciales de tipo similar.

Cada módulo se sostiene a partir de tres esbeltas columnas metálicas localizadas en la zona central y, cómo un árbol, lanza sus generosos voladizos hacia afuera. En algunos casos los módulos de las cubiertas se solapan uno encima del otro, a generar un juego arquitectónico de matriz dinámica, cuya finalidad es acoger los ciudadanos en un ambiente fresco, sombreado, y en diálogo constante con los variados elementos naturales seleccionados por el paisajista colombiano Nicolas Hermellín.

Interesante la colocación de plantas enredaderas en las columnas metálicas de las pérgolas, y en la piel de los locales comerciales: útiles desde el punto de vista bioclimático y estético: bloquean los rayos directos del sol tropical y generan un intenso contraste con la tonalidad oscura de la estructura.

Con el paso del tiempo, este sistema natural colonizará el extradós de la cubierta de las marquesinas urbanas, y mejorará de forma notable el desempeño bioclimático de estas estructuras, fundamental para un uso constante de los espacios abiertos, también en las horas más calientes del día.

Dos volúmenes más sencillos, de planta rectangular, están presentes en el costado occidental: el más pequeño es una reinterpretación tropical de la "caja de vidrio" de la tradición moderna. Estructura negra. Basamento verde con plantas que van colonizando las paredes exteriores. Piel en elementos de madera dispuesto verticalmente, para tamizar el sol abrasador de Medellín. Interesante vacío público central que facilita la penetración de los flujos peatonales.

El edificio más grande se reconoce por su estructura metálica negra, y sus extensas superficies vidriadas en correspondencia de los locales comerciales: cafetería, restaurante, servicios sanitarios y depósitos. El cincuenta por ciento del espacio construido es abierto pero cubierto: acoge las terrazas públicas, y una plaza cubierta multifuncional, para pequeños conciertos y espectáculos. 


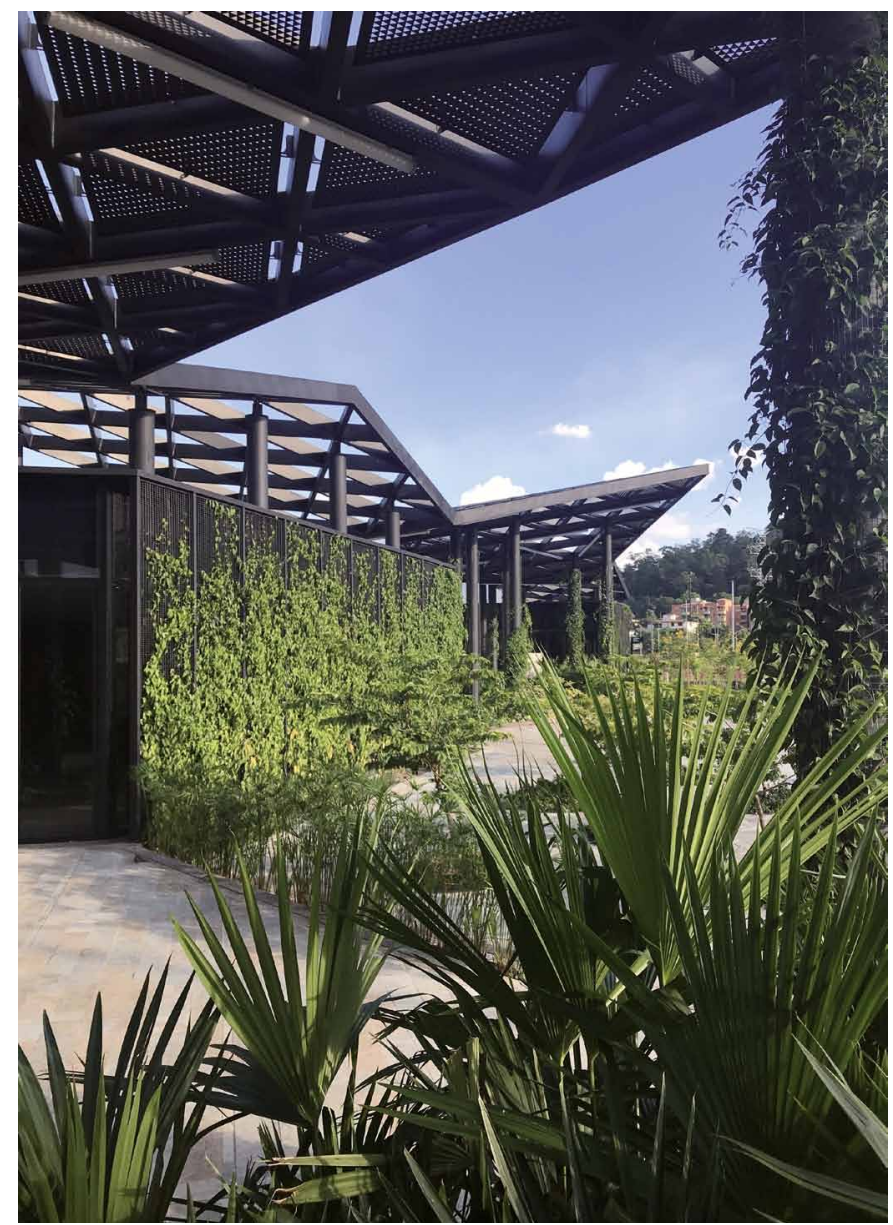

IG. 8/ El sistema de pérgolas y las paredes verdes de los quioscos.

Fuente: Foto de Luca Bullaro.

\section{Materiales utilizados}

Los materiales son sencillos, resistentes y de fácil mantenimiento. Se utilizan elementos porosos, como mallas, tejidos y láminas micro-perforadas en los puentes, los caminos y las plazas, "diluyendo -como afirman los arquitectos- el límite entre lo construido y lo natural".

Suelos de piedra y de concreto. Algunos de los bancos en hormigón armado, con estructura prefabricada y modular; otros se realizaron en malla metálica, pintada de negro y colma de piedras de diferentes formas y tonos a su interior, a reinterpretar algunos experimentos matéricos de Herzog y De Meuron.

El corazón de la franja oriental es un área dedicada al picnic. El área de juegos infantiles, de gran tamaño, presenta un suelo de arena blanca y una estructura dinámica que, como una ola artificial, sostiene una enorme red que permite una multiplicidad de juegos y aventuras: una fiesta para los niños-escaladores.

Algunas esculturas animan el nuevo espacio público. La más pequeña creada por Mario Vélez, talentoso artista colombiano, que reinterpreta la morfología de las piedras de canto rodado del río, tradicionalmente utilizadas para los pisos exteriores de la arquitectura antigua. Otra, configurada a partir de un sistema de prismas dinámicos colocados uno encima del otro, y repletos de verde, a simbolizar tal vez la nueva arquitectura ecológicas del próximo futuro. 


\section{Uso actual}

El nuevo Parque del rio se ha convertido en pocos meses en un espacio vital para los medellinenses. La fuerza urbana de este doble parque lineal radica, paradójicamente, en su transversalidad: se ha generado un potente sistema de pasos ciclo-peatonales que conecta el Centro cívico y cultural con los barrios residenciales de Conquistadores, San Joaquín y Laureles.

Los flujos peatonales se expanden fácilmente y conectan una de las áreas residenciales más importante de la urbe con el centro histórico y, al otro lado del rio, con la zona cultural y recreativa que se desarrolla alrededor del boulevard de la Carrera Setenta, que conecta la zona deportiva del estadio con el campus de la Universidad pontificia Bolivariana. La multiplicación de los flujos peatonales transversales ha sido posible gracias a la colocación de dos cómodos y amplios puentes peatonales, repletos de arbustos, flores y plantas aromáticas. Los diferentes y variados espacios multifuncionales del parque van facilitando la rápida apropiación social por parte de la comunidad.

\section{Bibliografía}

Arango, S. (1989): Historia de la Arquitectura en Colombia, Bogotá; Ed. Universidad Nacional de Colombia.

- (2012): Ciudad Arquitectura, Seis generaciones que construyeron la América Latina Moderna, México: Fondo de cultura económica nacional.

AA. VV. (2014): Guía de arquitectura de Medellín, Medellín: Mesa ed.

BASTLUND, K. (1967): José Luis Sert Architecture, city planning, urban design. New York: Praeger.

BullaRo, L. (2019): "Medellín: hacia una ciudad ecológica, interconectada y multicultural”, en Revista Universidad de Antioquia, n. 335, Medellín: UdeA ed., pp. 85-90.

- (2019): Hacia una transformación ecológica de las ciudades: un ensayo didáctico. En Builes Escobar, N. \& Builes Vélez, A.E. (Ed.): Creación y debate Discusiones acerca de la creación, la ciudad y el habitar, Medellín: UPB Universidad Pontificia Bolivariana, Escuela de Arquitectura y Diseño, pp.158-171.

— \& CALABRESE, F. (2018): "Riconversione a Medellín", en ANANKE, Quadrimestrale di Cultura, Storia e Tecniche della Conservazione per il Progetto, n. 84, Roma: Altralinea ed., pp.110-113.

Escovar, A. (2006): Medellín Guía de Arquitectura, Bogotá: Ediciones Gamma.

Gonzales Escobar, L. F. (2019): Ciudad y arquitectura urbana en Colombia, Medellín: Editorial Universidad de Antioquia.

Higueras, E. (2006): Urbanismo bioclimático, Barcelona: Gustavo Gili.

Rogers E. N., \& SERT J. L., \& TYRWHITT, J. (1955): El corazón de la ciudad: por una vida más humana de la comunidad, Barcelona: Hoepli.

Rogers, R. (2003): Ciudades para un pequeño planeta, Barcelona: Gustavo Gili.

RoviRA, J. M. (2005): Sert 1928-1979. Medio siglo de arquitectura. Obra completa, Barcelona: Actar.

SANIN, F. \& CRUz Teddy, F. (2014): Medellín, vida y ciudad, Medellín: RM ed.

SCHNITTER, P. (2002): Jose Luis Sert y Colombia. De la carta del Atenas a una carta del hábitat. Tesis Doctoral. Barcelona: ETSAB ed.

SERT, J. L. (1942): Can our cities survive? And ABC of urban problems, their analysis, their solutions, Cambridge: Harvard University Press. 


\title{
Estudios Comparados
}

\section{CIUDAD Y TERRITORIO \\ ESTUDIOS TERRITORIALES}

ISSN(P): 1133-4762; ISSN(E): 2659-3254

Vol. LIII, № 207, primavera 2021

Págs. $189-214$

https://doi.org/10.37230/CyTET.2021.207.12

\section{La protección, gestión y mejora del paisaje en España. Estudio comparado}

\author{
Rafael MATA-OLmo \\ Daniel FERRER-JIMÉNEZ
}

Departamento de Geografía, Universidad Autónoma de Madrid

RESUMEN: El renovado interés por el paisaje, impulsado por el Convenio Europeo del Paisaje del Consejo de Europa (2000) (CEP), se ha incorporado a la agenda política y a los desarrollos legislativos e instrumentales de las administraciones públicas españolas, en particular, de las Comunidades Autónomas y de algunas administraciones locales. Pese a la actualidad de la cuestión paisajística, el paisaje como objeto de tutela ha estado presente tradicionalmente en la legislación española, tanto en la de protección de la naturaleza y del patrimonio cultural, como en la urbanística y en otro tipo de normas sectoriales. Este Estudio comparado sintetiza el profuso y diverso tratamiento del paisaje en la legislación estatal y autonómica. En la última parte se abordan los avances e innovaciones introducidos por determinadas leyes específicas sobre paisaje aprobadas por las Comunidades Autónomas para la protección, gestión y ordenación del paisaje como elemento de calidad de vida y patrimonio territorial, de acuerdo con el CEP y en el horizonte de la Agenda Urbana Española.

\section{Landscape protection, management and improvement in Spain. Comparative study}

ABSTRACT: The renewed interest in landscape, promoted by the European Landscape Convention of the Council of Europe (2000) (CEP), has been incorporated into the political agenda and into the legislative and instrumental developments of Spanish public administrations, particularly those of the Autonomous Communities and some local administrations. Despite the topicality of the landscape issue, landscape as an object of protection has traditionally been present in Spanish legislation, both in the protection of nature and cultural heritage, as well as in urban planning and other types of sectoral regulations. This comparative study synthesizes the profuse and diverse treatment of landscape in state and autonomous community legislation. The last part deals with the advances and innovations introduced by certain specific laws on landscape approved by the Autonomous Communities for the protection, management and planning of landscape as an element of quality of life and territorial heritage in accordance with the CEP and within the horizon of the Spanish Urban Agenda.

Correo electrónico: rafael.mata@uam.es; N ORCID: https://orcid.org/0000-0002-3495-5599; Correo electrónico: daniel.ferrer@uam.es; NºRCID: https://orcid.org/0000-0001-7069-2581 


\section{Introducción}

a consideración del paisaje como elemento de calidad de vida e identidad de los lugares, y, a la vez, como patrimonio y recurso de desarrollo territorial sostenible ha emergido con fuerza en los últimos tiempos en la agenda política y los desarrollos legislativos e instrumentales de las administraciones públicas españolas, en particular, de las comunidades autónomas y de algunas administraciones locales como diputaciones, consejos y cabildos insulares, y numerosos municipios. Ese interés creciente y renovado por el paisaje debe mucho en el plano normativo, como se verá a continuación, al Convenio Europeo del Paisaje (CEP), del Consejo de Europa, puesto a la firma de los Estados integrantes de dicho organismo en Florencia, el 20 de octubre de 2000 y en vigor desde 2004, tras su ratificación por diez Estados miembros del Consejo. En España, ese hecho tuvo lugar el 26 de noviembre de 2007, estando en vigor desde el 1 de marzo de 2008.

Como hemos escrito en otro lugar (MATA OLMO, 2006:17), el aumento del interés ciudadano por el paisaje hay que incardinarlo en el avance general de la conciencia ambiental; pero el eco que la cuestión paisajística está alcanzando en los últimos tiempos tiene mucho que ver con la creciente importancia de los problemas territoriales, no sólo porque el deterioro del paisaje va estrechamente unido al consumo abusivo e imprudente de territorio, sino porque -con palabras de Roberto Gabino- "no se salva el paisaje si no se salva el país" (GAMBINO, 2002: 56). La Agenda Urbana Española concede de hecho al paisaje -a un entendimiento renovado del mismo- un tratamiento significativo y transversal, en primer lugar, en su Objetivo estratégico 1. Ordenar el territorio y hacer un usoracional del suelo (Territorio, Paisaje y Biodiversidad), promoviendo estrategias, no solo para proteger, sino para mejorar y poner en valor el paisaje como patrimonio territorial. Pero la atención al paisaje urbano figura también entre las líneas de actuación para la revitalización de la ciudad existente (Objetivo 2), como "una oportunidad y un valor de cada pueblo y lugar" para mejorar la resiliencia frente al cambio climático (Objetivo 3) y como un activo para fortalecer la economía urbana (Objetivo 7) (AgENDA URBANA Española, 2019; de la CRuz Mera, 2019).

Pese a la actualidad de la cuestión paisajística, el paisaje como objeto de tutela ha estado presente tradicionalmente en la legislación española, tanto en la de protección de la naturaleza y del patrimonio cultural, como en la urbanística y de ordenación del territorio, y en otro tipo de normas sectoriales; eso sí, con una consideración referida y acotada a paisajes de alto valor natural o cultural y con una función esencialmente protectora de tales valores. El renovado entendimiento del paisaje del Convenio de Florencia como una cualidad de todo el territorio -el "carácter" de cada territorio "percibido por la población"- supone una apertura conceptual y estratégica de la política de paisaje, de las normas que la regulan y de los instrumentos que la implementan. Sin perjuicio de la necesaria protección de los paisajes más valiosos, la actual agenda paisajística incorpora la gestión, la recuperación, la recualificación y la creación de nuevos paisajes en los entornos de la vida cotidiana, y preconiza así la necesidad de acción paisajística para el conjunto del territorio.

Justamente la estrecha relación conceptual y funcional entre territorio y paisaje (ZoIDO NARANJO, 2010) explica que, tradicionalmente, el urbanismo, por su función planificadora del espacio urbano y rural, haya prestado atención a la conservación del paisaje, sin perjuicio, como decimos, de la tutela específica de los paisajes de más alto interés por legislación protectora sectorial (AguDo GonZÁLEZ, 2009). Al ser el urbanismo y la ordenación del territorio competencia exclusiva de las Comunidades Autónomas (CC.AA.) de acuerdo con la Constitución Española de 1978, la diversidad de tratamientos que el paisaje ha merecido en los 17 ordenamientos jurídicos autonómicos es significativa, no solo ya en las correspondientes leyes de urbanismo y/u ordenación del territorio, sino en la legislación específica que en materia de paisaje han aprobado determinadas CC.AA., amparadas en el citado Convenio Europeo del Paisaje, en algunos casos, antes incluso de que el Estado español lo ratificara.

A la diversidad de ordenamientos en el ámbito de la planificación urbanística y territorial, y específicamente paisajística, se suma la existente en el de la protección del patrimonio natural y la biodiversidad, y del patrimonio cultural. En el marco de la legislación básica del Estado sobre ambas materias, las CC.AA. han aprobado sus respectivas normas, que otorgan tratamientos matizadamente distintos a los paisajes de alto valor natural -Paisajes protegidos como categoría de espacio protegido en las leyes de conservación de la naturaleza- y cultural -Paisajes culturales en aquellas leyes autonómicas que incluyen esa categoría, ausente en la ley del patrimonio histórico español de 1985. Asimismo, junto a las normas urbanísticas, de ordenación del territorio y de paisaje, y a las de protección del patrimonio natural y cultural, requieren una mención particular, aunque necesariamente breve en este "estudio comparado", las de evaluación ambiental en relación con el paisaje, tanto la básica del Estado como las autonómicas.

Los ámbitos normativos mencionados no agotan el tratamiento legislativo del paisaje en España. 
Su consideración indirecta aparece en otras leyes, tanto estatales como autonómicas, sobre infraestructuras, equipamientos, agricultura y desarrollo rural, turismo, agua o actividades económicas. Todo ello sin olvidar las muchas determinaciones y directrices paisajísticas que van apareciendo en los instrumentos de ordenación del territorio de escala autonómica -algunos de ellos aprobados con rango de ley por los parlamentos regionales, como las DOT de las Illes Balears, el Plan de Ordenación del Litoral de Cantabria, o pendientes de serlo, como las DOT de Extremadura-y de ámbito subregional, y en otros instrumentos, también autonómicos, de planificación territorial sectorial. Lo interesante en estos casos es que la ordenación del paisaje, con referencias frecuentes al CEP, tiene lugar tanto en Comunidades Autónomas con legislación específica sobre la materia como en aquellas otras -la mayoría- que, sin tener ley de paisaje, aprovechan las posibilidades del urbanismo y la ordenación del territorio, de la planificación de espacios protegidos y, en algunos casos, de la evaluación ambiental para fortalecer la dimensión paisajística de la acción pública.

En un contexto tan diverso, dinámico y expansivo sobre la consideración del paisaje en la normativa española, este "estudio comparado" va a centrarse en la legislación protectora de paisajes de alto valor natural y cultural, en la urbanística y de ordenación del territorio, en la legislación de evaluación ambiental y, lógicamente, en aquellas leyes autonómicas específicas sobre paisaje, o sobre urbanismo, ordenación territorial y paisaje, que asumen ya en todos los casos la perspectiva y objetivos del CEP. Por la trascendencia del citado Convenio, se dedicará un breve apartado al mismo, junto a otras iniciativas internacionales sobre tutela del paisaje que han influido en el propio CEP y en distintas normas nacionales y autonómicas sobre paisaje.

\section{Iniciativas internacionales por la salvaguarda de paisajes de alto valor. La renovación conceptual y estratégica del Convenio Europeo del Paisaje del Consejo de Europa}

\subsection{La Convención para la Protección del Patrimonio Mundial y el Programa Global de Áreas Protegidas de la UICN}

La protección de los valores de paisajes de alto interés ha sido objeto de atención desde hace tiempo por parte de tratados y programas de organismos internacionales multilaterales, bien es verdad que nunca con carácter exclusivo y casi siempre adjetivado (paisaje natural, rural, cultural, etc.). Sin pretensión de exhaustividad merecen una referencia expresa, por su incidencia en las políticas y normas nacionales y autonómicas de protección de paisajes, la Convención para la Protección del Patrimonio Mundial Natural y Cultural de la UNESCO y el Programa Global de Áreas protegidas de la International Union for Conservation of Nature (UICN), asumido por Naciones Unidas (MATA OLMO, 2014).

Como se señala en la introducción del Plan $\mathrm{Na}$ cional del Paisaje Cultural (IPCE, 2012), la cuestión del paisaje está ya implícitamente planteada en la citada Convención de la UNESCO de 1972 a través del concepto de "sitio" (site). El Comité del Patrimonio Mundial desarrolló gradualmente la idea del reconocimiento por parte de la Convención de sitios que serían oficialmente calificados como Paisajes Culturales, vinculados al último párrafo del Artículo 1 de la Convención. Tras largas discusiones, la $16^{\mathrm{a}}$ sesión del Comité del Patrimonio Mundial en Santa Fe (1992) adoptó la nueva Operational Guidelines for the Implementation of the World Heritage Convention e introdujo una nueva categoría, Paisajes Culturales (UNESCO, 1992), con la siguiente definición:

\begin{abstract}
"Los paisajes culturales son bienes culturales y representan las "obras conjuntas del hombre y la naturaleza" citadas en el Artículo 1 de la Convención. Ilustran la evolución de la sociedad humana y sus asentamientos a lo largo del tiempo, condicionados por las limitaciones y/o oportunidades físicas que presenta su entorno natural y por las sucesivas fuerzas sociales, económicas y culturales, tanto externas como internas. Deberían ser elegidos basándose en su Valor Universal Excepcional, su representatividad de una región geocultural claramente definida y su capacidad para ilustrar los elementos culturales esenciales y distintivos de esas regiones". (UNESCO, Centro del Patrimonio Mundial, "Directrices Prácticas para la aplicación de la Convención del Patrimonio Mundial", 2008 (versión en español).
\end{abstract}

El primer paisaje inscrito como tal en la Lista del Patrimonio Mundial, en 1993, fue el Tongariro National Park, en Nueva Zelanda. En España tienen esa consideración el Paisaje Cultural de Aranjuez (incorporado a la Lista del Patrimonio Mundial en 2001), el Paisaje Cultural de la Serra de Tramuntana (2011) y el recientemente declarado Paisaje Cultural de Risco Caído y Montañas Sagradas de Gran Canaria. En todo caso, los paisajes culturales reconocidos como tales por la UNESCO e inscritos en la Lista del Patrimonio Mundial deben poseer un "excepcional valor universal", según los criterios y procesos de evaluación, establecidos 
por el organismo declarante. La concepción de paisaje cultural de la Convención ha tenido una incidencia clara, como no puede ser de otra forma, en la formulación del citado Plan Nacional de Paisaje Cultural del Gobierno español (IPCE, 2012), que ha incorporado, no obstante, como se verá, la visión más abierta e inclusiva del CEP, y en las leyes de patrimonio cultural de aquellas comunidades autónomas que han incluido la categoría de "paisaje cultural" como tipo de bien de interés cultural.

Por su parte, la IUCN incorporó ya en 1978, en su primer sistema de áreas protegidas, la categoría denominada Paisaje Protegido, con una definición confusa. El sistema de 1978 fue sustituido por el actualmente vigente de 1994, en el que se mantiene la figura de Paisaje Protegido (Categoría $\checkmark$ de las seis establecidas por la organización), que aparece recogida en la tipología de espacios protegidos de la Ley 42/2007, de 13 de diciembre, del Patrimonio Natural y de la Biodiversidad, como en la anterior de 1989, y en la práctica totalidad de la legislación autonómica sobre la materia, con la excepción del País Vasco. Para la UICN, Paisaje Protegido es:

\begin{abstract}
"área de terreno, incluyendo las costas y el mar, donde la interacción de población y naturaleza a lo largo del tiempo ha producido un espacio de carácter distintivo con unos valores estéticos, ecológicos y/o culturales específicos, y a menudo con una rica diversidad biológica. Salvaguardar la integridad de esta tradicional interacción es vital para la protección, el mantenimiento y la evolución del área mencionada".
\end{abstract}

Algunos aspectos importantes de la definición de las categorías Paisaje Cultural de la Lista del Patrimonio Mundial y Paisaje Protegido de la IUCN son similares, concretamente el énfasis en la interacción ser humano/naturaleza o el reconocimiento de los valores del paisaje en relación con las tradiciones culturales. Pero hay también diferencias significativas. En los Paisajes Protegidos, el medio natural, la conservación de la biodiversidad y la integridad del ecosistema constituyen los rasgos principales, mientras que en los Paisajes Culturales del Patrimonio Mundial el acento se pone en la historia humana, en la continuidad de las tradiciones culturales, y en las aspiraciones y valores sociales (PHILLIPS, 2002). En ambos casos, no obstante, la referencia al paisaje, ya sea de dominante natural o cultural, se concreta en ámbitos o elementos singulares especialmente valiosos con un objetivo prioritario de protección y tutela.

\subsection{El Convenio Europeo del Paisaje y la renovación de la política paisajística}

Esa concepción del paisaje y de la acción pública circunscrita a la tutela de configuraciones naturales y culturales excepcionalmente valiosas se ha visto superada en Europa por una renovación profunda del propio concepto de paisaje y la ampliación del alcance de la política paisajística. La Estrategia Territorial Europea (ETE), acordada por los ministros responsables de ordenación del territorio de la UE en 1999, dio ya un paso importante en el proceso de apertura del interés social y político por el paisaje a espacios cada vez más amplios. Cuando la ETE trata de las "amenazas sobre los paisajes culturales" y de la necesidad de una "gestión creativa" de los mismos como objetivo para el territorio de la Unión, está refiriéndose de hecho a muchos de los paisajes rurales y urbanos de Europa, y no sólo al catálogo de los más notables o mejor conservados.

El proceso de apertura semántica y estratégica del paisaje en el terreno conceptual, metodológico, político y jurídico se ha materializado en el Convenio Europeo del Paisaje (CEP), del Consejo de Europa. El breve texto del Convenio está compuesto de un preámbulo y de 18 artículos, distribuidos en 4 capítulos, acompañado de un "Informe explicativo". Con posterioridad, en 2008, se aprobaron unas "Orientaciones para la aplicación del Convenio Europeo del Paisaje" (ConvENIO Europeo del Paisaje, 2007:112-145).

Los Estados miembros del Consejo de Europa, signatarios del Convenio, "preocupados por alcanzar un desarrollo sostenible" y "convencidos de que el paisaje es un elemento clave del bienestar individual y social", acuerdan una política específica "en materia de paisajes". Como se dice en el artículo 1. b), tal política, que tiene sus antecedentes en la Carta del Paisaje Mediterráneo (1992) (ZoIDo NARANJo, 2008), consiste en "la formulación, por parte de las autoridades públicas competentes, de los principios generales, estrategias y directrices que permiten la adopción de medidas específicas con vistas a la protección, gestión y ordenación del paisaje".

El Convenio comienza por definir su objeto, el paisaje. Se carecía, hasta entonces, de una definición explícita y no adjetivada en un tratado internacional. Paisaje es, según el CEP, "cualquier parte del territorio, tal y como la percibe la población, cuyo carácter sea el resultado de la acción y la interacción de factores naturales y/o humanos" (traducción del Instrumento de Ratificación del Convenio Europeo del Paisaje, BOE de 5 de febrero de 
2008). La definición del CEP se refiere en primer lugar al territorio, a "cualquier parte del territorio". Esta referencia es muy importante por dos razones. En primer lugar, porque, sin ignorar otros enfoques o aproximaciones, el Convenio se interesa por el paisaje desde la perspectiva territorial, como una cualidad específica del territorio. Y, en segundo término, porque en la propia definición, y en la de su "ámbito de aplicación" (art. 2), el Tratado no se restringe a los territorios paisajísticamente valiosos, sino que se aplica "a todo el territorio de las Partes y abarcará las áreas naturales, rurales, urbanas y periurbanas". Cualquier territorio, cada parte del mismo, se manifiesta en un paisaje y se percibe paisajísticamente. Todos los paisajes resultan, pues, de interés y merecen atención y gobierno, por lo que la política que preconiza el CEP no es meramente reactiva o protectora de lo notable; es sobre todo proactiva, dirigida a todos los paisajes, a los sobresalientes y a los banales, a los cotidianos y a los visitados, a la calidad del entorno vital de las personas. Porque -lo señala el "Informe explicativo" en su apartado 44- todos los paisajes "son determinantes para la calidad de los espacios vividos por las poblaciones europeas", es especial, los paisajes cotidianos u ordinarios, en los que "vive la mayor parte de los europeos".

Pero, además -y es el segundo componente básico de la definición- el paisaje no consiste sólo en la configuración material, en la fisonomía del territorio. El paisaje surge de la relación sensible, de la percepción sensorial (principalmente visual, aunque no sólo) del territorio observado y vivido por el ser humano. Percepción en el concepto de paisaje remite, entre otras cosas, a la participación social como vía para conocer -dice el Convenio- "las aspiraciones de las poblaciones" en materia de paisaje y la formulación de los denominados "objetivos de calidad paisajística".

La última parte de la definición señala que el "carácter" de cada paisaje es resultado de la acción de factores naturales y/o humanos y de sus interrelaciones. Carácter es, según el Diccionario de la Lengua Española, el "conjunto de cualidades o circunstancias propias de una cosa, de una persona o de una colectividad, que las distingue por su modo de ser u obrar, de las demás", y también, en su primera acepción, "señal o marca que se imprime, pinta o esculpe en algo" El sentido de carácter como seña o marca impresa, en este caso en el territorio, incorpora el tiempo histórico y está muy próximo a la idea de "huella". Dicho de otra forma, el paisaje es, en su configuración material, la huella de la sociedad sobre la naturaleza y sobre paisajes anteriores, la marca o señal que imprime "carácter" a cada territorio. La referencia a las relaciones entre naturaleza y cultura en la configuración del carácter de cada paisaje incorpora implícitamente otro aspecto esencial tanto para la interpretación del hecho paisajístico (realidad material, percibida y representada), como para su ordenación. Se trata del carácter evolutivo y dinámico del paisaje (porque dinámicas son tales relaciones) y a la necesidad de considerar el tiempo, histórico y reciente, en la compresión de la diversidad paisajística y en las propuestas para su gestión.

Reconocer que todos los paisajes importan implica disponer de formas de intervención diferenciadas, atendiendo a las características, a los valores y a las tendencias de cada uno de ellos. Eso es, justamente, lo que hace el Convenio cuando en su Artículo 3 establece que "tiene por objetivo promover la protección, gestión y ordenación de los paisajes", definiendo en el Artículo 1 cada una de esas nociones. En el mismo Capítulo I de Disposiciones generales se recoge, junto a las definiciones de "paisaje", "política en materia de paisajes", y "protección, gestión y ordenación paisajística", la de otra noción novedosa en elCEP, la de "objetivo de calidad paisajística", abordada posteriormente en distintos puntos del articulado. "Por 'objetivo de calidad paisajística' se entenderá, para un paisaje específico, la formulación, por parte de las autoridades públicas competentes, de las aspiraciones de las poblaciones en lo que concierne a las características paisajísticas de su entorno" (art.1c).

EI CEP dedica los capítulos II y III a los compromisos que adquieren las Partes, tras su ratificación. El capítulo II trata de las denominadas "Medidas Nacionales" y el III, de la "Cooperación Europea". El artículo 4, dentro del capítulo de "Medidas Nacionales", se refiere al "reparto de las competencias" en la aplicación del Convenio, de conformidad con los principios constitucionales de cada Parte y su organización administrativa, pero respetando el principio de subsidiariedad, "teniendo en cuenta la Carta Europea de la Autonomía Local". Es importante subrayar que el "Informe explicativo" enfatiza (apdo. 49) en la eficacia en materia de paisaje de los poderes más cercanos a los ciudadanos, pero reconoce también la necesidad de coordinación de los diferentes niveles políticos, "particularmente en cuanto concierne a los instrumentos de urbanismo y ordenación del territorio".

Las "Medidas generales" son las siguientes:

- Reconocer jurídicamente los paisajes como elemento fundamental del entorno humano, expresión de la diversidad de su patrimonio común, cultural y natural y como fundamento de su identidad. 
- Definir y aplicar políticas destinadas a la protección, gestión y ordenación de los paisajes mediante la adopción de medidas específicas contemplada en el artículo 6.

- Establecer procedimientos para la participación pública, así como de las autoridades locales y regionales y otras partes interesadas en la formulación y aplicación de las políticas en materia de paisaje mencionadas en el apartado anterior.

- Integrar el paisaje en las políticas de ordenación territorial y urbanística, y en las políticas en materia cultural, medioambiental, agrícola, social y económica, así como en cualquier otra política que puedan tener un impacto directo o indirecto sobre el paisaje.

Las "Medidas específicas" se refieren a:

a. Sensibilización de la sociedad civil, las organizaciones privadas y las autoridades públicas respecto del valor de los paisajes, su papel y sus transformaciones.

b. Formación y educación a distintos niveles: de especialistas y posgraduados; de profesionales del sector público y privado y de asociaciones interesadas; educación escolar y capacitación de los graduados universitarios.

c. Identificación y "calificación": identificación de los paisajes de cada y en todo el territorio; caracterización y estudio de las fuerzas y presiones que los transforman; seguimiento de tales transformaciones; calificación de los paisajes así definidos, teniendo en cuenta los valores que les atribuyen las Partes y la población interesadas.

d. Definición de objetivos de calidad paisajística para los paisajes identificados y valorados, previa consulta pública.

e. Aplicación de las políticas en materia de paisaje mediante el establecimiento de instrumentos destinados a la protección, gestión y/u ordenación del paisaje.

Como se ha señalado, el CEP fue ratificado por España en noviembre de 2007 y entró en vigor el 1 de marzo de 2008. Al menos dos leyes básicas del Estado, la de patrimonio natural y biodiversidad y la de evaluación ambiental, se han hecho eco del Convenio, asumiendo su definición de paisaje y algunos de sus planteamientos. Además, el CEP ha constituido el marco de referencia de las cuatro leyes de paisaje aprobadas hasta ahora por otras tantas comunidades autónomas (Comunitat Valenciana, Cataluña, Galicia y Cantabria) y del Decreto 90/2014, de 3 de junio sobre protección, gestión y ordenación del paisaje en la ordenación del territorio en la Comunidad Autónoma del País Vasco, que se tratarán en el epígrafe 5. EI CEP ha quedado recogido así mismo en el acervo urbanístico y de ordenación del territorio de algunas leyes autonómicas recientes sobre esas materias y ha inspirado e impulsado distintas Estrategias y Directrices de paisaje regionales e insulares, así como, según ya se ha dicho, numerosas determinaciones e iniciativas paisajísticas de instrumentos de ordenación del territorio, sobre todo de escala subregional, en los que no es posible entrar aquí. La trascendencia del Convenio resulta, pues, innegable en la renovación y desarrollo de la política de paisaje en España.

\section{La protección de paisajes de alto valor natural y cultural}

\author{
3.1. La protección del paisaje en \\ la legislación de patrimonio natural \\ y espacios protegidos
}

La conservación de la naturaleza cuenta en España, desde sus orígenes, con objetivos y figuras para la protección de paisajes naturales valiosos. Argumentos paisajísticos inspiraron la primera ley de parques nacionales de 1916; en las posteriores, esa inspiración se ha mantenido, aunque han ganado peso los objetivos biológicos y ecológicos, al igual que en las leyes de las comunidades autónomas sobre espacios protegidos promulgadas a partir de los años 80. La vigente Ley 42/2007, del Patrimonio Natural y la Biodiversidad (modificada en 2015) supone una renovación conceptual y política con respecto al paisaje desde la conservación de la naturaleza.

La protección del paisaje se mantiene como uno de los principios de la ley; se establece para ello la necesidad de que el análisis de los paisajes forme parte del contenido mínimo de los Planes de Ordenación de los Recursos Naturales, instrumento fundamental de la planificación de las áreas de alto valor natural; se señala igualmente el uso del paisaje, desde una perspectiva ecológica, como instrumento para dotar de coherencia y conectividad a la Red Natura 2000; se fomentan las actividades que contribuyan a su protección como externalidad positiva cuando el paisaje forme parte de un espacio protegido; y se establece, dentro de la clasificación de los espacios naturales protegidos una categoría de contenido específicamente paisajístico, la de Paisaje Protegido, sin perjuicio de los valores paisajísticos y su tutela en las demás categorías. 
"Artículo 35. Los Paisajes Protegidos.

1. Paisajes Protegidos son partes del territorio que las Administraciones competentes, a través del planeamiento aplicable, por sus valores naturales, estéticos y culturales, y de acuerdo con el Convenio del paisaje del Consejo de Europa, consideren merecedores de una protección especial.

2. Los objetivos principales de la gestión de los Paisajes Protegidos son los siguientes: a) La conservación de los valores singulares que los caracterizan. b) La preservación de la interacción armoniosa entre la naturaleza y la cultura en una zona determinada.

3. En los Paisajes Protegidos se procurará el mantenimiento de las prácticas de carácter tradicional que contribuyan a la preservación de sus valores y recursos naturales".

Hay en esta ley básica una novedad importante, que remite precisamente al CEP, ratificado por España el mismo año de la promulgación de la citada norma. Se señala en su Preámbulo que:

\begin{abstract}
"si bien la protección del paisaje se afirma como uno de los principios de la presente ley y en ella se regulan aspectos puntuales de la política de paisaje (...), no pretende, sin embargo, la presente ley ser el instrumento a través del cual se implantarán en España, de manera generalizada, las políticas de protección del paisaje como legislación básica del artículo 149.1.23. ${ }^{a}$, políticas cuyo contenido técnico y enfoque general, no exento de valor paradigmático, exigen la puesta en marcha de instrumentos de gestión como los establecidos, con carácter de mínimos, en el Convenio Europeo del Paisaje, hecho en Florencia el 20 de octubre del año 2000, en el seno del Consejo de Europa y que serán introducidos en la política ambiental española en un momento posterior".
\end{abstract}

En otras palabras, sin perjuicio de la protección de paisajes de alto valor natural por parte de la legislación de conservación de la naturaleza, a través incluso de una categoría específica como la de Paisaje Protegido, la ley reconoce que se requiere la puesta en marcha de instrumentos de gestión como los establecidos en el CEP, que habrán de ser introducidos posteriormente en la política ambiental española.

La mayor parte de leyes autonómicas que se ocupan de los espacios naturales protegidos, tanto las aprobadas antes como después de la Ley de Patrimonio Natural y Biodiversidad de 2007, incluyen, además de referencias genéricas a la conservación de los valores naturales del paisaje como objetivo o criterio inspirador, la categoría de "Paisaje protegido". No lo hacen las de Cataluña (Ley 12/1985, de 13 de junio, de Espacios Naturales) y el País Vasco (Decreto Legislativo $1 / 2014$, de 15 de abril, por el que se aprueba el texto refundido de la Ley de Conservación de la Naturaleza del País Vasco).

En las restantes normas reguladoras de la materia (carece de ella la Comunidad de Madrid), la categoría de Paisaje Protegido se define de manera diversa. En las leyes anteriores a 2007, son numerosas las que transcriben sin más la definición de esta categoría en la ley estatal vigente hasta ese año (Ley 4/1989, de 27 de marzo, de Conservación de los Espacios Naturales y de la Flora y Fauna Silvestres). Según ella (artículo 17) "Los Paisajes Protegidos son aquellos lugares concretos del medio natural que, por sus valores estéticos y culturales, sean merecedores de una protección especial". Así ocurre en las normas de la Illes Balears (Ley 5/2005, de 26 de mayo, para la conservación de los espacios de relevancia ambiental), Asturias (Ley 5/1991, de 5 de abril, de Protección de los Espacios Naturales), Cantabria (Ley 4/2006, de 19 de mayo, de Conservación de la Naturaleza de Cantabria), Castilla-La Mancha (Ley 9/1999, de 26 de mayo, de Conservación de la Naturaleza), Extremadura (Ley 8/1998, de 26 de junio, de Conservación de la Naturaleza y de Espacios Naturales de Extremadura), Navarra (Ley foral 9/1996, de 17 de junio, de Espacios Naturales de Navarra), La Rioja (Ley 4/2003, de 26 de marzo, de Conservación de Espacios Naturales de La Rioja) y la Comunidad Valenciana (Ley 11/1994, de 27 de diciembre, de espacios naturales protegidos de la Comunidad Valenciana). En las de Andalucía (Ley 2/1989, de 18 de julio, por la que se aprueba el Inventario de Espacios Naturales Protegidos de Andalucía y se establecen medidas adicionales para su protección) y de la Región de Murcia (Ley 4/1992, de 30 de julio, de Ordenación y Protección del Territorio de la Región de Murcia) solo se los nombra sin definirlos.

No obstante, hay algunas de esas leyes que añaden matices interesantes a la definición de la Ley 4/89 y que remiten al significado de las actividades agrarias tradicionales en los Paisajes protegidos y a la necesidad de su conservación, incidiendo en la interacción armónica entre sociedad y naturaleza en esta categoría de espacio protegido de la UICN. Así, por ejemplo, la ley castellano-manchega, en su artículo 46, dice que: "se entenderán incluidos en estos supuestos los
paisajes agrarios tradicionales y extensivos de
dehesas, praderas de diente, prados de siega
y estepas cerealistas que, adicionalmente a su
valoración estética y cultural, contribuyan a la 
conservación de una importante parte de la biodiversidad de la región (...). En los paisajes protegidos se procurará el mantenimiento de las prácticas agrarias de carácter tradicional y extensivo que contribuyan a la preservación de sus valores estéticos y culturales y sus recursos naturales".

En parecidos términos se manifiesta la ley extremeña en su artículo 20 y la valenciana, que en su artículo 13.2. establece que "el régimen de protección de los paisajes protegidos estará dirigido expresamente a la conservación de las relaciones y procesos, tanto naturales como socio-económicos, que han contribuido a su formación y hacen posible su pervivencia".

Las leyes autonómicas más recientes, aprobadas con posterioridad a la básica estatal, han incorporado en general la definición renovada de Paisaje Protegido y las referencias al CEP de la Ley de Patrimonio Natural y Biodiversidad. Un matiz significativo es que los paisajes protegidos dejan de ser, como en la ley estatal de 1989 y las autonómicas qua la siguen, unos "lugares" o "zonas del medio natural", para pasar a designarse simplemente como espacios, lugares o territorios de interés paisajístico, sin necesidad de su connotación "natural", lo que coincide con la visión más abierta y cultural del paisaje que preconiza el CEP.

Una mención específica en cuanto al tratamiento del paisaje merece la ley castellano-leonesa de 2015 (Ley 4/2015, de 24 de marzo, del Patrimonio Natural de Castilla y León). Junto al enunciado de las categorías de espacios protegidos, entre las que figura, con las de Parques, Reservas naturales y Monumentos naturales, la de Paisajes protegidos, la norma dedica su Título II al paisaje, sin calificativos. En el artículo 15, la preservación del paisaje, tal y como aparece definido en el 3.26 de la Ley 42/2007, se concibe como "un elemento integrador del patrimonio natural de Castilla y León", para lo que "la Junta de Castilla y León aprobará la normativa necesaria para garantizar el reconocimiento, protección, gestión y ordenación del paisaje, con la finalidad de preservar sus valores naturales, patrimoniales, culturales, sociales y económicos en un marco de desarrollo sostenible". Se trata de una apertura clara y novedosa sobre la consideración del paisaje por parte de una ley de conservación de la naturaleza, que se corresponde con unos principios generales de actuación de los poderes públicos, enunciados en el artículo 16, entre los que se reconoce el paisaje como un elemento del bienestar individual y colectivo, así como el derecho de los ciudadanos a vivir en un entorno culturalmente significativo, para cuya conservación habrán de considerarse las consecuencias sobre el paisaje de cualquier actuación de ordenación, urbanismo y gestión del territorio.

Aunque no es objeto de este "estudio comparado" hacer balance de la implementación de las normas señaladas, puede afirmarse que la figura de Paisaje Protegido ha tenido hasta la fecha una muy débil implantación territorial, con baja representatividad tipológica y criterios dispares de selección. Según datos de EUROPARC-España, los Paisajes protegidos declarados apenas suponen un $2 \%$ de la superficie total de los ENP y responden a criterios diversos (estéticos, geomorfológicos, ecológicos y de relación armónica entre sociedad y naturaleza). Son diversas también las figuras de gestión, predominando los planes especiales cuando existen (EUROPARC-España, 2019).

\subsection{La protección del paisaje en las leyes de patrimonio histórico y cultural}

La tutela del paisaje también ha estado presente tradicionalmente, más de forma implícita que explícita, en la legislación de patrimonio histórico-artístico y cultural. Hay que recordar aquí la temprana preocupación por la conservación de los entornos de los "conjuntos urbanos" históricos y la creación de la figura de las "zonas de protección de paisaje" en un Decreto-ley de 1926 (ZÁrate MARTín, 2011). La norma básica del Estado, la Ley 16/1985, del Patrimonio Histórico Español, no contiene de hecho ninguna mención al paisaje, aunque establece la protección de determinados bienes que por escala, características y complejidad podrían entrar dentro de la esfera de la protección del paisaje. Junto al contenido paisajístico de los Jardines Históricos, los Conjuntos Históricos o las Zonas Arqueológicas, es el Sitio Histórico, de entre los bienes integrantes del Patrimonio Histórico Español declarados de interés nacional, el de mayor significado paisajístico como "lugar o paraje vinculado a acontecimientos o recuerdos del pasado, a tradiciones populares, creaciones populares o de la naturaleza y a obras del hombre que posean valor histórico, etnológico, paleontológico o antropológico".

Es importante también el alcance paisajístico de la noción de "entorno" referida a monumentos, conjuntos y sitios históricos o zonas arqueológicas (Agudo GonzÁlez, 2007: 218 y ss.). La ley establece en su artículo 11.2 que la declaración de inmuebles como Bienes de Interés Cultural (BIC) "delimitará el entorno afectado por la declaración y, en su caso, se definirán y enumerarán las partes integrantes"; si se tratase de Conjuntos Históricos, "deberán considerarse sus relaciones con el área 
territorial a que pertenece, así como la protección de los accidentes geográficos y parajes naturales que conforman su entorno". En todos los casos, como reza el artículo 18, "un inmueble declarado Bien de Interés Cultural es inseparable de su entorno". La legislación autonómica ha dado traslado, con mayor o menor desarrollo, al concepto de "entorno" de los BIC, crecientemente considerado en la gestión patrimonial y territorial de los bienes culturales, siguiendo, por ejemplo, las recomendaciones de ICOMOS en materia de evaluación del impacto patrimonial (FERRER JIMÉNEZ \& MATA OเMO, 2020).

Pese a que, como se ha dicho, la ley básica del Estado no recoge como BIC ninguna categoría específicamente paisajística, algunas leyes autonómicas de patrimonio cultural han incorporado de forma explícita el Paisaje Cultural como un tipo de bien, adoptando definiciones similares a las de la Convención del Patrimonio Mundial (García CuestA \& Calderón CALDERón, 2017). Son, concretamente las leyes de Cantabria (Ley 11/1998, de 13 de octubre, de Patrimonio Cultural de Cantabria, art. 49.4.), de La Rioja, con una referencia concreta al "Paisaje Cultural del Viñedo" (Ley $7 / 2004$, de 18 de octubre, de Patrimonio Cultural, Histórico y Artístico de La Rioja, art. 12.1), de la Región de Murcia, cuando se ocupa de los denominados Planes de ordenación del patrimonio cultural (Ley 4/2007, de 16 de marzo, de Patrimonio Cultural de la Comunidad Autónoma de la Región de Murcia, art. 61), así como las más recientes de la Comunidad de Madrid, con una mención expresa en su preámbulo del CEP (Ley 3/2013, de 18 de junio, de Patrimonio Histórico de la Comunidad de Madrid, art. 3), la de Galicia (Ley 5/2016, de 4 de mayo, del Patrimonio Cultural de Galicia) y de Canarias (Ley 11/2019, de 25 de abril, de Patrimonio Cultural de Canarias, art. 23 g.). Todo ello sin perjuicio de la dimensión paisajística de otros bienes, en general, de la gestión del patrimonio cultural en España (Fernández CACHO, 2019; López SÁnchez, Tejedor CABRERA \& Linares Gómez del Pulgar, 2020). La ley gallega resulta innovadora porque busca la integración del patrimonio cultural en el territorio "incluso -se dice en el Preámbulo- con nuevas figuras como las áreas de amortiguamiento, o con nuevas categorías como los paisajes culturales". Estos se definen como consta a continuación, estableciéndose para su gestión la aprobación de "un instrumento específico de ordenación territorial o urbanística que contenga las determinaciones precisas para asegurar su protección y salvaguardar sus valores culturales" (artículo 59), cuyo contenido se detalla en el artículo 60.

"Artículo 10. Categorías de bienes inmuebles declarados de interés cultural o catalogados.
(...) h) Paisaje cultural: el lugar identificable por un conjunto de cualidades culturales materiales e inmateriales singulares, obras combinadas de la naturaleza y el ser humano, que es el resultado del proceso de la interacción e interpretación que una comunidad hace del medio natural que lo sustenta y que constituye el soporte material de su identidad".

Por último, en esta muy breve síntesis del tratamiento del paisaje en la normativa de patrimonio cultural, merece una referencia, pese a no tener rango legal, el Plan Nacional del Paisaje Cultural, aprobado el 4 de octubre de 2012 por Consejo de Patrimonio Histórico (Ministerio de Cultura y Deporte del Gobierno de España). Como es sabido, los Planes Nacionales, promovidos desde el Instituto del Patrimonio Cultural de España, se formulan con la vocación de ser instrumentos de gestión a través de criterios y metodologías de actuación unificados sobre conjuntos de bienes culturales, coordinando la participación de las distintas administraciones e instituciones, definiendo prioridades y líneas de intervención, y optimizando los recursos de acuerdo con las necesidades de conservación de dichos conjuntos patrimoniales. Aunque, según lo dicho, el paisaje cultural como categoría específica de bien no figura en la legislación de patrimonio histórico del Estado, ni de modo explícito en la mayor parte de las leyes autonómicas, el PNPC está impulsando y coordinando a través de su comisión de seguimiento las iniciativas en pos de la salvaguarda de los paisajes de alto interés cultural, y la cooperación interadministrativa y con la sociedad civil, en particular con las comunidades autónomas (MATA Olmo, 2017; CañIzares RuIz, 2017).

\section{El tratamiento del paisaje en la legislación urbanística y de ordenación del territorio}

Como ha escrito Jorge Agudo y señalan en parecidos términos otros juristas:

\begin{abstract}
"la versatilidad que caracteriza al urbanismo ha permitido que, desde las primeras leyes en la materia, se hayan incorporado técnicas e instrumentos cuyo objeto, sin ser ni mucho menos necesariamente específico, podía incidir en la protección del paisaje, siempre desde esa dimensión singularista que ha dominado en nuestro ordenamiento" (Agudo GonZÁlez, 2009: 208).
\end{abstract}

Efectivamente, las normas que regulan la planificación urbanística y territorial han incluido tradicionalmente criterios, técnicas e instrumentos para la tutela genérica o específica de los valores del paisaje. 


\subsection{Las referencias al paisaje en el Texto Refundido de la Ley del Suelo y Rehabilitación Urbana}

En este "estudio comparado" se aborda el tratamiento y alcance de la cuestión paisajística en las leyes urbanísticas, o de urbanismo y ordenación del territorio, de las comunidades autónomas, precedido de unas referencias a la consideración del paisaje en el vigente Texto Refundido de la Ley del Suelo y Rehabilitación Urbana (TRLSRU), aprobado por el Real Decreto Legislativo 7/2015, de 30 de octubre. En un epígrafe diferente, aunque puedan entenderse como normas del ámbito de la ordenación territorial, se procederá a la comparación de las leyes de paisaje aprobadas hasta ahora por las comunidades autónomas de Cataluña, Comunidad Valenciana, Galicia y Cantabria, junto a un decreto de la Comunidad Autónoma del País Vasco referido también específicamente a la protección, gestión y ordenación del paisaje en la ordenación del territorio.

El mencionado TRLSRU de 2015 incluye algunos preceptos novedosos con respecto al paisaje, como lo hizo ya la Ley 8/2007, de 28 de mayo, de Suelo. En primer lugar, el paisaje se vincula al principio de desarrollo territorial y urbano sostenible (art. 3), debiendo las políticas públicas relativas a la regulación, ordenación, ocupación, transformación y uso del suelo velar con eficacia por su protección. Asimismo, por primera vez, el paisaje se recoge entre las condiciones básicas de la igualdad en los derechos y deberes constitucionales de los ciudadanos, cuando se dice que estos tienen derecho a "disfrutar de una vivienda digna, adecuada y accesible (...) en un medio ambiente y un paisaje adecuados" (art. 5.a), al tiempo que se establece el deber de respetar y contribuir a preservar el paisaje natural y el paisaje urbano (art. 6. a y d). Como en leyes anteriores, el paisaje se toma en consideración a la hora de definir las denominadas "situaciones básicas del suelo", en particular la "situación del suelo rural", es decir, aquel preservado por la ordenación territorial y urbanística de su transformación mediante la urbanización, por los valores en ellos concurrentes, "(...) incluso los ecológicos, agrícolas, ganaderos, forestales y paisajísticos, así como aquéllos con riesgos naturales o tecnológicos, incluidos los de inundación o de otros accidentes graves, y cuantos otros prevea la legislación de ordenación territorial o urbanística" (Art. 21.a).

EI Texto Refundido recoge, como es tradición en la legislación urbanística española desde la Ley de 12 de mayo de 1956, de Régimen del Suelo y Ordenación Urbana, las denominadas normas de aplicación directa como técnica urbanística para la defensa de los valores paisajísticos (SÁNCHEZ GoyAnes, 1999; DE ViCEnTE GonZÁlez, 2011). Retomando en lo esencial el contenido del artículo 60 de la ley de 1956 y del 73 del TRLS de 1976, el artículo 20 del vigente TRLSRU sobre criterios básicos de utilización del suelo dice así:

\begin{abstract}
"2. Las instalaciones, construcciones y edificaciones habrán de adaptarse, en lo básico, al ambiente en que estuvieran situadas, y a tal efecto, en los lugares de paisaje abierto y natural, sea rural o marítimo, o en las perspectivas que ofrezcan los conjuntos urbanos de características histórico-artísticas, típicos o tradicionales, y en las inmediaciones de las carreteras y caminos de trayecto pintoresco, no se permitirá que la situación, masa, altura de los edificios, muros y cierres, o la instalación de otros elementos, limite el campo visual para contemplar las bellezas naturales, rompa la armonía del paisaje o desfigure la perspectiva propia del mismo" (art. 20.2).
\end{abstract}

Por último, hay también una consideración económica significativa del paisaje, o, con más precisión, de los valores paisajísticos, en el Título V. Valoraciones, en concreto en el artículo 36 sobre valoración en el suelo rural, en el que se establece que el valor del suelo rural obtenido por el procedimiento que se detalla en el citado artículo "podrá ser corregido al alza en función de factores objetivos de localización (...) o por la ubicación en entornos de singular valor ambiental o paisajístico, cuya aplicación y ponderación habrá de ser justificada en el correspondiente expediente de valoración" (art. 36. a).

Estos preceptos genéricos para la salvaguarda de los valores del paisaje del TRLSRU de 2015, algunos novedosos como se ha indicado, aunque en ningún momento se cite el Convenio Europeo del Paisaje, y en buena medida continuadores de la tradición urbanística española, se reiteran, con pocas diferencias relevantes, en la legislación urbanística de las comunidades autónomas. En las figuras adjuntas se recogen de manera sintética las referencias al paisaje de las distintas leyes autonómicas en su articulado. Se incluyen en primer lugar las normas exclusivamente urbanísticas y de suelo (FIG. 1), y, a continuación, las que integran ordenación del territorio y urbanismo (FIG. 2), excepto la Ley 5/2014, de 25 de julio, de Ordenación del Territorio, Urbanismo y Paisaje, de la Comunitat Valenciana, que, por su tratamiento explícito y detallado del paisaje, prosiguiendo lo establecido en la pionera Ley 4/2004, de 30 de junio, de Ordenación del Territorio y Protección del Paisaje, se aborda en el epígrafe siguiente sobre las leyes de paisaje. 


\subsection{El paisaje en la legislación urbanística autonómica ${ }^{1}$}

Los preceptos referidos al paisaje en las leyes urbanísticas o en la parte urbanística de las leyes mixtas de urbanismo y ordenación del territorio, se han organizado, tras su estudio, en cinco apartados: principios inspiradores y objetivos, régimen y clasificación del suelo, medidas de directa aplicación planes especiales, régimen sancionador y catálogos. Para las leyes de ordenación del territorio y urbanismo, además de esos apartados, se ha incluido otro general sobre el tratamiento del paisaje en la parte de ordenación territorial de dichas normas. Una primera conclusión del estudio comparado de este bloque de ordenamientos autonómicos es el carácter muy general, escaso, reiterado y muy similar del tratamiento del paisaje, sobre todo en las leyes de urbanismo, independientemente de su fecha de aprobación, hasta el punto que incluso las aprobadas después de la ratificación del CEP, ni siquiera contienen referencias al mismo. Las de ordenación del territorio y urbanismo, en particular las más recientes, suelen incluir, junto a la mención del CEP como marco de referencia, un mayor y más específico desarrollo instrumental del paisaje, de modo que pareciera que el legislador autonómico atribuye a la ordenación territorial, en particular a los instrumentos de planificación de escala autonómica y, sobre todo, subregional, la implementación de la renovada política de paisaje.

Todas las leyes urbanísticas de las comunidades autónomas, independientemente de su fecha de aprobación, incluyen la protección y en algunos casos la mejora del paisaje, como en las leyes de Andalucía, Aragón y las Illes Balears, como principio inspirador y objetivo de la actividad urbanística, junto al uso racional de los recursos naturales, la protección del medio ambiente, del litoral, del patrimonio cultural o la preservación de la diversidad biológica y los recursos hídricos. En las más recientes, la protección paisajística se establece conforme al principio de desarrollo territorial y urbano sostenible, de acuerdo con la ley estatal de suelo de 2007. En algunas leyes el paisaje aparece claramente vinculado al interés cultural e histórico y, también, en ocasiones, a los valores de los suelos rústicos.

Una segunda consideración del paisaje, recurrente en la normativa urbanística autonómica, está

1 Algunas Comunidades Autónomas (Andalucía, Canarias, Cataluña, Comunidad Valenciana e Illes Balears) han introducido en sus Estatutos de Autonomía referencias explícitas al paisaje como derecho de los ciudadanos y sobre el deber en relación con el régimen jurídico del suelo y su clasificación por el planeamiento general. La existencia de valores paisajísticos constituye uno de los motivos que justifican la exclusión de determinados suelos del proceso urbanizador y la clasificación de los mismos como suelo no urbanizable o rústico, asimilable a la situación de suelo rural del TRLSRU de 2015, todo ello sin perjuicio del régimen específico de protección en virtud de cualquier instrumento de ordenación del territorio, o por efecto directo de la aplicación de la legislación sectorial. Los valores paisajísticos se consideran junto a los geológicos, ecológicos, forestales, agrícolas, arqueológicos, etc. que pudiesen concurrir en el territorio. Determinadas normas autonómicas contemplan además suelos rústicos o no urbanizables de especial protección por razones paisajísticas, como las de Galicia, Castilla-La Mancha o la Comunidad de Madrid.

En general, el paisaje está presente también en ciertos artículos que establecen determinaciones para actuaciones en suelo rústico o no urbanizable, definiendo derechos y obligaciones de los propietarios de suelo y la integración del paisaje en los nuevos suelos urbanizables, especialmente en el sistema de espacios libres públicos, o en los núcleos rurales tradicionales de acuerdo con sus características tipológicas, estéticas y constructivas para las nuevas construcciones.

El tercer apartado referido al paisaje, que se repite también con pocos matices en la legislación de las Comunidades Autónomas, es el de las denominadas normas o determinaciones de aplicación directa. En algunas leyes, como la de Navarra, se habla del "deber de adaptación al ambiente" (art. 86 del TRLOTUN, de 2017) y en la asturiana, de "adaptación al entorno" (art. 106 del DLTROTUA, de 2004). La norma aragonesa, en su texto refundido de 2014, establece expresamente en el artículo 214 , dentro del capítulo dedicado a las normas de directa aplicación, "la protección del paisaje" en los siguientes términos: "1. La actividad urbanística deberá integrar la consideración del paisaje en todas sus fases de conformidad con lo establecido en la legislación de ordenación del territorio y la legislación sobre paisaje" (art. 206 TRLUA). Por lo general, se reproduce literalmente el texto ya citado del artículo 20 del vigente TRLSRU, heredero de las leyes de 1956 y 1976, si bien algunas normas autonómicas desarrollan o precisan algo más su contenido. Las de Aragón (art. 214.3 TRLUA), Castilla-La Mancha, Galicia o Cantabria se refieren

de su conservación por parte de las administraciones públicas. Otras, junto a las citadas, incluyen la política de paisaje como competencia exclusiva (Galicia, Región de Murcia, La Rioja, Castilla-La Mancha y Castilla y León). 
a la tipología de las construcciones, los materiales y colores empleados, que deberán favorecer la integración en el entorno y el paisaje, presentando las construcciones sus paramentos exteriores y cubiertas totalmente terminados. Las de Galicia y Cantabria prohíben expresamente la publicidad estática que por sus dimensiones, localización o colorido no cumpla las prescripciones de integración armónica en el paisaje, y la ley cántabra, además, en su artículo 36. Protección del paisaje, establece que "(...) 3. Los instrumentos de planeamiento concretarán, pormenorizarán y definirán los criterios a los que se refiere este artículo, bien con carácter general para todo su ámbito de aplicación, bien más específicamente para ámbitos concretos" (art. 36.3 LOTRUSCAN).

Sin restar interés a las disposiciones establecidas por las normas de aplicación directa, que han dado juego en numerosos planes urbanísticos (PAREJA, 2006: 393), se pone de manifiesto, como ha escrito Judith Gifreu, "el recurso a los conceptos jurídicos indeterminados vinculados a una noción estética del paisaje (limitación del campo visual, fractura de la armonía del paisaje, desfiguración de la perspectiva). Estos conceptos, que deben ser interpretados en el momento de su aplicación, tienen una innegable naturaleza reglada, aunque en su apreciación se introduzca una cierta subjetividad" (GIFREU, 2017: 53), como pone de manifiesto determinada jurisprudencia citada por la misma autora.

Siguiendo la tradición urbanística que introduce la Ley sobre Régimen de Suelo y Ordenación Urbana de 1956, con la creación de los Planes Especiales, atribuyéndoles, entre otras, funciones de "protección del paisaje y de las vías de comunicación, y conservación del medio rural en determinados lugares" (arts. 13 y 15), que reiterará la Ley de 1976 (arts. 17 a 19), la legislación urbanística autonómica considera en todos los casos la protección del paisaje como una de las finalidades enunciadas de los citados Planes Especiales, bien es verdad que con menor desarrollo que en las citadas leyes de 1956 y 1976. En tres casos, en las leyes de Asturias, Castilla y León y Galicia, se señalan específicamente los Planes Especiales de Protección, a los que se atribuye la protección de determinados valores del paisaje, y en la Ley 13/2015, de 30 de marzo, de ordenación territorial y urbanística de la Región de Murcia, de mayor contenido paisajístico en general, se especifican en su artículo 137, los denominados Planes Especiales de protección y gestión del paisaje, refiriéndose "(...) entre otros, a estos aspectos: a) Áreas de interés paisajístico. b) Predios rústicos de pintoresca situación, singularidad topográfica o recuerdo histórico. c) Edificios aislados que se distingan por su emplazamiento o belleza arquitectónica y parques y jardines destacados por su valor artístico, trascendencia histórica o importancia de las especies botánicas que en ellos existan. d) Agrupaciones de edificaciones que integren un conjunto de valores tradicionales o estéticos". Deberán contener las determinaciones necesarias para la puesta en valor de los elementos a proteger, estableciendo los mecanismos y normativas precisos para su eficacia.

Para finalizar el comentario de las referencias que se incluyen en la FIG. 1, hay que aludir al tratamiento del paisaje en los Catálogos, en particular de aquellos considerados de mayor interés o valor. Independientemente de las particularidades de la regulación de dichos Catálogos como instrumentos de planeamiento urbanístico por parte de las distintas leyes autonómicas (HERNÁNDEZ-PARTAL, 2020: 623), lo cierto es que el paisaje se menciona explícitamente como objeto de catalogación en algunas de ellas. El Reglamento de Urbanismo de Castilla y León señala, por ejemplo, que, al establecer la ordenación general, el Plan General de Ordenación Urbana deberá catalogar, entre otros elementos del término municipal que merezcan ser protegidos, conservados o recuperados por sus valores, " $5 .^{\circ}$ Los paisajes de interés cultural o histórico, así como aquellos elementos del paisaje que presenten un valor destacado por su singularidad, calidad o fragilidad" (art. 84 DLUCyL). Una mención expresa al paisaje o a los valores paisajísticos como objeto de catalogación se recoge también en el artículo 71 del TR de Ley de Urbanismo de Cataluña de 2010 y en el artículo 81 de la Ley de Suelo de Galicia. La norma catalana se refiere igualmente a los "criterios paisajísticos" que han de tenerse en cuenta a la hora de incluir en un catálogo específico, por parte del planeamiento urbanístico general o especial, las construcciones situadas en suelo no urbanizable (masías y otras casas rurales) susceptibles de reconstrucción o de rehabilitación y justificar las razones que determinan su preservación o, si procede, su recuperación (...) para la protección y el mejoramiento del paisaje" (art. 50.2, TRLUC).

Además de la información recogida en la tabla de la FIG. 1, algunas leyes se refieren explícitamente al paisaje en el capítulo de infracciones urbanísticas y régimen sancionador. En la ley aragonesa se tipifican como infracciones graves "la realización de construcciones que menoscaben gravemente la belleza, armonía o visión del paisaje natural, rural o urbano (art. 278. g TRLUA); en parecidos términos se expresan la ley del País Vasco en relación con el vertido de escombros u otros residuos, así como el depósito de materiales que deterioren en paisaje rural o natural" (art. 225.1. a LSUPV), la de Castilla-La Mancha con respecto, además, a la colocación de artículos de propaganda (art. 183.2. f. TRLOTAUCM) y la de Extremadura con respecto a "los movimientos de tierra que supongan alteración del paisaje, sin título habilitante" (art. 183.3. a) LOTUSE). 


\begin{tabular}{|c|c|c|c|c|}
\hline $\begin{array}{l}\text { Principios inspiradores } \\
\text { del desarrollo } \\
\text { urbanístico sostenible }\end{array}$ & $\begin{array}{l}\text { Régimen de suelo, } \\
\text { zonificación y } \\
\text { clasificación del suelo }\end{array}$ & $\begin{array}{l}\text { Determinaciones } \\
\text { de directa } \\
\text { aplicación }\end{array}$ & $\begin{array}{c}\text { Planes } \\
\text { Especiales }\end{array}$ & $\begin{array}{l}\text { Catálogos } \\
\text { con contenido } \\
\text { paisajístico }\end{array}$ \\
\hline \multicolumn{5}{|c|}{$\begin{array}{l}\text { ANDALUCIA } \\
\text { LEY 7/2002, DE } 17 \text { DE DICIEMBRE, DE ORDENACIÓN URBANÍSTICA DE ANDALUCÍA (LOUAN) }\end{array}$} \\
\hline Art. 3 & Art. 46 & Art. 57 & \multicolumn{2}{|l|}{ Art. 14} \\
\hline \multicolumn{5}{|c|}{$\begin{array}{c}\text { ARAGÓN } \\
\text { DECRETO-LEGISLATIVO 1/2014, DE } 8 \text { DE JULIO, DEL GOBIERNO DE ARAGÓN, POR EL QUE SE APRUEBA } \\
\text { EL TEXTO REFUNDIDO DE LA LEY DE URBANISMO DE ARAGÓN (TRLUA) }\end{array}$} \\
\hline Art. 4 & Art. 35 & $\begin{array}{l}\text { Arts. } 214,226 \text { y } \\
227\end{array}$ & \multicolumn{2}{|l|}{ Arts. 62 y 64} \\
\hline \multicolumn{5}{|c|}{$\begin{array}{c}\text { ILLES BALEARS } \\
\text { LEY 12/2017, DE } 29 \text { DE DICIEMBRE, DE URBANISMO DE LAS ILLES BALEARS (LUIB) }\end{array}$} \\
\hline Art. 3 & Arts. 26 y 37 & Art. 68 & Art. 45 & Arts. 100 y 148 \\
\hline \multicolumn{5}{|c|}{$\begin{array}{c}\text { CASTILLA Y LEÓN } \\
\text { LEY 5/1999, DE } 8 \text { DE ABRIL, DE URBANISMO DE CASTILLA Y LEÓN (LUCyL) }\end{array}$} \\
\hline Art. 4 & Arts. 32 y 36 & Art. 106 & Art. 48 & $\begin{array}{l}\text { Art. } 84 \text { del Decreto } \\
22 / 2004 \text {, de } 29 \text { de enero, } \\
\text { por el que se aprueba el } \\
\text { Reglamento de urbanismo } \\
\text { de Castilla y León. }\end{array}$ \\
\hline \multicolumn{5}{|c|}{$\begin{array}{c}\text { CATALUÑA } \\
\text { DECRETO LEGISLATIVO 1/2010, DE } 3 \text { DE AGOSTO, POR EL QUE SE APRUEBA EL TEXTO REFUNDIDO } \\
\text { DE LA LEY DE URBANISMO (TRLUC) }\end{array}$} \\
\hline \multirow[t]{2}{*}{ Art. 9} & Art. 32 & & Arts. 67 y 68 & Arts. 50 y 71 \\
\hline & \multicolumn{4}{|c|}{$\begin{array}{l}\text { GALICIA } \\
\text { LEY 2/2016, DE } 10 \text { DE FEBRERO, DEL SUELO DE GALICIA (LSG) }\end{array}$} \\
\hline Art. 5 & $\begin{array}{l}\text { Arts. } 24,26,34,37,39 \\
\quad 58 \text { y } 68\end{array}$ & Art. 91 & Art. 71 & Art. 81 \\
\hline \multicolumn{5}{|c|}{$\begin{array}{c}\text { COMUNIDAD DE MADRID } \\
\text { LEY 9/2001, DE } 17 \text { DE JULIO, DEL SUELO, DE LA COMUNIDAD DE MADRID (LSM) }\end{array}$} \\
\hline Art. 30 & Art.16 & Art. 30 & Art.50 & \\
\hline \multicolumn{5}{|c|}{$\begin{array}{c}\text { PAIS VASCO } \\
\text { LEY 2/2006, DE } 30 \text { DE JUNIO, DE SUELO Y URBANISMO (LSUPV) }\end{array}$} \\
\hline Art. 3 & Art. 13 & & Art. 59 & \\
\hline
\end{tabular}

Fuente: Leyes autonómicas. Elaboración propia

\subsection{El paisaje y la ordenación el territorio}

La legislación autonómica más reciente sobre ordenación del territorio, ya esté integrada en leyes que incluyen también el urbanismo, como ocurre en Canarias (LSENPC 2017), Extremadura (LOTUSE 2018), Navarra (TRLFOTUN 2017) y la Región de Murcia (LOTUM 2015) (FIG. 2), o tratada como legislación específica, como sucede en Aragón (TRLOTA 2015) (FIG. 3), conceden al paisaje un tratamiento más detallado y específico desde el punto de vista instrumental, asumiendo en todos los casos el Convenio Europeo del Paisaje.
En cuanto a las leyes anteriores a las mencionadas, la consideración del paisaje por parte de la ordenación del territorio resulta relativamente variada según comunidades autónomas. Son, en general, muy escasas o nulas las disposiciones sobre paisaje en las primeras normas. Así ocurre con la Ley 23/1983, de 21 de noviembre, de Política Territorial de Cataluña y con Ley 4/1990, de 31 de mayo, de Ordenación del Territorio del País Vasco, sin menciones al paisaje, aunque los instrumentos de planificación que las desarrollan, tanto autonómicos, como subregionales, sí que contienen disposiciones paisajísticas. Cataluña y el País Vasco cuentan además con ordenamientos específicos de paisaje, como se verá en el siguiente epígrafe. La Ley $1 / 1994$, de 11 de 
enero, de Ordenación del Territorio de la Comunidad Autónoma de Andalucía, tan solo establece en su artículo 11 como parte del contenido de los Planes de Ordenación del territorio de ámbito subregional "la indicación de las zonas para la ordenación y compatibilización de usos del territorio y para la protección y mejora del paisaje...". Pese a esa escueta mención en la ley, su desarrollo instrumental ha supuesto la incorporación de contenidos paisajísticos significativos y, en determinados aspectos, innovadores tanto en el Plan de Ordenación del Territorio de Andalucía, aprobado en 2006, en particular en la definición, objetivos y estrategias del Sistema de Patrimonio Territorial como uno de los ejes del modelo territorial andaluz, como en números POT subregionales. Desde 2012, Andalucía cuenta además con una Estrategia de Paisaje, aprobada por el Consejo de Gobierno autonómico. En 2005 se creó el Centro de Estudios Paisaje y Territorio, mediante un convenio de colaboración suscrito entre la Consejería de Obras Públicas y Transportes de la Junta de Andalucía y las universidades públicas andaluzas, que viene desarrollando una importante labor de estudio, catalogación provincial de paisajes y asesoramiento en materia de políticas de paisaje y ordenación del territorio.

Muy escueta pero significativa por su incidencia en la planificación territorial del litoral cántabro, es la referencia de la Disposición adicional cuarta de la Ley de Ordenación del Territorio y Régimen Urbanístico del Suelo de Cantabria (LOTRUSCA), de 2001, sobre el Plan de Ordenación del Litoral (POL), al que atribuye específicamente, entre otras funciones, "establecer criterios para la protección de los elementos naturales, de las playas y, en general, del paisaje litoral". De hecho, el POL, aprobado con rango de ley en 2004 (Ley 2/2004, de 24 de septiembre, del Plan de Ordenación del Litoral), presenta un alto contenido paisajístico, tomando ya en consideración el Convenio Europeo del Paisaje, tanto en su memoria informativa como en sus propuestas de ordenación. Un contenido paisajístico relevante tienen también las Normas Urbanísticas Regionales, uno de los instrumentos de ordenación territorial creados en el marco de la LOTRUSCA, aprobadas en 2010 por Decreto del Consejo de Gobierno de Cantabria (Decreto 65/ 2010, de 30 de septiembre, por el que se aprueban las Normas Urbanísticas Regionales).

Son también escasas las referencias al paisaje en la Ley 14/2000, de 21 de diciembre, de Ordenación Territorial, de las Illes Balears, que en su artículo 2 sobre principios de actuación de las administraciones públicas establece que los instrumentos de ordenación territorial regulados por dicha ley deberán, entre otras cosas, "definir las áreas territoriales que, por su idoneidad actual o potencial para la explotación agrícola, forestal o ganadera, o por la riqueza paisajística o ecológica, deban ser objeto de especial protección". A eso, el artículo 11 sobre los Planes Territoriales Sectoriales, añade que tal tipo de planes habrán de incorporar "la dimensión territorial, ambiental y paisajística de la planificación sectorial". No obstante, pese a estas escasas disposiciones paisajísticas en una ley temprana como la balear, los instrumentos de ordenación del territorio han ampliado sensiblemente su contenido paisajístico. Lo hacen las propias Directrices de Ordenación del Territorio aprobadas en 1999 con rango de ley (Ley 6/1999, de 3 de abril, de las Directrices de Ordenación Territorial de las Illes Balears y de Medidas Tributarias) y, sobre todo, los Planes Territoriales Insulares (PTI), en particular, el PTI de Menorca, aprobado en 2003 (MatA Olmo, 2009), que, en su reciente Revisión (Aprobación inicial de diciembre de 2020) ha incorporado las Directrices de Paisaje a partir de unos objetivos de calidad paisajística previamente enunciados, siguiendo las recomendaciones del CEP y las líneas de acción de otros territorios que cuentan con legislación específica de paisaje. En esa línea, el Consell de Mallorca, aprobó en 2019, a partir de una primeras Bases de 2009, la Estrategia de Paisaje del Consell de Mallorca, a partir de la cual se ha creado el Observatori del Paisatge de la isla.

No existe tampoco contenido paisajístico explícito en la parte correspondiente a ordenación del territorio del Texto Refundido de Ordenación del Territorio y Urbanismo del Principado de Asturias, de 2004, si bien hay referencias paisajísticas indirectas e interesantes en relación con el Catálogo de Núcleos Rurales. Tampoco contiene menciones expresas al paisaje en lo que a ordenación del territorio respecta una ley más reciente como la LOTAU de Castilla-La Mancha, de acuerdo con su Texto Refundido de 2010.

Como se ha señalado, las leyes autonómicas sobre la materia de ordenación del territorio aprobadas en los últimos años prestan en general mayor atención al tratamiento del paisaje, asumiendo en todos los casos el CEP. La de Extremadura, de 2018 (LOTUSE), aborda la cuestión paisajística en su Exposición de Motivos y remite a su desarrollo en las Directrices de Ordenación del Territorio de la comunidad autónoma, que habrán de aprobarse con rango de ley. En su Avance, de 27 de julio de 2020, se han incorporado efectivamente numerosas determinaciones paisajísticas y un capítulo específico dedicado a la ordenación del paisaje, con principios, criterios y objetivos de calidad paisajística, junto con el enunciado de valores paisajísticos relevantes por conjuntos territoriales. En términos parecidos se manifiesta 
la Ley Foral de Ordenación del Territorio y Urbanismo de Navarra, de 2017, que en su Disposición Adicional Decimoprimera establece que "los instrumentos de ordenación territorial y urbanística adoptarán la variable paisajística, de acuerdo con las indicaciones del Convenio Europeo del Paisaje, mediante una Estrategia Navarra del Paisaje a elaborar por el Gobierno de Navarra, en la que está trabajando el Consejo Social de Política Territorial del Gobierno de Navarra, a través de su Comisión de Paisaje.

La Región de Murcia ha formulado en el plano normativo, a través de su Ley 13/2015, de 30 de marzo, de ordenación territorial y urbanística, una línea de acción en materia de paisaje en el ámbito de la ordenación del territorio equiparable en determinados aspectos a la que contienen las leyes de paisaje que se comentan en el epígrafe siguiente. Tras asumir de modo expreso y detallado en Convenio de Florencia, la citada norma establece entre los instrumentos de planificación territorial, dos específicamente paisajísticos y de importante alcance. Uno son los llamados Estudios de paisaje, que "en coherencia con lo establecido en el Convenio Europeo del Paisaje, tendrán por objeto el análisis y la evaluación del impacto que sobre el paisaje podría tener una actuación, actividad o uso concreto sobre el territorio, y las medidas a adoptar para su correcta integración, y deberán realizarse en aquellos supuestos que así se prevean expresamente en la normativa de los instrumentos de ordenación territorial y urbanísticos" (art. 44.1 de la LOTUM), formado parte inseparable del proyecto o instrumento que corresponda, y cuyo contenido y documentación se detalla también en la ley. El otro instrumento es la Estrategia de Paisaje, que tiene como objetivo "reconocer el paisaje como expresión de la diversidad del patrimonio común cultural, residencial, industrial y natural, aplicar políticas de protección, gestión y ordenación de paisaje, establecer procedimientos de participación pública, e integrar el paisaje en las políticas de ordenación territorial y urbanística", comprometiendo a todas las administraciones públicas y a los particulares, y prevaleciendo sobre los planes urbanísticos municipales.

Por su parte, Aragón ha definido también las grandes líneas de su política de paisaje vinculada a la planificación territorial en su texto refundido de la Ley de Ordenación del Territorio de Aragón, de 2015, sin perjuicio de otras determinaciones en distinto tipo de normas urbanísticas y sectoriales. El título sexto de la ley aborda la tutela del paisaje, partiendo del CEP, reconociendo jurídicamente los paisajes aragoneses "como elemento fundamental del entorno humano, expresión de la diversidad de su patrimonio común cultural y natural, y como fundamento de su identidad", y siendo sus disposiciones de aplicación en todo el territorio de Aragón, en "las áreas naturales, rurales, urbanas y periurbanas", con referencia "a todos los paisajes, desde los excepcionales hasta los degradados" (art. 68 del TRLOTA). La política de paisaje, de acuerdo con la Estrategia de Ordenación Territorial de Aragón (EOTA), implica la formulación de estrategias y directrices para "la adopción de medidas específicas con vistas a la protección, gestión y ordenación de los paisajes" (art. 69) y la integración del paisaje en las políticas públicas (art. 70). Para ello constituyen una herramienta muy importante los llamados Mapas de Paisaje (arts. 58 y 71), cuyo contenido mínimo se recoge en la propia ley. Se definen como "instrumentos de información territorial" de carácter analítico y prospectivo, que identifican y caracterizan los paisajes del territorio aragonés, señalan "sus valores y estado de conservación, y proponen los objetivos de calidad paisajística que deben cumplir" (art. 71). La citada Estrategia Territorial de Aragón, aprobada en 2014, contiene ya un objetivo, el número 5, titulado "Escenario vital y patrimonio territorial", que presta especial atención al paisaje, con un desarrollo normativo que recoge objetivos específicos y estrategias para la implementación de la política de paisaje en el territorio aragonés. Por otra parte, se dispone ya de los 33 Mapas de Paisaje correspondientes a todas las comarcas, disponibles en la página web del Instituto Geográfico de Aragón.

Por su parte, la Comunidad Autónoma de Canarias, que ha incorporado a su Estatuto de Autonomía modificado por la Ley Orgánica 1/2018, el derecho de sus ciudadanos a "gozar de los recursos naturales y del paisaje terrestre y marino en condiciones de igualdad, realizando un uso responsable de los mismos", incluye en su Ley 4/2017, de 13 de julio, del Suelo y de los Espacios Naturales Protegidos de Canarias, el Observatorio del Paisaje, creado en 2016 y con Reglamento de 2019 (Decreto 35/2019, de 1 de abril, por el que se aprueba el Reglamento de Organización y Funcionamiento del Observatorio del Paisaje). Junto a las disposiciones paisajísticas referidas al planeamiento urbanístico, la ley atribuye a las Directrices de Ordenación, instrumento de ordenación territorial estratégica de Canarias, entre otros contenidos, "formular estrategias y criterios generales que permitan la integración del paisaje en la planificación territorial, ambiental y urbanística, así como la adopción de medidas específicas con vistas a su ordenación, gestión y protección". Asimismo, los Planes Insulares, que tienen por objeto la ordenación estructural del espacio insular, recogen entre sus fines "proteger y conservar los recursos naturales, el medioambiente, el paisaje y los bienes culturales" (art. 95). Para ello, en su contenido deberá figurar "la 
identificación, ordenación y evaluación de los paisajes representativos de la isla, a fin de preservar sus valores naturales, patrimoniales, culturales, sociales y económicos, con especial atención a los que, por su calidad, fragilidad o significación, deban tener un tratamiento especial" (art. 96.2.c). Las islas de Gran Canaria y Tenerife cuentan además con sendos Planes Territoriales Especiales de Ordenación del Paisaje, de 2010 y 2013.

$\begin{array}{cccccc}\text { Principios inspiradores } & \text { Régimen de suelo, } \\ \text { del desarrollo } & \begin{array}{c}\text { zonificación y } \\ \text { clasificación del } \\ \text { suelo }\end{array} & \begin{array}{c}\text { Determinaciones de } \\ \text { directa aplicación }\end{array} & \begin{array}{c}\text { Planes } \\ \text { especiales }\end{array} & \begin{array}{c}\text { Catálogos con } \\ \text { contenido } \\ \text { paisajístico }\end{array} & \begin{array}{c}\text { Tratamiento del paisaje } \\ \text { en la ordenación del } \\ \text { territorio }\end{array} \\ \text { urbanístico sostenible }\end{array}$

ASTURIAS

DECRETO LEGISLATIVO 1/2004, DE 22 DE ABRIL, POR EL QUE SE APRUEBA EL TEXTO REFUNDIDO DE LAS DISPOSICIONES LEGALES VIGENTES EN MATERIA DE ORDENACIÓN DEL TERRITORIO Y URBANISMO (TROTUA)
Art. 4
Arts. 57 y 61
Arts. 109 y 138.
Art. 68

\section{CANARIAS}

LEY 4/2017, DE 13 DE JULIO, DEL SUELO Y DE LOS ESPACIOS NATURALES PROTEGIDOS DE CANARIAS
Art. 82
Arts. 33 y 34 .
Art. 58.
Art. 146.
Art. 151
Arts. $25,87,95,95$

CANTABRIA

LEY 2/2001, DE 25 DE JUNIO, DE ORDENACIÓN TERRITORIAL Y RÉGIMEN URBANÍSTICO DEL SUELO DE CANTABRIA (LOTRUSCAN)

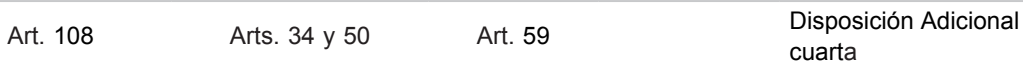

\section{CASTILLA LA MANCHA}

DECRETO LEGISLATIVO 1/2010, DE 18/05/2010, POR EL QUE SE APRUEBA EL TEXTO REFUNDIDO DE LA LEY DE ORDENACIÓN DEL TERRITORIO Y DE LA ACTIVIDAD URBANISTICA (LOTAUCM)
Arts. 5 y 6
Art.47.
Art. 55.
Art. 29.
Art. 17

\section{EXTREMADURA}

LEY 11/2018, DE 21 DE DICIEMBRE, DE ORDENACIÓN TERRITORIAL Y URBANÍSTICA SOSTENIBLE DE EXTREMADURA (LOTUSE)

\begin{tabular}{|c|c|c|c|}
\hline \multirow{2}{*}{\multicolumn{3}{|c|}{ Exposición de }} & \\
\hline & & & y remisión a las \\
\hline $\begin{array}{l}\text { IV, VI } \\
\text { Art. } 10\end{array}$ & 66 y 69 & Art. 51. & $\begin{array}{l}\text { Directrices de } \\
\text { Ordenación del } \\
\text { Territorio }\end{array}$ \\
\hline
\end{tabular}

REGIÓN DE MURCIA

LEY 13/2015, DE 30 DE MARZO, DE ORDENACIÓN TERRITORIAL Y URBANÍSTICA DE LA REGIÓN DE MURCIA (LOTUM)

$\begin{array}{lccc}\text { Preámbulo Tres } & \text { Art. } 83 & \text { Arts. } 127 \mathrm{y} & \text { Arts. } 45,46 \mathrm{y} 47 \\ \text { Arts. } 1,3,4 \text { y } 6 & & 137 & \end{array}$

Arts. 1, 3, 4 y 6

NAVARRA

DECRETO FORAL LEGISLATIVO 1/2017, DE 26 DE JULIO, POR EL QUE SE APRUEBA EL TEXTO REFUNDIDO DE LA LEY FORAL DE ORDENACIÓN DEL TERRITORIO Y URBANISMO (TRLOTUN)
Art. 4.
Arts. 51,52 y 92
Art. 86
Art. 61
Art. 64.
Disposición Adicional decimoprimera

LA RIOJA

LEY 5/2006, DE 2 DE MAYO, DE ORDENACIÓN DEL TERRITORIO Y URBANISMO DE LA RIOJA (LOTUR)

Exposición de Motivos IV

Arts. $45,62,63$ y 68

Art. 78

Arts. 72 y 26

Art. 19

Art. 2.

\section{COMUNIDAD VALENCIANA}

LEY 5/2014, DE 25 DE JULIO, DE ORDENACIÓN DEL TERRITORIO, URBANISMO Y PAISAJE, DE LA COMUNITAT VALENCIANA

\begin{tabular}{|c|c|c|c|c|c|}
\hline $\begin{array}{l}\text { Preámbulo } \\
\text { Arts. } 25 \text { y } 26\end{array}$ & Arts. 25 y 26 & Arts. 8 y 10 & Art. 43 & Art. 42. & $\begin{array}{c}\text { Capítulo II, Anexo I } \\
\text { (véase epígrafe } 5 \\
\text { y FIG. 4) }\end{array}$ \\
\hline
\end{tabular}

FIG. 2/ El paisaje en la legislación autonómica de ordenación territorial y urbanismo. 


\section{ANDALUCIA \\ LEY 1/1994, DE 11 DE ENERO, DE ORDENACIÓN DEL TERRITORIO DE LA COMUNIDAD AUTÓNOMA DE ANDALUCÍA}

Artículo 11, contenido de los Planes de Ordenación del Territorio de ámbito subregional para "la protección y mejora del paisaje"

\section{ARAGÓN}

DECRETO LEGISLATIVO 2/2015, DE 17 DE NOVIEMBRE, DEL GOBIERNO DE ARAGÓN, POR EL QUE SE APRUEBA EL TEXTO REFUNDIDO DE LA LEY DE ORDENACIÓN DEL TERRITORIO DE ARAGÓN

EI Título Sexto aborda la tutela del paisaje, partiendo del CEP. Reconocimiento jurídico de los paisajes aragoneses "como elemento fundamental del entorno humano, expresión de la diversidad de su patrimonio común cultural y natural, y como fundamento de su identidad". Artículo 69, formulación de estrategias y directrices para "la protección, gestión y ordenación de los paisajes" y la integración del paisaje en las políticas públicas (art. 70). Mapas de Paisaje (arts. 58 y 71),

\section{ISLAS BALEARES}

\section{LEY 14/2000, DE 21 DE DICIEMBRE, DE ORDENACIÓN TERRITORIAL}

Artículo 2, la "riqueza paisajística" como objeto de protección de determinadas "áreas territoriales". Artículo 11, incorporación de la "dimensión paisajística de la planificación sectorial" en los Planes Territoriales Sectoriales.

\section{CATALUÑA}

LEY 23/1983, DE 21 DE NOVIEMBRE, DE POLÍTICA TERRITORIAL

Sin referencias explícitas al paisaje

\section{COMUNIDAD DE MADRID}

\section{LEY 9/1995, DE 28 DE MARZO, DE MEDIDAS DE POLÍTICA TERRITORIAL, SUELO Y URBANISMO}

Muy escasas referencias. Artículo 14.4, valores paisajísticos como criterio para identificación de ámbitos territoriales supramunicipales objeto de los Planes de Ordenación del Medio Natural y Rural. Artículo 45, el paisaje entre los aspectos a evaluar en el impacto ambiental de los Centros Integrados de Desarrollo

PAIS VASCO

LEY 4/1990, DE 31 DE MAYO, DE ORDENACIÓN DEL TERRITORIO DEL PAÍS VASCO

Sin referencias explícitas al paisaje

FIG. 3/ El paisaje en la legislación autonómica de ordenación territorial.

Fuente: Leyes autonómicas. Elaboración propia.

\section{Las leyes de paisaje y sus instrumentos de desarrollo}

Cinco comunidades autónomas cuentan hasta ahora con normativa específica sobre paisaje, cuatro de ellas con rango de ley -la Comunidad Valenciana (2004 y 2014), Cataluña (2005), Galicia (2008) y Cantabria (2014)-, y una, la del País Vasco, a través de un decreto. La Comunidad Valenciana lo hizo en 2004 integrando en una misma norma la ordenación del territorio y la protección del paisaje y en la actualidad también el urbanismo (Ley 4/2004, de 30 de junio, de Ordenación del Territorio y Protección del Paisaje; Ley 5/2014, de 25 de julio, de Ordenación del Territorio, Urbanismo y Paisaje, de la Comunitat Valenciana). Dos de las normas citadas, las de Cataluña y el País Vasco, incluyen en su denominación la "protección, gestión y ordenación del paisaje", de acuerdo con los tres objetivos marcados por el CEP, a lo que el decreto vasco añade "en la ordenación del territorio", subrayando, como en realidad ocurre con las cinco normas citadas, la estrecha relación de la política de paisaje con la ordenación y la planificación territorial y urbanística. La ley gallega se denomina solo de "protección del paisaje", pero como se indica en el artículo 5, sus iniciativas lo serán para "la protección, gestión y ordenación del paisaje”.

Lo importante en cualquier caso es que estas cinco normas, de manera expresa, asumen y desarrollan los compromisos del Convenio Europeo del Paisaje. En ese sentido, todas comienzan por definir su objeto -el paisaje- sin calificativos, sin valoraciones previas, como lo hace el CEP y en idénticos términos, incorporando la definición que figura en el Instrumento de Ratificación del citado Convenio, o muy similar:

"por «paisaje» se entenderá cualquier parte del territorio tal como la percibe la población, cuyo carácter sea el resultado de la acción y la interacción 
de factores naturales y/o humanos" (Instrumento de Ratificación del Convenio Europeo del Paisaje, número 176 del Consejo de Europa, hecho en Florencia el 20 de octubre de 2000. Art. 1 a).

Existen lógicamente diferencias de contenido entre las cuatro leyes autonómicas y el decreto vasco, aunque todas comparten el objetivo del reconocimiento jurídico del paisaje y su integración en el planeamiento y en las políticas de ordenación territorial y urbanística, junto a su consideración por parte de las demás políticas sectoriales que inciden en el paisaje de forma directa o indirecta. Así mismo, siguiendo al CEP y dado que el paisaje se reconoce como una cualidad de todo el territorio, que "alcanza -dice, por ejemplo, la ley cántabra - tanto a los paisajes rurales, urbanos y periurbanos que puedan considerarse excepcionales como a los paisajes cotidianos y a los degradados" (art. 2), las cinco normas recogen como líneas de acción paisajística junto a la protección, la gestión y la ordenación del paisaje. Así quedan definidas, de acuerdo con el CEP, en la ley catalana de 2005:

“Artículo 6. Tipología de actuaciones sobre el paisaje.

1. Las actuaciones públicas que se ejecuten sobre el paisaje deben ir dirigidas a su protección, gestión y ordenación. 2. Son actuaciones de protección del paisaje las dirigidas a la conservación y el mantenimiento de los aspectos significativos o característicos de un paisaje, justificadas por los valores de este, que provienen de la configuración natural o de la intervención humana. 3. Son actuaciones de gestión del paisaje las dirigidas a guiar y armonizar las transformaciones inducidas por los procesos sociales, económicos y ambientales. 4. Son actuaciones de ordenación del paisaje las que presentan un carácter prospectivo particularmente acentuado y tienen por objetivo mantener, restaurar, mejorar, modificar o regenerar paisajes".

Por último, estas normas comparten igualmente la importancia de la participación pública en las políticas de paisaje y una noción, la de "Objetivo de calidad paisajística", recogida también en el Convenio de Florencia, que vincula la participación con las acciones en materia de paisaje. Así lo define la ley gallega:

"Artículo 3. Definiciones. A los efectos de la presente ley, y de conformidad con la terminología internacional definida por el Convenio europeo del paisaje, se entiende por:

(...) c) Objetivos de calidad paisajística: el planteamiento por parte de las autoridades públicas competentes, para un paisaje concreto, de las aspiraciones de la colectividad en relación a las características paisajísticas de su entorno".

En la tabla de la FIG. 4 se recogen de manera muy sintética los principales contenidos de las normas de paisaje de las comunidades autónomas citadas. Se han agrupado en cinco apartados a partir de su lectura comparada y del conocimiento que se tiene de su implementación. En este sentido hay lógicas diferencias entre las comunidades que cuentan con leyes aprobadas hace ya más de una década, y aquellas con normas más recientes y menos tiempo para implementarlas, aunque en el caso del País Vasco, las determinaciones de su Decreto de Paisaje de 2014 se han venido desarrollando a buen ritmo en el último quinquenio.

\subsection{Estudios e instrumentos de protección, gestión y ordenación}

El primer y más importante apartado, por su alcance normativo e implementación, es el que hemos titulado "Estudios e instrumentos de protección, gestión y ordenación", entre los que en todos los casos hay una relación estrecha. Una política de paisaje aplicable al conjunto del territorio, y no solo a determinadas configuraciones notables, requiere un análisis y diagnóstico a la escala pertinente de las características, tendencias, valores y problemas de todos los paisajes. Así lo establecen las normas que comentamos y ese está siendo su desarrollo, con una mejora muy significativa del conocimiento de los paisajes de las comunidades autónomas concernidas. Las leyes de Cataluña y Galicia y el decreto vasco optan por los Ilamados Catálogos de paisaje (SALA I MARTí, 2010), un repertorio, cartografía y caracterización de los paisajes del ámbito de referencia, que suele corresponderse con los de la planificación territorial subregional (Planes Territoriales Parciales en Cataluña y País Vaco) y no deben confundirse con los catálogos urbanísticos. Las leyes de la Comunidad Valenciana y de Cantabria optan por los denominados Estudios de paisaje, con contenido analítico similar, referidos en el caso de Cantabria a cada uno de los doce Ámbitos paisajísticos establecidos en la propia ley (art. 10), y, en el caso valenciano, a "los planes de acción territorial, planes generales estructurales, el plan de ordenación pormenorizada y pueden serlo para planes especiales y modificaciones de planes generales de amplio ámbito territorial".

Un rasgo importante de los catálogos y estudios de paisaje es que poseen no solo carácter analítico, sino también propositivo a partir del diagnóstico de las "unidades de paisaje" (se mencionan y 
hasta definen en todas las normas), entendidas como piezas paisajísticas con identidad propia. Así lo establece, por ejemplo, el decreto vasco en su artículo 4, que recoge entre los contenidos mínimos de los Catálogos de paisaje como "documentos de carácter descriptivo y prospectivo que abarcan la totalidad del paisaje de cada área funcional de la Comunidad Autónoma del País Vasco definidas en las Directrices de Ordenación Territorial", los siguientes:

"f) La definición de los objetivos de calidad paisajística, los cuales deben expresar las aspiraciones de la colectividad en cuanto a las características paisajísticas de su entorno.

g) La propuesta de las medidas y acciones necesarias para alcanzar los objetivos de calidad paisajística fijados.

h) La propuesta de los indicadores de carácter paisajístico que permitan evaluar la efectividad de las medidas y acciones que se establezcan para alcanzar los objetivos de calidad paisajística fijados".

Sobre la base de la información de los catálogos y estudios de paisaje, y de los objetivos de calidad paisajística formulados, las normas que comentamos recogen los instrumentos que deberán fijar las medidas para alcanzar tales objetivos, su encaje en los instrumentos de planificación territorial y urbanística, y su relación con otras políticas sectoriales de incidencia paisajística. Las leyes de Cataluña, Galicia y Cantabria establecen las denominadas Directrices de paisaje; el decreto vasco, las Determinaciones del paisaje; la norma valenciana incluye dentro de los Estudios de paisaje "las medidas y acciones necesarias para el cumplimiento de los objetivos de calidad paisajística, así como para prevenir, reducir y, en la medida de lo posible, compensar los efectos significativos importantes en el paisaje que puedan derivarse de la aplicación del plan" (Anexo I. Contenido del estudio de paisaje, h).

Hay algunas diferencias entre las distintas normas en el alcance de las directrices y determinaciones de paisaje y su integración en los instrumentos de ordenación territorial y urbanísticos y en otras políticas. Todas comparten el hecho de que emanan de los catálogos y estudios de paisaje y desarrollan los objetivos de calidad paisajística, identificando las medidas para su consecución. Su vocación es integrar tales medidas, ante todo, en los instrumentos de planificación territorial de escala subregional. Así lo señala -y se está haciendo en la práctica (EsteBAN, 2010)- la ley catalana, que en su artículo 12 establece que "las directrices del paisaje son las determinaciones que, basándose en los catálogos del paisaje, precisan e incorporan normativamente las propuestas de objetivos de calidad paisajística en los planes territoriales parciales o en los planes directores territoriales". En parecidos términos se manifiesta la norma del País Vasco en relación con los planes territoriales parciales de aquella comunidad, en los que las directrices se incorporarán con "carácter recomendatorio". La ley gallega, por su parte, señala en su artículo 10.4 que "las normas recogidas en las directrices de paisaje, una vez aprobadas, tendrán carácter vinculante para los instrumentos de planificación sectorial y urbanística"; algo similar fija la ley de paisaje Cantabria, para la que "las directrices de paisaje son determinaciones que definen las estrategias o pautas de actuación en materia de paisaje para todas las administraciones públicas cuyas actuaciones puedan tener incidencia paisajística, que deberán incorporarlas en los instrumentos de planificación territorial, urbanística y sectorial, y, en su caso, en los proyectos de desarrollo y ejecución" (art. 15).

Junto a las directrices y determinaciones de paisaje, las normas que comentamos suelen incluir otros instrumentos de carácter más operativo para el desarrollo de acciones concretas. Son los proyectos de actuación paisajística de la ley de Cantabria (art. 18), los planes de acción del paisaje de la ley gallega (art. 12) y del decreto vasco (art. 6) o los programas de paisaje de la LOTUP valenciana. En todos los casos se trata de instrumentos que tienen por objeto definir con un grado de detalle suficiente, actuaciones de preservación, restauración, mejora y puesta en valor de paisajes de alto interés o que lo requieran por su estado de deterioro, a ser posible, de acuerdo con los catálogos y estudios de paisaje del ámbito.

\subsection{Los estudios de impacto e integración paisajística}

Otro capítulo de las normas de paisaje que nos ocupan es el de la integración paisajística, un asunto importante en el terreno de la gestión del paisaje como cualidad dinámica del territorio, que ha de acoger con frecuencia nuevos usos e implantaciones de incidencia paisajística. Aunque ya la legislación de evaluación ambiental de planes, programas y proyectos aborda el impacto paisajístico, las normas de paisaje enfatizan en la necesidad y obligatoriedad de su consideración en distintos supuestos y marcan los contenidos mínimos de los denominados estudios de impacto e integración paisajística por la legislación catalana, gallega y cántabra, o simplemente estudios de integración paisajística en las normas de paisaje de la Comunidad Valenciana (MuÑOz CRIADO, 2008: 111-112) y el País Vasco, estableciendo el reglamento catalán el órgano competente que ha de informarlos. 
Todas las normas coinciden en considerar estos estudios, con pequeños matices, como "un documento técnico destinado a considerar las consecuencias que tiene sobre el paisaje la ejecución de actuaciones, proyectos de obras o actividades y a exponer los criterios adoptados para su integración" (Reglamento de Paisaje de Cataluña, art. 19) (BUSQUETS, 2009). Hay sin embargo ciertas diferencias en cuanto a los supuestos de obligatoriedad de tales estudios y sobre su contenido, si bien en general se remiten a las declaraciones de impacto ambiental reguladas por la legislación correspondiente, incidiendo, como lo hace la ley gallega, en que el estudio de impacto e integración paisajística será "un documento específico en el que se evaluarán los efectos e impactos que el proyecto pueda provocar en el paisaje y las medidas de integración paisajística propuestas por dichas entidades" (art. 11). Es interesante el caso del País Vasco, donde, más allá de los supuestos de obligatoriedad de estos estudios, "la Administración Pública de la Comunidad Autónoma y las entidades de su sector público incorporarán, como documentación adicional de los proyectos de obras o actividades de su competencia que puedan tener un impacto significativo sobre el paisaje, el correspondiente Estudio de integración paisajística" (art. 7). Por su parte, la ley de Cantabria, en su artículo 20 sobre integración paisajística, señala que "una actuación se considera integrada en el paisaje cuando no afecta negativamente al carácter del lugar y no impide la posibilidad de percibir los recursos paisajísticos", indicando a continuación en qué circunstancias se entenderá que una actuación no está integrada en el paisaje, y, por lo tanto, produce impacto paisajístico negativo.

\subsection{Observatorios de paisaje, concertación, educación y sensibilización}

Dos leyes de paisaje, la de Cataluña de 2005 y la de Galicia de 2008, crearon los Observatorios del Paisaje como

"entidad de apoyo y colaboración -dice la norma catalana sobre el suyo- con la Administración de la Generalidad en todas las cuestiones relacionadas con la elaboración, aplicación y gestión de las políticas de paisaje" (art. 13.1.).

El Observatorio Gallego del Paisaje, incluido en la ley de 2008, fue derogado por la Ley 2/2016, de 10 de febrero, del suelo de Galicia, atribuyendo su función de elaboración de los catálogos del paisaje al Instituto de Estudios del Territorio. El Observatori del Paisatge de Catalunya viene desempeñando desde su creación en 2004 unaimportante labor de estudio, asesoramiento, divulgación, formación y sensibilización en materia de paisaje, que trasciende los límites de la comunidad autónoma. Destaca la elaboración y actualización de los catálogos de paisaje (siete ya ejecutados y aprobados, y el último, el del Penedés, en ejecución), de los correspondientes objetivos de calidad paisajística y de las directrices de paisaje, de las que están aprobadas dos, las de Terres de l'Ebre y de las Comarques Gironines, con sus correspondientes disposiciones normativas incorporadas a los planes territoriales parciales.

También las leyes de paisaje de Cataluña y Galicia han incluido instrumentos más flexibles de concertación de estrategias para la conservación y activación de los valores del paisaje en determinados territorios. Se trata de las llamadas cartas del paisaje de la ley catalana, "que podrán ser promovidas por el Gobierno, los consejos comarcales, los ayuntamientos y las demás administraciones locales", cuyo contenido deberá tener en cuenta lo establecido por los catálogos del paisaje que inciden en su ámbito, así como, de estar aprobados, los catálogos del patrimonio cultural, artístico y natural municipales (art. 14). Hay en este momento siete cartas firmadas y una, la del Garraf, iniciada en 2017, pendiente de firma (CoRTINA, 2009). La ley gallega, en esa misma línea, recoge los denominados pactos por el paisaje "instrumentos de concertación entre las administraciones públicas, las entidades locales y otros agentes económicos y sociales de un determinado territorio que de manera voluntaria deseen promover acciones de protección y mejora de los paisajes y de la calidad de vida de los ciudadanos en el marco del desarrollo sostenible" (art. 14). Así mismo, la Xunta de Galicia se compromete a promover la realización de acuerdos voluntarios en las áreas de especial interés paisajístico entre las personas propietarias de las tierras y entidades públicas, a fin de colaborar y apoyar la conservación de los valores naturales y culturales presentes en estas áreas.

Por último, las cuatro leyes y el decreto de paisaje vasco incluyen medidas y acciones de formación, educación, sensibilización y apoyo en materia de paisaje. La ley de Cantabria hace en su artículo 9 una referencia expresa a la educación ambiental, para que las administraciones con competencias en la materia promuevan programas y acciones específicas encaminadas a difundir los valores paisajísticos de Cantabria. En ese sentido, "La Estrategia Cántabra de Educación Ambiental adoptará el paisaje como uno de sus ejes básicos" (art. 9). Por su parte, el reglamento de la ley gallega se refiere en su artículo 50 a los manuales y guías de buenas prácticas, que podrá elaborar el Instituto de Estudios del Territorio, "con la finalidad de divulgar los valores de los paisajes de Galicia, ofrecer orientaciones o recomendaciones para la 


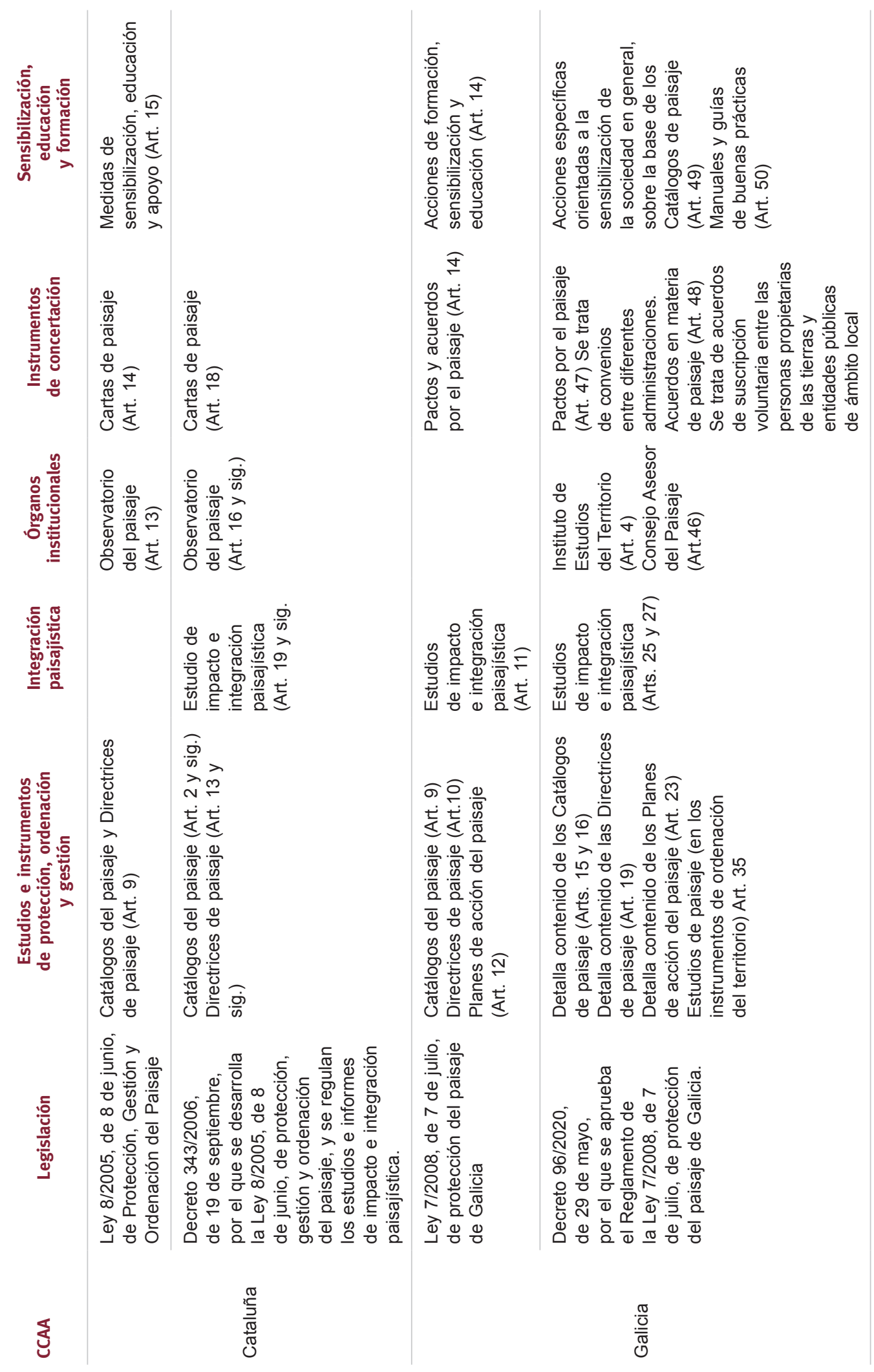




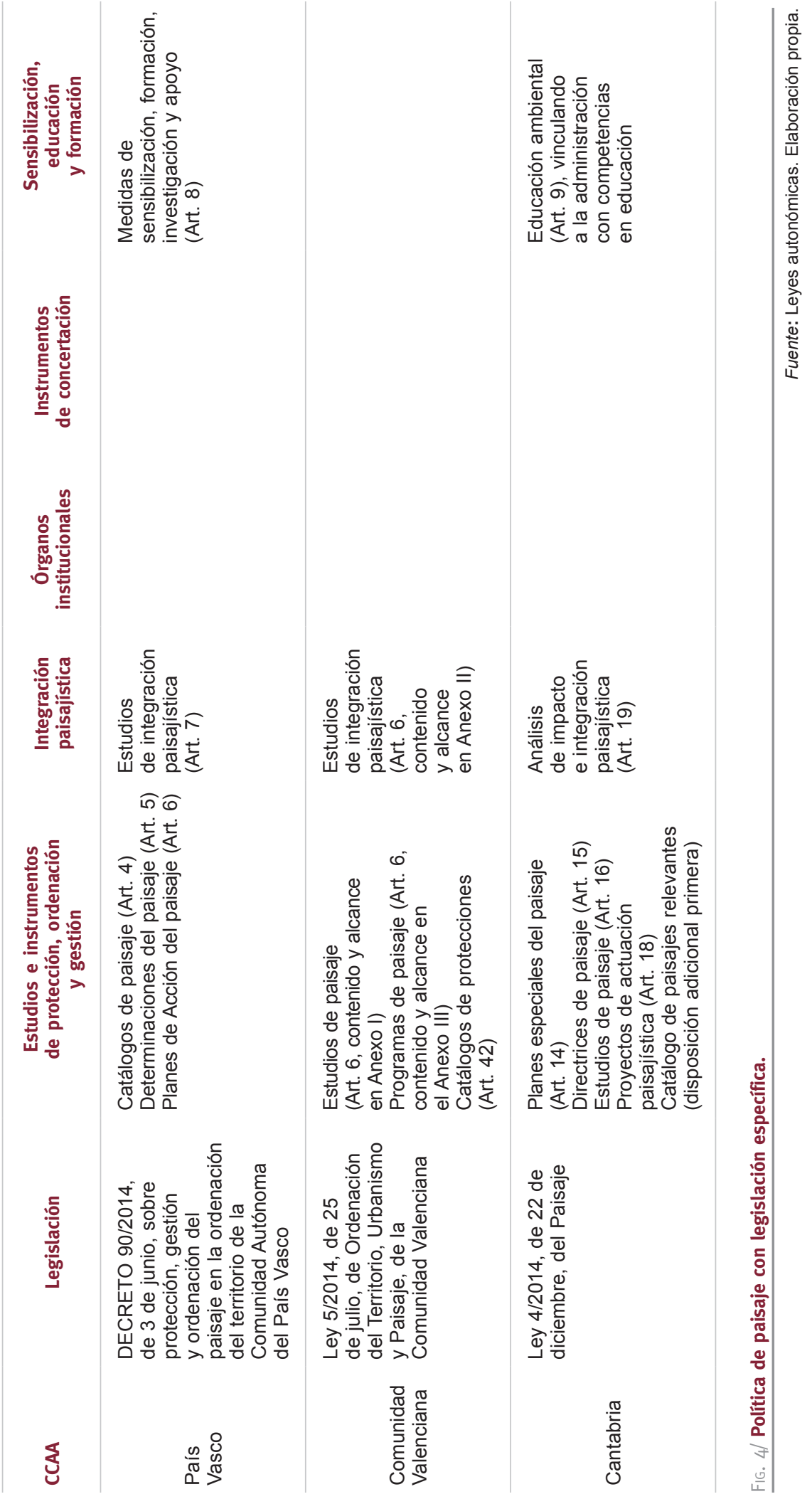


integración paisajística de determinadas actuaciones, facilitar la aplicación de las disposiciones de la legislación sobre paisaje y fomentar buenas prácticas de intervención en el paisaje". Se han publicado ya un total de ocho interesantes guías sobre asuntos diversos (Estudios de impacto e integración paisajística, sostenibilidad paisajística de los establecimientos de acuicultura litoral y buenas prácticas para la intervención en los núcleos rurales, cerramientos, sistemas playa-duna, colores y materiales de Galicia, espacios urbanos o espacios públicos, disponibles en el sitio web del Instituto de Estudios del Territorio de la Conselleria de Ordenación del Territorio, Medio Ambiente y Vivienda de la Xunta de Galicia). Este tipo de guías o recomendaciones de buenas prácticas no son exclusivas de Galicia. La Generalitat de Cataluña, pese a no mencionarse expresamente en su normativa, ha publicado distintas guías de integración paisajística de polígonos industriales y áreas de actividad económica, construcciones agrarias, huertos urbanos y periurbanos, o buenas prácticas vitivinícolas del Penedés. En 2012, la Conselleria de Infraestructuras, Territorio y Medio Ambiente de la Generalitat Valenciana publicó también una útil Guía metodológica para los Estudios de paisaje.

Solo la ley catalana, de las normas tratadas en este apartado, se refiere a la financiación de la política de paisaje, con la creación de un Fondo para la protección, gestión y ordenación del paisaje (capítulo V) como instrumento financiero de la Generalitat, "con el fin de destinarlo a las actuaciones de mejoramiento paisajístico que se lleven a cabo de acuerdo con los criterios establecidos por la presente ley y por la normativa que se dicte para su desarrollo" (art. 15). La aportación del Gobierno al Fondo procede de las partidas que los presupuestos de la Generalidad adscriben anualmente al Departamento competente en materia de paisaje, pudiendo recibir financiación del mismo, entes públicos, entidades privadas sin ánimo de lucro y personas físicas o jurídicas de naturaleza privada, para llevar a cabo actuaciones que tengan por objeto alguna de las finalidades establecidas en la propia ley.

\section{Sobre la legislación de evaluación ambiental y el paisaje}

No puede finalizar este estudio comparado sin una referencia, al menos, a la relación entre paisaje y legislación de evaluación ambiental. Como es sabido, la evaluación ambiental resulta indispensable para la protección del medio ambiente en general y del paisaje en particular, facilitando la incorporación de criterios de sostenibilidad en la toma de decisiones estratégicas a través de la evaluación de planes y programas, y garantizando la prevención de los impactos ambientales concretos -en particular de los paisajísticos- que puedan generar determinados proyectos. Al mismo tiempo la evaluación ambiental debe establecer mecanismos eficaces de corrección o compensación de dichos impactos. En este sentido, como la propia ley básica estatal (Ley 21/2013, de 9 de diciembre, de evaluación ambiental) y algunas autonómicas señalan, la evaluación ambiental de la dimensión paisajística sintoniza plenamente con los planteamientos del Convenio Europeo del Paisaje, abordando, más allá de la mera protección, la gestión y la mejora del paisaje con una mirada prospectiva y resiliente. No hay espacio para detallar en este "estudio comparado" el alcance de las leyes e instrumentos de evaluación ambiental en relación con la cuestión paisajística, pero sí para subrayar sus potencialidades en la protección, gestión y mejora de aquellos paisajes afectados por planes, programas y proyectos en la perspectiva que preconiza el CEP.

La ley básica estatal de 2013, que traspone la Directiva 2011/92/UE, de 13 de diciembre, de evaluación de las repercusiones de determinados proyectos públicos y privados sobre el medio ambiente, asume ese compromiso cuando señala en su Preámbulo "el hecho de que en España ya es plenamente aplicable el Convenio Europeo del Paisaje, ratificado el 26 de noviembre de 2007, por lo que deberá aplicarse tanto en la evaluación de impacto ambiental como en la evaluación ambiental estratégica”. El paisaje figura entre los aspectos a considerar en los informes ambientales estratégicos y estudios de impacto ambiental a la hora de analizar los efectos significativos que tienen o pueden tener sobre él los planes, programas y proyectos, y, en su caso, establecer las medidas de prevención, mitigación o corrección, antes de su adopción, aprobación o autorización. En el inventario ambiental que preceptivamente debe formar parte del Estudio de impacto ambiental, el paisaje ha de abordarse, según en el Anexo IV de la ley, "en los términos del Convenio Europeo del Paisaje". Eso, adecuadamente aplicado, debe tener consecuencias significativas, porque no se trataría solo de evaluar la incidencia sobre paisajes naturales o culturales relevantes, sino sobre el paisaje en general, como cualidad del territorio y entorno de vida cotidiano.

Las leyes autonómicas sobre la materia de evaluación ambiental, anteriores o posteriores a la estatal de 2013, incluyen el paisaje entre los aspectos que deben considerar los estudios de evaluación e impacto ambiental, en términos parecidos a los que se recogen en la ley básica de 2013 o en su antecesora de 2006. Sin embargo, 
hay algunas de esas leyes de última generación que van más allá de lo que, en materia de paisaje, establece la norma estatal. Así, la Ley 12/2016, de 17 de agosto, de evaluación ambiental de las Illes Balears, establece que "los estudios de impacto ambiental incluirán, además del contenido mínimo que establece la normativa básica estatal de evaluación ambiental, un anexo de incidencia paisajística que identifique el paisaje afectado por el proyecto, los efectos de su desarrollo, y, en su caso, las medidas protectoras, correctoras o compensatorias" (art. 17.4). Justifica esa disposición la ley balear con buen criterio:

\begin{abstract}
"teniendo presente tanto el activo que representa el paisaje en las Illes Balears como la vigencia del Convenio europeo del paisaje, aprobado por el Consejo de Europa el 20 de octubre de 2000, que entró en vigor en el Estado español el 1 de marzo de 2008" (Preámbulo).
\end{abstract}

Por su parte, la Ley 16/2015, de 23 de abril, de protección ambiental de la Comunidad Autónoma de Extremadura, dedica su Título IV al establecimiento del marco general aplicable para la protección del paisaje, algo excepcional en las normas autonómicas sobre evaluación ambiental. Se definen, así, los criterios generales en materia de protección paisajística, "con políticas destinadas a la protección, gestión y ordenación del paisaje”,

\begin{abstract}
"los procedimientos para la participación (...) de las partes interesadas en la formulación y aplicación de las políticas de paisaje" y la integración del paisaje en la ordenación territorial y urbanística, así como en cualquier política sectorial que pueda tener incidencia directa o indirectamente sobre el mismo. Entre las llamadas "medidas específicas" figuran la identificación y calificación de los paisajes, la definición de los objetivos de calidad paisajística, los mecanismos de intervención, la integración de la protección del paisaje en los instrumentos de intervención ambiental previstos en la propia ley, y el fomento de "la sensibilización de la sociedad civil, las organizaciones privadas y las autoridades públicas respecto del valor de los paisajes y su función" (arts. 119 y 120).
\end{abstract}

Como se ve, toda una agenda de política de paisaje, aprovechando una ley destinada prioritariamente a la evaluación ambiental.

\section{Conclusiones}

Como se decía en la introducción, el interés creciente por un entendimiento renovado del paisaje como elemento de calidad de vida y patrimonio territorial, de acuerdo con los postulados del Convenio Europeo del Paisaje, está teniendo un claro reflejo en el desarrollo legislativo reciente sobre la materia, sin perjuicio de la existencia de preceptos paisajísticos abundantes y variados en el ordenamiento jurídico anterior a la ratificación del citado Convenio.

Este "estudio comparado", centrado preferentemente, conforme a los objetivos de esta sección, en la síntesis y comparación de legislación autonómica, ha puesto de manifiesto la profusión de referencias al paisaje desde distintas perspectivas y ámbitos normativos, no siempre coordinados y con mayor o menor grado de indeterminación. Aunque el texto no ha pretendido, por su extensión y por la propia transversalidad del paisaje, agotar su tratamiento en la legislación estatal y autonómica, sí permite concluir cuáles son los tres grandes campos de la acción pública sobre el paisaje y la necesidad de su convergencia y cooperación.

Por una parte, con larga tradición, figuras específicas, aunque escasa concreción, está el ámbito de la protección de paisajes de alto valor natural y cultural (Paisajes protegidos y Paisajes culturales), sin olvidar el sentido paisajístico que, más allá de esas categorías concretas, impregna otros espacios naturales y bienes de interés cultural protegidos por la legislación de patrimonio natural y patrimonio cultural. Responderían esas leyes y figuras a la línea de "protección de los paisajes" que señala el CEP como conjunto de "acciones encaminadas a conservar o mantener los aspectos significativos o característicos de un paisaje, justificadas por su valor patrimonial derivado de su configuración natural y/o de la acción del ser humano".

La legislación urbanística de las comunidades autónomas ha mantenido a lo largo de los años, siguiendo de cerca la legislación básica del Estado, una serie de preceptos paisajísticos, reiterados en todas las leyes autonómicas de urbanismo y suelo. Se refieren a la consideración del valor del paisaje en el régimen y la clasificación del suelo rústico o no urbanizable, el establecimiento de normas o determinaciones de aplicación directa para la protección e integración paisajística, la conservación del paisaje como objeto preferente de los Planes Especiales y la inclusión de paisajes de especial valor en los catálogos del planeamiento municipal. A eso hay que añadir que todas las leyes consideran la conservación del paisaje como un objetivo o criterio inspirador, asociándolo en las más recientes, como lo hace la Ley de Suelo y Rehabilitación Urbana estatal, al principio del desarrollo territorial y urbano sostenible. No obstante, ninguna de esas leyes de urbanismo y suelo, con más diferencias formales que de fondo en su contenido paisajístico, han incorporado la concepción y el enfoque renovado del Convenio Europeo del Paisaje - ninguna lo cita, de hecho-, lo que 
no impide reconocer la virtualidad de las mismas, no solo ya para la protección de determinados paisajes de alto interés, sino para la "gestión de los paisajes", es decir, para, "desde una perspectiva del desarrollo sostenible", como señala también el CEP, "guiar y orientar las transformaciones inducidas por los procesos sociales, económicos y medioambientales".

Han sido las leyes de ordenación del territorio más recientes -exclusivas o unidas al urbanismoy, sobre todo, la legislación específica de paisaje aprobada por distintas comunidades autónomas las que han asumido el sentido renovado del paisaje como una cualidad de todo el territorio, como elemento de calidad de vida e identidad de los lugares, y como patrimonio común. Además de incorporar a sus ordenamientos jurídicos una definición de paisaje acorde con esa concepción, la Comunidades Autónomas se han dotado de instrumentos concretos para la identificación, caracterización y valoración de todos los paisajes -no solo de los notables o más apreciados-, de procedimientos para la elaboración de directrices y estrategias a partir de la previa definición de objetivos de calidad paisajística, que deben recoger las aspiraciones de la población, y de herramientas y figuras para la evaluación de impactos y la integración paisajística. Se asume así otro de los objetivos de la política de paisaje del CEP, la "ordenación paisajística", como acciones "con un carácter prospectivo particularmente acentuado con vistas a mejorar, restaurar o crear paisajes".

Para la protección, pero, sobre todo, para la gestión prudente de los cambios y para la mejora y creación de nuevos paisajes puede y debe jugar un papel fundamental la evaluación ambiental de planes, programas y proyectos, impregnada, eso sí, de sentido y alcance paisajístico, como algunas leyes de evaluación ambiental recientes ya plantean.

Una conclusión final es que, con legislación específica de paisaje y las ventajas que ello implica, o sin ella, el paisaje está penetrando en muchos instrumentos de planificación territorial y urbanística, no solo ya como un objetivo de protección, gestión u ordenación, sino como una vía integradora y participativa de lectura del territorio y de cualificación de la acción pública en materia de planificación urbanística, territorial o de áreas protegidas por su interés natural o cultural. El Convenio Europeo del Paisaje, que inspira muchas de esas iniciativas, planeta de forma más o menos explícita nuevas maneras de conocer y actuar en el ámbito de la calidad del habitar de las personas. Junto con la coordinación y la cooperación de las administraciones públicas, la acción paisajística requiere participación, implicación y concertación como la que promueven algunos de los instrumentos adoptados por las leyes de paisaje tratadas. Requiere también, además de procedimientos e instrumentos reglados, plataformas y redes de ciudadanos, de instituciones y de técnicos comprometidos con el paisaje más allá de coyunturas políticas, en un ejercicio de democracia deliberativa y de fomento de la cultura del territorio.

\section{Bibliografía}

Agudo GonzÁlez, J. (2007): Paisaje y gestión del territorio. Revista Jurídica de la Universidad Autónoma de Madrid, n. . 15: 197-237.

CañIzAres Ruiz, Ma C. (2017): "Cultural landscapes and planning in Spain”, en F. Manero Miguel \& García Cuesta, J.L. (Coords.), Territorial Heritage \& Spatial Planning (pp. 153-173), Navarra, Thomson ReutersAranzadi.

Convenio Europeo del Paisaje (2007): Textos y comentarios. Madrid, Ministerio de Medio Ambiente, $145 \mathrm{pp}$.

Cruz MerA, A. de LA (2019): La Agenda Urbana Española. Ciudad y Territorio. Estudios Territoriales, vol. LI, $\mathrm{n}^{\circ}$ 202: 675-686.

EUROPARC-EsPaña (2019): Anuario 2018 de las áreas protegidas en España, Madrid, Ed. Fundación González Bernáldez.

Fernández CACHo, S. (2019): "La dimensión paisajística en la gestión del patrimonio cultural en España", Estudios Geográficos, n. ${ }^{\circ} 80$ (287), e026.

Fernández Rodríguez, C. (2007): La protección del paisaje. Un estudio de Derecho español y comparado, Madrid, Marcial Pons.

Ferrer Jiménez, D. \& Mata Olmo, R. (2020): "Patrimonio arqueológico, paisaje e infraestructuras. Un estudio de evaluación de impacto patrimonial en Menorca Talayótica", en J. FARINós DASi (Coord.), Desafíos y oportunidades de un mundo en transición; una interpretación desde la Geografía (691-704), Valencia, Publicacions de la Universitat de València-Tirant lo Blanch.

GAmBINO, R. (2002): "Maniere di intendere il paesaggio", en A. Clementi, A. (Ed.), Interpretazioni di paesaggio (pp. 54-72), Roma, Meltemi editore, pp. 54-72.

GIFREU FONT, J. (2017): La tutela jurídica del paisaje en el décimo aniversario de la Ratificación española del Convenio Europeo del Paisaje. Especial referencia a las prescripciones paisajísticas en el derecho urbanístico. Revista Catalana de Dret Ambiental, vol. VIII, n. ${ }^{\circ}$ 1: 1-77.

Hernández-PARTAl, S. (2020): Los Instrumentos de Planeamiento Urbanístico en España. Ciudad y Territorio. Estudios Territoriales, vol. LII, $\mathrm{n}^{\circ}$ 205: 613-642.

iPCE (Instituto del Patrimonio Cultural de España) (2012): Plan Nacional de Paisaje Cultural. Ministerio de Educación, Cultura y Deporte.

López Sánchez, M., Tejedor Cabrera, A. \& Linares Gómez del Pulgar, M. (2020): El paisaje como vector estratégico para la gestión integral del patrimonio. Una observación desde el marco español, erph revista electrónica de patrimonio histórico, $n .{ }^{\circ} 27$.

Mata Oцmo, R. (2006): "Un concepto de paisaje para la gestión sostenible del territorio", en R. MatA Oцmo, R. \& A. TARroja (Eds.), El paisaje y la gestión del 
territorio. Criterios paisajísticos en la ordenación del territorio y el urbanismo (pp. 17-40), Barcelona, Diputació de Barcelona-CUIMP.

- (2009): "Plan Territorial Insular de Menorca", en J. Busquets y A. Cortina (Coords.), Gestión del Paisaje. Manual de protección, gestión y ordenación del paisaje (pp. 476-492), Barcelona, Ariel Patrimonio.

- (2014): El Convenio Europeo del Paisaje del Consejo de Europa. Notas sobre su aplicación en España. Patrimonio cultural y Derecho, n. ${ }^{\circ}$ 18: 175-206.

- (2017): "El Plan Nacional de Paisaje Cultural. Una iniciativa para el conocimiento, la cooperación y la salvaguarda de los paisajes de alto interés cultural", en A. SerRano Rodriguez (Coord.), Ordenación del territorio, urbanismo y medio ambiente en un mundo en cambio (pp. 287-302), València, Universitat de València.

MinisTERIO DE Fomento (2019): Agenda Urbana Española. Secretaría General Técnica, Centro de Publicaciones.

NoguÉ, J. \& SALA, P. (2008): El paisaje en la ordenación del territorio. Los Catálogos de Paisaje de Cataluña. Cuadernos Geográficos, n. ${ }^{\circ}$ 43: 69-98.

PAREJA, C. (2006): "Instrumentos legales para la ordenación del paisaje", en R. MATA OLmo, R. \& A. TARROJA (Eds.), El paisaje y la gestión del territorio. Criterios paisajísticos en la ordenación del territorio y el urbanismo (pp. 391-395), Barcelona, Diputació de Barcelona-CUIMP.

PhILLIPS, A. (2002): Management Guidelines for IUNC Category V Protected Areas/Protected Landscapes/
Seascapes, Gland, Switzerland and Cambridge, UK, IUCN.

SÁNCHEZ GoYANES, E. (1999): Las (mal) llamadas y (peor) entendidas normas de aplicación directa. Anulación por el TSJ de Cantabria de licencia de 17 viviendas junto a la costa de Liencres". Revista de Estudios Locales. Cunal, n. ${ }^{\circ}$ 33: 88-111.

UNESCO (1992): Operational Guidelines for the Implementation of the World Heritage Convention. World Heritage Committee. Sixteenth session.

VICENTE GonZÁlez, J. L. de (2003): Normas de aplicación directa y protección del paisaje en la Ley de Cantabria 2/2001 de 25 de junio. ¿Límites a la discrecionalidad de la administración o conceptos jurísdicos indeterminados? Revista de Estudios de la Administración Local y Autonómica, n. ${ }^{\circ}$ 292-293: 271-327.

Zárate Martín, A. A. (2011): Paisajes culturales urbanos. Entre la protección y la destrucción. Boletín de la Asociación de Geógrafos Españoles, n. ${ }^{\circ}$ 57: 175-194.

Zoido Naranjo, F. (2008): "El Convenio Europeo del Paisaje", en Busquets, J. \& CortinA, A. (coords.): Gestión del Paisaje. Manual de protección, gestión y ordenación del paisaje. Barcelona, Ariel Patrimonio, pp. 300-315.

- (2010): "Territorio y paisaje: conocimiento, estrategias y políticas", en Territorio, paisaje y sostenibilidad. Un mundo cambiante (pp. 87-114). Barcelona: Ediciones del Serbal. 


\section{Observatorio Inmobiliario}

CIUDAD Y TERRITORIO

ESTUDIOS TERRITORIALES

ISSN(P): 1133-4762; ISSN(E): 2659-3254

Vol. LIII, № 207, primavera 2021

Págs. $215-228$

https://doi.org/10.37230/CyTET.2021.207.13

CC BY-NC-ND

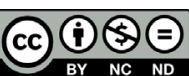

\section{Un ejercicio difícil para el mercado de vivienda}

Julio RodRíGuez-López

Vocal del Consejo Superior de Estadística del INE

“Para la mayoría de los arrendatarios del Reino Unido (condicionados por las perspectivas de alquileres crecientes, pobres condiciones de vida y la amenaza en curso de un desahucio) la idea de recibir una carta del propietario arrendador de la vivienda indicándoles la reducción de la renta mensual podría ser algo por completo impensable"

Alexander Vasudevan, "Berlin "rent cap offers a new way of thinking about Britain's Housing crisis” The Guardian, 25.11.2020.

\section{Introducción}

2020 ha sido un año marcado de forma decisiva por la aparición de un brote generalizado del coronavirus Covid 19. En el presente trabajo se describe en el primer apartado la incidencia que dicha circunstancia ha ejercido sobre el conjunto de la economía mundial. En el segundo apartado se resume la incidencia que sobre la economía española ejerció el conjunto de confinamientos derivados de la aparición del brote desde marzo de 2020. En el apartado tercero se resume la desaceleración experimentada por los niveles de precios de la vivienda y de los alquileres, evolución que reflejan de forma diferenciada los distintos indicadores disponibles. Todo apunta a que los precios citados habrán terminado 2020 en niveles inferiores a los alcanzados en el primer trimestre del año.

En el cuarto apartado se resume la evolución de la demanda, en la que todo indica que el número de ventas de viviendas puede ser inferior en un $20 \%$ a los niveles de 2019 . El quinto apartado recoge los descensos que los confinamientos han ocasionado en el ritmo de construcción y de iniciación de viviendas, subrayando como las ventas de viviendas nuevas son inferiores a las viviendas terminadas en este año, evolución que no se producía desde 2012. El sexto y último apartado resume las principales modificaciones aparecidas en materia de política de vivienda, entre las que destaca la extensión a 2022 del Plan Estatal de Vivienda 2018-21 y el fuerte aumento de las partidas de

Julio Rodriguez López es doctor en CC. Económicas. Ha sido presidente del Banco Hipotecario de España y de Caja Granada. Correo electrónico: julio.r.lopez@pataura.e.telefonica.net 
gasto publico destinados a vivienda, en especial las ligadas a la rehabilitación.

\section{Las experiencias de 2020 y las previsiones tras los procesos de confinamiento}

El momento más difícil para la economía mundial como consecuencia de la pandemia de la Covid 19 en 2020 se produjo en el mes de abril, al que sucedió una recuperación moderada en los meses de mayo y junio. A pesar de esto último el resultado global fue de un descenso acusado de la actividad y del empleo en el segundo trimestre del año. Tras una clara recuperación en el tercer trimestre, los rebrotes de la pandemia producidos a partir del verano han contribuido a frenar la senda de recuperación. De este modo en el último trimestre del año han podido producirse nuevos descensos del nivel de actividad, que pueden acentuar el retroceso de la actividad global en 2020 (OCDE, 2020).

En 2020 se ha puesto de manifiesto la seria dificultad para subsistir de numerosas empresas, que han precisado de importantes ayudas para mantener la actividad. Las dificultades han sido mayores en general en el sector de los servicios, especialmente en los subsectores del turismo y de los viajes aéreos. La vacunación intensa prevista para 2021 ayudará a recobrar una mayor confianza y a una recuperación gradual de la actividad en los años posteriores. A fines de 2021 podrían alcanzarse niveles de actividad equivalentes a los anteriores a la crisis, aunque en numerosos países todavía persistirán durante 2022 niveles inferiores a los de la etapa prepandemia.

De acuerdo con las previsiones del Fondo Monetario Internacional (FMI, 2020) el PIB mundial, tras crecer a un ritmo del 2,8\% en 2018, habrá retrocedido en un $4,4 \%$ en 2020 , mientras que en 2021 puede tener lugar una recuperación del $5,2 \%$ en 2021. El descenso de la actividad en 2020 va a ser superior en los países de economías avanzadas $(-5,8 \%)$ respecto de los países de economías emergentes (-3,3\%) (FIG. 1). El comercio mundial habrá descendido en un $10,4 \%$ en 2020 , previéndose una recuperación del mismo de un 8,3\% en 2021 (FMI, op. cit.)

La realidad de unos procesos de vacunación intensivos en 2021 puede aumentar la confianza general y rebajar las necesidades de ahorro precautorio. Esta evolución puede animar la demanda de consumo y permitir recuperaciones más acusadas de la economía, que se dejarán sentir sobre todo en 2022. La intensidad que parece presentar el nuevo rebrote de la pandemia en el último mes de 2020 puede generar nuevos retrocesos de la actividad. De este modo el retorno hasta los

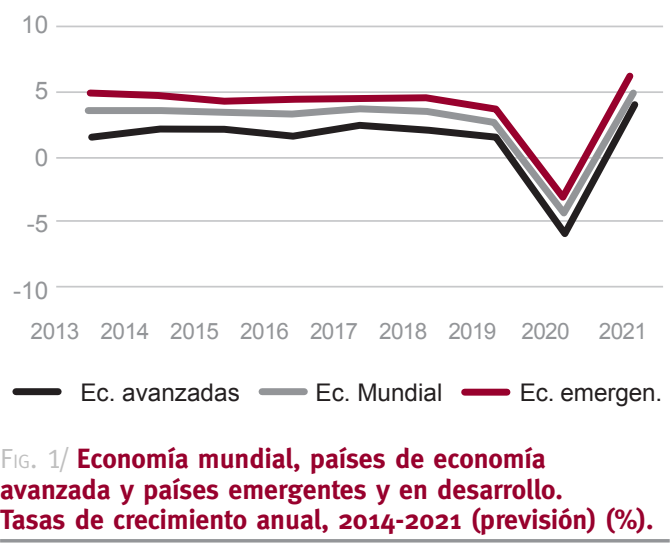

Fuente: FMI.

niveles previos a la pandemia puede sufrir un nuevo retroceso.

Los procesos de confinamiento asociados con la pandemia del coronavirus Covid 19 puede revertir buena parte de los logros conseguidos después de 1990. Esta evolución acentuará las desigualdades y los niveles de pobreza. La política monetaria desarrollada por los bancos centrales, basada en la adquisición masiva de deuda pública y de bonos, se ha convertido en una auténtica barrera que está permitiendo mantener mayores niveles de actividad. Los tipos de interés continúan situados en niveles reducidos, presentando un nivel negativo el Euribor a doce meses. La pandemia está asociada con los mayores aumentos de deuda pública registrados en 2020 después de la última guerra mundial.

Aunque la vacunación masiva prevista para 2021 puede generar una mejoría sustancial de las previsiones, los errores desarrollados en las primeras etapas de aparición de la pandemia generarán consecuencias negativas durante cierto tiempo. Los aumentos de las desigualdades y de la pobreza han sido espectaculares en Estados Unidos, mientras que las ayudas a las empresas y a los autónomos han impedido que la crisis social alcanzase un nivel similar en Europa.

En el periodo 2021-22 Europa vivirá bajo la sombra de la deflación (A. Touze, 2020). El mayor volumen de la deuda tendrá carácter interno, esto es, el principal acreedor será el respectivo banco central. El aumento del endeudamiento general, del déficit público y de la deuda pública llevará a replantearse la conveniencia o no de desarrollar políticas estabilizadoras. Deberá impedirse la repetición de los errores cometidos durante la crisis precedente de 2008-2011, de forma que sea posible ayudar a los sectores más necesitados, así como también llevar a cabo las inversiones asociadas con la transición energética necesaria para la descarbonización de las economías. 


\section{La incidencia negativa de la pandemia sobre la economía española}

La economía española registro una etapa de crecimiento continuado entre 2014 y 2019 , en cuya evolución el positivo comportamiento de las exportaciones desempeñó un papel importante. La aparición de un intenso brote del coronavirus Covid 19 en marzo de 2020 dio lugar a procesos de confinamiento obligatorio. Esta circunstancia contribuyó a reducir la actividad y el empleo, en especial en el turismo y otros servicios, que tienen un peso mayor en España que en el resto de países de la Eurozona.

EI PIB de la economía española presentó variaciones trimestrales negativas en los dos primeros trimestres del año. Los descensos de actividad tuvieron una especial intensidad en el segundo trimestre de 2020. En este periodo fueron notables los retrocesos trimestrales que tuvieron lugar en la inversión en bienes de equipo $(-29,9 \%)$, construcción (-22,5\%). Destacaron sobre todo los descensos asociados con el comercio internacional. Las exportaciones disminuyeron en un $33,4 \%$, por encima de la caída de las importaciones $(-29,5 \%)$.

A pesar de la fuerte recuperación de la actividad en el tercer trimestre de 2020 , el nivel del PIB en dicho periodo era inferior en un $9 \%$ al correspondiente al cuarto trimestre de 2019. En el conjunto de los tres primeros trimestres de 2020 el PIB de la economía española descendió en un $11,5 \%$ respecto del mismo periodo de 2019 (FIG. 2). La

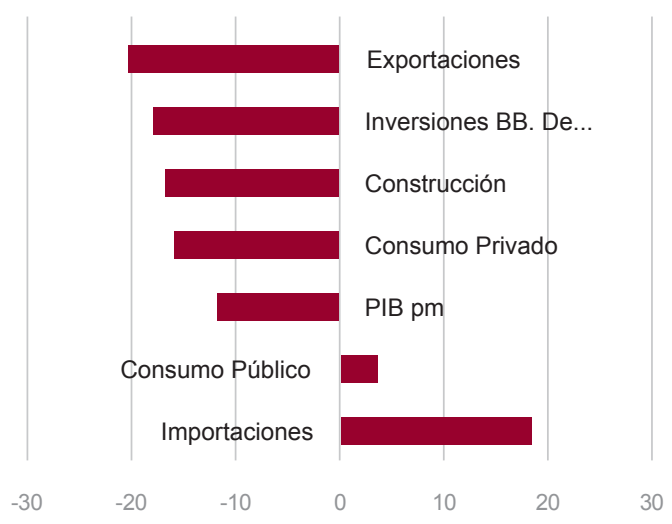

Economía española. Principales agregados macroeconómicos. Tasas de variación 2020/2019 (\%), tres primeros trimestres.

Fuente: INE.

demanda interna retrocedió en un $10,5 \%$, lo que indica que la aportación del resto del mundo fue negativa en este periodo, reflejo de la amplitud internacional de la crisis de actividad y de empleo.

La aparición de nuevos rebrotes del coronavirus desde septiembre frenó la intensidad del proceso de recuperación de la actividad perdida en la primera "ola" del Covid 19. Esta evolución ha llevado a que diferentes organismos internacionales hayan establecido previsiones muy negativas respecto de la evolución de la economía española en 2020.

Las previsiones del consenso de Funcas sitúan dicha variación en un retroceso del PIB en un 11,8\% (FIG. 3). La demanda interna descenderá

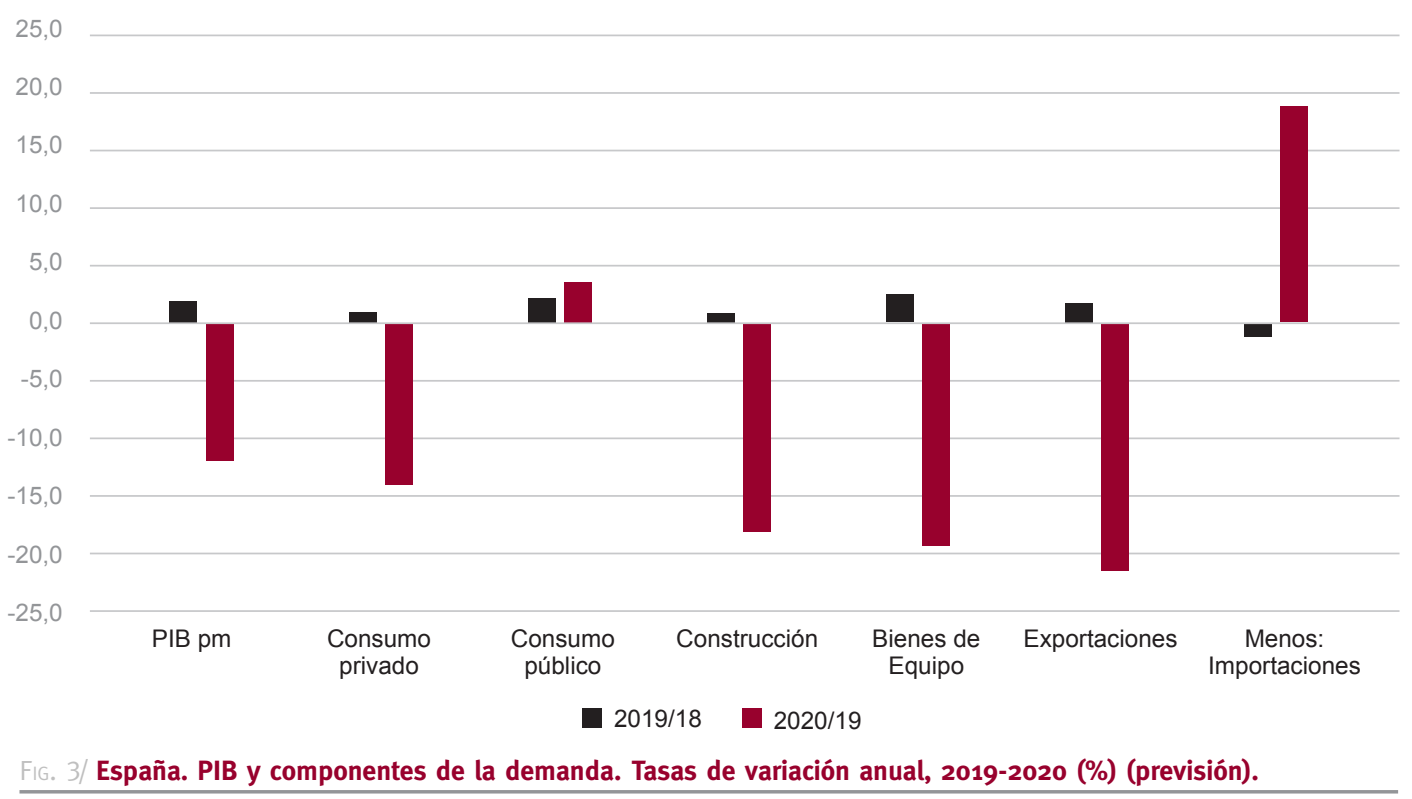

Fuente: INE y FunCAS 
un 10,6\% según dicha previsión, y la aportación neta del resto del mundo se aproximará un punto porcentual negativo. La previsión del FMI de octubre de 2020 anticipó para España un retroceso del $12,8 \%$ mientras que la OCDE, en su informe semestral aparecido en diciembre de 2020 , ha situado el descenso en cuestión en un 11,6\%. Dicho descenso supera la previsión correspondiente al conjunto de la Eurozona, el $-7,5 \%$ según el FMI y la OCDE.

La contracción de la actividad ha afectado de forma negativa a la evolución del empleo. Según la Encuesta de Población Activa del INE, los ocupados disminuyeron en los dos primeros trimestres del año, destacando la caída del empleo en un $6,7 \%$ en el segundo trimestre, según la serie trimestral corregida de variación estacional.

La tasa de desempleo, que se situó en el $14,1 \%$ en 2019 , aumentó hasta un 16,3\% de la población activa en el tercer trimestre de 2020 . En este periodo el empleo se redujo en un $3,5 \%$ respecto de 2019, descenso correspondiente a una disminución anual de los ocupados en 697.500. El número de afiliados a la Seguridad Social retrocedió en noviembre de 2020 en un 2,3\% sobre el mismo mes del año anterior, correspondiendo dicha variación relativa a una disminución absoluta de los afiliados en 440.800 (FIG. 4).

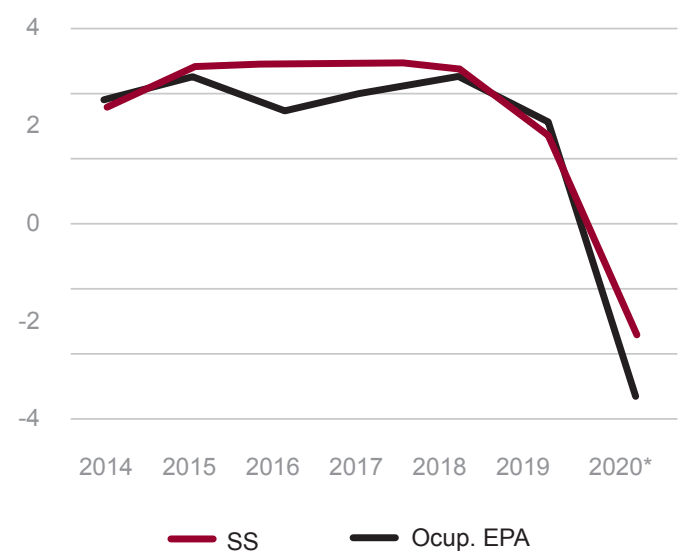

Empleo. Ocupados EPA y Afiliados a la S. Social. Tasas de variación interanual (\%). Datos a fin de año, 2014-2020 (previsión).

Fuente: INE y MINISTERIO de INCLUSIÓN Y SEGURIDAd SOCIAL.

El índice de precios de consumo disminuyó en un $0,8 \%$ en noviembre de 2020 sobre igual periodo de 2019. La inflación subyacente (productos no alimenticos y no energéticos), creció en un $0,7 \%$ en el mismo periodo de tiempo. Los productos alimenticios han crecido, destacando el $2 \%$ de variación anual registrada por los alimentos no elaborados, mientras que los productos energéticos han disminuido en noviembre en un $9,5 \%$. El saldo positivo de la balanza de pagos por cuenta corriente, que se elevó al $1,6 \%$ del PIB en 2019 , se ha previsto por Funcas que descienda hasta el 0,6\% en 2020.

En 2020 destaca la previsible aprobación de unos Presupuestos Generales del Estado para 2021 en los que el gasto publico crecerá en un $17,5 \%$, aumento que se cubrirá con un déficit mayor, cuyo nivel relativo ascenderá al $12,4 \%$ del PIB, mientras que la deuda publica pasará desde el 96,9\% del PIB en 2019 hasta el 116\% en 2020. El Estado y el sector privado podrán obtener financiación en los mercados de capitales en condiciones muy favorables. De ese modo, el reto para 2021 será sobre todo el de emplear mejor las mayores disponibilidades de recursos (R. TORRES, 2020).

\section{Mercado de vivienda (I). Precios y alquileres}

Después del hundimiento de precios que sucedió al "pinchazo" de la burbuja inmobiliaria, el mercado de vivienda se recuperó en España a un ritmo moderado pero firme entre 2013 y 2019. Tras un cierto enfriamiento de dicho mercado en 2019, en 2020 la pandemia de la Covid 19, con su secuela de confinamientos, ha ejercido una poderosa influencia negativa. A unos descensos importantes en los dos primeros trimestres del año sucedió un aumento espectacular de los indicadores del mercado de vivienda en el tercer trimestre de 2020.

Pero dicha evolución tuvo carácter más bien de "rebote" que de recuperación. La marcha de los indicadores en el último trimestre del año parece indicar que la reactivación no ha tenido continuidad. 2020 habrá sido un ejercicio negativo para el mercado inmobiliario. Lo importante ahora es que la economía española se recupere de forma significativa en 2021 y que la política de vivienda contribuya a mejorar la accesibilidad a la vivienda en el próximo ejercicio.

El índice de precios de la vivienda del INE registró un aumento trimestral del $1,1 \%$ en el tercer trimestre de 2020 (0,1\% en el trimestre precedente). Dicho aumento se debió sobre todo al importante incremento registrado por los precios de la vivienda de nueva construcción (4,7\%). El aumento interanual de los precios de la vivienda fue el $1,7 \%$ en el tercer trimestre de 2020 sobre el mismo periodo del año precedente (FIG. 5). 


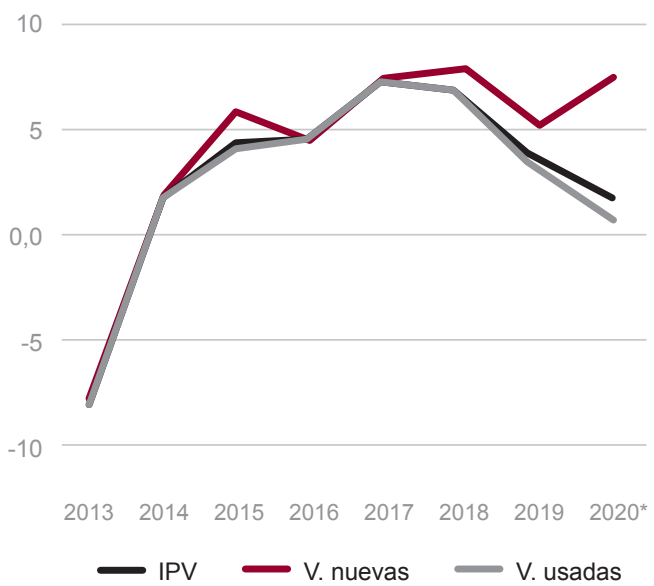

/ Índice de precios de vivienda. Total, nuevas y usadas. Tasas de variación anual, 2013-2020 (previsión) (\%).

Fuente: INE.
El crecimiento interanual de los precios de la vivienda nueva fue el $7,5 \%$, mientras que en el caso de la vivienda usada el crecimiento anual se redujo al $0,8 \%$. La escasez de la oferta de nuevas viviendas puede ser la variable que mejor explique el importante desnivel existente entre las variaciones de los precios de las viviendas de nueva construcción y las usadas. Así, en el tercer trimestre de 2020 , el valor medio de tasación ascendió a $1.899,4$ euros $/ \mathrm{m}^{2}$ para viviendas de hasta cinco años de antigüedad, mientras que dicho valor fue de $1.610,7$ euros $/ \mathrm{m}^{2}$ para las de más de cinco años. El valor de tasación medio de las viviendas de nueva construcción supera en casi un $18 \%$ al de las viviendas usadas.

Por comunidades autónomas el aumento interanual de los precios de la vivienda más elevado en el tercer trimestre de 2020 fue el de Baleares $(3,4 \%)$, seguido por Murcia (3\%). Las variaciones más modestas de los precios fueron las de la Comunidad de Madrid (1,2\%) y Extremadura (0\% (FIG. 6). El precio medio de venta de las viviendas

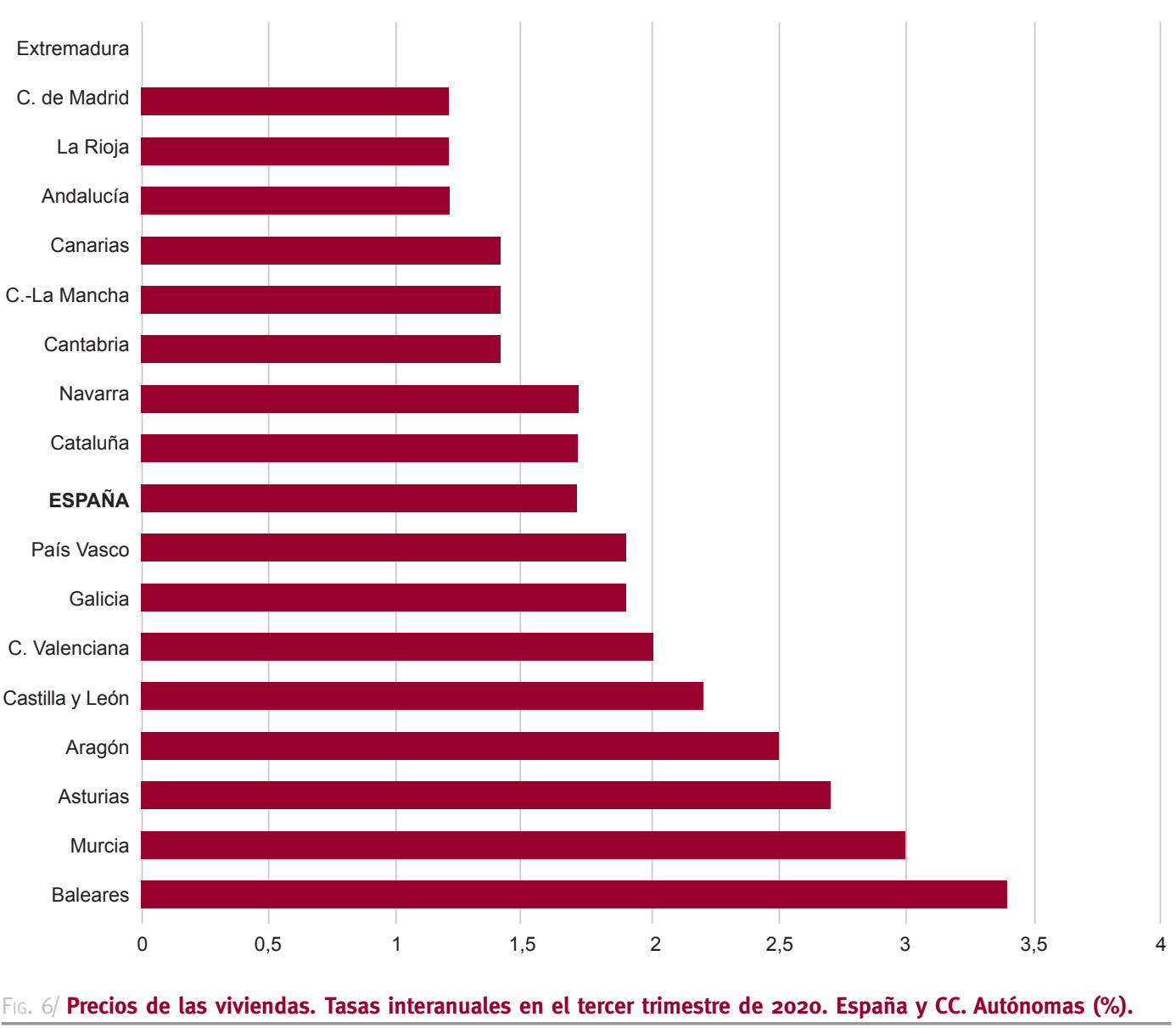

Fuente: INE. 
3500

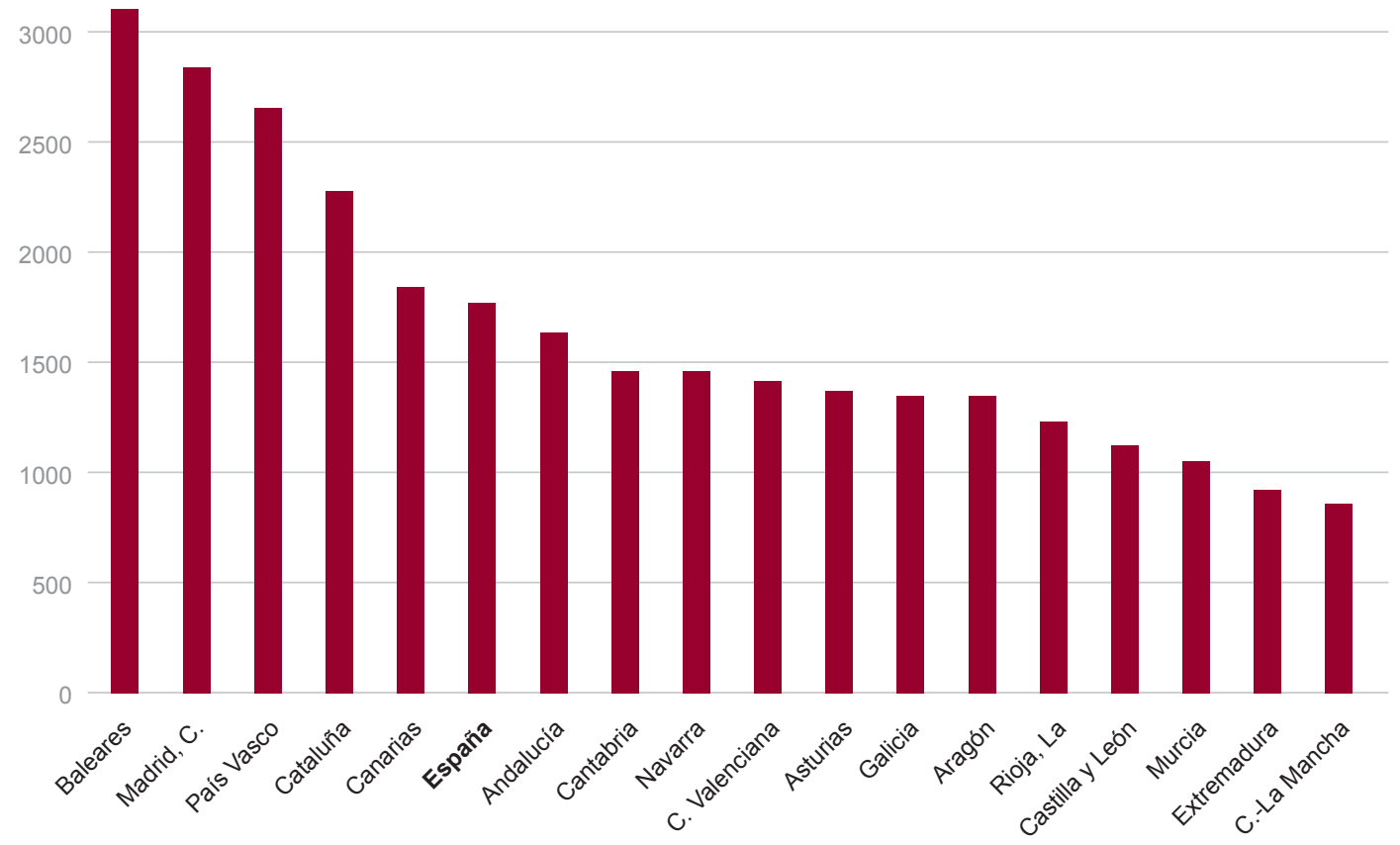

/ Precios de las viviendas, España y CC. Autónomas, tercer trimestre de 2020 euros $/ \mathrm{m}^{2}$.

según Idealista.com ascendió a 1.769 euros $/ \mathrm{m}^{2}$. Los precios de venta más elevados, según dicha fuente estadística, correspondieron a Baleares (3.103 euros $/ \mathrm{m}^{2}$ ) y a la Comunidad de Madrid (2.832 euros $\left./ \mathrm{m}^{2}\right)$. Las autonomías con precios de venta medios más reducidos fueron Extremadura (922 euros $/ \mathrm{m}^{2}$ ) y Castilla-La Mancha (856 euros/ $\mathrm{m}^{2}$ ) (FIG. 7). El aumento anual de los precios de venta de las viviendas según Idealista.com fue el $0,4 \%$ en noviembre de 2020 .

Tras los importantes aumentos registrados por los alquileres hasta 2019, la tendencia alcista se mantuvo más moderada en el primer trimestre de 2020. A partir de este periodo la evolución de los alquileres fue de estancamiento (FIG. 8), coincidiendo con la aparición del brote de corona virus en marzo de 2020. El nivel de los alquileres se situó en 11,2 euros $/ \mathrm{m}^{2}$-mes en noviembre de 2020, un 3,6\% por encima del mismo periodo de 2019. En dicho mes los niveles de alquileres más elevados correspondieron a la Comunidad de Madrid (14,5 euro/m²-mes), Cataluña (14 euros/ $\mathrm{m}^{2}$-mes). Los niveles medios más reducidos de alquileres en el mes citado fueron los de CastillaLa Mancha $\left(5,7\right.$ euros $/ \mathrm{m}^{2}$-mes) y Extremadura, con 5,3 euros $/ \mathrm{m}^{2}$-mes (FIG. 9).

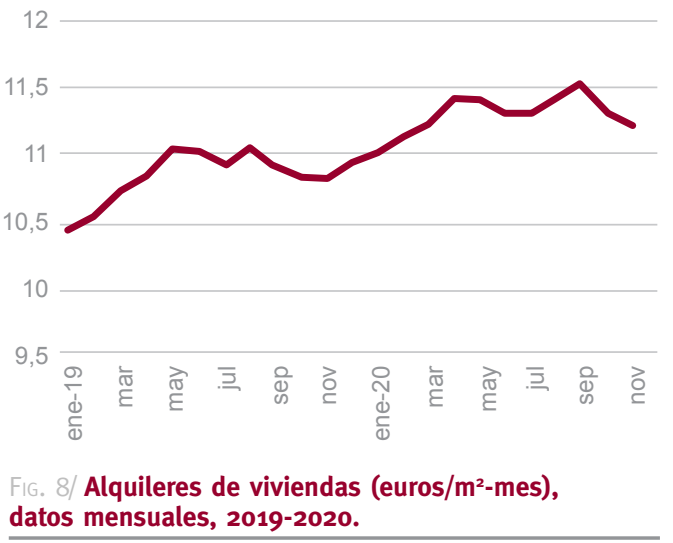

Fuente: Idealista.com.

La corrección a la baja de los aumentos de precios y de alquileres en 2020 no impidió que en dicho año dichas magnitudes registrasen aumentos ligeros, pero superiores a los de los salarios. En el periodo comprendido entre 2013 y 2020 los aumentos acumulados de los precios de los alquileres fue el $56,9 \%$, el de los precios de las viviendas alcanzó el 33,8\%, mientras que los salarios por persona ocupada, estimados por el 


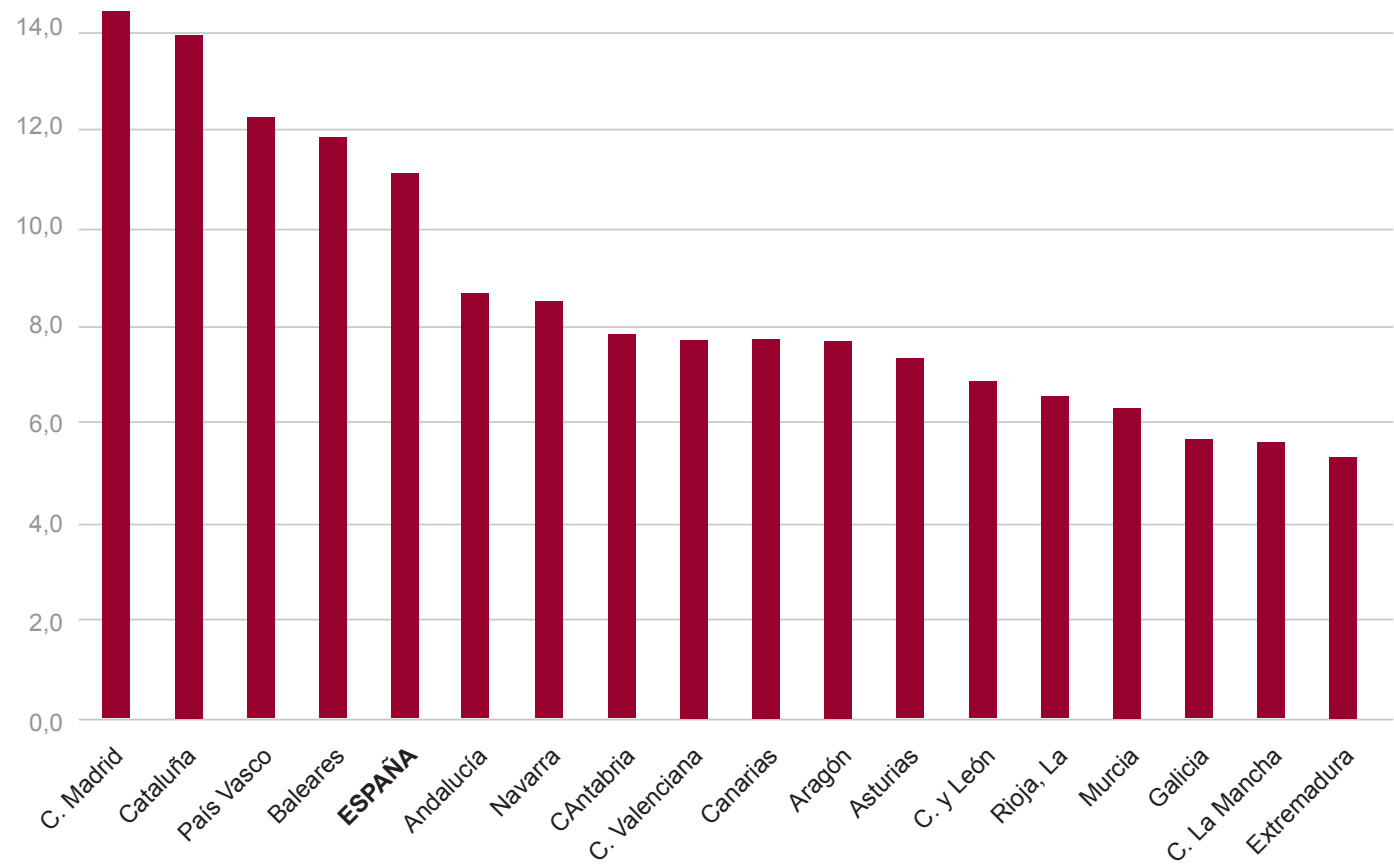

FIG. 9/ Alquileres. España y CC. Autónomas, euros/m²-mes. Datos de noviembre de 2020.

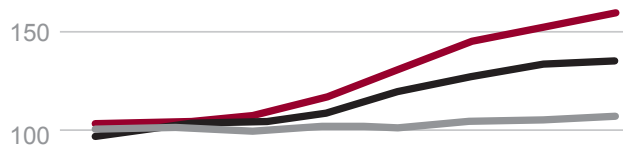

50

0 2013201420152016201720182019 2020*

- Precios Alquiler Salarios

Fig. 10/ Viviendas: Precios, alquileres y Salarios, $100=2013$. Datos anuales, 2013-2020 (previsión),

Fuente: INE e Idealista.com.

INE en su encuesta trimestral de salarios, fue solo el 3\% (FIG. 10). Dicha evolución conjunta de alquileres, precios de venta y salarios explican de forma clara las dificultades crecientes de acceso a la vivienda para los hogares, en especial para los de nueva creación.

\section{Mercado de vivienda (II) Demanda, financiación, tipos de interés}

Como antes se indicó, la debilidad del crecimiento de la economía española en el último trimestre de 2020 no ha ayudado a la persistencia del crecimiento de las variables básicas del mercado de vivienda. 2020 va a ser, como tantos otros mercados y actividades, un año negativo para el mercado de vivienda, como consecuencia de los sucesivos brotes de la pandemia del coronavirus Covid 19.

La caída del empleo ha producido un descenso en la renta disponible de los hogares, lo que ha frenado las compras de vivienda. Así, pues, las compraventas de viviendas pueden descender en 2020 en un $20 \%$, el número de préstamos hipotecarios puede disminuir en un $16 \%$ y el consumo aparente de cemento retrocederá en más del $10 \%$. Crecerá la morosidad bancaria por el lado de los préstamos a comprador de vivienda. Los precios de venta de las viviendas y los alquileres registrarán ligeros descensos. 
El retroceso del empleo, visible en la evolución de los afiliados a la Seguridad Social, que descendió en un $2,3 \%$ entre noviembre de 2020 y el mismo mes del año anterior (FIG. 11), unido al descenso medio de los salarios registrado en el promedio de los tres primeros trimestres del año $(-5,2 \%)$, contribuyó a que retrocediera la renta disponible de los hogares en los tres primeros trimestres de 2020. Dicha circunstancia contribuyó a deprimir la demanda de vivienda en este año.

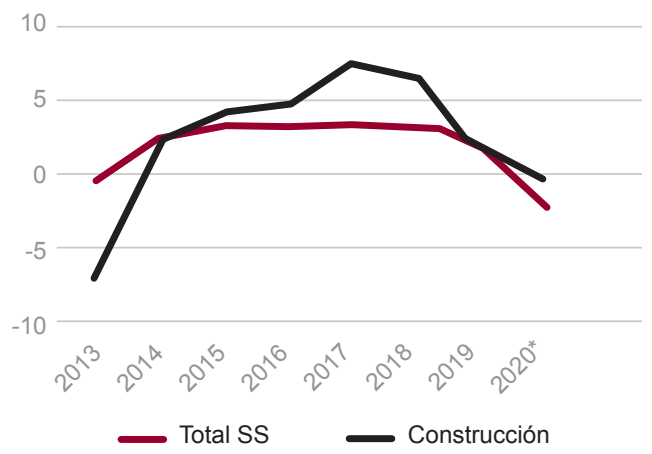

FIG. 11/ Afiliación a la Seguridad Social. Total afiliados y afiliados en el sector de la construcción. Tasas de variación interanuales, 2013-2020 (previsión) (\%).

Fuente: MinISTERIO de InCLUSIÓN Y dE LA SEgURIDAd SOCIAL.

El número de hipotecas formalizadas con garantía de una vivienda descendió en un 7,6\% en los nueve primeros meses de 2020 sobre el año anterior (FIG. 12). Dicho descenso fue más acusado en el número de préstamos hipotecarios destinados a la compra de vivienda, según la estadística notarial. Puesto que el descenso de las compraventas de viviendas fue superior al del número de hipotecas citado, la proporción de compras de viviendas financiadas con un préstamo hipotecario aumentó en 2020 , alcanzando dicha proporción un nivel del $84 \%$, muy superior al de los años anteriores (FIG. 13).

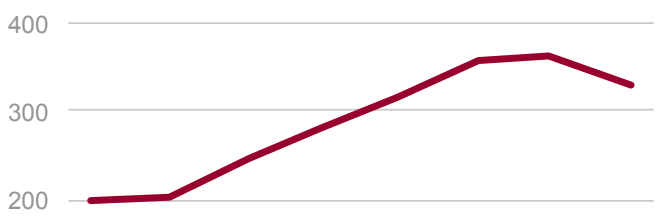

100

0

20132014201520162017201820192020

Número de hipotecas sobre viviendas (miles). Totales anuales, 2013-2020 (previsión).

Fuente: INE.

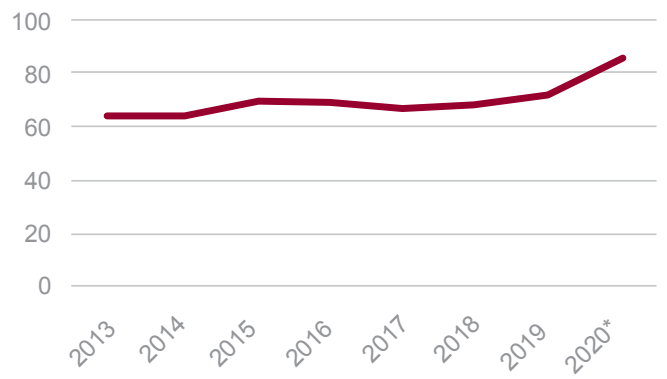

Proporción de hipotecas registradas sobre compraventas registradas de viviendas (\%). Datos anuales, 2013-2020 (previsión).

Fuente: INE.

En 2020 los tipos de interés de los préstamos a comprador de vivienda disminuyeron a un ritmo moderado a lo largo del año, situándose en noviembre en el 1,66\% (FIG. 14). El tipo de interés del índice de referencia de los préstamos hipotecarios para compra de vivienda, el Euribor a doce meses, descendió asimismo en los nueve primeros meses de 2020. El diferencial entre los tipos de interés de los préstamos y el Euribor creció ligeramente a lo largo de 2020, situándose en noviembre en el nivel de 2,14 puntos porcentuales.

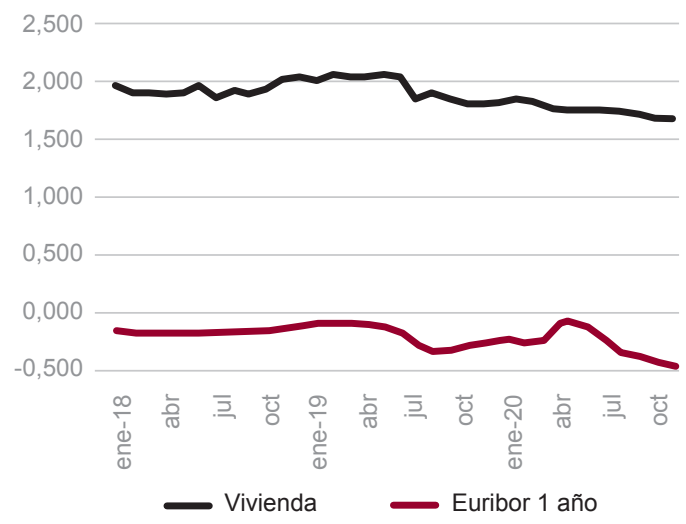

FiG. 14/ Tipos de interés de los préstamos a comprador de vivienda y euribor a 12 meses (\%). Datos mensuales, 2018-2020.

Fuente: BANCO DE España.

El volumen de nuevos préstamos a comprador de vivienda, estimado mediante encuesta por parte del Banco de España, descendió en un $3,3 \%$ en 2020 sobre el ejercicio precedente en el periodo enero-octubre, alcanzando un volumen previsiblemente superior a los 42.100 millones de euros en este año. El descenso fue mayor en el caso de las operaciones no renegociadas, que disminuyeron en un $6,9 \%$. 
La evolución de las dos magnitudes citadas implicó que en 2020 ha tenido lugar un fuerte aumento de las operaciones de crédito renegociadas. Dichas operaciones alcanzaron los niveles más elevados en los meses de mayo y junio, y en el periodo septiembre-octubre mantuvieron niveles muy superiores a los correspondientes a los cuatro primeros meses del año (FIG. 15). Esta evolución revela la presencia de dificultades para hacer frente a las cuotas de los préstamos a comprador de vivienda, como consecuencia del descenso registrado en los niveles de actividad y empleo en los meses correspondientes a la "primera ola" de la pandemia.

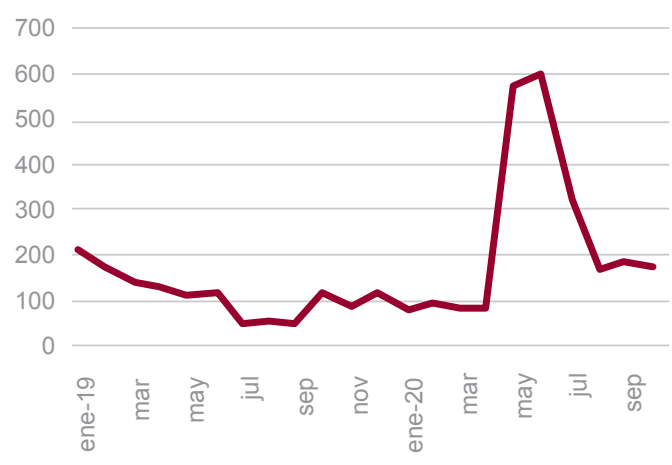

Créditos a comprador de vivienda,

operaciones renegociadas, millones de euros.

Datos mensuales, 2019-2020.

Fuente: BANCo de EsPaña

Según datos procedentes de los registros de la propiedad publicados por el INE, las compraventas de viviendas disminuyeron en un $21,2 \%$ en el periodo enero-octubre de 2020 sobre el año precedente. El nivel previsible de compraventas para 2020 puede estar por debajo de las 400.000 compraventas, unas cien mil viviendas menos vendidas que en 2019, año en el que el volumen de ventas ascendió a 501.086 (FIG. 16). El descenso fue más acusado en las ventas de viviendas de segunda mano, que retrocedieron en un $22,8 \%$ sobre el año precedente, mientras que el retroceso de las ventas de viviendas de nueva construcción fue el $14,3 \%$.

El descenso de las compraventas de viviendas estimado en la estadística de los notarios fue el $19,5 \%$ en el periodo enero-octubre de 2020 . El número de préstamos hipotecarios destinados a la compra de una vivienda disminuyó en un $13,9 \%$ en el periodo citado. En la información estadística publicada por el Consejo General del Notariado destaca la cifra correspondiente a las ventas mensuales de viviendas corregidas de estacionalidad. A la vista del perfil mensual de dichas ventas en 2020 (FIG. 17) se deduce

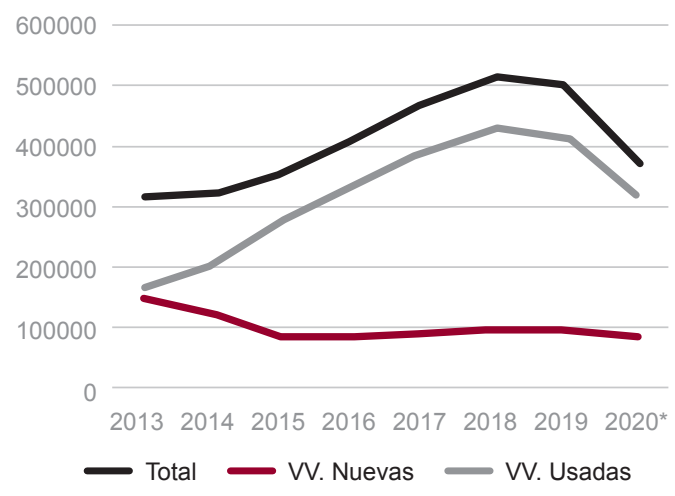

FIG. 16/Compraventas registradas de viviendas. Totales anuales, 2013-2020 (previsión), viviendas nuevas y usadas.

Fuente: INE.

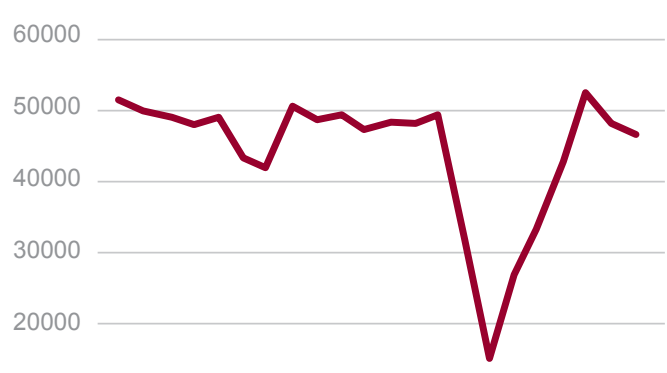

10000

0

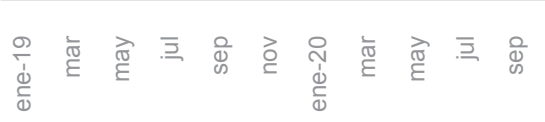

17/ Compraventas de viviendas, Serie mensual, 2019-2020, corregida de variación estacional.

Fuente: Estadística Registral, Consejo General del Notariado.

que dichas ventas registraron disminuciones destacadas entre los meses de marzo y junio de este ejercicio. La recuperación de las ventas fue importante en el tercer trimestre de 2020, desacelerándose la recuperación en octubre.

\section{Mercado de vivienda (III). La nueva oferta}

Las viviendas iniciadas, estimadas mediante los visados de obra nueva emitidos por los Colegios de Arquitectos Técnicos, descendieron en un $17,5 \%$ en los nueve primeros meses de 2020. La previsión para 2020 es de un total de iniciaciones que puede estar por debajo de las 90.000 (106.300 fue el total correspondiente a 2019) (FIG. 18). 


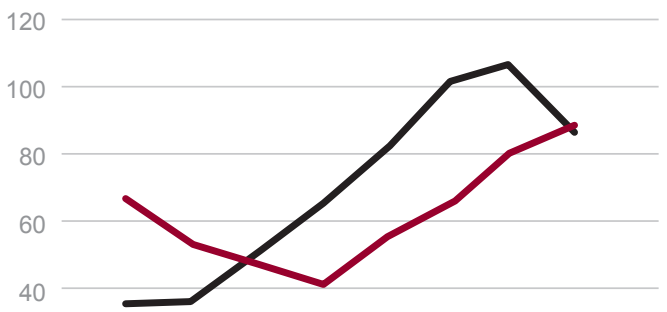

20

0

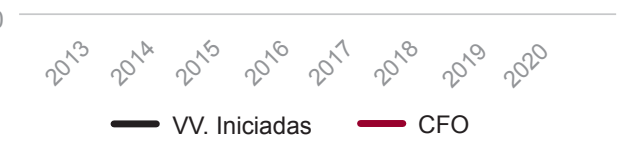

Viviendas. Visados de obra nueva y certificados de fin de obra (CFO). Datos anuales, 2013-2020 (previsión).

Fuente: $M^{\circ}$ DE Transportes, MoviLidad y Agenda URbana.

Las viviendas terminadas, estimadas a partir de los certificados de fin de obra emitidos asimismo por los Colegios de Arquitectos Técnicos, crecieron en un $10,9 \%$ en el periodo correspondiente a los tres primeros trimestres de 2020.La previsión para 2020 es de un total de viviendas terminadas de 87.400 .

Las nuevas viviendas construidas después de la crisis de 2008-11 han evolucionado en unos niveles reducidos si se comparan los totales anuales del periodo 2013-2019 con las construcciones previas a la etapa de la "burbuja" inmobiliaria. En las compraventas de viviendas registradas ha habido un fuerte predominio de las ventas de viviendas usadas frente a las de nueva construcción. Esta últimas han destacado en 2020 por el sensible mayor aumento de los precios de venta, el $7,5 \%$ anual en el tercer trimestre de 2020 , frente al $1,7 \%$ de aumento de los precios del conjunto de las viviendas.

A pesar del aumento experimentado por las viviendas terminadas en 2020 , los niveles alcanzados por dicha magnitud en el periodo de recuperación comprendido entre 2013 y 2019 han sido también muy inferiores a los correspondientes a la etapa pre-burbuja. En 2020 ha sido importante el aumento de las viviendas terminadas promovidaspor cooperativas, mientras que ha descendió ligeramente el número de viviendas terminadas promovidas por las administraciones públicas.

La previsión para 2020 es de un total de viviendas terminadas de 87.400 , de los que 4.165 habrían sido promovidas por cooperativas y unas 480 lo habrían sido por las administraciones públicas. El conjunto de viviendas promovidas por

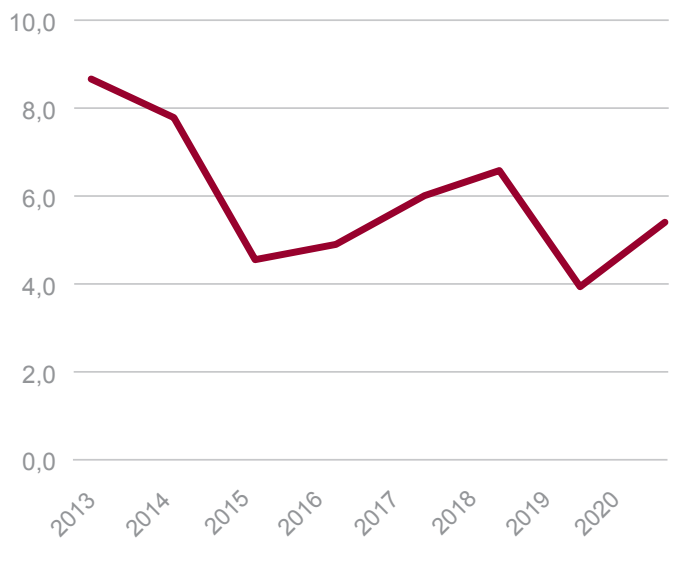

Viviendas terminadas. Proporción de viviendas construidas por cooperativas y por administraciones públicas (\%). Datos anuales, 2013-2020 (previsión).

Fuente: MITMA.

cooperativas y administraciones públicas podría suponer en 2020 el 5,3\% del total de viviendas terminadas, proporción reducida pero superior a la del año precedente (FIG.19).

En la etapa de recuperación del mercado de vivienda comprendida entre 2013 y 2019 las ventas de viviendas de nueva construcción han superado ampliamente a las viviendas nuevas terminadas. Ello puede implicar que en el periodo citado de recuperación de la demanda se ha dado salida a una parte importante del amplio stock de viviendas terminadas y no vendidas que existía al término de la fase de recesión posterior a la "burbuja". En 2020 las viviendas terminadas pueden superar por primera vez desde 2012 al número de ventas de viviendas de nueva construcción (FIG. 20).

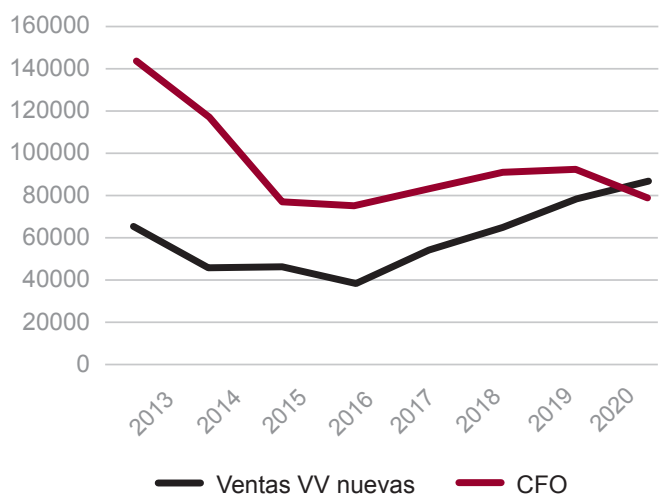

FIG. 20/Viviendas terminadas (CFO) y ventas de viviendas de nueva construcción. totales anuales, 2013-2020 (Previsión).

Fuente: INE y MITMA. 


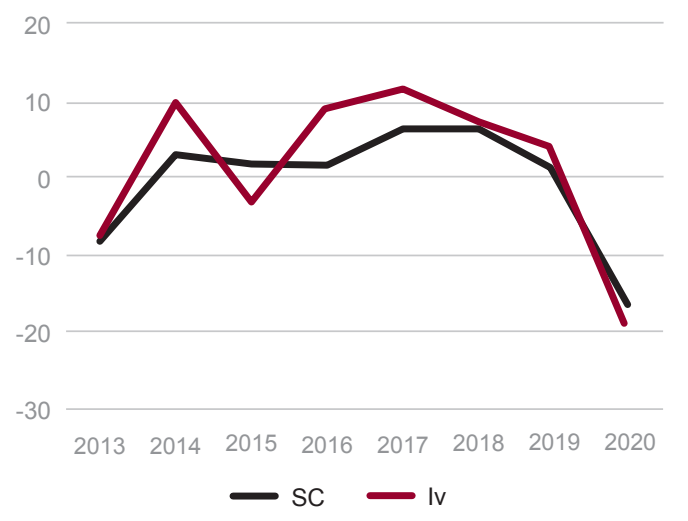

FIG. 21/ Vivienda y sector de la construcción. Tasas de variación interanual, precios constantes, 2013-2020 (previsión).

Fuente: INE.

Como consecuencia de la pandemia y de los confinamientos derivados de la misma, el sector de la construcción ha sufrido un descenso importante en los tres primeros trimestres de 2020. Según la Contabilidad Nacional Trimestral, en los tres primeros trimestres de 2020 el retroceso del sector de la construcción por el lado de la demanda ha alcanzado un ritmo del $-16,6 \%$, resultando superado dicho descenso por el subsector de la vivienda (-19,3\%). En este último el prolongado confinamiento ha impedido un mayor ritmo de nueva construcción y de iniciaciones de nuevas viviendas (FIG. 21).

\section{Política de vivienda}

En 2020 las ventas de Viviendas de Protección Oficial (VPO) han descendido a un ritmo superior al del conjunto de las ventas. En los diez primeros meses de este ejercicio dichas ventas retrocedieron en un $25,4 \%$, con lo que la previsión de ventas para 2020 se aproximará a un total de 35.500 VPO (FIG. 22). La mayoría de dichas ventas debe corresponder a viviendas protegidas usadas. Dicho total supone un $9,5 \%$ del total de ventas de viviendas en España previsto para 2020. La proporción resultó interior a la de 2019 (9,5\%).

En los tres primeros trimestres de 2020 el total de lanzamientos judiciales practicados en España descendió en un $53 \%$ sobre el año anterior. Dicha evolución no recoge las moratorias practicadas, que afectaron sobre todo al componente de lanzamientos asociados con el impago de alquileres. El retroceso de los lanzamientos asociados con los alquileres fue de un $51,8 \%$, mientras que en el caso de los lanzamientos asociados con el impago de un préstamo hipotecario la disminución fue de un 40,2\% (FIG. 23).

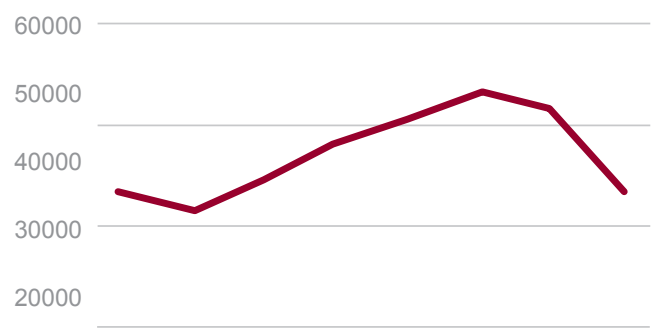

10000

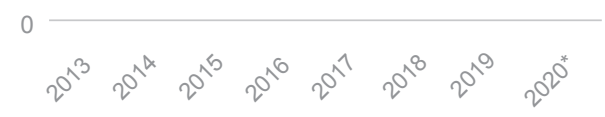

Compraventas de VPO. Número de viviendas, totales anuales, 2013-2020 (previsión).

Fuente: INE.

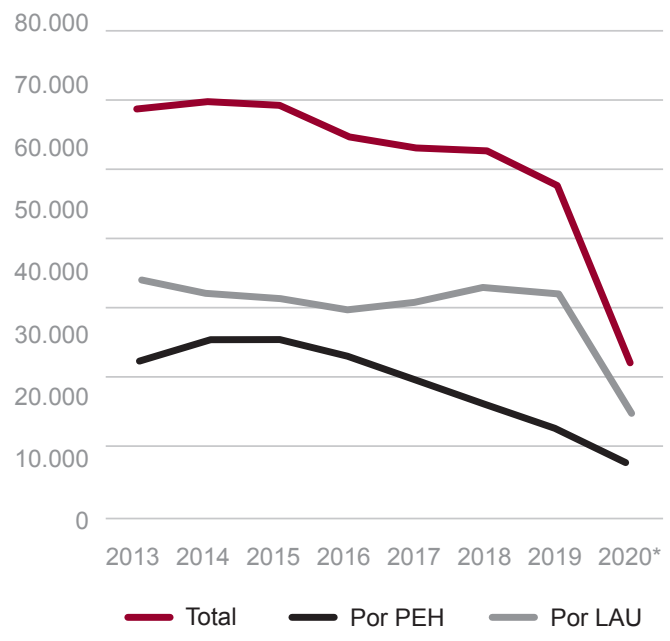

FIG. 23/ Lanzamientos judiciales practicados.

Total, por ejecución hipotecaria y por aplicación LAU. Datos anuales, 2013-2020 (previsión).

Fuente: Consejo General del Poder Judicial.

Los datos trimestrales revelan que el descenso de los lanzamientos tuvo lugar sobre todo en el segundo trimestre de 2020, periodo en el que fue mayor la incidencia de la pandemia, aunque los niveles del tercer trimestre también estuvieron por debajo de los del mismo periodo de 2019.

No se dispone de datos correspondientes al conjunto de 2020. Los datos disponibles por Comunidades Autónomas para 2019, revelan que, en materia de lanzamientos por impago del contrato de alquiler, de un total anual de 36.467 correspondió a Cataluña el nivel más elevado anual (8.427 lanzamientos), seguida de Andalucía (5.135) y Madrid (4.849) (FIG. 24). 


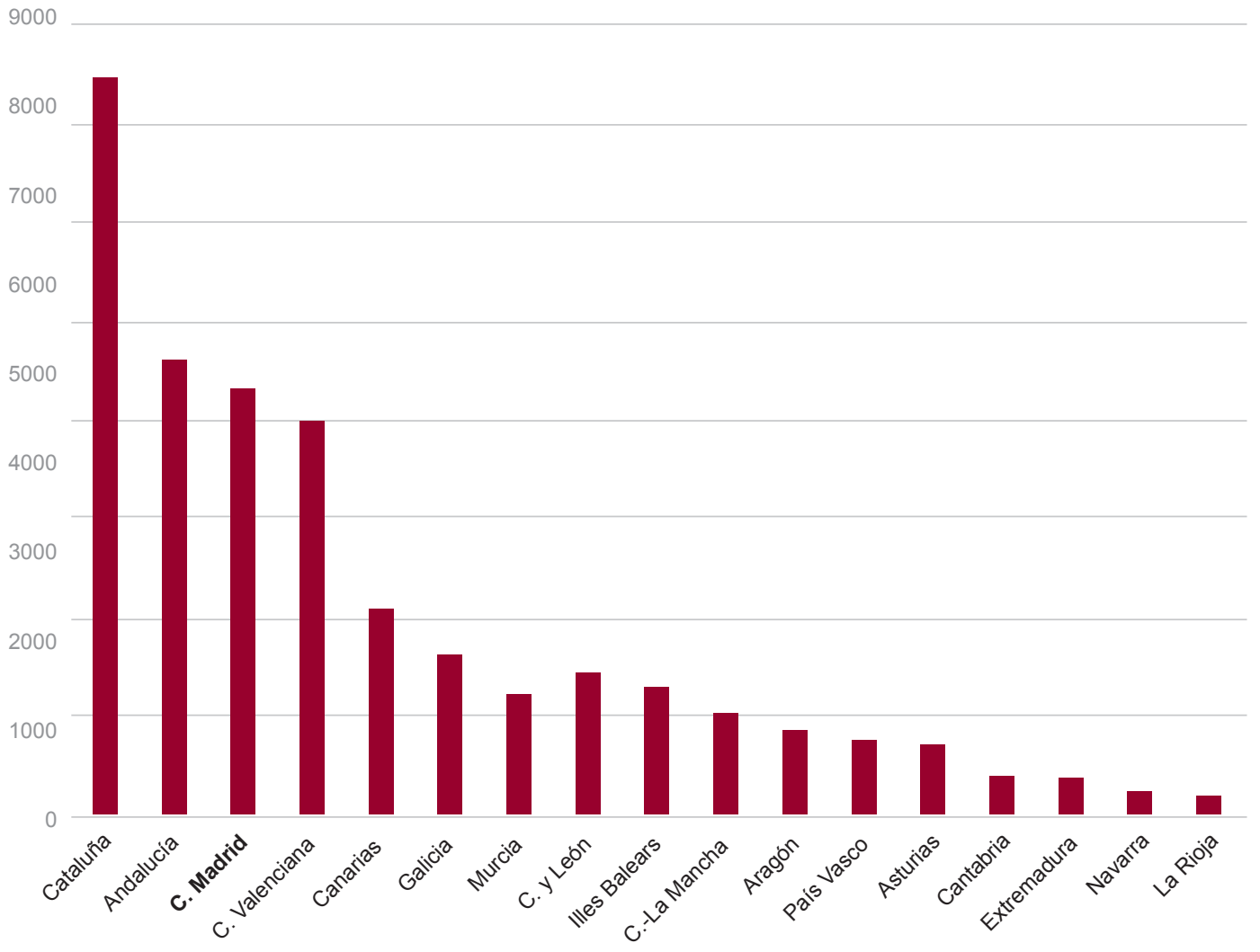

4/ Lanzamientos judiciales por impago de alquileres (LAU). Totales anuales en 2019.

Fuente: Consejo General del Poder Judicial.

En cuanto a los lanzamientos derivados de la ejecución de préstamos hipotecarios, de un total de 14.193 lanzamientos en 2019, fue Andalucía la autonomía con más desahucios de dicho tipo (3.117), seguida por la Comunidad Valenciana (2.633). Navarra y La Rioja aparecen en los últimos puestos en materia de lanzamientos judiciales, tanto en los ligados al cumplimiento de la ley de arrendamientos urbanos (LAU) como en los derivados de un préstamo hipotecario impagado.

El contenido del Proyecto de Presupuestos Generales del Estado para 2021 (PGE 2021) correspondiente a Vivienda implica un crecimiento significativo en el conjunto de las ayudas al gasto en vivienda y en el importe de las desgravaciones fiscales incluidas respecto del Proyecto de Presupuestos para 2018. Una parte de los gastos previstos se va a financiar con recursos procedentes del instrumento Next Generation EU. Se está todavía lejos de los niveles relativos de ayudas a la vivienda de hace más de diez años. Sin embargo, por primera vez en bastante tiempo hay un repunte de cierto alcance en la dimensión de las ayudas previstas para el acceso a la vivienda.
El gasto público directo destinado a la Vivienda asciende a 2.253 millones de euros en los PGE 2021 (474 millones en 2018). Dentro de dicha partida hay 72,0 millones de euros destinados a pagar subvenciones de intereses de planes precedentes. Esta partida tiene un lógico carácter decreciente. Dentro del apartado de gasto, 354 millones se destinarán a subvencionar el vigente Plan de Vivienda 2018-21. En dicho plan se incluyen sobre todo ayudas a los inquilinos para pagar el alquiler y subvenciones a la construcción de viviendas sociales.

En cuanto a las ayudas al alquiler, podrán desde 2021 subsidiar a alquileres de hasta 900 euros mensuales, mientras que hasta ahora el tope era de alquileres de hasta 600 euros al mes. Se conoce poco acerca de las viviendas sociales construidas por medio de las ayudas previstas en el vigente Plan Estatal de Vivienda 2018-21. El desconocimiento del destino de las partidas de gasto realizado a través de las autonomías impide valorar el alcance de las ayudas para la construcción de dicho tipo de viviendas. Airef señaló en su día que las partidas de gasto público 
peor conocidas en su destino final dentro de los presupuestos anuales estatales eran las ayudas a la vivienda concedidas a las autonomías.

Los PGE 2021 incluyen 100,4 millones de euros para el denominado Plan 20.000, que prevé la construcción del mismo número de viviendas sociales destinadas al alquiler. Dichas viviendas se construirían en solares pertenecientes hasta ahora al organismo SEPES, donde se incluyen los situados en la zona de los antiguos cuarteles del ejército en Madrid. El Ministerio de Transportes, Movilidad y Agenda Urbana no específica qué carácter tendrían dichas viviendas, si serian viviendas protegidas o viviendas libres con posibilidades o no de reventa rápida.

La novedad del Plan es la partida de gasto correspondiente a "Rehabilitación para la recuperación económica y social a través de las comunidades autónomas". Dicha partida asciende a 1.550,6 millones de euros y cubre actuaciones de rehabilitación que desarrollarían las comunidades autónomas y que el gobierno estatal subvencionaría con recursos procedentes de la Unión Europea. La rehabilitación de viviendas tiene buena prensa en España, está bien vista por todas las fuerzas políticas, pero el escaso parque de viviendas sociales existente solo aumenta si se rehabilitan viviendas vacías.

En las viviendas ocupadas, con la rehabilitación se mejora la calidad de vida de los ocupantes, pero no aumenta, pues, con ello la oferta de viviendas de alquiler. El gobierno hace una seria apuesta por la rehabilitación financiada mediante transferencias a las autonomías. Sin embargo, en los presupuestos no se introducen partidas de gastos significativas como para inducir un aumento importante del exiguo parque disponible de viviendas sociales de alquiler.

Las ayudas fiscales al acceso a la vivienda se aproximan a 2.700 millones de euros (2.172 en los PGE de 2018). Dentro de dicha partida destaca el alcance de las partidas destinadas a desgravar fiscalmente el acceso a la vivienda. El primer componente de la partida total antes citada es el relativo a la deducción en la cuota del IRPF a los compradores de vivienda habitual, cuya cuantía se eleva a unos 940 millones de euros y que está suprimida para nuevos adquirentes desde 2013. De momento disfrutan dicha deducción en la cuota del IRPF unos tres millones de contribuyentes. La deducción en la cuota a los inquilinos por alquiler de la vivienda habitual asciende a 41,5 millones de euros, también en régimen transitorio tras la supresión de dicha figura por parte del gobierno popular. La deducción citada la disfruta un total de 213.709 contribuyentes.

La segunda deducción fiscal más relevante es la que obtienen los particulares que destinan viviendas al alquiler. El importe total de las deducciones se eleva a 671,2 millones de euros en 2021, correspondientes a reducciones en la base imponible del IRPF. Dicha reducción la disfruta un total de casi dos millones de contribuyentes. Están exentas del IRPF las ganancias patrimoniales obtenidas en la venta de una vivienda si se destinan a la compra de otra vivienda habitual. El alcance de las exenciones asciende a 340 millones de euros y la obtuvieron en 2019 un total de 61.850 contribuyentes. Las ganancias patrimoniales obtenidas por los mayores de 65 años por la venta de la vivienda habitual también están exentas en el IRPF, previéndose una exención en 2021 de 65 millones de euros por este concepto, disfrutada por un total de 7.841 contribuyentes.

Las entidades dedicadas al arrendamiento de viviendas obtienen una bonificación en la cuota íntegra del impuesto sobre sociedades prevista para 2021 de 48 millones de euros, disfrutada por 1.250 contribuyentes. Por último, la aplicación de un tipo impositivo del $10 \%$ en el IVA aplicado a la venta de viviendas de nueva construcción implica un tipo reducido de dicho tributo, ascendiendo el beneficio fiscal a 585,9 millones de euros.

El conjunto de las ayudas a la vivienda en forma de gasto (2.253 millones de euros) y de ayudas fiscales (2.697 millones de euros), 4.950 millones de euros, equivalen al $0,45 \%$ del PIB de la economía española previsto para el próximo año en los PGE 2021. Dicha proporción está entre las más reducidas en los países de la Unión Europea $(0,6 \%$ del PIB).

Los PGE 2021 introducen, pues, algunas modificaciones sensibles en materia de política de vivienda, en especial dentro del componente del gasto destinado a la ayuda al acceso a la vivienda. Parce conveniente, sin embargo, un mayor crecimiento en las partidas destinadas a favorecer un aumento significativo en el parque total de viviendas sociales de España, uno de los más reducidos de Europa.

El Real Decreto 1084/2020, de 9 de diciembre (BOE de 10.12.2020) ha modificado toda la normativa existente en materia de programas incluidos en el Plan 2018-21. Destaca sobre todo la extensión del plazo de las ayudas contempladas en dicho Plan hasta el 31 de diciembre de 2022. Entre otras medidas, se amplía el plazo de ejecución de las actuaciones de fomento del parque público de vivienda en alquiler y fomento de la regeneración y renovación urbanas, articuladas al amparo del Plan Estatal 2013-16 y su prórroga, en dos años, hasta el 31.12.2022.

El Consejo de Ministros de 22.12.2020 aprobó un nuevo Real Decreto-ley de medidas urgentes 
para hacer frente a las situaciones de vulnerabilidad social y económica en el ámbito de la vivienda, el Real Decreto-ley 37 /2020, de 22 de diciembre (BOE de 23.12.2020). Para asegurar la protección de las personas arrendatarias de vivienda en situación de vulnerabilidad, se amplía el alcance temporal y subjetivo de las medidas establecidas para responder a la gravedad de las consecuencias de la pandemia.

En este sentido destaca la extensión hasta la finalización del estado de alarma de la posibilidad de suspensión del procedimiento de desahucio. La suspensión del lanzamiento se mantendrá por el tiempo necesario para aplicar las medidas sociales que procedan, siempre dentro del periodo del estado de alarma (RD 956/2020, de 3 de noviembre).

En el contexto del estado de alarma se ofrece especial protección a aquellos hogares afectados por procedimientos de lanzamiento de su vivienda habitual, que no se deriven de contratos de arrendamiento, cuando existan personas dependientes, víctimas de violencia sobre la mujer o menores de edad a su cargo. En la nueva norma se prevé que las comunidades autónomas podrán emplear los recursos del Plan Estatal de Vivienda 2018-21, regulado por RD 106/2018, a fin de hacer frente a las compensaciones previstas.

\section{Bibliografía}

FMI (2020): Economic Outlook, octubre.

OCDE (2020): Economic Outlook, diciembre.

TORRES, Raymond (2020): "El binomio Estado-mercado". El País de los Negocios, 20 de diciembre.

Touze, Adan (2020): "Talk of a global economic reset must no ignore grim realities". The Financial Times, diciembre. 


\title{
Documentación
}

\author{
CIUDAD Y TERRITORIO \\ ESTUDIOS TERRITORIALES
}

ISSN(P): 1133-4762; ISSN(E): 2659-3254

Vol. LIII, № 207, primavera 2021

Págs. 229-256

https://doi.org/10.37230/CyTET.2021.207.14.1

\section{BY-NC-ND}

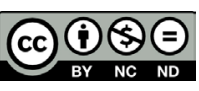

\section{El Plan General de Ordenación Urbana de Valladolid 2020, en el lado soleado de la calle}

\author{
Manuel Saravia-MadrigaL
}

Concejal de Planeamiento Urbanístico y Vivienda del Ayuntamiento de Valladolid.

\begin{abstract}
RESUMEN: Este artículo presenta las principales ideas del reciente Plan General de Ordenación Urbana de la ciudad de Valladolid, aprobado en 2020. En él se abordan las principales propuestas estratégicas sobre el modelo de ciudad, la estructura urbana y las infraestructuras, poniéndolas en relación con el planeamiento precedente y los retos urbanos futuros. Se incide especialmente en la necesidad de construir una ciudad amable para los ciudadanos, expresiva de los derechos. Desde el punto de vista más técnico, se describe la clasificación del suelo y se presentan las principales características sobre ordenación y normalización de las determinaciones urbanísticas. Se resumen también, de una forma autocrítica, el proceso de elaboración del plan y la participación pública. Finalmente, y en relación con los retos puestos de manifiesto por la pandemia del COVID-19, también se reflexiona sobre su impacto en la ciudad y el impulso de la resiliencia urbana.
\end{abstract}

PALABRAS CLAVE: Planeamiento urbanístico; Plan General de Ordenación Urbana; Valladolid; Estrategia ciudad; Urbanismo.

\section{Valladolid 2020 Urban Master Plan, on the sunny side of the Street}

ABSTRACT: This paper presents the main ideas of the recent Urban Master Plan of Valladolid city, approved in 2020. The text addresses its main strategic proposals about the city model, urban structure and infrastructures, putting them in relation to previous planning and future urban challenges. Special emphasis is placed on the need to build a friendly city for citizens, expressive of rights. From a more technical point of view, land classification is described and the main characteristics of the planning and normalization of urban determinations are presented. The paper also summarizes, in a self-critical way, the process of preparing the plan and the public participation. Finally, and in relation to the challenges revealed by the COVID-19 pandemic, there is reflection on its impact in the city and the promotion of urban resilience.

KEYWORDS: Urban Planning; Urban Master Plan; Valladolid; City strategy; Urbanism.

Correo electrónico: msaravia@ava.es 
E I viernes 19 de junio de 2020 se publicó (al fin) la aprobación definitiva de la Revisión del Plan General de Ordenación Urbana (PGOU) de Valladolid. Un trabajo largo, que empezó en 2012 con un gobierno del PP, y que ha concluido (tras numerosos replanteamientos y ajustes, como puede fácilmente sospecharse) con otro gobierno muy distinto, de coalición entre PSOE y VTLP ${ }^{1}$. Cualquier plan puede explicarse a partir de sus objetivos, criterios, determinaciones, lo que dice el acuerdo de aprobación, los epígrafes de la Nueva Agenda Urbana o los enunciados de la propia reglamentación urbanística. Pero me quedo con la siguiente exposición, mucho más personal, aunque (creo) suficientemente útil' .

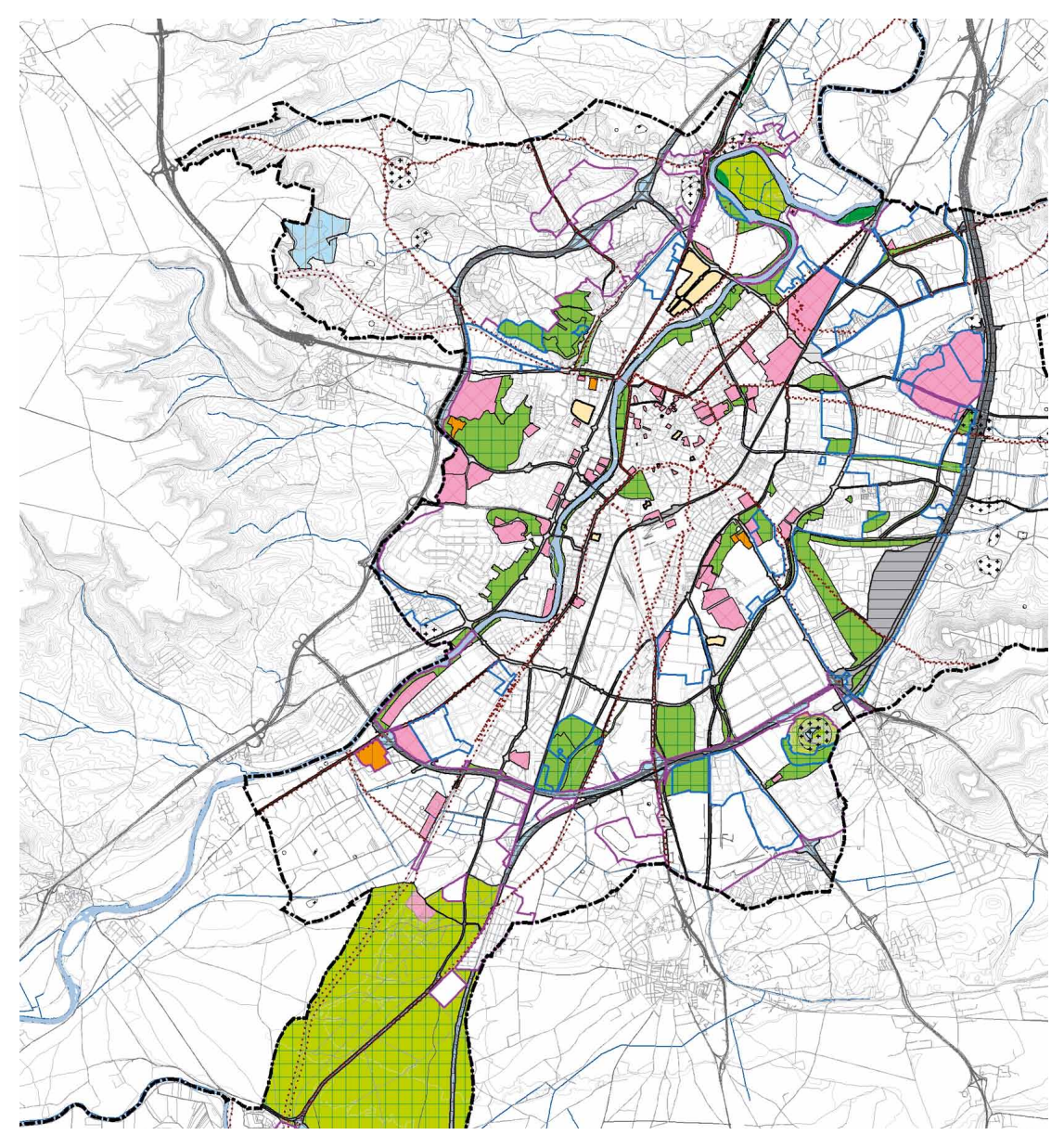

FIG. 1/ Plano de estructura urbana y sistemas generales del Plan General de Ordenación Urbana de Valladolid 2020 (en adelante PGOU de Valladolid 2020).

Fuente: PGOU de Valladolid 2020

\begin{abstract}
1 VTLP es el acrónimo de Valladolid Toma la Palabra, una formación política en la que participan personas a título individual, colectivos y activistas sociales y culturales que apoyaron la creación de un espacio que contó con el respaldo de Equo e Izquierda Unida.

${ }^{2}$ EI PGOU ha entrado en vigor el mismo día que también entró el verano de 2020. Estaban vigentes un PGOU de 2004 y un PECH de 1997, a los que sustituye. El 16 de diciembre de 2011 el Ayuntamiento de Valladolid adjudicó a la empresa Prointec S.A. un contrato de servicios para la redacción de la Revisión. El 26 de julio de 2012 se aprueba la exposición del Avance, y el 25 de febrero de 2015 se aprueba inicialmente una primera formulación del nuevo PGOU, que posteriormente se revoca, por el nuevo equipo de gobierno, el 1 de marzo de 2016. El 24
\end{abstract}

de julio de 2017 se produce una nueva aprobación inicial. Y el 26 de noviembre de 2018 se acuerda por el Pleno una tercera aprobación inicial y exposición pública. Posteriormente, el 20 de mayo de 2019 se lleva a cabo la aprobación provisional. El 5 de septiembre de 2019, la Dirección General de Vivienda, Arquitectura y Urbanismo requiere al Ayuntamiento algunas subsanaciones del documento aprobado provisionalmente. $Y$ en el Pleno municipal del 4 de febrero de 2020, se acuerda remitir el documento corregido para su aprobación definitiva. El 20 de mayo de 2020 se propone la aprobación definitiva por el Consejo de Consejo de Medio Ambiente, Urbanismo y Ordenación del Territorio, que el 19 de junio del mismo año se publica. (Ultimas condiciones requeridas, aprobadas en el Consejo del 20 de enero de 2021). 
CLASES Y CATEGORÍAS DE SUELO

\begin{tabular}{|c|c|c|c|c|c|c|c|}
\hline \multirow{2}{*}{ Clase $\left(^{*}\right)$} & \multirow{2}{*}{ Categoría } & \multirow{2}{*}{$\begin{array}{c}\text { Ámbitos } \\
(n-0)\end{array}$} & \multicolumn{2}{|c|}{ Superficie } & \multicolumn{2}{|c|}{$\%$ superficie } & \multirow{2}{*}{$\begin{array}{c}\text { № } \\
\text { Viviendas }\end{array}$} \\
\hline & & & $m^{2}$ & $\mathrm{Ha}$ & Clase & Término & \\
\hline \multirow{10}{*}{ (1) Urbano } & Zonas de Ordenanza & (3) - & $41.289 .021,56$ & $4.128,90$ & 88,12 & 21,04 & (3) 7.680 \\
\hline & Planeamiento Asumido (APP-SUc) & 2 & $17.941,31$ & 1,79 & 0,04 & 0,01 & (4) 148 \\
\hline & Actuaciones Aisladas (AA) & 82 & $525.080,41$ & 52,51 & 1,12 & 0,27 & 1.460 \\
\hline & Subtotal CONSOLIDADO & 135 & $41.832 .043,28$ & $4.183,20$ & 89,28 & 21,32 & 9.288 \\
\hline & Planeamiento Asumido (SE-APP) & 27 & $869.520,89$ & 86,95 & 1,86 & 0,44 & (5) 2.802 \\
\hline & Sectores Ordenados SE(o) & 67 & $2.547 .643,58$ & 254,76 & 5,44 & 1,30 & 8.940 \\
\hline & Sectores Remitidos SE(r) & 17 & $1.267 .963,01$ & 126,80 & 2,71 & 0,65 & 3.135 \\
\hline & SSGG Adscritos SE(o) - SE(r) & - & $336.709,52$ & 33,67 & 0,72 & 0,17 & \\
\hline & Subtotal NO CONSOLIDADO & 111 & $5.021 .837,00$ & 502,18 & 10,72 & 2,56 & 14.877 \\
\hline & Total Suelo Urbano & 246 & $46.853 .880,28$ & $4.685,39$ & 100,00 & 23,88 & 24.165 \\
\hline \multirow{8}{*}{$\begin{array}{l}\text { (1) } \\
\text { Urbanizable }\end{array}$} & Sectores Asumidos S-APP & 11 & $3.434 .029,35$ & 343,40 & 29,15 & 1,75 & 13.058 \\
\hline & Sectores con Ordenación Detallada $\mathrm{S}_{(0)}$ & 1 & $658.334,39$ & 65,83 & 5,59 & 0,34 & 3.545 \\
\hline & Sectores S & 11 & $4.257 .105,26$ & 425,71 & 36,13 & 2,17 & 8.237 \\
\hline & SSGG Adscritos Sectores S-APP & - & $610.036,04$ & 61,00 & 5,18 & 0,31 & - \\
\hline & SSGG Adscritos Sectores $\mathrm{S}_{(0)}$ & - & $934.952,99$ & 93,50 & 7,94 & 0,48 & - \\
\hline & SSGG Adscritos Sectores S & - & $1.728 .507,60$ & 172,85 & 14,67 & 0,88 & - \\
\hline & $\begin{array}{l}\text { (6) SSGG Existentes } \\
\text { en Suelo Urbanizable }\end{array}$ & - & $159.456,69$ & 15,95 & 1,35 & 0,08 & \\
\hline & Total Suelo Urbanizable & 23 & $11.782 .422,39$ & $1.178,24$ & 100,00 & 6,00 & 24.840 \\
\hline (2) Rústico & Total Suelo Rústico & - & $137.607 .610,29$ & $13.760,76$ & 100,00 & 70,12 & \\
\hline \multicolumn{2}{|c|}{ TOTAL MUNICIPIO } & - & $196.243 .912,96$ & $19.624,39$ & - & 100,00 & 49.005 \\
\hline
\end{tabular}

(1) En planeamientos asumidos se han computado las superficies de la GDB, salvo en el caso del S(o)12. Canal del Duero San Isidro donde se han computado los superficies de SS.GG adscritas definitivamente por planeamiento.

(2) Las superficies de las categorías SRPN Vías Pecuarias, SR Protección Cultural se contabilizan como superficies que se superponen con otras categorías de Suelo Rústico de Protección.

(3) Suelo Urbano Consolidado procedente de los ámbitos regulados en el Art. 202 de la Normativa Urbanística. Se incorporan suelos ya urbanizados, algunos no totalmente edificados. Se incluyen SSGG existentes.

(4) No se incluyen APP.11.01 antigua UAE-67, por su escasísima dimensión.

(5) En algunos ámbitos se ha calculado tomando como referencia la máxima densidad permitida por la legislación vigente, si bien los instrumentos de desarrollo aprobados determinan en cada caso el horizonte máximo de viviendas.

(6) Se computan los SS.GG Existentes en Suelo Urbanizable no incluuidos en ámbitos de Sector.

FIG. 2/ Cuadro resumen de datos generales de clasificación del suelo del PGOU 2020.

Fuente: PGOU de Valladolid 2020.

\section{Definir (con modestia) la estructura urbana}

Para empezar, no deberíamos asustarnos con la palabra modestia que figura en el título del epígrafe. Podemos usarla sin recelos. Pues la reclama Richard SENNETT ${ }^{3}$ (un sociólogo de confianza) para

\footnotetext{
${ }^{3}$ Richard SenNetT, Construir y habitar: ética para la ciudad (Barcelona, Anagrama, 2019. "La conexión ética entre el urbanista y el urbanita reside en la práctica de cierto tipo de modestia, en vivir entre muchos asumiendo el compromiso con un mundo que no es el espejo de uno mismo".

${ }^{4}$ La ley (o principio) de la segunda persona la enunció Edmund N. BAcon en su libro "Diseño de ciudades". Alude al proyecto de la Piazza della Santissima Annunziata, en Florencia. Que se comenzó a configurar con el proyecto (1427)
}

el diseño de la ciudad. Y tiene razón. Mucho antes, y de otra forma, también lo reclamaba Edmund Bacon en su principio de la segunda persona ${ }^{4}$. Si hay un proyecto en marcha que es adecuado o suficiente para un lugar, o simplemente funcional: ¿por qué cambiarlo? No hay por qué intentar dejar impronta propia sin necesidad.

del Ospedale degli Innocenti, de Fillippo Brunelleschi. Cuando, después de otras intervenciones, hubo que acabar el diseño de la plaza, en 1516, Antonio da Sangallo el Viejo, en lugar de intentar su propia obra, venciendo la "urgencia por la auto-expresión", siguió, casi al pie de la letra, el diseño inicial de Brunelleschi, de hacía casi un siglo. Porque, según BACON, "es el segundo hombre el que determina si la creación del primero será llevada adelante o será destruida". 
En Valladolid el planeamiento general comenzó en 1939 con el denominado Plan Cort $^{5}$, un urbanista al que no le gustaba nada la ciudad y deseaba su sustitución completa. No obstante, diseñó una propuesta que ocupaba la Huerta del Rey (al oeste, al otro lado del río), mientras intentaba transformar drásticamente el casco histórico. Con los planes de alineaciones de las décadas siguientes, mereció el dudoso honor de haber contribuido decisivamente a la destrucción del legado arquitectónico y urbanístico de la ciudad.

Después llegó el Plan Comarcal (de 1969), que, de nuevo, intentaba redefinir todas las infraestructuras urbanas "con ambición", planteando un enorme crecimiento al sur de la ciudad. Por supuesto fracasó en ese propósito, y casi ninguna de sus propuestas sobrevivió.

Tras el cambio de régimen se propuso un nuevo PGOU, está vez dirigido por Bernardo Yncenga, que, en este caso, aun siendo enormemente holgado, era mucho más comedido y sensato que los

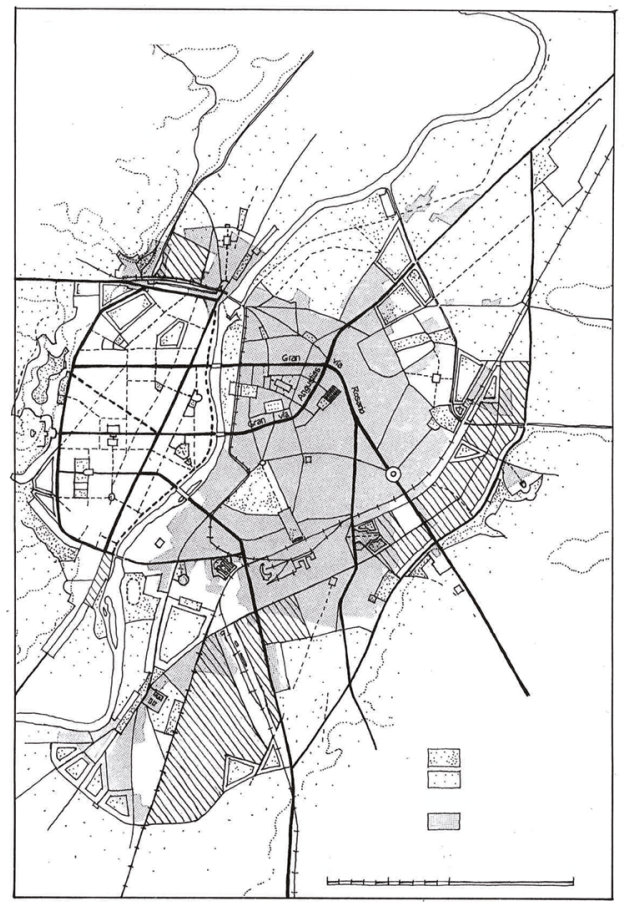

FIG. 3/ Imagen de la estructura general del Plan de César Cort (1939).

Fuente: P. Gigosos y M. SARAVIA, Arquitectura y urbanismo de Valladolid en el siglo XX, Ateneo 1997.

${ }^{5}$ P. Gigosos \& M. SARAVIA, Arquitectura y Urbanismo de Valladolid en el siglo XX (Valladolid, Ateneo, 1997). Para las últimas décadas, y sobre la estructura de los planes, de los mismos autores: "Cincuenta años de urbanismo municipal", en el anteriores. $Y$ ha sido el que ha dirigido el desarrollo de la ciudad en los últimos 40 años.

La actualización de 1996, reconociendo la estructura inicial planteada en 1984, insistía en el modelo del plan anterior, incorporando piezas y recomponiendo nuevas pautas de movilidad o de equipamiento (nuevo hospital, Cortes, etc.). Más tarde, en 2004, se aprobó un nuevo PGOU con la pretensión de construir una ciudad diferente (el nuevo gobierno reclamaba entonces otra ideología urbanística). Pero aparte de clasificar como urbanizable las denominadas "áreas homogéneas", nada nuevo se diseñó, sino que se continuó con la estructura básica prevista 20 años antes. El sistema de rondas, por ejemplo, se mantuvo invariable. Y la carga de sistemas generales, también con un rango parecido.

Y ahora, corrigiendo elementos y añadiendo alguna pieza, lo fundamental de aquella estructura (ese esquema de redes de infraestructuras y equipamientos, con un sistema básico de áreas caracterizadas), se mantiene. Las áreas de centralidad, por ejemplo, también se mantienen. La red básica

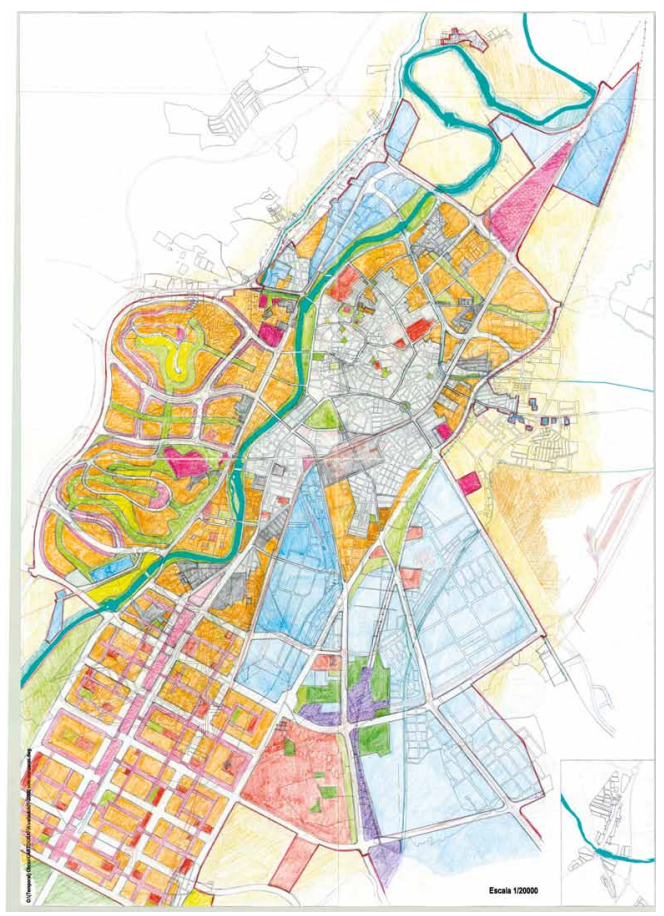

FIG. 4/ Imagen de la estructura general del Plan Comarcal de Mesones (1969).

Fuente: P. Gigosos y M. SARAVIA, op. cit.

Catálogo de la exposición Del Plan al plano. 50 años de urbanismo en Valladolid 1969-2019, coord. por Miguel FERNÁNDEZ MAROTO (ed. por Ayto. de Valladolid e Instituto U. de Urbanística, 2019). 
estructural continúa y, con modestia, se asume y porfía en ella. No hay ahora necesidad alguna de plantear nuevas grandes infraestructuras, sino, eso sí, de pautar, corregir, reequilibrar zonas e incluso de incorporar un nuevo sector al este. Pero manteniendo la base de hace años, con modestia ${ }^{6}$.

\section{Negociar el equilibrio y el reequilibrio (el realismo)}

Un principio básico de la ordenación territorial es el de trabajar para corregir la tendencia al desequilibrio. Algunos planes (otros no) se proponen reequilibrar, compensar entre áreas, contrapesar. Porque la dinámica económica y social espontánea no sigue, con frecuencia, la pauta de mantener oportunidades y ventajas urbanísticas semejantes entre las distintas áreas urbanas. Por eso los planes deben intentar continuamente volver al reequilibrio. Algunos de ellos incluso trazaban una línea imaginaria que distinguía la "media ciudad" más desarrollada de la más necesitada de acción pública y ponderación. En Valladolid esa línea debería dibujarse incluyendo, como segunda mitad, amplias zonas del norte y el este. De hecho, la retórica de las últimas dos décadas en muchos debates se ha centrado en poner de manifiesto esa diferencia.

Se ha jugado con la idea de promover el reequilibrio a partir de una argumentación falaz, aunque muy bien pagada (e interesada). Pues casi dos millones de euros se dedicaron a vender la propuesta urbanística que el anterior equipo de gobierno planteaba como solución de todos los problemas ${ }^{7}$ de la ciudad: soterrar el tren. Lo curioso es que, aunque era, según decían, un proyecto crítico, no se recogió en el plan del 2004 (aun estando cuando se aprobó el PGOU ya formulado el objetivo). Pero eso sí, la sociedad creada al efecto ${ }^{8}$, destinó una enorme cantidad de recursos a asegurar que habría "un antes y un después" en la ciudad. Que el cambio urbanístico sería de tal magnitud que soterrando el tren la riqueza llegaría automáticamente a la media ciudad más necesitada (llegaría incluso a los barrios del norte, aunque no les afectase la obra). Lo cierto es que esa forma de actuar, por mucho que se encargase el proyecto a Richard Rogers, es de una enorme simpleza, inmenso coste y más que dudosos resultados.

SENNETT (nuestro sociólogo de cabecera, como puede verse) también ponía un ejemplo sobre la labor de los artesanos de la madera que viene muy bien para ilustrar otra forma (urbanística) de

\footnotetext{
"La discusión académica de diferenciar una "modificación" de una "revisión" es, en mi opinión, a efectos prácticos, totalmente irrelevante. ${ }^{7}$ Creo que se llama "bálsamo de Fierabrás". Pero lamentablemente
}

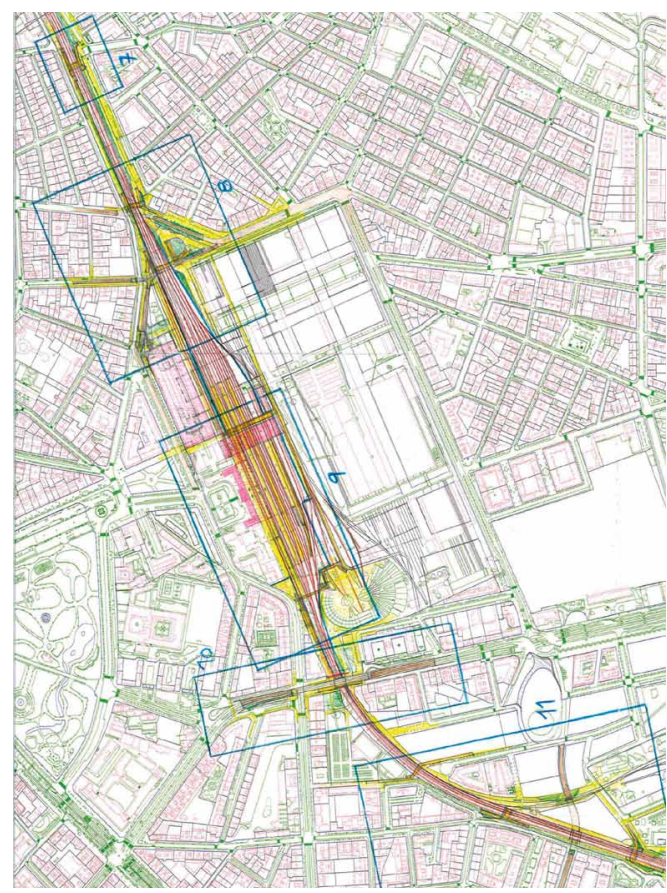

FIG. 5/ Esquema de la integración ferroviaria (fragmento).

Fuente: Archivo personal del autor.
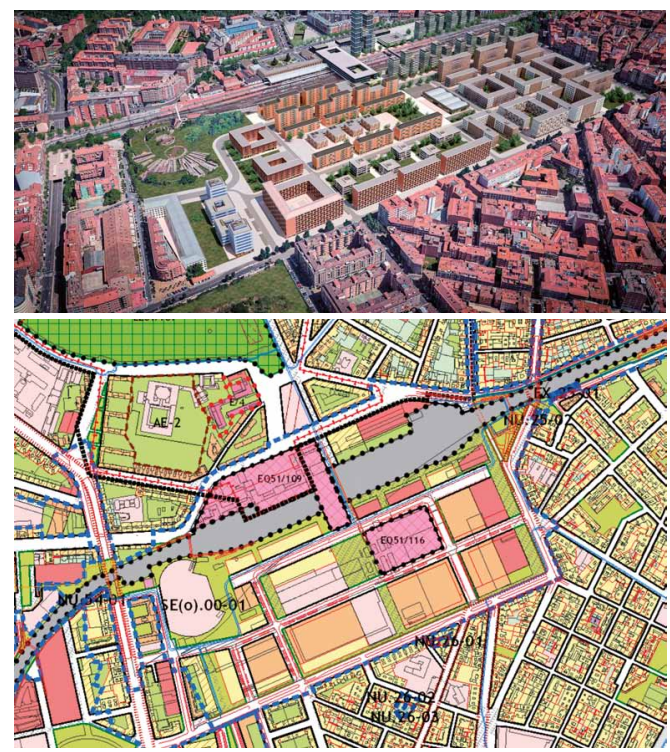

FIG. 6/ Infografía (versión de la primera aprobación inicial) y plano de ordenación (aprobación definitiva) de la zona de los antiguos Talleres.

Fuente: Memoria del PGOU 2020.

en el urbanismo, o mejor, en el mundo real, ese bálsamo sólo existe en la propaganda política.

${ }^{8}$ Valladolid Alta Velocidad 2003, S.A. 
proceder. Pues cuando se vio que la operación de soterramiento era inviable y que Adif proponía la disolución de la sociedad VAV (que ya tenía una deuda, antes de haber soterrado un solo metro de las vías en la ciudad, 400 millones de euros por los múltiples gastos realizados, como los del traslado de los Talleres) se pensó, como digo, que sería mejor actuar como los artesanos en los nudos de la madera $^{9}$, no viéndolos como problema, sino como oportunidad ${ }^{10}$.

En Valladolid ya se había actuado así (el artesano ante los nudos) en otras ocasiones con buenos resultados. Por ejemplo, cuando se quiso actuar en el Esgueva. Primero se pensó en construir grandes vías rodadas a lo largo del recorrido fluvial. Pero la solución alternativa, tranquila, de aprovechar la traza para nuevas vías de peatones y ciclistas fue un completo éxito. Lo mismo que cuando se paralizaron las demoliciones de edificios y la transformación drástica del espacio central, tomando como excusa el novedoso catálogo del plan del 84. Quedaron trozos de calles anchos y altos junto a otros fragmentos bajos y estrechos, pero esa misma condición se consideró como un recurso, la variedad de las calles, y funcionó.Y podríamos relatar muchos más ejemplos de este proceder sensato, creativo y sereno.

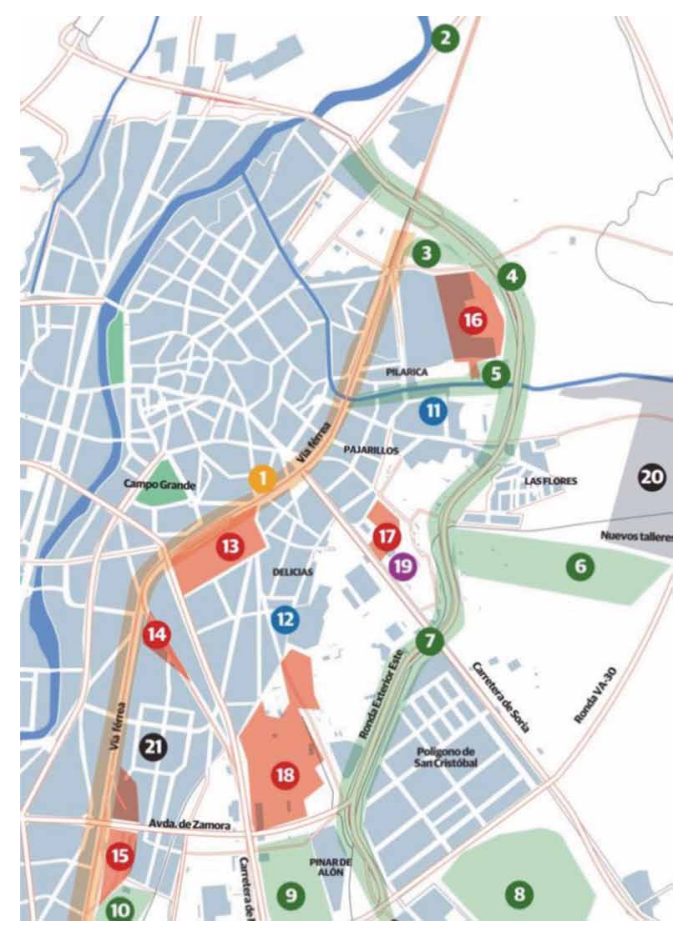

1 Proyecto de integración del ferrocarril y permeabilidad.

2 Soto de Medinilla. Parque, con Somacyl.

3 Corredor verde junto a la VA-20.

4 El Tomillo. Habilitación de una campa como espacio de reunión en las afueras.

5 Parque inundable Urban Green Up, junto al Esgueva.

6 Parque forestal Fuente Amarga.

7 Recuperación márgenes Canal del Duero.

8 Cerro de San Cristóbal. Parque forestal de 23,4 hectáreas. 9 y 10 Pinar de Jalón y Argales.

11 El 29 de Octubre. Proyecto de regeneración urbanística.

12 Las Viudas-Jesús Aramburu. La primera medida (en ejecución) es la urbanización de la avenida de Segovia.

13, 14 y 15 Talleres. Ariza. Argales. Nuevos barrios en los terrenos hasta ahora ocupados por las vías.

16 Los Santos 2. Prolongación de Los Santos Pilarica.

17 San Isidro. Vinculado a la cesión por parte del Estado de los antiguos cuarteles de San Quintín (San Isidro).

18 La Florida. Ocupa un espacio estratégico, con terrenos de Zambrana y la antigua Uralita.

19 Cuartel de San Quintín (San Isidro). Cesión Defensa para un espacio dotacional.

20 Parque agroalimentario y logístico. Conectado con los nuevos talleres de Renfe.

21 Rehabilitación del Polígono industrial de Argales.

\footnotetext{
${ }^{9}$ R. Sennett, El artesano (Barcelona, Anagrama, 2009).

${ }_{10}$ Sobre la integración ferroviaria:
}

valladolidaltavelocidad.es/proyecto/integracion-urbana-delferrocarril-2017/ 


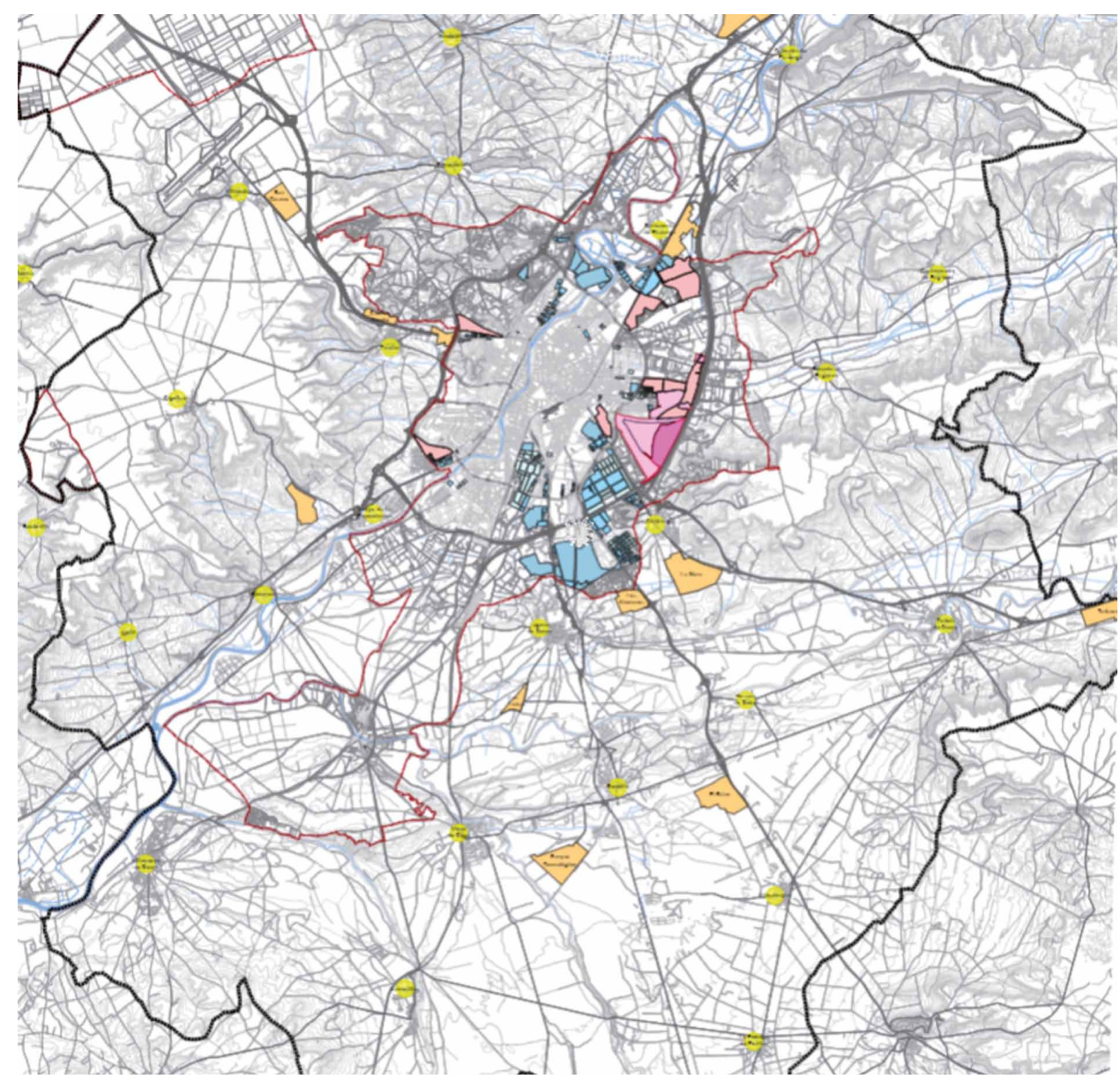

FIG. 8/ Suelos que se pretende vincular a la "Estrategia Racimo".

Fuente: Plano PO-A4 del PGOU 2020.

Pero también había que reequilibrar, curiosamente (aunque a menor escala), el centro. Que estaba siendo objeto de vaciamiento de las sedes institucionales que tradicionalmente se asentaban en él y que habían comenzado a abandonarlo. Con efectos importantísimos en el comercio y la actividad del área. De hecho, en los últimos años del anterior gobierno se había promovido el traslado de Hacienda o la Seguridad Social, y estaba en marcha la creación de un Campus de la Justicia al oeste de la ciudad. Un proceso, este último, que afortunadamente se pudo paralizar a tiempo. Se llevaron a cabo varias actuaciones urbanísticas, muy complejas, para mantener (y ampliar) los equipamientos judiciales en el área central.

11 "Renault reduce la producción y mantiene la incertidumbre", en El Día de Valladolid, 6 de junio de 2020. "Las fábricas de Renault en Valladolid han vivido muchos momentos de

\section{Bajar a la playa, luchar por las propuestas críticas (Aquiles)}

En la Estrategia del Este aparece, como una de las actuaciones fundamentales, la creación de un amplio sector (al este del este), destinado, además, a reducir la dependencia tan fuerte que tiene la ciudad del sector de la automoción ${ }^{11}$. Y que debía servir también para promover nuevo empleo. Se trataría de crear un "Parque Agroalimentario y Logístico", aprovechando precisamente el traslado de los Talleres de Renfe, la construcción de un bypass de mercancías ferroviarias y la creación de una nueva estación de mercancías que se podría vincular al Eje Atlántico.

incertidumbre, con amenaza de cierre incluida en algún caso. Pero quizá en ninguno de ellos había tantos frentes abiertos como el actual". 


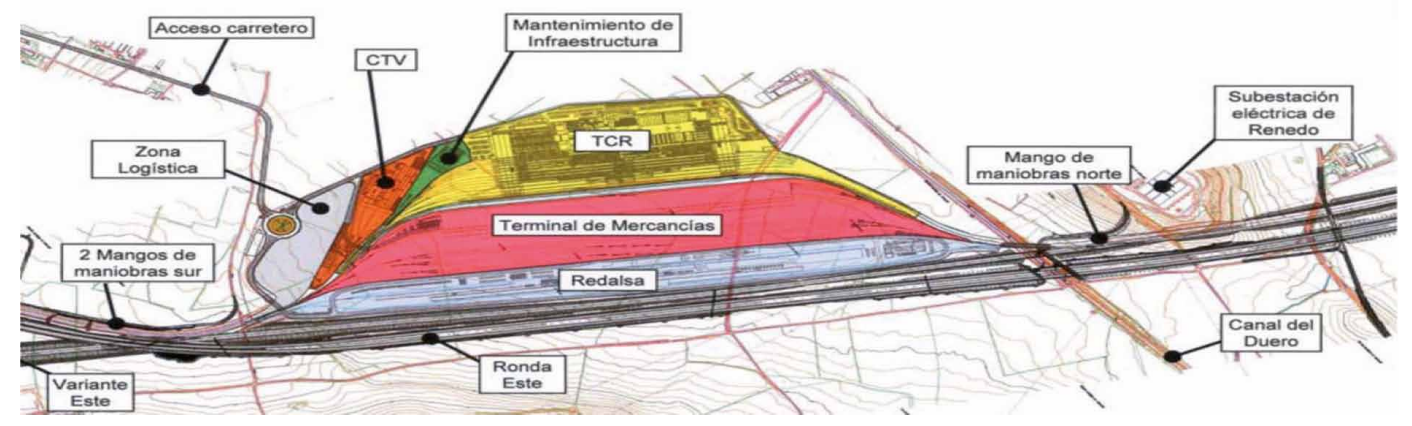

9/ Nuevos Talleres de Renfe y Terminal de Mercancías (23 has.), con un haz de 12 vías de más de $750 \mathrm{~m}$.

Fuente: Archivo personal del autor.

Sería un elemento fundamental de la nueva ordenación. Tanto que incluso en la presentación del PGOU para su primera aprobación inicial se consideraba el elemento cardinal. Se veía (era una licencia poética) que la actuación urbanística en la ciudad podía resumirse como una colección de proyectos vistos como metáforas de la Odisea. "¿Qué hacer?: ¿Armarse el pecho con coraza de acero, como Aquiles, para asaltar las murallas de Troya o construirse una barca, como Ulises, y perderse en el mar?"2 La ciudad, que es un microcosmos completo, podría acoger ambas propuestas. Y también a esa Penélope que tejía y destejía, con el paso del tiempo, un mismo tejido (la ciudad existente). Como sabemos -decíamos-, cada plan ha de tener un proyecto que lo pone en marcha. Un propósito claro que aúne esfuerzos públicos. Un proyecto que se afronte "con ánimo alzado". Y como el tema básico seguía siendo el del empleo (estábamos en 2015), no cabía duda. Y el proyecto crítico, el de Aquiles, sería la puesta en marcha de un conjunto articulado de suelos para favorecer ese propósito.

Se proponía en un primer momento, pendiente del ajuste final y los acuerdos que se pudieran firmar más adelante, un amplio ámbito para construir una nueva Plataforma Agroalimentaria y Logística de 239 Has, aparte de un suelo de reserva de posible desarrollo posterior. Se planteaba, además, el propósito de establecer un marco de gestión que intentase acordar programas comunes con otros espacios industriales existentes y ociosos del entorno, incluyendo entre ellos a los de Villanubla y su aeropuerto. Esta articulación se denominaba "Racimo".

La Plataforma planteada se dirige a la especialización agroalimentaria, buscando tanto la atracción de gran industria como de la pequeña y mediana empresa (integrada tanto en el sector principal, como en su clúster o en otros complementarios). En el medio-largo plazo, se pensaba integrar también un nuevo proyecto de ampliación de Mercaolid "de tercera generación" (12 Has). Y se pensaba además en la integración de los usos logísticos, de la logística inversa y el e-commerce.

\section{Construir una ciudad amable, expresiva de los derechos}

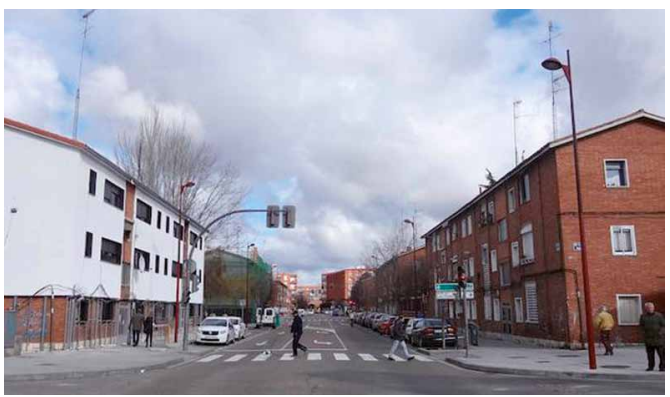

FIG. 10/ Actuación de regeneración en el "29 de Octubre".

Fuente: El Norte de Castilla, 27 de enero de 2018.

Pero un plan no se agota en sus propuestas más determinantes, grandes o llamativas. No le bastan sus luchas en la playa. También se la juega en lo menudo. Por ejemplo, en el tejido disperso de centros y equipamientos. $Y$ así conviene recordar que en los programas electorales (que también tienen derecho a la vida) de VTLP se viene hablando, como título principal de todas las propuestas desde 2011, de la idea de construir una "ciudad amable". Y decir amable es decir "digna de ser amada". O lo que es lo mismo: una ciudad de derechos. Porque el urbanismo es un elemento crítico para la

\footnotetext{
${ }^{12}$ Nos acogemos a un texto de Manuel VICENT del 22 de mayo de 2011, en El País (“La huida”).
} 
materialización de muchos de los derechos reconocidos en la Declaración de 1948. Y lo cierto es que (créanme) se han revisado las propuestas del PGOU desde esa óptica.

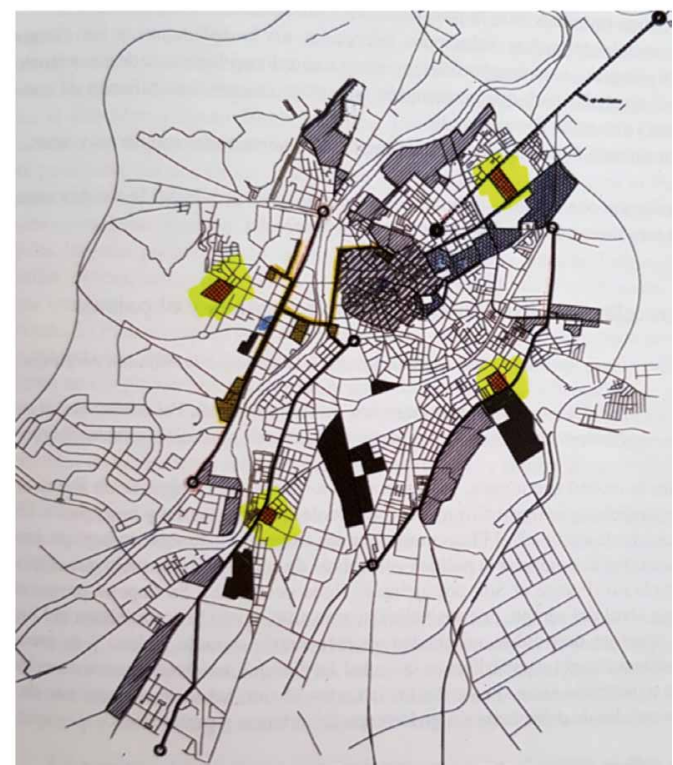

FIG. 11/ Los cuatro centros integrados de equipamiento (en amarillo).

Fuente: Archivo personal del autor.

Por supuesto, habría que empezar por los derechos civiles, pero enseguida también por los económicos y sociales. Por ejemplo, aunque sea una cuestión que se podría considerar menor (no es más que un equipamiento de tamaño medio, entre cientos), la previsión de construir un nuevo albergue para las personas indomiciliadas nos parece absolutamente relevante. Como también la estructuración y desarrollo (que se planteó en el PGOU de 1996) de cuatro "centros integrados" de equipamiento en los cuatro puntos cardinales de la ciudad (algunos están muy avanzados, al este y al sur; pero otros aún incipientes o totalmente a la espera).

Y aquí habría que hablar, obviamente, de la política de vivienda. Porque el PGOU debe estar integrado con el Plan de Vivienda, aunque lleven ritmos diferentes y dependan de estructuras administrativas muy distintas (para la política de vivienda se cuenta con una sociedad de suelo y vivienda específica, Viva S.L.). Para el seguimiento de la política de vivienda se ha creado una Mesa de la Vivienda en la que participan organizaciones políticas y sociales, además de varias instituciones y administraciones. Tiene su propia dinámica.

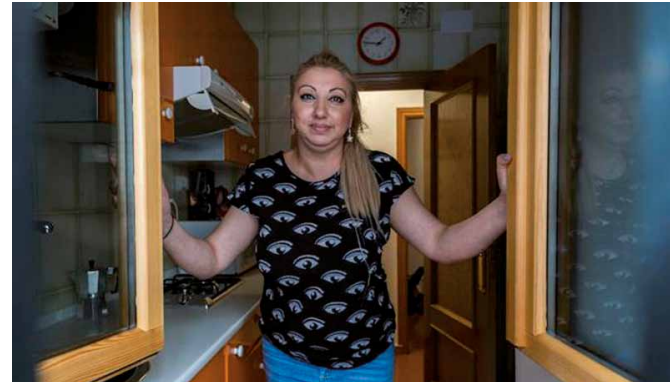

FIG. 12/ Una de las viviendas del parque municipal de alquiler.

Fuente: El Norte de Castilla, 3 de junio de 2018

El primer desarrollo, básico, de la política de vivienda, es el de la creación de un Parque Municipal de Viviendas Blancas, de alquiler social, que se va ampliando todos los años (desde 2016) con un presupuesto estable de más de $3 \mathrm{M}$ de euros; y que ha pasado de 12 viviendas en 2015 a 145 en 2020. También el Programa Alva de promoción del alquiler y fomento del uso de las viviendas vacías. O el desarrollo, por la misma Sociedad, de la gestión de sectores de VPP en La Florida y Zambrana. El ejercicio del tanteo y retracto. La promoción de nuevas tipologías y formas de tenencia (el impulso de las primeras "viviendas colaborativas" en el Barrio España). Hacer frente al deterioro de la convivencia vecinal limitando (mediante normativa) el desarrollo incontrolado de viviendas turísticas, o haciendo frente a situaciones de mala convivencia en determinadas áreas, o a la posible gentrificación y terciarización de otras. E impulsando convenios con la Universidad de Valladolid y el VRAC (un equipo de rubgy ${ }^{13}$ ) para que residan deportistas y universitarios en algunos de los barrios más complicados, comprometiéndose a mejorar la convivencia.

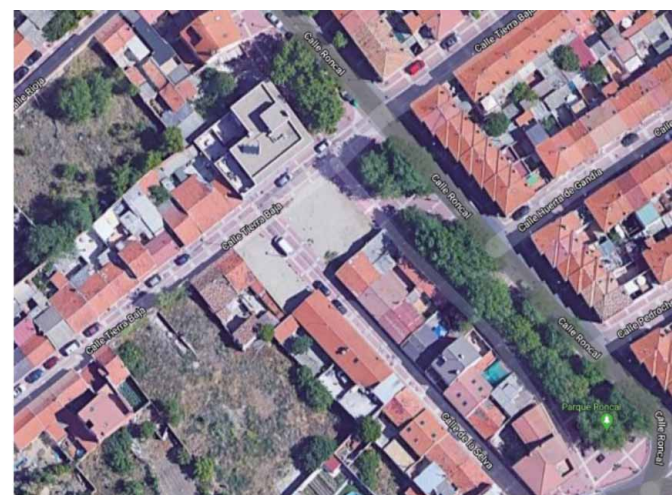

FIG. 13/ Parcelas del Barrio España para las viviendas colaborativas municipales.

Fuente: Archivo personal del autor

\footnotetext{
${ }^{13}$ https://vracrugby.com/
} 
Además, también se impulsa la mejora de la calidad de la vivienda, con ayudas a la rehabilitación (1,5 $\mathrm{M}$ de euros). Y con la redacción de un Plan de rehabilitación general de la ciudad (el "libro de la ciudad"). Así como el impulso, en los últimos años, de la implantación de ascensores en edificios de los años 60 y 70 . O el gran esfuerzo en un Plan de rehabilitación social, con intervenciones de rehabilitación a cargo del municipio en los barrios más vulnerables, entre los que están el 29 de octubre y Aramburu-Las Viudas. Y por supuesto, con el estímulo a la mejora de la calidad de la vivienda, cuidando los procesos de "filtrado" y la demanda de mejora ${ }^{14 .}$

\section{Ser contemporáneo (el buenismo)}

Pero además de atender a los derechos, como decíamos, este PGOU quiere ser buenista. Abiertamente buenista. Pretende mejorar la estructura de 1984 y las determinaciones de 1996 y posteriores abrazando una serie de políticas que muchas veces han sido criticadas por "bienintencionadas pero ingenuas", quizá inmaduras, aunque (así lo veo) decididamente progresistas. Es verdad que todos conocemos algunos ejemplos típicos de ridiculización del buenismo. El apoyo al multiculturalismo, a la discriminación positiva, a la educación basada en la tolerancia y diálogo, al pacifismo, a la corrección política, incluso a la renta básica, son frecuentemente materia de enfrentamiento político y cultural. Por citar un tema concreto, la necesaria aplicación (como también se ha hecho en este plan) de un informe de género ha sido objeto de debates municipales muy poco filosóficos. $Y$, sin embargo, esos informes también hacen ciudad. El tiempo pone muchas cosas en su sitio. Y no hace tantos años que se ridiculizaba el uso de términos como "sostenibilidad" (lo recuerdo perfectamente), que hoy no les cabe en la boca a quienes se burlaban entonces ${ }^{15}$.

\footnotetext{
${ }^{14}$ En Valladolid, como en la mayoría de las ciudades, el ritmo de licencias de vivienda es muy variable. En los años $60 \mathrm{del}$ pasado siglo se dieron, algún año, licencias para más de 8000 viviendas. En los primeros años 2000 no se llegó a las 2000 viviendas de media al año. En 2008, por ejemplo, fueron 1919 viviendas. Pero bajaron drásticamente hasta las 96 en 2015. El último año, 2019, ya se había recuperado la cifra hasta las 1284. Y en el primer semestre de 2020 , aun siendo un periodo muy difícil (pandemia y tramitación final del nuevo PGOU), se concedieron licencias para 520 viviendas. A ver cómo evoluciona.

${ }^{15}$ Corey Robin, La mente reaccionaria (Madrid, 2019). "Estos términos de urbanismo de género son caducos", dijo el portavoz del PP en el debate del PGOU que lo trató.

${ }^{16}$ Elvira Lindo, "Buenistas sin fronteras", El País, 26 de marzo de 2017.

${ }^{17}$ Las imágenes y las referencias fluyen habitualmente desde los países ricos hacia los demás. Frente a la colonización
}

Dicho de otra forma, este PGOU quiere ser contemporáneo. Y tal propósito significa estar atento a los temas de nuestro tiempo, los que definen los últimos anhelos de la justicia social, e intentan hacerlos avanzar. Por eso el PGOU ha asumido, con mejor o menor fortuna, pero con determinación, propuestas de igualdad, de hacer frente a la corrupción urbanística (acabar con la discrecionalidad, máxima transparencia de los expedientes); o de seguridad (el fomento de la "vigilancia natural" por medio de los trazados urbanos). La Nueva Agenda Urbana recoge alguno de estos asuntos. Pero ¿hasta dónde llegar? La clave está en el tratamiento de la inmigración.

"El buenista piensa que Europa está siendo mezquina con los refugiados, porque el buenista es un insensato que no sabe, porque no se entera, que esta es una forma de invasión bárbara como otra cualquiera" 16 .

Es necesario volcarse en el reconocimiento multicultural (con un barrio diseñado para "interurbanizar"). ${ }^{17}$

Respecto al medio ambiente, poniendo, para empezar, el énfasis en el apoyo a la promoción de passivhaus en la normativa del PGOU ${ }^{18}$. Y también recordar que en Valladolid se ha aprobado una moción con el compromiso de descarbonizar el $100 \%$ de la edificación de la ciudad en los próximos años, y de adhesión a la Iniciativa Global Net Zero Carbon Buildings Commitment (una moción, según se dijo al aprobarla, "para redoblar los esfuerzos dirigidos a frenar el calentamiento global"), siendo la primera ciudad española en adherirse a este compromiso que ya han suscrito otras 26 ciudades en el mundo como Copenhague, Los Ángeles, Melbourne, Nueva York, París y Londres.

Y en el ámbito de la igualdad, además del informe antes mencionado, la promoción del urbanismo de

intelectual defendemos la interurbanización: un neologismo claramente derivado de la intertextualidad. Y si ésta alude al conjunto de relaciones que vinculan un texto determinado a otros de distinta procedencia (fuentes, citas, influencias, plagios, lo que se quiera), en urbanismo significa que la ciudad es de todos, y que debería haber el mismo interés por conocer (y, en su caso, aplicar) las obras y los diseños que se hacen en cualquier lugar, sin peaje alguno.

18 "Artículo 462. Cómputo de edificabilidad. 1. Para calcular la edificabilidad se considerarán todo tipo de superficies cubiertas y cerradas en cualquier planta del volumen edificado (una superficie edificada no se considerará cerrada cuando, al menos, uno de sus paramentos verticales carezca completamente de cerramiento, excepto petos o barandillas). Se excluyen las superficies ocupadas por las fachadas del volumen edificado tanto a calle como a patio, teniendo en cuenta que no se considerará fachada ningún cerramiento medianero o que linde con otra propiedad, computando éstos, por tanto, edificabilidad". 

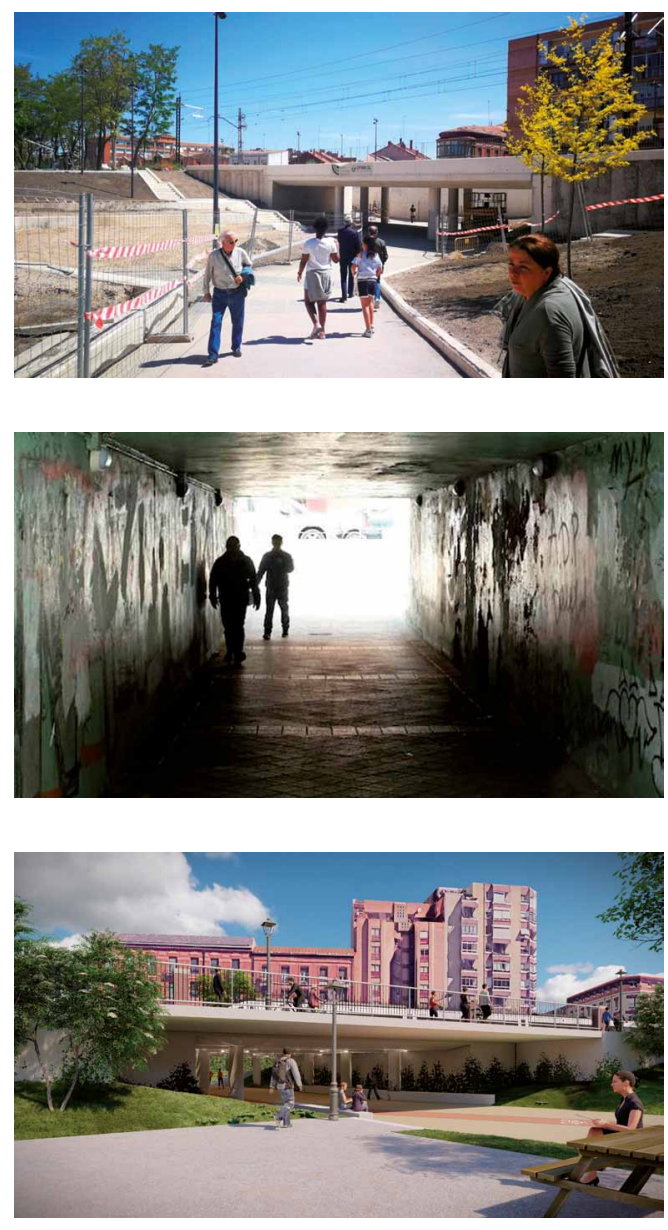

FIG. 14/ El nuevo paso de Rafael Cano. Túnel precedente en Rafael Cano. Proyecto del nuevo paso bajo las vías en Labradores-Panaderos.

Fuente: El Día de Valladolid; El Norte de Castilla e infografía del Ayuntamiento, respectivamente.

género, por más que suscitase "risitas" en 2015 en el PP y ahora en 2020 en Vox. Entre los muchos temas que le afectan (son muchos), hay que recordar que se ha elaborado el mapa del miedo y se ha actuado en consecuencia. Se hizo una consulta ciudadana sobre zonas de riesgo en Valladolid, donde se incluía la perspectiva de género. Se recogieron datos sobre calles mal iluminadas, parques y jardines, calles peatonales, soportales, pasos inferiores y puentes, etc. por los que las mujeres tenían un sentimiento de alerta constante o miedo si caminaban solas de noche. Obviamente, los túneles de Labradores, Delicias y Vadillos aparecían como puntos críticos. Y en las propuestas del Plan se dibujaban en ellos pasos mucho más amplios. Como el de Rafael Cano, ya construido, con una anchura de $20 \mathrm{~m}$., y una amplitud, luz y visibilidad que atenúa de forma terminante la sensación de miedo del túnel anterior. Ha quedado fenomenal.

\section{Clasificar el suelo razonablemente (un arte)}

Cualquier PGOU clasifica suelo, y esta decisión es lo primero, inexorablemente, que los frikis del planeamiento vamos a buscar en él. Es mucho, es poco, se diseña para un crecimiento de tantos miles de personas, el crecimiento se dirige al norte o al sur, al este o al oeste. Un tipo de cuestiones que se plantean en muchas ocasiones de una forma exageradamente ingenua, incluso por personas que se supone que saben de qué hablan.

Veamos tres equívocos frecuentes que tergiversan la información y los datos.

$\left.1^{\circ}\right)$ Confundir capacidad y previsión. Tener capacidad no es prever la edificación próxima de todo lo que cabe. De hecho, en Valladolid hay sectores planteados en 1970, por ejemplo, que se están acabando de construir ahora (en Parquesol, por ejemplo, todavía quedan unas 800 viviendas). Cuando se formularon había esa capacidad; ahora se construyen. Por eso tomar la cifra de capacidad total del PGOU y decir que se prevé construir todo en un periodo próximo es una aberración.

$2^{\circ}$ ) La traducción de la capacidad a cifras de crecimiento de población es peor aún ${ }^{19}$. Pues puede haber nuevas viviendas que, por diversos efectos (demanda de mejora, reducción del tamaño de los hogares, segundas residencias, etc.), no se traduzcan en la llegada de nueva población. Por tanto, tomar la cifra de la capacidad y traducirla a que "se espera nueva población" es igualmente equivocado.

$\left.Y 3^{\circ}\right)$ Una cosa es la necesidad de viviendas y otra la demanda. Esta última depende del mercado, y se determina como la cantidad de viviendas que la población de la ciudad (o la que pudiera venir a residir a ella) desea y puede consumir para los niveles de precio vigentes o previsibles. Lo cual, con frecuencia tiene poco que ver con el número de viviendas que son necesarias. ¿Cuántas son necesarias? 


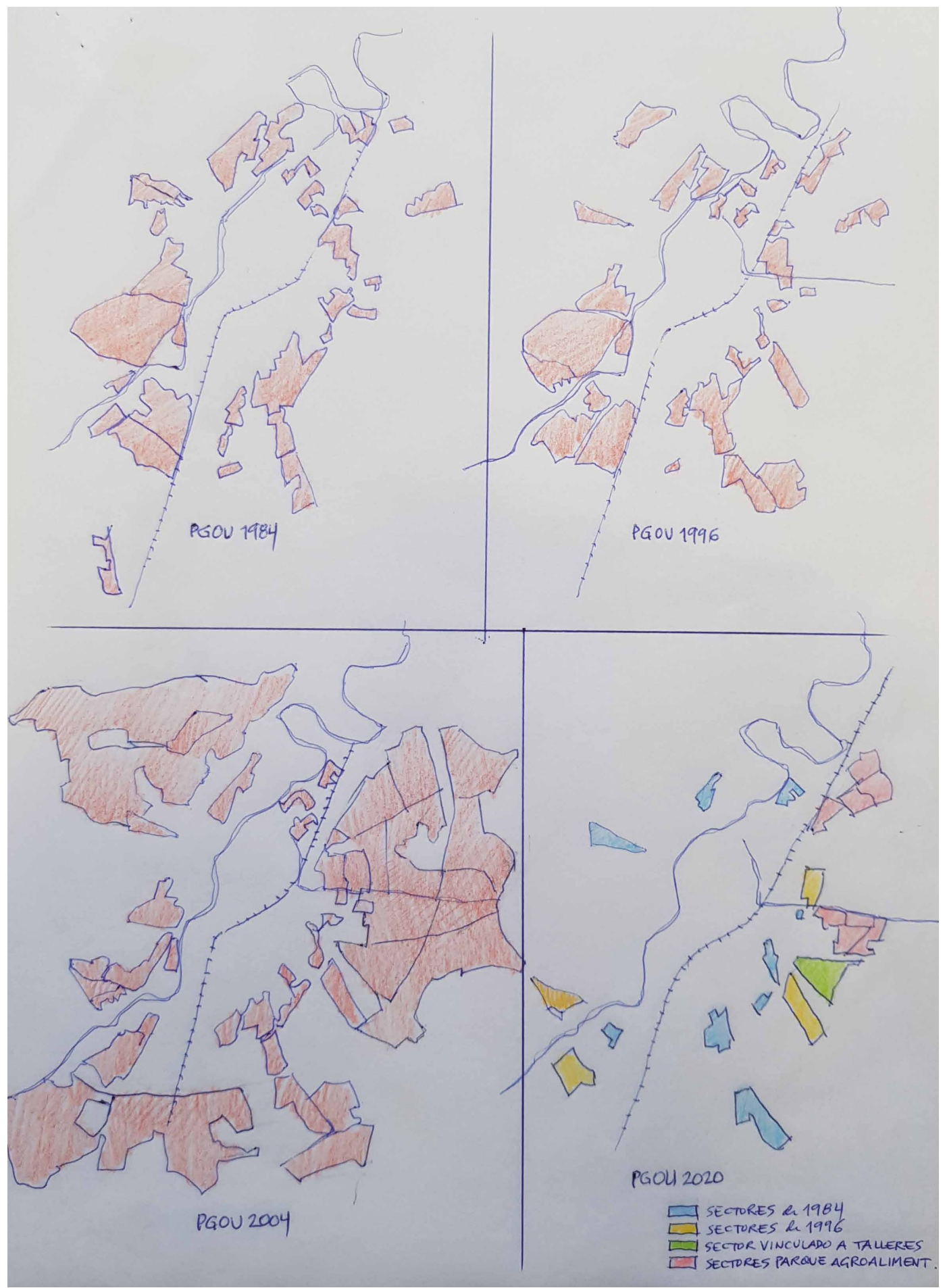

FIG. 15/ Suelo urbanizable en los planes generales de Valladolid de 1984 y 1996 (arriba); 2004 y 2020 (abajo). De este último: en azul, sectores clasificados desde 1984; en amarillo, de 1996; en verde, de 2004 (vinculado a la obtención del suelo para los Nuevos Talleres). Y en rosa, vinculados al parque agroalimentario.

Fuente: Elaboración propia. 


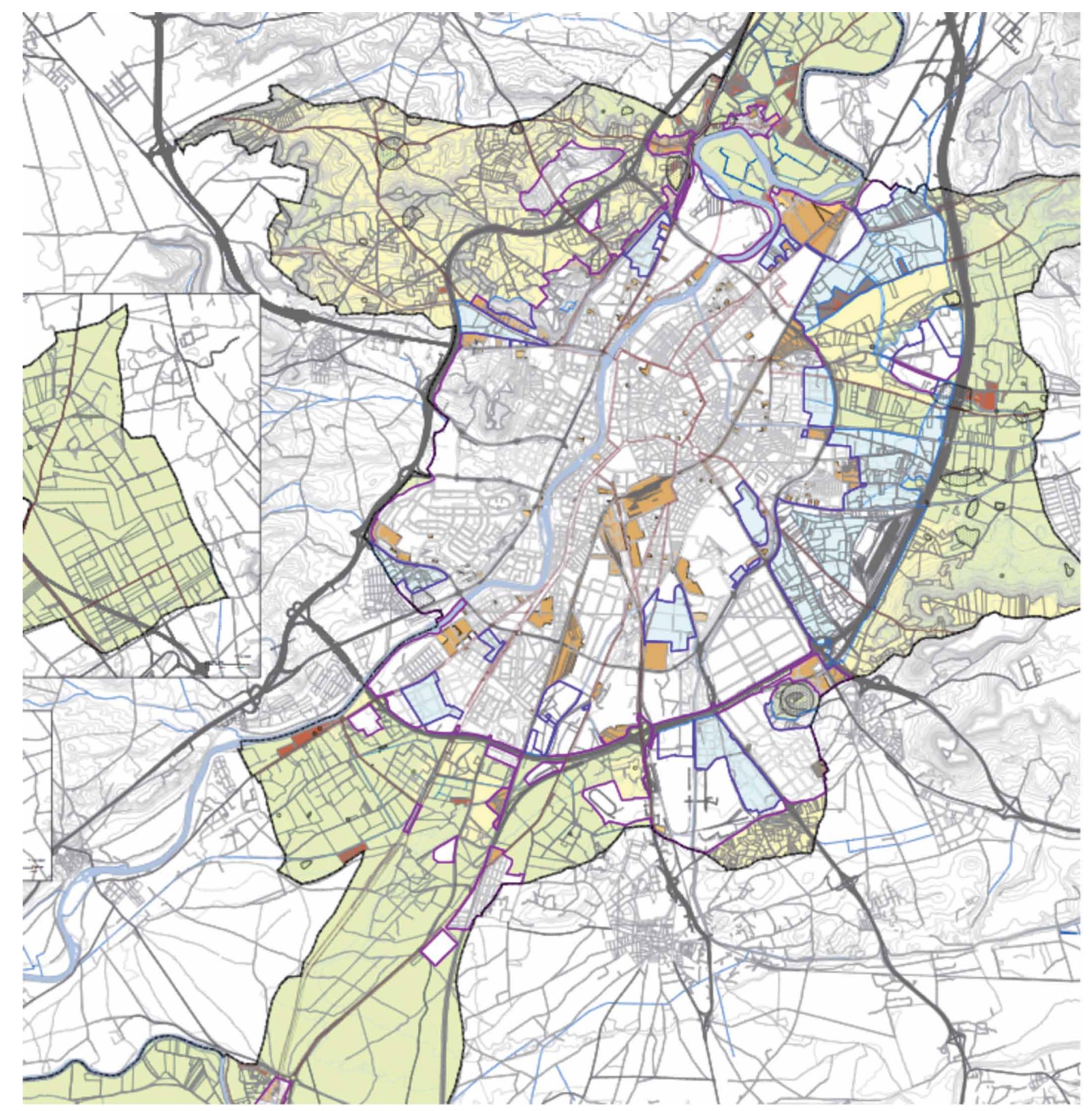

FIG. 16/ Plano de clasificación del suelo.

Fuente: PGOU de Valladolid 2020

La fórmula clásica para el cálculo de las necesidades de vivienda prevé, al estimarlas, tener en cuenta el número necesario para alojar a hogares que ocupan otros inaceptables; los que hacen falta para proporcionar alojamiento separado a hogares que conviven por necesidad; el número necesario para reducir a un nivel aceptable la densidad media; el número necesario para sustituir a los que están por debajo de la media o en ruina; el número necesario para alojar, en su

\footnotetext{
${ }^{20}$ ¿Qué interés tiene, por ejemplo, decir que en Valladolid hay 18.000 viviendas con un tamaño inadecuado, insuficiente, inferior a $60 \mathrm{~m}^{2}$ ? ¿Quiere decir que hay que preparar espacio para construir 18.000 viviendas de mayor tamaño? ¿Quién, cómo y cuándo lo hará? ¿Qué valor tiene decir que más de un $10 \%(15.000)$ se encuentran en mal estado? ¿Y qué decir de que un $15 \%$ del parque necesita
}

caso, al incremento previsto; el número necesario para los que causarán baja en el mismo periodo; etc. Y (también se considera siempre) un "coeficiente de viviendas vacantes" (la "tasa remanente de viviendas vacantes"), que es necesario para permitir la movilidad de los hogares.

Y por supuesto, referirlo todo ello a un número determinado de años. Naturalmente, este tipo de cálculos vale para muy poco ${ }^{20}$. Lo mismo que

mejorar la accesibilidad? ¿O que 48.243 viviendas tienen más de 50 años? ¿Cuál es, por tanto, la necesidad efectiva de viviendas? ¿Qué repercusión tiene el hecho de que el número medio de personas por hogar pase de 2,4 -en el comienzo de la redacción del Plan- a 2,1 -al final- (pues significa nada menos que una necesidad de 21.000 viviendas más)? 
considerar la demanda que se denomina "demanda de mejora" como si fuese la clave de la nueva ordenación. Pues, como es lógico, varía enormemente de unos años a otros. En 2011, cuando se hicieron los estudios informativos para el nuevo PGOU, la situación socioeconómica era completamente diferente a la de 2020, cuando se aprueba. No se puede jugar con los números. Y debe convenirse, como se hace habitualmente, en que los nuevos planes deben realizarse con sentido de la medida, pero que la determinación de la cabida (que también ha de considerar factores territoriales, morfológicos, jurídicos, incluso económicos) es un arte, y no un cálculo exacto, obtenido científicamente.

En el nuevo PGOU se han mantenido únicamente los sectores que procedían de los planes de 1984 y 1996. Y uno de 2004 que se vinculaba a la obtención de los suelos de los talleres. También se han incorporado los del nuevo parque agroalimentario. Pero todos los demás se han eliminado. Por eso decimos que hacer la clasificación de suelo no es una decisión autónoma (el número, sin más). Sino compleja. En el PGOU que se revisaba (de 2004) se clasificaba suelo urbanizable con capacidad para 94.385 viviendas. En el nuevo, para 24.856: cuatro veces menos. Ése es el sentido que, según creo, debería retenerse ${ }^{21}$.

\section{Ordenar y normalizar las determinaciones urbanísticas vigentes}

Hacer un nuevo PGOU (revisión o modificación, pero general) es hacer zafarrancho. Aunque no necesariamente de combate. Basta con que sea de limpieza y orden. Y eso es, verdaderamente, lo que asusta. Porque poner en orden toda la normativa urbanística (general, local, sectorial,

\footnotetext{
21 De las 49.413 viviendas nuevas que caben en el PGOU revisado, una parte importante, las 24.572 del suelo urbano (consolidado: 8.881; y no consolidado: 15.691) nadie discute. $Y$ de las 24.841 restantes (urbanizables), hay 19.261 que corresponden a sectores que proceden de los planes generales de 1984 (en su mayor parte), de 1998 y, en un solo caso, del de 2004, porque está vinculado a la obtención de los terrenos en que se asientan los nuevos Talleres de Renfe, y que ya cuenta con el planeamiento aprobado. De manera que se trata de sectores, como se ve en los gráficos adjuntos, que incluso en la mayor parte de los casos están en los intersticios de la ciudad consolidada (La Florida, Raposas, Cerámicas...). ¿Por qué se incorporaron otros sectores, con capacidad para 5.580 viviendas? Para la creación del Parque Agroalimentario y Logístico (el planeamiento sostenible recomienda la mezcla de usos: la "esencia" de la ciudad compacta es la densidad y la mezcla de usos, admitiendo la mayor compatibilidad de las
}

antigua, moderna...) asusta por el volumen del trabajo que se viene encima. Con razón. Porque la entropía, la oscuridad y la obsolescencia se van haciendo hueco con los años. $Y$ un nuevo plan, que por definición camina hacia la luz, la claridad recuperada y el orden ${ }^{22}$, tiene que reducir el estrés urbanístico. Y nunca me canso de recordar que existe un derecho al orden. Porque, aunque Camus tenga razón (entre el desorden y la injusticia, prefiero el desorden, venía a decir), cuando el desorden es solo expresión de la desidia y la pereza, prefiero el orden.
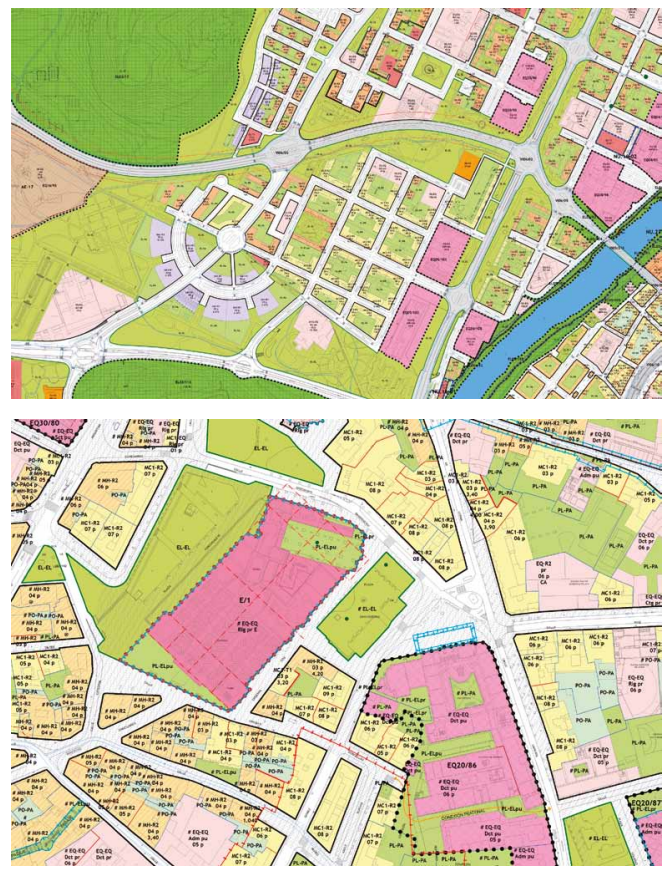

FIG. 17/ Zona de Villa de Prado y zona de la Catedral y la Universidad, con los códigos del nuevo PGOU 2020.

Fuente: PGOU de Valladolid 2020.

actividades productivas con el uso residencial). Tal es la razón de que se incorporasen, en sectores mixtos (industrialresidencial) esas 5.580 viviendas, que suponen un $3,7 \%$ del parque de viviendas existente en la ciudad. ¿Es lógico? ${ }^{22}$ Existe un derecho al orden. En el artículo 28 de la Declaración de 1948 se dice claramente: "Toda persona tiene derecho a que se establezca un orden social e internacional en el que los derechos y libertades proclamados en esta Declaración se hagan plenamente efectivos". En último término, urbanismo es orden urbano, no otra cosa. No cabe urbanismo sin "ordenación", sin algún tipo de planeamiento o proyecto. Un orden necesariamente complejo, si se quiere justo. Pero también preciso y seguro. El derecho al orden nos remite a la seguridad jurídica generalizada. A una primera visión que todo el mundo entiende: que el derecho urbanístico no sea ni un cachondeo, ni una lotería (una sospecha largamente extendida). 


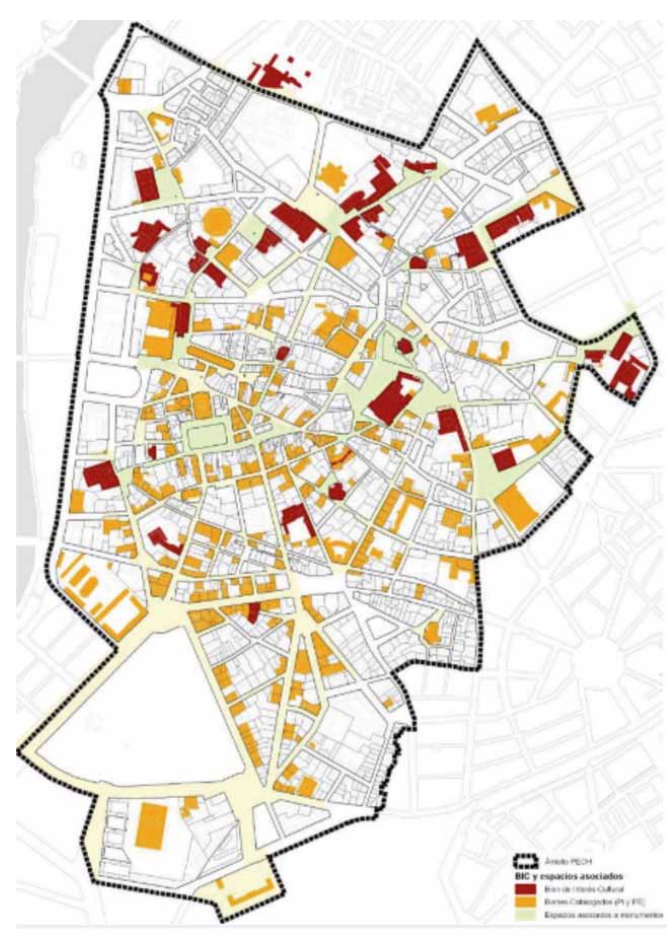

Fig. 18/ Catálogo Arquitectónico en el centro histórico, plano PO-F1.

Fuente: PGOU de Valladolid 2020.
Ha habido que investigar la situación de miles de archivos, expedientes, documentos, parcelas. Que han dado lugar a 9.019 archivos digitales, $Y$ me quedo corto. Se ha llevado todo a un mismo código, a un lenguaje único. Se han "traducido" todos los planes parciales y documentos a una misma nomenclatura y sistemática. 542 planos de ordenación. Un trabajo arduo y enormemente desagradecido (¿quién lo valora?). Pero necesario $y$, con el tiempo, muy rentable. La legislación ha cambiado enormemente ${ }^{23}$. $Y$ todo se ha puesto al día. $Y$ otro aspecto fundamental: se ha referido el conjunto de la ordenación a una nueva cartografía de base ${ }^{24}$. La estadística también se ha remozado. Incluso el $\mathrm{PECH}^{25}$ se ha llevado a ese proceso de traducción. De manera que hoy toda la normativa y planos urbanísticos de la ciudad están integrados en un solo documento.

Y por supuesto, los números se han llevado también a un único planteamiento para toda la ciudad. Tanto en el suelo urbano no consolidado como en el urbanizable se han regularizado y homogeneizado los aprovechamientos. Se ha calculado como punto de partida el aprovechamiento medio de cada uno de los sectores, sin considerar la adscripción e sistemas generales (aunque sí considerando los sistemas generales incluidos). $Y$ se ha tomado un aprovechamiento medio de referencia de 0,44 para todos los sectores de SUNC, conforme al que se ha calculado la superficie máxima inicial de sistemas generales que podría adscribirse a cada sector (con excepción de los "de regeneración"), para que todos los sectores tuvieran esas 0,44 unidades

\begin{tabular}{|c|c|c|c|}
\hline \multicolumn{2}{|r|}{ PGOU 1996} & \multirow{2}{*}{$\begin{array}{c}\text { PGOU } 2004 \\
\begin{array}{c}\text { Aprovechamiento medio } \\
\text { máximo }\end{array}\end{array}$} & \multirow{2}{*}{$\begin{array}{c}\text { PGOU } 2020 \\
\text { Aprovechamiento medio } \\
\text { de referencia }\end{array}$} \\
\hline SUELO URBANIZABLE & $\begin{array}{c}\text { Aprovechamiento } \\
\text { tipo }\end{array}$ & & \\
\hline $3^{\circ}$ cuatrienio & 0,277949 & 0,277949 & $0,33^{(3)}$ \\
\hline \multirow[t]{2}{*}{$4^{\circ}$ cuatrienio } & 0,328747 & & \\
\hline & Aprovechamiento medio & Aprovechamiento medio & \\
\hline $\begin{array}{l}\text { SUELO URBANO } \\
\text { NO CONSOLIDADO }\end{array}$ & No existía esta categoría de suelo & $\begin{array}{l}\text { A calcular en el planeamiento } \\
\text { de desarrollo (no se establecieron } \\
\text { medidas de distribución entre } \\
\text { los diferentes sectores) }\end{array}$ & $0,44^{(3)}$ \\
\hline
\end{tabular}

FIG. 19/ Síntesis de aprovechamientos en Suelo Urbano No Consolidado y Suelo Urbanizable.

Fuente: PGOU de Valladolid 2020.

${ }^{23}$ Solo durante los años en que se estaba redactando el
nuevo PGOU (de 2012 a 2020) he podido contabilizar 38
cambios legislativos que afectan directamente a la ordenación
urbana. Algunos de enorme envergadura: la modificación de
la Ley de Ordenación del Territorio, la del Reglamento de
Urbanismo de Castilla y León, la Ley de prevención ambien-
tal, la Ley de medidas sobre rehabilitación, regeneración y
renovación urbana y sobre sostenibilidad, coordinación y
simplificación en materia de urbanismo, la Ley del patrimonio natural, la Norma Técnica Urbanística sobre el equipamiento comercial, etc. Ése ha sido el contexto de trabajo (como el de cualquier plan, por otra parte, donde los cambios se amontonan en un proceso que debe ir ajustándose permanentemente). (Fuente: Código de Urbanismo de CyL. Nota del autor).

${ }^{24}$ Hay que reconocer el enorme trabajo del Servicio de Cartografía e Información Urbanística.

${ }^{25}$ PECH: Plan Especial del Casco Histórico. Aprobado en 1997. 
de aprovechamiento (en uso residencial/vivienda libre) por cada metro cuadrado de superficie aportada. Luego se ha ponderado en función de la localización del sector (coeficiente $\mathrm{Cl}$ ), y de los costes previstos de urbanización (coeficiente $\mathrm{Cu}$ ).

En el suelo urbanizable el procedimiento ha sido parecido, pero el aprovechamiento medio de partida ha sido de 0,33 . Por supuesto, siempre parece poco. Pero hay que recordar que en 2004 y 1996 era de 0,278 en el primer cuatrienio, y 0,329 en el siguiente. En SUNC no se establecieron en 2004 medidas de equidistribución entre los sectores.

\section{Revisitar y estudiar cada una de las piezas de la ciudad}

La revisión de un plan general es una ocasión para la ciudad revisitada. Volver a recorrer todos los barrios, las calles, los rincones. Y efectivamente al redactar el nuevo PGOU se ha reestudiado todo, con cuidado. Con un amplio trabajo de campo. En todos los casos en que ha sido posible se ha tenido ocasión de hablar con los propietarios, los promotores, los vecinos y los estudiosos. Y se ha elaborado un gran número de fichas (podría decirse que hay "adoradores de fichas"). Solo del catálogo arquitectónico suman 1080 fichas de elementos protegidos (entre ellos, $50 \mathrm{BIC}$ ). También se han redactado fichas de las "unidades urbanas". Y de la ordenación renovada de algunos ámbitos. De los sectores. También se han hecho, obviamente, del catálogo arqueológico. Y un fichero completo del patrimonio natural (espacios, arboles, arboledas).

También se ha llevado a cabo un grandísimo trabajo de reestudio y cuidado de cada pieza susceptible de ordenación, casi diríamos de cada parcela. Que por otra parte no deja de ser un estudio previo, preliminar, incipiente. Que necesitará siempre del proyecto posterior. Pero que, por de pronto, ha servido para desempolvar la zona. Y también se ha revisado la normativa, artículo a artículo, hasta 503. Buscando tanto en ese diseño pormenorizado como en la revisión de las normas oportunidades escondidas. Porque muchos rincones de la ciudad están dormidos (algunos se van durmiendo con los años, y el plan los despeja). Y algunas normas también han perdido su sentido originario, y deben renovarse.

Puede comentarse la revisión de algunas piezas concretas. Como la de la Feria de Valladolid, por

${ }^{26} \mathrm{El}$ nombre viene de que la propuesta recoge una serie de espacios y edificios que bajan hacia el río, y que se inician en la llamada Casa del Sol, el Palacio del Conde de Gondomar,

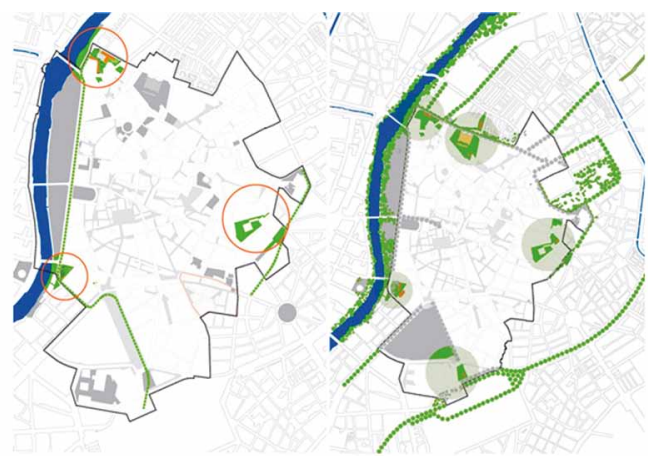

FIG. 20/ Localización de ámbitos de reordenación "estratégicos" y de acciones de rearticulación en los accesos al centro histórico ("acciones intersticiales de micromejora").

Fuente: PGOU de Valladolid, 2020.

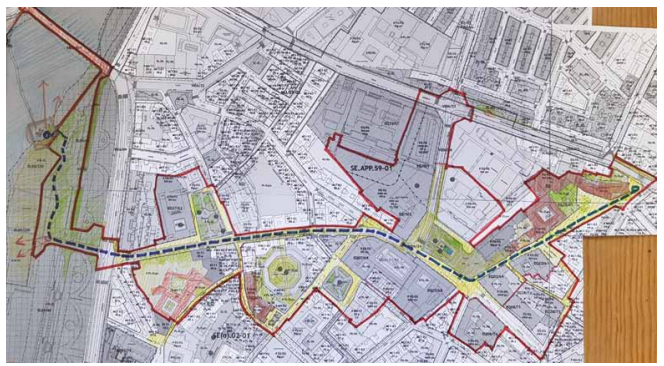

FIG. 21/ Primer boceto del proyecto de la Bajada del Sol.

Fuente: Archivo personal del autor.

ejemplo, que se ha modificado para poder albergar congresos con una reestructuración razonable de los pabellones que permita, a su vez, abrir las instalaciones (cerradas en sí mismas) a un parque próximo y a la ciudad. Algunos sectores se han estudiado y proyectado desde el propio Servicio de Planeamiento y Gestión. En otros casos se ha intentado resolver problemas enquistados (como en Alamillos, por poner un ejemplo). $Y$ en otros más se han llegado a plantear varias soluciones (como en la parcela de la Electra, ese objeto de deseo de tantos promotores).

E incluso se han diseñado ordenaciones conjuntas nuevas y completas, como la que hemos denominado Bajada del Sol ${ }^{26}$ : un ámbito del Valladolid histórico más relevante, en el que las actuaciones del siglo XVI y primer XVII son claves y no están suficientemente aprovechadas. Se concentra en el entorno de San Pablo un buen número de atractivos monumentales: Palacio Real, Fabio Nelli,

en cuya fachada luce, en el centro mismo, arriba, un sol de piedra no muy sonriente, pero tranquilo. 
Convento de Santa Catalina, Viejo Coso, Palacio del Licenciado Butrón, Palacio de los Condes de Benavente. Un conjunto de edificios que carece de un eje que los vertebre y que permitiría llegar hasta las Aceñas y el Palacio de la Ribera, en la otra orilla del Pisuerga, en una solución integrada.

La peatonalización de la Plaza de las Brígidas o la apertura del Patio de Saboya son dos de las actuaciones más complejas y relevantes. $\mathrm{El}$ punto más delicado es el concerniente al Palacio Real, en el que se ha pretendido (sin éxito) conseguir la apertura pública, al menos, del Patio de Saboya. La calle de San Quirce, que conduce la ruta del casco histórico hasta el río, se adecuaría con elementos que permitan, primero, reducir la velocidad del tráfico, y después, dar coherencia cultural al eje de que hablamos.

\section{Resistir los golpes (la paciencia)}

Una parte importante (muy importante) del trabajo de redacción de un PGOU consiste en soportar los golpes. Encajar críticas, por supuesto. Pero también, y, sobre todo, resistir las presiones que llegan desde muy diversos ámbitos. Siempre he defendido que cuantas más alegaciones se presentasen, el plan era mejor, porque había sido más compartido y analizado ${ }^{27}$. Ahora también digo que cuantas más presiones resistidas: más coherente, más independiente, también mejor. Porque es fundamental la autonomía en las decisiones. Incluso para equivocarse. Por lo tanto, un valor primordial del buen urbanista es éste: resistir los golpes. Porque, lo sabemos perfectamente, por bien que esté el trabajo, no se evitan los golpes. $Y$ debe organizarse la resistencia. Los intereses son múltiples y los embates van llegando desde muchos frentes.

\footnotetext{
${ }^{27} \mathrm{Al}$ Plan de Cort solo se presentaron 2 alegaciones. Al de Mesones, 25. En la tramitación del plan que se comenta hubo 416 alegaciones en 2015; 263 en 2017 y el mismo número en 2019. ${ }_{28}$ Veamos algunos comentarios de los debates en el Pleno municipal. "No se puede apoyar el plan porque carece absolutamente de proyectos estratégicos para Valladolid". Y si se habla de parque agroalimentario, que sí que está, se dice que "sobre el papel se vende muy bien, pero a día de hoy no cuenta con financiación". En el plan se ponen, según dicen, "excesivas trabas que coartan y limitan de forma excesiva la iniciativa privada". De hecho "puede llevar a la ciudad a la parálisis urbanística". "Ha configurado un elefante normativo". Y "la propuesta ruraliza Valladolid, pues aumenta la dotación de suelo rústico". Se critica porque "reduce espectacularmente el suelo urbanizable, una reducción del $70 \%$, y la pregunta es si ésa es la actividad que merece y necesita Valladolid". Se "alega que es un Plan General con más calles peatonales, tanto en el centro como en los barrios". También "está el imperio de la bici", y se le recrimina "su empeño en declarar Valladolid Ciudad Imperial de la Bicicleta". Porque "lo dicen con claridad, quieren desincentivar el uso del vehículo particular". Así fueron los comentarios de los grupos de la oposición en el Pleno de aprobación inicial del 24 de julio de 2017.
}

Primero, por supuesto, de otros grupos políticos (por no hablar del propio). De hecho, cualquier plan que no plantee el proyecto de una Nueva Atenas será objeto de críticas múltiples. Lo solemne y pomposo, aunque no tenga ninguna virtualidad, siempre se demanda. Y los grupos políticos, lo mismo que las asociaciones empresariales y sindicales, buscan inmediatamente la definición de nuevas áreas empresariales, parques de innovación, políticas de crecimiento y sectores logísticos, nuevas infraestructuras de todo tipo, innovaciones, atractivos, convertirse en referentes, estudios, estadísticas o planes sectoriales (de la industria, del turismo, del sector gastronómico, de lo que sea), que nunca son bastante ${ }^{28}$. Siempre se dice que es necesario que el nuevo plan "impulse la economía" y solucione los "problemas sociales". Todo lo cual se sintetiza en esa expresión que tanto gusta: un nuevo "modelo de ciudad". Aunque, lamento romper el encanto, ese término es más propio de los Macguffin de Hitchcock ${ }^{29}$ que de propuestas políticamente sensatas.

Luego están algunas asociaciones, que también asestan golpes a diario. También siento decirlo claramente. Pero la mejor participación en urbanismo es la que se formula en las alegaciones. Es verdad que hay muchas instancias magníficamente diseñadas para fomentar el conocimiento de un plan, promover las aportaciones y la creatividad del vecindario, recoger el pensamiento y los deseos de la población sin tener que presentarse de forma desarrollada y técnica ${ }^{30}$. Pero no hay nada como, finalmente, poder exponer las propuestas por escrito, ordenadamente, y que sean atendidas, razonadas y contestadas también de esa forma. Y en este PGOU ha habido nada menos que 6 periodos de alegaciones. Primero, un "avance" con varias alternativas. Después, tres aprobaciones iniciales, dos estudios ambientales,

\footnotetext{
${ }^{29}$ RYKWERT, en su libro sobre "La idea de ciudad", habla de las dificultades de hablar de este asunto, una vez que se han perdido "todas las hermosas certezas acerca de la forma en que funciona el universo". Pero lo cierto es que las dos ideas más básicas que tiran del concepto, la de la ciudad ideal y la de la ciudadanía (por encima de las construcciones), siguen vigentes. Ambas formulaciones no son contradictorias. La ciudad podría plantearse como un espacio utópico a alcanzar, que podría representarse como ciudad imaginada maravillosa como reconstrucción de los modelos míticos, o simplemente como ese fondo del cuadro que asoma en las ventanas de algunos retratos renacentistas. De acuerdo con el segundo, mejor que se comporte como una pantalla en blanco, donde lo importante es la vida, la acción de la gente, para la cual el espacio urbano constituye un fondo que nunca debería robar el protagonismo. Algo así como lo que decía Nicias a los soldados atenienses en las playas de Siracusa: "Vosotros sois la ciudad, allá donde decidáis asentaros son las personas, no los muros ni los navíos, las que dan forma a la ciudad". Ahí está.

${ }^{30}$ Referencia de instrumentos, herramientas y actividades de participación: The Community Planning Handbook (Londres, Earthscan Publ., 2000).
} 
diez debates en el pleno municipal. Lo han informado 35 organismos públicos (algunos de ellos hasta en tres ocasiones) y los 22 ayuntamientos próximos al de Valladolid. Y sin embargo, las acusaciones de falta de participación también están ahí ${ }^{31}$. Pero lo cierto es que se han llevado a cabo muchísimas reuniones. Generales, temáticas, por barrios (bajo el título de "Pensar y vivir Valladolid", se desarrollaron cerca de 40 reuniones). Pero siempre son insuficientes.

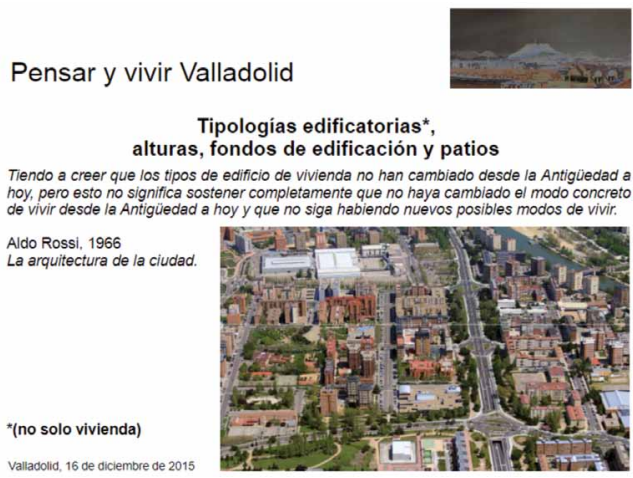

FIG. 22/ Un ejemplo de convocatoria de reunión para debate del Plan en diciembre de 2015.

Fuente: Archivo personal del autor.

Obviamente nos encontramos, además, con el escollo (perdón por considerarlo así) de las distintas administraciones. Con sus informes sectoriales. Algunos son propositivos. Positivos. Razonables. Pero otros directamente problemáticos. Hay que decir que en este caso la administración más directamente responsable del Urbanismo, la Consejería de Fomento de la Junta de Castilla y León, ha tenido un comportamiento cabal y sensato. En su papel, controlando, corrigiendo todo lo que ha considerado oportuno, pero intentando que las cosas avancen y lleguen a buen puerto. Sin embargo, ha habido otras que, bien por ley (la insufrible y sinsentido, totalmente desmesurada y burocrática legislación medioambiental, por ejemplo), o bien por actitud propia, han conseguido acabar con el ánimo del más templado. Y así todo se eterniza sin necesidad. Sin sentido. Ni modificar la Constitución Española ni el parto de un elefante lleva

\footnotetext{
${ }^{31}$ Terrible tragedia (según algún alegante): uno de los periodos de información (el sexto) coincidió con la Navidad de 2018

${ }^{32} \mathrm{El}$ embarazo y gestación de un elefante dura aproximadamente 22 meses. La propuesta de reforma de la Constitución Española se hizo el 23 de agosto de 2011. Se publicó en el BOE el 27 de septiembre de ese mismo año. (Debo estas comparaciones a Antón Sagarra).

${ }^{33}$ Es curioso el caso del informe preceptivo y vinculante de la Dirección General de Infraestructuras del Ministerio de Defensa. Fue desfavorable. Pero no por cuestiones relativas a la defensa, sino por el aprovechamiento que se daba a unos cuarteles ya vacíos. Lo cual es trampa.

${ }^{34}$ elblogdefarina.blogspot.com.

${ }^{35}$ Es curioso cómo fue el Consejo de aprobación. Votaron a
}

tantísimo tiempo y esfuerzo como la redacción de un $\mathrm{PGOU}^{32}$. Y peor aún, cuando te encuentras con cargos que actúan más como políticos de una formación política contraria a la municipal que como responsables de un área administrativa ${ }^{33}$.

Y, por último, los jueces, la amenaza de los tribunales. Las advertencias de recursos son continuas, desde el primer día. Y es verdad que el campo abierto para recursos es inmenso. Y que es facilísimo encontrar (o suponer) defectos de forma, de fondo, de comunicación, de traslación. Y las resoluciones de los posibles recursos: siempre una incógnita. Últimamente, incluso, está la moda amenazar con acudir a la fiscalía y al ámbito penal. Para eliminar las "áreas homogéneas", por ejemplo, hubo un enorme despliegue. Y para ilustrar de lo que hablamos baste señalar que, si el nuevo PGOU se publicó el viernes 19 de junio a las 8 de la mañana, ese mismo día, a las 9 , ya nos visitaron para instarnos a modificarlo y nos anunciaron un recurso "ad cautelam". Una sola hora de tregua. No está mal.

Hay una imagen muy gráfica de lo que suele ser la redacción de un nuevo PGOU. En el blog de José Fariña (arquitecto, licenciado en Derecho y catedrático de Urbanismo de la Escuela de Arquitectura de Madrid) se dice que "el plan es como un saco de arena al que todo el
mundo golpea. El resultado final, compendio de
todas las presiones, es el plan" 34 .

Pues bien: en este Plan estamos muy bien golpeados. Pero se ha resistido a todas las presiones ${ }^{35}$.

\section{Abrazar otras propuestas territoriales e integrarlas}

Es una obviedad, pero no está de más recordarlo. El plan general no es el único instrumento que ordena la ciudad. Muchas veces, ni siquiera es el principal. Pero sí se pretende con él, bajo ese término "general", un propósito de dar coherencia, en lo posible, a las demás ordenaciones en marcha. No es el único que prevé actuaciones. No es el único instrumento que piensa en la ciudad futura, ni el Ayuntamiento el

favor 22 de 26 . Hubo una abstención que podríamos decir "técnica": un consejero que había trabajado en la primera fase y quería quedarse al margen. Pero también hubo otra abstención del Colegio de Arquitectos que estaba muy molesto porque a los propietarios se les planteaban, en su criterio, demasiadas cargas. Nada de cuestiones de diseño o de "modelo de ciudad". Directamente las cargas a los potenciales clientes. Votaron en contra la UGT (con una argumentación disparatada, al margen de que nunca habían dicho nada, ni habían presentado alegación alguna en ninguno de los procesos de exposición). Y lo más lamentable, el voto en contra de Ecologistas en Acción, porque "no tiene ningúnsentido una previsión de construcción de más de 45.000 viviendas". Indefendible, desde cualquier punto de vista. Penoso. ¿Quién dijo golpes? 
único agente que interviene en su desarrollo. Hay otros instrumentos y agentes con gran incidencia. Decisiones económicas, localización de actividades, incluso de diseño al margen del planeamiento, que tienen otros cauces. Otros agentes públicos, otras administraciones, empresas, entidades sociales, financieras, etc.

Incluso algunas áreas "hermanas" a la de Urbanismo (Movilidad y Medio Ambiente) tienen sus propias reglas e instrumentos, a veces más potentes o incisivos que el PGOU. Aunque también con sus problemas. Un plan esencial es, obviamente, el de movilidad. El nuevo PGOU recoge los estudiosy propuestas del PIMUSSVA, actualmente en redacción y que podrá traer cambios. También hay proyectos de otros ámbitos, pues casi todas las áreas municipales hacen proyectos de obras. Como la de Innovación, con el proyecto europeo denominado Urban Green Up ${ }^{36}$. O con el proyecto Indnatur, en el polígono de Argales (una propuesta de renovación de la zona, en colaboración con Urbanismo). También en Cultura se hacen propuestas para las medianeras $u$ otras de arte cívico. Con las que también hemos de buscar coherencia. De hecho, en el desarrollo del PGOU se propuso desde el equipo redactor incluir elementos de arte cívico en algunas áreas, para subrayar el carácter singular de algunos puntos relevantes. Y en el área de Hacienda también se hacen propuestas sobre bienes del patrimonio inmobiliario. Y en Servicios Sociales o Educación sobre nuevos equipamientos.

Por supuesto, en Medio Ambiente llevan varios proyectos de índole territorial. No solo el proyecto de definición de las ZBE (Zonas de Bajas Emisiones) o las actuaciones en el "anillo verde". Las obras de mejora de parques, riberas de los ríos o actuaciones de la entidad pública Aquavall para mejorar la red de agua y saneamiento son esenciales para la política urbanística ${ }^{37}$. Como también las decisiones de la Agenda Local 21, o las propuestas de la Agenda 2030. Lo mismo que el ya citado Plan de vivienda. O los acuerdos derivados de los "presupuestos participativos"38.

Pero no solo hay que hablar de actuaciones del Ayuntamiento. La Diputación trabaja, por ejemplo, en los recorridos peatonales y ciclistas de la Esgueva. La Junta de Castilla y León construye el "parque de proveedores" de Renault. Y algunas

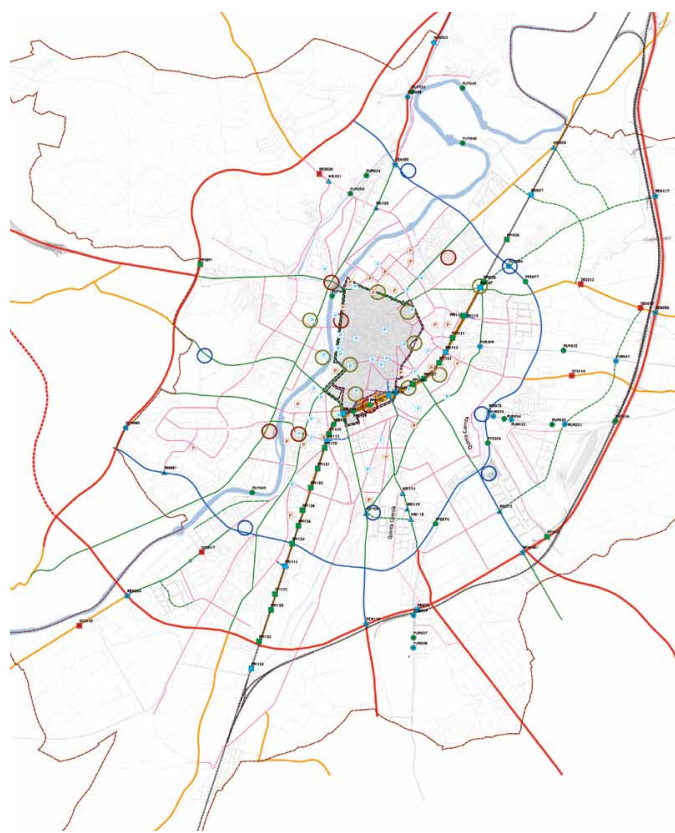

FIG. 23/ Puertas o intercambiadores y áreas de intermodalidad. Plano de jerarquía y acciones en el viario.

Fuente: PGOU de Valladolid 2020.

empresas como Iberdrola recomponen, con sus propias pautas, la red eléctrica en el suelo urbano. Otras instalan aerogeneradores en enclaves críticos (cerro del Águila). Y el PGOU no puede considerarse el árbitro de todo. Ni mucho menos.

Por supuesto, también hemos de considerar las obras de urbanización. Porque puede resultar determinante para el éxito de la regeneración de determinadas áreas el impacto que sobre ellas tenga el plan municipal de obras. Especialmente cuando se trata de las que podrían considerarse obras "estructurales". De hecho, se ha incluido en el PGOU un apartado con las trece propuestas principales que se recogen en la memoria, bajo el epígrafe "Trecena" (una palabra que existe, y es tan legítima como docena o quincena).

Mas es fundamental, para que esta sistemática de integración de piezas de distinto origen funcione, que el Plan se haga desde casa, con un equipo interno, con técnicos de los servicios

\footnotetext{
${ }^{36}$ El proyecto europeo UrbanGreenUP, 'Nueva Estrategia para la Re-naturalización de las ciudades a través de Soluciones Basadas en la Naturaleza', tiene como objetivo desarrollar una metodología para la implementación de planes de renaturalización a través de la aplicación de Soluciones Basadas en la Naturaleza (Nature-Based Solutions-NBS) para paliar los efectos del cambio climático en las ciudades y

mejorar su gestión del agua. Valladolid es, junto con Liverpool e Izmir, una de las tres urbes elegidas como «ciudades faro demostradoras».

${ }^{37}$ Recientemente remunicipalizada (en 2017).

38 Ver: www.pimussva.es/;

www.smviva.com/anexos/430/1496745970.pdf;

Y www.valladolid.es/es/temas/hacemos/agenda-local-21
} 


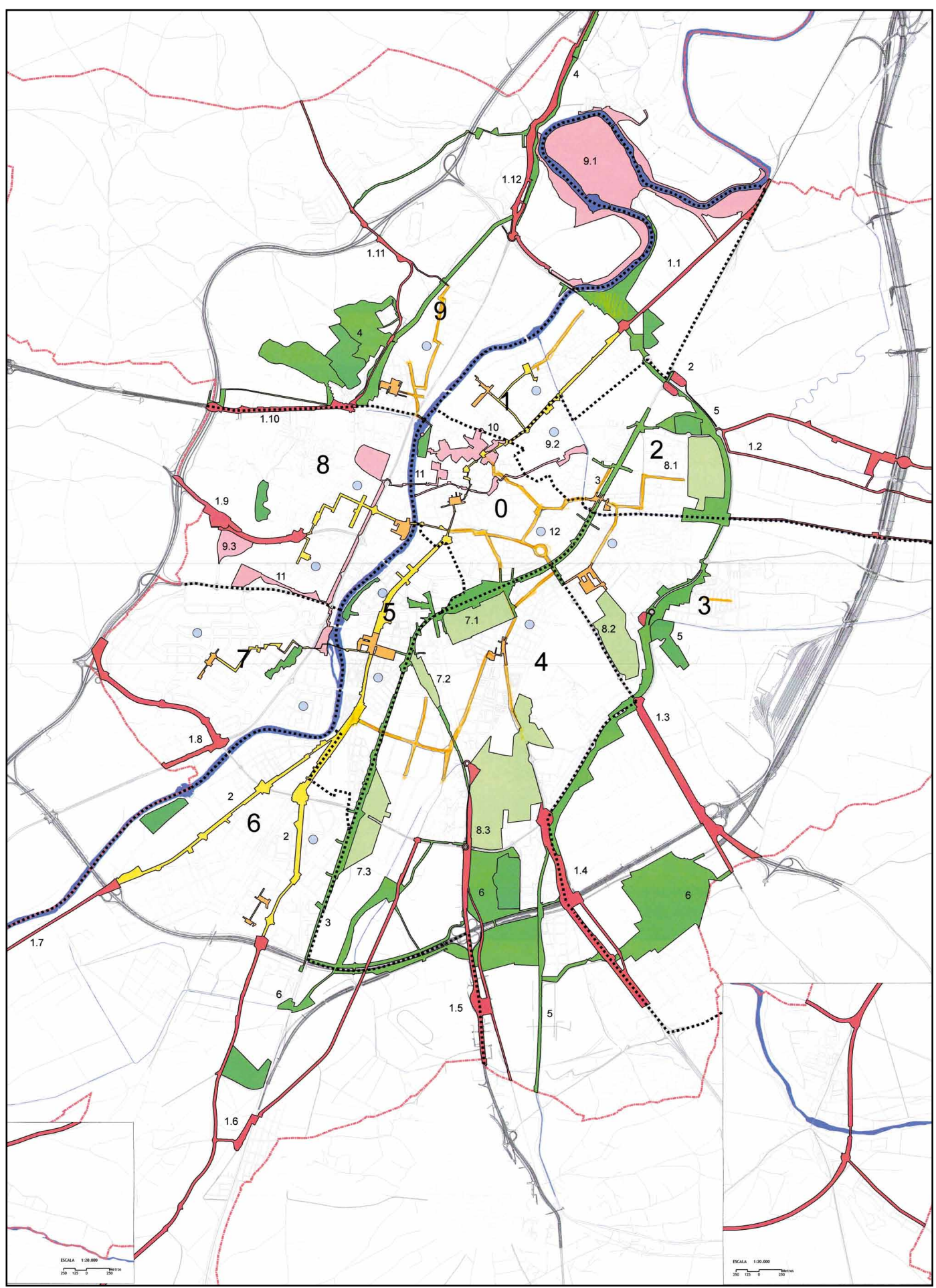

Leyenda: 1: Puertas. 2: Red civil. 3: Trenza ferroviaria. 4: Paseo del norte. 5: Parques del este. 6: Paseo del sur. 7: Barrios ferroviarios. 8. Barrios Quinta Cuerda. 9: Recorrido arqueológico. 10: Bajada del sol. 11: Exposiciones y Congresos. 12: Viviendas blancas. 13. Plazas. 


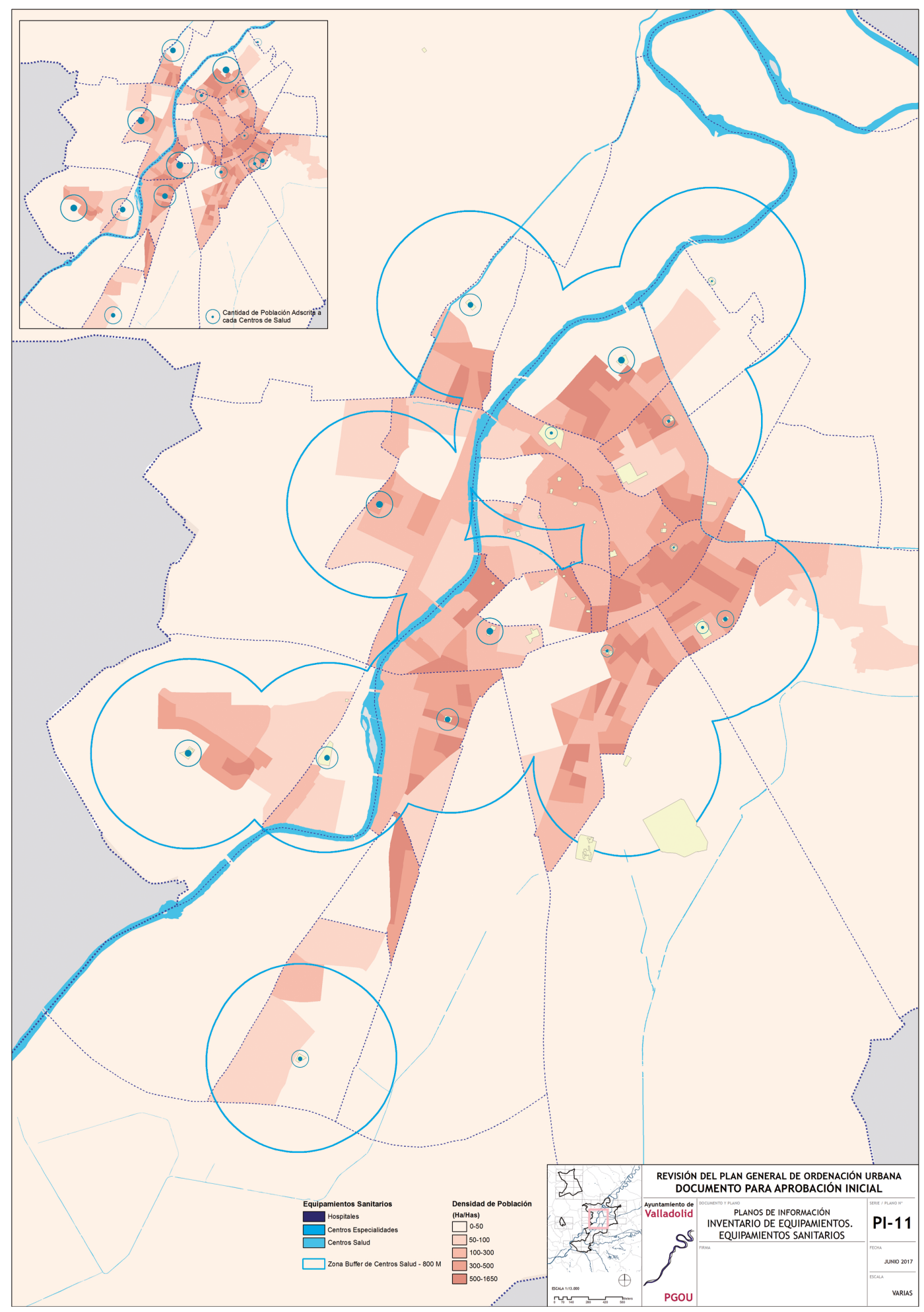

FIG. 25/ Inventario de equipamientos sanitarios. Plano PI-11. 
municipales. Porque donde se cruzan propuestas, análisis y pautas de los distintos ámbitos conviene que estén técnicos que conocen la administración, que conozcan bien cómo funciona esta administración concreta, y sepan integrar las propuestas. En nuestro caso se constituyó (en 2015) un equipo en el Área de Urbanismo que, manteniendo la colaboración externa de la empresa contratada inicialmente, para los trabajos de asistencia técnica y GIS, ha funcionado perfectamen$t^{39}$. Entre todos, se ha hecho un buen trabajo ${ }^{40}$.

\section{Avanzar en la resiliencia (la seguridad y el miedo)}

Obviamente, no podemos dejar de hablar de los últimos meses y semanas. Porque de alguna forma nos hemos visto bajo la maldición de MusIL:

"El hombre moderno nace en una clínica y muere en una clínica; jasí que también ha de vivir como en una clínica!".

Lo exponía en El hombre sin atributos, quejándose de la arquitectura de vanguardia de los años 30. Pero hoy, sin embargo, y por otras razones bien conocidas, se ha visto ese designio de inquietante actualidad. Vivir como en una clínica.

Interesa comentar, en ese sentido, un aspecto más del nuevo PGOU. Pues este nuevo instrumento, recién construido, supone, según creo, un elemento muy útil para montar una suerte de cuadro de mando de la ciudad. Porque el Plan nos va a dar agilidad administrativa. Nos ofrece un diagnóstico reciente. Ofrece seguridad jurídica. Pone al operador público en lugar preferente. Aprovechando la plataforma ya existente del GIS se pueden evaluar los servicios de cada área, y su funcionalidad ante las nuevas exigencias. Permite construir, como decíamos, un "cuadro de mando" de la ciudad que incorpore tanto datos abiertos como estudios derivados y el cruce de los mismos ${ }^{41}$. Y permite también encajar algunas pequeñas actuaciones, como el desarrollo de viviendas colaborativas en parcelas municipales, vinculadas a la creación de una escuela taller que favorezca el empleo y la innovación. Proyectos que (así lo veo) pueden aportar "energía política"42 a la acción voluntariosa de la administración.

\footnotetext{
${ }^{39}$ Créditos. El PGOU de Valladolid se ha elaborado por un equipo coordinado por Irene Serrano, y fundado en el trabajo de Mario Rodríguez, José $\mathrm{M}^{\mathrm{a}}$ Hernanz, Santiago Vega, Jesús Valverde, Jesús Pizarro, Luisa Santos, Sonia Arranz y Montserrat Carro, aparte de una amplia relación de otra veintena de técnicos que figuran en el documento "Equipo municipal responsable de la redacción del documento" de la memoria del Plan. El director del Servicio de Planeamientoen este periodo ha sido Javier Llorente, y el del Área, Pablo Gigosos.

${ }^{40}$ Nos acogemos a la definición del bueno de E. F. SCHUMACHER,
}

Pero lo relevante, en este contexto, es la respuesta a esta pregunta: Una ciudad con un PGOU reciente ¿está en mejor posición? Creo que sí. Porque con él, cualquier cambio será mucho más fácil. Todo está preparado para actuar. En Valladolid, donde se ha conseguido el acuerdo de todos los grupos municipales (menos Vox), para afrontar la situación excepcional, se proponen medidas que, o vienen ya recogidas o son coherentes con las propuestas medioambientales, sociales y económicas recogidas en él. Incluso se ha dicho que la propuesta de "la ciudad del cuarto de hora", tan comentada en estos días, está latente en el nuevo PGOU ${ }^{43}$.

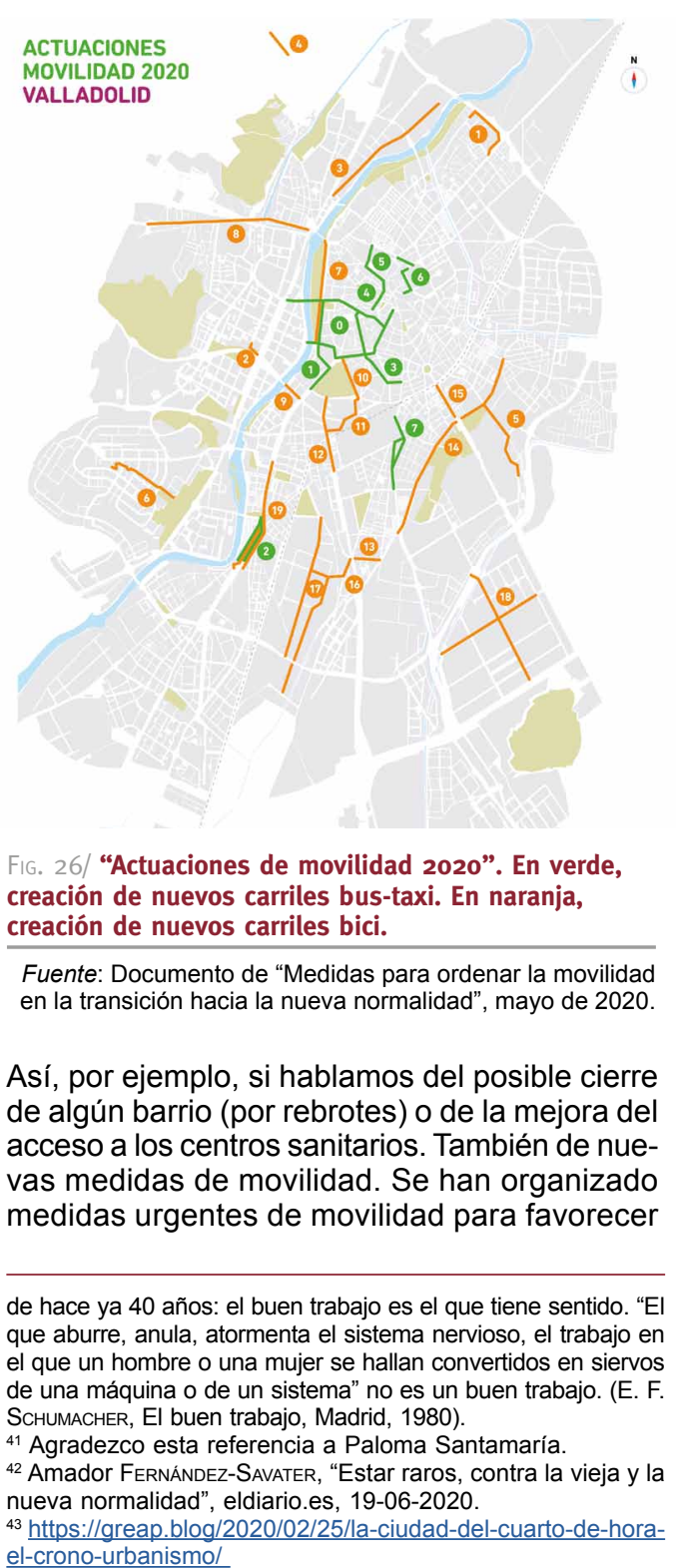




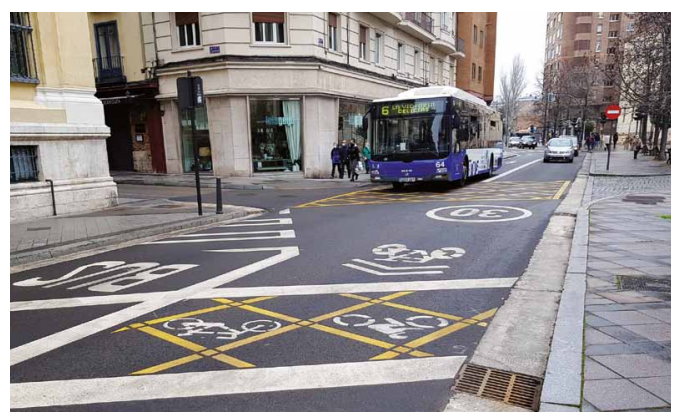

FIG. 27/ Imagen de la reordenación del tráfico en Rinconada.

Fuente: Archivo personal del autor.

el tránsito seguro de peatones y ciclistas. Y para mejorar radicalmente el transporte público. También se ha ofrecido una constelación de suelos dotacionales para la instalación de empresas o creación de empleos sobre ellos por distintas entidades. Se analiza dónde podrían ubicarse hospitales de emergencia. Se propone la revisión de las exigencias de vivienda relacionadas con el soleamiento y los espacios exteriores. Se elabora un "atlas de calles" para compatibilizar el uso de estancia con el de movilidad, en tiempos de pandemia. Se plantea (como dijimos) un programa enormemente exigente de descarbonización, con compromisos públicos. Y se ha avanzado, como se dijo antes, en poner en marcha nuevas escuelas taller, para impulsar la formación y el empleo en la construcción.

\section{Todo en su punto, con sentido de la medida}

EI PGOU, por definición, está siempre a medio hacer. Es un marco. Que, incluso en su ámbito específico, no dice nunca la última palabra. Pues siempre en su aplicación real se reajusta y modifica. El plan es un marco de referencia sobre el que se ha trabajado cuando se redacta, pero que requiere el contacto permanente con una realidad cambiante. Exige una tramitación para llevar a cabo las determinaciones, que hay que saber aprovechar, porque forman parte del proceso.

En la ciudad se mueven pocas cosas, muy concretas. No todas las que se dibujan en el PGOU. Lo habitual es que cuando se vayan a hacer o construir se vea lo que dice el plan, y en ese momento se constate que hay que darle otra vuelta. El plan, por tanto, implica un proceso posterior de concreción y reelaboración. Y es que las implicaciones

\footnotetext{
${ }^{44}$ Algunos datos sobre modificaciones. EI PGOU de 2004 ha tenido 96 modificaciones. Una media de 6,4 al año.

${ }^{45}$ En Valladolid se cuentan 116 plazas de distinto tamaño y
}

a largo plazo tampoco se ven inmediatamente. Pero desde el PGOU se pone el germen y se anima a llevarlas a cabo: se genera un proceso. Por eso hay que convenir que las modificaciones son buenas (y necesarias) ${ }^{44}$. Deberían llamarse ajustes.

Y lo cierto es que algunas propuestas están dibujadas de forma muy esquemática. Por ejemplo, los aparcamientos disuasorios que faltan por crear: únicamente se indica el espacio que ocupan, sin más concreción. Pero también se actúa de forma semejante en otros ámbitos civiles más característicos. Por ejemplo, en las plazas ${ }^{45}$. En el PGOU se han seleccionado 10 de ellas (una por distrito) para constituirse como lugar central, como espacios abiertos que inviten a la reunión y faciliten los encuentros. Diez plazas de suficiente dimensión, buena posición y accesibilidad, y de innegable carácter civil. Que se pretenden limpias (en lo posible) de artefactos, proporcionadas, preparadas para acoger grandes encuentros ciudadanos. Como decimos, en el PGOU únicamente se indica de ellas su posición, dimensiones y superficie (como las de las 11 "campas" también distribuidas en las afueras de cada distrito), o los recorridos de los "itinerarios culturales", o las características de la "red civil" de las calles más significativas. Más adelante se irán completando (y en algún caso corrigiendo) las primeras pautas de todo ello. Como está sucediendo ahora, por ejemplo, en la Plaza del Carmen, en las Delicias (actualmente en fase de proyecto de obras).

Incluso podría considerarse también en proceso, sin concluir, la información y el relato del propio plan. Pues ahí radica otro equívoco habitual sobre los PGOU. Estos planes no son una tesis doctoral sobre la ciudad. No conllevan un relato científico que recoge datos, plantea objetivos y camina por la senda del razonamiento deductivo y lineal. No. Las implicaciones e interacciones son complejas y la respuesta se parece en este sentido (aunque solo en éste) más a un proyecto de arquitectura que a una investigación universitaria. Es decir: a un proceso de trabajo interactivo, en el que se acopia información, se ordenan los mandatos legales y los objetivos iniciales, y después se establecen múltiples relaciones. Se avanza con las herramientas del diseño, generando orden y consolidando propuestas. No es una ciencia. No hay un único relato. Es un ajuste progresivo de varios relatos. $Y$, por si fuera poco, al durar tanto tiempo su elaboración las informaciones iniciales (e incluso la legislación, como vimos) no son estables. Hay cambios constantes, y los habrá después, en el proceso de aplicación.

función: un número escaso, de tipologías muy variadas pero distribuidas de forma irregular. 


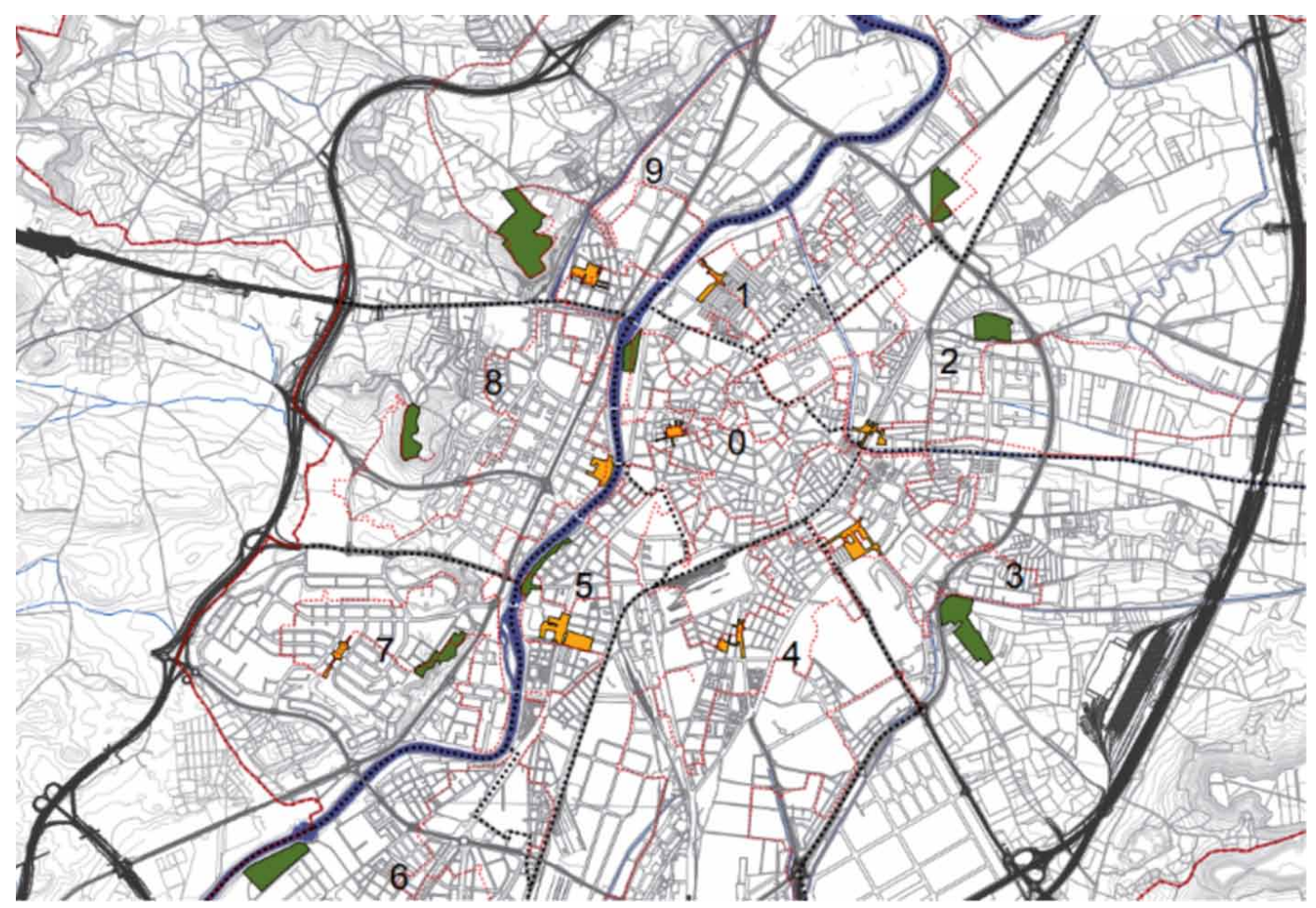

FIG. 28/ Plano con las 10 plazas centrales de los diez distritos de la ciudad (en amarillo), y las 11 campas (en verde). Plano PO-A6.

Fuente: PGOU de Valladolid 2020. (C. Ed.: Si viene bien para maquetación, se puede poner más grande)

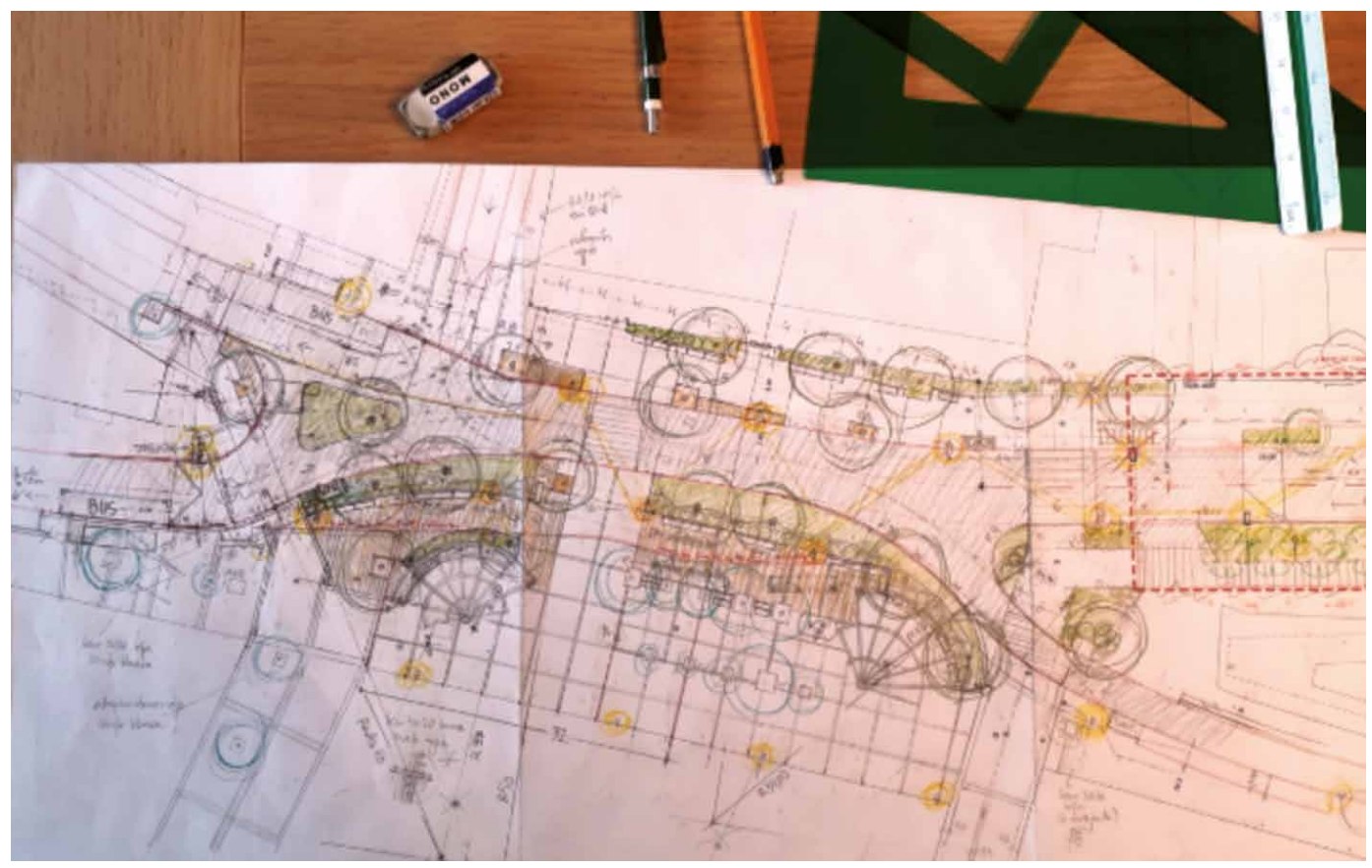

FIG. 29/ Desarrollo de la ordenación de la plaza del Carmen (P. Gigosos, en teletrabajo, meses de abril-mayo). 


\section{Voluntad de forma y estilo (el diseño)}

Algunas de las iniciativas, como decimos, están definidas de manera incipiente. Casi en esbozo. No por falta de estudio (aunque es evidente que no se puede determinar cada pieza a nivel de anteproyecto), sino en ocasiones incluso por no estar aún definida la función, el uso. Y es bueno que así sea. Muchas propuestas nacen de la oportunidad. Pero esa condición, esa vaguedad, no exime de la voluntad de forma. Que en ningún caso ha de estar atada a la tiranía del momento ${ }^{46}$. Y así nos encontramos con ámbitos destinados a ser centrales en la vida urbana que permanecen en el PGOU con un destino abierto. La antigua Azucarera Santa Victoria, por ejemplo. O las $\mathrm{Ca}-$ talinas, el convento recientemente adquirido por el Ayuntamiento. O el teatro Lope de Vega. En todos estos casos la ordenación es muy discreta y despejada. Pero también induce, en las pocas líneas que se dibujan, un orden morfológico futuro al que no se renuncia.

Me gustaría señalar algunos ámbitos de proyecto en los que el PGOU no puede ser (ni lo ha sido) tibio en la definición formal. El primero, el de las infraestructuras. En Valladolid tenemos el trazado de la vía férrea originaria, de 1856, con una geometría magnífica. Pero también otros posteriores, mucho menos cuidadosos del aspecto estético. Y lo cierto es que las redes de ingeniería condicionan decisivamente el desarrollo del territorio, urbano o rural. En el PGOU se plantea, por ejemplo, el diseño de una vía parque que estructura el conjunto del parque agroalimentario y logístico, cuya definición es esencial no solo para el buen funcionamiento de ese ámbito, sino también para consolidar una imagen apropiada, pregnante, de la zona.

De hecho, el paisaje se constituye como la condición de partida para el diseño. Tanto fuera de la ciudad (en el suelo rústico) como en el sistema de espacios libres y cauces fluviales (ese peculiar paisaje interior $)^{47}$. En ambos casos hay un elemento crítico que configura su esencia y articula el conjunto de condiciones que dirigen las actuaciones que a este sistema se refieren.

Para el suelo rústico, la "estrategia agroalimentaria", que supone la apuesta del Ayuntamiento vallisoletano por la relocalización del sistema alimentario como fuente de empleo, salud, sostenibilidad y reequilibrio territorial, así como un intento de recuperación de las producciones agrarias en el territorio metropolitano.

46 "El estilo escapa a los requerimientos del tiempo". Jean CLAIR, La responsabilidad del artista (París, 1997).

${ }^{47}$ Las ciudades con río tienen ventajas si se relacionan bien con su cauce. En Valladolid se cuenta con planes especiales de los principales cursos de agua, alguno de los cuales debe
Para las "zonas verdes" (lamentablemente ya nadie las llama así), parques, jardines y otros espacios libres, su función medioambiental y social. Enfatizando el desarrollo de grandes itinerarios verdes de enlace entre los distintos ámbitos existentes y de nueva creación (por ejemplo, parques forestales del Tomillo o de San Cristóbal).

$Y$ en este momento hemos de referirnos también a la memoria profunda. No solo la de los catálogos de espacios y edificios, sino sobre todo la de los restos arqueológicos (infraestructura) o monumentos en lo alto (superestructura). De los primeros, se han formulado en el PGOU varios recorridos y una visión completa de la historia lejana de la ciudad, desde el Soto de Medinilla hasta la Villa de Prado, pasando por los restos romanos junto a la Antigua o los recorridos subterráneos del Esgueva. Y en cuanto a los monumentos, se ha eliminado la enorme estructura situada en el cerro de San Cristóbal, cuya imagen sobrevolaba toda la ciudad y que ahora ha sido eliminada ${ }^{48}$.

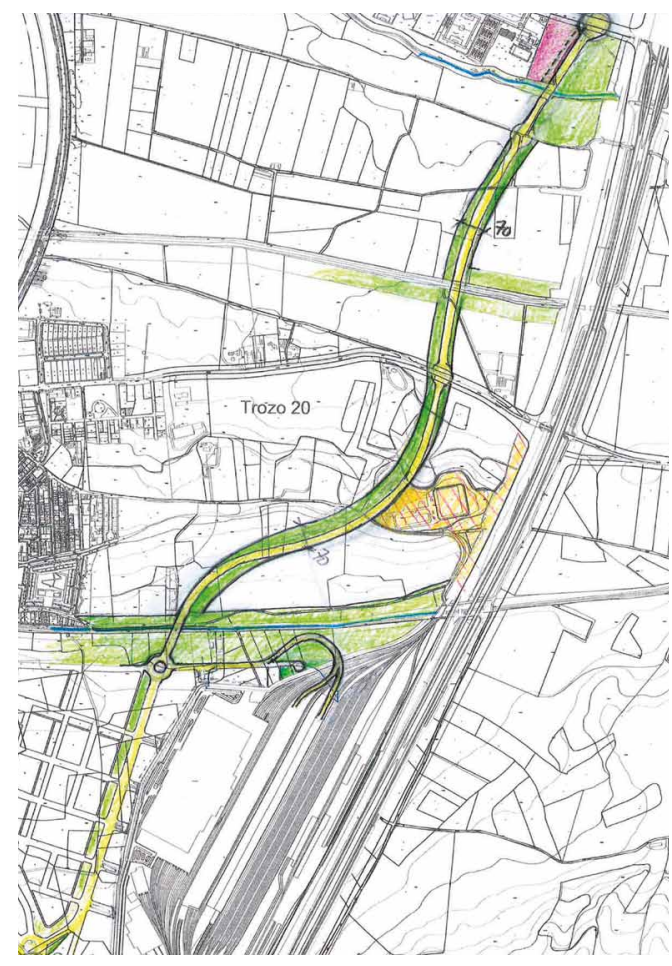

FIG. 30/ Esquema inicial del trazado de la vía parque de los nuevos sectores (arriba), y primera ordenación de la sección (abajo).

Fuente: Archivo personal del autor.

revisarse en los próximos meses

${ }^{48}$ De hecho, podría decirse que ha sido sustituida por el Memorial construido en el cementerio del Carmen en recuerdo de las víctimas de la represión. Un radical cambio de contenido y también de estilo. 

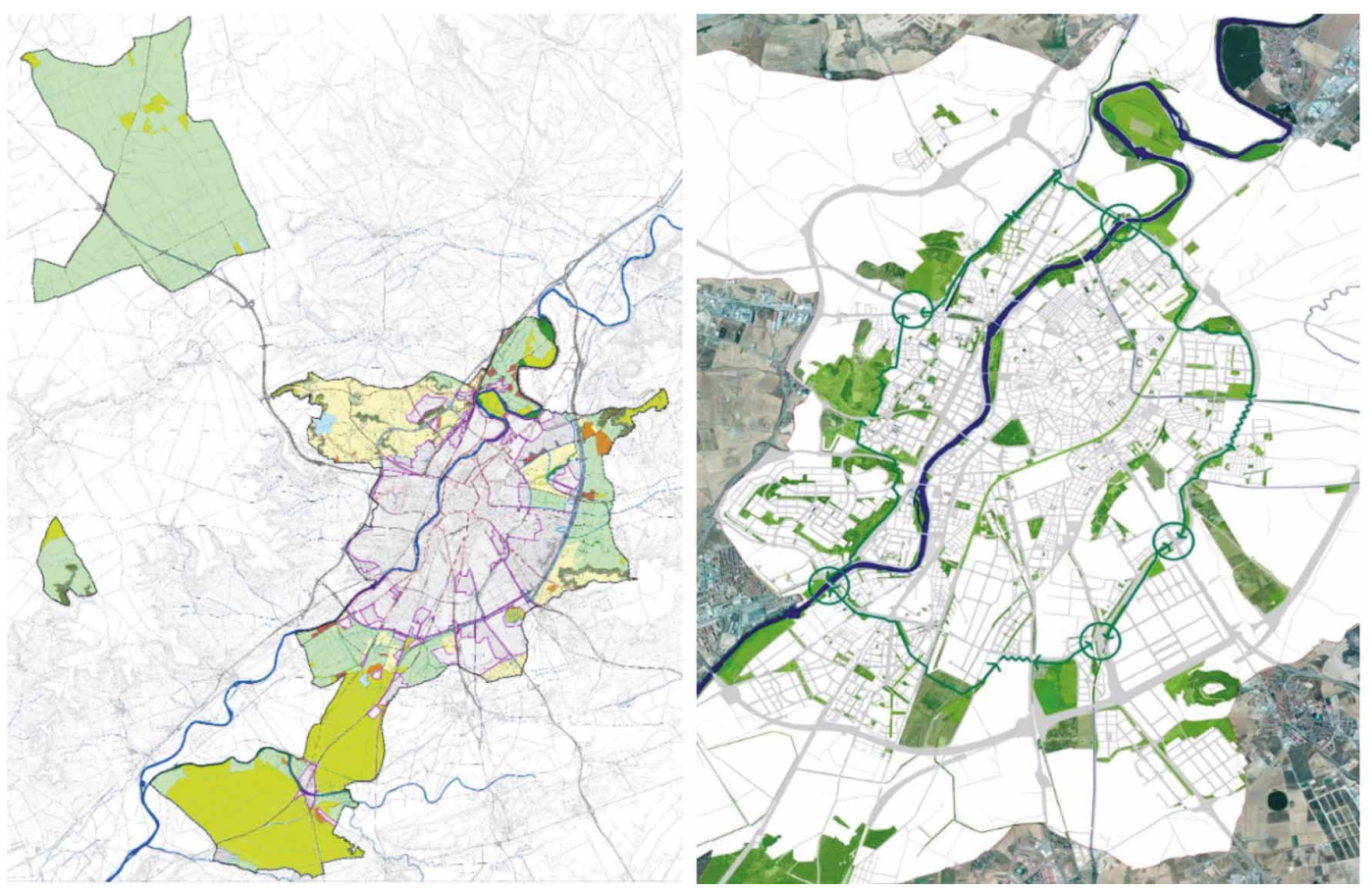

FIG. 31/ Izquierda: Plano del suelo rústico. Derecha: Plano de espacios libres (anillo verde interior, a partir de los parques existentes y previstos, relacionado con los espacios abiertos periféricos (anillo verde exterior). Planos PO-A2 y G4.

Fuente: PGOU de Valladolid 2020.

Usos reales del suelo en 2012, con independencia de su clasificación

\begin{tabular}{|c|c|c|c|c|}
\hline USOS DEL SUELO (2012) & VALLADOLID CENTRAL & NAVABUENA & EL REBOLLAR & $\begin{array}{c}\text { TOTAL } \\
\text { VALLADOLID }\end{array}$ \\
\hline Urbanizado & $4.699,95$ has & & & $4.699,95$ has \\
\hline Agropecuario & \multirow{2}{*}{$8.362,73$ has } & & & $10.520,87$ has \\
\hline Forestal & & & & $3.360,86$ has \\
\hline Masas de agua & 178,09 has & & & 178,09 has \\
\hline $\begin{array}{l}\text { Otros usos urbanos } \\
\text { (infraestructuras } \\
\text { y diseminados) }\end{array}$ & 864,62 has & & & 864,62 has \\
\hline TOTAL & $14.105,39$ has & $5.129,00$ has & 390,00 has & $19.624,39$ has \\
\hline
\end{tabular}

FIG. 32/ Cuadro de superficies del suelo rústico en 2012.

Fuente: PGOU de Valladolid 2020.

De manera que, cumpliendo esta condición de nuestro tiempo, la ciudad se sigue fundamentando en sus restos más viejos y más antiguos. Las construcciones nuevas, “demasiado perezosas para existir por sí mismas, menos aún para dar vida a un entorno arquitectónico, no sobreviven más que acampando en monumentos del pasado, como tropas en desbandada o merodeadores". ${ }^{49}$

49 Jean CLAIR, La responsabilidad del artista. 


\section{Marchar por el lado soleado. Un estándar del jazz}

¿Qué hacemos? Mantener la estructura urbana, aunque reinstaurando el reequilibrio y proponiendo una nueva área económica al este. Insistir en los derechos (los del 48 y los emergentes, los buenistas), mediante actuaciones dispersas pero numerosas y bien distribuidas. Poner a punto la ordenación anterior, normalizarla, revisitar cada esquina. Limpiarla, restaurarla, devolverle, en lo posible, los colores originarios. $Y$ hacerlo resistiendo las presiones. Acoger propuestas de múltiples procedencias e intentar la coherencia territorial de todas ellas. Trabajar la resiliencia. $\mathrm{Y}$ hacerlo todo con sentido de la medida y voluntad de forma. Es decir: un trabajo de mejora y desarrollo de la ciudad que tenemos. Un esfuerzo para hacer avanzar a la ciudad, con ambición, pero sin altanería. Ése es el plan. El nuevo PGOU.

Los dos grandes inventos de la civilización son las ciudades y los derechos. Pero hay quien sigue confundiendo las utopías (los derechos por venir) con las construcciones de unas ciudades más o menos soñadas. Equivocándolo todo. Pues la utopía no se encuentra en las fábricas construidas,

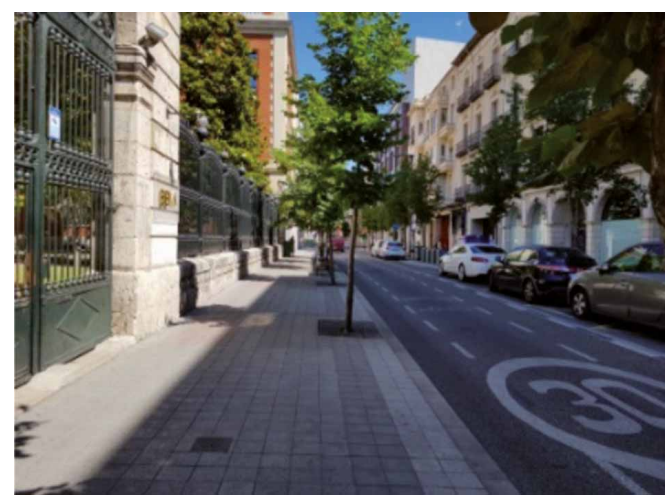

FIG. 33/ Acera soleada de la calle Duque de la Victoria, de Valladolid, en junio de 2020.

Fuente: Archivo personal del autor.

\footnotetext{
${ }^{50}$ Carl SANDBURG, Rootabaga StoRIES:

en.wikipedia.org/wiki/Rootabaga Stories. Como sabemos hay miles (y cuando digo miles, digo miles) de proyectos de ciudades imaginarias, a cual más... estrambótica. La de Sandburg se pensó para niños, eso es verdad.

51 Un primer paso, el Ingreso Mínimo Vital.

52 LEVY-STRAuss, en Tristes Trópicos: "No es de manera metafórica como se tiene derecho a comparar una ciudad con una sinfonía". Y veamos cómo insistía en la comparación: "Son objetos de la misma naturaleza. Más preciosa quizá todavía, la ciudad se sitúa en la confluencia entre la naturaleza y el artificio".

53 Por un lado, tenemos a Eduardo GALEANO diciéndonos
}

en los edificios, sino en los derechos. Utópica no sería una nueva Atenas, ni una celestial Tecla, ni otra renovada Brasilia, ni la sostenibilísima Amaravati (madre mía). Ni tan siquiera la Ciudad de los Sombreros Vacíos ${ }^{50}$. Sino más bien, por ejemplo, la renta básica universal ${ }^{51}$.

Y aunque también hay otros andadores (la compasión, la solidaridad, la ternura, el amor) es sabido que la utopía sirve especialmente para caminar. Con todo, como mejor se anda es con música. ¿Qué música? Decía Claude Lévi-Strauss que la ciudad podía asemejarse a una sinfonía ${ }^{52}$. Es decir, una obra completa, solemne y cerrada. Qué metáfora tan enormemente hinchada para una pieza tan falta de vanidad como la ciudad. Una figura que puede resultar incluso paralizadora. Por el contrario, lo que nos ha de venir bien es el ritmo del jazz. $Y$ así nos gusta ver el PGOU como un instrumento que puede ayudar a acomodar el paso ${ }^{53}$. A quien quiera caminar hacia el horizonte.

Establecer un ritmo suave, siguiendo un estándar del jazz donde quepan mil proyectos distintos y también puedan darse mil improvisaciones. Siguiendo ese pitter-pat, ese repiqueteo. Y, por cierto, ¿recuerdan ese viejo tema, Sunny Side Of The Street, en la versión, por ejemplo, de Rod Stewart?

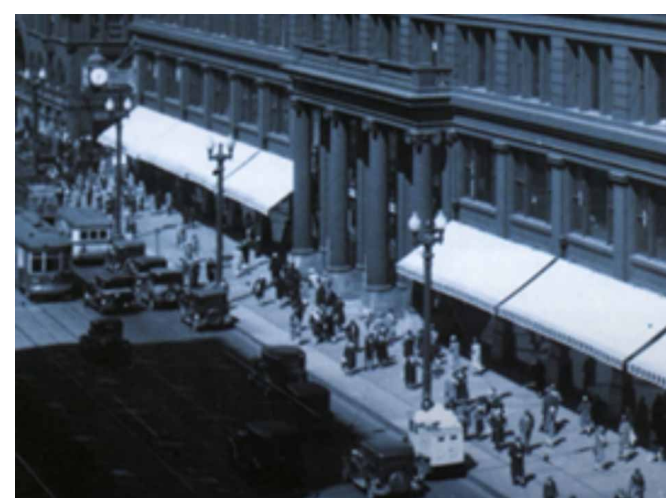

FIG. 34/ Una acera soleada en el territorio del jazz.

Fuente: Archivo personal del autor.

(una cita conocidísima) que "la utopía está en el horizonte. Camino dos pasos, ella se aleja dos pasos y el horizonte se corre diez pasos más allá. Entonces, ¿para qué sirve la utopía? Para eso, sirve para caminar". Y luego MILLÁN, según lo veo, la completaba, en un artículo precioso: "El balanceo de la marcha humana ha acunado intrauterinamente a los recién llegados. Los libros de pediatría recomiendan para mecer al niño un ritmo 'similar al de la persona que anda'. Cuando movemos la cuna, estamos remedando un paseo tranquilo: 'duerme, niño', decimos en realidad, 'que estamos en marcha". José Antonio MıLÁN, "Caminante en un paisaje inmenso", en Archipiélago, invierno de 1994. 


\section{Bibliografía}

BACON, Edmund (1967): "Design of cities". Penguin Books. CLAIR, Jean (1997): "La responsabilidad del artista". París, La balsa de la Medusa.

COREY, Robin (2019): "La mente reaccionaria". Madrid, Ed. Capitán Swing.

Fernández Maroto, Miguel (Coord.) (2019): “Cincuenta años de urbanismo municipal”, en el Catálogo de la exposición "Del Plan al plano. 50 años de urbanismo en Valladolid 1969-2019". Editado por Ayto. de Valladolid e Instituto Universitario de Urbanística.

Gigosos, Pablo \& SARAVIA, Manuel (1997): "Arquitectura y Urbanismo de Valladolid en el siglo XX". Valladolid, Ateneo.

LeVY-Strauss, Claude (1997): “Tristes Trópicos”. Barcelona, Ed. Paidós.
MillÁN, José Antonio (1994): “Caminante en un paisaje inmenso", en Archipiélago: Cuadernos de crítica de la cultura, № 18-19, 1994, págs. 59-64.

MusiL, Robert (1947): "El hombre sin atributos”, Barcelona, Editorial Seix Barral, 2010.

RYKWERT, Joseph (1976): "La idea de ciudad. Antropología de la forma urbana en Roma, Italia y el mundo antiguo". Ediciones Sígueme.

SenNetT, Richard (2009): "El artesano". Barcelona, Anagrama.

- (2019): "Construir y habitar: ética para la ciudad". Barcelona, Anagrama.

SCHumACHER, E. F. (1980): "El buen trabajo". Madrid, Debate.

WATES, Nick (2000): "The Community Planning Handbook: How People Can Shape Their Cities, Towns and Villages in Any Part of the World". Earthscan Tools for Community Planning, Paperback. 


\section{CIUDAD Y TERRITORIO}

\section{ESTUDIOS TERRITORIALES}

ISSN(P): 1133-4762; ISSN(E): 2659-3254

Vol. LIII, № 207, primavera 2021

Págs. 257-260

https://doi.org/10.37230/CyTET.2021.207.14.2

CC BY-NC-ND

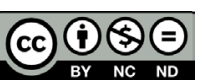

\section{Información sobre Tesis doctorales}

\section{Doctoral thesis information}

Título:

"La implantación normativa del modelo de desarrollo urbano sostenible"

Autor: Doctor Jesús María RAmíREZ-SÁncheZ imramirez@icatudela.com

Universidad de lectura:

Universidad de Zaragoza

\section{Departamento:}

Urbanismo y Ordenación del Territorio

\section{Programa de doctorado:}

Programa de Doctorado en Derecho de la Universidad de Zaragoza

Centro de lectura de la tesis:

Facultad de Derecho de la Universidad de Zaragoza

Fecha de lectura:

14.07.2020

\section{Calificación:}

Sobresaliente

\section{Mención Europeo / Mención Internacional: \\ No Solicitado}

\section{Director/es de la Tesis y filiación:}

Fernando López Ramón (Catedrático de Universidad, UNIZAR)
Tribunal y filiación de los miembros:

Marcos VAquer-CABallería (Catedrático de Derecho Administrativo, Universidad Carlos III).

Julí Ponce-Solé (Catedrático de Derecho Administrativo, Universidad de Barcelona), Julio Cesar Tejedor-Bielsa (Profesor Titular de Derecho Administrativo, Universidad de Zaragoza).

Enlace a documento de la Tesis completo en repositorio de la Universidad o Ficha Teseo:

https://zaguan.unizar.es/record/94468? ln=es

ISSN 2254-7606

Repositorio de la Universidad de Zaragoza

- Zaguan http://zaguan.unizar.es

\section{Resumen:}

La tesis tiene como objetivo principal estudiar la realidad actual del urbanismo español en relación con el principio de desarrollo territorial y urbano sostenible. En concreto, analizar cómo se ha producido la integración normativa del citado principio, así como conocer la aplicación del nuevo modelo urbano en los instrumentos de planeamiento general y en la jurisprudencia más reciente.

Conocer el alcance real y efectivo de esos principios legales y si los mismos han configurado ya un nuevo modelo urbano, distinto y mejor que los anteriores; si se han interiorizado por la práctica profesional, los agentes sociales y las administraciones; o si se limitan a ser un catálogo de buenas prácticas - «promesa de un urbanismo sostenible» en palabras del profesor López Ramón,- ideas necesitadas de desarrollo pero poco eficaces y nada asumidas por los planeamientos urbanísticos, 
y que serán olvidados en un nuevo ciclo de expansión económica.

La irrupción de la sostenibilidad como nuevo principio central de nuestro urbanismo, viene a sustituir ese modelo expansivo caracterizado por las bajas densidades, la movilidad motorizada individual, la zonificación, o el mito de la liberalización del suelo, etc., por la idea hoy dominante en la doctrina de la ciudad compacta, mixta, diversa, respetuosa con el medio ambiente, y más humana, por otra forma de entender y desarrollar el territorio.

Todo ello para poder concluir cuales son los elementos en que se fundamenta la afirmación, que mantengo como conclusión, y es que estamos ante un nuevo y único paradigma del urbanismo español para el siglo XXI, sustentado en el bloque ambiental de la Constitución Española de 1978, que supera el concepto de la producción de la ciudad como una factor de desarrollo económico para ser sustituido por un urbanismo sostenible preocupado por dar cumplimento a distintos derechos sociales de los ciudadanos.

La tesis se interesa no solo por los aspectos legales de los instrumentos para lograr un desarrollo urbano sostenible, sino también los aspectos sociales, ambientales, económicos y arquitectónicos del modelo. El urbanismo siempre ha sido una realidad compleja y multisectorial, en la que son necesarias intervenciones sociales; la garantía de derechos de los habitantes legales; políticas activas de vivienda o de fomento de actividades económicas diversas; la renovación o supresión de grandes infraestructuras, o la creación de nuevas dotaciones. Las referidas actuaciones de construcción de la ciudad deberán contar con una previa participación ciudadana; un respaldo y consenso social para ser aceptadas, y una definición y dirección multidisciplinar que permita superar los viejos estereotipos de entender el urbanismo como una disciplina encomendada — casi en exclusiva- a técnicos, expertos y a los arquitectos. Y más en este nuevo paradigma ambiental o de urbanismo ciudadano, ecológico o ecosistémico.

El trabajo pretende conocer y analizar la repercusión en nuestro sistema urbanístico del principio y modelo de desarrollo urbano sostenible, convertido por la Ley de Suelo de 2007, y posteriores legislaciones autonómicas, en nuevo paradigma del sistema. También conocer el origen y la construcción de un modelo urbano que sustituye a nuestro tradicional urbanismo de Ensanche nos permite extraer conclusiones sobre la forma y modo en que nuestra legislación nacional, la práctica urbanística y la jurisprudencia están atendiendo esta nueva realidad que conforma un modo único e inequívoco de planificar y ejecutar los desarrollos urbanos del futuro, limitando la discrecionalidad del planeamiento y convertirá los citados principios en rectores del sistema urbanístico español.

El trabajo reflexiona sobre algunos de los nuevos retos que debe afrontar el modelo de desarrollo urbano en el futuro. La gentrificación y turistificación de los centros urbanos y barrios más atractivos; la movilidad como factor determinante de la salud; las nuevas formas de dar cumplimiento al Derecho constitucional de acceso a la vivienda, la cohesión e integración social; la nueva gobernanza urbana; o la necesidad de evaluar la sostenibilidad los instrumentos de planeamiento urbanístico y territorial. Por ello se esbozan alguna propuesta, sobre esas cuestiones, como por ejemplo ¿Cuáles deben ser las premisas para la construcción de un nuevo tipo de plan municipal —estratégico o normativo-?; o sobre la necesaria incorporación de lo que he dado en llamar test de sostenibilidad de los instrumentos urbanísticos.

\section{Título:}

"El papel de la gran propiedad en el proceso de construcción de la ciudad europea durante el último tercio del siglo XX. Las propiedades militares como referente"

\author{
Autor: Federico CAMERIN \\ federico.camerin@uva.es
}

Universidad de lectura:

Universidad UVA de Valladolid

\section{Departamento:}

Urbanismo y Representación de la Arquitectura (UVA)

\section{Programa de doctorado:}

Programa de Doctorado en Arquitectura (UVA) en cotutela doctoral con la BUW Bauhaus-Universität Weimar, Fakultät Architektur und Urbanistik (Alemania) dentro del programa European Joint Programme "urbanHist" para la obtención del doble título de Doctor (Doctor y Doctor Philosophiae por la BUW)

\section{Centro de lectura de la tesis:}

Facultad de Derecho de la Universidad de Zaragoza 
Fecha de lectura:

24.06.2020

\section{Calificación:}

Sobresaliente (Universidad UVA de Valladolid)

Magna cum laude (BUW Bauhaus-Universität Weimar)

\section{Mención Europeo / Mención Internacional: No Solicitado}

\section{Director/es de la Tesis y filiación:}

Álfonso Álvarez Mora, Profesor Emérito Honorífico (Universidad UVA de Valladolid)

Max Welch Guerra, Prof. Dr. phil. habil., Director del Instituto Bauhaus de Historia y Teoría de la Arquitectura y de la Planificación (BUW BauhausUniversität Weimar)

Víctor Perez Eguíluz, Doctor en Arquitectura (Universidad UVA de Valladolid)

\section{Tribunal y filiación de los miembros:}

CAstrillo-Romón, María Ángeles (presidente), Profesora Titular, Universidad UVA de Valladolid; GALUZzı, Paolo (secretario), Professore Associato, DASTU de Politecnico di Milano; ZUPAN, Daniela (vocal), Dr.-Ing. MAG. phil., Assistant Professor en BUW Bauhaus-Universität Weimar

Enlace a documento de la Tesis completo en repositorio de la Universidad o Ficha Teseo:

http://uvadoc.uva.es/handle/10324/42217

https://e-pub.uni-weimar.de/opus4/frontdoor/index/ index/docld/4201

\section{Resumen:}

El objetivo es abordar el entendimiento del proceso de construcción de la ciudad europea durante el último tercio del siglo $\mathrm{XX}$, desde el protagonismo y el papel ejercido por la Gran Propiedad, en especial, aquella que se identifica con las instalaciones militares.

Ello implica, en primer lugar, abordar un análisis referido al comportamiento de la Gran Propiedad en la construcción histórica de la ciudad, tipificando su diversidad, atendiendo a las, a su vez, distintas manifestaciones en las que se expresa en función del "capital en suelo" con el que está vinculada. Estamos hablando de la Propiedad que se identifica con categorías espaciales propias de la ciudad, lo que implica su vinculación con aquella fracción del capital que se expresa desde sus compromisos con la "producción del espacio". En este sentido, es la relación entre "propiedad" y "capital en suelo" lo que define lo específico de aquella.

Con este planteamiento general se persigue contextualizar el papel de la Gran Propiedad en el proceso de construcción de la ciudad, los determinantes que impone a la "producción del espacio", así como las formas que adopta tal "producción" según se trate de un tipo de propiedad o de otro. Téngase en cuenta que, al tipificar dichas propiedades en función del "capital en suelo" que las moviliza en el espacio, nos vamos a referir, como mínimo, a "capitales industriales propietarios de suelo" (industriales, ferroviarios, militares, religiosos, servicios y equipamientos...etc.); "capitales comerciales" que se convierten en grandes propietarios tras su materialización como tales (Grandes Almacenes y Superficies comerciales, en general); "capitales financieros" y su relación con Instituciones Públicas y "grandes promotores inmobiliarios" (desde las "promociones" emprendidas y materializadas por el "capital financiero", hasta aquellas otras caracterizadas por su contenido financiero exclusivo); y, "pequeños propietarios" con escasa capacidad de gestión inmobiliaria (constituyen el universo del "sistema parcelario" tradicional que caracteriza nuestras ciudades).

Con todo este recorrido, intentamos esbozar un planteamiento teórico que nos permita un entendimiento de los fenómenos que asisten al proceso de construcción histórico de las ciudades europeas. Bien entendido, que los presupuestos teóricos esbozados se verificarán, en un intento por elaborar una "praxis-teórica", con ejemplos, casos estudio, extraídos de la realidad construida que identifica a algunas ciudades europeas.

Todas estas cuestiones, con las que se persigue, decimos, contextualizar el objetivo de la investigación, constituyen el contenido de la primera parte de esta tesis. La segunda parte se centra en lo específico del papel ejercido por las Propiedades Militares, especialmente, las italianas, en el marco del proceso de construcción de las ciudades europeas, en su versión más actualizada, es decir, desde la "regeneración urbana" a la que son sometidas tras su desmantelamiento y abandono. Se justifica la elección del caso italiano, como referente básico, aunque sin dejar de otear sobre otros países europeos, por la amplitud e importancia que adquiere este fenómeno en dicho país.

Entre los objetivos propuestos nos proponemos aclarar conceptos específicos a los que recurrimos para desarrollar esta investigación, conceptos que son requeridos por exigencias del trabajo. Es el caso, sobre todo, del "concepto de propiedad". Estamos hablado de la "propiedad del suelo", 
aquella que se realiza en la medida en que produce una "renta", la llamada "renta del suelo". Dicha propiedad, por otro lado, es entendida como un "capital" con el que emprender operaciones futuras no previstas de inmediato, aunque previsibles a medio-largo plazo. De ahí que, con este tipo de propiedades, siempre estén abiertos los procesos de "regeneración urbana". Aclarando este concepto de propiedad, por tanto, abrimos el camino para entender los procesos de cambio que recaen sobre los elementos construidos que soportan.

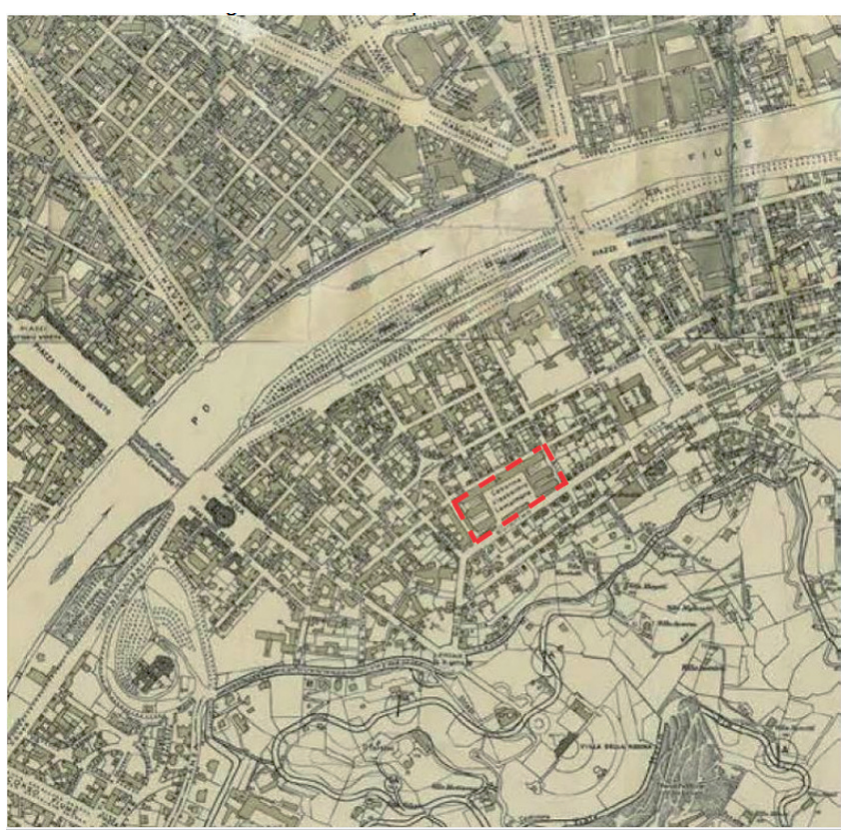

FIG. 1/ Turín. Centralidades residenciales existentes e instalaciones militares. La regeneración del cuartel "La Marmora" y el reforzamiento del carácter burgués de Borgo Po. Extracto del plano de Turín en 1935.

Fuente: Servizio Tecnico Municipale dei Lavori Pubblici (1935), "Pianta di Torino coll'indicazione dei due Piani Regolatori e di Ampliamento rispettivamente delle Zone piana [...] e collinare [...] aggiornati colle Varianti deliberate successivamente sino a Giugno 1935", contenido en DAVICO \& al. (2014: 198).
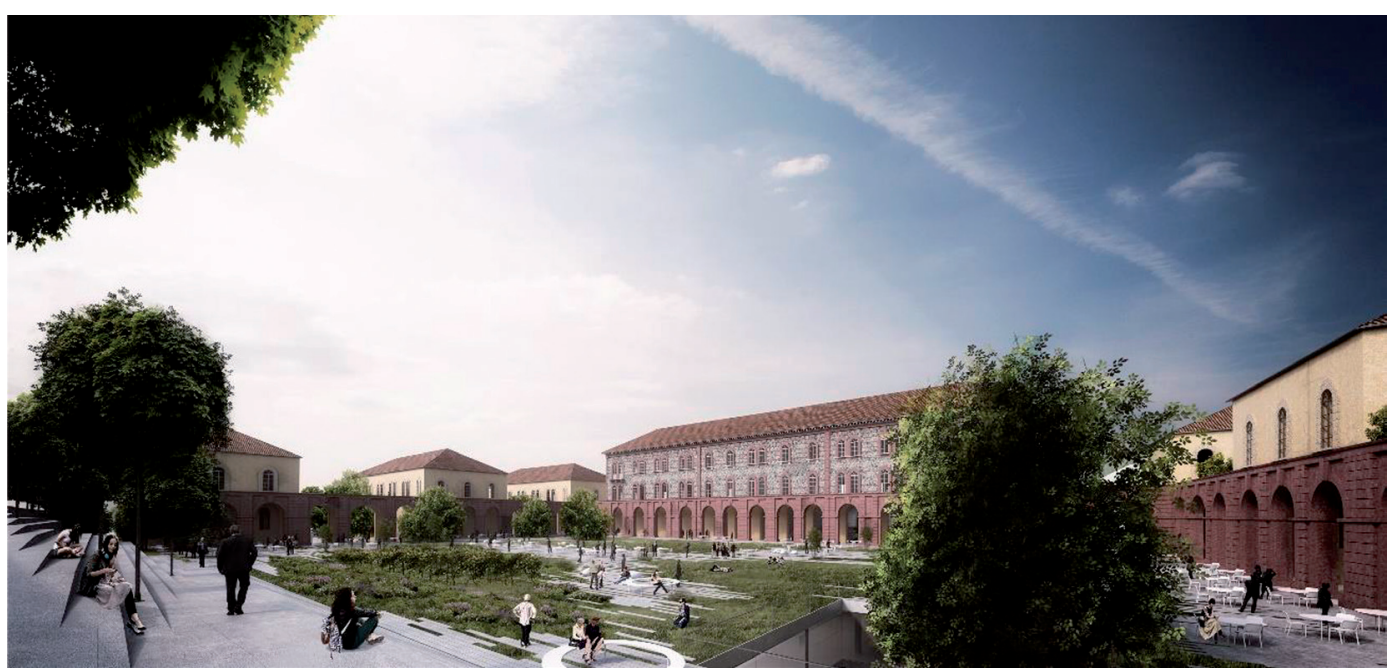

FIG. 2/ Escenario de regeneración propuesto para el cuartel La Marmora.

Fuente: Carlo RattI Associatı (2017). 


\section{Recensiones y reseñas de libros recibidos}

Todos los libros reseñados están catalogados y disponibles para consulta en la Biblioteca General del Ministerio de Transporte, Movilidad y Agenda Urbana:

https://www.fomento.gob.es/WebOpaclnternet/abnetcl.exe/

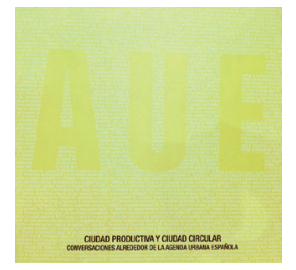

Ciudad productiva y ciudad circular.

Conversaciones alrededor de la Agenda Urbana

DGAVS- MINISTERIO DE

TRANSPORTES, MOVILIDAD Y Agenda Urbana \& GutiéRREZDE LA FuENTE Arquitectos, $2020.23 .5 \times 23.5 \mathrm{~cm}$, 122 pp, rústica. NIPO: 796-20-117-7

Dos ejemplares: español e inglés

La ciudad productiva y la representación del colectivo en la ciudad circular es una reflexión sobre la nueva proximidad en la ciudad productiva postindustrial, en el contexto europeo, y sus impactos a nivel político, ecológico, espacial, social y económico. La propuesta estudia la relación entre este fenómeno y los objetivos estratégicos perseguidos por la recientemente aprobada Agenda Urbana Española, en febrero de 2019.

La publicación se basa en los diez objetivos que conforman el decálogo de propuestas contenidas en la Agenda Urbana para lograr ciudades más sostenibles, inclusivas, seguras y resilientes en España.

\section{Índice de contenidos:}

- Presentación

- Introducción

- El decálogo de los objetivos estratégicos: conversaciones alrededor de la Agenda Urbana Española

- Objetivo estratégico 01 AUE: Ordenar el territorio y hacer un uso racional del suelo, conservarlo y protegerlo

- Objetivo estratégico 02 AUE: Evitar la dispersión urbana y revitalizar la ciudad existente

- Objetivo estratégico 03AUE: Prevenir y reducir los efectos del cambio climático y la resiliencia

- Objetivo estratégico 04 AUE: Hacer una gestión sostenible de los recursos y favorecer la economía circular

- Objetivo estratégico 05 AUE: Favorecer la proximidad y la movilidad sostenible

- Objetivo estratégico 06 AUE: Fomentar la cohesión social y buscar la equidad

- Objetivo estratégico 07 AUE: Impulsar y favorecer la Economía Urbana

- Objetivo estratégico 08 AUE: Garantizar el acceso a la Vivienda

- Objetivo estratégico 09AUE: Liderar y fomentar la innovación digital

- Objetivo estratégico 10 AUE: Mejorar los instrumentos de intervención y la gobernanza

- Consideraciones finales: Agentes / Biografías

Ministerio de Transportes, Movilidad y Agenda Urbana, Dirección General de Agenda Urbana y Arquitectura, Subdirección General de Políticas Urbanas.

GutiéRREZ-DE LA Fuente Arquitectos (G-dIF) es un estudio de arquitectura, urbanismo e investigación, afincado en Madrid y con alcance internacional, fundado en 2006 por Natalia Gutiérrez yJulio de la Fuente. En laactualidad Natalia combina 
su trabajo como co-directora del estudio con el de Arquitecta Municipal. Julio es Miembro del Comité Técnico de Europan Europa (2013-), y tuvo el honor de ser Corresponsal Oficial del COAM en Alemania (2015-2018). G-dIF ha ganado numerosos premios en concursos nacionales e internacionales.

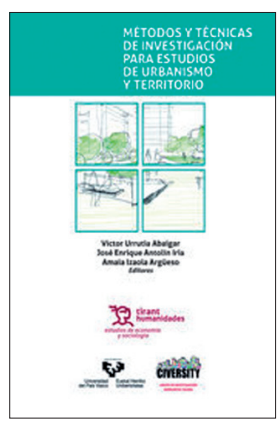
Métodos y técnicas de investigación para estudios de urbanismo y territorio Víctor URRUTIA-ABAIGAR, José Enrique ANTOLÍN-IRIA, Amaia IZAOLA-ARgÜESO (Edits.); Tirant Humani- dades, Valencia; 2019; 15 x 22 cm; 267 pp.; 29 ilustraciones en $\mathrm{b} / \mathrm{n} ; 21,75 €$ : ISBN: 978-84-17508-60-9.

La obra conforma un manual actual que presenta algunos métodos y herramientas para el análisis y ejercicio de la planificación en el ámbito urbanoterritorial. Los autores y autoras, la mayor parte expertos en sociología urbana, incorporan en esta publicación puntos de vista interesantes para la compresión de los fenómenos y dinámicas urbanas recientes, con especial énfasis en los aspectos sociales de la ciudad, es decir, sobre la población y su relación con la ciudad. El manual se dirige a un público amplio, no necesariamente especializado o familiarizado en la práctica del Urbanismo, ya que emplea un lenguaje accesible y directo para profesionales de diversas procedencias: Arquitectura, Geografía, Ingeniería, Sociología, Demografía, Economía, etc.

La obra está editada por Víctor URRUTIA-ABAIGAR, José Enrique ANTOLÍN-IRIA y Amaia IZAOLA-ARGÜESO; y cuenta con aportaciones (capítulos) elaborados por otros ocho expertos: Antía DomínguezRodrígueZ, José Manuel FernÁndEZ-SoBrado, Unai Martin-Rocero, Marian Ispizua-Uribarri, Miguel Calvo-Melero, Andrés DaVILA-LegerÉn, José Ignacio LORENTE-BILBAO y Begoña CRESPO-HIDALGo. Los contenidos se organizan en diez capítulos, además de una introducción explicativa sobre el interés y objetivos del libro elaborada por Víctor URRUTIA. El primer capítulo se centra en las metodologías de análisis demográfico orientado a urbanistas, para lo que presenta métodos de análisis de la población en diferentes ámbitos (estructura, crecimiento, sectores de actividad). Los capítulos segundo, tercero y cuarto dan continuidad al estudio general de la población como referencia para la planificación urbana, presentando medidas, índices y herramientas socio-espaciales para el análisis de la segregación, la obtención de proyecciones lineales y demográficas, y la estimación de la previsión de vivienda. El capítulo sexto aborda el análisis de la provisión de equipamientos esenciales para el funcionamiento de la vida urbana, desarrollando varias tipologías e interrelacionando la demanda con la clase de equipamiento y su planificación. El séptimo capítulo sirve para presentar las potencialidades de los Sistemas de Información Geográfica para la planificación urbana, aunque en ningún momento pretende ser una guía para el uso de los mismos. El capítulo octavo abarca algunas técnicas para la investigación cualitativa como son la observación, la encuesta, los grupos focales o de discusión; incluyendo reflexiones sobre el interés de representar los hechos urbanos mediante mapas, relatos o fotografía, entre otros. A continuación, el capítulo noveno recopila algunas metodologías de carácter participativo útiles para el análisis y planificación de la ciudad, para lo que se dan lineamientos sobre el funcionamiento de los procesos participativos, la identificación de los actores y técnicas para la recogida y análisis de la información obtenida en este tipo de procesos. Por último, el décimo capítulo cierra la obra analizando el caso de la gestión del suelo urbano en el País Vasco.

Todos los capítulos cuentan con una introducción al tema que abordan, y por lo general combinan adecuadamente la teoría con su aplicación mediante el uso de diferentes ejemplos. Asimismo, son numerosas las tablas y figuras que ilustran los ejemplos y casos de análisis, lo que contribuye a comprender los contenidos para todo tipo de público. Es, al mismo tiempo, una publicación interesante para la docencia universitaria ya que presenta un gran número de técnicas de análisis que pueden ayudar a los docentes en prácticas o estudios de campo con el alumnado. Asimismo, también puede ser de ayuda para iniciarse en la investigación en temas urbano-territoriales. La mayor parte de datos y casos tratados se centran en la realidad española junto a análisis sectoriales, por temáticas, de algunos casos específicos del País Vasco.

\section{Índice de contenidos:}

- Introducción

- Análisis demográfico para urbanistas

- Índices socio-espaciales

- Proyecciones lineales

- Proyecciones demográficas: Análisis básico de 
la magnitud y estructura de una población y su proyección futura

- Vivienda

- El análisis de equipamientos en los estudios de urbanismo

- Fuentes básicas de información estadística y cartografía (programas GIS)

- Utilización de técnicas de investigación social cualitativa para el análisis urbano

- Metodologías participativas para el desarrollo urbano

- Gestión del suelo urbano

El editor y autor Víctor URRUTIA-ABAIGAR falleció anteriormente a la publicación del libro. doctor en Ciencias Políticas y Sociología por la Universidad de Deusto, ha dirigido el Instituto Vasco de Estadística y fue catedrático de Sociología Urbana en la Universidad del País Vasco. Especializado en estudios que interrelacionan la sociología y las políticas urbanas.

José Enrique Antolín-IRIA es doctor en Sociología y Profesor Titular del Departamento de Sociología II de la Universidad del País Vasco. Su investigación se centra en el estudio de los procesos de regeneración urbana desde el punto de vista del ecologismo.

Amaia IzAola-ArgüEso es licenciada y doctora en Sociología por la Universidad del País Vasco. Especializada en la investigación en torno a la sociología de los asentamientos humanos, es profesora interina en el departamento de Sociología y Trabajo social de la Universidad del País Vasco.

Los demás autores disponen de una descripción curricular en las páginas finales del libro. Editado por Tirant Humanidades en colaboración con la Universidad del País Vasco y del grupo de investigación Civersity.

Carlos López Escolano

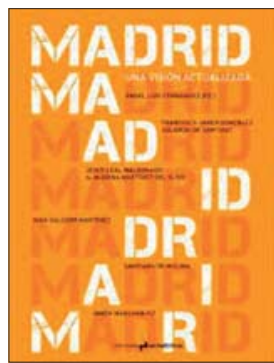

Madrid.

Una visión

actualizada

Ángel Luis FERNÁNDEZ

MuÑoz (ed.);

Ediciones Asimétricas,

Madrid; 2020;

$14,8 \times 21 \mathrm{~cm}$;

184 pp.; rústica; $18 €$ :

ISBN: 978-84-17905-34-7.
Este libro surge como expresión pública de las reflexiones y actividad desarrolladas por el Centro de Investigación en Diseño Urbano de ESNE (Escuela Universitaria de Diseño, Innovación y Tecnología), un grupo de trabajo de perfil transversal en lo disciplinar y caracterizado por el elevado nivel académico y científico de varios de sus miembros.

Contiene una serie de visiones sobre Madrid que quieren añadir a las aportaciones de la disciplina urbanística otras sobre la realidad de la ciudad y que confluyen en un más atinado modo de enfrentar sus problemas a través de la aceptación de su complejidad. Sus enfoques incluyen desde cuestiones de carácter global como las políticas de vivienda y de seguridad urbana, el rescate de proyectos y planes no desarrollados, reflexiones sobre el crecimiento o la regeneración de su tejido, hasta aproximaciones más específicas, como la observación de su paisaje contemporáneo o el de alguna de sus vías más representativas.

Todas juntas componen un mosaico de visiones y sugerencias sobre el presente y el inmediato futuro que esperamos sean útiles como contribución a imaginar el mañana de la ciudad. Con ello ESNE retoma la senda de compromiso con los fenómenos urbanos iniciada en 2017, cuando organizó, dentro de la iniciativa de ONU-HABITAT, un "Urban Thinkers Campus" que reunió a la mayor parte de los actores que planifican, proyectan, viven y trabajan en Madrid, en un encuentro no repetido que fomentaba y permitía el diálogo directo y propositivo de todos los agentes políticos, profesionales, económicos y sociales sobre la realidad de esta metrópoli.

\section{Índice de contenidos:}

- Sueños posibles. Ángel Luis Fernández Muñoz.

- El mito del Ave Fénix. Francisco Javier GonZÁLEZ \& Eduardo dE SANTIAGo.

- Los desafíos de la vivienda en Madrid. Jesús LeAL-MaldonAdo \& Almudena Martínez-del Olmo.

- La seguridad de los ciudadanos y el diseño urbano del siglo XXI. Juan SALCEDo-MARTíneZ.

- Madrid desde la retina. Santiago de Molina.

- El resplandor moderno de la Gran Vía o lo que el viento se llevó. Simón MARCHÁN-FIZ.

Ángel Luis Fernández-Muñoz (ed.): Director de Centro de Investigación en Diseño Urbano en ESNE- Madrid. 
Francisco Javier GonzáLE-GonzÁLEZ: Doctor arquitecto. Miembro del Comité ONU-Hábitat España de buenas prácticas y de la Mesa de Rehabilitación del Ayuntamiento de Madrid.

Jesús Leal-Maldonado: Catedrático de Sociología de la Universidad Complutense de Madrid.

Simón MARChÁn-Fiz: Catedrático Emérito de Estetíca y Teoría de las Artes, UNED.

Almudena Martínez-del Olmo: Doctora Europea en Sociología, especialista en urbanismo y vivienda, por la Universidad Complutense de Madrid.

Santiago de MoLina-Rodríguez: Doctor Arquitecto. Compagina labores docentes con el trbajo en su oficina de arquitectura.

Juan Salcedo-Martínez: Catedrático de Economía en la Universidad de Valladolid y en la Universidad Complutense.

Eduardo de SANTIAGo-Rodriguez: Arquitecto y Urbanista. Consejero Técnico de Suelo y Políticas Urbanas en la Dirección General de Arquitectura, Vivienda y Suelo del MITMA.

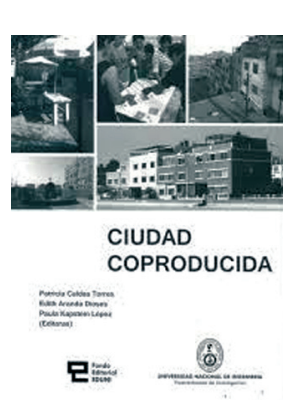

\section{Ciudad Coproducida}

Patricia CALDAS-TORRES \& Edith ARANDA-DIOSES \& Paula KAPSTEIN-LÓPEZ (ed.) Fondo Editorial EDUNI- Universidad Nacional de Ingeniería; Perú 2019

$17 \times 24 \mathrm{~cm} ; 144$ pp.; rústica; $\mathrm{S} / 45.00$; ISBN: 9786124736629

La planificación urbana y la arquitectura para sectores de bajos ingresos en el país enfocan la ciudad, el barrio y la vivienda social convencionalmente como "producto terminado" sin considerar las necesidades ni los patrones de organización y autogestión de los habitantes. El sector público y el sector privado no han reconocido el potencial de las estrategias de la ciudad informal para el desarrollo urbano. Este libro muestra evidencias sobre estrategias informales y semiformales de coproducción de la ciudad en el caso de Lima y Piura que ayudan a dilucidar el valor de otras alternativas concebidas de «abajo hacia arriba" para la práctica profesional del urbanista y el arquitecto. El estudio del sistema de las periferias interiores (SPI) de Lima conformado por los asentamientos informales más antiguos de la ciudad revela el impacto de la coproducción a escala territorial y se plantea como instrumento de planificación en contextos informales. El análisis de la coproducción en relación con la apropiación de la modernidad por parte de los residentes de un modelo de barrio representativo de la vivienda social en el Perú, como es la unidad vecinal en Lima, hace legible nuevas formas de vivienda colectiva que crecen en el tiempo, donde los residentes completan lo planificado, y contribuye con aproximaciones teóricas desde el diseño urbano, la arquitectura y la sociología urbana para comprender el concepto de la ciudad como proceso de vida. El estudio de un reciente laboratorio urbano formado en Piura con enfoque de «arriba hacia abajo" y a la vez de «abajo hacia arriba» dirigido a sectores sociales de bajos ingresos de Piura, incorpora a profesionales de distintas especialidades, entre ellos arquitectos, urbanistas, que desarrollan métodos participativos novedosos a partir de las necesidades, deseos y aspiraciones de los pobladores para lograr el desarrollo sostenible. El libro revela en su conjunto las interconexiones entre la ciudad formal» $\mathrm{y}$ «la ciudad informal tradicionalmente vistas como desconectadas y devela el potencial transformador de las estrategias participativas en el entorno construido.

\section{Índice de contenidos:}

- Las periferias interiores de Lina

- La coproducción de barrios, Unidad Vecinal de Lima

- Habitar en las Unidades Vecinales de Lima

- FUTUROPIURA. Un laboratorio urbano participativo

- Texto fundamento de la propuesta "Lima: coproduced city"

Edith Aranda-Dıoses: Doctora en Ciencias Sociales, Magister y Licenciada en Sociología. Profesora principal de la Universidad Nacional de Ingeniería. Becaria del Centro Latinoamericano de Formación Interdisciplinaria de la Universidad de Córdoba, Argentina. Investigadora calificada RENACIYCONCYTEC, Perú. Publica artículos en revistas indexadas nacionales e internacionales. Miembro del equipo que desarrolló el proyecto Lima: co-produced 
city, premiado y expuesto en la Conferencia Habitat III, OMU, Quito, 2016.

Patricia CALdAs-Torres: Arquitecta y Magister en Arquitectura. Becaria en la TU-Berlín. Grado doctoral Dr. Rer.pol. Docente en la Faua-Uni desde 1998. Directora del INIFAUA, Ubvestugadira REGUBA dek-cibcttec desde 2018. Coautora del proyecto Lima: co-produced city, premiado y expuesto en la Conferencia Habitat III, OMU, Quito, 2016. Ponente en congresos internacionales y autora de artículos en revistas especializadas.

Paula KaPSTEIN-LóPez: Doctora por el Departamento de Urbanística de la ETSA de Universidad Politécnica de Madrid (2010). Máster en Tecnologías Avanzadas en Construcción Arquitectónica de la UPM (1996) y Arquitecta por la Universidad de Valparaíso. Ha sido profesora en varias universidades. Actualmente es profesora Universidad de Piura (Perú) y colaboradora en el Magister en Diseño de Entornos Sustentables de la Facultad de Arquitectura y Artes de la Universidad Austral de Chile, además de participar como investigadora en el Proyecto "Morgenstadt Global Smart Cities Iniciative". Sigue varias líneas de investigación sobre la ciudad.

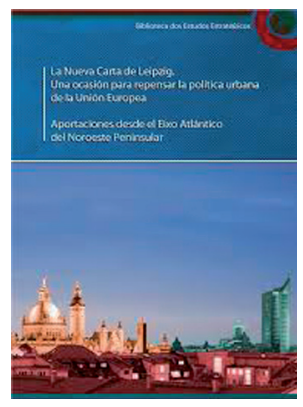

La Nueva Carta de Leipzig. Una ocasión para repensar la política urbana de la Unión Europea Aportaciones desde el Eixo Atlántico del Noroeste Peninsular. Martín FERNÁNDEZPRADO (coordinador), Ángela DE LA CRUZMera, Miguel Sopas de Melo-Bandeira, José Santos-Soeiro. Biblioteca de Estudios Estratégicos.

Eixo Atlántico do Noroeste Peninsular, 2020. ISBN versión impresa: 978-989-54875-8-5; ISBN versión digital: 978-989-54875-9-2; Depósito Legal: VG 418-2020

Dos volúmenes: inglés y español/portugués.

Esta publicación ha sido cofinanciada por el Fondo Europeo de Desarrollo Rexional FEDER a través del programa Interreg V-A España-Portugal (POCTEP) 2014-2020. Las opiniones son responsabilidad exclusiva del autor que las emite.
El día 30 de noviembre de 2020 se firmará la Renovación de la Carta de Leipzig, inicialmente firmada en 2007con el objetivo de establecer unos principios y estrategia común para la política de desarrollo urbano de los Estados miembros de la UE. Todo lo que se relaciona con la cooperación y la política urbana es de gran relevancia para el Eixo Atlántico, especialmente en este caso ya que la nueva Carta de Leipzig será firmada en un contexto en el que las ciudades cobran fuerza como garantes del bienestar, la sostenibilidad y el desarrollo territorial.

\section{Índice de contenidos:}

- Introdução à publicação

- O desenvolvimento regional e a política de ciudades. Contributo dos fundos europeus estruturais e de investimento para a sustentabilidade das cidades portuguesas

- La evolución de la política urbana de la UE. Su contribución al desarrollo equilibrado de todos los territorios

- A carta de Leipzig: a cidade sustentável e a sustentabilidade da ideia treze anos depois

- La nueva Carta de Leipzig. Una ocasión para redefinir el papel de las ciudades en la Unión Europea

- Bibliografía comentada de los principales documentos de política urbana europea.

Martín Fernández-Prado: Dr. Arquitecto, Master en Urbanismo por el GSD de Harvard University (MAUD-95). Profesor de urbanismo en la Escuela Técnica Superior de Arquitectura de la Universida de da Coruña (UDC). Concejal del Ayuntamiento de A Coruña, Teniente de Alcalde responsable urbanismo 2011-15. Diputado en el Parlamento de Galicia legislaturas X y XI. Co-director de la Agenda Urbana del Eixo Atlántico. Director General de Urbanismo del X Gobierno Gallego. En la actualidad sus principales campos de investigación son las estrategias urbanas y las Smart cities.

Ángela de LA CRUz-Mera: Licenciada en Derecho y Técnica del Cuerpo Superior de Administradores Civiles del Estado. Subdirectora General de Políticas Urbanas del Ministerio de Transportes, Movilidad y Agenda Urbana desde el año 2008 (con denominaciones de la Subdirección y del propio Ministerio, diferentes). Jurista especializada en 
urbanismo, ha formado parte del equipo redactor de numerosa legislación estatal. Es profesora asidua en Cursos de Formación y conferenciante en seminarios y eventos nacionales e internacionales. Posee numerosas publicaciones en Revistas especializadas.

Miguel Sopas de Melo-BAndeIRA: Doutor com Agregação pelo Instituto de Ciências Sociais da Universidade do Minho; e Vereador do Município de Braga, com os pelouros da regeneração urbana, mobilidade, património, ligação às universidades, urbanismo e planeamento urbano (2013-20). Sendo Investigador no Centro de Estudos de Comunicação e Sociedade/UMinho (CECS). Tem desenvolvido trabalhos de pesquisa e reflexão nas áreas dos Estudos Urbanos e Planeamento Urbano, Estudos Culturais/História, e Património Cultural. Foi Secretário-Geral da Fundação, Centro de Estudos Euro-Regionais Galiza (Sp) - Norte de Portugal (CEER) (Pt). Leciona/ou em Arquitectura, Planeamento, e outras Ciências Sociais na Universidade do Minho.

José SANTOS-SoeIRo: Licenciado emAgronomia pelo Instituto Superior de Agronomia, da Universidade Técnica de Lisboa. Exerceu funções de Presidente da Agência para o Desenvolvimento e Coesão em Portugal. Antigo Presidente do Instituto Financeiro para o Desenvolvimento Regional, foi também Diretor-Geral do Desenvolvimento Regional. Foi ainda Curador do Beneficiário dos Fundos Europeus Estruturais e de Investimento e gestor da Iniciativa Comunitária Interreg III. Consultor na área dos Fundos Europeus Estruturais e de Investimento.

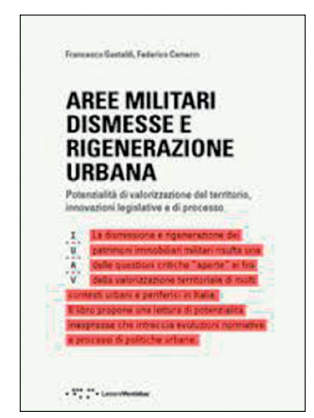

Aree militari dismesse
e rigenerazione
urbana: potenzialità
di valorizzazione del
territorio, innovazioni
legislative e di proceso.
(Áreas militares enaje-
nadas y regeneración
urbana: potenciales
de valorización territo-
rial, innovaciones
legislativas y de proceso)

Francesco GASTALDI \& Federico CAMERIN; Lettera Ventidue, Siracusa; 2019; 14 x $21 \mathrm{~cm}$; 224 pp.; $n^{\circ}$ de ilustraciones o planos en color 32 ; $15 €$; ISBN: 9788862424080
El libro explora uno de los temas relacionados con las políticas públicas italianas en conexión con el gobierno del territorio en los últimos 30 años en Italia: la enajenación y reutilización de los bienes inmuebles pertenecientes al Ministerio de Defensa en relación con las cuestiones de regeneración urbana y territorial. El texto, escrito en italiano, es un estudio inédito en el ámbito de los estudios urbanos italianos e internacionales en cuanto abarca el tema, hasta ahora parcialmente analizado, de las instalaciones militares enajenadas a nivel estatal, proponiéndose como un manual de divulgación a un público académico y non académico. Estudia toda una serie de instalaciones militares, como almacenes, arsenales, cuarteles, depósitos, polvorines, localizadas en todo el territorio italiano, en ámbito urbano y periférico, declaradas como redundantes para los fines de la defensa nacional, y sujetas a un estado de prolongado abandono, infrautilización y degradación de los espacios abiertos y sus arquitecturas.

Este libro es resultado de toda una serie de investigaciones que los autores han llevado a cabo entre 2011 y 2019 a través de una actividad de desk research, trabajos de archivo y de campo, entrevistas a los actores involucrados en la gestión de los bienes militares enajenados y la confrontación con otros investigadores durante la participación en conferencias nacionales e internacionales sobre el tema objeto de estudio (como los eventos "Commons/Comune" y "Military Landscapes" organizados respectivamente por la Società di Studi Geografici en diciembre de 2015, y por la Università di Cagliari en junio de 2017).

El manuscrito interpreta las repercusiones del marco normativo fragmentado y variable en materia de enajenación del patrimonio inmobiliario público, con un enfoque especial en el de uso militar, de las últimas tres décadas. El resultado es una lectura crítica e interpretativa de un conjunto heterogéneo de cuestiones entrelazadas entre ellas: la evolución de la legislación estatal; el papel de las administraciones estatales y territoriales e actores privados en la gestión de los antiguos bienes militares locales y la relación entre ellos; el contenido de los instrumentos de planificación urbana y territorial; la evolución de la relación entre políticas públicas en materia de gobierno del territorio, dinámicas urbanas, tendencias del mercado inmobiliario y coyuntura económica, y los enfoques 
innovadores y en cierta medida infrautilizados para realizar operaciones de reutilización del antiguo patrimonio inmobiliario del Ministerio de Defensa. A través de esta lectura interdisciplinar de las cuestiones que rodean los antiguos patrimonios militares se realiza, por primera vez, un inventario del estado del arte de los varios procesos de enajenación de esta particular tipología de patrimonio inmobiliario público: los "protocolos de colaboración interinstitucional" entre entidades estatales y locales (principalmente ayuntamientos), el Programa Unitario de Valorización Territorial, la actuación del artículo 24 del Decreto Ley "Desbloquea Italia" y el "federalismo demaniale".

En el contexto de los estudios urbanos en Italia, la investigación presentada se propone como una "reflexión problemática": el lector descubrirá los factores que han llevado a la inercia, la lentitud y los éxitos parciales e insatisfactorios de los procesos de enajenación, los cuales se basan en una normativa que se focaliza principalmente en objetivos financieros de reducción de la deuda pública desplazando en segundo plano aquellos de gobierno del territorio. Pese a las dificultades encontradas para dar nueva vida a los antiguos inmuebles militares, Gastaldi y Camerin ofrecen algunas posibilidades para la reutilización a través de nuevas prácticas "bottom-up" (de abajo hacia arriba) que pueden ser elementos desencadenantes de una posible regeneración urbana exitosa basada en la reutilización de los bienes militares enajenados.

\section{Índice de contenidos}

- Introducción

- C. 1: Dificultades y cuestiones abiertas en la gestión del patrimonio militar

- C. 2: La normativa en materia de enajenación y explotación de los bienes del Ministerio de Defensa ya no útiles para sus finalidades institucionales

- C. 3: La relación de la Agencia del Dominio Público con el Ministerio de Defensa en la gestión del patrimonio militar para enajenar y regenerar

- C. 4: Los procedimientos en curso, aprender de las experiencias

- C. 5: Las relaciones problemáticas entre normativa, políticas urbanas y dinámicas de mercado
- Conclusiones generales

- Referencias bibliográficas

Francesco GASTALDI (1969), graduado en Arquitectura (1996) por la Università degli Studi di Genova, doctor en "Pianificazione territoriale e sviluppo locale" por el Politecnico di Torino (2001). Ha sido becario de investigación por el Dipartimento Polis de la Università degli Studi di Genova (2004-2007) y profesor a contrato por la Università di Parma y el Politecnico di Torino. Actualmente es profesor titular en el sector científico-disciplinar italiano ICAR/21 Urbanismo en el Dipartimento di Culture del Progetto de la Universidad IUAV di Venezia (Italia). Lleva a cabo investigaciones sobre políticas de promoción territorial y desarrollo local, gestión y regeneración urbana, y procesos de desarrollo urbano de la ciudad de Génova desde el período de posguerra hasta la fecha. Participa en investigaciones de la Università IUAV di Venezia y del Ministerio de Educación, Universidad e Investigación y en la consultoría de temas públicos y privados. Autor de artículos y ensayos publicados en revistas internacionales, ha impartido conferencias en cursos de maestría y doctorado (http://www.iuav.it/Ateneo1/docenti/ pianificaz/docenti-st/Gastaldi-F/index.htm).

Federico Camerin (1989), se graduó en planificación territorial por la Università IUAV di Venezia (2014). Ha sido becario de investigación por el Dipartimento di Progettazione e Politiche in Ambienti Complessi de la misma Universidad (2014-15 y 2016-17), siendo luego Early Stage Researcher dentro del proyecto europeo "urbanHist", obteniendo un doble título de doctor en Arquitectura por la Universidad UVA de Valladolid y Doctor philosophiae por la BUW BauhausUniversität Weimar (Alemania) (2017-2020). Actualmente es becario posdoctoral en el sector científico-disciplinar italiano ICAR/21 Urbanismo en el Dipartimento di Culture del Progetto de la Universidad IUAV di Venezia (Italia), con estancia en el Instituto Universitario de Urbanística de la Universidad UVA de Valladolid (2021). Camerin ha realizado varias estancias de investigación (Colegio Oficial de Arquitectos de Madrid, COAM; Center of Social and Psychological Sciences Institute of Social Sciences en Košice, Eslovaquia; Fakultät Architektur und Urbanistik, BauhausUniversität Weimar, Alemania), participando a 
Libros y Revistas

varios talleres internacionales y más de 30 conferencias como orador, además de haber logrado publicar cincuenta entre artículos en revistas, conference proceedings, capítulos de libros y dos libros (https://www.aesop-youngacademics.net/yal members/profile/federico-camerin).
Este libro ha sido financiado por la Università IUAV di Venezia dentro de una convocatoria para publicar monografías de la colección "IUAV Saggi" de 2019 a través de la editorial LetteraVentidue.

Federico CAmERIN \& Francesco GastaldI 


\section{Documentación}

\section{Evaluadores 2020}

\section{Experts 2020}

Los evaluadores del año 2020 de la revista CyTET han sido los siguientes:

Adrián Gutiérrez Cabello Agustín Hernández Aja

Alberto Matarán Ruiz

Alejandro Román Márquez

Almudena Martínez del Olmo

Ana Zazo Moratalla

Ángel Pueyo Campos

Ángela García Carballo

Antonio Álvaro Tordesillas

Armando Arteaga Rosero

Armando Chávez Hernández

Armando Ortuño Padilla

Asunción Blanco Romero

Basilio Calderón Calderón

Camilla Mileto

Cándida Gago García

Carlos Alberto Abalerón Vélez

Carlos Fernández Salgado

Carmen Alemany Bay

Carmen Delgado Viñas

Catalina Quiroga Manrique

Cayetano Espejo Marín

Diego Barrado Timón

Eduardo de Santiago Rodríguez

Elizabeth Espinosa Dorantes

Enrique Rajevic Mosler

Fernando Díaz del Olmo

Fernando García Martín

Fernando López Ramón

Francisco J. Goerlich

Francisco José Villar Rojas

Graziella Trovato

Henar Pascual Ruiz-Valdepeñas

Ignacio Bisbal Grandal

Ignacio Kunz Bolaños

Inés Sánchez de Madariaga

Íñigo Sanz Rubiales

Javier Benayas del Amo
Universidad Nacional de San Martín de Argentina

ETSAM - Universidad Politécnica de Madrid

Universidad de Granada

Universidad de Sevilla

Universidad Antonio de Nebrija de Madrid

Universidad del Bío-Bío (UBB), Concepción, Chile

Universidad de Zaragoza

Universidad Autónoma de Madrid

Universidad de Valladolid

Universidad Nacional de Colombia

Universidad de Guadalajara-México

Universidad de Alicante

Universidad Autónoma de Barcelona

Universidad de Valladolid

ETSA - Universidad Politécnica de Valencia

Universidad Complutense de Madrid

Fundación Bariloche de Argentina

Patronato Mpal. Vivienda y U. Ay. Salamanca

Universidad de Alicante

Universidad de Cantabria

Universidad Nacional de Colombia

Universidad de Murcia

Universidad Autónoma de Madrid

S.G. Políticas Urbanas, MITMA

Universidad Autónoma Metropolitana- Azcapotzalco Universidad Alberto Hurtado, Santiago de Chile

Universidad de Sevilla

Universidad Politécnica de Cartagena

Universidad de Zaragoza

Universidad de Valencia

Universidad de La Laguna de Santa Cruz de Tenerife

Universidad Politécnica de Madrid

Universidad de Valladolid

Universidad del Bío-Bío de Chile

Universidad Nacional Autónoma de México-UNAM

Universidad Politécnica de Madrid

Universidad de Valladolid

Universidad Autónoma de Madrid 
Jesús María Erquicia Olaciregui Joan Carles Membrado Tena Joana María Seguí Pons Jorge Olcina Cantos José Fernando Viviescas Monsalve José María Feria Toribio José Miguel Rodríguez Antón José Miguel Santacreu Josefina Domínguez Mújica Josep Padullés Juan Francisco Ojeda Rivera Juan Manuel Alegre Ávila Juan Manuel Barragán Muñoz Juan Manuel Trillo Juan Sevilla Álvarez Libardo Rodríguez Rodríguez Lucía Casado Casado Lucía Pesci Luis Ángel Collado Cueto Luís Moya González María Jesús Lago Ávila Marc Vilalta Reixach Marcos Antonio Espinoza Mina María José Piñeira Martiñán María Teresa Verdú Martínez María Velasco González María-Elia Gutiérrez-Mozo Marisol Esteban Galarza Montserrat Gómez Fernández Omar Bouazza Ariño Oriol Nel.lo Colom Pablo Giménez Font Purificación Ruiz Flaño Rafael Mata Olmo

Ramón Pascual Remedios Zamora Roselló Roberto Nicolás Bustos Cara Rodrigo Aguilar Pérez Salvador Ivorra Chorro Sandra Milena Ortiz Laverde Sandra Turbay Ceballos Sonia Hernández Partal Tomás Mazón Vives Miró
Gobierno Vasco-Ordenación del Territorio y Planeamiento Universidad de Valencia

Universidad de las Islas Baleares

Universidad de Alicante

Arquitecto Urbanista

Universidad Pablo de Olavide de Sevilla

Universidad Autónoma de Madrid

Universidad de Alicante

Universidad de Las Palmas de Gran Canaria"

Universidad Autónoma de Zacatecas de México

Universidad Pablo de Olavide de Sevilla

Universidad de Cantabria

Universidad de Cádiz

Universidad de Santiago de Compostela

Universidad de Oviedo

Instituto Internacional de Derecho Administrativo-IIDA

Universitat Rovira i Virgili de Tarragona

Foro Latinoamericano de Ciencias Ambientales

Universidad Autónoma de Madrid

ETSAM - Universidad Politécnica de Madrid

Universidad CEU San Pablo de Madrid

Universidad de Barcelona

Universidad Tecnológica Ecotec de Ecuador

Universidad de Santiago de Compostela"

S.G. Políticas Urbanas, MITMA

Universidad Complutense de Madrid

Universidad de Alicante

Universidad del País Vasco/EHU

Universidad de Alcalá de Henares

Universidad Complutense de Madrid

Universitat Autònoma de Barcelona

Universidad de Alicante

Universidad de La Rioja

Universidad Autónoma de Madrid

Instituto de Investigación en Energía de Cataluña-IREC

Universidad de Málaga

Universidad Nacional del Sur (UNS) de Argentina

Universidad de Santiago de Chile

Universidad de Alicante

Universidad Externado de Colombia

Universidad de Antioquía de Colombia

S.G. Políticas Urbanas, MITMA

Universidad de Alicante

Universidad de las Islas Baleares

Nuestro más sincero agradecimiento a la valiosa y desinteresada colaboración de todos ellos que, con sus comentarios y sugerencias, han contribuido a mejorar y enriquecer los manuscritos originales. 


\section{DIRECTRICES PARA AUTORES}

Las Directrices completas para autores pueden descargarse en:

https://recyt.fecyt.es/index.php/CyTET/about/submissions\#authorGuidelines

\section{Normas comunes para la presentación de originales en todas las Secciones abiertas a envíos:}

1. Carácter original e inédito: Los trabajos serán necesariamente originales e inéditos en ninguna otra publicación ni lengua. La presentación del manuscrito original a CyTET implica el compromiso ético formal por parte del autor de no haberlo enviado antes o simultáneamente a ningún otro editor para su publicación. Una vez acusada puntualmente su recepción por la Revista y antes de notificar el resultado del arbitraje de su evaluación científica tampoco podrá ser remitido a otros editores, salvo que el autor solicite por escrito retirarlo sin esperar el resultado de la evaluación. Otro proceder anómalo por parte del autor será éticamente reprobado en los círculos editoriales.

2. Envíos: Los trabajos completos se enviarán en soporte informático con dos copias: una original completa y otra "ciega" en la que se habrá suprimido nombre y señales identificadoras del autor (para poder enviarla a evaluar anónimamente). Los envíos incluirán el texto original completo y el "ciego" (ambos con las Figuras incorporadas en el texto, como se indica abajo), y además se enviarán aparte las imágenes y tablas de Excel en archivos separados.

La dirección de correo para envíos es: cytet@fomento.es

3. Extensión de los trabajos, título, estructura, etc.: Cada sección de la Revista tiene sus propias normas, que se desarrollan más adelante.

4. Notas a pie de página: Irán numeradas correlativamente por todo el texto; serán publicadas siempre al pie de la página. Las notas al pie contendrán exclusivamente comentarios ad hoc, nunca se utilizarán sólo para citar referencias bibliográficas, las cuales deben ir siempre en el texto (ver punto 6) y recopiladas al final (ver punto 7).

5. Abreviaturas: Se incluirá un listado de acrónimos o siglas (organismos, revistas, etc.) al final del texto, detrás de la bibliografía. La primera vez que aparezca en el texto, se escribirá primero el nombre completo, seguido (entre paréntesis) por el acrónimo o sigla. En la segunda y sucesivas apariciones, irá ya sólo el acrónimo o sigla.

6. Inserción de citas en el texto (textuales o referencias bibliográficas): Deberán insertarse en el propio texto entre paréntesis con un solo apellido en VeRSALITAS, remitiendo a la bibliografía final. Por ejemplo: «cita textual» (PÉREZ, 1985: 213-8).

7. Normas sobre bibliografía citada: Al final del texto se incluirá un listado de "Bibliografía citada», en orden alfabético de apellidos (siempre en VERSALITAS). Este listado solamente incluirá las obras citadas en el texto. Las normas para confeccionarlo serán las Normas APA (https://www.apastyle.org/manual/), accesibles en castellano en: http://normasapa.com/.

A modo de ejemplo, se incluyen algunos de los casos más comunes:

Referencias de citas en libros:

Apeluidos, Iniciales nombre autor, (Año): Título del Libro en cursiva, Ciudad, País, Editorial.

Ascher, F. (2001): Les nouveaux principes de l'urbanisme, París, Francia, Éditions de l'Aube.

Referencias de capítulos de libros (y ejemplo con dos autores):

Apelidoos, A. A. \& Apeluidos, B. B. (Año). Título del capítulo o la entrada. En X. X. Apellidos (Eds. ó Coord.): Título del libro (pp. xx-xx). Ciudad, País: Editorial

JIMÉNEZ, E. \& DONAT, C. (2018): "El estudio de la segregación urbana: estrategia metodológica”. En I. BLANCo \& O. NeL'LO (Eds.), Barrios y crisis. Crisis económica, segregación urbana e innovación social en Cataluña (pp. 56-89), València, Ed. Tirant lo Blanch. 
Referencias de artículos en revistas:

Apelidos, A. A. (Fecha): Título del artículo. Nombre de la revista. Volumen (Número), pp-pp.

Ureña, J. M., Pillet F. \& Marmolejo C. (2013): Policentrismo en los espacios urbanos. Ciudad y Territorio. Estudios Territoriales, Volumen XLVI, n 176: 249-266

Referencias de artículos en revistas electrónicas:

Ben-Elia, E., Alexander, B., Hubers, C. \& EtTema, D. (2014): Activity fragmentation, ICT and travel: An exploratory Path Analysis of spatiotemporal interrelationships. Transportation Research Part A: Policy and Practice, 68, 56-74. doi:10.1016/j.tra.2014.03.016

Cuando las referencias de cada autor(es) sean varias se ordenarán cronológicamente, y las del mismo año se ordenarán añadiéndoles una letra [(1996a; 1996b; etc.)].

Los segundos y siguientes coautores irán siempre precedidos del signo \& (et latino) para diferenciar los apellidos compuestos [Ramón Y Cajal], por ejemplo: Ben-Elia, E., Alexander, B., Hubers, C. \& Ettema, D.

8. Figuras, imágenes, ilustraciones, tablas y gráficos: (1) Las imágenes, planos, gráficos, tablas, cuadros, fotos, etc., se identificarán todos ellos por igual con el nombre convencional de Figura poniendo en su título la abreviatura FIG.xx. (2) Los textos enviados incluirán las figuras que correspondan en el lugar aproximado donde el autor considere. La edición final puede implicar la necesidad de modificar ligeramente el lugar de colocación. (3) Irán correlativamente numeradas por su orden de aparición y convenientemente referenciadas en su contexto mediante la indicación (ver FIG. XX). (4) Se indicará siempre su procedencia o fuente de referencia de autor y, en caso de comportar reproducción de gráficos ajenos, deberán contar con la pertinente autorización respectiva de la editorial y autor. El autor, al presentar el artículo para evaluación a CyTET, se hace responsable de tener las autorizaciones y permisos necesarios para publicar las ilustraciones que el artículo incluya. (5) Además de incluirse en el propio texto (puede ser en menor calidad), los envíos de originales deben incluir en archivos independientes aparte las imágenes en alta calidad y las tablas. Por cada Figura se enviará un archivo independiente, nombrado con el mismo número de la Figura que aparece en el texto (por ejemplo, Figura 1.jpg, Figura 2. xls, etc.)

9. Número máximo y formato para enviar las figuras: Las figuras serán 10, como máximo.

Las tablas sólo de texto pueden ir insertadas como tablas de texto en el propio documento, pero deben enviarse también en archivo aparte para facilitar su maquetación.

Las tablas numéricas deben enviarse en un archivo Excel, Open Office o similar, al igual que los gráficos elaborados con estos programas, para poder ser maquetados.

Las fotografías, planos e imágenes deben enviarse cada una en un archivo independiente; su calidad debe ser como mínimo de 300 ppp (píxeles por pulgada), aceptándose sólo formatos JPG ó TIFF. Los gráficos o dibujos sólo de línea se presentarán en archivos vectoriales (EPS o PDF vectorial). Por limitaciones técnicas, la editorial se reserva el derecho de seleccionar la calidad, cantidad y formato de las ilustraciones publicables.

10. Datos personales: Cuando el o los autores reciban la notificación de haberse decidido la publicación de su artículo, deberán enviar la Ficha de Datos Personales que oportunamente se facilitará, donde se incluyan sus datos personales, con el objeto de enviarles un ejemplar de la revista impresa en papel e incorporarlos a la Base de Datos de CyTET. En cualquier momento, los autores podrán ejercer sus derechos de acceso, rectificación, cancelación u oposición dirigiéndose a CyTET: cytet@fomento.es

11. Corrección pruebas: Los autores se comprometen a corregir las primeras pruebas de imprenta en un plazo de cinco días desde su recepción, entendiéndose que, de no tener respuesta, se otorga la conformidad con el texto que aparece en ellas. No se podrá modificar sustancialmente el texto original a través de esta corrección de pruebas, limitándose a corrección de erratas y subsanación de errores u omisiones.

12. Cláusula de responsabilidad: Los trabajos firmados expresan únicamente la opinión de sus autores y son de su exclusiva responsabilidad, a todos los efectos legales. Los autores son expresamente responsables de tener los permisos necesarios para la reproducción de las imágenes que incluyan.

\section{Normas específicas para la Sección de Artículos/Articles:}

13. Extensión: La extensión de los Artículos estará comprendida entre un mínimo de 45.000 y un máximo de 90.000 caracteres (incluyendo espacios). Al mismo tiempo, el original presentado (con figuras incluidas) deberá tener entre 15 y 22 páginas (numeradas) en formato UNE A-4 (DIN A4), con márgenes de 2,5 cm, letra Times New Roman, cuerpo 12, e interlineado sencillo.

14. Título del artículo: Debe ser claro y conciso, y puede incluir un subtítulo, teniendo en total una extensión máxima de 100 caracteres, incluyendo espacios. No contendrá abreviaturas, ni notas o llamadas a notas al pie en el mismo. Las referencias sobre el origen, relación del artículo con proyectos de investigación o tesis, agradecimientos, etc. irán en nota al pie de página.

15. Autores: Bajo el título del artículo, irá el nombre y apellidos de cada uno de los autores (poniendo los apellidos completos en VERSALITAS y negrita, para poder identificarlos) incluyéndose debajo la profesión o cargo principal con el que desean ser presentados y una dirección de correo electrónico. 
16. Número de identificación ORCID de los autores. CyTET incluye el identificador digital de ORCID $®$ como sistema de normalización de la referencias de los autores. Cada autor deberá proporcionar su número de identificación ORCID (Open Researcher and Contributor ID). Los autores que no dispongan previamente de ORCID, pueden obtenerlo gratuitamente en: https://orcid.org/register

17. Resumen/Abstract: Antes del texto del artículo deberá incluirse obligatoriamente un resumen en español de su contenido (no un índice), de extensión comprendida entre 700 y 900 caracteres (incluyendo espacios). Éste debe resumir de forma concisa el objeto, la metodología y las conclusiones del artículo, sin notas a pie. Los autores deben enviar también una traducción al inglés del resumen (Abstract), cuyo lenguaje, en todo caso, podrá ser revisado por el Comité de Redacción.

18. Palabras Clave/Keywords: Se incluirán cuatro o cinco Palabras Clave como descriptores de las referencias temáticas, mediante las cuales se pueda clasificar el artículo, a juicio del autor. No obstante, la editorial se reserva su homologación con el Tesauro y descriptores propios para confeccionar los Índices Anuales de la Revista. Se incluirán también traducidas al inglés (Keywords).

19. Apartados del artículo: El texto del artículo se organizará por epígrafes. Siempre que sea posible y adecuado al planteamiento del artículo, se seguirá preferentemente la estructura IMRyD: Introducción, Metodología, Resultados y Conclusiones/Discusión de Resultados. En caso de no seguirse esta estructura, conviene incluir un apartado de Conclusiones. La numeración de los apartados se hará sólo con caracteres arábigos de hasta tres dígitos. Por ejemplo: 3., 3.1., 3.1.1). Las restantes subdivisiones inferiores llevarán letras mayúsculas y minúsculas o números $[A), b), 1), i), \ldots]$.

\section{Normas específicas para las Secciones de Estudios comparados/ Comparative Studies; Experiencias/Urban Practices y Libros y Revistas/Book Reviews:}

Consultar en: https://recyt.fecyt.es/index.php/CyTET/about/submissions\#authorGuidelines

\section{Declaración de Ética/Publication Ethics}

La redacción de la revista CyTET Ciudad y Territorio Estudios Territoriales está comprometida con la comunidad científica en garantizar la ética y calidad de los artículos publicados. Nuestra revista tiene como referencia el Código de conducta y buenas prácticas que, para editores de revistas científicas define el Comité de Ética de Publicaciones (COPE). Al mismo tiempo, garantiza una adecuada respuesta a las necesidades de los lectores y autores, asegurando la calidad de lo publicado, protegiendo y respetando el contenido de los artículos así como la integridad de los mismos. El Comité Editorial se compromete a publicar las correcciones, aclaraciones, retracciones y disculpas cuando sea preciso.

En cumplimiento de estas buenas prácticas, CyTET Ciudad y Territorio Estudios Territoriales tiene publicado el sistema de arbitraje que utiliza para la selección de artículos así como los criterios de evaluación que deben aplicar los evaluadores externos -anónimos y por pares. CyTET Ciudad y Territorio Estudios Territoriales mantiene actualizados estos criterios, basados exclusivamente en la relevancia científica del artículo, originalidad, claridad y pertinencia del trabajo presentado.

Nuestra revista garantiza en todo momento la confidencialidad del proceso de evaluación: el anonimato de los evaluadores y de los autores, el contenido evaluado, el informe razonado emitidos por los evaluadores y cualquier otra comunicación emitida por los comités editorial, asesor y científico si así procediese.

De la misma forma, se mantendrá la confidencialidad ante posibles aclaraciones, reclamaciones o quejas que un autor desee remitir a los comités de la revista o a los evaluadores del artículo.

CyTET Ciudad y Territorio Estudios Territoriales declara su compromiso por el respecto e integridad de los trabajos ya publicados. Por esta razón, el plagio está estrictamente prohibido y los textos que se identifiquen como plagio, o su contenido sea fraudulento, no se publicarán. En caso de que se detecte el plagio con posterioridad a la publicación en papel, se insertará en el número corriente de la revista que corresponda una nota haciendo público el plagio detectado. La revista actuará, en estos casos, con la mayor celeridad posible.

Al aceptar los términos y acuerdos expresados por nuestra revista, los autores han de garantizar que el artículo y los materiales asociados a él son originales o no infringen los derechos de autor. También los autores tienen que justificar que, en caso de una autoría compartida, hubo un consenso pleno de todos los autores afectados y que no ha sido presentado ni publicado con anterioridad en otro medio de difusión. 


\section{Proceso de Revisión por Pares/Peer Review}

Todos los originales recibidos para las secciones abiertas a envíos, incluidos los números monográficos, se someten a un proceso de doble revisión:

\section{Revisión preliminar por el Comité de Redacción.}

En una primera ronda preliminar, cada artículo recibido es revisado por los miembros del Comité de Redacción de la revista, que comprueban si el artículo es original e inédito y sus contenidos son acordes con la línea editorial de CyTET, si el trabajo posee una mínima estructura científica, y si se cumplen las Directrices para Autores. El Comité de Redacción descartará los artículos que no cumplan los siguientes aspectos:

a. Originalidad: se descartarán los artículos que no sean originales e inéditos, por haberse publicado previamente de forma total o parcial ("salami slicing", autoplagio, etc.).

b. Forma: se descartarán aquellos documentos que incumplan las Directrices para Autores.

c. Temática: no se aceptarán trabajos que no consideren explícitamente como componente relevante la dimensión urbana o territorial.

d. Alcance y carácter innovador: se descartarán aquellos artículos cuyo carácter sea excesivamente restringido o local, o que carezcan de un enfoque novedoso en relación con el "estado del arte" del tema tratado.

La decisión del Comité de Redacción (rechazado o aceptado para revisión por pares) se comunicará al autor en el plazo máximo de 15 días.

\section{Segunda Revisión por Evaluadores externos.}

En caso de que el Comité de Redacción considere el trabajo como inicialmente apto, éste designará dos expertos revisores anónimos y ajenos a la institución de adscripción del autor(es), a quienes remitirá el artículo, que será evaluado en una segunda ronda por estos evaluadores externos, mediante el sistema de revisión por pares doble ciego.

La valoración por parte de los evaluadores externos atenderá al interés del artículo, su contribución al conocimiento del tema tratado, las novedades aportadas, las correctas relaciones establecidas, el juicio crítico desarrollado, las referencias bibliográficas utilizadas, su correcta redacción, etc., indicando recomendaciones, si las hubiera, para su posible mejora.

De acuerdo con las recomendaciones de los revisores, el Comité de Redacción comunicará por correo electrónico al autor(es) el resultado motivado de la evaluación por correo electrónico -junto con las observaciones y comentarios de los revisores-, que podrá ser:

a. Publicable sin cambios;

b. Publicable con leves mejoras o correcciones menores;

c. Publicación con correcciones importantes y/o cambios en los aspectos de fondo y forma;

d. No publicable sin una nueva reelaboración con cambios sustanciales;

e. No publicable en CyTET.

En caso de discrepancia entre los dos revisores, el texto será enviado a un tercer árbitro, cuya decisión dirimirá el resultado final. Los resultados del proceso del dictamen académico serán inapelables en todos los casos. En los casos b) y c) - es decir: si el manuscrito ha sido aceptado, pero con modificaciones (leves o importantes)los autores deberán reenviar (en un plazo máximo de 2 meses) una nueva versión del artículo revisado, atendiendo a las demandas y sugerencias de los evaluadores externos. Para facilitar la reevaluación, el envío de la revisión por parte de los autores debe consistir en dos archivos: uno con el nuevo texto revisado y otro donde consten los cambios introducidos (por ejemplo, enviando también la opción del documento con control de cambios). Si lo desea, el autor(es) podrá aportar además una carta al Comité de Redacción en la que se justifiquen las modificaciones introducidas en el artículo. El plazo que deberá cumplirse por el autor(es) para el envío del artículo revisado (en dos archivos: con y sin control de cambios) será de 2 meses, contadas desde el envío de la notificación oficial de las observaciones por parte del equipo editorial. Transcurrido dicho plazo, los artículos que no hayan sido corregidos y reenviados por sus autores serán inapelablemente considerados como artículos caducados y por lo tanto, eliminados del sistema de arbitraje.

Los artículos sometidos a correcciones importantes y/o cambios en los aspectos de fondo y forma (caso c) deberán revisarse por los autores en el plazo de dos meses desde la comunicación del Comité de Redacción y podrán ser objeto de una segunda reevaluación por parte de los evaluadores externos, para comprobar la adecuación de la revisión a sus recomendaciones.

En caso que la nueva versión de un artículo revisado no cumpla con lo solicitado por los revisores, serán devueltos a sus autores para ser modificados por segunda vez, lo que debe ocurrir en un nuevo plazo de otros 2 
meses. Una vez transcurrido este nuevo plazo, los artículos que no hayan sido corregidos y enviados por sus autores también serán considerados, como artículos caducados y eliminados del sistema de arbitraje.

En función del grado de cumplimiento de las modificaciones solicitadas, el Comité de Redacción se pronunciará finalmente sobre si procede o no la publicación del artículo. Dicha decisión será nuevamente comunicada al autor(es).

Los artículos evaluados como no publicables sin una nueva reelaboración con cambios sustanciales (caso d) o los que hayan caducado como consecuencia del agotamiento del plazo para su revisión, deberán considerarse como nuevos envíos y reiniciar todo el proceso editorial desde el principio.

\section{SUMMARY OF AUTHOR'S GUIDELINES IN ENGLISH}

a. Languages accepted for submission. In principle, CyTET only publishes papers in Spanish, although it includes Abstracts and Keywords in English. Nevertheless, the Editorial Board can accept for evaluation papers written in English or French. Normally, this is the case of monographic issues -eventually open for submission in other languages -, but it is also possible that the Editorial Board accepts an article in English or French for a miscellaneous issue. Once evaluated and accepted, the paper will be translated by the Editors and finally published in Spanish.

b. Originality. The papers submitted for evaluation to CyTET must be original and unpublished works. Plagiarism, salami slicing and self-plagiarism are not acceptable. Authors, by submitting a paper for evaluation, do certify this fact. Papers being evaluated in other Journals do not qualify for being accepted in CyTET. In the case of papers derived from works previously presented in Congresses they cannot be exactly the same in extension nor in contents, and must state this fact in a footnote indicating the name of the Congress, edition and data of celebration. The same apply for papers derived from thesis, which should indicate the academic program from which they originate

Submission of a manuscript implies the author's commitment to publish in this journal. If an author submits a manuscript to CyTET, it should not be submitted to another journal; nor should the manuscript repeat information published elsewhere in substantially similar form or with substantially similar content. Authors in doubt about what constitutes prior publication should consult the editors.

c. Instructions for submission. Original papers submitted for evaluation should be accompanied by a copy with the contact details removed, for the peer review process. Anything designated as 'supplemental file for review' will also be made available to the reviewers. If you want to include a manuscript file with identifying information, please upload this as 'supplementary file not for review'. The papers should embed figures figures, illustrations, graphs, etc. in the Word text (it can be in low quality), but all of them must be sent in separate files, in full quality.

Submission and contact: cytet@fomento.es

\section{d. References.}

Please avoid using footnotes wherever possible. However, where their use is unavoidable, please use superscript numbers within the text corresponding with the number of the relevant footnote.

References in the text should be made in the following ways:

As Scott (1996) points out, this may not be so.

However, this might not be so (Scott, 1996).

(Jones, 1995, 17; Smith, 1998)

(Jones, 1995; 1997)

For a reference with three or more authors, name only the first with et al. Do not use 'ibid.' when referring to the same work twice in succession.

You must make sure that all references which appear in the text are given in full in the references section. Where there is more than one reference to the same author for the same year, they should be listed as 1995a, 1995b etc.

The references section should be a continuous alphabetical list. Do not divide the list into different sections (books, reports, newspaper articles etc.). Where there is more than one reference to the same author, that author's references should appear in chronological order, with references to that author in conjunction with others coming after the last reference to the author alone.

References should follow APA Guidelines: https://www.apastyle.org/manual/ 
e. Figures and tables. All maps, diagrams, charts and photographs should be referred in text as 'Figures' and should be numbered in a single sequence in the order in which they are referred to in the paper. To show where in the text you would ideally like figures or tables to appear, please put 'INSERT FIG. 1 AROUND HERE' at the appropriate point. All figures should have brief descriptive captions. Figures should be supplied digitally, as TIFF, or JPG files at a resolution of $300 \mathrm{dpi}$ and a size appropriate to the page size of the journal. The Graphs and Tables should also be sent in EXCEL or Open Office.

f. Author's identification. Contributors are asked to include a brief biographical note with their submissions including contact information (position, institution, email, etc.). All authors must provide their ORCID® (Open Researcher and Contributor ID). It can be obtained at: https://orcid.org/register

g. Extension. Full-length papers should be 45,000-90,000 characters long (including notes, references and Figures).

h. Abstract and Keywords. Your paper should begin with an abstract of about 250/300 words that go into some detail about the methods, findings and conclusions of the paper and should allow users of these to make an informed decision as to whether your paper will be of relevance and interest to them. Four or five Keywords should also be included.

i. Other journal sections. For instruction in English for contributions to the Experiencias/Urban Practices or Libros y Revistas/Book Reviews please contact cytet@fomento.es

\section{Dirección de Correspondencia/Submission To:}

Toda la correspondencia, envíos y demás actuaciones referentes a los contenidos y confección editorial con la Revista, deberán dirigirse a la siguiente dirección:

CIUDAD Y TERRITORIO Estudios Territoriales

Ministerio de Transportes, Movilidad y Agenda Urbana

Dirección General de Agenda Urbana y Arquitectura

Subdirección General de Políticas Urbanas Despacho C-630

Po de la Castellana, 67 - 28071 MADRID (España)

Teléfono: (34) 915977431

Correo electrónico: cytet@fomento.es 


\title{
BOLETÍN DE SUSCRIPCIÓN
}

\author{
SUSCRIPCIÓN ANUAL (4 números): \\ España: $30 €$ (IVA incluido) \\ Extranjero: 42€ (Precio sin IVA) \\ NÚMERO SENCILLO \\ España: $9 €$ (IVA incluido) \\ Extranjero: $12 €$ (Precio sin IVA)
}

correo electrónico: $\underline{\text { CyTET@fomento.es }}$

Puede realizar la suscripción:

> On Line: directamente en este enlace: https://apps.fomento.gob.es/CVP/Soporte/default2.htm

\section{$>$ Correo electrónico:}

\section{cpublic@fomento.es}

Facilitando: Nombre y Apellidos / Empresa, CIF / NIF, dirección, teléfono, E-mail y forma de pago (transferencia o domiciliación bancaria)

> Información y suscripciones: +34 915977261

Ministerio de Transportes, Movilidad y Agenda Urbana

Centro de Publicaciones

Po Castellana, 67 - 28071 MADRID

El Centro de Publicaciones o el suscriptor podrán interrumpir la suscripción sin más tramite que la comunicación a la otra parte.

El Centro de Publicaciones del Ministerio de Fomento ha adoptado las medidas necesarias para el cumplimiento de lo dispuesto en el Reglamento (UE) 2016/679 del Parlamento Europeo y del Consejo, de 27 de abril de 2016, relativo a la protección de las personas físicas en lo que respecta al tratamiento de datos personales y a la libre circulación de estos datos y por el que se deroga la Directiva 95/46/CE (Reglamento general de protección de datos), publicado en el Diario Oficial de la Unión Europea de 4 de mayo de 2016 asegurando la correcta utilización de los datos personales de los usuarios y actualizando los procedimientos de gestión de tratamiento de los mismos, de política de uso de los datos y de obtención del consentimiento.

Se recuerda que la recogida y tratamiento automatizado de los datos personales tiene como finalidad la gestión, prestación, ampliación y mejora de los servicios solicitados en cada momento por el usuario y la adecuada atención, respuesta y seguimiento de las consultas planteadas por los mismos.

Los datos proporcionados se conservarán mientras se mantenga la relación comercial o durante los años necesarios para cumplir con las obligaciones legales. En ningún caso se cederán a terceros, salvo que exista una obligación legal.

Usted podrá ejercer en cualquier momento los derechos de oposición, acceso, rectificación y cancelación ante el Centro de Publicaciones del Ministerio de Fomento, bien dirigiendo un escrito a la dirección postal, Paseo de la Castellana, 67 - 28071 Madrid o, si lo prefiere, mediante correo electrónico a la dirección cpublic@fomento.es 

Indización y Bases de Datos en que está incluida la revista CyTET:

\begin{tabular}{|c|c|}
\hline Emerging Sources Citation Index (ESCI). & \\
\hline Scopus & Scopus \\
\hline $\begin{array}{l}\text { Avery Index of Architecture Periodicals. } \\
\text { University of Columbia }\end{array}$ & $\overline{\overline{\bar{l}}} \mid$\begin{tabular}{|l} 
AVERY \\
INDEX
\end{tabular} \\
\hline Actualidad Iberoamericana & 191 Actualidad lberoamericana \\
\hline Citefactor & teFactor \\
\hline DIALNET & - Dialnet \\
\hline InDICEs CSIC & $\begin{array}{l}\text { ÍnDICEs } \\
\equiv \text { ESIC }\end{array}$ \\
\hline JISC Library Hub & Jisc Library Hub \\
\hline Periodicals Index Online (PIO) & ProQuest \\
\hline Red de Bibliotecas Universitarias Españolas (REBIUN) & CRUE $\underset{\text { Red de }}{\text { REBlilotecas Universitarias }}$ \\
\hline SUNCAT & \\
\hline Ulrichs' Periodicals DirectoryTM & $\begin{array}{l}\text { ULRICHSWEB } \\
\text { GLOBAL SERIALS DIRECTORY }\end{array}$ \\
\hline URBADOC & 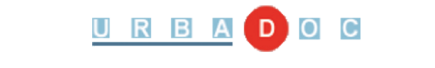 \\
\hline Wageningen UR & D. WAGENINGEN \\
\hline WorldCat & ST WorldCat \\
\hline
\end{tabular}

Índices de Impacto y Evaluación de la revista CyTET en:

\begin{tabular}{|l}
\hline CARHUS Plus +2018 \\
\hline CIRC \\
DICE \\
ERIHPlus \\
FECYT \\
IBRA (Indicadores Bibliométricos de Revistas de Arquitectura) \\
IN-RECS \\
LATINDEX. Catálogo v1.0 \\
MIAR \\
\hline RESH
\end{tabular}

\begin{tabular}{|c|}
\hline 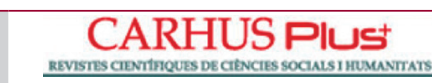 \\
\hline CCIR \\
\hline D I CE \\
\hline ERIHPLUS \\
\hline 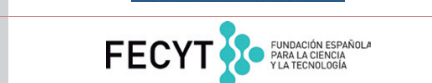 \\
\hline 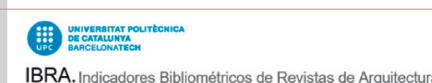 \\
\hline IN $\sim R E C S$ \\
\hline latindex \\
\hline MIAR \\
\hline rěsh \\
\hline
\end{tabular}


Métricas de la revista CyTET en:

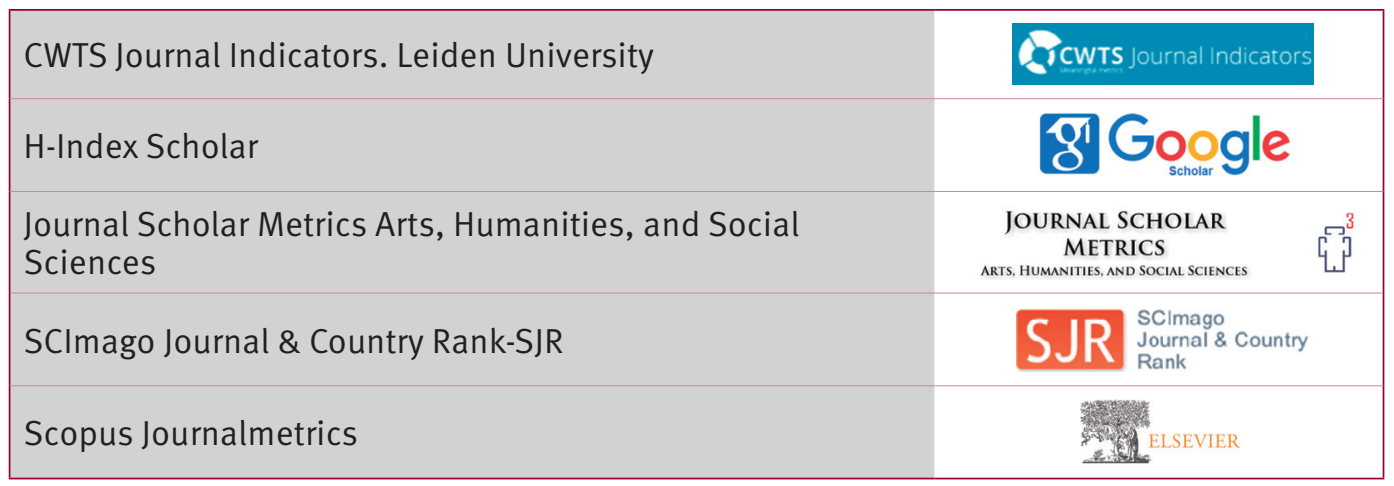

\section{Políticas Open Access:}

Dulcinea

SUt, DULLINEA

\section{Acreditaciones y Sellos de Calidad:}

La revista CyTET está acreditada por la ANVUR italiana (Agenzia Nazionale di Valutazione del Sistema Universitario e della Ricerca) como revista de Clase A y tiene el Sello de calidad de FECYT (Fundación Española para la Ciencia y la Tecnología).

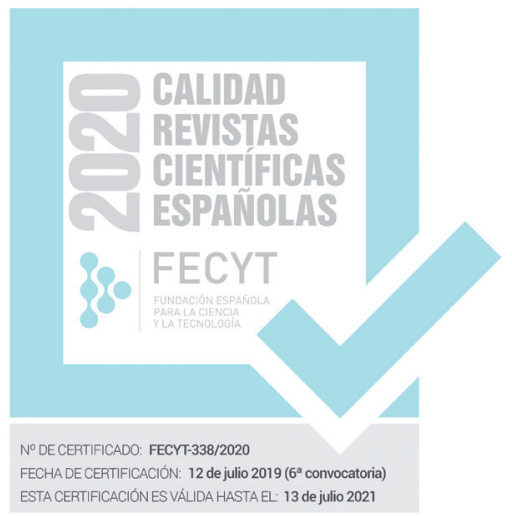


noticias que supongan una aportación sobre algunos de los siguientes temas:

- Ordenación del Territorio

- Urbanismo

- Ciencia regional

- Infraestructuras territoriales y urbanas

- Planificación y desarrollo

- Vivienda y suelo

La correspondencia para todo lo referente a Redacción, diríjase a:

CIUDAD Y TERRITORIO ESTUDIOS TERRITORIALES

Ministerio de Transportes, Movilidad y Agenda Urbana Secretaría de Estado de Transportes, Movilidad y Agenda Urbana

Secretaría General de Agenda Urbana y Vivienda Dirección General de Agenda Urbana y Arquitectura Subdirección General de Políticas Urbanas

P. ${ }^{\circ}$ de la Castellana, 67 28071 Madrid - España

Teléfono: 915977431 - Fax: 915975061

correo electrónico: CyTET@fomento.es

Administración y suscripciones:

Ministerio de Transportes, Movilidad y Agenda Urbana Pza. San Juan de la Cruz, s/n 28071 Madrid

La Dirección General de Agenda Urbana y Vivienda y la Redacción de la Revista no se hacen partícipes de las opiniones expresadas por los autores en los artículos que se insertan.

Edita:

Ministerio de Transportes, Movilidad y Agenda Urbana

(c) Secretaría General Técnica

Centro de Publicaciones

Redacción:

Dirección General de Agenda Urbana y Arquitectura

Diseño original

Nic \& Will, S. L.

Creación ilustración de portada Anaïs García Pérez

Maquetación:

Cristina Rico Iboleón

Imprime:

Etiquetas Alhambra S.L.

Suscripción Anual:

España: 30 euros / Extranjero: 42 euros

Números sueltos:

España: 9 euros / Extranjero: 12 euros

Depósito Legal: M-10.422-1970

ISSN: $1133-4762$

ISSN (E): $2659-3254$

NIPO: $796-20-003-5$

NIPO (E): 796-20-004-0

DOI: $10.37230 /$ CyTET

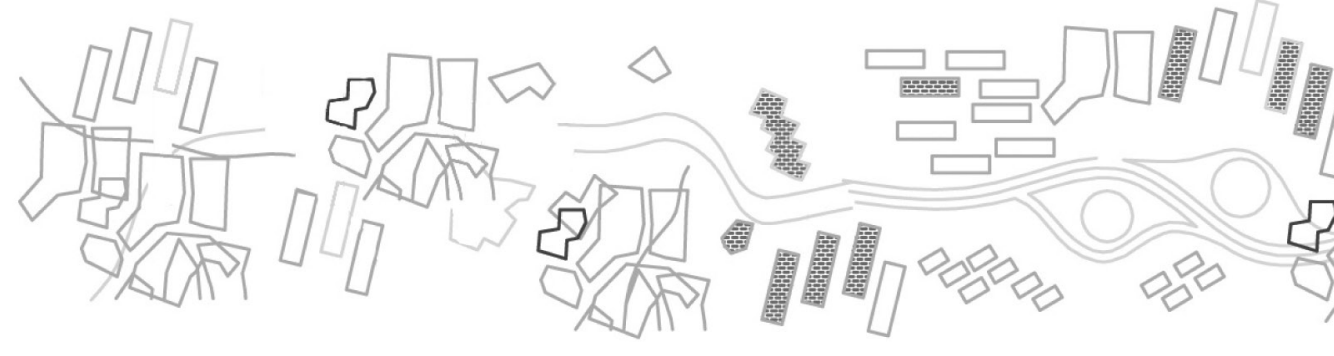

Land Act 2015: Sustainable urbanism and housing accessibility Green Infrastructure and Spatial Planning in Spain

Evaluation of the effectiveness in the urban regeneration of our cities

Mobility, migrations and nomadism in the city of the 21st century

Is the city recoverable as a space for children? A theoretical approach

Logistic sprawl in Madrid urban mega-region

Methodological proposal for the study of livestock trails from the landscape perspective

Informal city and territorialities of social production of urban space: Armenia, Colombia.

Russell Sage Foundation and Forest Hills Gardens: an urban laboratory in New York

Origins of the use of urbanism in cities competition: Houston

\begin{tabular}{|c|c|c|}
\hline \multirow{2}{*}{ 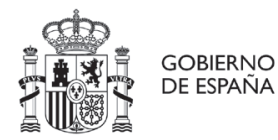 } & \multirow{2}{*}{$\begin{array}{l}\text { MINISTERIO } \\
\text { DETRANSPORTES, MOVILIDAD } \\
\text { YAGENDA URBANA }\end{array}$} & $\begin{array}{l}\text { SECRETARRA GeNERA } \\
\text { TÉCNICA }\end{array}$ \\
\hline & & \begin{tabular}{|l} 
CENTRO \\
DE FUULCACIONES
\end{tabular} \\
\hline
\end{tabular}

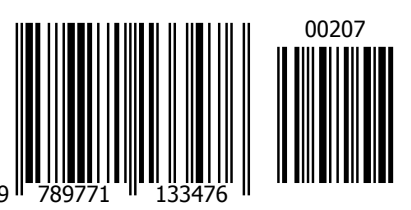

